
C.Lewis Gazin 


VERT. PAL.

\section{HISTORICAL GEOLOGY}

WITH SPECIAL REFERENCE TO

NORTH AMERICA

BY

WILLIAM J. MILLER

PROFESSOR OF GEOLOGY, S'MITH COLLEGE

238 ILLUSTRATIONS

SECOND PRINTING
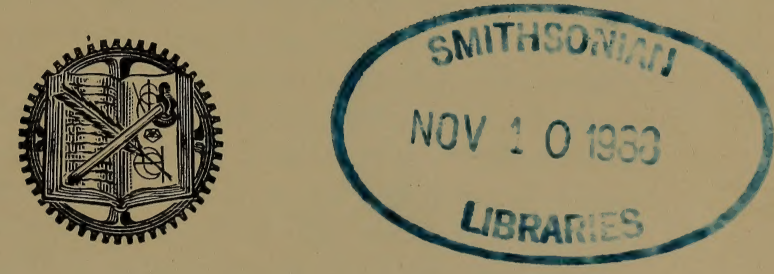

NEW YORK

D. VAN NOSTRAND COMPANY

Eight WarRen Street 
C OP Y I G T T, I 9 I 6, B Y

D. VAN NOSTRAND COMPANY 


\section{PREFACE}

IT is the author's hope that this book may find a place as a class-book dealing with the historical geology portion of a one-year course in general geology, and that it may also serve as a text for special courses in historical geology. An elementary knowledge of what is generally comprised under dynamical and structural geology is presupposed. It is assumed that a proper amount of laboratory and field work will be pursued in connection with the text.

It will be seen that more introductory space is devoted to a discussion of the broad fundamental principles of historical geology than is customary in text-books. The experience of the author has been that careful attention to these general principles at the beginning of the subject is well repaid in satisfaction to both teacher and student when the great events of earth history are taken up in regular order.

A definite plan is strictly adhered to in the discussion of each period from the Cambrian to the Tertiary inclusive. Such definiteness of presentation, in spite of some objections which may be raised against it, should greatly aid the beginner, who must constantly compare periods and note the important changes in the evolution of both land-masses and organisms. The topical arrangements are such that any desired comparisons can be readily made. A plan of treatment, the same for both the Archeozoic and Proterozoic eras, permits a ready comparison of these two. By the very nature of the subject-matter, a somewhat more special method of discussion has been necessary for the Quaternary period.

Important features are the summaries of Paleozoic and Mesozoic history which will aid the student in fixing in mind the salient points in the history of those two great eras. It is believed that the two tabular summaries - one of Paleozoic life and the other of Mesozoic life - will be helpful. Group by group and period by period, from the Cambrian to the Cretaceous inclusive, the principal evolutionary changes in organisms are brought before the student at a giance by the use of these tables. 
Students beginning the study of geology usually have either very little knowledge of biology or their study has not emphasized the classification of organisms. The evolution of organisms is a fundamental consideration in the study of earth history, and the instructor finds it well-nigh necessary to present to his classes outline classifications of plants and animals accompanied by brief descriptions of the more common types. Such matter is presented in the first chapter of this book.

In certain texts, especially those portions dealing with historical geology, there is a tendency to overwhelm the student by the introduction of a multiplicity of technical terms, especially the names of fossils. The present author's idea has been to reduce such terms to a reasonable minimum required for a proper understanding of the great principles of earth history. The genus and species names accompanying illustrations are given in the interest of scientific accuracy and with no thought that these are to be remembered by the student.

Various distinctly appropriate illustrations, more or less familiar because of their appearance in other text-books or manuals of geology, have not been abandoned merely for the sake of something new or different. Many of the illustrations, however, appear in a text-book here for the first time. Among the numerous original sources of illustrations, particular mention should be made of the publications of the United States Geological Survey, the New York State Museum, The American Museum of Natural History, and the Maryland Geological Survey.

The Macmillan Company, Henry Holt and Company, Ginn and Company, D. Appleton and Company, and John Wiley and Sons have generously allowed the use of various cuts. Careful attention has been given to the selection of only such views, fossils, diagrams, and maps as would systematically illustrate the text without overdoing this feature of the book.

The author is under particular obligation to Professor Bailey Willis of Stanford University for the use of his excellent series of paleogeographic maps of North America. These maps, together with his U. S. G. S. Professional Paper 71, have proved to be veritable storehouses from which to draw in the preparation of the manuscript of this book.

The well-known manuals and text-books of geology, especially 
those by Dana, Chamberlin and Salisbury, Pirsson and Schuchert, LeConte, Scott, Norton, Blackwelder and Barrows, Geikie, Kayser, and De Lapparent, have been freely consulted, and due acknowledgment is here made for the help derived from these sources.

Among those who have read portions or all of the manuscript are the following: Dr. J. M. Clarke and Mr. C. A. Hartnagel of the New York State Museum; Professors W. B. Clark and C. K. Swartz and Mr. E. W. Berry of the Johns Hopkins University; and Dr. L. W. Stephenson of the United States Geological Survey. Special acknowledgment is made to these men for valuable suggestions and criticisms, but the author holds himself strictly responsible for all errors the book may contain.

Smith College,

WILLIAM J. MILLER

Northampton, Mass., August, 1916 



\section{CONTENTS}

$\begin{array}{ll}\text { CHAPTER } & \text { PAGE }\end{array}$

I. General Principles . . . . . . . . . . . . . . 1

II. General Principles - Concluded . . . . . . . . 23

iII. Origin and pre-Geologic History of the Earth . . . . 35

IV. The Archeozolc ErA. . . . . . . . . . . . . . . 40

V. The Proterozolc Era . . . . . . . . . . . . . 47

VI. The Cambrian Period . . . . . . . . . . . . . . 56

VII. The Ordovician (Lower Silurian) Period . . . . . . . 77

VIII. The Silurian (Upper Silurian) Period . . . . . . . . . 103

IX. The Devonian Period . . . . . . . . . . . . . . 120

X. The Mississippian (Lower Carboniferous) Period . . . 143

XI. The Pennsyluanian (Upper Carboniferous) Period . . . 158

XiI. The Permian Period . . . . . . . . . . . . . . . . . . 180

XIII. Summary of Paleozoic History . . . . . . . . . . . . . 194

XIV. The Triassic Period . . . . . . . . . . . . . . 201

XV. The Jurassic Period . . . . . . . . . . . . . . . . . 219

XVI. The Cretaceous Period . . . . . . . . . . . . . . . 236

XVII. Summary of Mesozolc History . . . . . . . . . . . . 274

XVIII. The Tertiary Period . . . . . . . . . . . . . . 281

XIX. The Quaternary Period . . . . . . . . . . . . 328 



\section{LIST OF ILLUSTRATIONS}

FIGURE

1. A Protozoan (Amœba) without a shell. Greatly enlarged . . . . 14

2. Shelled Protozoans (Foraminifers) . . . . . . . . . . . . . . 14

3. Sponges on a shell . . . . . . . . . . . . . . . . 14

4. Modern Hydrozoans. Part of a colony much enlarged . . . . . 15

5. A group of modern Corals showing the internal structure of one individual . . . . . . . . . . . . . . 16

6. Stemmed Echinoderms (Pelmatozoans) . . . . . . . . . . . . 16

7. A modern Asterozoan ("Starfish") . . . . . . . . . . . . . . 17

8. Modern Echinoids ("Sea-urchins"), one with spines in position . . 18

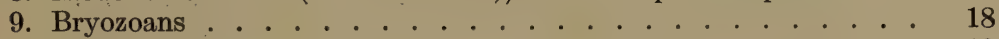

10. Brachiopod shells (fossil forms) . . . . . . . . . . . . . . . . 19

11. A modern Pelecypod . . . . . . . . . . . . . . . . . . . . . 19

12. Gastropods . . . . . . . . . . . . . . . . . . . . . . . 20

13. A modern chamber-shelled Cephalopod (Nautilus) showing the internal shell structure . . . . . . . . . . . . . 21

14. A modern Squid ... . . . . . . . . . . . . . . . . . . . . 21

15. Diagram to illustrate correlation of rock formations by continuity of deposit . . . . . . . . . . . . . . . .

16. Diagram to illustrate correlation of rock formations by similarity of sequence . . . . . . . . . . . . . . . . .

17. Diagram to illustrate correlation of rock formations by degree of change or structure . . . . . . . . . . . . . . . . 25

18. Diagram to illustrate the significance of unconformities . . . . . 27

19. A very symmetrical spiral nebula in Pisces (M. 74) . . . . . . . 37

20. Diagram to illustrate the formation of a spiral nebula . . . . . . 38

21. Archean (Grenville) sedimentary gneiss in the central Adirondacks. 43

22. Map showing the surface distribution of pre-Cambrian (Archeozoic and Proterozoic) rocks in North America . . . . . . . . . . .

23. Diagram showing the principal subdivisions of the Proterozoic and their relation to the Archeozoic in the Lake Superior district . .

24. A view in the Grand Canyon of Arizona (Shinumo quadrangle) exhibiting the relations of Archean, Algonkian and Paleozoic rocks to each other

25. Part of a pre-Cambrian (Huronian) Alga . . . . . . . . . . . .

26. Map showing the surface distribution (areas of outcrops) of Cambrian, and some very closely associated Lower Ordovician, strata in North America . . . . . . . . . . . . . . . . . .

27. Geologic section through northeastern Iowa, showing how character, thickness, and distribution of deeply buried rock formations can be determined by a comparison of well records 
FIGURE

28. Upper Cambrian (Potsdam) sandstone in the Ausable Chasm of northeastern New York

29. Paleogeographic map of North America during Lower (early) Cambrian time

30. Paleogeographic map of North America during late Middle and Upper (late) Cambrian time

31. Structure section in Saratoga County, New York, showing how Upper Cambrian strata overlap upon a hillock of pre-Cambrian rock (Grenville)

32. Calcareous Algæ, Cryptozoön proliferum, forming a reef in Upper Cambrian limestone near Saratoga Springs, New York .

Cambrian limestone near Saratoga Springs, New York . . . .

33. A Cambrian Sponge, Leptomitus zitteli . . . . . . . . . .

34. A Cambrian Jelly-fish, Brooksella alternata . . . . . . . . . .

35. A Cambrian Sponge or Coral, Archeocyathus rensselaericus . . .

36. Cambrian Brachiopods . . . . . . . . . . . .

37. A Cambrian Pelecypod (Fordilla troyensis) . . . . . . . . . .

38. Cambrian Gastropods . . . . . . . . . . . . .

39. Cambrian Trilobites, restored forms . . . . . . . . . . . . .

40. A Middle Cambrian Trilobite, Neolemus serratus, with well-preserved appendages

41. Map showing the surface distribution (areas of outcrops) of chiefly Middle and Upper Ordovician strata in North America

42. Generalized structure sections through various parts of New York State, showing the attitude and relations of the various great rock systems

43. The Trenton (mid-Ordovician) limestone at its type locality, Trenton Falls, New York

44. Geologic (columnar) section in eastern Tennessee, showing the predominance of limestone in the Lower and Middle Ordovician, and of shale and sandstone in the Upper Ordovician

45. Paleogeographic map of North America during Middle Ordovician

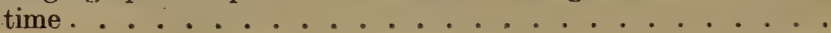

46. Structure section through a portion of the Highlands of the Hudson in southeastern New York

47. Sketch map showing the relations of land and water in Europe during Ordovician time

48. Ordovician Seaweeds, Callithamnopsis fructicosa

49. Ordovician Graptolites

50. Ordovician Echinoderms

51. Varous Ordonician Bryozoans on . . . . . . . . . . . 93

51. Various Ordovician Bryozoans on a slab of limestone . . . . . . 94

52. Ordovician Brachiopods . . . . . . . . . . . . . . 95

53. Ordovician Pelecypods . . . . . . . . . . . . . . . . . . . 96

54. Ordovician Gastropods . . . . . . . . . . . . . . . . . . . . . . 96

55. Ordovician Cephalopods . . . . . . . . . . . . . . . . . . . 97

56. An Orthoceras restored . . . . . . . . . . . . . . . . . 98

57. Bits of Ordovician sea-bottom . . . . . . . . . . . 100

58. Ordovician Trilobites . . . . . . . . . . . . . . . . . . . . . 101

59. Map showing the surface distribution (areas of outcrops) of Silurian strata in North America. 
60. Paleogeographic map of North America in the Silurian period . . . 109

61. Sketch map showing the relations of land and water in Europe during Silurian time

62. Silurian and Devonian Corals

63. Silurian Echinoderms

64. Silurian Trilobites

65. A Silurian Eurypterid, Eurypteris remipes, restored to show dorsal side

66. A Silurian Scorpion, Paleophonus cxledonicus

67. A bit of Silurian sea-bottom showing Crinoid, Bryozoan, Brachiopod, and Trilobite remains

68. Map showing surface distribution (areas of outcrops) of Devonian strata in North America

69. Paleogeographic map of North America during early Devonian time .

70. Paleogeographic map of North America during Middle Denovian time.

71. Upper Devonian shales along the Genesee River in western New York

72. Sketch map showing the general relations of land and water in Europe during the Devonian

73. A Devonian Asterozoan, Palexster eucharis, on a Pelecypod shell.

74. Devonian Brachiopods.

75. Devonian Pelecypods

76. Devonian Gastropods . . . . . . . . . . . . . . . . . . . 136

77. A Devonian Goniatite, Manticoceras patersoni . . . . . . . . . . 136

78. Devonian Trilobites . . . . . . . . . . . . . . . . . . 137

79. A very simple Devonian Vertebrate, Palesopondylus gunni . . . . 137

80. Devonian Ostracoderms . . . . . . . . . . . . . . . . . . . 138

81. A Paleozoic (early Mississippian) Selachian or Shark, Cladoselache fyleri

82. Devonian Fishes . . . . . . . . . . . . . . . . . . . . . 139

83. Structure of a Ganoid tooth . . . . . . . . . . . . . . . . . 140

84. Types of Fish tails . . . . . . . . . . . . . . . . . . . . . 141

85. Map showing the surface distribution (areas of outcrops) of Mississippian and Pennsylvanian strata in North America

86. Map showing the surface distribution (areas of outcrops) of Mississippian strata in eastern North America . . . . . . . .

87. Paleogeographic map of North America in Mississippian time . . .

88. Generalized section in Iowa, showing how the Pennsylvanian system $(C)$ rests unconformably upon the Mississippian $(M)$. . .

89. Sketch map showing the relations of land and water in Europe during Mississippian (Lower Carboniferous) time

90. Mississippian Cup-corals, Lonsdaleia canadense, forming a compact mass or colony

91. A Mississippian Blastoid head, Pentrimites elongatus

92. A Mississippian Crinoid head, Forbesiocrinus wortheni

93. Map showing the surface distribution (areas of outcrops) of Pennsylvanian rocks in eastern North America. 
FIGURE

94. Geologic structure section through one of the anthracite coal fields of eastern Pennsylvania

95. Geologic (columnar) section in western Pennsylvania showing the vertical distribution of coal beds (heavy black bands) and their relations to associated strata

96. Paleogeographic map of North America during Pennsylvanian time

97. Sketch map showing the relations of land and water in Europe during Pennsylvanian (Upper Carboniferous) time.

98. Lepidodendron bark $(a)$ and Sigillarian bark $(b)$, showing arrangement of leaf scars

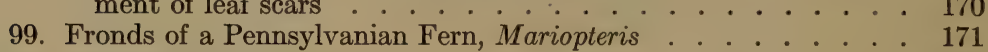

100. A Living Tree-fern

172

101. A Permo-Carboniferous landscape, showing some of the most conspicuous plants of the great Coal Age

102. A Cycadofilices or Seed-fern . . . . . . . . . . . . . . . 174

103. Cordaites restored . . . . . . . . . . . . . . . . 175

104. A Pennsylvanian Goniatite . . . . . . . . . . . . . . 175

105. Pennsylvanian Eucrustaceans . . . . . . . . . . . . . . 176

106. Pennsylvanian Arachnids . . . . . . . . . . . . . . . . . . 176

107. A Pennsylvanian Insect, Corydaloides scudderi (Brogniart) . . . . 177

108. A Pennsylvanian Amphibian (Labyrinthodont), Eryops . . . . . 178

109. Transverse section of a Labyrinthodont tooth . . . . . . . . 179

110. Late Permian or early Triassic "Red Beds" in Red Butte, eastern Wyoming .

111. Paleogeographic map of North America during latest Paleozoic (Permian) time

112. Highly generalized structure sections across the Appalachian Mountains and adjoining districts to illustrate certain important features in the history of the region . . . ......

113. Structure section through a portion of the Appalachian Mountains of western Virginia showing the typical deformation of Paleozoic strata

114. Sketch map showing the relations of land and water in Europe during later Permian time.

115. A Permian chambered Cephalopod, Waagenoceras cumminsi (White), showing highly folded suture (partition) lines . . . .

116. A Permian Reptile, Pareiasaurus serrideus . . . . . . . . . .

117. A Permian Reptile (Pelycosaurian), Naosaurus claviger . . . . .

118. Highly generalized paleogeographic map of North America during the Paleozoic era . . . . . . . . . . . . .

119. Map showing the surface distribution (areas of outcrops) of Triassic and Jurassic strata in North America .

120. Structure section across the Triassic basin of the Connecticut Valley near Northampton, Mass., showing the tilted and faulted character of the rocks

121. Tilted and faulted Triassic sandstone in the Connecticut Valley near Northampton, Mass.

122. Columnar (geologic) section showing ages, character and thickness of strata in northeastern Wyoming . 
123. Paleogeographic map of North America during Triassic time . . . 207

124. The steep western front of the Holyoke Range as seen from Easthampton, Massachusetts

125. Sketch map showing the relation of land and water in Europe in the early Triassic

126. Parts of a Triassic Conifer, Voltzia heterophylla

127. A Triassic Ceratite, Ceratites trojanus, with part of shell removed to show suture structure

128. A Triassic long-tailed Macruran Decaped, Pemphix Sueurii . . .

129. A Ganoid, Catopterus redfieldi, from the Triassic sandstone of Connecticut

130. Tracks of a small two-legged Dinosaur on a slab of Triassic sandstone from the Connecticut Valley . . . . . . . . . . .

131. Tracks of a large two-legged Dinosaur on Triassic sandstone from the Connecticut Valley, showing how both feet slid some distance in the soft material after which the creature suddenly sat down, the end of the backbone having left a distinct impression.

132. Structure section through a portion of the central Sierra Nevada Mountains, exhibiting the highly folded character of the Jurassic and late Paleozoic rocks

133. Paleogeographic map of North America during late Jurassic time

134. Sketch map showing the relations of land and water in Europe during late Jurassic time

135. A living Cycad, Dioon edule, of Mexico . . . . . . . . . . . . 226

136. A fossil Cycad tree trunk, Cycadeoidea pulcherrima . . . . . . . 227

137. Jurassic Cycad leaves . . . . . . . . . . . . . . . . 228

138. A Jurassic Crinoid, Pentacrinus fossilis . . . . . . . . . . . . .

139. A regular or radially symmetrical Echinoid, Pseudodiadema texanum, of Lower Cretaceous age . . . . . . . . . . . .

140. An irregular or bilaterally symmetrical Echinoid, Hemiaster texanus, of Cretaceous age .

229

141. An Ammonite with part of shell removed to show the very complicated (frilled) sutures . . . . . . . . . . . . 230

142. Internal shell of a Belemnite, restored . . . . . . . . . . . . . 231

143. A Jurassic Belemnite, Belemnoteuthis antiqua . . . . . . . . . 231

144. A Jurassic long-tailed Decapod (Macruran) . . . . . . . . . . 232

145. Three stages in the life history of a modern Crab . . . . . . . 233

146. A primitive or ancestral Jurassic Teleost, Hypsocormus insignis $\quad . \quad 233$

147. The earliest known Bird, Archeopteryx macrura, from the Jurassic.

148. Map showing the surface distribution (areas of outcrops) of Lower Cretaceous strata in North America . . . . . . . . . . .

149. Map showing the surface distribution (areas of outcrops) of Upper Cretaceous strata in North America . . . . . . . . .

150. Paleogeographic map of North America during Lower Cretaceous time

234

151. Paleogeographic map of North America during Upper Cretaceous time

152. Typical exposure of Upper Cretaceous (Selma) chalk in Alabama. 
153. Structure section across Nebraska from the Rocky Mountains to Omaha . . . . . . . . . .

154. Structure section in the Rocky Mountains of western Montana showing moderate folding of Cretaceous and older rocks .

155. Diagrammatic section through the Atlantic slope at about the latitude of northern New Jersey, showing the structures and relations of the various physiographic provinces as they now exist.

156. Sketch map showing the relations of land and water in Europe during Lower Cretaceous time.

157. Sketch map showing the relations of land and water in Europe during early Upper Cretaceous time

158. Cretaceous Foraminifers, greatly enlarged

159. A Cretaceous Brachiopod, Terebratula harlani

160. Typical Cretaceous Pelecypods

161. Typical Cretaceous Ammonites

162. A Cretaceous Teleost Fish, Osmeroides Lewesiensis, restored

163. A Cretaceous toothed Bird, Ichthyornis victor

164. A group of Ichthyosaurs, Ichthyosaurus quadricissus, of the Enaliosaur division of Mesozoic Reptiles

165. A well-preserved Ichthyosaur found in Germany

166. A restored Plesiosaur, Plesiosaurus dolichodeirus, of the Enaliosaur division of Mesozoic Reptiles .

167. A Mosasaur, Tylosaurus dyspelor, of the Enaliosaur division of Mesozoic Reptiles . . . . . . . . . . . .

168. The hugest of all known Dinosaurs, a Sauropod, Diplodocus . . .

169. A Stegosaur, an armored Dinosaur . . . . . . .

170. A Triceratops, Triceratops prorsus, of the Dinosaur division of Mesozoic Reptiles

171. Theropods, Allosaurus agilis, of the Dinosaur division of Mesozoic Reptiles

172. A small two-legged Dinosaur, Podokesaurus holyokensis from the Triassic of Massachusetts .

173. An Ornithopod, Claosaurus annectens, of the Dinosaur division of Mesozoic Reptiles

174. A Rhamphorhynchus of the Pterosaur division of Mesozoic Reptiles

175. Map showing the surface distribution (areas of outcrops) of Lower Tertiary (Eocene and Oligocene) strata in North America.

176. Map showing the surface distribution (area of outcrops) of Upper Tertiary (Miocene and Pliocene) strata in North America . . .

177. Eocene sandstone resting by sharp contact upon Upper Cretaceous white chalk in Alabama . . . . . . . . . . .

178. Eocene-Oligocene strata as seen in the Wind River Basin of

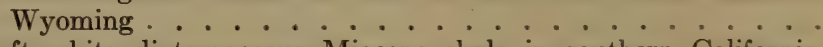

179. Soft white diatomaceous Miocene shale in southern California. 180. Paleogeographic map of North America during Lower Tertiary (Eocene-Oligocene) time . . . . . . . . . .

181. Paleogeographic map of North America during Miocene time .

182. "Toadstool Park": a view in the Bad Lands of western Nebraska. 266 
183. Structure section across a portion of the Coast Range Mountains of central-western California, showing the character of the Tertiary folding and faulting

184. Map showing the surface distribution (areas of outcrops) of Tertiary and later volcanic rocks in North America

185. Structure section in central Washington showing sheets of Miocene lava piled up to a thickness of fully a mile

186. Mount Lassen in northern California in eruption August 22, 1914.

187. Sketch map showing the relations of land and water in Europe during Middle Eocene time . . . . . . . . . . . . . .

188. Sketch map showing the relations of land and water in Europe during Middle Pliocene time

189. Sketch map showing the relations of land and water in Europe during Middle Pliocene time. . . . . . . . . . . . .

190. Diatoms from diatomaceous earth of Tertiary age . . . . .

191. A well-preserved fossil Palm, Thrimax eocenica, from the Eocene of Georgia .

192. An Eocene Foraminifer, Nummulina levigata.

312

313

193. Large Oyster shells, Ostrea georgiana, in Eocene strata of Georgia.

194. Tertiary Pelecypods

314

195. Tertiary Gastropods

315

196. A nearly perfect fossil Teleost Fish, Diplomystus densatus, from the Eocene of Wyoming . . . . . . . . . . . .

197. A Shark's tooth from the Eocene of the Gulf Coastal Plain . . .

198. Head of an Eocene Bird, Odontopteryx toliapicus, showing

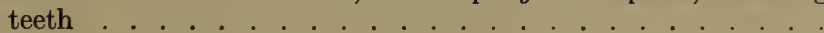

199. Sketches to illustrate increase in size of brains of Mammals from the Eocene to the present .

200. A nearly perfect skeleton of the Eocene Phenacodus primaevus .

201. Chart to illustrate the evolution of the Horse family . . . . . .

202. Primitive or ancestral Horses, Eohippus, of the Eocene . . . . by existing forms

204. $a$, Mastodon tooth; $b$, Mammoth tooth

205. a, Mastodon tooth; b, Mammoth tooth . . . . . . . . .

205. A Mammoth Elephant, Elephas primigenius

322

323

206. Chart to illustrate the evolution of the Elephants . . . . . . . 321

207. Skeleton of an Eocene Creodont, Patriofelis . . . . . . .

208. One of the earliest Monkeys, Mesopithecus pentelici, from the Miocene of Europe . . . . . . . . . . . .

209. Map showing the areas occupied by ice in North America at the time of maximum glaciation .

210. Diagram to show how successive glacial drift sheets are distinguished

211. Smoothed and striated (glaciated) limestone.

212. Structure section across the Black River Valley of northern New York, to illustrate the effect of ice erosion and glacial lake disposition

213. Typical drumlins (side view) in western New York

214. A group of kames in New York state 
FIGURE

215. First stage in the history of the Great Lakes, when all the rest of the lake basins were still buried under the ice . . . . . . . .

216. Lake Whittlesey stage of the Great Lakes history, when the eastern and western ice-margin lakes combined with outlet past Chicago.

217. Glacial Lake Warren

218. Glacial Lakes Duluth, Chicago and Lundy

219. The Algonquin-Iroquois stage of the Great Lakes, with outlet through the Mohawk-Hudson Valleys of New York

220. The Nipissing Great Lakes and their correlatives .

221. Sketch map of central New York, showing the relation of the preGlacial drainage to that of the present

222. Sketch map of the southeastern Adirondack region, showing the relation of the pre-Glacial drainage to that of the present

223. Sketch map of the Niagara River gorge . . . . . . . . . . . .

224. Pre-Glacial drainage of the Upper Ohio River Basin

225. Pre-Glacial drainage (dotted lines) of a part of northwestern Illinois ... . . . . . . . . . . . .

226. Diagram showing effect of Precession . . . . . . . . .

227. Map showing extent of the extinct Lakes Bonneville $(a)$ and Lahontan $(b)$ in the western United States . . . . . . . .

228. Map showing the extent of ice in Europe at the time of maximum glaciation .

229. A great Ground-sloth, Megatherium americanum

230. Great armored Glyptodonts, Doedicurus clavicaudatus and Glyptodon clavipes

231. Table to show the principal geologic stages in the history of

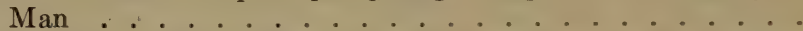

232. Comparison of skull profiles of lowest types of Men and highest Apes ... . . . . . . . . . . . . .

233. Restoration of the head of Pithecanthropus erectus . . . . . . .

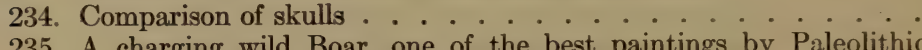

235. A charging wild Boar, one of the best paintings by Paleolithic Man in the cave at Altimira, Spain

236. The "Procession of Mammoths"; a painting by Paleolithic Man in a cave at Font-de-Gaume in west-central France . . . . .

237. Line cut copy of a Paleolithic painting in the cave at Cogul, Spain.

238. Map of the United States showing the principal physiographic provinces frequently referred to in the text 


\section{HISTORICAL GEOLOGY}

\section{WITH SPECIAL REFERENCE TO NORTH AMERICA}

\section{CHAPTER I}

\section{GENERAL PRINCIPLES}

\section{What Historical Geology Teaches}

Historical geology deals with the evolution of earth structures and organisms. Its object is to arrange the events of earth history in the regular order of their occurrence. The records of these events are preserved in the rocks of the crust of the earth, the layers (strata) of which have been likened to the leaves of a great book. Many times the pages of this vast "nature-book" contain remarkable records and illustrations, while at other times they are comparatively barren. In order that the reader may, at the outset, form some general idea of the scope and character of the subject, the following summary of the more important conclusions derived from the study of earth history is here presented.

Inorganic Inferences. - 1. The age of the earth must be measured by at least tens of millions of years. One great mountain range after another has been built up and then worn away by the ordinary processes of erosion. Many thousands of feet (in thickness) of strata have been accumulated by the deposition of sediments slowly derived by the removal of thousands of feet of materials from the lands. Such facts force us to the inference of a vast antiquity for the earth.

2. The physical geography of the earth has been notably different in earlier geological time from that of the present. For example, many millions of years ago (during the Ordovician period) an interior sea spread over much of what are now the Mississippi Valley and the Appalachian Mountain regions, as well as regions still farther westward. 
3. All, or nearly all, of the surface of the lithosphere has at some time, or times, been covered by sea water. Stratified rocks of marine origin now constitute fully five-sixths of the exposed surface of the lithosphere, and it is certain that from most, at least, of the remaining surface such stratified rocks have been removed by erosion.

4. The continents were roughly outlined in early geologic time. This is proved by the facts that even the oldest known rocks contain much land-derived sediment of comparatively shallow water origin and that there are no deposits which show that great oceanic abysses ever extended across what are now continental areas. Much evidence points to a very early development of oceanic basins and continental masses which have occupied essentially the same positions to the present time.

5. During geologic time there has been a progressive tendency for the continental masses to become higher and broader. There have been many oscillations of level, accompanied by transgressions or retrogressions of the sea, but the processes of elevation (relatively speaking) have been predominant, while, at the same time, the sea bottoms have become narrower and deeper. Just prior to the last Ice age, and only a short time ago, geologically considered, North America was even higher and broader than at present, for then the shallow marginal sea bottoms (continental shelves) were also dry land.

Organic Inferences. ${ }^{1}-1$. Organisms inhabited the earth many millions of years ago. All but possibly the very oldest known series of rocks contain organic remains.

2. Throughout the known history of the earth organisms have continuously changed. Each epoch of earth history or series of strata has its characteristic assemblage of animals and plants. The more ancient strata contain no species like those living today, the latter being found only in rocks of comparatively (geologically) recent date. Further, "the organisms which inhabited the earth during any geological epoch were descended from organisms of preceding epochs" (W. H. Norton).

3. The change in organisms has been progressive. In early geological time the animals and plants were comparatively simple and low in the scale of organization and structure, and through the

1 These statements of organic inferences follow, in the main, Norton's Elements of Geology. 
succeeding epochs higher and more complex types were gradually developed until the highly organized forms of the present time, culminating in man, were produced. It should be remembered, however, that not all change in organisms has been progressive, but rather only a single thread.

4. No species once extinct has ever reappeared. Numerous important species have lived through many epochs of geologic time, while others have had only brief existence. In no case, however, has a species once become extinct been known to reappear.

5. While higher and higher types have been developed during geologic time, many of the earlier and simpler types have persisted. Thus Foraminifers, which are exceedingly simple, single-celled animals, have lived in the sea from early geologic time to the present.

6. The broader or larger biological groups of organisms have persisted longer than the smaller. No subkingdom has ever become extinct, though species frequently have not outlived even a single geological epoch. As a rule, genera have survived longer than species, orders longer than genera, etc.

7. The life history of the individual tends to recapitulate the evolution or history of the race. A Frog, which is a typical Amphibian, shows certain fish-like characters during its embryonic development, as, for example, the presence of gills and tail. Again, the modern Crab, which is a Crustacean, shows a gradual shortening of the tail portion during its embryonic development. The earliest known Crustaceans were practically all long tailed.

\section{Fossils and their Significance}

Traces or remains of plants and animals preserved in the rocks are known as fossils. The term originally referred to anything dug out of the earth, whether organic or inorganic, but for many years it has been strictly applied to organisms. Paleontology, which literally means "science of ancient life," deals primarily with fossils.

Darwin thought that the stratified rocks contain only a very incomplete record of the geologic history of life. Though many thousands of species of fossils have been described from rocks of all ages except the very oldest, and more are constantly being brought 
to light, it must be evident that, even where conditions of fossilization were most favorable, only a small part of the life of any period is represented by its fossils. Comparatively few remains of organisms now inhabiting the earth are being deposited under conditions favorable for their preservation as fossils. So it has been throughout the long periods of earth history, though the fossils in the rocks known and unknown are a fair average of the groups of organisms to which they belong. In spite of such imperfections in the life record, it is, nevertheless, remarkable that so vast a number of fossils are embedded in the rocks, and from these we are enabled to draw many fundamental conclusions regarding the history of life on our planet.

Preservation of fossils. - 1. Preservation of the entire organism by freezing. Fossilization by this method is rare, though remarkable examples are afforded by extinct species of the Mammoths and Rhinoceroses, the bodies of which, with flesh, hide, and hair intact, have been found in frozen soils in Siberia.

2. Preservation of the entire organism by natural embalmment. Fine examples are the perfectly preserved Insects in the famous amber of the Baltic Sea region. This amber is a hardened resin, the Insects having been caught in it while it was still soft and exuding from the trees.

3. Preservation of only the hard parts of the organisms. This is a very common kind of fossilization in which the soft parts have disappeared by decomposition, while the hard parts, such as bones, shells, etc., remain. Fossils of this kind are abundant in rocks of later geological time, though original shell material is frequently found, even in very ancient rocks.

4. Preservation of carbon only (carbonization). This is particularly true of plants where, as a result of slow chemical change or decomposition, the hydrogen and oxygen mostly disappear, leaving much of the carbon, but with the original structure often beautifully preserved. Many excellent examples are furnished by the fossil plants of the great coal (Pennsylvanian) age.

5. Preservation of original form only (casts and molds). Fossils of this class, which are very abundant, show none of the original material, but only the shape or form has been preserved. When a fossil becomes embedded in sediment, which hardens around the entire organism or any part of it, and the organism then decomposes or dissolves away, a cavity only is left and this is called a 
mould. A cast may be formed by filling a mould with some substance such as sediment or mineral matter carried by underground water, or by filling a hollow organism like a shell with some solid substance. The cast reproduces the internal form of the shell or organism. Frequently original shell, mould, and cast may be seen in a single specimen, while more commonly the original shell has been dissolved away. Only in rare instances have casts of wholly soft animals, or the soft parts of other animals, such as the Jellyfishes and Cuttle-fishes, been found in ancient rocks.

6. Preservation of original form and structure (petrifaction). Here again we have a common kind of fossilization. When a plant or hard part of an animal has been replaced, particle by particle, by mineral matter, we have what is called petrifaction. Often organic matter, such as wood, or inorganic matter, such as a carbonate-of-lime shell, have been so perfectly replaced that the original minute structures are preserved as in life. Conditions favorable for the petrifaction of flesh seem never to have obtained.

7. Preservation of tracks of animals. Footprints of animals, made in moderately soft mud or sandy mud which soon hardens and becomes covered with more sediment, are especially favorable for preservation. Thousands of examples of tracks of great extinct Reptiles have been found in the red sandstone of the Connecticut River Valley alone. Tracks or trails of Clams or similar animals, and burrows of Worms, are also not uncommon in the ancient rocks of the earth.

Rocks in which Fossils occur.-1. Land deposits. Old soils sometimes contain bones or other organic remains. Peat-bogs are especially favorable for the preservation of fossils, as, for example, the wealth of plants directly associated with the resulting coal seams; remains of animals, such as Frogs, Snakes, etc., which inhabited the swamp or bog; and the bones of other animals which wandered in and became entombed. Cave deposits often cover animal remains, many bones of extinct animals, even including prehistoric Man and the things he used, having been found in such deposits. Wind-blown deposits, like dune-sand, loess, and desert deposits, may contain plant or animal remains. Interglacial deposits sometimes contain fossils, as, for example, the layers of vegetable matter with occasional bones of animals found in the interglacial deposits of the upper Mississippi Valley. Lavas 
rarely contain fossils, but volcanic ash deposited in water may be rich in organic remains, this being especially true of certain portions of the western interior of the United States.

2. River and lake deposits. River deposits often carry river forms themselves, or land forms which fell into the stream and became entombed in its deposits. Lakes offer very favorable conditions for fossilization. "Surrounding trees drop their leaves, flowers, and fruit upon the mud-flats, Insects fall into the quiet waters, while quadrupeds are mired in mud or quick-sand and soon buried out of sight. Flooded streams bring in quantities of vegetable debris, together with the carcasses of land animals drowned by the sudden rise of the flood" (W. B. Scott).

3. Marine deposits. By far the largest number and variety of organic remains are found in rocks of marine origin, because on the sea bottom the conditions for their preservation have been most favorable. The distribution of fossils in strata of marine origin is, however, exceedingly irregular, ranging from those strata which are almost entirely made up of fossils to others which are nearly barren. Longshore deposits are usually not rich in fossils, because of the grinding action of the waves, while deposits formed in the quiet waters off shore often contain vast numbers of fossils. Many conditions have produced great diversity in the distribution of marine organisms throughout known geologic time: temperature, depth of water, supply of food, degree of salinity, nature of the sea bottom, clearness of the water, etc. The oldest fossiliferous strata seem to contain practically no land forms, probably because land forms were but slightly, if at all, developed so early. In marine strata of more recent date terrestrial organisms are often found, especially in delta deposits, where such remains have been swept into the sea at the mouths of rivers.

Significance of Fossils. - It would be difficult to overestimate the value of fossils in the study of earth history. They furnish most important evidence regarding earth chronology, ancient geographic and climatic conditions, as well as a basis for a proper understanding of the evolution relations and distribution of modern organisms. Leonardo da Vinci (1452-1519), the famous artist, architect, and engineer, while engaged in canal construction in northern Italy, saw many fossils embedded in the rocks. He concluded that these organisms had actually lived in marine water which once spread over the region. William Smith (1769-1839) 
of England was, however, the first to recognize the fundamental significance of fossils for determining the relative ages of stratified rocks. His announcements, based upon much careful detailed work, were made in the latter part of the eighteenth century and the early part of the nineteenth century. He has been called by the English the "Father of Historical Geology."

1. Earth chronology. In any given region the best way to learn the relative ages of the stratified rocks is to determine their "order of superposition," the general assumption being that the older strata underlie the younger because the underlying sediments must have been first deposited. While this is a fundamental method, it is very limited in its application when used alone in regard to the construction of the whole earth's history. The succession of strata seen in any one locality or region represents only a small part of the earth's entire series and this, taken in connection with the fact that the lithologic character of strata of the same age frequently changes, makes it clear that "order of superposition" alone will not suffice to determine the relative ages of sedimentary rocks on a single continent or even large portion of a continent, not to mention the utter inadequacy of the method when applied to comparing the relative ages of strata of different continents.

"Order of superposition," however, when used in connection with the fossil content of the strata, furnishes us with the method of determining earth chronology. "Life, since its introduction on the globe, has gone on advancing, diversifying, and continually rising to higher and higher planes ... . Accepting, then, the undoubted fact of the universal change in the character of the organic beings which have successively lived upon the earth, it follows that rocks which have been formed in widely separated periods of time will contain markedly different fossils, while those which are laid down more or less contemporaneously will have similar fossils. This principle enables us to compare and correlate rocks from all the continents and, in a general way, to arrange the events of the earth's history in chronological order . . . A geological chronology is constructed by carefully determining, first of all, the order of superposition of the stratified rocks, and next by learning the fossils characteristic of each group of strata ... The order of succession among the fossils is determined from the order of superposition of the strata in which they occur. When that succession 
has been thus established, it may be employed as a general standard." 1

The student should bear in mind that strata cannot be determined as precisely contemporaneous, because geologic time has been very long and the evolution of organisms very slow, and almost exactly similar fossils may be expected in strata showing an age difference of at least some thousands of years. Also, at any given ancient time of earth history, as now, organisms were not the same in all parts of the world, so that rocks formed at exactly the same time in different parts of the world always show certain differences in fossil content. As compared with the vast length of geologic time, however, practical contemporaneity of the strata can usually be determined.

An excellent example of well-marked differences in the distribution of organisms over a comparatively limited area during one of the ancient epochs of earth history has been worked out by J. M. Clarke. During the Portage epoch of the Devonian ${ }^{2}$ period an arm of the sea or gulf extended over much of the southern part of New York state, and "the distinctions in the life provinces over the north shore of this ancient gulf are marked with wonderful clearness. No such striking illustration of distinct faunal associations in an area of so slight extent is elsewhere afforded by the rocks of New York." 3

For the determination of geologic chronology, certain organisms are more valuable than others, the best being those which have had wide geographic distribution and short geologic range. For example marine organisms, which live near the ocean surface (so-called pelagic forms) and are easily distributed over wide areas, while, at the same time, the species are extant for only a comparatively short time, are the best chronologic indicators. The Graptolites of the early Paleozoic era furnish excellent illustrations.

2. Past physical geography conditions. Typical stratified rock occupying any region proves the former presence of water over that region. By the study of the fossils we can further usually tell whether the water was ocean or lake, fresh or salt, open sea or arm

${ }^{1}$ W. B. Scott: An Introduction to Geology, 2nd Edition, pp. 521-522 and 525 .

2 The subdivisions of geologic time are tabulated near the end of chapter 2.

${ }^{3}$ J. M. Clarke: N. Y. State Mus. Memoir No. 6, 1903, p. 209. 
of the sea, deep or shallow, close to or far from land, etc. Lithologic character alone may give some idea as to the depth of water and proximity to land where a given stratum was deposited, but the presence of considerable numbers of terrestrial organisms gives important additional data. Thick limestones filled with fossil Corals point to long-continued conditions of clear sea water. Tree stumps, on the other hand, with roots still in their original position, plainly prove a former land surface. By means of fossils, many land areas have been proved to have existed as effective barriers to migrations of marine organisms. Certain lands now separated by water may be shown to have been formerly connected, as was true of Alaska and Siberia, by a land connection across Bering Strait. Also the fossils found in the rocks of the Isthmus of Panama show that North and South America were there connected at a comparatively recent time in earth history.

3. Past climatic conditions. Some strata afford an idea of the climatic conditions under which they were laid down. Thus salt and gypsum beds, more or less associated with certain red sandstones or shales, indicate an arid climate at the time of their formation. But the study of fossils is much more fruitful in this connection. Certain strata in southern England contain fossil Palms, Gourds, Crocodiles, etc., thus proving a subtropical climate for the time of their origin. Other strata, representing a later date in southern England, carry remains of Arctic animals and hence indicate a cold climate for that time. The finding of Walrus remains in New Jersey and Musk-ox remains in Arkansas indicate a former colder climate for those regions. Again, many fossil Palms, Ferns, and other temperate to subtropical plants, as well as animals, clearly point to former warmer climate in those same regions.

Much strong evidence for climatic conditions over various portions of the earth during different geologic periods has been furnished by the study of true marine organisms. Certain kinds of Corals live only in shallow tropical seas, and so, if in any region we find a bed of limestone rich in Corals of this kind, it is to be inferred that this limestone was formed in warm, shallow sea water. Such coral limestones are known even in the interior of North America.

In deducing climatic inferences, as above explained, certain care must be exercised, because we are not justified in assuming that 
because a given species now lives under warm climatic conditions, every species of the same genus has lived under similar conditions. When, however, we are dealing with species still living, or in older rocks, with whole groups of organisms pointing to certain climatic conditions, we are reasonably safe in our inferences.

4. Relations and distribution of modern organisms. It is evident that, if we are to properly understand the present-day relations and distribution of organisms, we must learn about their ancestry and history, because all modern plants and animals have directly descended from those which lived in earlier geologic epochs. In many cases existing plants or animals, notably different in structure, can be traced back to a common ancestry. Again, certain peculiarities in the distribution of some of the present-day animals are readily explained in the light of their geologic ancestry and habitats. A good example is Australia, where practically all of the present-day Mammals (barring those introduced by Man) are of very simple types, that is, non-Placentals such as the Kangaroo, Spiny Ant-eater, etc., found only in and close to Australia, and which are clearly much more like the Mammals of distinctly earlier geologic time than like typical Mammals of the present day. The explanation is that Australia was separated from Eurasia before the higher (Placental) Mammals had been evolved, and that the very different, or probably much less severe, struggle for existence in isolated Australia has not been favorable for the evolution of Placentals as was the case elsewhere.

\section{Outline Classifications of Animals and Plants}

Since a knowledge of the classifications of animals and plants and the principal characteristics of the more important groups of organisms is a fundamental consideration in the study of the life of each period, and in understanding the bearings of these life records upon the great doctrine of organic evolution, outline classifications of plants and animals, with simple explanations, are here given. The classifications are necessarily very brief, and no great degree of biologic refinement is intended. Rather the purpose is to have a convenient arrangement, essentially in biologic order, of the principal groups of organisms to form a simple basis for the discussion of the life of each period of geologic history as presented in this text-book. 
Organisms are divided into many groups, such as kingdoms (e.g. plant and animal), subkingdoms, branches, classes, orders, genera, and species. A species is "the smallest group of plants or animals having certain characters in common that make them different from all other plants or animals" (G. W. Hunter). Species are grouped together into larger subdivisions called genera (singular "genus"), etc. The scientific name of an organism generally consists of two words - the first signifying the genus and the second the species, as, for instance, "Archeopteryx macroura," which literally means "primitive winged creature with a long tail," and is the name of the earth's first known Bird.

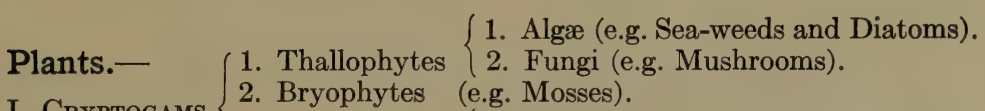

I. Cryptogams $\begin{cases}\text { 2. Bryophytes (e.g. Mosses). } & \text { 1. Lycopods (e.g. Club-mosses). }\end{cases}$

3. Pteridophytes $\{$ 2. Equisetæ (e.g. Horse-tails).

3. Filices (e.g. Ferns).

(Cycadofilices, e.g. Seed-ferns).

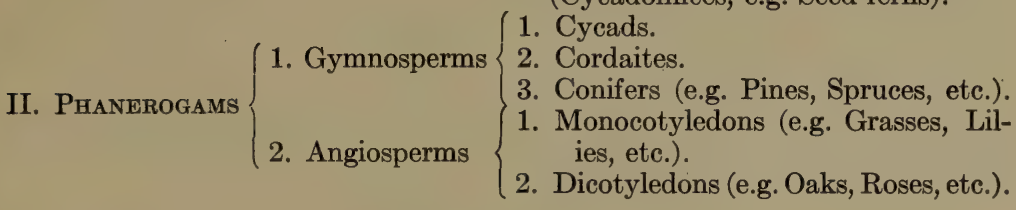

I. The Cryptogams comprise all of the flowerless and seedless plants, the reproductive organs being single cells called spores.

1. Thallophytes show "no definite axis of upward growth, and no distinction of root, stem, and leaf. They all consist entirely of cellular tissue, being entirely destitute of wood" (J. D. Dana). In general there are two groups of Thallophytes - Algæ and Fungi - the former containing chlorophyl and able to live upon inorganic substances, while the latter are without chlorophyl and live upon organic matter.

2. Bryophytes are like Thallophytes in being woodless, but they develop a sort of axis of upward growth and possess leafy stems.

3. Pteridophytes (Fig. 101) comprise the highest types of non-flowering plants, and these have a clear distinction of root, leaf, and stem, the stem possessing woody fibres. These plants have been much more favorable for fossilization than most of the foregoing, and they assume considerable importance in the fossil 
forests, especially of the great Coal (Pennsylvanian) age. (1) Lycopods usually have branching stems upon which are crowded numerous small, single-nerved, needle-like leaves. Modern representatives are the small "Ground-pines" or "Club-mosses" so familiar as Christmas decorations. (2) Equisetæ have erect growth, hollow or pithy segmented stems, and leaves arranged in whorls around the stems. (Fig. 101.) Modern representatives are the "Horse-tails," which are rush-like plants often seen along our streams. Both Lycopods and Equisetæ grew to be large trees during the great Coal (Pennsylvanian) age. (3) Filices or Ferns of temperate climates usually have fronds springing from a buried stem, while tropical forms may have fronds arranged around the summit of tree-like trunks.

Cycadofilices are fern-like plants (Fig. 102) which have been recently recognized as a group seemingly intermediate between the highest Cryptogams (i.e. Filices) and the lowest Phanerogams (i.e. Cycads). They possess seeds but not true flowers, and show certain other characters intermediate between Ferns and Cycads. These plants are all extinct, but from the fossil and evolution standpoints they are important.

II. Phanerogams comprise the seed-bearing, flowering plants whose reproductive organs are stamens and pistils and whose seeds contain embryo plants.

1. Gymnosperms or the so-called "naked seed" plants include all those which do not have their seeds inclosed in a case or ovary. They possess very simple flowers, and their mode of growth is exogenous. $^{1}$ (1) Cycads are palm-like in appearance (Fig. 135), certain of them being erroneously called "Sago Palms." True Palms, however, are Angiosperms with endogenous growth. In some ways Cycads also resemble the Ferns. Though now uncommon, the Cycads are of considerable geological importance. (2) Cordaites (Fig. 103) are now entirely extinct, but during the latter part of the Paleozoic era they grew extensively as tall, slender trees "with trunks rising to great height before branching, and bearing at the top a dense crown, composed of branches of various orders, on which simple leaves of large size were produced in abun-

1 Exogenous plants grow from without; have distinct bark, wood, and pith; and show concentric rings of growth, a new ring usually being added each year. Endogenous plants grow from within and have neither pith nor concentric rings of growth. 
dance" (D. H. Scott). (3) Conifers include the familiar Pines, Spruces, etc., all of which have dense, cone-like clusters of very simple flowers.

2. Angiosperms all have their seeds enclosed in a case or ovary, and have more highly developed, typical flowers as well as greater complexity than the Gymnosperms. (1) Monocotyledons, such as the familiar Palms, Grasses, Lilies, etc., produce only a single leaf from the germinating seed, are endogenous, and usually have parallel-veined, simple leaves. (2) Dicotyledons, such as Oaks, Roses, and many other familiar plants, produce two leaves from the embryo, are exogenous, and usually have net-veined leaves.

\section{Animals. ${ }^{1}$}

\section{Sub-kingdoms}

I. Protozonns.

II. Porifers (e.g. Sponges).

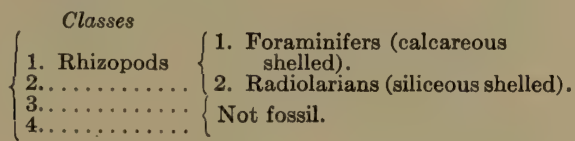

1. Hydrozoans (e.g. Jelly-fishes, Graptolites).

2. Anthozoans (e.g. Corals).

III. Coelenterates.

1. Cystoids (Bladder-like forms).

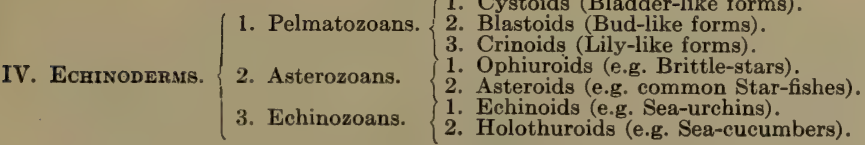

V. Vermes (e.g. Worms), Not important as fossils.

VI. Molluscoids.

VII. MoLLusKs.

VIII. ARthropods.

IX. Vertebrates.
\{1. Bryozoans (e.g. Sea-mosses).

2. Brachiopods (e.g. Lamp-shells).

1. Pelecypods (e.g. Oysters, Clams).

$3 . \ldots \ldots \ldots \ldots \ldots$, Not common as fossils.

4. Gastropods (e.g. Snails).

5. Cephalopods $\left\{\begin{array}{c}\text { 1. Tetrabranchs (e.g. Ammonites, } \\ \text { Nautilus). Dibranchs (e.g. Squids, Cuttle- } \\ \text { fishes). }\end{array}\right.$

(1. Merostomes (e.g. Horse-shoe

1. Crustaceans. $\{$ 2. Trilobites.

3. Eucrustaceans (e.g. Crabs, Lobsters).

2. Arachnids (e.g. Spiders, Scorpions, Eurypterids).

3. Myriapods (e.g. Centipedes).

4. Insects (e.g. Grasshoppers, Flies).

1. Ostracoderms (e.g. Armor-fishes).

2. Fishes.

3. Amphibians (e.g. Frogs, Salamanders).

4. Reptiles (Lizards, Snakes).

5. Birds.

6. Mammals (e.g. Dog, Man).

1 This classification is after Zittel with certain modifications and omissions. 


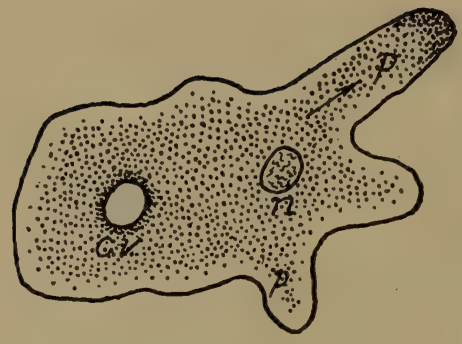

Fig. 1

A Protozoan (Amœba) without a shell. Greatly enlarged. (From Shimer's "Introduction to the Study of Fossils," courtesy of The Macmillan Company.)

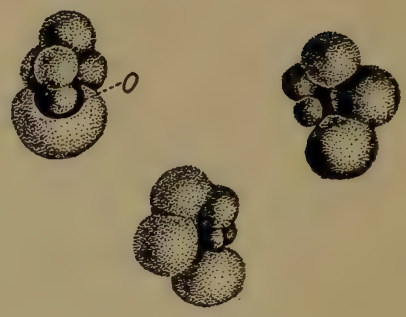

Fig. 2

Shelled Protozoans (Foraminifers). (From Shimer's "Introduction to the Study of Fossils," courtesy of The Macmillan Company.)

I. Protozonss are the simplest of all animals. They consist of single cells of protoplasm and are without distinct organs. Rhizopods are the only Protozoans which are encased in shells, the

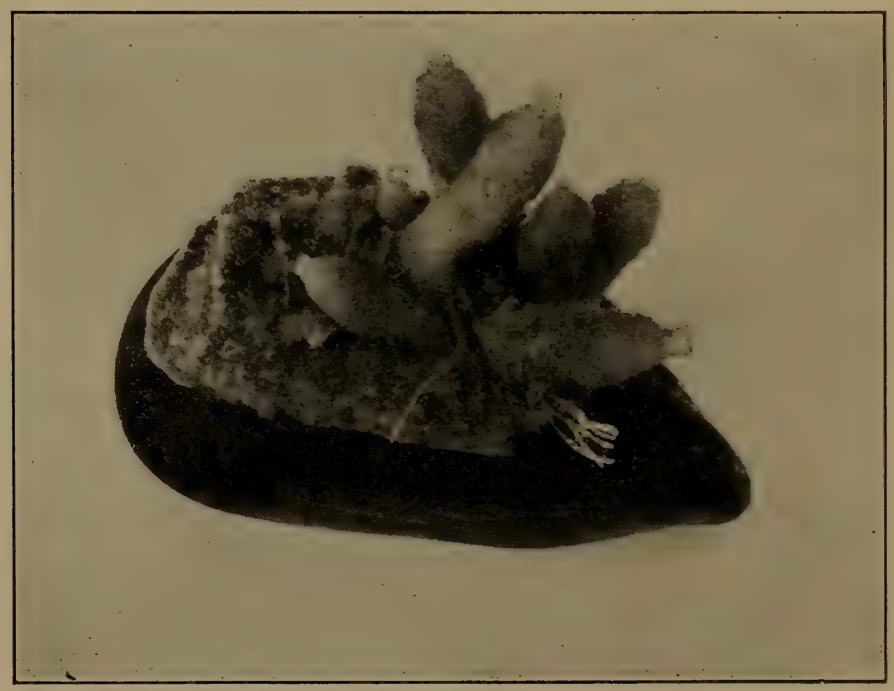

Fig. 3

Sponges on a shell. (Courtesy of the American Museum of Natural History.) 
Foraminifers having carbonate of lime shells and the Radiolarians shells of silica. Though very small, these shells have frequently built up limestone (chalk), or chert beds.

II. Porifers or Sponges, which are the simplest of the manycelled animals, are sac-like forms supplied with numerous pores or canals through which water containing food circulates to feed the cells. Distinct organs are lacking. Most Sponges have either siliceous or calcareous skeletons.

III. Ceelenterates are also very simple many-celled animals, but they possess distinct mouth, body (or stomach) cavity, and usually have radiating tentacles surrounding the mouth. The canal system of the Sponges is absent. Hydrozoans are little creatures consisting of tube-like sacs with mouth at one end surrounded by tentacles. Anthozoans are very much the same, but have a more or less distinct esophagus, and have the body cavity divided by radiating vertical partitions. Some Hydrozoans and Anthozoans colonize and some do not. Among

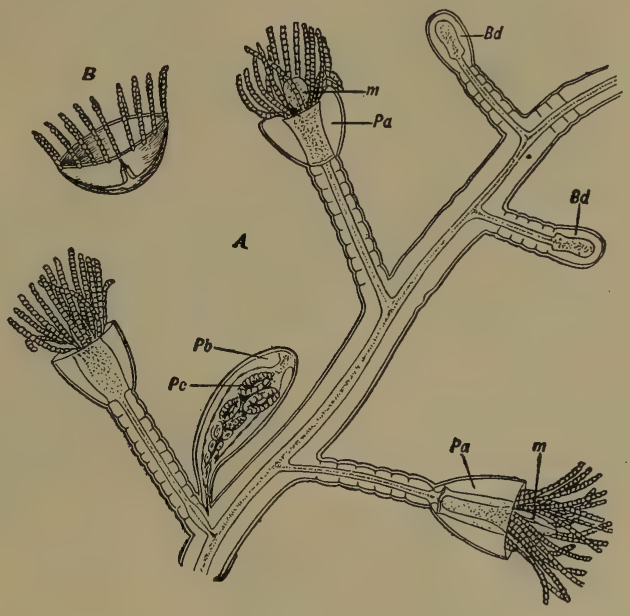

Fig. 4

Modern Hydrozoans. Part of a colony much enlarged. (From Schuchert's "Historical Geology," permission of John Wiley and Sons.)

the former, the Graptolites (now extinct) are numerous and important in early Paleozoic rocks, while the latter or Corals have always been prominent since pretty early geologic time.

IV. Echinoderms possess a distinct body cavity which contains the digestive or alimentary canal, distinct nervous system, and a water circulatory system. Most Echinoderms are radially segmented and protected by shells. 1. Pelmatozoans are characterized by having segmented stems by which they are attached to the sea-floor or some object during at least part of their existence. 


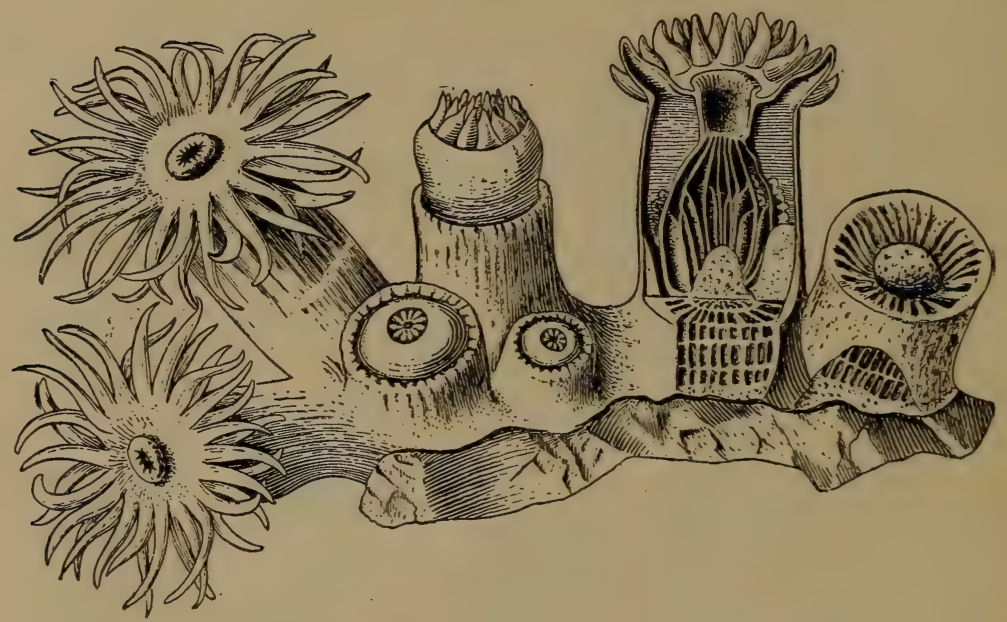

Fig. 5

A group of modern Corals showing the internal structure of one individual. (After Pfurtscheller, from Schuchert's "Historical Geology," permission of John Wiley and Sons.)

Among Pelmatozoans, the Cystoids are small, bladder-like forms with irregular radial arrangement of plates of the shell and arms

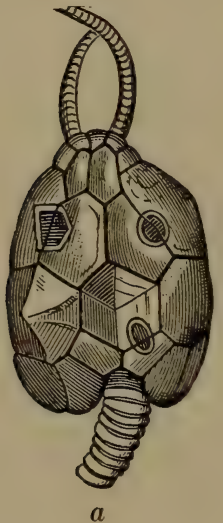

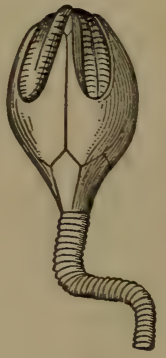

$b$

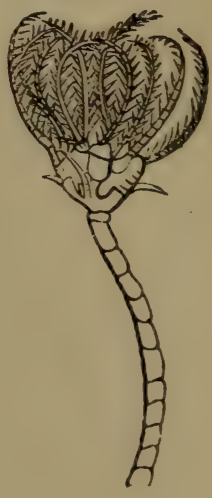

$c$

Fig. 6

Stemmed Echinoderms (Pelmatozoans). a, Cystoid, b, Blastoid, $c$, Crinoid. 
wholly absent or only slightly developed; the Blastoids are budlike forms with plates of the shell in very regular radial order, and without arms; and the Crinoids are lily-like forms with regular radial arrangement of plates of the shell, and with long, feathery arms surrounding the mouth. 2. Asterozoans are the free-moving, star-shaped Echinoderms usually with five arms or rays radiating

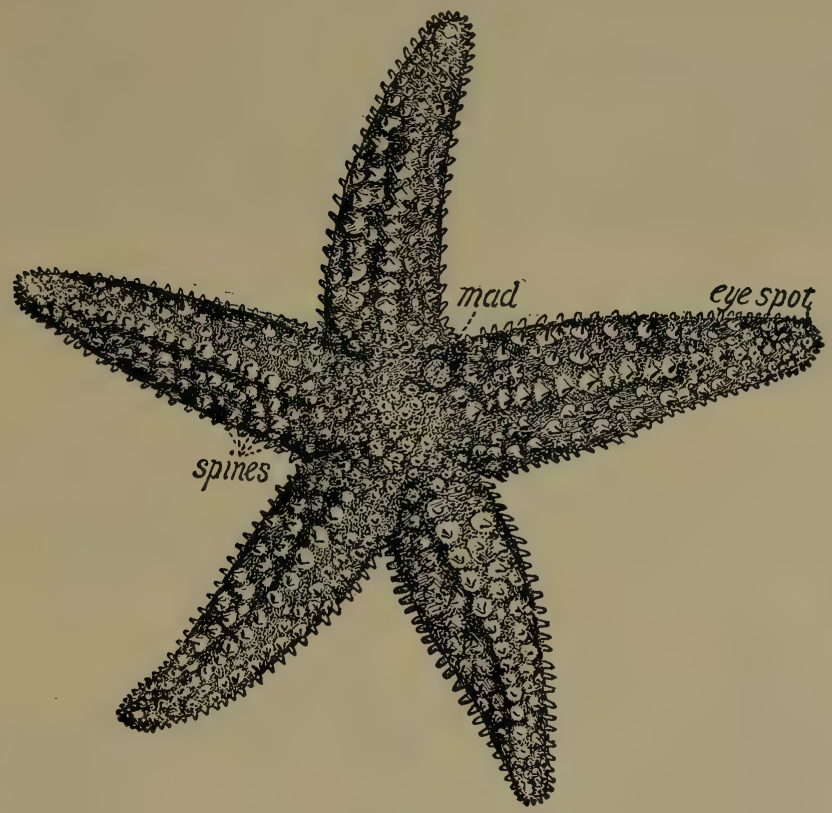

Fig. 7

A modern Asterozoan ("Starfish"). (From Shimer's "Introduction to the Study of Fossils," permission of The Macmillan Company.)

from a central disk. Of these the Ophiuroids (Brittle-stars) have slender, flexible rays very distinct from the central disk, while the Asteroids have thicker rays not so sharply separated from the central disk, and the alimentary canal extends into the rays. 3. Echinozoans are not free-moving, are without free arms, and are stemless. Of these the Echinoids (Sea-urchins) have hard shells made up of calcareous plates usually immovably joined and covered with numerous movable spines; and the Holothuroids 
(Sea-cucumbers) are soft bodied, with leathery covering, tentacles around the mouth, and skeletons of scattering limey spicules.

A

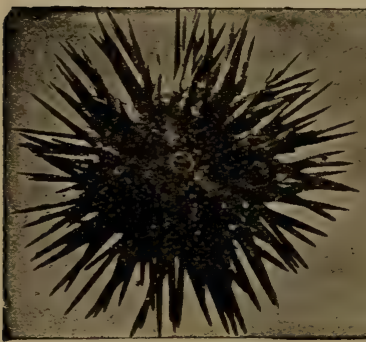

$B$

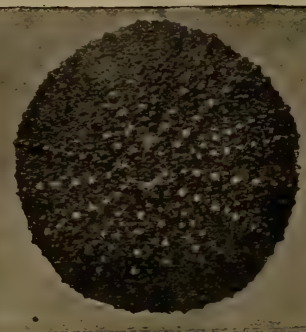

Fig. 8

Modern Echinoids ("Sea-urchins"), one with spines in position. (After Coe, from Schuchert's "Historical Geology," permission of John Wiley and Sons.)

V. Vermes or Worms include a large group of forms more complex in organization than the preceding groups. Some are segmented and others are not. Since hard parts are very rarely developed, the Worms are of no great importance as fossils, their
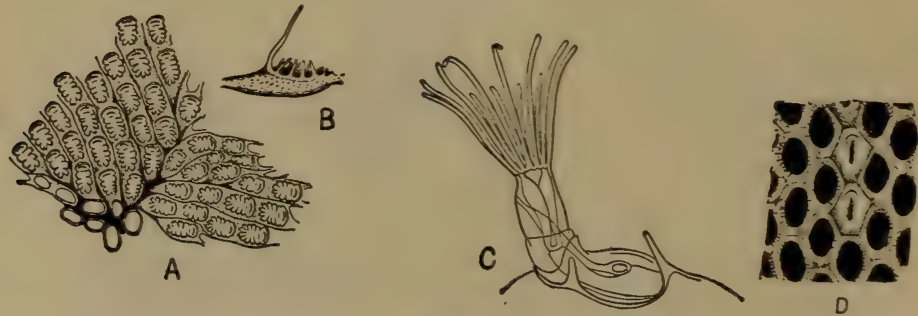

Fig. 9

Bryozoans: $A$, portion of modern colony seen from above $(x 15) ; C$, an individual expanded; $D$, fossil form. $A-C$ after Verrill and Smith; $D$, from Ulrich. (From Shimer's "Introduction to the Study of Fossils," permission of The Macmillan Company.)

presence usually being indicated by trails, burrows, or tubes made in mud or sand.

VI. Molluscoids, as the name suggests, bear a resemblance to the Mollusks. They differ from the Anthozoans, Echinoderms, 
Worms, and Arthropods in the entire absence of body segmentation. Absence of distinct head and foot, the lower development of the nervous system, and usual lack of locomotive power distinguish them from Mollusks. A highly characteristic feature of the Molluscoids is a sort of collar, or pair of arms (often containing carbonate of lime) of varying shapes and bearing fringe-like tentacles around the mouth. 1. Bryozoans form tiny moss-like tufts which nearly always colonize and suggest the Anthozoans in outward appearance, though they are much more highly organized. With few exceptions the Bryozoans secrete calcareous Coral-like skeletons. 2. Brachiopods are characterized by two distinct, external shells (valves) which contain the soft portion of the animal, and also

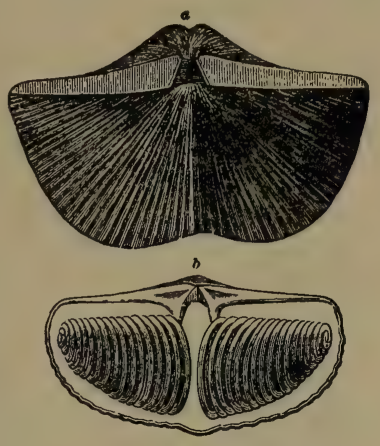

Fig. 10

Brachiopod shells (fossil forms). The lower one shows the internal spiral arms. a pair of long, spirally coiled, fringed arms. In fossil form the Brachiopods are most readily distinguished from certain Mollusks (Pelecypods), which are also bivalves, by the bilateral symmetry of
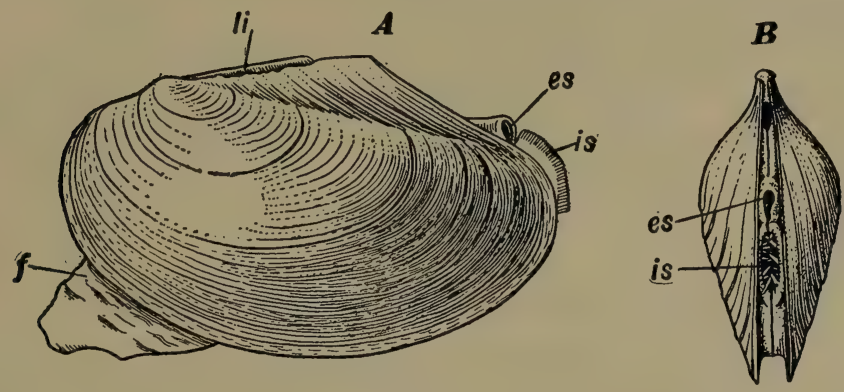

Fig. 11

A modern Pelecypod. $A$, side view; $B$, end view. (After Howes, from Schuchert's "Historical Geology," permission of John Wiley and Sons.)

the shells. That is, a plane of symmetry may be passed through the valves at right angles to the hinge line. Bryozoans and Brachiopods are both very abundant as fossils, especially in the older rocks. 
VII. Mollusks, like Molluscoids, lack segmentation, but they are more highly organized with more or less distinctly developed locomotive organs and head. Nearly all have shells, generally external, and gills for respiration. 1. Pelecypods (e.g. Oysters and Clams) are always supplied with a pair of external shells nearly alike and hence they are bivalves, but they differ from the Brachi-

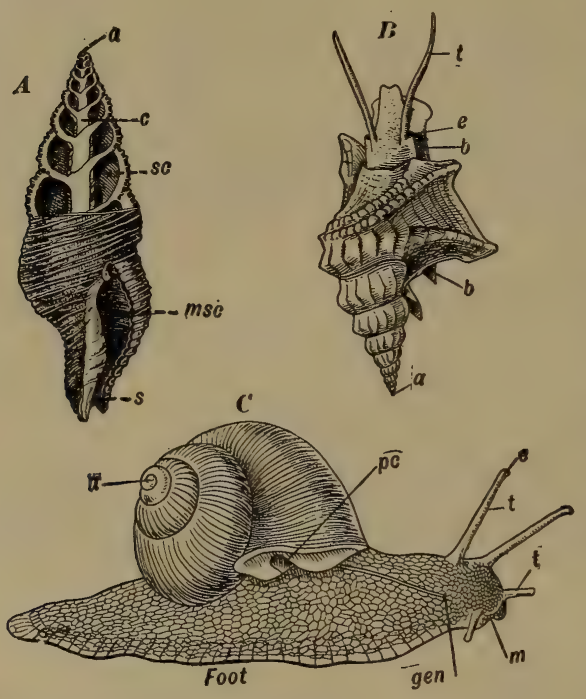

Fig. 12

Gastropods: $A$ and $B$, marine forms; $C$, land Snail. (From Schuchert's "Historical Geology," permission of John Wiley and Sons.)

four-gilled and with numerous tentacles. Dibranchs (e.g. so-called Cuttle-fishes) are two-gilled; with either eight or ten tentacles; bag for secreting an inky fluid; and almost invariably without external shell. Usually there is a sort of cigar-shaped internal shell. Mollusks of all classes have been abundantly preserved in rocks of all but the earliest geologic ages.

VIII. ARTHRopods are highly characterized by longitudinal body segmentation; jointed appendages (usually a pair from each segment); and usually by a pair of nerve centres in each segment. 1. Crustaceans (e.g. Lobsters and Crabs) are water animals breath- 
ing by means of gills or through the body; usually with two pairs of well-developed antennæ (feelers); and covered with a chitinous or calcareous crust or shell. 2. Arachnids (e.g. Spiders and Scorpions) are land Arthropods breathing by air-sacs; have four pairs of legs; and no antennæ. 3. Myriapods (e.g. Centipedes) are land Arthropods with numerous legs; one pair of antennæ; and no wings. 4. Insects (e.g. Grasshoppers and Butterflies) are also land Arthropods with one pair of antennæ, but with three pairs of legs, and nearly always with wings.

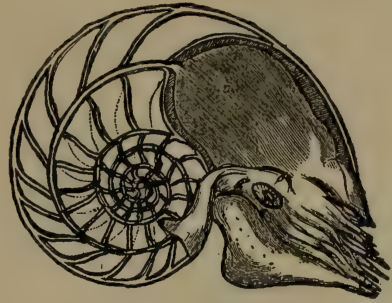

Fig. 13

A modern chamber-shelled Cephalopod (Nautilus) showing the internal shell structure. characterized by the possession of a vertebral column, which, in all but the very low forms, is a thoroughly ossified backbone. Vertebrates include the highest known of all animals. 1. Ostracoderms (e.g. Armour-fishes, now wholly extinct) are among the very simplest of Vertebrates (see Fig. 80). They are of particular interest from the standpoint of the evolution of the Fishes and higher Vertebrates. Characteristic features will be

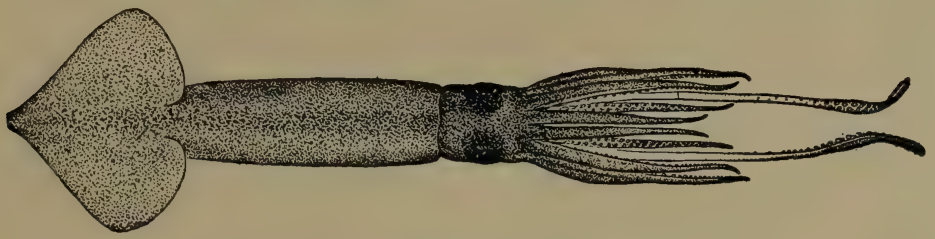

Fig. 14

A modern Squid. (After J. H. Blake, from Shimer's "Introduction to the Study of Fossils," permission of The Macmillan Company.)

given beyond in connection with the life of the Devonian period. 2. Fishes always live in water; have distinct cartilaginous or bony vertebral column; distinct jaws; pairs of fins; and gills. Subclasses of Fishes will be described later. 3. Amphibians (e.g. Frogs and Salamanders) live either in water or on land. In the early stage of development of the individual (e.g. Tadpole stage), they are aquatic, and breathe by gills, while in the adult stage they breathe by lungs and are largely terrestrial in habit. They never 
have fins. 4. Reptiles (e.g. Snakes and Crocodiles), though in many ways like Amphibians, never have gills, and always have scales or bony plates developed from the skin. They are the most highly organized cold-blooded animals. 5. Birds are plainly distinguished from all other animals by their covering of feathers. They are too familiar to need special description. They are warmblooded creatures with well-developed heart and circulation of blood. 6. Mammals (e.g. Dog and Man) include the highest of all organisms, a characteristic being that they all suckle the young. They are mostly quadrupeds, covered with hair, and dwellers on land. The Whale is an exceptional mammal.

Vertebrate fossils are common and of special interest because they show the development of the higher animals. The simplest (Ostracoderms) have been found in rocks of Ordovician age (see below), and higher and higher forms were gradually introduced and developed until the most complex Mammals appeared in comparatively recent time. 


\section{CHAPTER II}

\section{GENERAL PRINCIPLES - CONCLUDED}

\section{Correlation of Rock Formations}

By Stratigraphy is meant that branch of geologic science which "arranges the rocks of the earth's crust in the order of their appearance, and interprets the sequence of events of which they form the records" (A. Geikie). All stratified rocks may be subdivided into formations or groups of strata, each of which is marked either by a characteristic facies or assemblage of fossils, or, to greater or lesser extents, by similarity of lithologic features, or by both. A rock formation is generally considered to be a mappable unit, that is its area can be delimited upon a geologic map. Subdivisions of formations are usually called members. By correlation of formations is meant the determination of the equivalence, or practical equivalence, of rock groups or formations in various parts of the earth. Exact contemporaneity for widely separated districts cannot be expected as above explained in chapter 1 . In general the criteria of correlation may be divided into two classes, namely, geological (physical) and paleontological (biological). ${ }^{1}$

I. Geological (Physical) cRITeria. In many cases formations carry no fossils or very few, and it is then necessary to seek means of correlation without their aid. None of the geological (physical) methods can, however, be applied over wide areas such as opposite sides of a continent, or different continents. For such wide correlations, criteria derived from a study of fossils only can be used.

1. Continuity of deposit. If, as shown in the accompanying diagram (Fig. 15), continuity can be traced from A to B, it is quite certain that the rock masses at A and B are of the same, or very nearly the same, age. There is probably no more important means of correlation used by the geologist except over wide areas.

${ }_{1}^{1}$ The criteria of correlation as here presented are based largely upon university lectures by $\mathrm{Dr}$. W. B. Clark. 
2. Similarity of materials. Rock formations not actually continuous, though not too widely separated, are often correlated by noting similarity or identity of lithologic character, especially

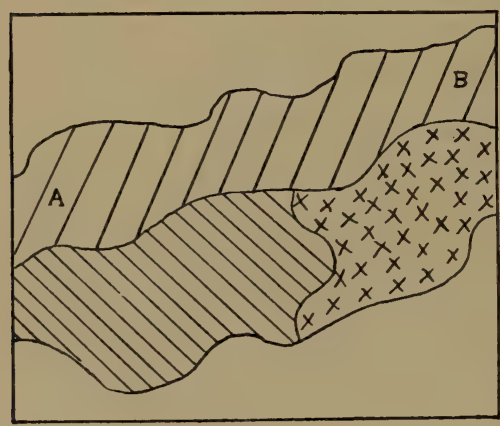

Fig. 15

Diagram to illustrate correlation of rock formations by continuity of deposit. (W. J. M.)

like A and B (Fig. 16), and not be correlated on the basis of similarity of sequence, particularly when each formation at one place (A) shows little or no difference in lithologic character or thickness as compared with each formation at the other place (B).

4. Similarity of degree of change, or structural relations. By finding similarly changed or metamorphosed rocks in the same vicinity, they may thus be correlated. For instance, in the accompanying diagram (Fig. 17) it is evident that the rocks of group $A$ are older than those of group B, and these in turn older than C. Outcrops over limited areas at least can thus be placed in one of these three groups. By way of illustration, the (pre-Paleozoic) rocks of the Highlands of the Hudson in southeastern New if there are any locally peculiar features. Older geologists were inclined to overwork this method of correlation by applying it over areas of too great extent, in some cases even suggesting identity of age of deposits on opposite sides of the ocean by this means. The danger of such application is apparent when we realize that, for example, a sandstone of very early (Cambrian) age may be exactly like sandstone of much later (Tertiary) age.

3. Similarity of sequence. A succession of strata in two places continuous on the surface, may

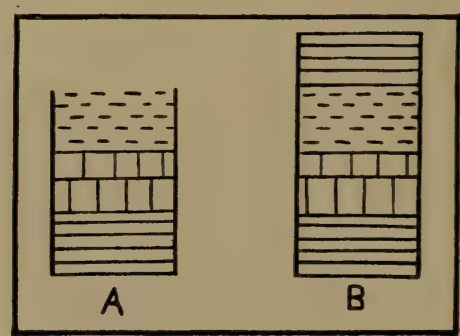

Fig. 16

Diagram to illustrate correlation of rock formations by similarity of sequence. (W. J. M.) 
York are highly metamorphosed and folded, with indurated, folded (Ordovician) strata resting upon their north side, and indurated, non-folded, and slightly tilted (Triassic) strata coming against them on the south side. Each of these groups of rocks represents a distinctly different geologic age. This method cannot be used over wide areas such as different parts of a continent, because for instance, certain strata (Cretaceous) in the eastern part of the United States may be unconsolidated and horizontal, while rocks of the same age are highly folded in the western United States.

5. Study of adjacent lands. Examination of the materials of

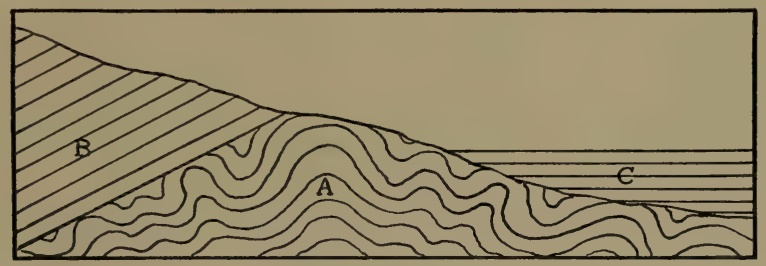

Fig. 17

Diagram to illustrate correlation of rock formations by degree of change or structure. (W. J. M.)

the Coastal Plain of our Atlantic sea-board clearly shows them to have been largely derived from the rocks of the Piedmont Plateau and Appalachians, and hence these Coastal Plain materials are the younger. Also the peneplain character of the surface of the Piedmont Plateau proves the greater age of this region because the peneplain was being produced by wearing off the very materials which were deposited in the adjacent ocean to produce what are now called the Coastal Plain deposits.

6. By diastrophism. According to Chamberlin, ${ }^{1}$ the great deformations of the earth's crust have been of periodic occurrence. Each great movement has "tended toward the rejuvenation of the continents and toward the firmer establishment of the great (oceanic) basins." Between any two great diastrophic movements there has been a time of quiescence when the base-leveling processes have more or less lowered the continents. Such "baseleveling of the land means contemporaneous filling of the sea

1 T. C. Chamberlin: Diastrophism the Ultimate Basis of Correlation, in Jour. Geol., Vol. 17, 1909, pp. 685-693. 
basins by transferred matter" with resultant encroachment of the sea over the land "essentially contemporaneous the world over," which in turn implies "a homologous series of deposits the world over." Thus the times of great diastrophism (recognized by great unconformities and overlapping deposits) should form the basis of correlating at least the larger groups, or even systems, of strata in the earth's crust.

II. Paleontological (Biological) criteria. The significance of fossils in the determination of geological chronology has already been discussed, but it should here be repeated for emphasis that "order of superposition" of the strata, studied in connection with their fossil content, furnishes the general standard for building up a geological chronology, and affords the best basis for the correlation of formations. In fact, for correlation of formations in distant portions of a continent, or different continents, paleontological criteria alone are satisfactory.

1. Identity of species. This is an extremely important method of correlation, especially when species with wide geographic distribution and short geologic range are employed. It is not wise to depend upon a single species for the correlation of far distant formations, because then the time necessary for the migration of the species must be considered. This seldom gives trouble because the geologist usually deals with a number of rapid-moving species. In a restricted area, where formations are to be correlated, the same organisms may have continued for a long time, but nearly always some peculiar species furnishes the clew.

2. Aggregations of forms. When groups of strata in different areas carry similar aggregations of similar forms, the groups of strata may be safely correlated. Even though a small percentage of the species vary, the method still holds because such variations are to be expected on account of migratory and geographic conditions.

3. Stage in the evolution of organisms. Since there has been a gradual development of life with increasing complexity throughout geologic time, the stage of development or evolution shown by the fossils in a group of strata will serve as a basis for general correlation at least. Each era, or even period, shows a characteristic stage of evolution of forms.

4. Percentage of living species. This applies only to rock formations of later geologic time, because the older rocks contain no 
species like those now living. The percentage of living species becomes greater and greater as the present is approached, and on this basis Lyell sub-divided a late period (Tertiary) into three epochs.

In any correlation problem the geologist strives to use as many of the above criteria as possible, the certainty of the correlation being more firmly established when several geological and paleontological criteria are used together.

\section{SignificANCE OF UNCONFORMities}

Thus far our discussion has been based largely upon the assumption of conformable strata, but many times the succession of strata (so-called "section") under study shows one or more unconformities. Since an unconformity represents a time of erosion, or possibly a time of non-deposition of sediments, it is obvious that it signifies an absence of both the strata and life records for a greater or lesser length of time. The missing records for a given region can, however, generally be found by going to some other locality where deposition of sediments was not interrupted at the time when the unconformity was being produced.

Without the aid of fossils, in the ordinary case of unconformity, we could tell that the land emerged above water, was eroded, and again

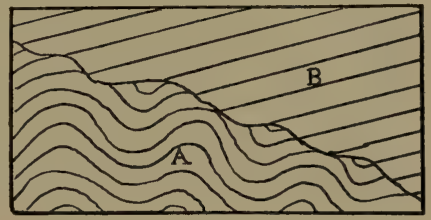

Fig. 18

Diagram to illustrate the significance of unconformities. The lower strata $(A)$ were folded, raised above water, eroded and then submerged, after which the upper strata $(B)$ were deposited and then tilted. (W. J. M.)

submerged, but we could not tell how much time the erosion interval involved (Fig. 18). But by noting the fossils in the youngest strata just below the eroded surface, and in the oldest strata just above it, we could tell what epochs or periods are represented by the erosion interval by a comparison with the standard geologic section of the world (see table near the close of this chapter).

Because the fossils immediately above and below the line of a profound unconformity show such marked differences, the earlier geologists were misled into thinking that each great unconformity 
signified an awful catastrophe (physical and organic) which devastated the earth and destroyed all organisms, after which came a period of tranquillity when a new set of organisms was created. This has been called the doctrine of catastrophism. In opposition to this view Sir C. Lyell promulgated the doctrine of uniformitarianism which holds that the evolution of the earth and its inhabitants has progressed practically uniformly, and that missing records in one place are to be found in other places. Today Lyell's view is generally accepted with the modification that times of comparatively more rapid earth disturbance, and probably changes in organisms, have occurred.

\section{Trangressions and Retrogressions of the Sea}

During our study of the clearly recorded portion of the earth's history we shall find positive evidence of repeated transgressions and retrogressions of marine waters over various portions of what are now the continental areas. Since subsidences or elevations of the lands are not the only known causes of sea transgressions and retrogressions, we shall, in the following pages, refer to submergences and emergences of the lands unless there is good evidence for more specific statement in any case.

Submergence may be caused either by (1) sinking of the land; (2) rise of the sea; or (3) both together. "Both the lowering of the land and the rise of the sea may be due to gradation, to diastrophism, or to the two combined. Gradation is perpetual and inevitable where land and sea exist. . . . It has been computed that if the earth, in its present condition, were to remain without deformation long enough for the continents to be base-leveled, the deposition of the sediments thus derived in the sea would raise the sea-level about 650 feet. This would submerge a large part of the base-leveled land. . . . Base-leveling implies a nearly undisturbed attitude of the land and sea, and hence in itself favors the view that no great deformation affected the continent while it was going on." 1 Much submergence of lowlands would take place long before such wide-spread base-leveling had been accomplished. Sinking of the land (see below) would of course cause submergence, but whether submergence of the land, in any given case, has been

1 Chamberlin and Salisbury: College Geology, p. 479. 
due only or largely to sinking or gradation or to both is at present often difficult or impossible to determine, though it is quite certain that both processes have often been operative.

Emergence may be caused either by (1) rise of the land; (2) lowering of the sea; or (3) both combined. Except rather locally as in the cases of mountain-making (orogenic) movements, it seems doubtful if there is any good evidence for very considerable actual uplifts of extensive land areas thus causing great sea retrogressions. On the other hand, the earth is certainly a contracting body with its whole surface approaching nearer and nearer to its centre. It appears that "the rigidity of the earth may be such that its outer parts are able to withstand for a time the strain set up by contraction. As the strain accumulates, it ultimately overcomes the resistance, and the outer part of the earth yields. If the yielding results in the sinking of the ocean basin, the surface of the water is drawn down, and the surrounding lands seem to rise, unless they sink as much as the surface of the sea does at the same time. The lowering of the sea surface, because of the sinking of the sea-bottom, is probably the most fundamental single cause of the apparent rise of the land. The periodic emergences of the continents, alternating with periodic submergences in the course of geological history, are perhaps to be thus explained. Periodic submergences, on the other hand, might be explained by the sinking of the continental segments of the earth, or by such sinking combined with the processes already referred to which cause the rise of the sea." 1

\section{Paleogeography}

Paleogeography literally means "ancient geography" and deals with the geographic conditions of the earth during geologic time. In making a paleogeographic map to represent North America at a given time in its history, the attempt is made to show the relations of lands and waters with distinctions between deep and epicontinental seas where possible, areas of continental deposition, directions of ocean currents, etc. Until quite recent years there were only crude attempts at making such maps for North America, for the knowledge of the continent was not sufficient to form a

1 R. D. Salisbury: Physiography, Advanced Course, pp. 401-402. 
reasonable basis upon which to work. Within the last few years, however, several sets of paleogeographic maps, notably those by Bailey Willis ${ }^{1}$ and Charles Schuchert, ${ }^{2}$ have been prepared. The Willis maps are used in this text, but the student will do well to compare the Schuchert maps with these as the different periods are taken up.

Willis gives a general statement of the lines of evidence used in the construction of his maps as follows: "A certain period having been selected as that which should be mapped, the epicontinental strata pertaining to that time interval have been delineated. The phenomena of sedimentation and erosion have then been correlated, with a view to determining the sources of sediment and topographic conditions of land areas, and from these data the probable positions of lands have been more or less definitely inferred. Thus, certain areas within the continental margin are distinguished as land or sea, and these areas may be defined as separate bodies or connected according to inferences based upon isolated occurrences or upon later effects of erosion. It is assumed that the great oceanic basins and such deeps as the Gulf of Mexico and Caribbean have been permanent features of the earth's surface at least since some time in the pre-Cambrian ...

"From the geographic conditions thus developed, inferences regarding the climate and the life habitats of the time may be drawn. If now we turn to the records of paleontology, and compare the distribution of faunas and floras ${ }^{3}$ with the conditions of distribution which should result from the inferred physical phenomena, we may check the whole line of reasoning and by a readjustment draw a step nearer to the truth. This is the method which has been pursued in making the maps of North America." 4

It should be borne in mind that such paleogeographic maps are generalized and rather tentative as regards many details generalized because each map represents a considerable time period so that certain more local geographic changes during the period

1 B. Willis: Jour. Geol., Vol. 17, 1909.

2 C. Schuchert: Bull. Geol. Soc. America, Vol. 20, 1910.

3 The term "fauna" refers to an assemblage of animals populating a given area during a certain epoch. In a similar sense the term "flora" is applied to an assemblage of plants.

${ }^{4}$ B. Willis: Jour. Geol., Vol. 17, 1909, pp. 201-202. 
are not indicated, and tentative because of lack of knowledge concerning many areas and lack of certainty in the correlation of formations in certain other areas. With progress in knowledge of the strata, less generalized and more accurate maps will be made. Nevertheless the series of maps used in this text will serve to give the beginner a very good idea of the broader features in the geographic development of our continent.

\section{Classification of Geologic Time}

We have already shown how, by employing the law of superposition of the strata together with the law of included fossils, the rock formations of various parts of the earth may be correlated and built up according to their natural order of age into a standard for comparison or a geologic column. The subdivisions of the geologic column represent the times when the successive rock formations were deposited. Different names have, from time to time, been assigned to these divisions which are in more or less general use.

For a long time the subdivisions of the geologic column were made almost solely on the basis of marked differences in fossils, but it is now recognized that such differences were, in no small degree, caused by corresponding changes in the environment in which the organisms lived, or, in other words, by changes in the climate, the topography, the relations of land and sea, etc. So we now try to divide the geologic record at the points where the revolutionary physical changes are indicated, and to make corresponding divisions of geologic time itself. Thus there are two kinds of divisions - one for the rocks themselves, and the other for the time represented by the rocks.

The following time and rock scales have been adopted by the International Geological Congress. Immediately following these scales is given in descending the table of main geological divisions as now recognized in North America.

Time scale

Rock scale

Era ........................ Group

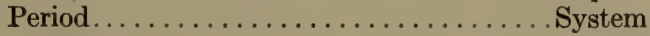

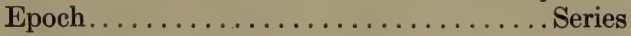

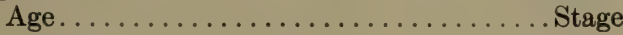


Table of Main Geological Divisions

Era and group Period and system

Cenozorc $\left\{\begin{array}{l}\text { Quaternary. } \\ \text { Tertiary. }\end{array}\right.$

Mesozorc $\left\{\begin{array}{l}\text { Cretaceous. } \\ \text { Jurassic. } \\ \text { Triassic. }\end{array}\right.$

PaleozorC $\left\{\begin{array}{l}\text { Permian. } \\ \text { Pennsylvanian (Upper Carboniferous). } \\ \text { Mississippian (Lower Carboniferous). } \\ \text { Devonian. } \\ \text { Silurian. } \\ \text { Ordovician. } \\ \text { Cambrian. }\end{array}\right.$

Proterozoic \{ Algonkian.

Archeozolc \{Archean.

The names of eras follow a definite plan depending upon the great life stages. Thus Archeozoic means literally "primitive or beginning life"; Proterozoic means "earlier or less primitive life"; Paleozoic means "ancient life"; Mesozoic means "intermediate life;" and Cenozoic means "recent life." The period names do not follow such a definite plan of nomenclature, various ideas being represented. These names will be explained when the different periods are taken up for discussion.

\section{Comparison of Human and Geologic History}

One of the most striking differences between human and geologic history is the extreme brevity of the one as compared with the vast time represented by the other. Human history is to be measured by some thousands of years, while geologic history must be measured by at least tens of millions of years. A recent event, geologically speaking, like that of the building of the Coast Range Mountains, or the carving out of a tremendous canyon like the Grand Canyon of the Colorado in Arizona, required some hundreds of thousands, if not a few millions, of years. Human history is roughly divided into certain ages according to the predominant influence of some person, nation, principle, or force. Thus we speak of the "Age of Pericles," the "Roman Period," the "Age of the French Revolution," or the "Age of Electricity." Geologic 
history is sub-divided according to great predominant physical or organic phenomena as, for example, the "Appalachian Revolution" (toward the close of the Paleozoic era), the "Rocky Mountain Revolution" (toward the close of the Mesozoic era), the "Age of Fishes" (Devonian period), the "Age of Mammals" (Cenozoic era).

Students of earth history, like students of human history, must be very careful to make a distinction between events and records of events, because by no means all historical events are recorded. Events are continuous, while their records are usually much interrupted and apparently sharply separated from each other. In both geologic and human history, times or periods of comparatively quiet and slow change have often given way to times of comparatively rapid, to even revolutionary, change.

\section{Selected General References}

Wiluis: Index to the Stratigraphy of North America, Accompanied by a Geologic Map of North America. Prof. Paper 71, U. S. Geol. Survey. A very comprehensive work with many references and quotations.

Chamberlin and Salisbury: Geology, Vols. 2 and 3 (Henry Holt Co., 1906). A very elaborate recent American work.

Chamberuin and Salisbury: College Geology, Part 2 (Henry Holt Co., 1909). A briefer discussion than in the larger work of these authors.

Dana: Manual of Geology, Part 4 (American Book Co., 1895). A very elaborate older American work.

GeikiE: Text-book of Geology, Vol. 2 (Macmillan Co., 1903). A comprehensive English work with emphasis upon European geology.

KaYser: Lehrbuch der Geologie, Part 2 (F. Enke, Stuttgart, 1912). A comprehensive German work with emphasis upon European geology.

HaUG: Traité de Géologie, Vol. 2 (A. Colin, Paris, 1911). A comprehensive French work with emphasis upon European geology.

Willis and SaLisbury: Outlines of Geologic History with Especial Reference to North America (University of Chicago Press, 1910). Not a text-book, but contains important general papers by various American geologists.

BLACKWELDER: Regional Geology of the United States of North America (Stechert \& Co., 1912). Contains brief outlines of the stratigraphy and geologic history of the United States.

Le Conte: Elements of Geology, Part 3 (Appleton and Co.) An older fairly comprehensive treatment of historical geology with special reference to North America.

Sсотт: An Introduction to Geology, Part 4 (Macmillan Co., 1907). A fairly comprehensive discussion of earth history.

Pirsson and Schuchert: Text-book of Geology, Part 2 (John Wiley \& Sons, 1915). A fairly comprehensive treatment of historical geology.

Clemand: Geology, Physical and Historical, Part 2 (American Book Co., 1916). A fairly comprehensive treatment of historical geology. 
Blackwelder and Barrows: Elements of Geology, Part 2 (American Book Co., 1911). An elementary discussion of historical geology.

Norton: Elements of Geology, Part 3 (Ginn and Co., 1905). A very elementary discussion of historical geology.

TARR: Elementary Geology, Part 3 (Macmillan Co., 1897). A very brief discussion of earth history.

Brigham: $A$ Text-book of Geology (Appleton and Co., 1902). Contains a brief treatment of historical geology.

Dana: Text-book of Geology, Part 4 (American Book Co., 1897). A brief discussion of earth history.

Grabau: The Principles of Stratigraphy (A. G. Seiler and Co., 1913). An elaborate account of stratified rocks and their significance.

ShImer: An Introduction to the Study of Fossils (Macmillan Co., 1914). An elementary treatment of the subject of paleontology.

Zittel-Eastman: Text-book of Paleontology, 2 Vols. (Macmillan Co., 1913). An elaborate treatment of the subject of paleontology.

Woons: Paleontology (Cambridge University Press, 1902). A brief discussion of invertebrate paleontology.

Jordan AND Kellogg: Evolution and Animal Life (Appleton and Co., 1907). Organic evolution discussed in an easily understood manner.

Moutron: Introduction to Astronomy, Chapter 15 (Macmillan Co., 1906). A brief discussion of the evolution of the Solar System.

Certain of the larger works above named, especially Willis' "Index to the Stratigraphy of North America," Chamberlin and Salisbury's "Geology," and Geikie's "Text-book of Geology," are very rich in important references to the literature dealing with historical geology. 


\section{CHAPTER III}

\section{ORIGIN AND PRE-GEOLOGIC HISTORY OF THE EARTH}

If we define geology as the study of the history of the earth and its inhabitants as revealed in the rocks, it is evident that the problems of the origin and very early development of the earth are strictly astronomic rather than geologic. It is generally agreed that geological history did not begin till the ordinary earth processes, such as weathering and erosion, transportation and deposition of sediments, etc., began to operate. Since, however, the pre-geologic condition of the earth must have gradually given way to its geologic condition, it is a matter of interest for the geologist to consider the hypotheses regarding the very early development of the earth.

\section{The Solar System}

The sun has a diameter of about 866,000 miles, and a volume $1,300,000$ times that of the earth. Around this central sun eight planets - Mercury, Venus, Earth, Mars, Jupiter, Saturn, Uranus, and Neptune - revolve in nearly circular orbits. Three of these planets - Mercury, Venus, and Mars - are smaller than the earth, while the others are larger, Jupiter being 1,300 times as large. The earth is about $93,000,000$ miles from the sun and requires one year for a trip in its orbit around the sun, while Neptune, the most distant planet, is about 2,800,000,000 miles from the sun and requires 164 years for a revolution about the sun. Each planet also rotates upon its axis, the earth accomplishing a rotation every twenty-four hours. Most of the planets have smaller bodies called satellites or moons revolving about them, such as Earth with its one moon, Saturn with eight moons, etc. The sun and the eight planets with their satellites, together with a group of many small independently revolving bodies called "planetoids," comprise the solar system. That this solar system constitutes only a very small part of the universe is clearly proved by the fact that the nearest fixed star is several trillions of miles from the earth. 
Some of the well-known facts which any hypothesis of the origin of the solar system must explain are as follows: (1) The planet orbits are all elliptical, but nearly circular; (2) the orbits lie in nearly the same plane; (3) all planets revolve about the sun in the same direction; (4) the sun's direction of rotation is the same as that of the planets' revolution; (5) the planes of the planets' rotation nearly coincide with the planes of their orbits (except Uranus and Neptune); (6) the direction of the planets' rotation is the same as that of their revolution; and (7) the satellites revolve in the direction of rotation of their planets (two or three exceptions).

\section{Hypotheses of Earth Origin}

Nebular or Ring Hypothesis. - In 1796 Laplace published a remarkable work on astronomy, and in its last chapter he put forth his now well-known hypothesis regarding the origin of the solar system. He postulated a spheroidal mass of very highly heated, incandescent gas or nebula greater in diameter than the present solar system, this whole mass rotating in the direction of the revolution of the existing planets. Due to loss of heat by radiation, this mass contracted and its shrinkage necessarily made it rotate more rapidly upon its axis, at the same time causing the centrifugal force on its outside to become stronger and stronger. Finally the centrifugal force at the equator became equal to the force of gravity and the equatorial portion was left off (not thrown off) as a ring surrounding the contracting remainder. The materials of the ring condensed to form the outermost planet. By continued contraction of the rotating nebula, the other rings and planets were formed. The satellites were produced in a similar manner by rings left off by the shrinking planets.

Briefly, according to this hypothesis, the earth was originally highly heated and much larger than now. During its cooling and contraction, its original hot and dense atmosphere, which contained all the earth's water in the form of vapor, gradually became thinner due to absorption by the earth. When the conditions of pressure and temperature were favorable, water vapor condensed to form the hydrosphere. The oldest rocks must have been igneous, that is they were portions of the original crust formed by cooling of the molten globe.

For over a hundred years the Laplacian hypothesis has exerted 
a profound influence upon science, philosophy, and theology, and certainly many of the important phenomena of the solar system are explained by it. Some serious objections to it may, however, be briefly stated as follows: (1) Nearly all existing nebulas are spiral and not circular; (2) spectroscopic study shows that these nebulas do not consist of gas, but rather of discrete liquid or solid particles; (3) the backward revolutions of certain satellites oppose the hypothesis; (4) rings could not have been left off, that is there could have been no intermittent process of the sort; and (5) it is not at all clear how the matter of the rings could have condensed into planets.

Planetesimal or Spiral Hypothesis. - It is a remarkable fact that, although many thousands of nebulas are known, there are very few examples of ring nebulas of the Laplacian type among them. Spiral forms are very common, especially the smaller ones. Also, as above stated, spectroscopic study of these nebulas shows them to be made up of discrete (liquid or solid) particles rather than of gas. The Planetesimal hypothesis, ${ }^{1}$ formulated by

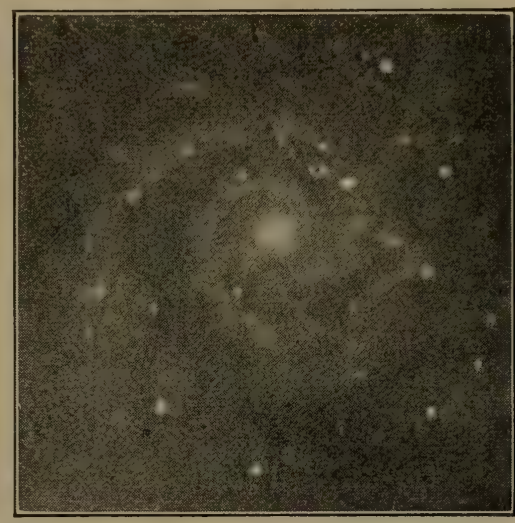

Fig. 19

A very symmetrical spiral nebula in Pisces (M. 74). Photo by Lick Observatory. (From Chamberlin and Salisbury's "Geology," permission of Henry Holt and Company.)

Chamberlin and Moulton, "postulates that the matter of which the sun and the planets are composed was, at a previous stage of its evolution, in the form of a great spiral swarm of discrete particles whose positions and motions were dependent upon their mutual gravitation and their velocities" (Moulton). A nebula of this sort comprised a luminous central mass (the future sun) from the opposite sides of which two luminous spiral arms streamed out with occasional larger masses or knots along each arm, and with dark lanes between the arms (see Fig. 19). Also some nebulous

1 An elaborate discussion of this hypothesis may be found in Chamberlin and Salisbury's Geology, Vol. 2. 
matter occupied the spaces between the arms. Such a distribution of matter in a spiral shows that the form could not have been maintained by gaseous pressure, as in the Laplacian hypothesis, but rather by the movements of the separate particles or masses. Since these particles are thought to have moved like miniature

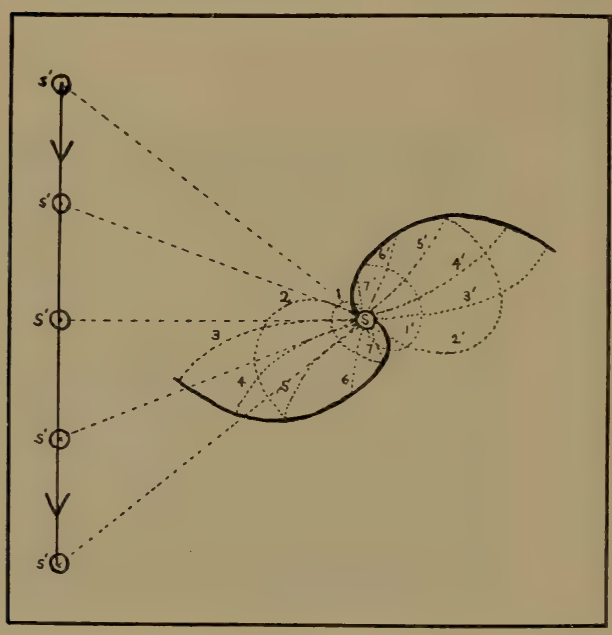

Fig. 20

Diagram to illustrate the formation of a spiral nebula, $S$, sun; $S^{\prime}$, passing star whose direction of motion is indicated by the arrows. The numbered dotted lines show the paths followed by masses pulled out from $S$ by $S^{\prime}$. The straight dotted lines are paths which the rupted masses would have followed had $S^{\prime}$ remained stationary in the respective positions indicated. (Modified after Moulton by W. J. M.) planets, they are called planetesimals. Each planetesimal is considered to have moved in its own orbit around the central mass. The planetesimals did not move along the arms of the spiral, but rather crossed them at considerable angles (Fig. 20). "When we see a spiral we do not see the paths which the separate masses have described, but the positions which they occupy at the time. In the present case (Fig. 20) if a smooth curve is drawn through the regions where the matter is densest, it will form a sort of double spiral as represented by the full lines" (Moulton). The dotted lines in

the figure represent orbits of some of the particles or knots. Due largely to crossing of orbits, the knots increased in size by a gathering in or accretion of the planetesimals. Meteors, which now strike the earth, are thought to be planetesimals still gathering in, though very slowly at present. The spiral orbits of the knots (planets) gradually gave way to the elliptical orbits due to a sort of wrapping up process around the central attracting body (sun). 
The origin of the spiral is suggested as having been due to the disrupting influence of the central body or sun by a passing star, the disrupted particles or masses at first moving straight toward the passing star, but, because of change in position of the passing body, the disrupted masses gradually became pulled around and their paths curved into spirals as shown in Fig. 20. In accordance with the principle of the well-known tide producing force, similar disrupted masses must also have shot out from the opposite side of the sun or central body. Finally when the passing star had so far gone by as to have largely lost its power of effectively attracting the sun, the spiral orbits of the planetesimals gradually became coiled into elliptical or nearly circular orbits around the sun.

Briefly, according to this hypothesis, the earth was never a highly heated gas and never necessarily more highly heated than at present, hence sedimentary as well as igneous materials may well be expected among the earliest formed rocks. Instead of a much larger original earth, it increased in size by accretion of planetesimals. With increase in size came increase in force of gravity, causing compression of the earth's matter and generation of more and more interior heat. Accompanying this increasing pressure and heat, gases (including water vapor) were driven out to form an atmosphere which gradually became larger and denser. When the water vapor had sufficiently accumulated, precipitation resulted to initiate the hydrosphere.

\section{Tabular Summary of Stages of the Earth's History ${ }^{1}$}

9. Cenozoic era

8. Mesozoic era

7. Paleozoic era Sedimentation predominant over vulcanism. Higher forms of organisms.

6. Proterozoic era

5. Archeozoic era $\{$ Vulcanism predominant over sedimentation. Either initial or at least only very simple organisms.

\section{Nebular hypothesis}

4. Hydrospheric (oceanic) stage.

3. Lithic (congelation) stage.

2. Molten stage.

1. Nebular (gaseous) stage.

\section{Planetesimal hypothesis} Initial hydrospheric (oceanic) stage. Initial volcanic stage. Initial atmospheric stage. Nuclear (non-gaseous) stage.

1 Modified after Chamberlin and Salisbury. 


\section{CHAPTER IV}

\section{THE ARCHEOZOIC ERA}

The Oldest Known Geologic Records. - In earth history, as in human history, the recorded events of earliest times are fewest and most obscure, and hence the least intelligible of all. In spite of a certain disadvantage in beginning with the least known part of the history of the earth, the only satisfactory method of presenting the subject is "to follow the natural order of events. This has the great advantage of bringing out the philosophy of the history the law of evolution" (J. Le Conte). The earliest known geologic history is recorded in the rocks of the Archean system. While it is true that the most obscure records of any rock system are here, partly because the original structures of these rocks have generally been so profoundly changed (metamorphosed) and partly because of the utter absence of anything like determinable fossils, nevertheless, certain very important conclusions regarding the earliest known era of geologic time may be reached through a study of the rocks of the Archean system. The present state of our knowledge does not warrant the subdivision of the Archeozoic into two or more definite periods or systems.

General Character and Origin of the Archean Rocks. - "Archean Complex," "Basal Complex," "Fundamental Complex," etc., are all terms which have been applied to the rocks of the Archean system which invariably occupy a basal position with reference to all other rock systems. "The Archean system is a crystalline complex beneath the base of the determined sedimentary succession. ... The United States Geological Survey has restricted the term to a complex of basic and acidic surface and deep-seated igneous rocks, of schists and gneisses in part derived from them and in part of unknown origin, and of shreds and small masses of metamorphosed sediments, all unconformably below and older than the Algonkian sedimentary rocks, which are the lowest series in which ordinary stratigraphic methods have been applied. Their litho- 
logical variations are many. ... The Archean as a whole is homogeneous in its heterogeneity." 1

Briefly stated, the Archean system exhibits the following characteristics: (1) So far as observed, it always shows a profound unconformity or erosion surface at its summit; (2) its lower limit or base has never been determined, and is likely inaccessible; (3) its thickness is very great, at least tens of thousands of feet, and possibly many miles; (4) its rocks are always crystalline and usually highly metamorphosed and tilted or folded; (5) it comprises a most heretogeneous group of rocks, often intimately associated, such as lavas and tuffs; shales, sandstones, and limestones which have been highly metamorphosed to schists and gneisses, quartzites, and marbles; some beds of iron ore; and great volumes of granite or granitic gneisses; (6) almost invariably igneous rocks (granites or lavas) greatly predominate; (7) it never contains distinct fossils, though certain evidences of life do exist; and (8) so far as known it is universally present at or under the earth's surface.

The Archean has been more or less studied in various countries, and the above named features always appear to characterize it. Caution must be exercised, however, in assigning groups of rocks in different regions to the Archean merely because they present some or many of these characteristics. Many rocks formerly classed with the Archean have been proved to be of later age. If rocks with all the characteristics of Archean lie below definitely determined (by fossils) Cambrian strata, and are separated from the Cambrian by a great series of sedimentary or metamorphic rocks (Proterozoic), then we may be pretty certain that the rocks belong to the Archean system. If crystalline rocks of Archean appearance are directly overlaid by Cambrian strata, or by Mesozoic strata, the crystalline rocks in the first instance may be either Archeozoic or Proterozoic, and in the second instance of any age preceding the Mesozoic era.

Subdivisions of the Archean System. - Wherever studied the Archean appears to be separable into two pretty distinct groups or classes of rocks, namely, (1) a volcanic and sedimentary series, and (2) a plutonic series.

The volcanic and sedimentary series is largely composed of metamorphosed lava flows and volcanic tuffs; some massive igne1 Van Hise and Leith: U. S. Geol. Survey Bull., 360, p. 26. 
ous rocks; and more or less schist, gneiss, quartzite, marble, and some iron ore, representing all the common types of sedimentary rocks in a highly metamorphosed condition. In the Lake Superior district this series is called the Kewatin, and in eastern Canada and the Adirondacks the Grenville.

The plutonic series consists of tremendous masses of deepseated igneous rocks which are mostly red to gray granites, often of different ages, and at times with more basic syenitic to even gabbroic facies. A most important feature of this series, called the Laurentian in the Lake Superior district and in eastern Canada, is the fact that it is invariably intrusive into the first or lavasedimentary series. Thus as regards actual position in the earth's crust, the Laurentian rocks generally lie under the Kewatin or the Grenville, but since the contact is clearly an intrusive one, the law of superposition cannot here be applied for relative age determination.

The following tabular summary will serve to make clear the subdivisions of the Archeozoic and its relation to the Proterozoic in a portion of North America where the pre-Cambrian rocks have been most carefully studied.

\section{Lake Superior District}

Paleozoic................... Cambrian

\section{Great Unconformity}

Proterozorc
(Algonkian) $\left\{\begin{array}{c}\begin{array}{c}2 . \text { Keweenawan } \\ \text { (unconformity) }\end{array} \\ \text { 1. Huronian }\end{array}\left\{\begin{array}{c}\text { Upper (Animikian) } \\ \text { (unconformity) } \\ \text { Middle } \\ \text { (unconformity). } \\ \text { Lower }\end{array}\right.\right.$

\section{Great unconformity}

ARCheozoIC $\left\{\begin{array}{l}2 . \text { Laurentian granite } \\ \text { (Intrusive into Kewatin) } \\ \text { 1. Kewatin series }\end{array}\right.$

Correlation of Archean Rocks. - Because of the complete absence of satisfactory methods of correlation, pre-Cambrian rocks in one region cannot certainly be regarded as equivalent to those in another region separated from it. Thus the Grenville of eastern Canada cannot at present be certainly correlated with 
the Kewatin of the Lake Superior region, though all available evidence strongly points to such a correlation. If this be true, it is evident that the whole of the Proterozoic is absent from eastern Canada and the Adirondacks where Upper Cambrian strata rest upon Grenville and Laurentian. The Grenville is essentially a sedimentary series, many thousands of feet thick, consisting largely of gneisses, quartzites, and crystalline limestones, representing what were once shales, sandstones, and limestones. These are often distinctly banded because of original alternations in deposition of the sediments, and sometimes igneous rocks of Grenville age appear to be mingled with the strata. The Kewatin, on the other hand, is essentially a volcanic series of lavas and tuffs with sediments in minor quantity.

It must be remembered that the

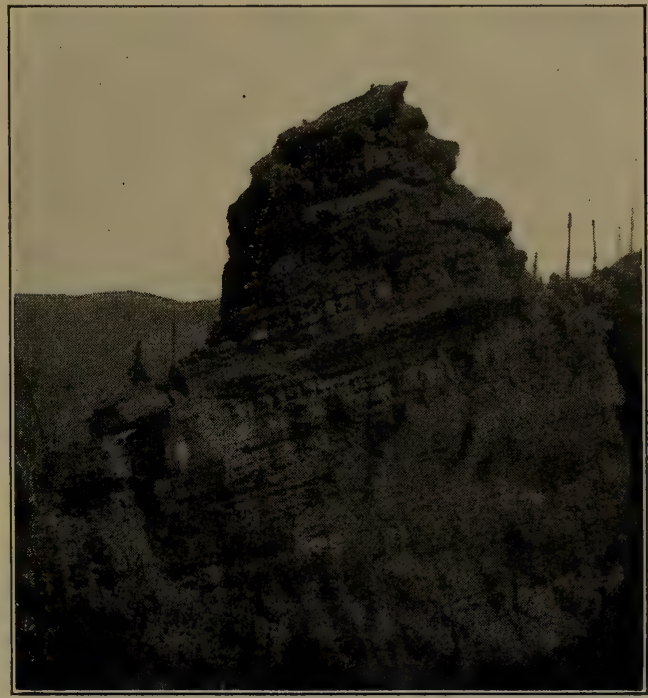

Fig. 21

Archean (Grenville) sedimentary gneiss in the central Adirondacks. Note the distinct stratification. (W. J. Miller, photo.)

Archeozoic represents a vast length of time. In fact the Archeozoic era may have been longer than all subsequent time, particularly if the Planetesimal hypothesis be accepted, because, according to that view, volcanic extrusions with gradually increasing accumulation of sediments might well enough have taken place long before the earth had attained anything like its present size. Realizing the very great thickness of rocks and time which the Archean represents, it scarcely seems probable that its base, or even the base of that portion which carries sediments, is anywhere exposed to view. Bearing these things in mind we also see 
that though in many regions rocks may be confidently referred to the Archean system, nevertheless, such rocks may really represent vast age differences within that system.

Distribution of the Archean. - So far as known, Archean rocks appear to be universally present at or below the earth's

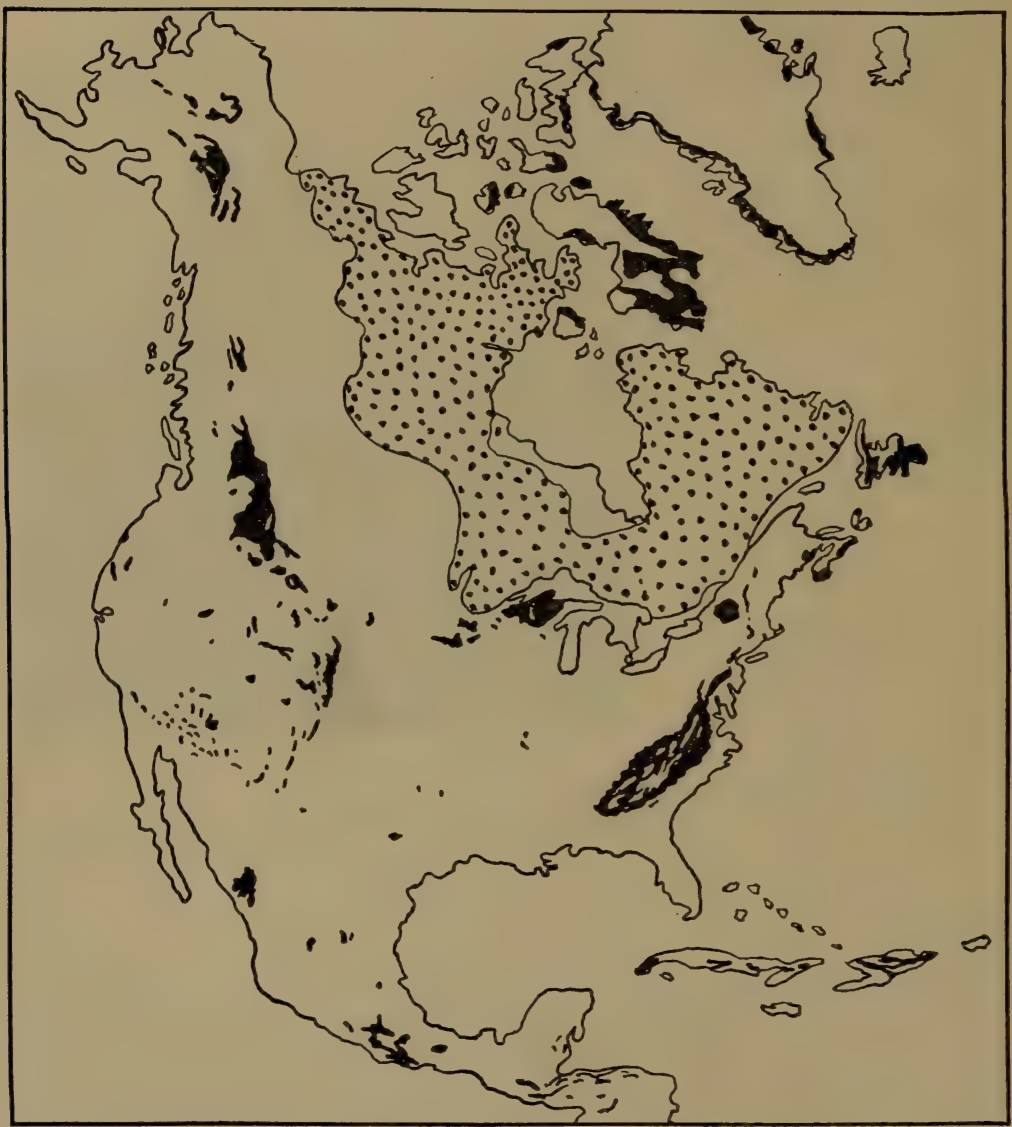

Fig. 22

Map showing the surface distribution of pre-Cambrian (Archeozoic and Proterozoic) rocks in North America. Largest area shown by dotted pattern; smaller areas by solid black. (Modified by W. J. M. after Willis, U. S. Geological Survey.) 
surface. If this be true, and all evidence strongly favors such a view, it is a most remarkable characteristic of the Archean, since no other rock system has such a distribution.

A rock formation may be so distributed in the earth's crust as to be present (1) at the surface where mere superficial deposits, such as mantle rock, glacial drift, etc., are disregarded; (2) under cover of later rocks, but where its presence is certainly known from surface observations, well borings, etc., and (3) under cover of later formations, but where its presence cannot be definitely proved. Considering all regions which have been geologically explored, the Archean is estimated to appear at the surface over about onefifth of the land area of the earth.

On the accompanying map (Fig. 22) the surface distribution only of the Archean rocks in North America is shown. In the Canadian region especially, some portions mapped as Archean may really belong to the Algonkian or even later systems, because so much of that area has not been mapped in detail. At any rate, the map shows the greatest area of Archean in North America to be around Hudson Bay. This vast area of fully 2,000,000 square miles consists mostly of Archean. Among the principal smaller areas are those of Newfoundland, New England states, Adirondack Mountains, Piedmont Plateau district, Michigan, Wisconsin, Minnesota, and numerous small areas in the Rocky Mountain district (including Alaska) and westward. In drilling deep wells in many places, particularly in the upper Mississippi Valley, rocks of the Archean complex have been encountered, and so we may be confident of the presence of Archean under cover of thousands of square miles of later rocks. These facts of distribution, together with the fact that wherever erosion has gone deep enough the Archean never fails, leave little room for doubt concerning the universal presence of the Archean in North America.

Foreign Archean. - Judging by exposures along its borders, Greenland appears to be largely occupied by Archean rocks.

The Highlands of Scotland show one of the most clearly exposed areas of Archean in the world, and detailed studies have shown it to be remarkably like that of the Lake Superior region.

Scandinavia exhibits the largest area of Archean rocks in Europe, and considerable study has shown the rocks to be very similar to those of North America. 
Archean rocks are also known in Finland, France, Bavaria, Bohemia, Spain, India, Australia, China, and Japan.

Life and Climate of the Archeozoic Era. - If the term "Archeozoic" is properly applied, rocks of that age should show the earliest evidences of life. Certain beds of graphite; beds of iron ore which were derived from carbonates; the not uncommon occurrence of numerous flakes of graphite in certain Archean schists, gneisses, and crystalline limestones; and the very existence of the limestone itself, altogether quite certainly imply the existence of life in Archeozoic time. Limestone has sometimes been of chemical origin, but the presence of clearly bedded graphitic schists and crystalline limestones in a distinct sedimentary series almost certainly shows the influence of organisms in the production of both the graphite and the limestone.

As to the character of the life nothing definite can be said, not even whether it was plant or animal or both. Nothing like determinable fossil forms have been found in Archean rocks, and even if such ever were present they must have been obliterated by the intense metamorphism to which the rocks have been subjected. In the light of the evolution which took place during much better known geologic time, it is quite certain that the Archeozoic organisms must have been much simpler forms than those of the early Paleozoic which, in turn, were much simpler than those of the present day.

All we can say about Archeozoic climate is that, during some of the time at least, it was favorable for the existence of life and for ordinary geologic processes such as erosion and sedimentation.

Economic Products. - Iron ore in workable beds occurs in the Archean of the Lake Superior district.

Granting the Archean age of the Grenville series, it contains valuable marble deposits as at Gouverneur in northern New York.

Granites intrusive into the Grenville contain rich magnetite deposits in Essex county, New York.

The cobalt and nickel deposits of Ontario, Canada, are, in part at least, associated with Archean rocks. 


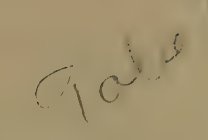

\section{CHAPTER V}

\section{THE PROTEROZOIC ERA}

The Proterozoic era, represented by the Algonkian system of rocks, includes the time between the Archeozoic and the earliest Paleozoic (Cambrian) period, the Cambrian system comprising the oldest known rock system with abundant fossils.

Great Unconformity between the Archean and Algonkian Systems. - As already stated, wherever observations have been made under favorable conditions, the summit of the Archean complex appears to be marked by a profound unconformity. Such an unconformity, however, cannot be universal because the very fact of extensive erosion of certain areas implies the deposition of the eroded sediments in other areas. Such sediments, if found, would contain the records of the time interval indicated by the great unconformity. So far at least, this sedimentary record has not been brought to light, probably either because (1) these sediments were deposited in ocean basins not since exposed as dry land; or (2) these sediments are not at present exposed to view because concealed under later formations; or (3) these sediments have not been recognized as such. Also it is not at all unlikely that some or even many of these sedimentary areas may subsequently have become land areas so that, as a result of erosion, more or less of the sediments were again removed to again be deposited as Proterozoic or later sediments. Future researches may bring to light some of the now "lost records" which represent the great unconformity or time gap between the Archeozoic and Proterozoic.

General Character and Origin of the Algonkian Rocks. Emphasis should be placed upon the fact that the Proterozoic was the first era during which ordinary processes of weathering, erosion, and deposition of great series of strata became dominant processes, such processes having been dominant ever since. Judging by the records, the Proterozoic, on one hand, was marked by less igneous activity than the Archeozoic, while, on the other hand, it was marked by distinctly more igneous activity than any subsequent 
era. In this respect, therefore, the Proterozoic was transitional in character.

"The Algonkian system as this term is used by the United States Geological Survey, includes sedimentary formations and their metamorphosed equivalents with associated igneous rocks beneath the Cambrian and resting upon the Archean complex. It includes the greater part of the sedimentary rocks of pre-Cambrian age and practically all to which present stratigraphic methods have been found to apply, though it contains also sedimentary rocks so deformed and metamorphosed that their stratigraphy is obscure. ... The Algonkian sediments are known to contain a few fossils, representing the earliest forms of life yet found." 1

An important feature, especially of the later Proterozoic rocks, is the frequent presence of great series of non-metamorphosed strata which are therefore the oldest known unaltered strata of the geologic column. Such strata include all common types of sedimentary rocks as conglomerates, sandstones, shales, and limestones. Basal conglomerates, which were derived from the lands over which the Proterozoic seas at various times spread or transgressed, are frequently found at the bottoms of the great sedimentary series. Other great series of Proterozoic rocks of undoubted sedimentary origin are more or less metamorphosed to schists, quartzites, and crystalline limestones. The earliest Algonkian sediments were derived from exposed portions of the Archean, while later Algonkian sediments may have been derived either from exposed Archean or older Algonkian. That the processes of sedimentation during the Proterozoic era were essentially the same as those of today is clearly proved by the very character of the sediments, the typical stratification to even lamination, shallow-water marks, etc.

Beside the sedimentary deposits, there is much igneous rock both in the forms of intrusions into the sediments, and as extrusions or lava-flows. In the latest (Keweenawan) Algonkian series of the Lake Superior district lava flows or beds predominate over sediments, while in the older Algonkian series igneous rocks (either intrusive or extrusive) may locally predominate.

In addition to the frequent metamorphism, the Algonkian rocks have often been subjected to great deformative movements in the earth's crust so that the rocks have either been tilted or highly

1 Van Hise and Leith: U. S. Geol. Survey Bull. 360, 1909, p. 32. 
folded. Sometimes they have been infolded among the Archean rocks.

Subdivisions of the Algonkian. - In many regions where detailed studies have been made, the Algonkian system may be subdivided into from two to four series separated by distinct unconformities. In some places only one series has been recognized. At present no such subdivision into series has a worldwide or even continent-wide application. Generally each of these series shows a thickness of at least a few thousand feet, while the whole Algonkian system has a maximum thickness of many thousands of feet, or, according to some estimates, at least ten miles in

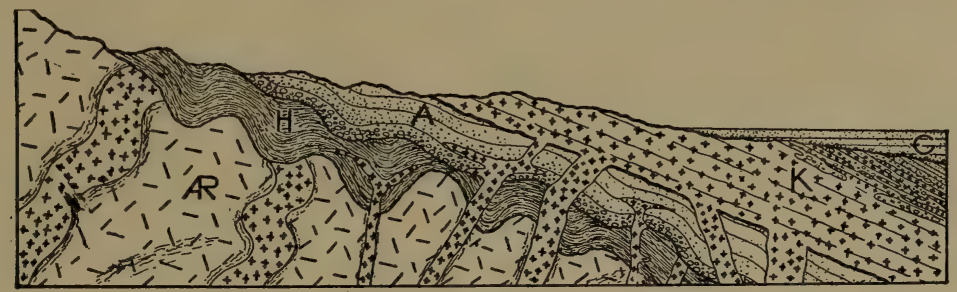

Fig. 23

Diagram showing the principal subdivisions of the Proterozoic and their relation to the Archeozoic in the Lake Superior district. $A R$, Archean; $H$, Huronian; $A$, Animikean; $K$, Keweenawan. (From Chamberlin and Salisbury's "Geology," permission of Henry Holt and Company.)

the Lake Superior district. These subdivisions or series of Algonkian rocks will perhaps be best understood by briefly describing a few of the better known regions.

Lake Superior District. - One of the best and most carefully studied Algonkian districts in the world is that around Lake Superior. Algonkian rocks are there divided into four distinct, largely sedimentary series separated from each other by unconformities, and named Lower Huronian, Middle Huronian, Upper Huronian (Animikian), and Keweenawan (Fig. 23). At some localities not all of these series are represented. The relations of these series to each other and to the Archeozoic below and Paleozoic above are brought out in the tabular arrangement given on page 42. As indicated by the unconformities, the deposition of each series was succeeded by emergence of the region accompanied by erosion, and this in turn followed by submergence accompanied 
by deposition of the next series. Such repeated changes of relative level between land and sea, as here recorded for Proterozoic time, are among the most common and important phenomena of geologic history.

The Huronian rocks are principally quartzites, slates, schists, limestone (usually dolomitic), and some conglomerates and beds of iron ore, all of which are metamorphosed sediments. Locally some of these beds have not been metamorphosed. Considerable masses of igneous rock, some intrusive and some lava flows, also are included among the Huronian rocks. The Lower and Middle Huronian are usually much more metamorphosed and folded than the Upper, the latter being at times scarcely at all deformed or metamorphosed. Estimates show the aggregate (maximum) thickness of the Huronian rocks to be no less than two or three miles.

The Keweenawan, or latest Proterozoic series, is characterized by a great preponderance of lava flow which constitute the lower portion of the series; are prominent in its middle portion; and are practically absent from the upper portion. Some idea of the stupendous and continuous volcanic activity of Keweenawan time may be gained from the fact that lava sheets, mostly not over a hundred feet thick each, accumulated to a depth of at least five or six miles. Between some of the later lava sheets, thin beds of sediment were deposited, while the upper part of the Keweenawan consists altogether of sediments, chiefly conglomerates and sandstones. The sediments are estimated to have a thickness of about three miles, so that the whole Keweenawan series must be some eight or ten miles thick.

Rocky Mountain Region. - Perhaps the largest known area of Algonkian rocks in North America is that in the Rocky Mountains of the northern United States and southern British Columbia. These rocks generally rest upon eroded Archean and they are overlain unconformably by Cambrian or still younger strata. The rocks consist mostly of quartzites, sandstones, shales, and limestones, more or less associated with igneous rocks. Their thickness is at least two or three miles. Some of the strata (in Montana) contain fossils. In central Montana at least the Algonkian strata appear to have been upturned, folded, and somewhat eroded before the deposition of the Cambrian. At present no satisfactory subdivision of these rocks has been determined. 
Grand Canyon of the Colorado. - In the Grand Canyon of the Colorado River, there are excellent exposures of Algonkian rocks with their relations to the Archeozoic and and Paleozoic well exhibited (Fig. 24). The Archean complex comprising "granites, gneisses, and schists was almost completely leveled before the deposition of the next overlying series. The unconformably overlying series is the Grand Canyon (Algonkian) series, 11,950 feet thick, consisting of two groups - the Unkar, 6,830 feet thick, and the Chuar, 5,120 feet thick. The Unkar group consists of sandstones and limestones interstratified with basalts, and has at its base a conglomerate. . . . Resting upon the Unkar group with a slight unconformity is the Chuar group. It consists of shales, sandstones, shaly limestones, and limestones." 1

Correlation of Algonkian Rocks. - The statements made regarding the difficulties of correlating the Archean rocks apply almost equally well here. Algonkian rocks being, however, more largely distinctly sedimentary, and usually not so severely metamorphosed; usually separated into series by well-defined unconformities; and with fossils gradually coming to light in certain of the uppermost series, afford a much more satisfactory basis for applying ordinary stratigraphic methods of correlation than do the Archean rocks. Remarkable similarities such as exist between the Superior and Grand Canyon Algonkian series are highly suggestive of correlation, though far from actually demonstrable at present. Lithologic and structural similarities alone are not safe methods of correlation. Future studies, however, are quite likely to yield satisfactory results in some cases at least.

Not only the lack of fossils, but also the vast length of time of the Proterozoic era, are great difficulties in the way of correlation. Considering the time necessary for the deposition of the tremendous thickness of Algonkian rocks, and the several long unrecorded time intervals, it seems reasonable to believe that the Proterozoic era was fully as long as the Paleozoic. Hence two similar series of Algonkian rocks resting directly upon the eroded surface of the Archean in widely separated regions may in reality be far different in age because the Archean in one region may have remained unsubmerged very much longer than in the other. Or again, an Algonkian series of one district may actually have been deposited during a time represented by an unconformity in another district.

${ }^{1}$ Van Hise and Leith: U. S. Geol. Survey Bull. 360, 1909, p. 778. 


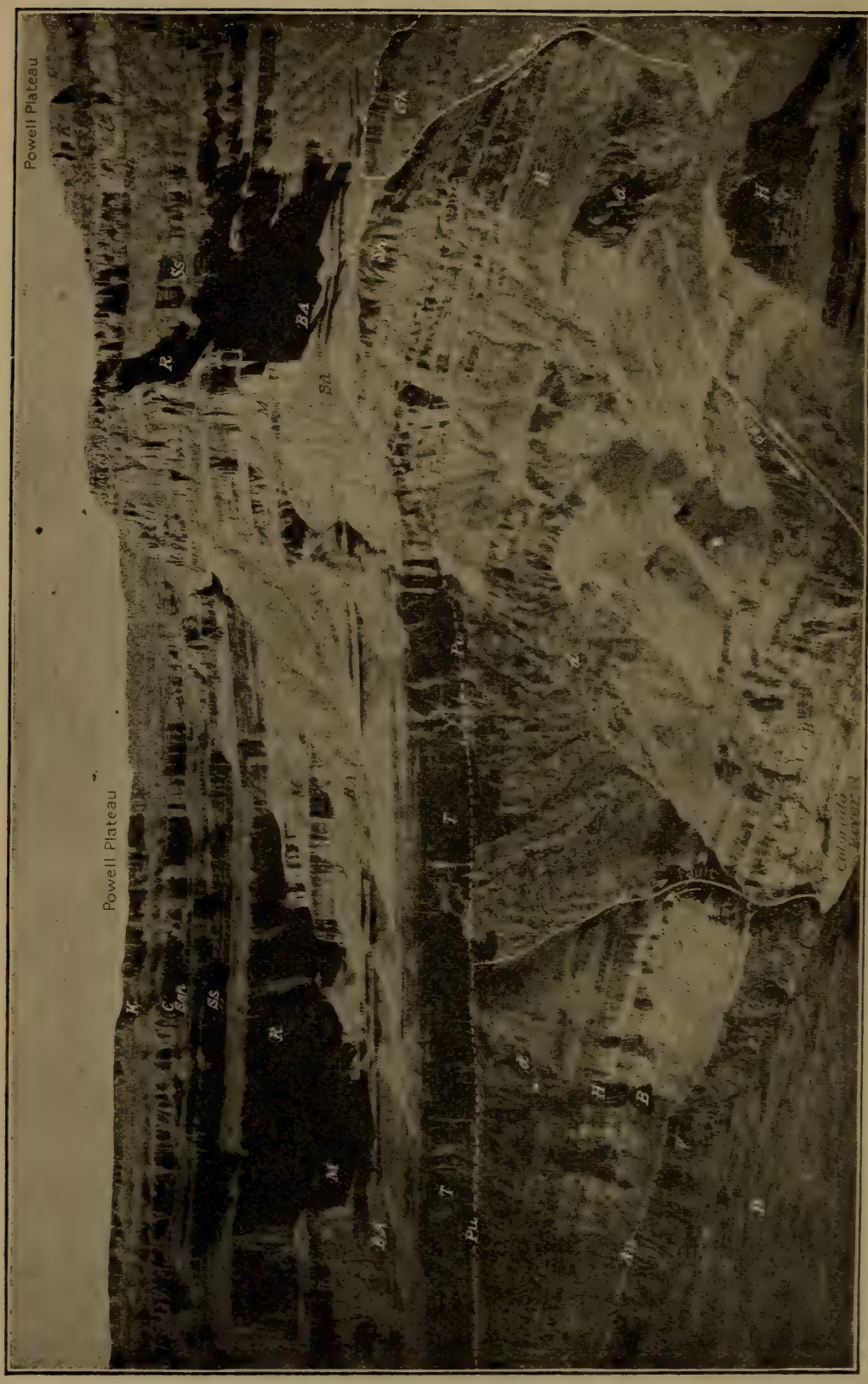

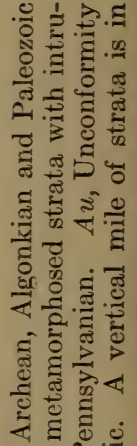

“

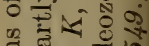

气ี

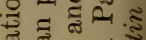

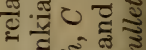

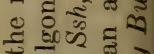

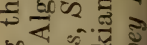
60 次

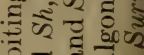
믈 ส సี si $\frac{0}{2} \approx$

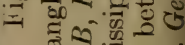
ㅅ..응

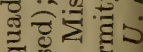

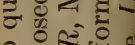
\& $\frac{0}{2} \ldots \frac{0}{0}$

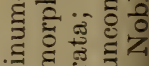

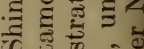

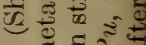

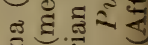
도을

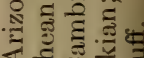

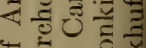

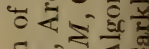

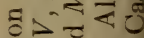
ลี ส ర๊

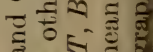

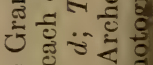
용 ב $\overline{3}$ $\Xi \frac{1}{0} \frac{3}{0}$ . 
Distribution of the Algonkian. - As already stated, perhaps the largest Algonkian area in North America is that of the Rocky Mountains in the northern United States and southern British Columbia. The well-known Lake Superior district of Algonkian is also of large extent. There are considerable areas in eastern Canada west of Hudson Bay, and smaller areas in Newfoundland, Nova Scotia, the Piedmont Plateau, at several places in the Mississippi Basin, Texas, Arizona (especially in the Grand Canyon), Nevada, and at various places in the Rocky Mountain system throughout the United States and Canada.

Foreign Algonkian. - Algonkian rocks are thought to exist in all continents. In the Highlands of Scotland, the Torridon sandstones and shales, about 10,000 feet thick, are quite certainly of Algonkian ${ }^{1}$ age, since they lie unconformably between the Archean complex below and well-defined Cambrian above.

The large pre-Cambrian rock area in Scandinavia, which in many respects is similar to that of Scotland, also contains considerable bodies of sediments (at least 10,000 feet thick) of Algonkian age, the term "Algonkian" having actually been applied there. As in the Lake Superior region, iron ore occurs in some of the Swedish Algonkian.

In Finland, France, Germany, Spain, and probably in India and Brazil, Algonkian rocks are known.

It should be noted that in several of the foreign countries there appears to be a division of the Algonkian system into at least two series separated by unconformities.

Life and Climate of the Proterozoic Era. - As has been mentioned, determinable fossils have been found in the upper Algonkian rocks of Montana and the Grand Canyon of the Colorado. These fossils include Worm tracks, a Brachiopod, and fragments of Crustaceans. In Europe a few similar fossils have been found. Recently the discovery of Radiolarians in the Proterozoic rocks of France has been reported. "The traces of pre-Cambrian life, though very meager, are sufficient to indicate that the development of life was well advanced long before Cambrian time began. ... Stratigraphically, this fragment of what must have been a large fauna occurs over 9,000 feet beneath an unconformity at the base of the upper portion of the Lower Cambrian in northern

1 Thus far the term "Algonkian" has not often been used in foreign countries. 
Montana." 1 More and still older forms are quite likely to be discovered, though the remains thus far found are those of very thin-shelled animals and hence not so favorable for fossilization. Most animals of the time were probably without shells or other hard parts.

Very recently Walcott has described a number of species of calcareous Algæ from the Belt series (Algonkian) of Montana

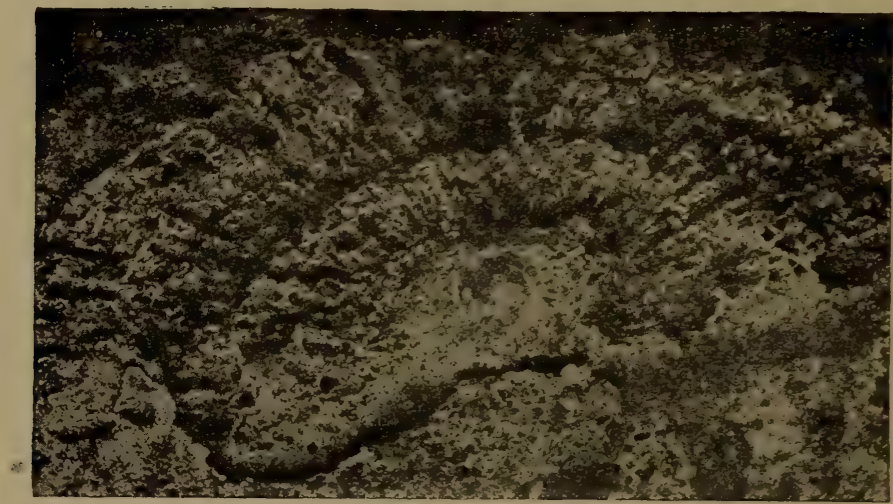

Fig. 25

Part of a pre-Cambrian (Huronian) Alga. This is one of the oldest known definitely determinable fossils. After Geol. Sur. Canada. (From Schuchert's "Historical Geology," permission of John Wiley and Sons.)

and one (discovered by Lawson) from a Huronian limestone of western Ontario, this latter being the oldest known well preserved fossil. These Algæ were very simple plants (Thallophytes) which lived in water. They were hemispherical or cylindrical bodies which secreted crudely concentric layers of carbonate of lime from 1 to 15 inches in diameter. They occur in distinct beds through hundreds or even thousands of feet of Algonkian limestones.

Graphite and carbonaceous material so often disseminated through the shales and schists almost certainly indicate the existence of life. Likewise beds of limestone (even near the base of

1 C. D. Walcott: Jour. Geol., Vol. 17, 1909, p. 196. 
the Algonkian) and iron ore are rarely ever known to have been formed except through the agency of organisms.

Since the great masses of Proterozoic sediments are of quite the usual sort like those formed in later eras, and since life surely existed, we can be certain that the climate of the time was favorable for the operations of ordinary geologic processes and hence not fundamentally different from that of comparatively recent geologic time.

According to a discovery made a few years ago, there is positive evidence for considerable glaciation in Canada during early Algonkian time. Conglomerate beds at the base of the Huronian are regarded as of glacial origin since there are "angular and subangular boulders of all sizes up to cubic yards, enclosed in an unstratified matrix. These boulders are often miles from any possible source. Recently, striated stones have been broken out of their matrix in the Lower Huronian of the Cobalt-Silver region, giving still stronger proofs that the formation is ancient boulder clay." 1 A climatic condition favorable for glaciation so early in the earth's history is, to say the least, distinctly opposed to ideas of climate of such early geologic time based upon the Laplacian hypothesis of earth origin.

Economic Products. - The greatest iron mining region in the world is the Lake Superior district in Minnesota, Michigan, and Wisconsin. Some of these iron ores are in the Archean, and some in the older Huronian rocks, but the principal deposits are in the Upper Huronian. These iron ores occur as thick beds in the sedimentary series. Often the iron ore deposits have been enriched by the work of underground waters. The Lake Superior district produces many millions of tons of iron ore, or far more than the production of any foreign country.

The greatest deposits of native copper in the world are in the Keweenawan series on Keweenaw Point, Michigan. Copper has been found in small quantities in the lava beds, and underground waters have dissolved out this copper and deposited it in more concentrated form in fissures and openings of the rock, and also in porous conglomerates. Immense quantities of native copper have been mined here during the past forty years.

1 A. P. Coleman: Jour. Geol., Vol. 16, p. 149. 


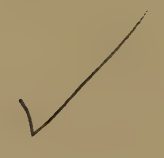

\section{PALEOZOIC ERA}

\section{CHAPTER VI \\ THE CAMBRIAN PERIOD}

The Cambrian represents the earliest period of the great Paleozoic era, and the rocks which make up the Cambrian system include the oldest known of the normal fossiliferous strata. Since these strata are the oldest which carry abundant organic remains, it follows that they are the earliest formed rocks to which the ordinary methods of subdividing and correlating rock masses can be applied. From the Cambrian on, the legible records of events of earth history are far more abundant and less defaced than those of pre-Cambrian time. From now on we shall be able to trace the changing outlines of the relief features of the continents and the evolution of organisms with some degree of definiteness and satisfaction, though a vast amount of work yet remains to be done both as regards discovery of new records and the interpretation of records old and new.

Origin of Name, Subdivisions, Etc.

The oldest Paleozoic rocks were first carefully studied independently in the British Isles by the two able geologists, Sedgwick and Murchison, before the middle of the nineteenth century. Murchison applied the name "Silurian" to the great series of oldest fossiliferous strata and divided them into Lower and Upper Silurian. Sedgwick, however, considered that the very oldest fossil-bearing rocks should be separately designated, hence his application of the term "Cambrian," from Cambria an old Latin name for a part of Wales. The Cambrian is now recognized the world over as the oldest Paleozoic system.

In North America a threefold subdivision of the Cambrian system is recognized as follows: 
General

3. Upper Cambrian..... Saratogan (Croixian) series (Dikellocephalus fauna)

2. Middle Cambrian. (Paradoxides fauna)

1. Lower Cambrian.... Georgian (Waucobian) series (Olenellus fauna)

\section{New York and New England}

Little Falls dolomite.

Potsdam sandstone.

Stissing limestone.

Georgia slate, quartzite and limestone.

Poughquag quartzite.

In the typical regions these strata are superposed one above the other in regular order without unconformity, but careful study has shown that, passing upward in the system of strata, there is a gradual change in the character of the fossils, particularly the Trilobites which are so common and widespread in the rocks. Thus the Lower Cambrian strata are generally characterized by the Trilobite genus Olenellus, with its various species, and this characteristic assemblage of Trilobites is called the Olenellus fauna. This does not mean that Olenellus invariably occurs in Lower Cambrian strata, or that other genera of Trilobites and other fossils may not be present. In a similar way the Paradoxides and the Dikellocephalus faunas are the chief characteristics of the Middle and Upper Cambrian respectively. Such stages or life zones in the geologic column are commonly referred to as horizons. It should be made clear that the genus Olenellus became extinct before the Middle Cambrian strata were deposited; the Paradoxides disappeared before the Upper Cambrian was deposited; and the Dikellocephalus before the deposition of the succeeding Ordovician strata, though it is not meant that sharp lines separate these faunas. Thus each of the faunas becomes an important geologic time or horizon marker. A representative of each of these genera of Trilobites is shown in Fig. 39.

These principles, here laid down as a basis for the subdivision of the Cambrian system, apply equally well to the succeeding rock systems, though many organisms other than Trilobites are used for the purpose.

\section{Distribution and Character of the Rocks}

General Distribution. - On the accompanying map (Fig. 26) the surface distribution of Cambrian rocks is shown, that is to say the locations of the areas in which Cambrian strata are known to outcrop. The principal areas are seen to be in Newfoundland, 
New York, through the Appalachian range, south of Lake Superior, southeastern Missouri, Oklahoma, central Texas, and at various

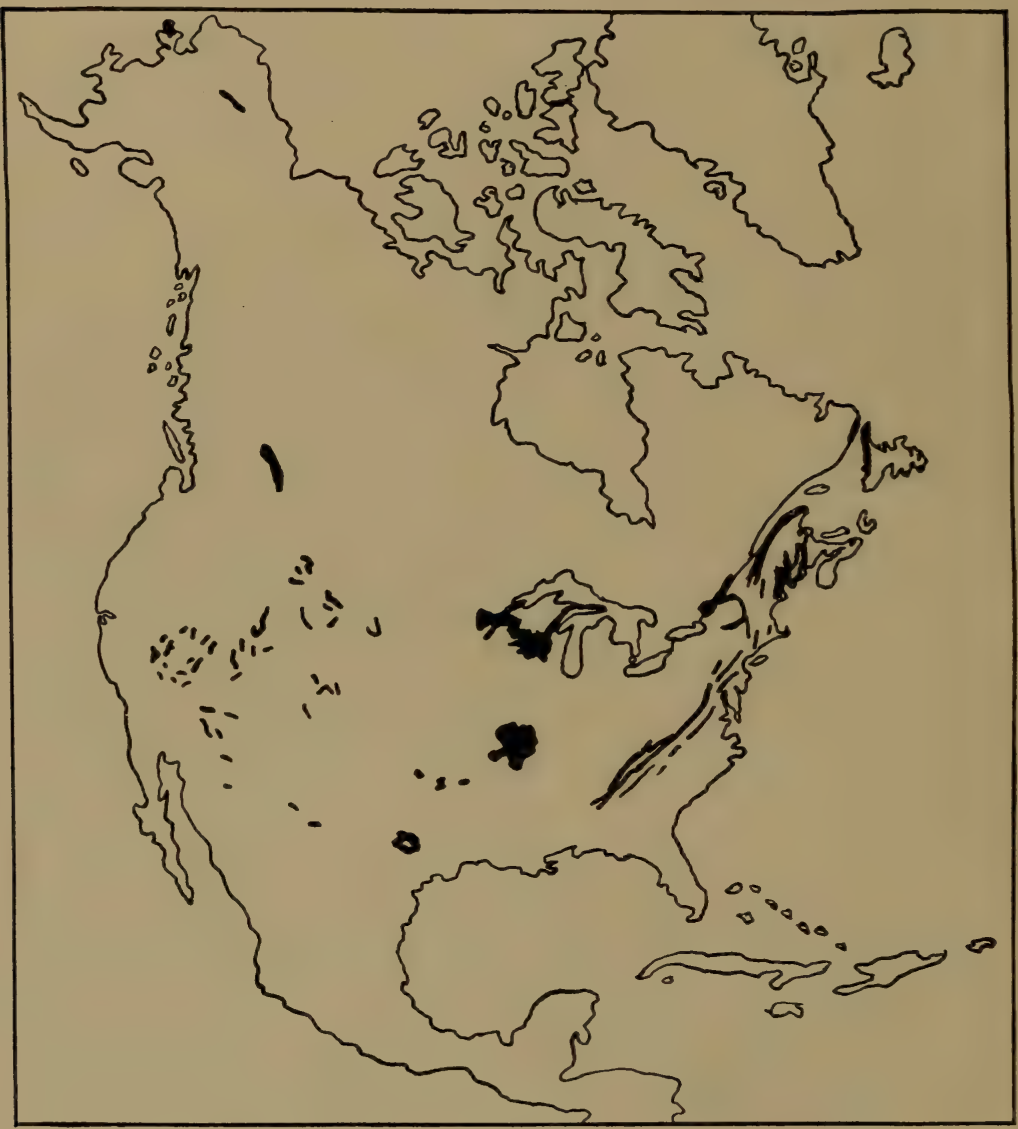

Fig. 26

Map showing the surface distribution (areas of outcrops) of Cambrian, and some very closely associated Lower Ordovician, strata in North America. (Modified by W. J. M. after Willis, U. S. Geological Survey.)

places in the Rocky Mountain region. Because Cambrian rocks have so often been removed by erosion, or have been so largely covered by later sediments, or highly folded so that outcropping 
edges only are now exposed, the surface distribution as indicated on the map fails to give any adequate idea of the former or even present real extent of strata of this age. Thus Cambrian strata are definitely known to have been almost completely removed from several thousand square miles of the northern New York region, and Cambrian rocks have certainly been similarly removed from many other regions. Again, the distribution of the outcrops, together with many deep well sections (Fig. 27), make it certain that Cambrian strata concealed under nearly horizontal later strata spread across much, if not all, of the Mississippi Valley from the Rockies to the Appalachians, while in the Appalachian Mountains Cambrian rocks are really much more extensive than the mere outcropping edges of the upturned strata. There is no reason, however, to think that the vast area of pre-Cambrian rock around Hudson Bay, the Atlantic Coast from New Jersey southward, the Pacific Coast including the Coast Range, Sierra Nevada, and Cascade Mountain areas, were ever covered by the Cambrian sea.

The difference in the distribution of the Lower and Upper Cambrian strata is a prime consideration. Thus the Lower Cambrian is entirely absent from the whole Mississippi Valley except probably its southern border. Otherwise the same general areas are occupied by both Lower and Upper Cambrian strata.

Character of the Rocks. - Cambrian rocks consist very largely of shallow water sediments such as conglomerates, sandstones (Fig. 28), and shales, with well-preserved ripple marks very common. Deeper or clearer water deposits such as limestone, are, however, important in the Appalachians, Vermont, Nevada, and British Columbia. When these sediments were deposited in the Cambrian sea they were like ordinary gravels, sands, marls, and limy oozes now forming in the ocean, especially over the continental shelf areas and their borders. Since their deposition they have been changed into the corresponding harder rocks such as conglomerates, sandstones, shales, and limestones, or, in some cases as in New England, metamorphosed into quartzites, schists or slates, and crystalline limestones (marbles). In many regions the Cambrian strata have been highly folded and faulted.

Thickness of the Cambrian and Igneous Rocks. - The thickness of Cambrian strata in North America varies from less than 1,000 feet to a maximum of over 10,000 feet. North American 


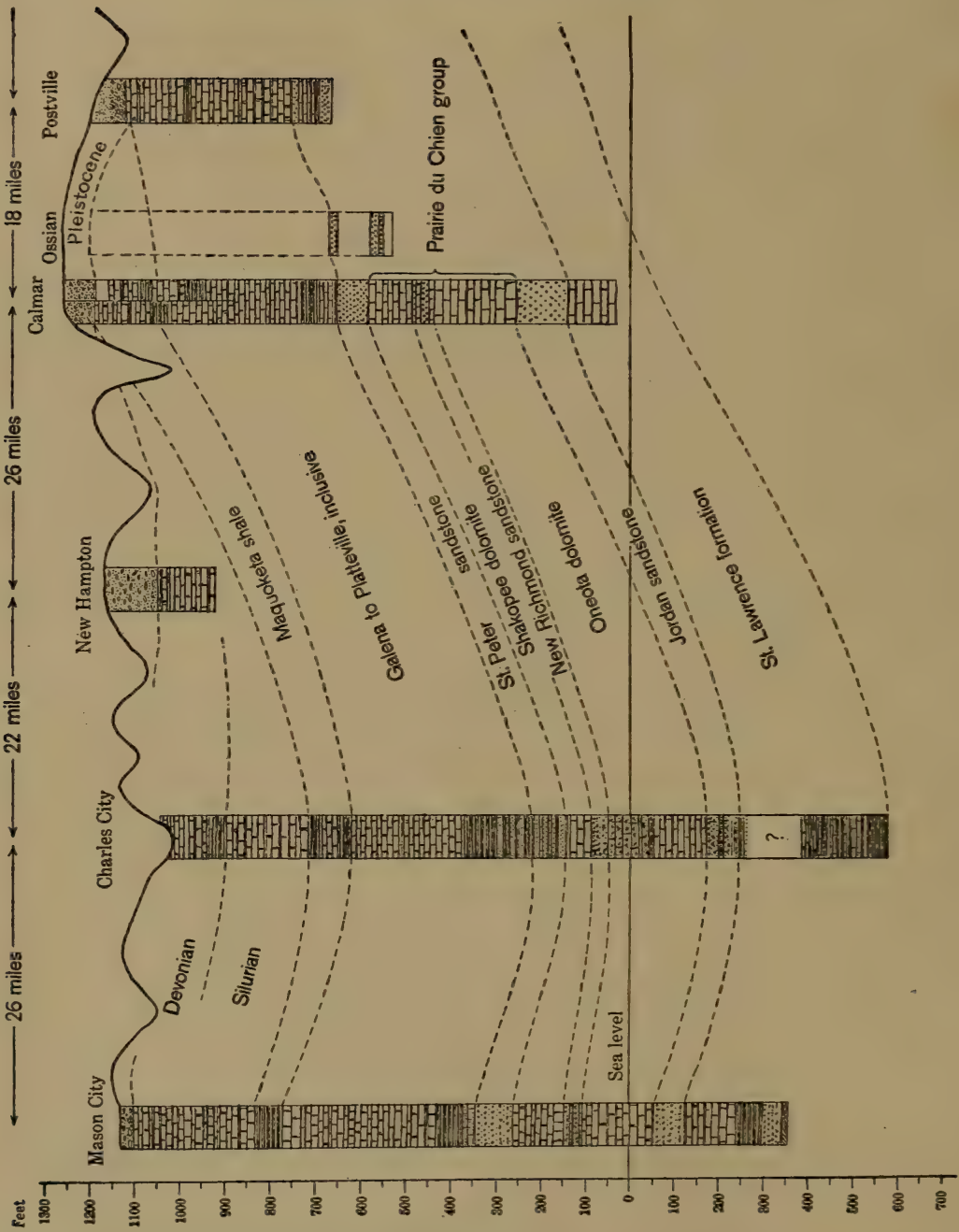

Fig. 27

Geologic section through northeastern Iowa, showing how character, thickness, and distribution of deeply buried rock formations can be determined by a comparison of well records. St. Lamrence and Jordan formations are Cambrian; Oneota to Maquoketa inclusive are Ordovician; and above these are Silurian and Devonian strata as indicated. (After W. H. Norton, U. S. Geological Survey.) 
Cambrian is singularly free from igneous rocks and thus presents a remarkable contrast with the preceding eras.

\section{Physical History}

Great Basal Unconformity. - We have already learned that a profound and seemingly almost universal unconformity separates the Archean and Algonkian rocks. Another great unconformity separates the Algonkian and Paleozoic rocks. Cambrian strata rarely, if ever fail to rest upon the eroded surfaces of either the Archean or the Algonkian. C. D. Walcott has recently (1914) stated that no definitely proved transition rocks between the Cambrian and pre-Cambrian are known in North America. It has been definitely proved, as for example in the Adirondack region, to be quite the rule that the Cambrian sediments not only rest upon an eroded surface of older rocks, but that the surface of these latter had been worn down to the condition of a more or less welldeveloped peneplain. Accordingly, just before and during early Cambrian time, most of North America must have been dry land suffering erosion. Conglomerates containing pebbles of the older rocks are of very common occurrence at the base of the Cambrian sediments. The great duration of this erosion interval which produced such a profound unconformity, not only in North America but in other continents as well, is regarded as one of the greatest physical events of its kind in the history of the earth since the beginning of Paleozoic, or rather late Proterozoic, time.

Early Cambrian. - "The great physical event of the Cambrian period in North America was the progressive submergence of the continent" (Chamberlin and Salisbury). As we have already learned, such a submergence may have been produced either by rising sea level, or subsidence of the land, or both. In the case of the Cambrian submergence there appears to be no escape from the conclusion that a rise of the sea was an important factor, since the development of such an extensive peneplain surface implies that the continent must have remained almost unaffected by diastrophic movements for a long time, and the tremendous volume of material removed and dumped into the sea must have very appreciably raised its level.

Wherever Lower Cambrian marine strata (actually exposed or concealed) rest directly upon pre-Cambrian rocks we can be sure 


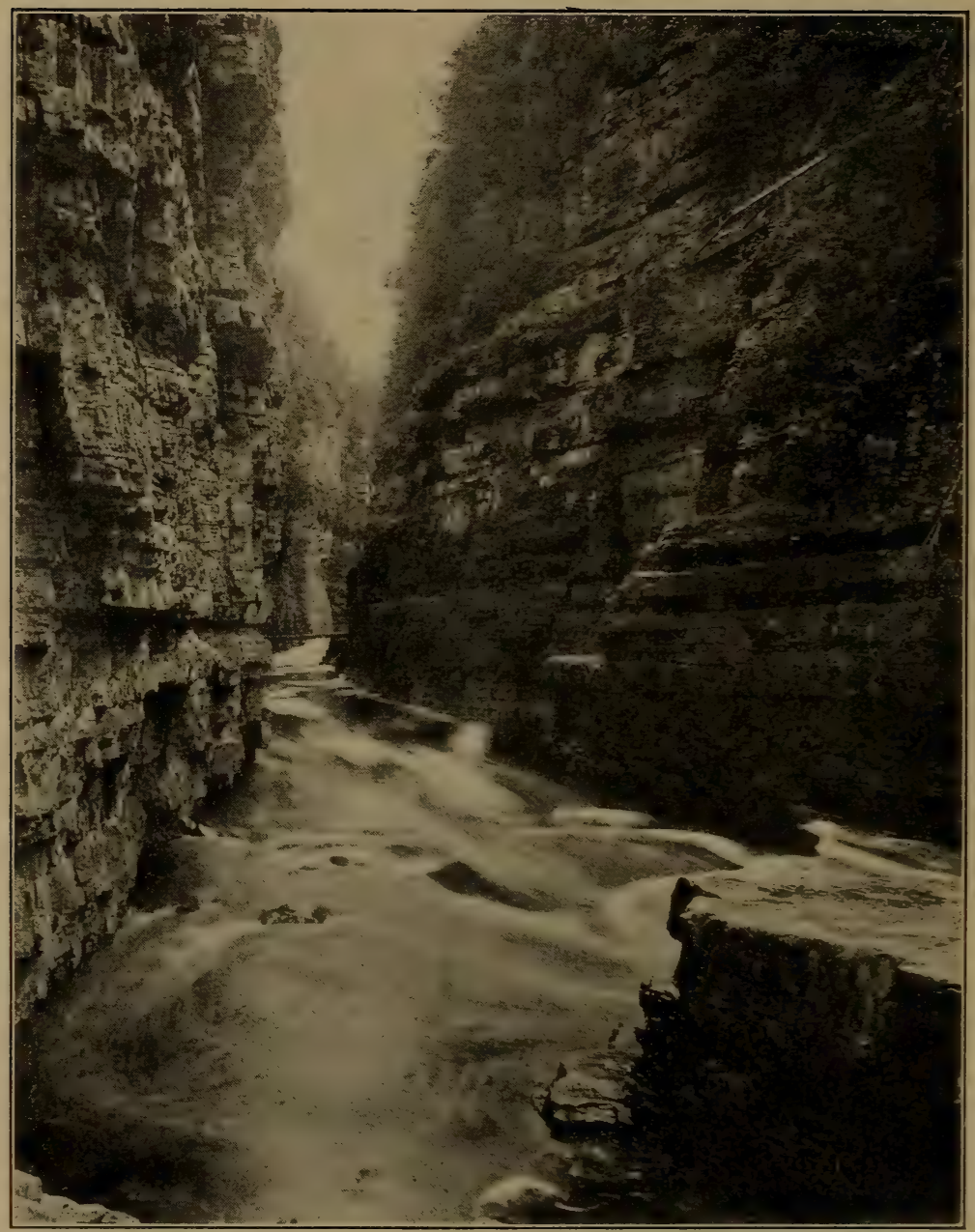

Fig. 28

Upper Cambrian (Potsdam) sandstone in the Ausable Chasm of northeastern New York. The rock is distinctly stratified and full of ripple-marks. (Courtesy of the New York State Museum.) 
that such areas were submerged under the early Cambrian sea, because Lower Cambrian strata could have formed only during that time. To these areas must be added still others from which the rocks have been removed by erosion. Further, since the later Cambrian strata almost invariably rest in perfect conformity upon the earlier, we can be sure that any region occupied by later, but not earlier, Cambrian rocks was never covered by the earlier Cambrian sea because the conformity proves that there was no erosion interval during which any of the earlier Cambrian strata were removed before the deposition of the later. Again, some other areas were almost certainly dry land during early Cambrian time because there is not the slightest evidence of any sort that deposition went on over those areas during that time. The principles here set forth are of fundamental importance in constructing a paleogeographic map of North America for early Cambrian time, and the same principles must be kept in mind in considering the paleogeography of any given region during succeeding time.

In accordance with the above principles, we can be sure that the general outlines of the continent of North America in early Cambrian time were much as indicated upon the accompanying map (Fig. 29). The great central region, between what are now the Rocky Mountains on the west and the Appalachian Mountains and St. Lawrence Basin on the east, was dry land.

Bordering this central mass on the west and on the east were two long, narrow sounds or mediter anean seas, the one on the west covering the present site of the Rocky Mountains, and the one on the east the present sites of the Appalachian Mountains and the Champlain and St. Lawrence Valleys. Lower Cambrian sediments were accumulated in these sounds.

Along the Atlantic side, and bordering the eastern sound, an important land mass, called "Appalachia," extended from New Brunswick southward to the Gulf of Mexico and doubtless included much of the present continental shelf area. As we shall learn, Appalachia apparently persisted, though with more or less changing outlines, throughout the Paleozoic era.

Along the Pacific side, and bordering the western sound, there were considerable (possibly mostly continuous) land masses which separated the sound from the Pacific ocean.

Middle and Late Cambrian. - During middle and late Cambrian time more and more of the continent gradually became sub- 


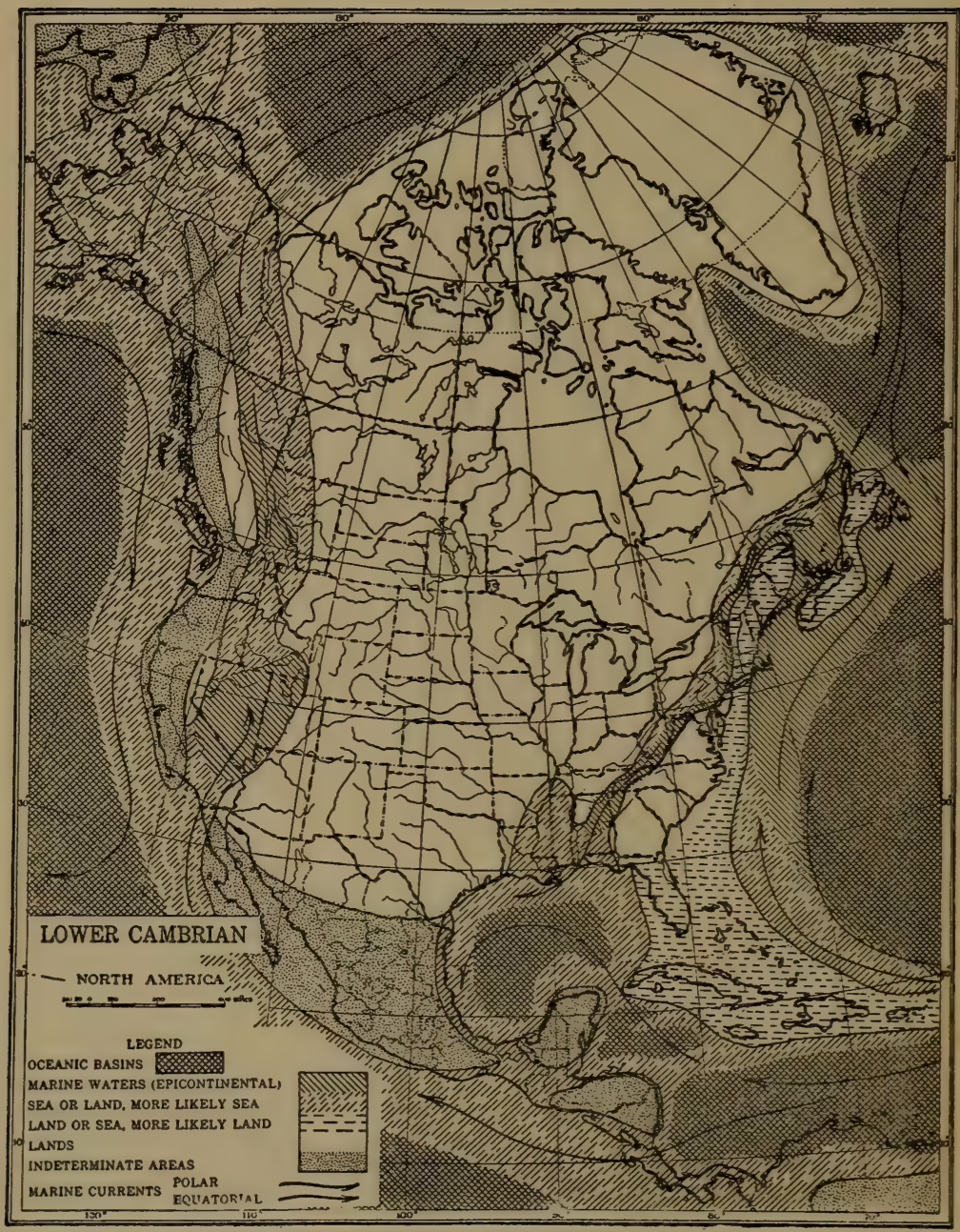

Fig. 29

Paleogeographic map of North America during Lower (early) Cambrian time. (Slightly modified after Bailey Willis, courtesy of The Journal of Geology.) 
merged until the geographic conditions were much as depicted upon the next paleogeographic map (Fig. 30). ${ }^{1}$ The sea transgressed northward over the great interior land to about the northern border of the United States, the early Cambrian sounds merging into this vast interior sea. Around Hudson Bay a large land area still persisted, while Appalachia, and the lands along the Pacific Coast, remained much as they were in the early Cambrian. From Wyoming to Arizona a considerable area appears to have remained as an island above even the latest Cambrian sea. The northward trangression of this great interior sea is clearly established by the fact that studies of actual outcrops and deep well sections show successively younger and younger Cambrian sediments deposited by overlap northward upon the pre-Cambrian rock surface. We also know that this interior sea was shallow because of the character of the sediments which are very largely clastic such as sandstones and shales often ripple marked, and with conglomerates at the base. Some heavy limestone beds like those in eastern New York, and between Virginia and Missouri, tell of clearer, possibly deeper, water in those places.

Close of the Cambrian. - The physical events above outlined prove that the Cambrian period represents a long time, the best estimates ranging from 2,000,000 to $3,000,000$ years, though it should be emphasized that we have no exact standard of comparison in years. The only object in presenting such figures is to impress upon the student the fact of the vast length of time involved. Though the succeeding periods were by no means equal in duration, the best estimates would make no one of them less than $1,000,000$ years long.

Throughout Cambrian time, and even at its close, North America was not affected by any great physical disturbances such as vulcanism, mountain making, or emergence of large areas of land. Only locally, as for example in northern New York, and possibly in the upper Mississippi Valley, is there any unconformity

${ }^{1}$ Recent studies seem to show that "near the close of Upper Cambrian time a broad-spread movement resulted in the temporary withdrawal of the Cambrian sea from the upper Mississippian (valley) area" (C. D. Walcott, 1914). According to Ulrich (Geol. Soc. Am. Bull., Vol. 23, pp. 627-647) the time represented by this marine retrogression and immediately following transgression should be called a separate period - the "Ozarkian." Strata of this age would include some of the latest Cambrian and some of the earliest Ordovician. 


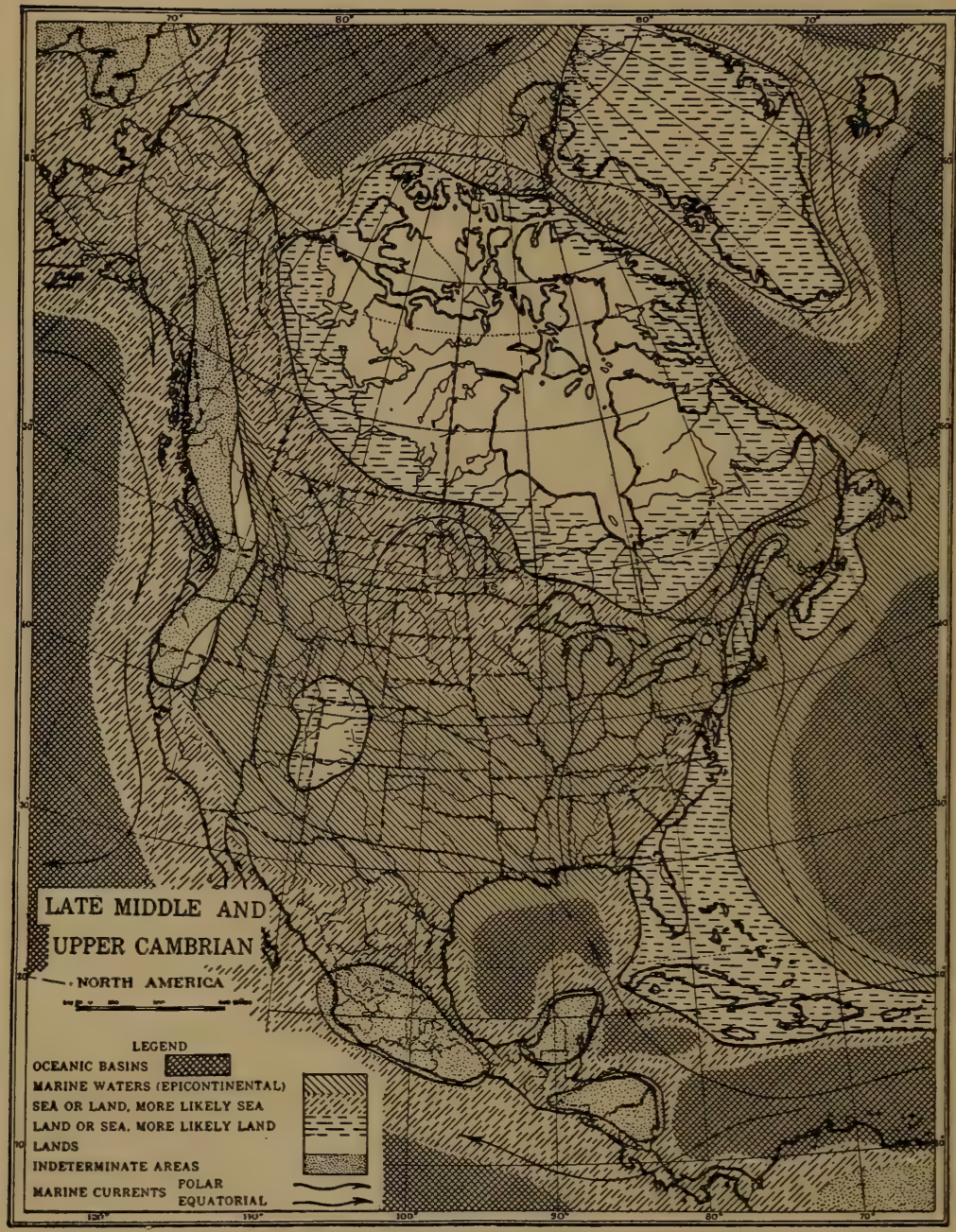

Fig. 30

Paleogeographic map of North America during late Middle and Upper (late) Cambrian time. (Slightly modified after Bailey Willis, courtesy of The Journal of Geology.) 
between the Upper Cambrian and the succeeding Ordovician. Thus we know that the Cambrian period closed quietly. As above outlined, the one great physical event of the Cambrian was the gradual submergence of large portions of the continent.

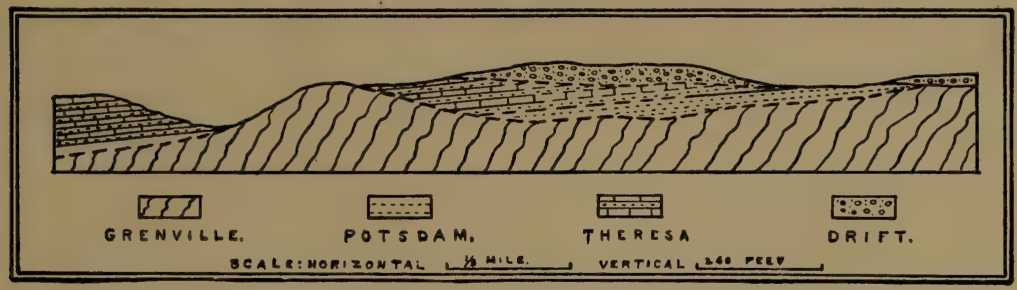

Fig. 31

Structure section in Saratoga County, New York, showing how Upper Cambrian strata overlap upon a hillock of pre-Cambrian rock (Grenville). (After W. J. Miller, N. Y. State Mus. Bul. 153.)

The failure of any important stratigraphic break (unconformity) between the Cambrian and Ordovician systems has forced a rather arbitrary separation of these two systems, based almost wholly upon important changes in organisms.

\section{Foreign Cambrian}

Europe. - Like that of North America, the Cambrian rocks of Europe generally rest upon the profoundly eroded surface of either Algonkian or Archean rocks. The physical geography of the continent, however, differed considerably because the distribution of the rocks shows that the early Cambrian sea was almost wholly limited to northern Europe, while the middle Cambrian sea transgressed farthest over much of France, Germany, Bohemia, Spain, and Sardinia, and by the beginning of the late Cambrian the sea had retrogressed to occupy only northern Europe. Thus much of Europe did not become progressively submerged like North America.

In Wales and Brittany the Cambrian strata appear to have a maximum thickness variously estimated at from 12,000 to 20,000 feet, while in southern Sweden the whole Cambrian is only about 400 feet thick. Like those of North America, the rocks are mainly clastic sediments of shallow water origin such as conglomerates, 
sandstones, and shales. In western Europe, for example in Wales and southern Scandinavia, the Cambrian strata are thoroughly indurated and usually highly folded, but in eastern and central Europe, for example in Russia, the strata are mostly practically horizontal, and even unconsolidated beds of sand and clay have been found. Unconsolidated beds of so great age are truly remarkable.

The Cambrian period closed in Europe without any important physical disturbance.

Other Continents. - The Cambrian of other continents has generally not been well studied, but rocks of this age are known in Australia, Tasmania, India, China, Korea, Siberia, and Argentina. Only slightly folded or tilted strata of Cambrian age up to 20,000 feet thick are known in northern China. Glacial deposits in China, Norway, and Australia will be described under the next heading.

\section{Climate}

Very distinct evidences of glaciation are known in the earliest Cambrian or possibly late Algonkian of China, Norway, Australia, and perhaps also South Africa. At the base of the thick section of Cambrian strata in China "on the Yangtse River, $31^{\circ}$ Lat., i.e. as far south as New Orleans, not high above sea level, a large body of glacial material (170 feet thick) was discovered. . . . It demonstrates the existence of glacial conditions in a very low latitude in the early Paleozoic." 1

At Lat. $70^{\circ} \mathrm{N}$. in Norway, glacial deposits containing clearly striated pebbles have been found resting upon a distinctly smoothed and striated surface of hard rock.

In southern Australia glacial beds of similar age and considerable thickness are distinctly folded along with the enclosing strata.

The significance of these earliest Paleozoic glacial deposits is difficult to exaggerate in considering the climate of the time. The old idea, based upon the Laplacian Nebular hypothesis, that early Paleozoic climate was notably warmer, moister, and richer in carbon dioxide than now, is directly refuted by the evidence of glaciation. Such evidences of glaciation, combined with the character and distribution of the organisms, indicate that Cambrian

${ }^{1}$ B. Willis: Researches in China (Vol. 2), Published by Carnegie Institution of Washington. 
climate was not essentially different from that of comparatively recent geologic time, but that climatic conditions were much more uniform over the earth than now.

\section{Economic Products}

Cambrian rocks, such as the Potsdam sandstone and Little Falls dolomite in New York, furnish considerable quantities of building stone for local use.

Roofing and other slates of Cambrian age are extensively quarried in Vermont and eastern New York. Also the famous slate quarries of Wales are in rocks of this age.

No very important metalliferous deposits are known in Cambrian rocks.

\section{Life of the Cambrian}

Stage of Evolution of Cambrian Life. - The life of the Cambrian possesses a particular importance because, excepting the few scant organic remains found in upper Algonkian rocks, the rocks of this age contain the oldest known assemblage of distinct fossils. Many hundreds of Cambrian species have been described. Even here, however, the organic record is very incomplete both because many Cambrian fossils have not yet been discovered and because a vast number of Cambrian organisms must never have been preserved as fossils. Although Cambrian fossils are scant as compared with those of other Paleozoic systems, nevertheless a striking fact is the large number and complexity of organisms represented. All of the sub-kingdoms of invertebrate animals are represented, though nearly always by only the simpler types of each sub-kingdom, and this together with the positive evidences for pre-Cambrian life, make it perfectly evident that organisms existed and developed (evolved) for a vast length of time before the opening of the Cambrian. It is generally agreed that fully half of the evolution of organisms had taken place before the beginning of the Cambrian period.

In spite of so much pre-Cambrian evolution of organisms, it is to be remembered that, as a result of post-Cambrian evolution, literally enormous advancement has been made, so that Cambrian forms are really simple or primitive as compared with many of the highest living forms. To illustrate, there is a vast gulf between the degree of organization of the highest Mammals of today and 
the highest forms (simple Arthropods) of Cambrian time, and all of this development has been gradually accomplished since Cambrian time.

Passing upward in the Cambrian system, the fauna shows a gradual progress toward more highly developed or organized forms.

Apparent Suddenness of Appearance of the Cambrian Forms. - The apparent suddenness of appearance of so many highly developed organisms even in the early Cambrian has caused much discussion by way of attempted explanation. Geologists are agreed that this seeming sudden appearance of so many forms is due to imperfection of the record either because of unfavorable conditions for the preservation of fossils in the pre-Cambrian sediments, or because fossils, though once present in those rocks, have been obliterated by subsequent changes or metamorphism. Further, it is agreed that the first organisms were plants because animal life is ultimately dependent upon vegetable matter as a food supply.

It should be recognized that the metamorphic, or crystalline, character of all Archean and most Algonkian rocks is obviously unfavorable for preservation of determinable fossils. Thus, Archean sedimentary rocks have flakes of graphite (carbon) disseminated through them and, though such carbon is of organic origin, the original organic structures have been entirely obliterated so that crystallized carbon only remains after the intense metamorphism. Such an explanation, however, does not by any means answer the whole question, because, at a number of localities, thousands of feet of non-metamorphosed pre-Cambrian strata are known and, except in very few cases in the later of these rocks, distinct fossil forms are not known.

Brooks ${ }^{1}$ has advanced the hypothesis that the early living forms (plants and animals) were single celled, and that they originated and lived in the surface portions of the ocean. Because of the lack of severe struggle for existence in such environment, pelagic (free-swimming) plants have to this day remained largely primitive or single celled. For similar reasons the unicellular animals long failed to evolve higher forms because of easy existence in contact with much food and sunlight. Such forms were of gelatinous consistence and not favorable for preservation as fossils. Not until the attachment to the bottom or along shore were con-

1 W. K. Brooks: Jour. Geol., Vol. 2, 1894. 
ditions favorable for the development of higher forms by the aggregation of cells. The plants first spread to the shore waters and thence over the land, so that gradually the shore waters became clearer and richer in organic material and hence more suitable habitats for animals. The animals once established along shore, about the beginning of the Cambrian or late in the pre-Cambrian, are conceived to have made rapid progress in evolution because the struggle for existence became severe on account of greater crowding in this more restricted environment. Support became necessary as well as means of defense, therefore hard parts were developed, and such hard parts could be preserved as fossils. In harmony with this hypothesis is the important fact that preCambrian and early Cambrian fossil shells are mostly very thin, heavy shells apparently not having been evolved till later.

Another hypothesis "assumes that the first forms of life were simple plants that originated in the land waters. . . . This hypothesis further assumes that the early animals, to a greater or less degree, had their origin in the same waters, and like the plants on which they were dependent spread thence to the sea and out upon the land. It is assumed that there might be considerable development of aquatic forms of animal life ... in the land waters before they became denizens of the seas, and their appearance in the latter might be at some rather advanced stage of their evolution and hence be seemingly sudden." 1

Plants. - There are certain rather obscure impressions and other more distinct cluster-like forms which may be sea-weeds, but their identification is not at all positive. As stated above, simple plants at least must have been abundant since animals ultimately depend upon plants for food. Their scarcity as fossils is doubtless due to the unfavorable character of the simple (soft) marine plants for fossilization.

Recently certain problematical Cambrian fossils, long known by the name "Cryptozoön," have been determined as Algæ by Walcott. They secreted concentric layers of carbonate of lime and lived in water. In some localities, as near Saratoga Springs, New York, distinct beds or "reefs" of such Algæ occur in limestone (see Fig. 32).

Protozoans. - Foraminifers have been found even in Lower Cambrian rocks. These forms are very much like the modern ${ }^{1}$ Chamberlin and Salisbury: Geology, Vol. 2, p. 302. 
marine forms, and it is an interesting and important fact that such very simple types have persisted throughout all of geologic time from the Cambrian to the present, while profound evolutionary changes were taking place in the animal kingdom. Radiolarians are not known as fossils. Many Protozoans doubtless existed, but very few secreted shells, and hence not many species could have been preserved as fossils.

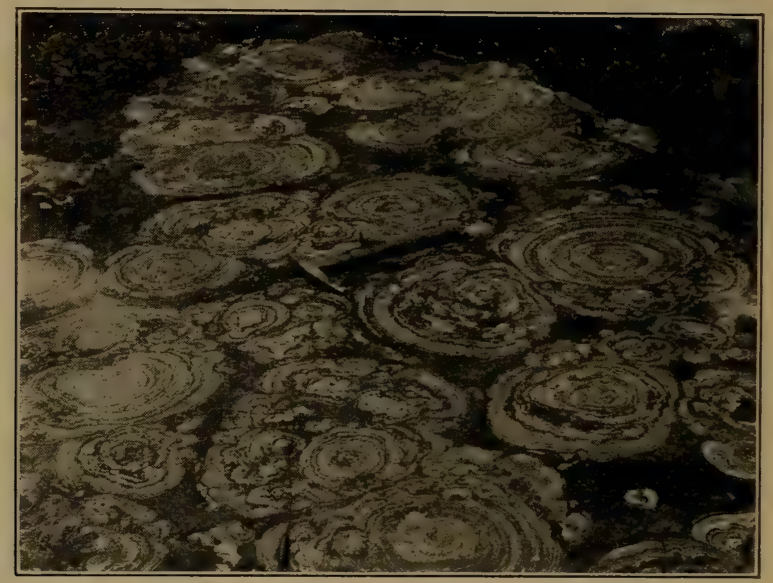

Fig. 32

Calcareous Algæ, Cryptozoön proliferum, forming a reef in Upper Cambrian limestone near Saratoga Springs, New York. (After H. P. Cushing, N. Y. State Mus. Bul. 169.)

Porifers. - True Sponges (Fig. 33) were fairly abundant throughout the period, their siliceous spicules being especially common as fossils.

Cœlenterates. - Hydrozoans were represented by both the so-called "Jelly-fishes" and the Graptolites. The finding of many recognizable casts and impressions of Jelly-fishes (Fig. 34), which consist wholly of soft parts, is a remarkable freak of fossil preservation. Graptolites (Fig. 49) were common, especially in the later Cambrian. These were slender, plume-like, delicate forms consisting of colonies of cells. They were pelagic or free to float in the open sea. One genus of Graptolites, confined to a horizon near 
the summit of the Cambrian, is well-nigh world-wide in its distribution and beautifully illustrates the importance of such forms

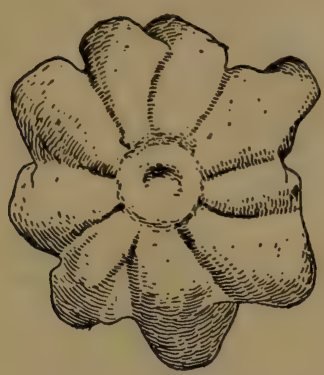

A

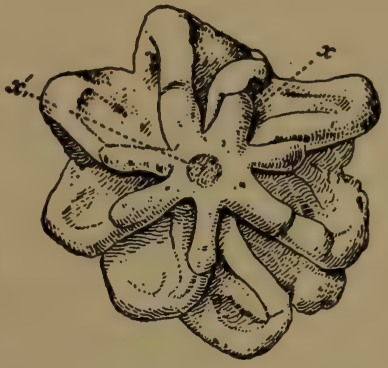

B

Fig. 34

A Cambrian Jelly-fish, Brooksella alternata. (After Walcott, from Shimer's "Introduction to the Study of Fossils," permission of The Macmillan Company.)

for purposes of correlation over wide areas. It should be stated that Graptolites occur only in the older Paleozoic strata.

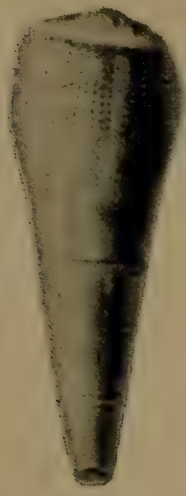

Fig. 35

A Cambrian Sponge or Coral, Archeocyathus rensselaericus. (After Walcott.)

Anthozoans (Corals) were more doubtfully present be-

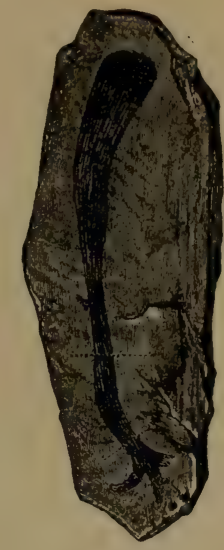

Fig. 33

A Cambrian Sponge, Leptomitus zitteli. (After Walcott.) cause the fossil forms so greatly resemble Sponges (Fig. 35), but recent study seems to indicate that some at least were true Corals. Locally such coral-like forms were common enough to form reefs.

Echinoderms. - Of the Echinoderms the very simplest class, called Cystoids, are known to have existed. These were the bladder-like forms, sometimes with rudimentary arms, set on segmented stems. Holothuroids ("sea cucumbers") have been found in the Cambrian of British Columbia but these are of no special geologic importance.

Worms. - Tracks and borings of marine Worms are common, but no actual remains are known.

Molluscoids. - Brachiopods, next after the 
Trilobites (Crustaceans), are the most important Cambrian fossils (Fig. 36). There are two important general groups of Brachio-

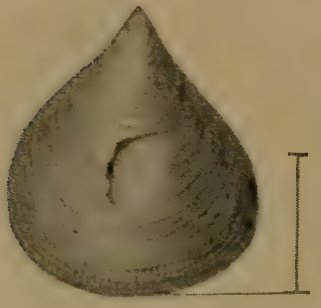

a Fig. 36

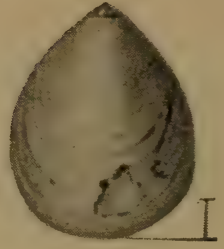

$b$

Cambrian Brachiopods: a, Lingulella prima; $b$, Lingulella acuminata. (After Walcott.)

pods, namely, the Inarticulates, in which the horny shells or valves are not joined together by a hinge, and the Articulates, in which the heavier calcareous shells are joined together by a hinge structure. The former are simpler and lower in organization, and, from the standpoint of evolution, it is important to note that the Cambrian (and also pre-Cambrian) Brachiopods were mostly Inarticulates, the Articulates not becoming common till in the Upper Cambrian. In the post-Cambrian periods the Articulates greatly outnumbered the Inarticulates, and they are the most common of all fossil shells in the Paleozoic rocks. The Brachiopods stand out conspicuously as a re-

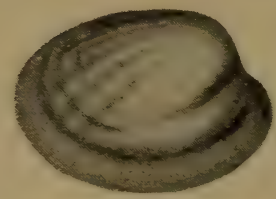

Fig. 37

A Cambrian Pelecypod (Fordilla troyensis). Shell on right and cast on left, much enlarged. (After Walcott.) markably persistent class of animals ranging from pre-Cambrian time to the present, and, although there have been very many

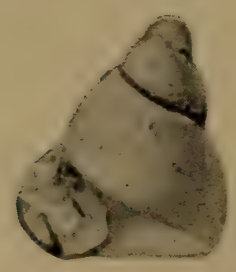

$$
\text { a } \quad \text { Fig. } 38
$$

Cambrian Gastropods: $a$, Matherella saratogensis; $b$, Pelagiella minutissima. (After Walcott.) species and genera changes, the class as such has been very little changed. Many hundreds of species are known from the Paleozoic rocks alone, and by studying their gradual changes in species and genera, they have come to rank among the most valuable fossils as geologic time markers and for purposes of correlation. 
Mollusks. - All the principal fossil-forming types of Mollusks were represented. Pelecypod shells are small and comparatively rare, being mostly found in the Lower Cambrian (Fig. 37). From Cambrian time to the present they have steadily increased, both as regards number of species and individuals. In later geologic times the shells often attained great size. Gastropods, mostly of simple, low-conical types, were fairly common throughout the period (Fig. 38). Cephalopods comprise the highest class of Mollusks
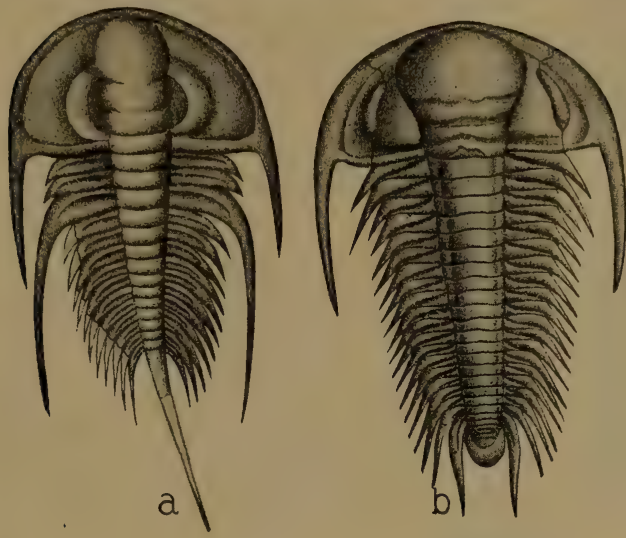

Fig. 39

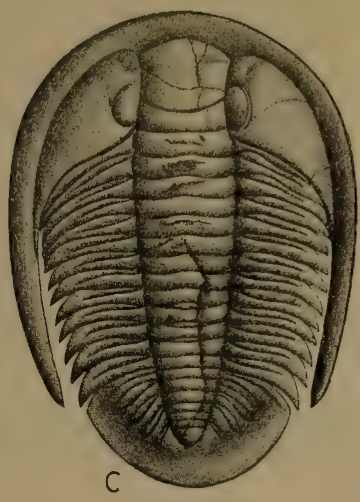

Cambrian Trilobites, restored forms: a, Olenellus gilberti, characteristic of the Lower Cambrian; $b$, Paradoxides bohemicus, characteristic of the Middle Cambrian; c, Dikellocephalus pepinensis, characteristic of the Upper Cambrian. (From Chamberlin and Salisbury's "Geology," permission of Henry Holt and Company.)

and they have been rarely found only in Middle Upper Cambrian strata. They were simple, straight, or curved, chambered-shelled forms. The Cephalopods became very important in subsequent periods, and the evolution of the class will be dwelt upon in succeeding chapters.

Arthropods. - Among the Arthropods the simpler forms (Crustaceans) only are known from the Cambrian. Trilobites are by far the most abundant and significant Cambrian Arthropods (Figs. 39-40). In fact they are the most important Cambrian fossils. We have seen that the threefold subdivision of the Cambrian system is based upon the changes in the Trilobite fauna. Examples of the most characteristic Cambrian genera are shown in Fig. 39. 
They were inhabitants of the sea and they were the most highly organized animals of the time. Trilobites persisted only till the close of the Paleozoic era, and were especially numerous in the earlier periods of that era. The name Trilobite refers to the threelobed character of the body. The creature possessed a distinct head-shield with compound eyes, and a more or less distinct tail-

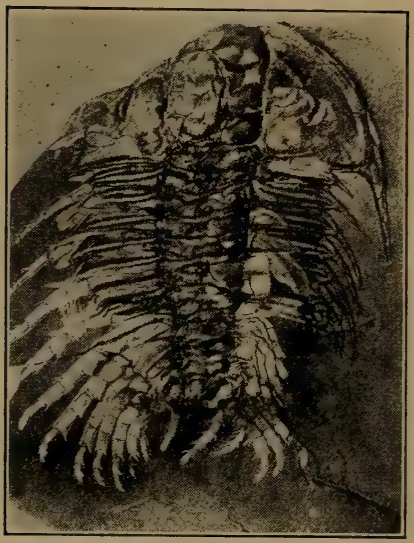

Fig. 40

A Middle Cambrian Trilobite, Neolemus serratus, with well preserved appendages. (After Walcott.) shield. Between the shields there was a highly segmented body portion. They ranged in length from an inch or less to about two feet. "The Trilobites display an extraordinary variety in form and size, in the proportion of the head-andtail-shields, in the number of free segments, and in the development of spines. Already in the Cambrian this wealth of forms is notable, though far less than it became in the Ordovician. As compared with those of later times, the Cambrian Trilobites are marked by the (usually) very small size of the tail-shield, the large number of free segments, and their inability to roll themselves up." Eucrustaceans of rather simple types (e.g. Ostracods) were present, but not important.

Arachnids (e.g. Eurypterids) are only sparingly known from the Cambrian. These forms will be discussed beyond.

No Known Land Animals or Vertebrates. - Thus far no fossil land animals of any kind have been found, but this by no means proves their non-existence during the Cambrian. Vertebrates are entirely unknown, and if any existed in the Cambrian we know, from our study of Vertebrates of succeeding periods, that they must have been of the very simplest types. It is exceedingly doubtful if any existed.

1 W. B. Scott: An Introduction to Geology, 2nd Ed., p. 556. 


\section{CHAPTER VII}

\section{THE ORDOVICIAN (LOWER SILURIAN) PERIOD}

\section{Origin of Name, Subdivisions, etc.}

IN the preceding chapter we learned how the basal portion of Murchison's great Silurian system came to be called the Cambrian. In 1879 Lapworth proposed to divide the remaining Silurian system into two parts, the lower portion to be called Ordovician, and the upper to retain the name Silurian. The term Ordovician was taken from an old tribe (Ordovici) which once inhabited Wales. When it is realized that one of the most profound stratigraphic breaks (unconformities) in the whole Paleozoic group lies within Murchison's old Silurian system, and between what are now called the Ordovician and Silurian systems, the justification of Lapworth's proposal is evident. In America and England the Ordovician system is now generally recognized, though on the continent of Europe the term Lower Silurian is still largely employed instead. The following tabular arrangement will serve to make clear the history of these terms:

\begin{tabular}{l|l|l}
\hline (Murchison, 1835) & $($ Sedgwick $)$ & $($ Lapworth, 1879) \\
\cline { 2 - 3 } Silurian system $\left\{\begin{array}{l}\text { Upper Silurian } \\
\text { Lower Silurian }\end{array}\right.$ & $\begin{array}{l}\text { Upper Silurian } \\
\text { Lower Silurian } \\
\text { Cambrian }\end{array}$ & $\begin{array}{l}\text { Silurian } \\
\text { Ordovician } \\
\text { Cambrian }\end{array}$
\end{tabular}

Since the North American Ordovician was first carefully studied in New York state, the section there has become, to a very considerable degree, the standard to which the subdivisions in other parts of the continent are referred. During recent years several unconformities, though rather minor ones, have been discovered in the New York Ordovician, so that this section is not as perfect or continuous (stratigraphically) as was formerly supposed, certain records being entirely missing. Following are the principal subdivisions of the New York Ordovician system according to the most recent classification by the State Geological Survey: 
Cincinnatian series
(Upper Ordovician) $\left\{\begin{array}{l}\text { Pulaski. } \\ \text { Frankfort. } \\ \text { Utica shale. }\end{array}\right.$ Lorraine shale and sandstone.

MoHawkian Series $\{$ Trenton limestone and shale.

(Middle Ordovician) $\{$ Black River limestone.

Canadian SERIES
(Lower Ordovician) $\left\{\begin{array}{l}\text { Chazy limestone. } \\ \text { Pamelia limestone. } \\ \text { Beekmantown limestone. } \\ \text { Tribes Hill limestone. }\end{array}\right.$

The reader should not be led to think that these New York formation or stage names are the only ones now used in North America. Many other, more or less local, names have been applied either to formations (stages) found elsewhere but missing in New York, or to formations which have not yet been definitely correlated with those of New York. It is generally agreed, on the basis of priority, that when two widely separated formations become definitely correlated, the name given the formation where first studied is to be applied to both. In this way many of the New York names have come to be used over wider and wider areas. Also the kind of rock (lithologic character) making up a formation in New York may or may not be the same in other areas. Thus a sandstone or shale in New York may be replaced by a shale or limestone elsewhere, etc.

In New York, and usually elsewhere, the Ordovician strata, especially the Middle and Upper, and more especially the Trenton beds, are wonderfully rich in organic remains, and much attention has been given to the description of the fossils and the correlation of the strata. Unconformities within the Ordovician system are relatively uncommon, those which do occur seldom ever being of more than local extent. In other words, with certain slight exceptions, deposition of Ordovician strata in North America was a continuous process, and the subdivisions are very largely on the basis of fossils.

\section{Distribution and Character of the Rocks}

General Distribution. - The accompanying map (Fig. 41) shows the distribution of chiefly Middle and Upper Ordovician rocks in North America. Some Lower Ordovician rocks are included with the Cambrian on the preceding map (Fig. 26), but 
since Lower Ordovician rarely occurs in any areas not also occupied by the Middle Ordovician, the accompanying map shows the surface distribution of practically all Ordovician strata. By comparing the maps (Figs. 26 and 41) it will be seen that the distri-

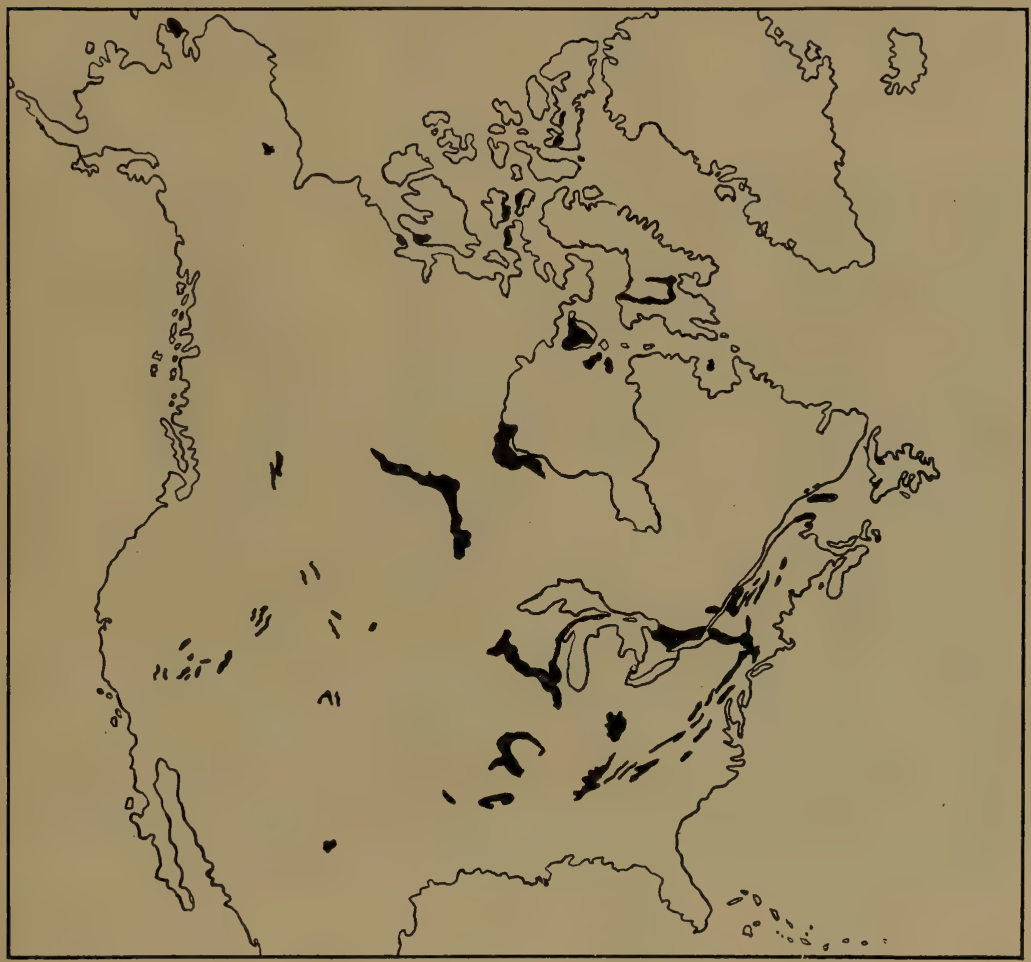

Fig. 41

Map showing the surface distribution (areas of outcrops) of chiefly Middle and Upper Ordovician strata in North America. (By W. J. M., based upon maps by Bailey Willis, U. S. Geological Survey.)

bution of Ordovician rocks is essentially the same as that of Upper Cambrian, with two important differences. These differences are the presence of two large areas of Ordovician west of Hudson Bay, and a number of smaller areas in the Arctic Islands region.

As in the case of the Cambrian, so the surface distribution of 


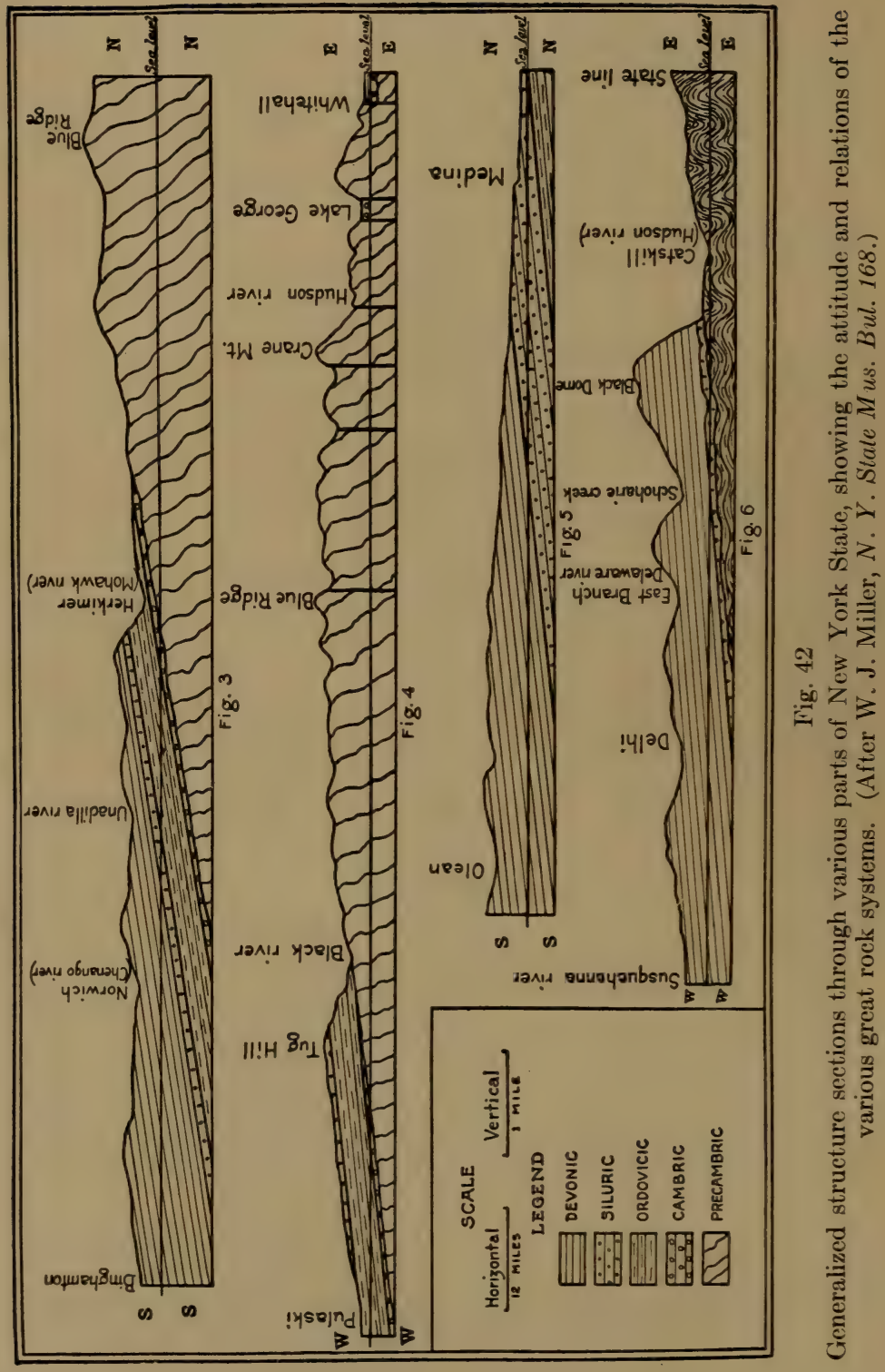


the Ordivician rocks as indicated on this map gives no adequate idea of the former or present real extent of strata of this age, since strata have either been removed from so many districts by erosion, or are concealed under later formations, or are highly folded so that outcropping edges only are at present visible. Some regions can quite certainly be shown to have been formerly covered by Ordovician strata, as, for instance, nearly all of the Adirondack Mountain region, and a wide belt between the Great Lakes and

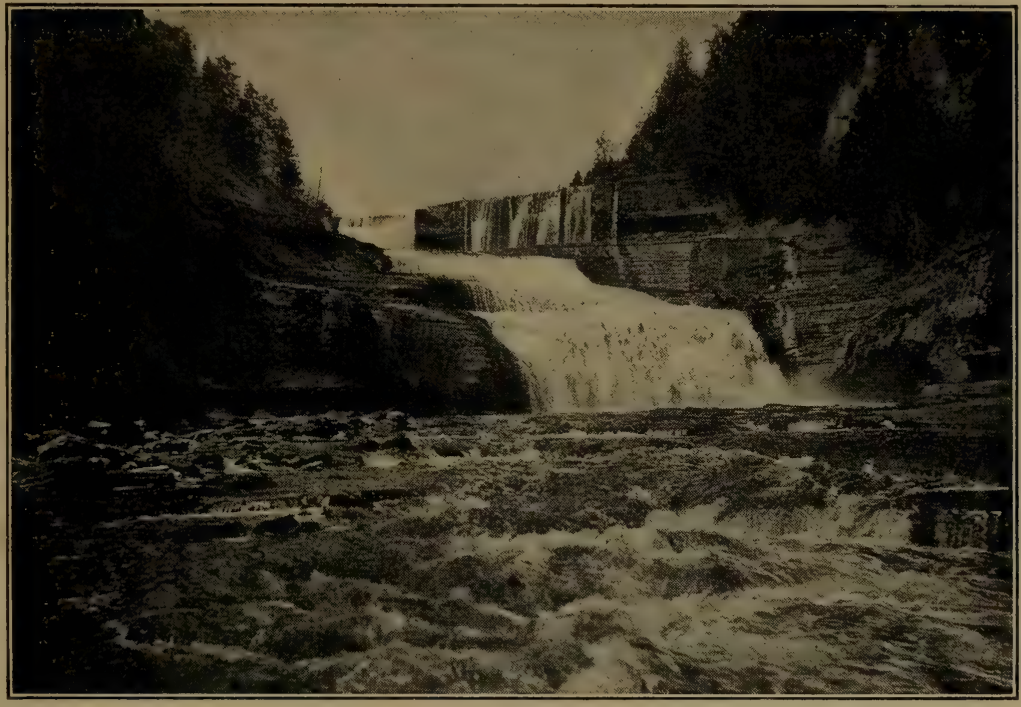

Fig. 43

The Trenton (mid-Ordovician) limestone at its type locality, Trenton Falls, New York. (Photo by F. B. Guth, Utica, N. Y.)

Hudson Bay. Also the distribution of outcrops, together with numerous deep-well sections, conclusively prove that much, if not all, of the Mississippi Basin contains concealed Ordovician rocks. In the Appalachians, New England, and some of the western mountains extensive Ordovician strata are actually exposed only along comparatively narrow belts following the strike of the highly folded rocks.

Lower and Middle Ordovician Rocks. - Viewed in a broad way, the Ordovician rocks (especially the Lower and Middle) are 
of quite different character from those of the Cambrian. Clastic sediments, such as conglomerates, sandstones, and shales, were the dominant Cambrian sediments, while, throughout the Lower and Middle Ordovician, limestones greatly predominate (Fig. 44). Mid-Ordovician is generally regarded as one of the greatest limestone making times in the earth's history, though it should not be inferred that limestones were then universally made in the seas, because those areas of deposition close to, or receiving wash from, the lands show clastic sediments. Middle Ordovician, especially Trenton, limestones are remarkably widespread, occurring in New York, New England, New Brunswick, southeastern Canada, and near Hudson Bay, across the northern part of the Mississippi Basin, Black Hills, Wasatch and Uinta Mountains, and even in the Great Basin. An illustration of an exception to universal limestone-making during Trenton time is in the Mohawk Valley region of New York, where the limestone passing eastward becomes almost wholly replaced by hundreds of feet of shale. Also through the Appalachians rocks of this age contain much clastic material.

Upper Ordovician Rocks. - In the Upper Ordovician of eastern North America shales and alternating shales and fine-grained sandstones (e.g. Utica and Lorraine) greatly predominate, doubtless due to rejuvenation and more active erosion of the lands probably accompanied by some shoaling of the water (Fig. 44). In the western part of the continent limestones appear to predominate, even in the Upper Ordovician.

Thickness and Metamorphism of the Ordovician. - The aggregate thickness of Ordovician strata in New York is from 2000 to 3000 feet; in Tennessee about 4000 feet; and in the central Mississippi Valley (e.g. Missouri) only a few hundred feet.

Among the changes which the strata have undergone since their deposition we have mentioned their highly folded condition in certain regions, but in New England, parts of the Piedmont Plateau, and parts of the western United States the rocks are also highly metamorphosed.

Igneous Rocks. - There is no certain evidence for volcanic or other igneous activity during the North American Ordovician, though some granite intrusions in the Wichita Mountains of Oklahoma and some very small dikes in New York may be of this age. 


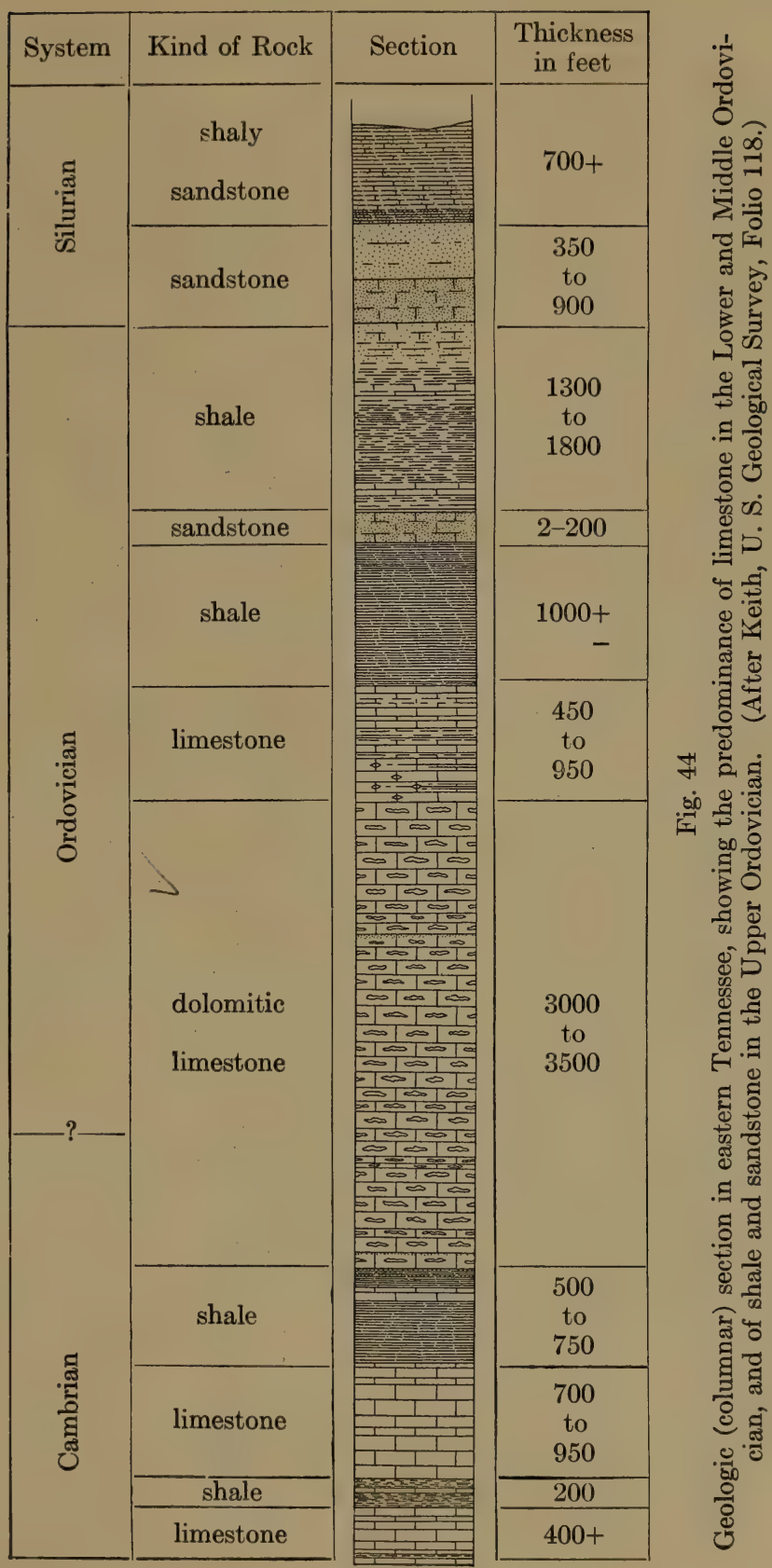




\section{Physical History}

Early and Middle Ordovician. - The progressive submergence ${ }^{1}$ which caused so much of North America to be covered by marine waters by late Cambrian time continued well into the Ordovician, so that during mid-Ordovician time more of the continent appears to have been covered by the sea than at any other time in its history since the beginning of the Paleozoic era. A good idea of the general relations of land and sea at this time may be gained from the paleogeographic map (Fig. 45). The principal land areas were Appalachia (except the Piedmont Plateau district in the early Ordovician) along the Atlantic Coast; the Labrador region; Lake Superior and southward; west of Hudson Bay; Wyoming to Arizona; Ozark Mountains of Missouri; and certain rather indefinitely known and possibly connected areas to the west of the Rocky Mountains.

Because Ordovician strata often show a thickness of 2000 to 4000 feet, it should not be inferred that the Ordovician sea was necessarily ever 2000 to 4000 feet deep. Even the limestones often abundantly prove by ripple-marks, mud-cracks, fossils, etc., that they were laid down in shallow water. The very character of the thickest materials (old muds and sands) in the Upper Ordovician implies that they could not have been deposited in deep ocean water. Such sediments are not now forming on the deep sea bottom. But how are these statements to be harmonized with the fact that Ordovician strata several thousand feet thick actually exist over considerable areas? During the early and middle portions of the period (with certain rather local exceptions above mentioned) the land gradually became submerged, and stratum after stratum was formed upon the relatively sinking sea floor (or submerging land), so that at no time is it necessary to assume great depth of water. In general, the early to middle Ordovician sea of North America must be thought of as a vast shallow (epicontinental) ocean which spread over most of the slowly submerging continent. There were no ocean abysses at all comparable to those of the present Atlantic or Pacific.

${ }^{1}$ This disregards the probable temporary withdrawal of the late Cambrian sea from the upper Mississippi Valley region as explained in the preceding chapter. 


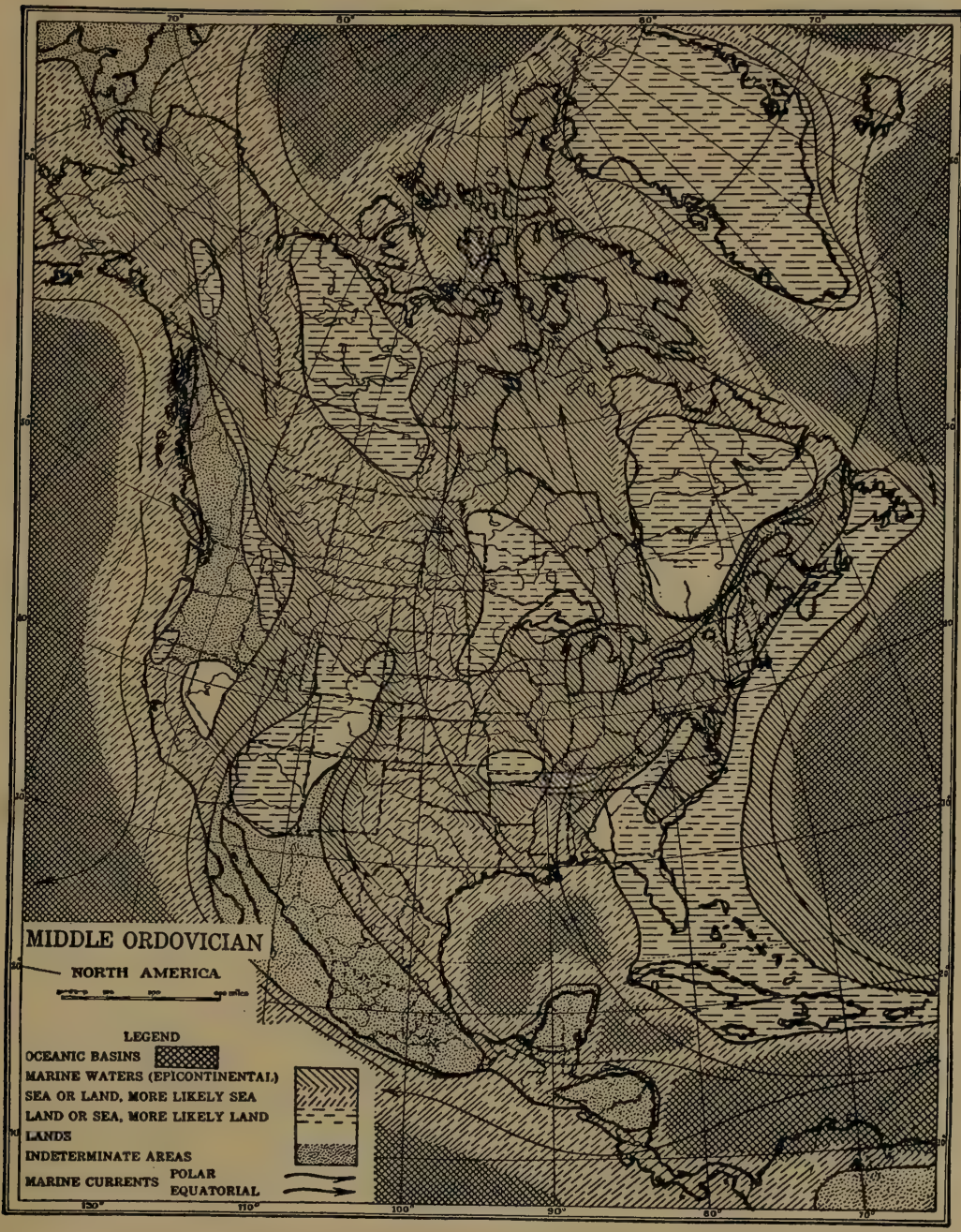

Fig. 45

Paleogeographic map of North America during Middle Ordovician time. (Slightly modified after Bailey Willis, courtesy of The Journal of Geology.) 
Late Ordovician. - Soon after Trenton time in the Wichita Mountain district of Oklahoma there was a rather local crustal disturbance, when the strata were upturned and granite intrusions are thought to have taken place.

Since the later Ordovician sediments are mostly clastic (shales and sandstones), it is evident that an important change in the physical geography conditions took place during the latter portion of the period. Considerable areas of sea bottom were gradually converted into dry land, and other portions were shoaled. Either an uplift of the land, or a withdrawal of epicontinental sea waters by sinking of the ocean bottoms (Atlantic and Pacific), or both may have produced the change. The newly exposed lands, and the relatively higher old lands, suffered pretty rapid erosion, and clastic sediments accumulated comparatively fast. As we shall presently see, considerable crustal disturbances (orogenic), acpanied by uplifts, reached their climax toward the close of the period in eastern North America, and there is much evidence to show that such actual uplifts began well before the close of the period.

Close of the Ordovician (Taconic Revolution). - In marked contrast with the quiet close of the Cambrian, the Ordovician ended with important physical or crustal disturbances and mountain-making. Much of the interior (epicontinental) sea appears to have been drained as a result of relative changes in level between land and sea, gradually increasing during late Ordovician time. In this interior region the land was mostly but slightly elevated to remain dry only till the early part of the next period.

We have learned that sedimentation was practically uninterrupted during the Cambrian and Ordovician periods, and that some thousands of feet of strata had accumulated in the seas which covered eastern New York, all of the regions of the present Berkshire Hills, Green and White Mountains, as well as southward at least to Virginia and over the region occupied by the present Piedmont Plateau. Toward the close of the Ordovician period a great compressive force was brought to bear in the earth's crust upon the mass of sediments which reached from Nerw England to Virginia, and possibly farther southward. As a result of this compression the strata were tilted, highly folded, and elevated far above sea level into a magnificent mountain range which has been called the Taconic Range, and this great physical (orogenic) 
disturbance has been called the Taconic Revolution. In structure, the range consisted of a series of folds, both great and small, whose axes were parallel to the main axis of the range, that is north-northeast by south-southwest. Examination of Fig. 46 will give the reader a good conception of the character of the folding. It is quite the rule, throughout this region of Taconic disturbance, to find the strata either on edge or making high angles with the plane of the horizon. Many times the folds were actually overturned, and in places notable thrust faults were developed. These facts all go to prove that the mountain-making compressive force applied to the region was of rather an extreme type. Though we have no way of telling just how high the range may have been, nevertheless the structural features and the vast amount of erosion since the folds were produced clearly indicate that the uplift was at least some thousands of feet. The Green and White Mountains, Berkshire Hills, Highlands of the Hudson, and the Piedmont Plateau are, in a sense, the remnants or roots of the great Taconic Range.

In passing westward from the main axis of the range, the folding is less and less intense, till finally the folds die out altogether.

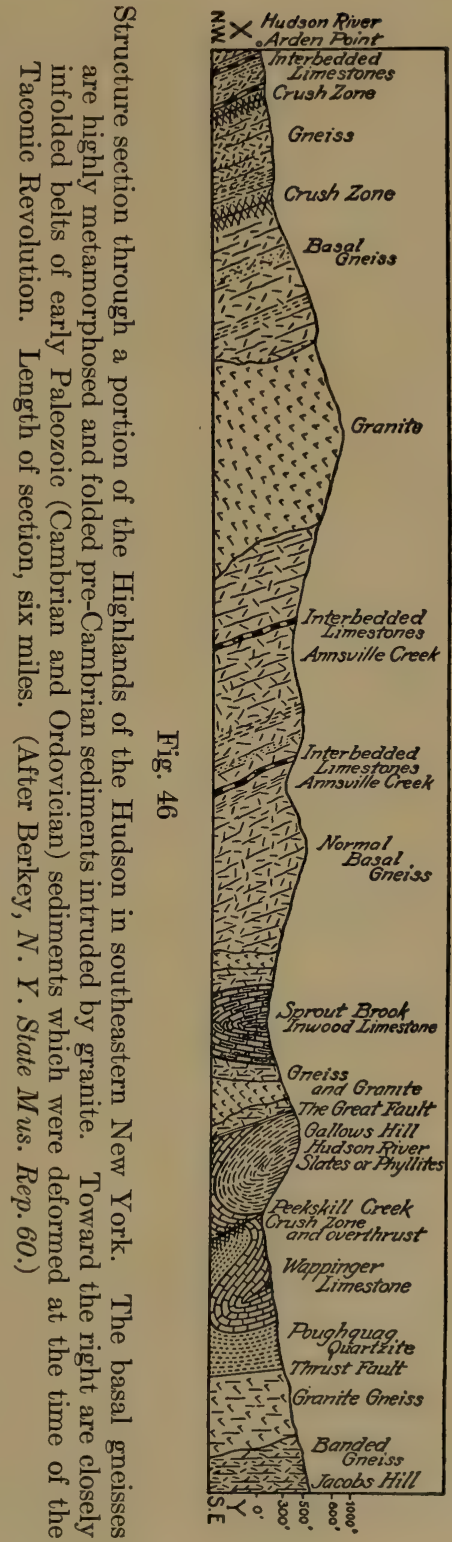


How do we know that the Taconic disturbance took place toward the close of the Ordovician period? Strata of the next succeeding period (Silurian) rest directly in places upon the eroded edges of late Ordovician rocks; hence it is obvious that the disturbance occurred before the Silurian strata were deposited. Also the disturbance doubtless began before the close of the Ordovician period. This is borne out by the fact that, for example, in central New York a distinct eroded surface at the summit of the Frankfort shales proves that region to have been dry land before the end of the period, this uplift quite certainly having been produced by the early movements of the Taconic disturbance.

Another feature which must not be overlooked is the profound metamorphism of the strata along the main axis of the Taconic Range. The very intense compression, accompanied by heat and moisture, caused the deeply buried strata, along the main axis of the uplift, to become rather plastic, and hence the sediments became more or less foliated and crystallized into the various metamorphic rock types, the limestone becoming marble, the shale becoming slate or schist, and the sandstone becoming quartzite.

In New Brunswick, Silurian strata rest upon the eroded edges of upturned Ordovician strata, and this upturning may have been coincident with the Taconic disturbance.

Sufficient lateral pressure was brought to bear in a portion of the Mississippi Basin, during the latter part of the period, to produce a long, very low arch in the rocks from southern Ohio into Tennessee. This has been called the "Cincinnati Anticline."

The late Cambrian and Ordovician connection of the interior sea with the Atlantic Ocean through the St. Lawrence Valley was closed by the disturbances toward the end of the Ordovician.

\section{Foreign Ordovician}

Map Fig. 47 gives a general idea of the relations of land and sea in Europe during the Ordovician. Also, barring certain areas from which the strata have been removed by erosion, the dotted (shaded) portion represents the present extent (surface and concealed) of Ordovician strata. There were two distinct provinces, a northern and a southern, as proved by important differences between the fossils of northern and southern Europe. Ordovician fossils of northern Europe are closely related to those of North 
America, thus implying a shallow sea connection between North America and Europe. The scarcity of limestone in the European Ordovician is in marked contrast with that of North America.

In the British Isles, where the European Ordovician is thickest (being many thousands of feet), great igneous intrusions and extrusions took place, so that this region ranks as one of the greatest ancient volcanic areas in Europe.

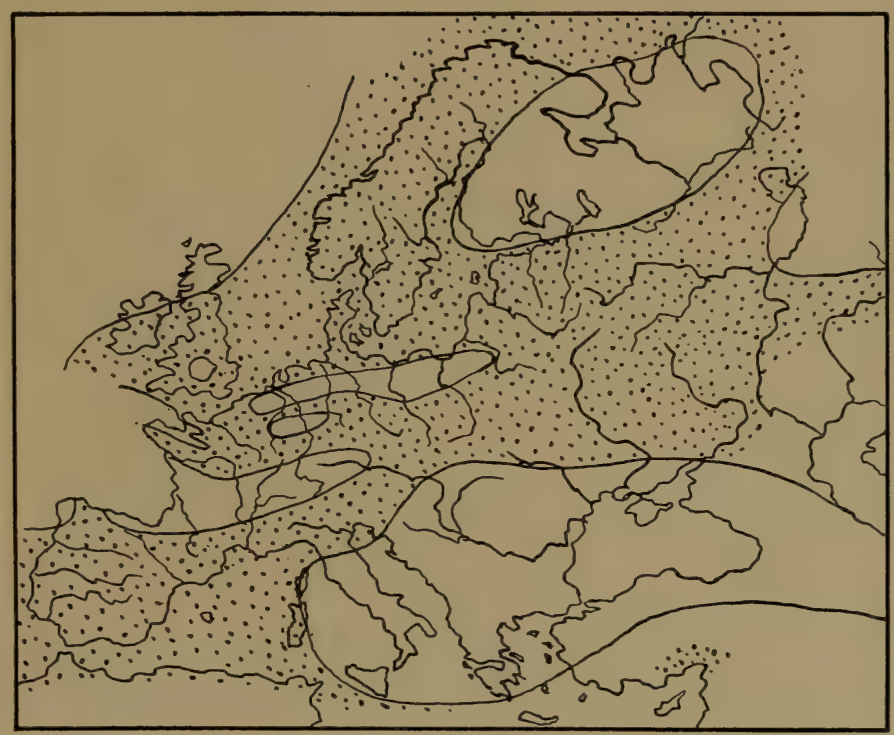

Fig. 47

Sketch map showing the relations of land and water in Europe during Ordovician time. Dotted area, water. (Slightly modified after De Lapparent.)

As in North America, important geographic changes took place toward the close of the period, and the Silurian often rests by unconformity upon the Ordovician. In the British Isles the Ordovician rocks were folded, upraised, and often metamorphosed, with Silurian strata resting upon their eroded edges.

Ordovician rocks are also known in Peru, Argentina, Australia, Tasmania, New Zealand, Africa, India, eastern China, and northern Siberia. 


\section{Climate}

Red sandstones, salt, and gypsum in the Upper Ordovician of northern Siberia clearly imply an arid climate in northern Asia during the late Ordovician. So far as can be determined from the character of the rocks, geographic conditions, and distribution of the fossils, the climate of North America and Europe must have been mild and much more uniform than now. Ordovician fossils, even from Arctic lands, are very similar to those of low latitudes.

\section{Economic Products}

Many great marble quarries are located in metamorphosed Ordovician limestone in New England and the Piedmont Plateau. Also much non-metamorphosed limestone is quarried for building purposes or burnt for lime in various parts of the United States. In the Lehigh district of Pennsylvania much Trenton (argillaceous) limestone is used in the manufacture of Portland cement.

Among the greatest lead and zinc ore deposits in the world are those of the Mississippi Valley, especially in Missouri, Wisconsin, Iowa, and Illinois. These ores, which were originally disseminated through the limestones, were dissolved and redeposited in more concentrated form in openings in the rocks.

Manganese ores of Arkansas and phosphate deposits of Tennessee occur in limestones of this age.

The great oil and gas field of Ohio and Indiana derives its principal supply from the Ordovician rocks, especially the Trenton limestone. The oil and gas were formed by the decomposition of the rich organic accumulations in the limestones.

\section{Life of the ORdovician}

Abundance of Marine Life. - The Ordovician epicontinental seas literally swarmed with marine organisms, few systems containing a fuller record of marine forms than the Ordovician because of very favorable conditions of fossilization. As regards both diversity and abundance of known organisms, this period is far superior to the Cambrian. Schuchert states that over 1600 species of animals are known from the middle Ordovician alone. It is to be noted, however, that, with very slight exception, Vertebrate animals are not known to have existed in the Ordovician. Also 
our knowledge of land plants and animals is very scant. The scarcity of land organisms may have been due to prevalent oceanic conditions not favorable for fossilization, though it is also likely that land plants and animals had not progressed far or become very abundant so early in the history of the earth. Because of the unusual abundance and diversity of invertebrate animal forms in such an ancient fossiliferous system, a fuller discussion will be devoted to these forms than in succeeding chapters.

Plants. - In this period, as well as in the Cambrian, plant life of very simple types at least must have been abundant to serve as a direct or indirect food supply for the myriads of animals. Various fossil seaweeds (marine Algæ) are definitely known, especially in the Trenton series and younger Ordovician shales (Fig. 48). The rather imperfect record is doubtless
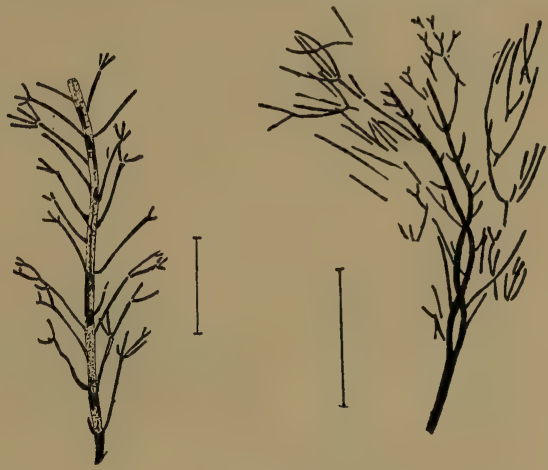

Fig. 48

Ordovician Seaweeds, Callithamnopsis fructicosa. (After Ruedemann). due to the fact that such very simple forms were unfavorable for fossilization. Definite knowledge of land plants is lacking, though a few rather doubtful higher Cryptogams are said to have been found in Europe. In view of the abundant land flora of the Devonian, it seems more than probable that land plants existed as early as the Ordovician, and some may yet be discovered.

Protozoans. - Both Foraminifers and Radiolarians must have been common in the seas, because in some places many fossil forms have been found. As in the preceding period, many forms without shells almost certainly existed.

Porifers. - Sponges were more abundant and diversified than in Cambrian time, and some were of large size. Mostly only those Sponges which secreted skeletons were favorable for fossilization.

Cœlenterates. - Hydrozoans were abundantly represented by the Graptolites (Fig. 49), and in fact the Ordovician may be said to have been the period of culmination of this remarkable, long extinct group of animals. They are so abundant and varied in 
Upper Ordovician shales that definite stages or horizons have been determined largely by their use. Since the Graptolites were mostly floating forms and widely distributed at a given time, they have been of great value in correlating even minor subdivisions of the system in such far separated regions as Great Britain, eastern North America, and Australia. When it is further stated that all known Graptolites are confined to the first four great fossiliferous systems (Cambrian, Ordovician, Silurian, and Devonian), ${ }^{1}$ their additional importance as stratigraphic indices becomes evident. In Fig. 49 the forms represent skeletons or axes of colonies, a single
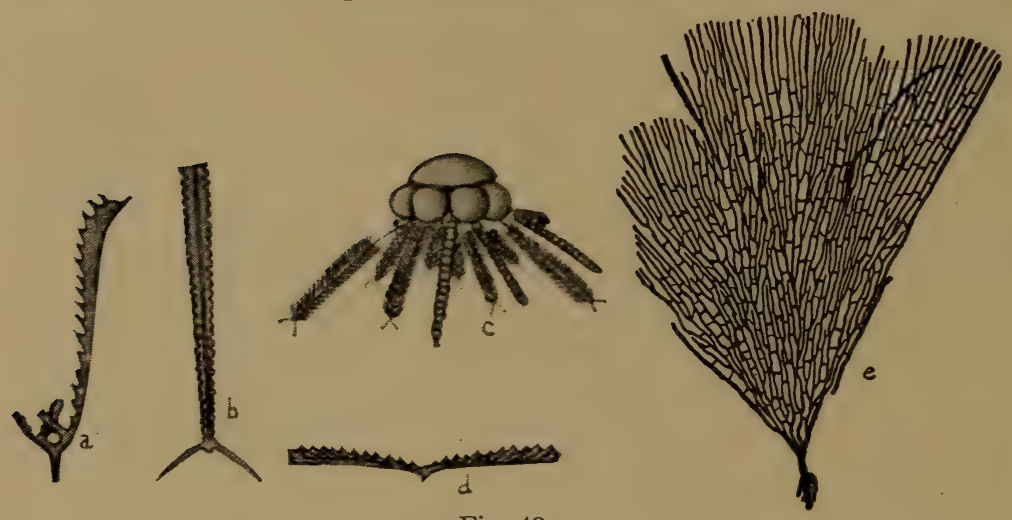

Fig. 49

Ordovician Graptolites: $a$, Tetragraptus fructicosus; $b$, Climacograptus bicornis; $c$, Diplograptus pristis; $d$, Didymograptus nitidus; e, Dictyonema flabelliforme. ( $a, b, d$, after Hall; $c$, after Ruedemann; e, after Matthew.)

or a double row of protoplasmic cells having been arranged along an axis. Forms with cells on both sides of the axis were very characteristic of the Ordovician.

Anthozoans (Corals) were common, more especially where the mid-Ordovician limestones were forming. It will serve our purpose to divide the principal Paleozoic Corals into three groups or types as follows: (1) Cup Corals (solitary or compound), (Fig. 62a); (2) honeycomb Corals (compound), (Fig. 62b); and (3) chain Corals (compound), (Fig. 62c). These Paleozoic Corals were all Tetracoralla, that is, the radiating partitions (septa) of the individuals or polyps were four in number or multiples of four, while modern Corals, which first appeared in the Mesozoic era, are ${ }^{1}$ A very few Graptolites also occur in the Mississippian. 
Hexacoralla or Octacoralla. Modern Corals are nearly all profusely branched and the polyps are very small, while Paleozoic Corals were rarely branched and the polyps were much larger, the cup Corals usually ranging from half an inch to a foot or more in length. All three types of Corals above mentioned existed in the Ordovician, but solitary cup Corals were predominant. Compound forms, especially honeycomb Corals, were sometimes locally abundant. Among modern Corals the compound or colonizing forms are by far more common than the solitary forms.

Echinoderms. - All the classes of the Echinoderms were represented in the Ordovician, and all of these but the Cystoids and

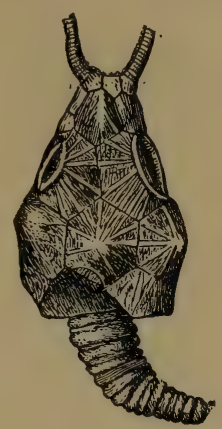

$a$

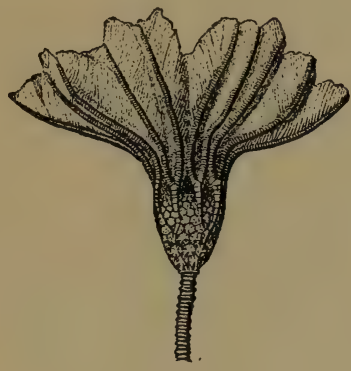

$b$

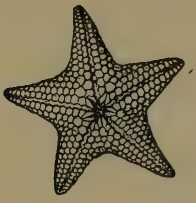

$c$

Fig. 50

Ordovician Echinoderms: a, Cystoid, Pleurocystis filitextus; $b$, Crinoid, Glyptocrinus dyeri; c, Asterozoan, Paleasterina stellata. ( $a, c$, after Billings; $b$, after Meek.)

Holothuroids made their first appearance. Cystoids (Fig. 50a) reached their climax of development in this period, though they did not become extinct till the Devonian. Blastoids were rare and represented by very primitive forms, with distinct Cystoid affinities. In fact the Blastoids assumed little importance till the Mississippian. Crinoids (Fig. 50b) became prominent, and, because of their hard parts, were well suited for fossilization, though, on account of their highly segmented character, they usually fell apart after the decay of the soft parts, and consequently entire specimens are not common. Ophiuroids, Asteroids (Fig. 50c), and Echinoids were uncommon, the latter being represented by very primitive forms. Holothuroids are not known as fossils. 
Molluscoids. - Bryozoans were abundant often as reef builders, particularly in the later portion of the period. Hundreds of Ordovician species are known. Though structurally (organically) very closely related to the Brachiopods, they are far different from them in outward appearance, while they look so much like the

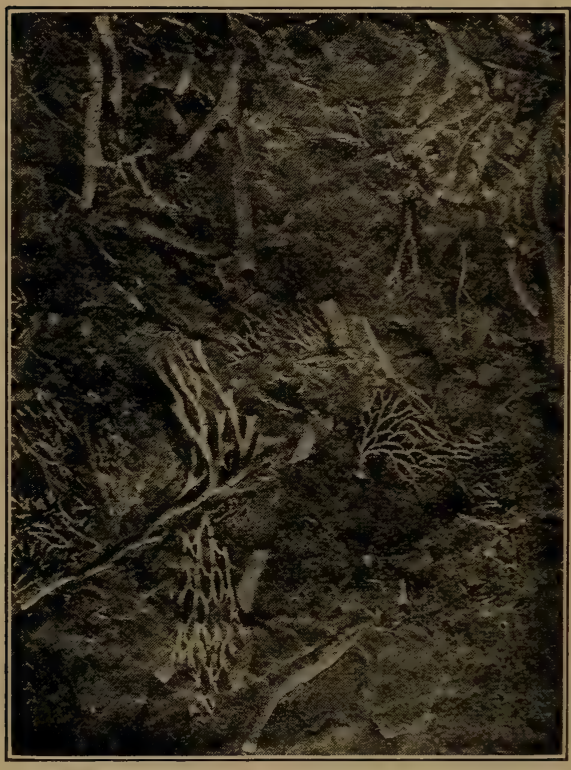

Fig. 51

Corals as often to be distinguished from them with difficulty (Fig. 51). The Bryozoans afford a fine illustration of a class of creatures whose genera have changed very little from very ancient times to the present day.

Brachiopods became much more abundant, more varied, and more complex than in the Cambrian (Fig. 52). Those with hinged shells (Articulates) greatly outnumbered the Inarticulates for the first time. Also the shells usually were thicker and more difficult for their enemies to open because of long-hinged lines, or a fluted or ribbed structure, or both. As for the early Paleozoic in general, nearly all were straight-hinged. Many genera and species are known, certain of them having been much used in subdividing the Ordovician system. Along with the Trilobites, the Brachiopods were the most prominent known organisms of the period. About 300 species are known from the Middle Ordovician of North America alone.

Mollusks. - As compared with the Cambrian, a wonderful development of Mollusks, both as regards numbers of individuals and species, took place in the Ordovician.

Pelecypod bivalves were more abundant, usually larger, and of 


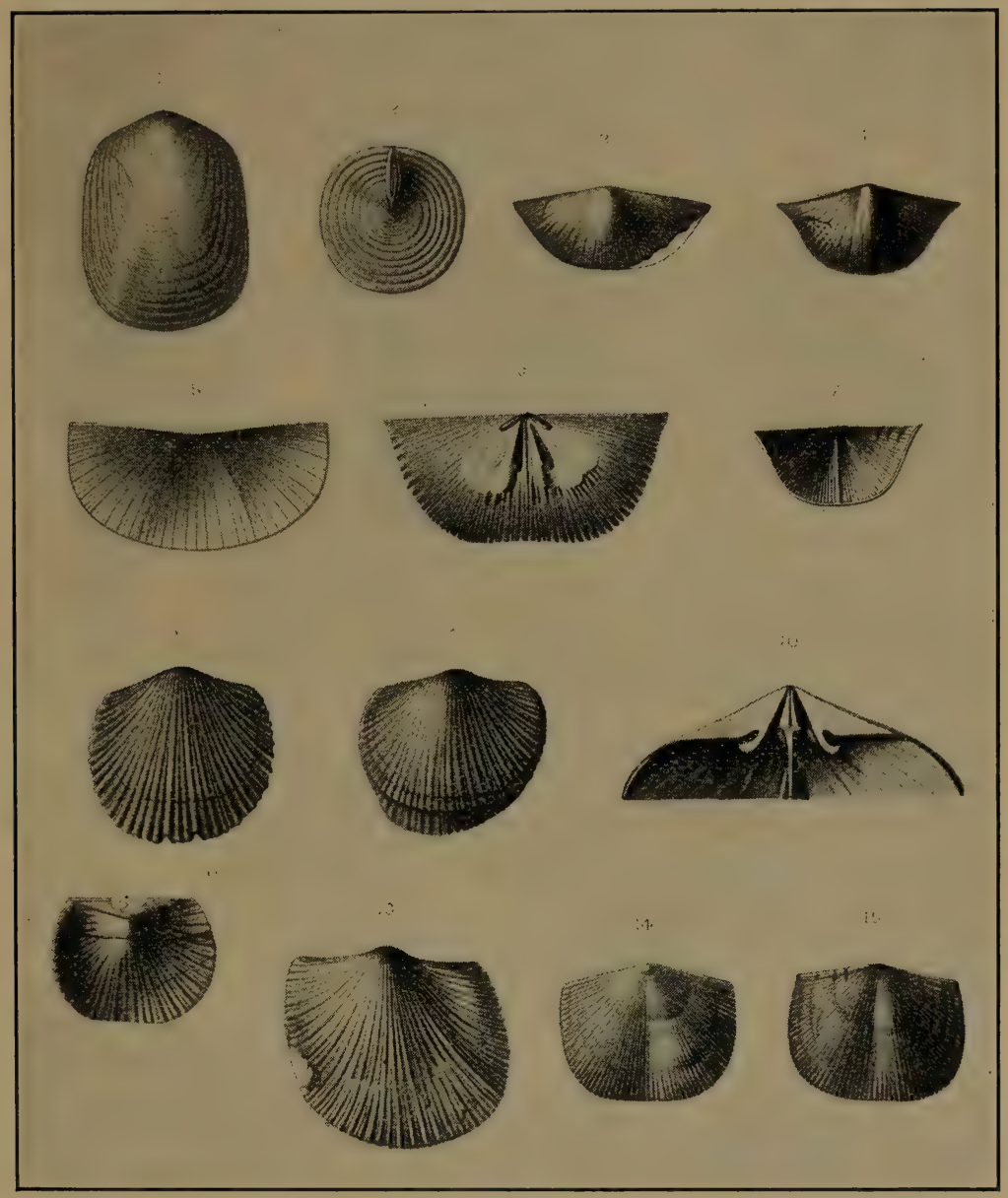

Fig. 52

Ordovician Brachiopods: 1, Lingula rectilateralis; 2, Orbiculoidea tenuistriata; 3, 4, 5, 6, Plectambonites sericeus; '\%, Plectambonites centricarinatus; 8, Plectorthis whitfieldi; 9, 10, 11, Plosiomys retrorsa; 13, Ploesiomys porcata; 14, 15, Clitambonites americanus. (From Ruedemann, N. Y. State Mus. Bul. 162.) 
more modern aspect than before. Typical forms are shown in Fig. 53. Ordovician Pelecypods, like their modern representatives (e.g. Clams and Oysters), appear to have thrived unusually well

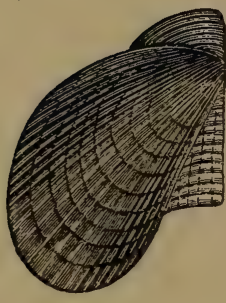

$a$

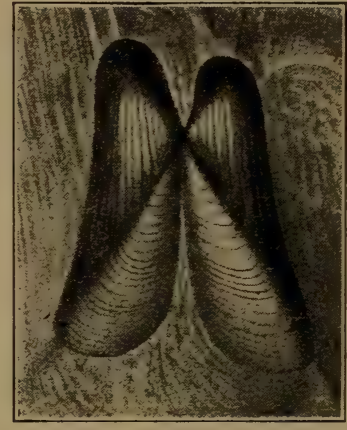

$b$

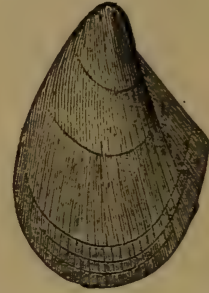

c

Fig. 53

Ordovician Pelecypods: a, Cardiola interrupta (Hall); $b$, Orthodesma? subcarinatum (Ruedemann); c, Ambonychia bellistriata (Hall).

where muds and sands were being deposited, and they are therefore much more numerous as fossils in the Upper Ordovician shales and sandstones. One important contrast for the reader to keep in mind is the distribution of the Pelecypod bivalves through geologic

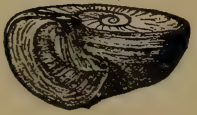

$a$

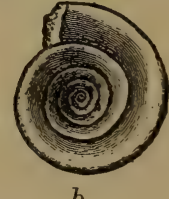

Fig. 54 time as compared with the Brachiopod bivalves. Brachiopods were very abundant and more varied than Pelecypods in the earlier Paleozoic periods, but they have steadily declined almost to extinction at the present time, while

Ordovician Gastropods: $a$, Maclurea logani (Salter); $b$, Ophileta complanata (Vanuxem).
Pelecypods have steadily increased in numbers and variety to recent time.

Gastropods, which comprise the non-chambered, univalve Mollusks, also deployed to a marked degree in this period and predominated over the Pelecypods. These Gastropods were in no essential manner different (except as to species or genera) from existing forms (e.g. the common Snail), and we have here another 
of the few excellent illustrations of an important class of animals which has shown surprisingly little change since early Paleozoic time (Fig. 54).

Cephalopods. "The largest, most powerful, and perhaps the most predaceous of the known forms of Ordovician life were the Cephalopods, which seem to have developed into prominence with extraordinary suddenness. Unless the Fishes, of which very little is known, contested their supremacy, they were doubtless the undisputed masters of the sea. Their relics first appear at the time of the transition from the Cambrian to the Ordovician, but they
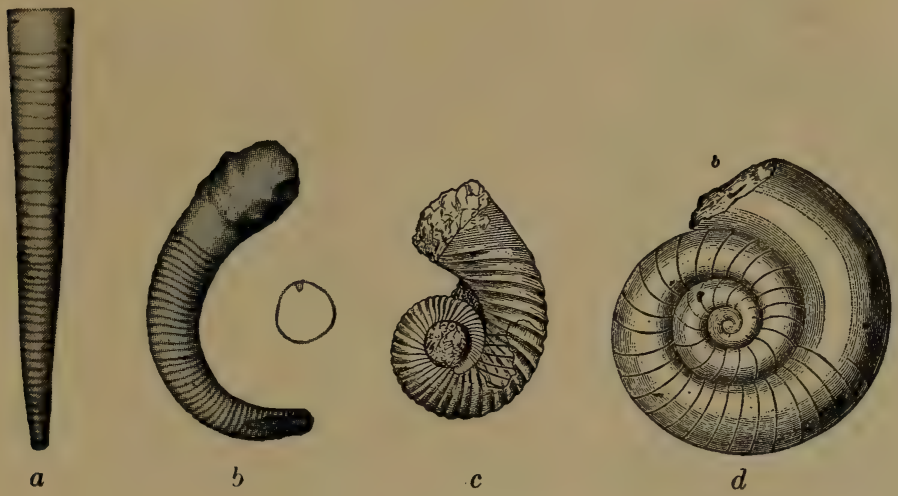

Fig. 55

Ordovician Cephalopods: a, Orthoceras sociale (Hall); $b$, Cyrtoceras neleus (Hall); $c$, Trochoceras-like form (Silurian specimen after Barrande); $d$, Trocholites ammonius (Hall).

were then so far advanced and so widely differentiated from allied forms as to render it probable that they had already lived a long time. ... The size attained by the Ordovician Cephalopods was probably never surpassed by representatives of the class. Some of the shells were 12 or 15 feet in length, and a foot (maximum) in diameter. From this great size they ranged down to or below the size of a pipe stem." 1 These Cephalopods all belonged to the Tetrabranch or chambered-shelled subdivision of the class (Fig. 55).

${ }^{1}$ Chamberlin and Salisbury: College Geology, pp. 525-527. 
The Tetrabranch Cephalopods, for two reasons, constitute one of the most interesting and instructive illustrations of evolutionary changes, ranging from the early Paleozoic to the present time, first because we have such an abundant record in the rocks of all these periods, and second because the evolutionary changes have expressed themselves in the external or shell portions in a remarkable and easily recognizable manner. The only known Cambrian Tetrabranchs were of the very simple, straight, or curved cham-

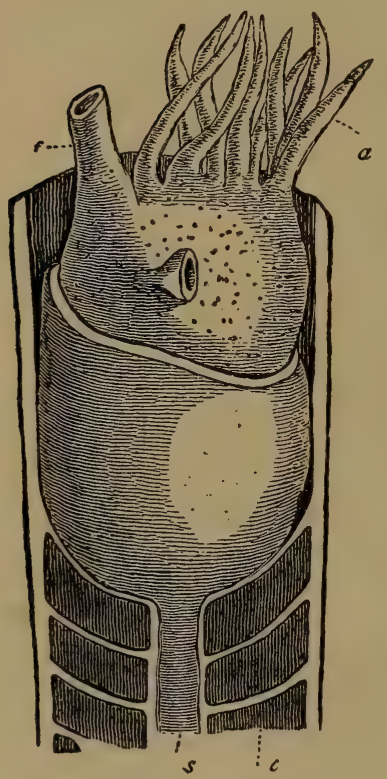

Fig. 56

An Orthoceras restored. (After Nicholson, from Le Conte's "Geology," courtesy of D. Appleton and Company.) bered-shelled types like the Orthoceras and Cyrtoceras. In the Ordovician the straight form, e.g. Orthoceras (Fig. 55a) was still dominant, but many advances were made giving rise to more curved forms (e.g. Cyrtoceras, Fig. $55 \mathrm{~b}$ ), open-coiled forms (e.g. Trochoceras, Fig. 55c), and close-coiled forms (e.g. Trocholites, Fig. 55d). All of these forms belonged to the Nautiloid division of the Tetrabranchs, that is, their septa or chamber partitions, where in contact with the walls of the shell, were straight or at least very simple. Closecoiled Nautiloids of the Ordovician greatly resembled the modern Pearly Nautilus, which is one of the very few living representatives of the now almost extinct Nautiloids (Fig. 13). The persistence of these simple close-coiled forms from the Ordovician to the present is noteworthy. Ammonoids, that is to say Tetrabranchs with more complex septa junctions, appeared in the Devonian and became increasingly prominent well into the Mesozoic era, but they have not continued to the present.

Since the Tetrabranchs are of such special interest from the standpoint of evolution, the following tabular summary is given to more clearly bring out certain prominent changes of shell structure from Cambrian time to the present. 


\section{Evolution of the Chamber-shelled (Tetrabranch) Cephalopods}

\begin{abstract}
(Chamber-shelled Cephalopods rep-
QUATERNARY $\quad$ resented only by a few genera of close-coiled Nautiloids, e.g. modern Pearly Nautilus (Fig. 13).
\end{abstract}

Tertiary

Cretaceous

JURASSIC

Triassic

Permian

Mississippian Pennsylvanian

Devonian

Silurian

ORDOVICIAN

Cambrian
$\{$ Ammonoids very rare and in lowest Tertiary (Eocene) only.

(Ammonoids much like Jurassic though somewhat diminished and with straight forms (e.g. Baculites, Fig. 161f), and curved or open-coiled forms more common.

Ammonoids greatly advanced in numbers, species, and complexity of septa, and they reach their climax, e.g. Ceratite with scalloped septa (Fig. 127); Ammonite with highly frilled septa (Fig. 141); and some curved and straight Ammonoids.

(Ammonoids common, some showing distinctly increased (highly curved) complexity of septa (e.g. Waagenoceras, Fig. 115). what increased.

(Ammonoids first appear with only slight (angular) complexity of septa junctions, e.g. Goniatite (Fig. 77).

$\{$ Much like Ordovician. No Ammo- $\}$ noids.

Close-coiled forms, e.g. Trocholites (Fig. 55d).

Open-coiled forms, e.g. Trochoceras (Fig. 55c).

Curved forms, e.g. Cyrtoceras (Fig. 55b).

Straight forms, e.g. Orthoceras (Fig. 55a).

$\{$ Straight and curved forms only.
Nautiloids, including Orthoceras, persist, but subordinate.

Nautiloids still predominate.

Simpler forms (Nautiloids) continue as in Silurian.

Coiled Nautiloid

forms predominate.

Close coiled Nautiloids only persist, e.g. Nautilus, but more varied than now.

Some Nautiloids present, but Orthoceras becomes extinct in Triassic.

Straight forms predominate. 
Arthropods. - Crustaceans were represented by both Trilobites and Eucrustaceans. Trilobites, which were the chief Ordovician Arthropods, reached their climax or culmination of development in numbers and species, more than a thousand species being known from the Ordovician alone (Fig. 58). These animals, after the Brachiopods, appear to have been among the most numerous animals of the time. Their variation in size was much like that of the Cambrian, but their eyes were usually larger and better developed. Eucrustaceans were represented by comparatively few simple forms, e.g. Ostracods and Cirripeds (Barnacles).

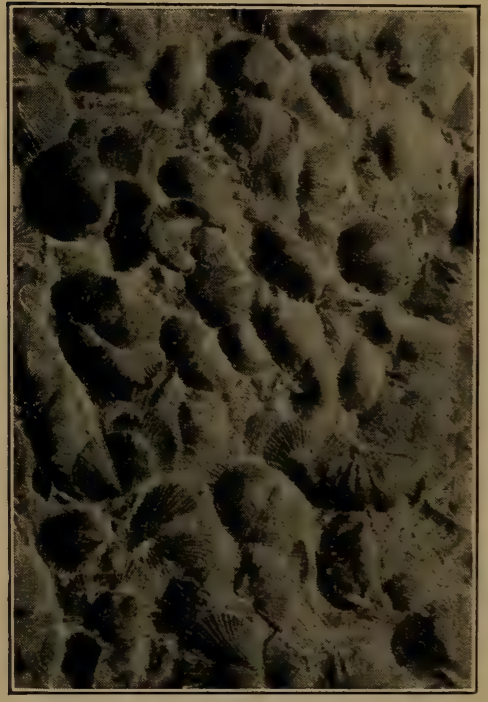

$a$

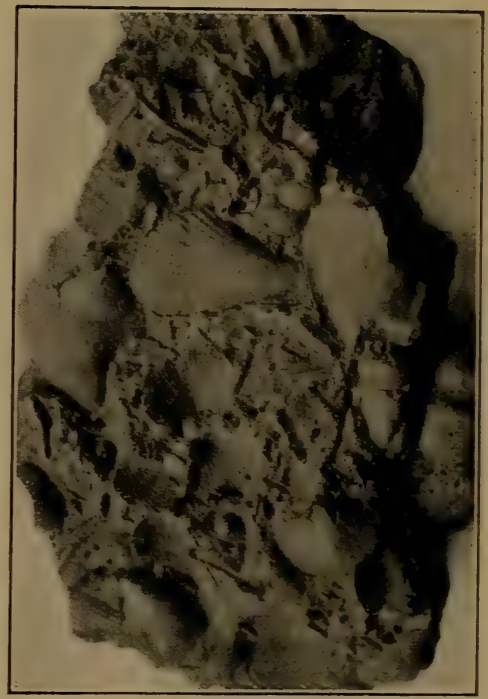

$b$

Fig. 57

Bits of Ordovician sea-bottom: $a$, Brachiopod shells on limestone; $b$, Crinoid, Bryozoan, Brachiopod, Pelecypod, Gastropod, and Cephalopod remains in calcareous sandstone. (W. J. Miller, photos.)

Arachnids, which date from Algonkian time, were represented, though not abundantly, by the remarkable group of Eurypterids. Since these creatures reached a much fuller development during the Silurian period, further discussion is reserved for the next chapter. Insects are not known to have existed during this period. 

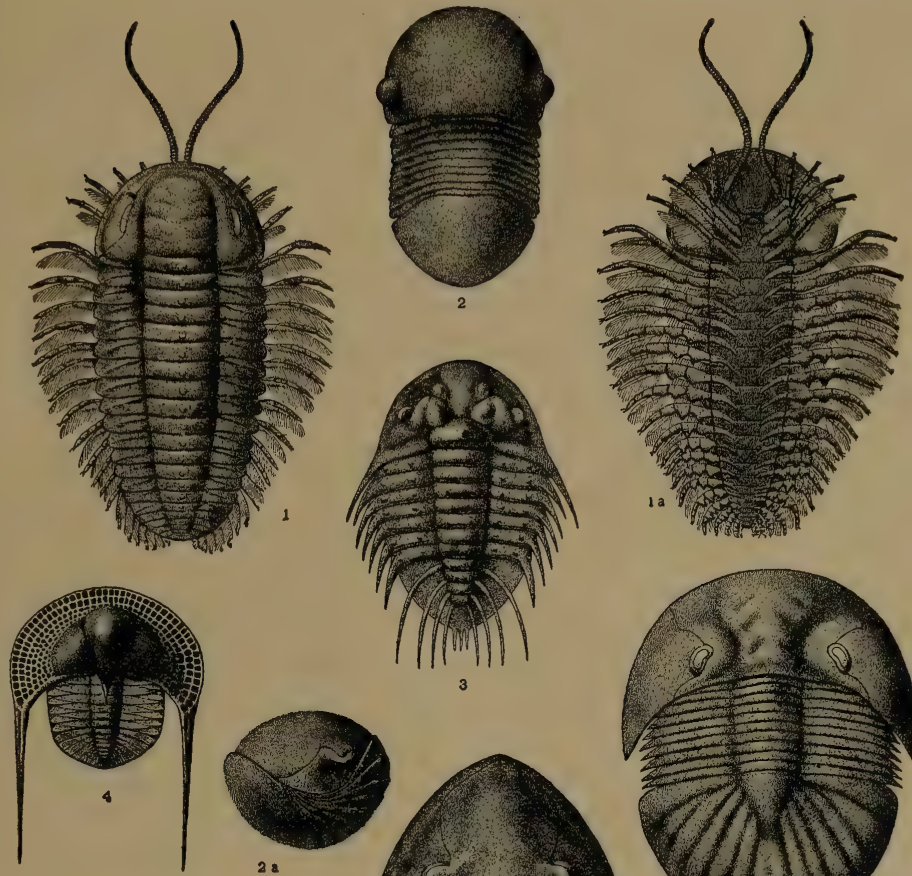

3
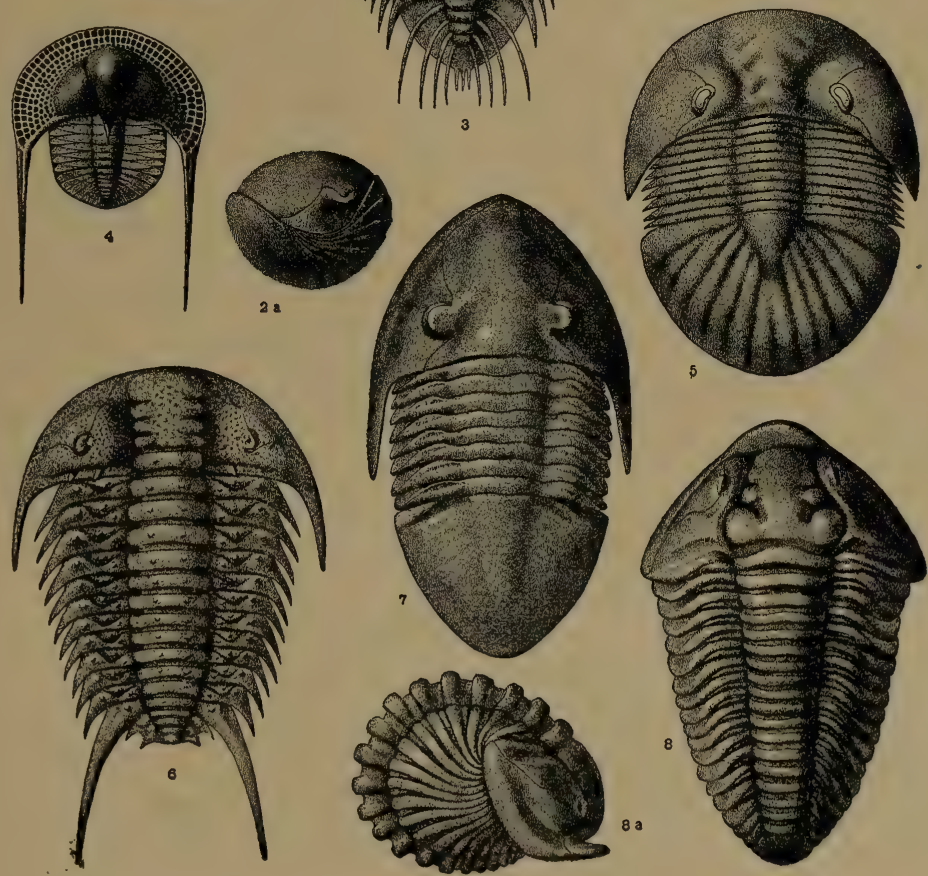

Fig. 58

Ordovician Trilobites: 1, 1a, Triarthrus becki (restorations by Beecher); 2, 2a, Bumastus trentonensis; 3 Acidaspis crosotus; 4, Trinucleus concentricus; 5, Bronteus lunatus; 6, Ceraurus pleurexanthmus; 7, Isotelus maximus; 8, 8a, Calymmene calicephala. (From Scott's "Introduction to Geology," permission of The Macmillan Company.) 
Vertebrates. - From the standpoint of evolution, perhaps the most significant feature of the Ordovician is the occurrence of the earliest known vertebrates. These were very primitive fishlike forms such as Ostracoderms, which have been found in Ordovician strata at certain places in Colorado and Wyoming. The fossils are mostly very fragmentary, consisting chiefly of scales or plates, but some nearly complete dermal plates are known. They strongly suggest the Ostracoderms, but since such forms are much better known from the Devonian, we shall postpone a fuller discussion of these curious creatures. 


\section{CHAPTER VIII}

\section{THE SILURIAN (UPPER SILURIAN) PERIOD}

\section{Origin of Name, Subdivisions, etc.}

WE have already learned how the great body of lowest fossiliferous strata in the British Isles was called the Silurian system by Murchison in 1835. The name was derived from Silures, an old tribe which once lived in part of Wales. In the preceding chapter we have also shown how the Silurian has since been divided into three systems - Cambrian, Ordovician, and Silurian. In view of the priority of Murchison's term "Silurian," and the fact that the Ordovician strata are now known to be more important and widespread than those we call Silurian, it seems inappropriate that the terms Ordovician and Silurian are not employed in the reverse order.

Since the Silurian strata, too, were first carefully studied in New York, the section for that state becomes to a very considerable degree a standard of comparison for all American Silurian strata. Like the Cambrian and Ordovician systems, the Silurian is generally subdivided into three major portions or series, these in turn being subdivided into various stages. The most recent classification by the New York Geological Survey is as follows:

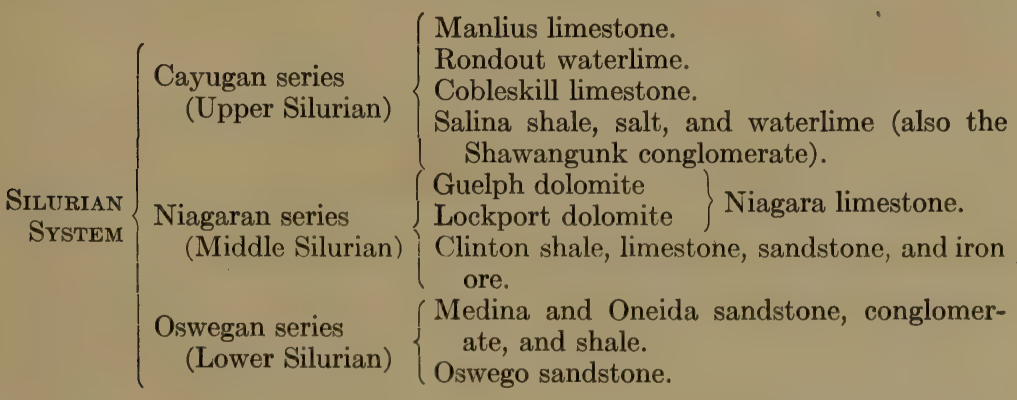

The New York Silurian section is more complete than the Ordovician, because the unconformities are fewer and of lesser 
importance, so that few horizons are missing. As was stated in connection with the Ordovician, so here, it should be remembered that many formation or stage names have been more or less locally applied in North America to formations not yet definitely correlated with those of New York, or to a few others not represented in New York. Also the lithologic character of formations may be quite different in different regions.

\section{Distribution and Character of the Rocks}

General Distribution. - The present surface distribution of the Silurian rocks in North America is shown on map, Fig. 59, which is largely self-explanatory. Certain points of comparison with the Ordovician (see map, Fig. 41) need to be mentioned. Thus to a very considerable degree the Silurian and Ordovician rocks occur in the same areas, the chief differences being much more extensive areas of Silurian strata in the Arctic Islands region, their almost complete absence from the upper St. Lawrence Valley, and their much smaller representation in the mid-Mississippi Basin, Rocky Mountains, and Great Basin of the west.

As stated in connection with the two preceding areal distribution maps, so here, the surface distribution of Silurian rocks by no means indicates the former or even present actual extent of these rocks in North America. From many regions Silurian strata have been removed by erosion, while in other regions they are concealed under cover of later rocks. Thus most of the upper Mississippi Basin, with its essentially horizontal strata, is underlain with Silurian rocks, and only the eroded edges of upturned Silurian strata are exposed in the Appalachian Mountains.

The Oswegan Series. - This series, in the northeastern United States, consists principally of the Oswego sandstone, and Medina sandstone, shale, and (Oneida) conglomerate. Ripple-marks, cross-bedding, and the character of the fossils prove these to have been deposited in a very shallow, probably encroaching, sea. The Oneida conglomerate is made up of well-rounded pebbles, bears all the marks of a typical marine-beach or very shallow-water deposit, and in central New York rests upon the eroded edges of the Upper Ordovician shales.

The Niagaran Series. - This series is of special interest both because of its lower or Clinton beds and its higher or Lockport and 
Guelph dolomitic limestones. The Clinton formation rests conformably upon the Medina beds, but is more widespread than they.

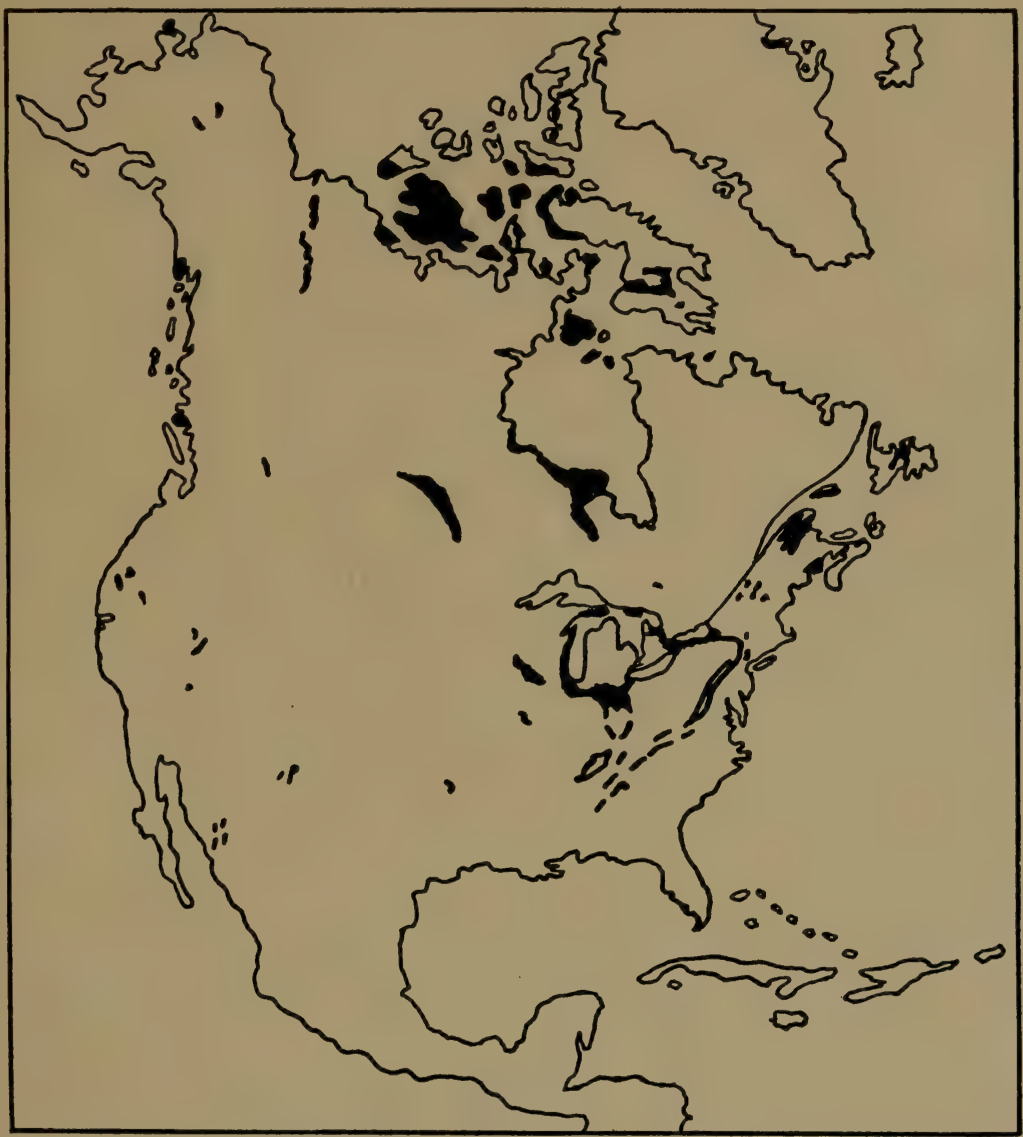

Fig. 59

Map showing the surface distribution (areas of outcrops) of Silurian strata in North America. (Modified by W. J. M. after Willis, U. S. Geological Survey.)

It extends through the Appalachian Mountains, westward from central New York to Lake Huron and Indiana into Wisconsin, and probably through Illinois and Missouri. It is also known in 
Nova Scotia. Lithologically this formation is quite variable, being mostly shales and sandstones in the Appalachians and central New York, and largely limestone in western New York and farther west and southwest. This limestone does not imply deep marine water, but merely shallow water comparatively free from land-derived sediments. A remarkable and well-nigh universal feature of the Clinton formation is its interstratified beds of iron ore (hematite). This iron ore is especially well developed throughout the Appalachians, from central to western New York, Wisconsin, and in Nova Scotia. The ore is concretionary or oölitic in character and apparently a contemporaneous deposit enclosed within the shales or limestones. It is often highly fossiliferous, hence the name "fossil ore."

Conformably above the Clinton beds lies the Niagara limestone, which has a still wider distribution than the Clinton. Its type locality is at Niagara Falls, and in New York state it is divided into the Lockport and Guelph dolomitic limestone formations. This mid-Silurian time was another great limestone-making age almost comparable to that of the mid-Ordovician. In the United States, Niagara limestone is known throughout much of the upper Mississippi Valley and Great Lakes region, southward to Tennessee, and westward to Missouri, Oklahoma, and northern Texas. In Canada it is widely distributed in Manitoba, just west of Hudson Bay, and in the Aretic Islands. Niagara limestone also quite certainly occurs in parts of the western Lnited States, though definite correlations are not yet made. Coral reefs are of common occurrence in the formation. It should not be understood, however, that limestone was universally forming during Niagara time, exceptions being, for example, Niagara shales in central New York and in Nova Scotia.

The Cayugan Series. - The Salina formation rests directly upon, but is much less extensive than, the Niagara formation, being found only through parts of Pennsylvania, New York, Ontario, Onio, and Michigan. Lithologically the formation is quite variable, including all the common types of sediments as well as waterlime (hydraulic limestone), red shales, and salt and gypsum beds. The Shawangunk conglomerate, until quite recently classed with the Oneida, is of Salina age. The eroded edges of its resistant, tilted strata form the Shawangunk Ridge (so-called Range) of southeastern New York and the Kittatinny Range of 
New Jersey and Pennsylvania. The Delaware Water Gap is cut through this formation.

Overlying the Salina beds, but considerably more extensive, are the limestones and waterlimes of Cobleskill, Rondout, and Manlius ages which reach from Pennsylvania and New York westward to Indiana and Wisconsin.

Silurian of the West. - Definite subdivisions and correlations of the Silurian strata of the West have not yet been made, but in certain regions, like the Great Basin, there appears to be a practically unbroken succession of largely limestone strata ranging in age from Middle Ordovician (Trenton) to Devonian.

Thickness of the Silurian. - From central to western New York the thickness of the Silurian system is from 1000 to 1500 feet. Its maximum thickness is from 2000 to 4000 feet in the Appalachians, while in the Mississippi Valley the thickness is generally less than 1000 feet. The Niagara limestone is a notable exception to the usually greater thickness of the early Paleozoic strata in the Appalachian region, since in Wisconsin it is some 700 or 800 feet thick, while in the east it is only from 100 to 300 feet.

Igneous Rocks. - In North America the only igneous rocks regarded as of Silurian age are some in Maine, Nova Scotia, and New Brunswick. Igneous intrusives of later date have sometimes penetrated Silurian strata.

\section{Physical History}

Early and Middle Silurian. -- We have learned that, as a result of physical disturbance toward the close of the Ordovician, much of the interior Paleozoic sea was drained, causing the land area to be so much enlarged as to have been more extensive than at any time since the beginning of the Paleozoic era. This was essentially the geographic condition of the continent at the beginning of the Silurian. The boldest topographic feature was the presence of the newly formed Taconic Range along the Atlantic sea-board. Doubtless there were some areas of sedimentation, but our present knowledge of the earliest Silurian physiography of North America does not admit of their delimitation.

This condition of the continent was not of (geologically) long duration, because pretty early in the Silurian another great transgression of the sea took place, gradually increasing the extent of 
the marine waters to a maximum in the mid-Silurian (Niagaran) epoch. On the accompanying map (Fig. 60), the relations of land and water are graphically depicted, and it will be seen that the extent of marine waters was almost comparable to that of midOrdovician time, though with the following chief differences in the mid-Silurian: Appalachia was larger and higher because of the Taconic uplift; the land areas east and west of Hudson Bay and in the Cordilleran region were larger; and there was more land in the Gulf border (especially Texas) region. That this Niagaran sea was a true epicontinental or shallow water body is definitely known for reasons similar to those given in the discussion of the midOrdovician sea.

In order to further impress upon the reader not only how a marine transgression of this sort is proved, but also how the direction of encroachment can be determined, we may briefly consider the excellent example afforded by the disposition of Silurian strata in New York state. That central and western New York were submerged before the Hudson Valley region is proved as follows. In central New York the first deposit to form upon the eroded surface of the Ordovician shales was the Oneida conglomerate. In the Hudson Valley of New York (e.g. Shawangunk Range), the first deposit to be laid down upon the eroded Ordovician shales was the Shawangunk conglomerate which belongs with the Salina division and is therefore much younger than the Oneida conglomerate. Also the Clinton and Niagara formations, well developed in central and western New York, were never formed in the eastern or southeastern parts of the state, though they do extend somewhat farther eastward than the Oneida. Thus we prove that the Silurian sea overspread central and western New York long before it reached the Hudson Valley region of southeastern New York.

Late Silurian. - Two prominent events mark the physical history of late Silurian time, namely a very considerable withdrawal of the extensive (Niagaran) sea in early Cayugan (Salina) time, and a considerable, though only partial, reëxtension of the sea in later Cayugan time. That a very appreciable retrogression of the Niagaran sea ushered in Salina time is proved by both the comparatively restricted distribution and the character of the Salina strata. Thus in the eastern United States and Canada Salina strata occur only through parts of Pennsylvania and south- 


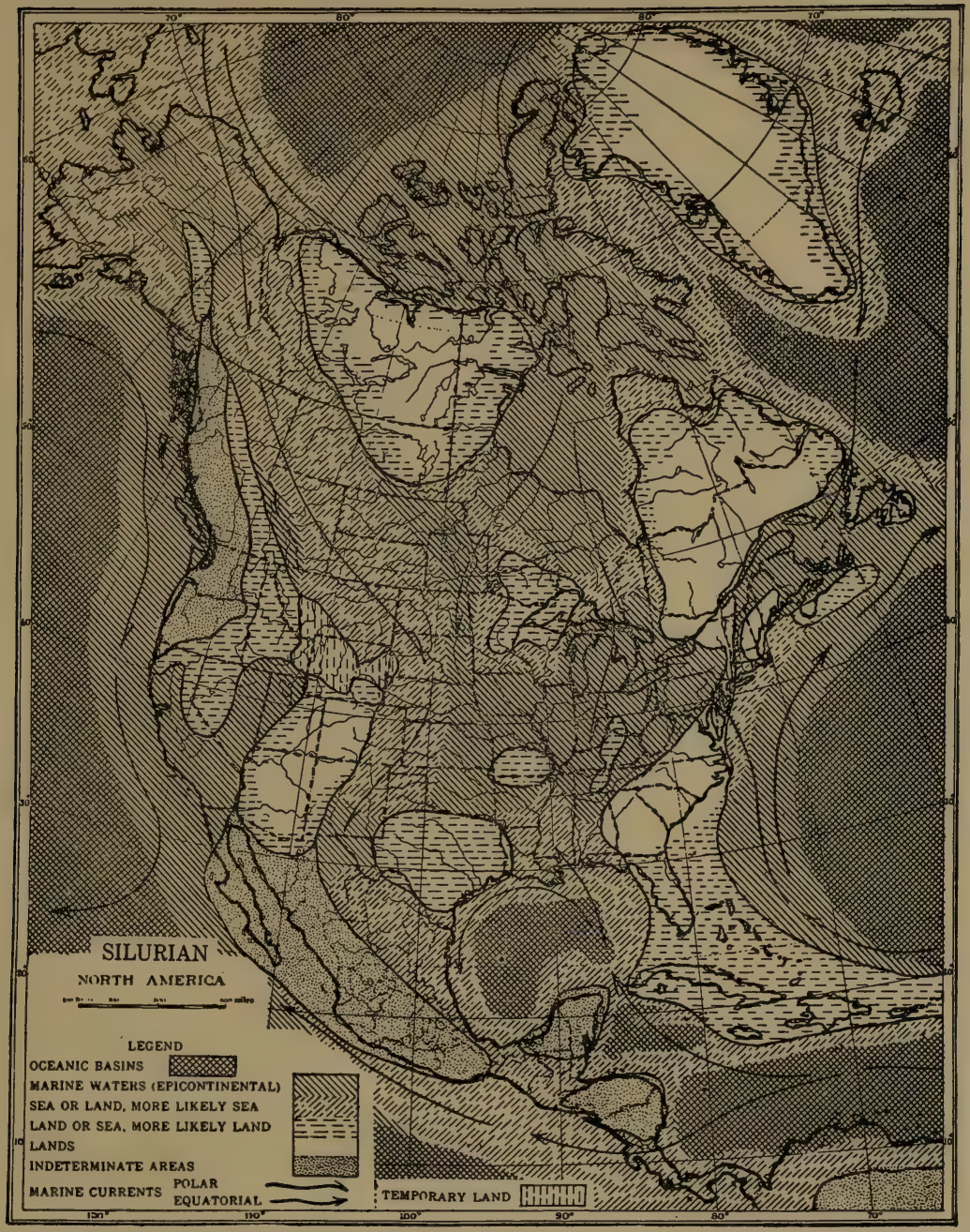

Fig. 60

Paleogeographic map of North America in the Silurian period. (Slightly modified after Bailey Willis, courtesy of The Journal of Geology.) 
ward to Virginia in the Appalachians, New York, Ontario, Ohio, and Michigan, and are quite generally characterized by red shales and sandstones and salt and gypsum deposits. Such materials imply arid climate conditions, with deposition in extensive lagoons or more or less cut-off arms of the sea, rather than typical open sea conditions.

Since the immediately overlying Cayugan formations (Cobleskill, Rondout, and Manlius) are mostly marine deposits and more extensive than the Salina, it is evident that there was at least a partial restoration of more widespread marine waters during later Cayugan time. This later Cayugan sea spread from eastern New York westward over the Salina lagoon areas and into eastern Wisconsin, and from eastern New York southward through the Appalachian district. So far as known the rest of the continent was dry land.

In addition to these broader and more important geographic changes during the Silurian period, there were of course various minor and generally local changes of relative level between land and sea, some of these now being known and some not yet determined.

Close of the Silurian. - At the close of the Silurian, or opening of the Devonian, the Cayugan sea withdrew from the area from central New York to Wisconsin, and but a few comparatively small areas of eastern North America were submerged, as shown on map (Fig. 69). This was essentially the geography of the continent in earliest Devonian time and will be discussed in the next chapter.

There appear to have been no mountain-making (orogenic) movements, and no important epeirogenic disturbances at the close of the Silurian in North America. Because of the comparatively quiet and gradual transition into the succeeding period, the Silurian and Devonian systems are usually not sharply separated from each other, and often, as in New York, there has been difficulty in satisfactorily dividing the systems.

\section{Foreign Silurian}

The Ordovician division of Europe into two great provinces or basins of deposition - northern and southern - was continued in the Silurian, though the latter strata are not so widely distributed. 
The faunas of these two provinces show greater differences than does the northern province as compared with North America, or even other continents. This implies a lack of free communication between the southern European province and the more typical Silurian provinces of the earth.

As in America, European Silurian strata are largely concealed beneath later formations. Usually the Silurian rests conformably

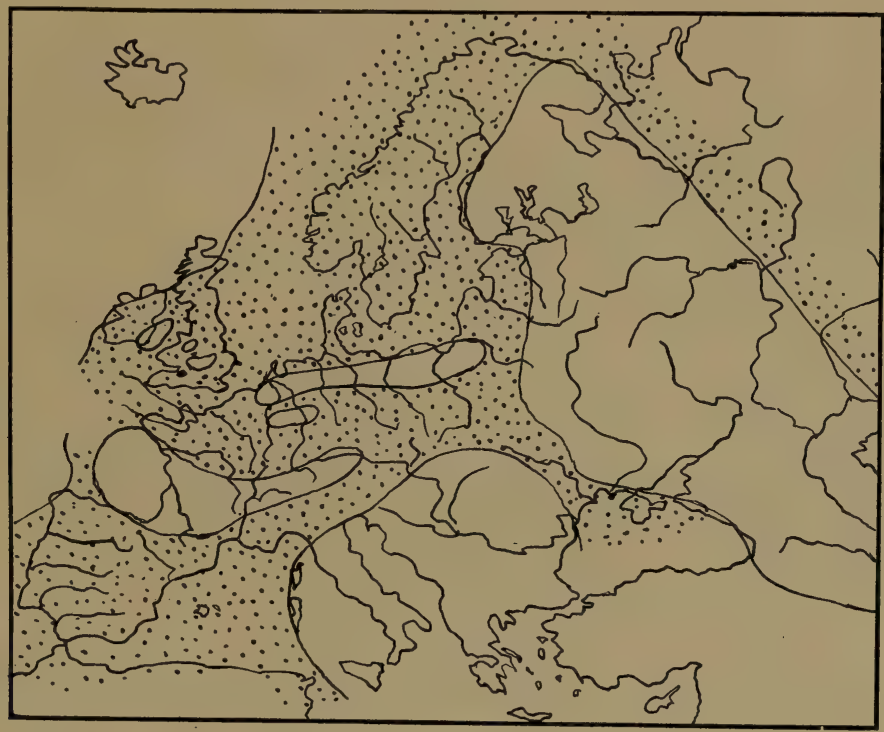

Fig. 61

Sketch map showing the relations of land and water in Europe during Silurian time. Dotted areas, water. (Slightly modified after De Lapparent.)

upon the Ordovician, except in the British Isles. Also in most of Europe the transition to the Devonian was gradual, except in the British Isles, where the Silurian strata were tilted and eroded before the deposition of the Devonian. In much of the southern province the rocks are folded and tilted, though this deformation took place sometime after the close of the Silurian. In mid-Silurian, as in North America, much limestone was formed across the British Isles, southern Scandinavia, and well into Russia. Silurian strata 
of Europe are not as thick as those of the two immediately preceding systems, being from 3000 to 5000 feet in the British Isles, and generally less elsewhere. Igneous rocks of Silurian age are almost unknown.

In other continents Silurian rocks have seldom been well studied and separated from the Ordovician, though they are definitely known in China, Africa, Australia, and South America.

\section{Climate}

The general distribution and character of the rocks and their fossil content point to more uniform climatic conditions than those of today. Fossils in the Arctic Silurian rocks are not essentially different from those of low latitudes.

From central New York across to Michigan at least, there was an arid climate during the Salina epoch, as already mentioned, but this was probably only local.

\section{Economic Products}

Silurian sandstones and limestones are extensively quarried for building purposes, or the limestones burned to make quick-lime. The waterlimes of late Silurian age were until quite recently considerably used for the manufacture of hydraulic cement, especially in the Hudson Valley of New York state.

We mentioned the widespread and almost universal occurrence of hematite iron ore in the Clinton formation. This ore is mined to some extent in central and western New York, but in the Birmingham, Alabama, district, which is the second greatest iron mining region of America, the Clinton formation is the source of the ore.

Another important economic product of Silurian age is the salt of the Salina formation. In New York alone salt beds underlie most of the western part of the state or an area of about 10,000 square miles. Sometimes there is one bed and sometimes several interstratified with other rocks. Single beds locally attain a thickness of from 50 to 80 feet. In the southern part of the state the salt is most deeply buried under later rocks, a well at Ithaca having passed through 248 feet of salt in seven beds below 2244 feet from the surface. Toward the north the beds gradually come near the surface. Important salt beds also occur near Cleveland, Ohio, 
and Saginaw, Michigan. The usual method of obtaining the salt is by pumping brine from deep wells, and then evaporating.

Much gypsum is mined along the lines of outcrop of Cayugan strata in western New York.

Oil and gas are obtained from the Clinton sandstone of Ohio, and some gas from the Medina sandstone of New York.

\section{Life of the Silurian}

Plants. - Sea-weeds, though not abundant as fossils, are well known, especially in the Medina-Oneida sandstones and conglomerate, and Clinton formation, all of which were deposited in very shallow water. Knowledge of the land plants of the period is still very meagre, though some rather doubtful specimens are known. Perhaps the most authoritative example is a fossil Fern

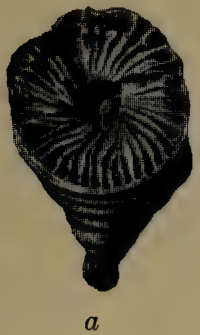

$a$

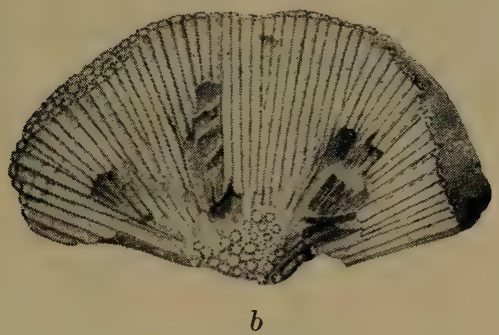

Fig. 62

Silurian and Devonian Corals: a, Cup-coral, Zaphrentis roemeri (M. Edwards and Haime) (Devonian form); $b$, Honeycomb-coral, Heliolites pyriformis (Guettard); Chain-coral, Halysites catenulatus (Linn.).

found in France, and this shows that the Pteridophytes at least were in existence. Considering the profuse land vegetation of the next (Devonian) period, it seems certain that their progenitors must have been well represented in the Silurian, and that either their remains may yet be discovered, or the conditions for their preservation were unfavorable.

Protozoans have not been found as fossils, but they must have existed, because they are known from both the preceding and succeeding periods.

Porifers. - Sponges were common, and in the Silurian strata of western Tennessee they are exceedingly abundant. A genus of 
nearly spherical forms with deep grooves was particularly prominent.

Cœlenterates. - Graptolites, though greatly diminished in importance, were still fairly common. The more complex colonies,

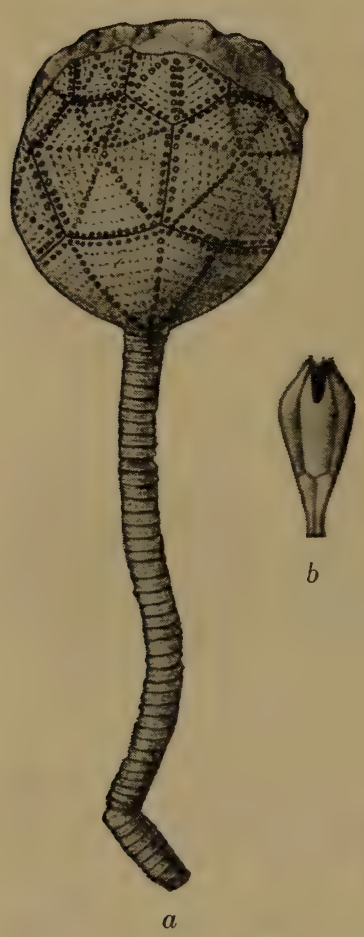

Fig. 63

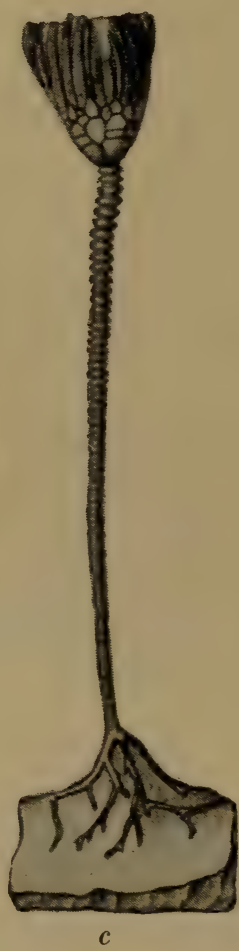

$c$

Silurian Echinoderms: $a$, Cystoid, Caryocrinus ornatus; $b$, Blastoid, Troostocrinus reinwardti; c, Crinoid, Eucalyptocrinus crassus. (After Say, Troost, and Hall respectively.) such as branching forms and those with double rows of cells on their axes, were nearly extinct, the simple forms mostly only remaining. Anthozoans (Corals) increased in prominence to a very notable degree, and the simple Cup Corals (Fig. 62a) of the Ordovician were superseded in importance by the colonizing or compound forms. Chain Corals (Fig. 62c), which were rare in the Ordovician, reached their climax of development, but became nearly extinct by the close of the period. Honeycomb Corals (Fig. $62 \mathrm{~b})$ were also common.

Echinoderms.Though the Cystoids reached their climax in the Ordovician, they were still abundant in the Silurian, the $\mathrm{Ni}$ agara limestone near

Chicago being particularly rich in them. Many were unusually large, and some showed greater degree of symmetry in arrangement of plates than before (Fig. 63a).

Blastoids still remained rare, only two genera being known (Fig. 63b). 
Crinoids very considerably increased in numbers and species as well as in complexity of structure (Fig. 63c). "They attained such abundance in certain localities that their fragments formed the main substance of the limestone. These spots became veritable 'flower-beds' of 'stone lilies,' and certain localities, as Lockport, N. Y., Waldron and St. Paul, Ind., Racine, Wis., Chicago, Ill., Gotland, Sweden, and Dudley, England, have become noted as peculiarly rich crinoidal fields, where beautiful and varied forms
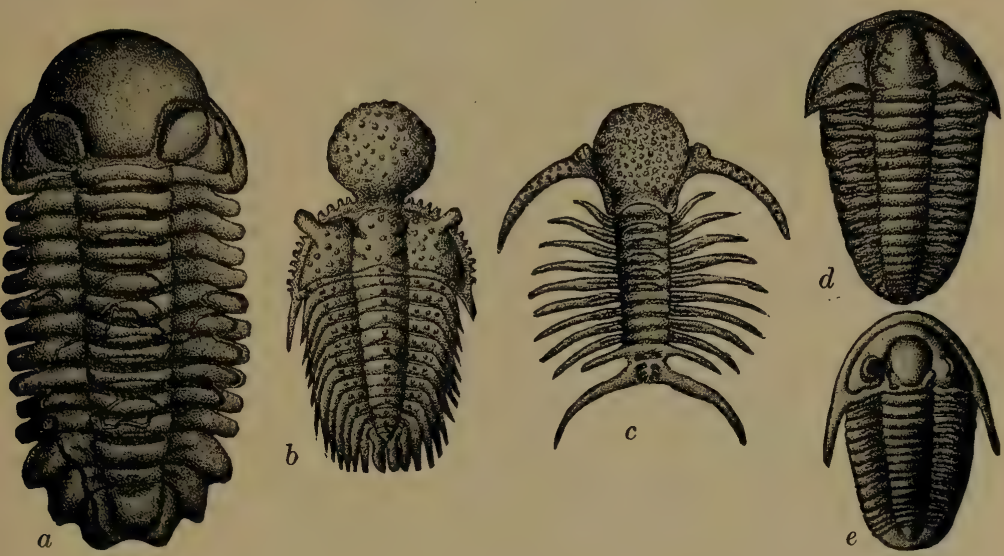

Fig. 64

Silurian Trilobites: $a$, Sphcrexochus mirus (Bey.); $b$, Staurocephalus murchisoni (Barr.); c, Deiphon forbesi (Barr.); d, Calymene niagarensis (Hall); e, Cyphaspis christyi (Hall). (From Chamberlin and Salisbury's "Geology," courtesy of Henry Holt and Company.)

grew in groves, as it were." 1 About 400 species are known from the Silurian of North America.

Asterozoans (Star-fishes) and Echinoids (Sea-urchins) became more common, though by no means abundant. Modern Sea-urchins have exactly twenty rows of calcareous plates tightly fitted together, while Paleozoic forms had a variable number of plates, and in some forms the plates were only loosely joined together, this latter feature apparently being a primitive characteristic.

Molluscoids. - Bryozoans were less prominent than in the Ordovician, but, nevertheless, they were often common as reef

${ }^{1}$ Chamberlin and Salisbury: Geology, Vol. 2, p. 400. 
builders. Their lack of abundance may be somewhat apparent only, due to the fact that more delicate forms prevailed.

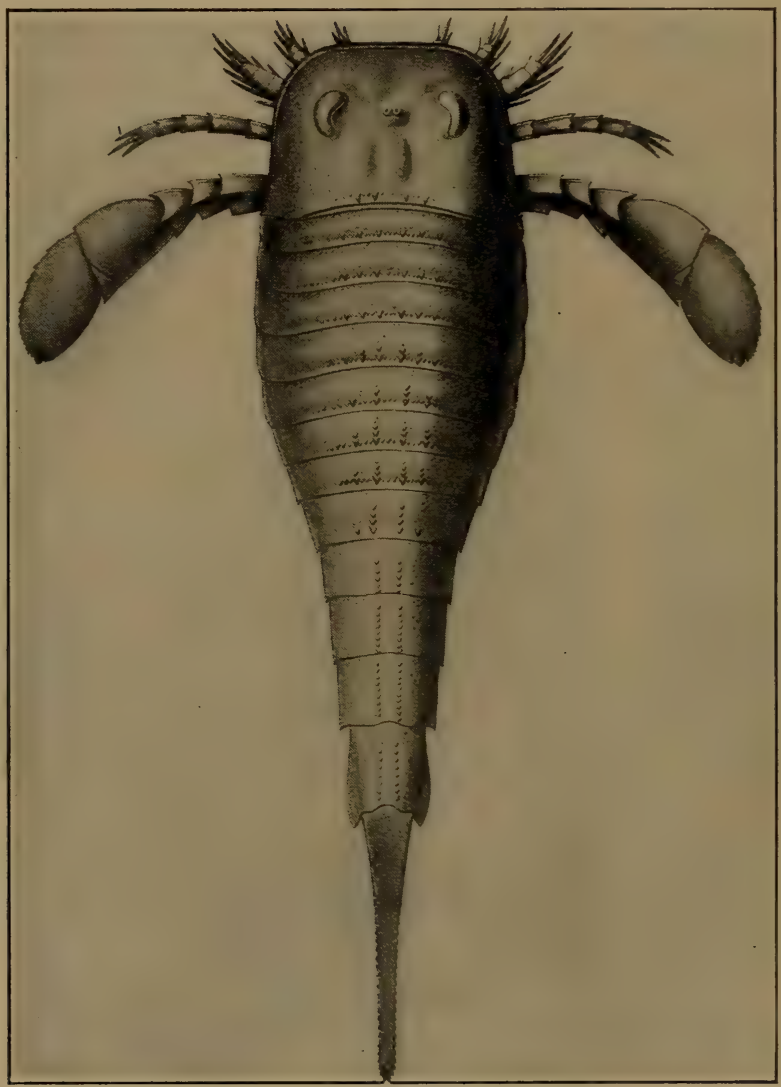

Fig. 65

A Silurian Eurypterid, Eurypteris remipes, restored to show dorsal side. (After Clarke and Ruedemann, N. Y. State Mus. Mem. 14.)

Brachiopods continued to be the most prominent of all organisms as regards both number of individuals and species, and this in spite of the fact that very few Ordovician species, and not many genera, continued from the Ordovician into the Silurian. Two 
genera, Spirifer and Pentamerus, made their first appearance and were especially prominent in the Silurian, but became even more so in the Devonian. The Spirifer developed a long, straight, hinge line, while the Pentamerus had a sort of hook-shaped beak projecting over the hinge line.

Mollusks. - The Pelecypods and Gastropods were still common, but they were in no important way different from those of the preceding period.

Cephalopods were represented only by the Nautiloids. Of these, the straight (Orthoceras) forms were still common, but the curved and coiled forms became predominant. Some of the Nautiloids were notably ornamented externally. Otherwise, except for many genera and species changes, the Cephalopods were much like those of the Ordovician, which we rather fully discussed.

Arthropods. - Crustaceans were represented by Merostomes, Trilobites and Eucrustaceans. Horse-shoe Crabs, representing the Merostomes, first appeared in the Silurian. Trilobites culminated in the preceding period, but they still continued to be common.

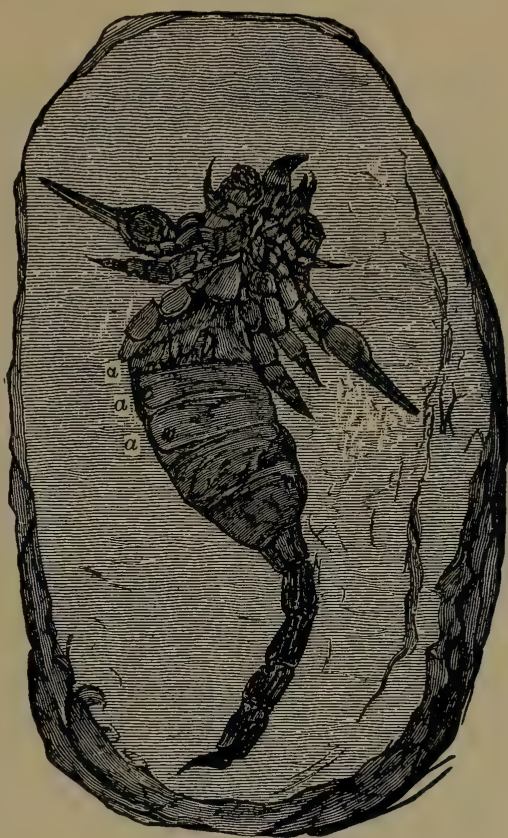

Fig. 66

A Silurian Scorpion, Paleophonus caledonicus, by Hunter after Peach. (From Le Conte's "Geology," permission of D. Appleton and Company.)

A few new genera appeared, but more disappeared. Silurian Trilobites were perhaps more diversified than in any other period. "Like the decadent nations revealed to us in human history, they indulged in extravagant and futile eccentricities, ill befitting their approaching overthrow. Odd and highly ornate forms appeared in profusion (Fig. 64b, c), and in most instances the spines, tubercles, and horns which they produced seem to have 
had little or no real value in their life activities. We shall see in studying later periods that similar eccentricities mark the fall of other groups, such as the Ammonites and the Reptiles." ${ }_{1}$ Eucrustaceans were much like those of the Ordovician.

Arachnids, represented by the Eurypterids, greatly increased in numbers, species, and size, and they appear to have culmi-

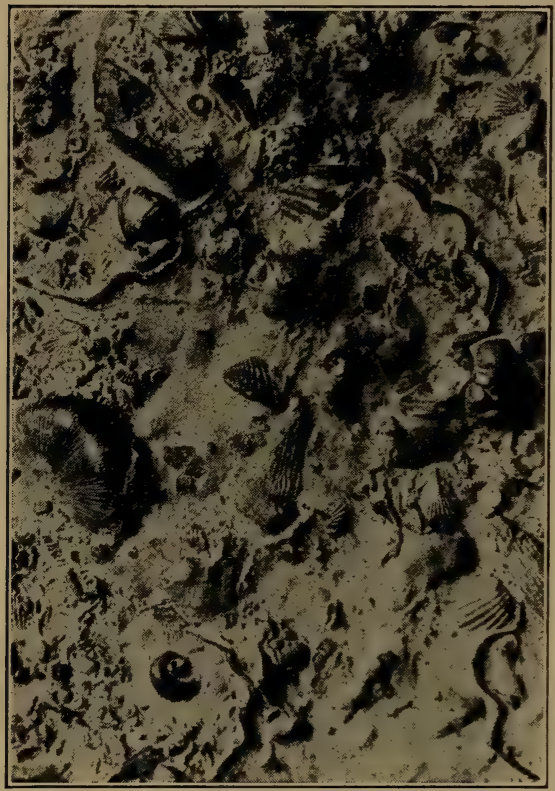

Fig. 67

A bit of Silurian sea-bottom showing Crinoid, Bryozoan, 'Brachiopod, and Trilobite remains. (W. J. Miller, photo.) nated in this period. The following brief description, together with an examination of Fig. 65, will serve to give a fair idea of the appearance and structure of these remarkable creatures. In the typical Eurypterid, a quadrate or semicircular head has behind it twelve movable segments making up the abdomen, and attached to the last segment is either a spine or plate-like tail. The five pairs of appendages all come out from the head portion, thus being markedly different from the Trilobites. The first pair of appendages are much enlarged, sometimes provided with pincers and sometimes not, while the fifth pair are usually long and they serve as swimming paddles. They varied greatly in size, one species, from the Silurian, having attained a length of over six feet and so is one of the largest known Arthropods. Many Eurypterids appear to have been marine animals, while others probably lived in fresh or brackish water lagoons. The Arachnids included also the earliest known Scorpions (Fig. 66), which were in many respects similar to the Eurypterids.

${ }^{1}$ Blackwelder and Barrows: Elements of Geology, pp. 352-353. 
Insects are not known from the Silurian.

Vertebrates. - The only known Silurian Vertebrates were of very simple types, such as the Ostracoderms and primitive Fishes, probably Sharks. All of the Ostracoderms were small, odd-shaped creatures, but pretty closely related to the more prolific Devonian forms to be described later. 


\section{CHAPTER IX}

\section{THE DEVONIAN PERIOD}

\section{Origin of Name, Subdivisions, etc.}

IN 1839 Sedgwick and Murchison gave the name of Devonian to strata in the county of Devonshire in England where rocks of this age were first carefully studied. Because of the metamorphosed and highly disturbed character of the English Devonian, the sub-divisions in Europe were not well worked out until the more undisturbed rocks of Belgium and along the Rhine were studied.

In North America the New York subdivisions are taken as the standard, because the Devonian strata were first carefully studied there. The New York Devonian section is a remarkably complete one of very considerable thickness (fully 4000 feet), with not a single stage missing, except possibly the very lowest one, and with a surface distribution over fully one-third of the area of the state. There was well nigh continuous deposition of strata during Devonian time in New York, and if locally a stage or sub-stage is missing, it is present elsewhere in the state. It is doubtful if a greater degree of refinement of knowledge exists, regarding so complete a section of the Devonian or any other Paleozoic system in North America, than that of New York state.

The latest classification of the New York Devonian system by the State Geological Survey follows:

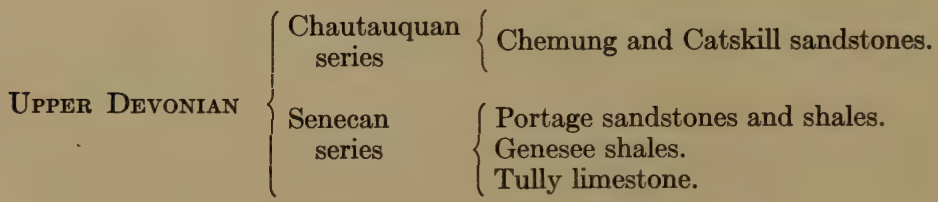

Middle Devonian $\begin{cases}\begin{array}{c}\text { Erian } \\ \text { series }\end{array} & \left\{\begin{array}{l}\text { Hamilton shales and limestone. } \\ \text { Marcellus shales and limestone. }\end{array}\right. \\ \begin{array}{c}\text { Ulsterian } \\ \text { series }\end{array} & \left\{\begin{array}{l}\text { Onondaga limestone. } \\ \text { Schoharie grit. }\end{array}\right. \\ & 120\end{cases}$ 
Lower Devonian $\begin{cases}\begin{array}{c}\text { Oriskanian } \\ \text { series }\end{array} & \left\{\begin{array}{l}\text { Esopus grit. } \\ \text { Oriskany sandstone and Glenerie lime- } \\ \text { stone. } \\ \text { Connelly conglomerate. } \\ \text { Port Ewen limestone. }\end{array}\right. \\ \begin{array}{l}\text { Helderbergian } \\ \text { series }\end{array} & \begin{array}{l}\text { Becraft limestone. } \\ \text { New Scotland limestone. } \\ \text { Kalkberg limestone. } \\ \text { Coeymans limestone. }\end{array}\end{cases}$

For a long time the Helderbergian series was placed with the Silurian system, but on the basis of careful study of its fossils, it is now generally agreed that it really represents the lowest portion of the Devonian system. This is a good example of the difficulty in drawing the line between two systems when no sharp stratigraphic break or unconformity exists.

As stated in connection with the preceding system, so here the reader should know that in many parts of America where definite correlations have not been made, local subdivisions or stage names are employed, and also that the lithologic character of the various stages in New York may be quite different from those in other regions.

\section{Distribution and Character of the Rocks}

General Distribution. - The map (Fig. 68) gives the surface distribution of all known Devonian rocks in North America. A comparison with the Silurian strata map (Fig. 59) will show that, in the eastern part of the continent, these two rock systems are very similar in distribution, though the Devonian is absent from Newfoundland and is of much larger surface extent in New York. As compared with the Silurian the only other important differences are the much larger Devonian area in the Mackenzie River region and the much smaller areas in the Arctic Islands region.

It should again be borne in mind that these surface areas of Devonian rocks fall far short of indicating the actual former, or even present extent of rocks of this age, because considerable Devonian rock has been removed by erosion, and much is now buried under later formations. Thus in the Appalachians and the mountains of the western United States, the Devonian strata have been highly folded with others, so that only the outcropping 
edges are visible. In the Mississippi Basin, where the strata are essentially horizontal, deep well borings have proved that the Devonian strata are extensively distributed under cover of later rocks.

Lower Devonian Rocks. - The Helderbergian series is very limited in its distribution, and is found almost wholly in eastern North America in three regions: (1) Maine, eastern Quebec, Nova Scotia, and New Brunswick; (2) the northern and middle Appalachians; and (3) in the lower Mississippi Valley in Oklahoma, southeastern Missouri, and western Tennessee and Kentucky. Limestone almost everywhere makes up the series which ranges in thickness up to 600 feet. In the West, this series has been recognized only in the great body of Paleozoic limestone in Nevada. Rocks of this age are also known on Kennedy Island west of northern Greenland.

The Oriskanian series is chiefly represented by the Oriskany sandstone, the other members of the series being only of mere local importance. The Oriskany formation is extensively developed from central New York southward through the Appalachian region to Alabama, and in the eastern Mississippi Valley. Its thickness varies from a few feet in New York, to several hundred feet in western Maryland. In northern Maine, New Brunswick, and Nova Scotia, the Oriskany (much of it limestone) is well developed though not much studied.

Middle Devonian Rocks. - The Ulsterian rocks, except the Schoharie grit which is limited to eastern New York, are much more extensive than the Lower Devonian.

The Onondaga limestone formation extends from eastern New York and Pennsylvania westward to northern Michigan and southern Illinois, except over the Cincinnati anticline area. Its entire absence from all but the northern portion of the Appalachians is particularly noteworthy. Its thickness is seldom over 200 feet, and it is often largely made up of Corals, as for example at the Ohio River rapids near Louisville. In northern Maine, New Brunswick, and Nova Scotia, the Onondaga limestone is widespread and apparently many hundreds of feet thick. It also occurs at the south end of Hudson Bay. In most of the Devonian areas of western North America (see Fig. 68), the Onondaga formation is doubtless present though not yet carefully studied.

The Erian series, represented by the Hamilton and Marcellus 
shales and limestones, has very much the same distribution as the Onondaga, except for the absence of Erian from the south end of

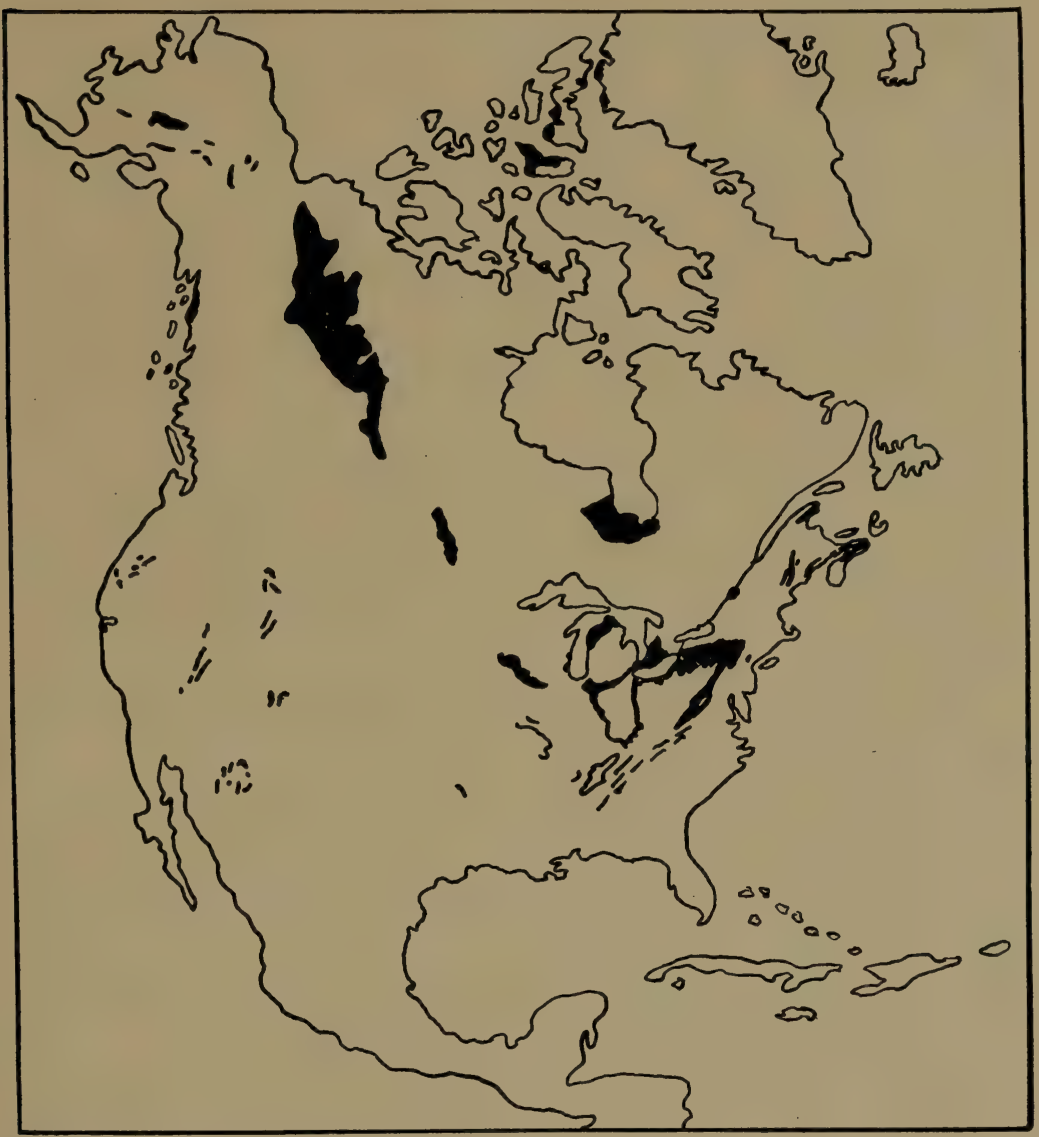

Fig. 68

Map showing surface distribution (areas of outcrops) of Devonian strata in North America. (Modified by W. J. M. after Willis, U. S. Geological Survey.)

Hudson Bay, and additional Erian areas in the middle Appalachians, Iowa, northern Missouri, and just west of Lake Winnipeg. In the east, shales were deposited, attaining a thickness of 1500 
to 5000 feet in Pennsylvania, while in the upper Mississippi Basin, where much limestone still formed, its thickness is notably less. A good idea of the distribution (surface and concealed) of the Middle Devonian rocks is afforded by noting the water areas on the paleogeographic map (Fig. 70), though from these areas some Devonian strata have been removed by erosion.

Upper Devonian Rocks. - These show a distribution very similar to the Middle Devonian, except that the southern Appalachians and region immediately westward also contain them. Leaving out the area of Onondaga at the south end of Hudson Bay, a good conception of the distribution of the Upper Devonian rocks may be gained by examining the map (Fig. 68), because almost everywhere that any Devonian is present, the Upper Devonian also occurs.

The Senecan series, except for the comparatively thin and local Tully limestone, consists of the Genesee shales, and Portage sandstones and shales. The Genesee ranges in thickness from a few feet in western New York, to several hundred feet in central Pennsylvania, while the Portage is over 1000 feet thick in western New York.

The Chautauquan (Catskill ${ }^{1}$ and Chemung) series of sandstones have a thickness of 1000 to 1500 feet in western New York; 3000 feet in eastern New York; and a maximum of 8000 feet in eastern Pennsylvania. The Catskill was quite certainly mostly a fresh or brackish water deposit.

In the Mississippi Valley, westward from New York and the Appalachians, the Upper Devonian is much thinner; subdivisions are not so well represented, or recognized; and the New York names have not been applied. Also in western America, the Upper Devonian subdivisions have not been well made out.

Comparison of Ordovician, Silurian, and Devonian Systems. "Comparing the rocks of the Ordovician, Silurian, and Devonian, as these are developed in the Appalachian and adjoining regions, a certain rhythmic or periodic recurrence of events may be discovered among them. Each system is characterized by a great and very widespread limestone formation, the Trenton, LockportGuelph (Niagara), and Onondaga, respectively, and in each the limestone is succeeded by shales or other clastic rocks, the Utica York.

1 The Catskill is essentially an eastern phare of the Chemung in New 
(and Frankfort), Salina, and (Marcellus to) Portage (respectively), due to an increase of terrigenous material, and each was closed by a more or less widespread emergence of the sea-bottom. Each began with a subsidence which gradually extended to a maximum at the time when the great limestone was formed. The parallelisms are not exact, but they are certainly suggestive." 1

Thickness of the Devonian. - In the northern Appalachian Mountains the Devonian system attains a maximum thickness of some 14,000 or 15,000 feet. In New York state the system has a thickness of fully 4000 feet. Over much of the upper Mississippi Valley the thickness is generally less than 1000 feet, though rather locally, in Ohio, a thickness of fully 3000 feet is reached, 2600 feet of this being Upper Devonian shales practically equivalent to the Portage and Chemung beds of the east. In Nevada the system appears to show 6000 feet of limestone and 2000 feet of shale.

Igneous Rocks. - As in the earlier Paleozoic periods, evidences of igneous activity in the Devonian period are almost lacking. Some lava sheets in New Brunswick, Nova Scotia, eastern Quebec, and northern California, appear to be interbedded with Devonian shales. These occurrences prove at least some volcanic activity during the period.

\section{Physical History}

Early Devonian. - In earliest Devonian (Helderberg) time most of North America appears to have been dry land. Inspection of the Paleogeographic map (Fig. 69) of that time shows that marine waters occupied only three rather limited areas in the east. These were Nova Scotia-New Brunswick; the northern Appalachian region to central New York; and a portion of the southern Mississippi Basin. Of these the first two were doubtless connected with the Atlantic, and the last with the Gulf Basin as the map suggests. These three submerged areas must have been pretty freely connected, probably along the Atlantic Coast, because the faunas are so similar. Since the Helderberg formation is chiefly limestone, the waters were clear and this implies no adjacent high lands, or at least no rapid erosion. In the west an arm of the sea must have reached into the Nevada Basin as proved by the Helderberg limestone there, the connection with the Pacific prob-

${ }^{1}$ W. B. Scott: An Introduction to Geology, 2nd Ed., pp. 577-578. 
ably having been across California as suggested by the later geographic conditions (see Fig. 69).

The Oriskany sea was more widespread and covered the whole Appalachian region from central New York to Alabama and west-

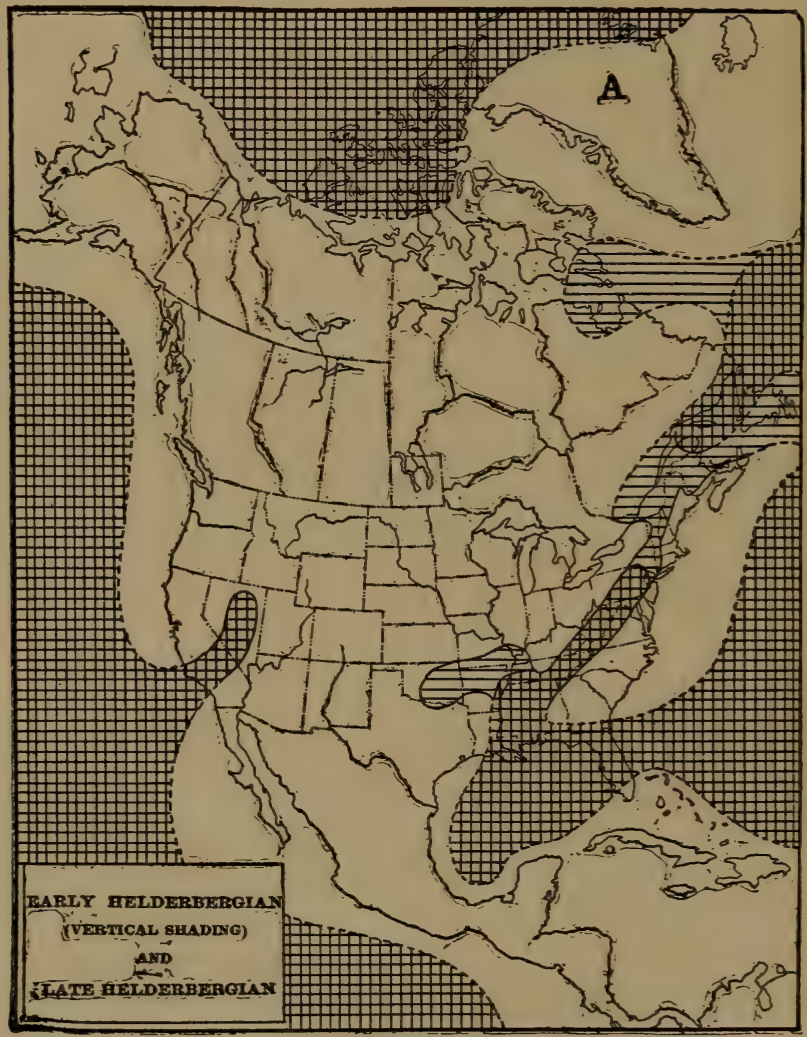

Fig. 69

Paleogeographic map of North America during early Devonian time. (From Schuchert's "Historical Geology," courtesy of John Wiley and Sons.)

ward over much of the eastern upper Mississippi Basin, except probably the Cincinnati anticline area. Nova Scotia-New Brunswick remained submerged. The sharp change to deposition of 


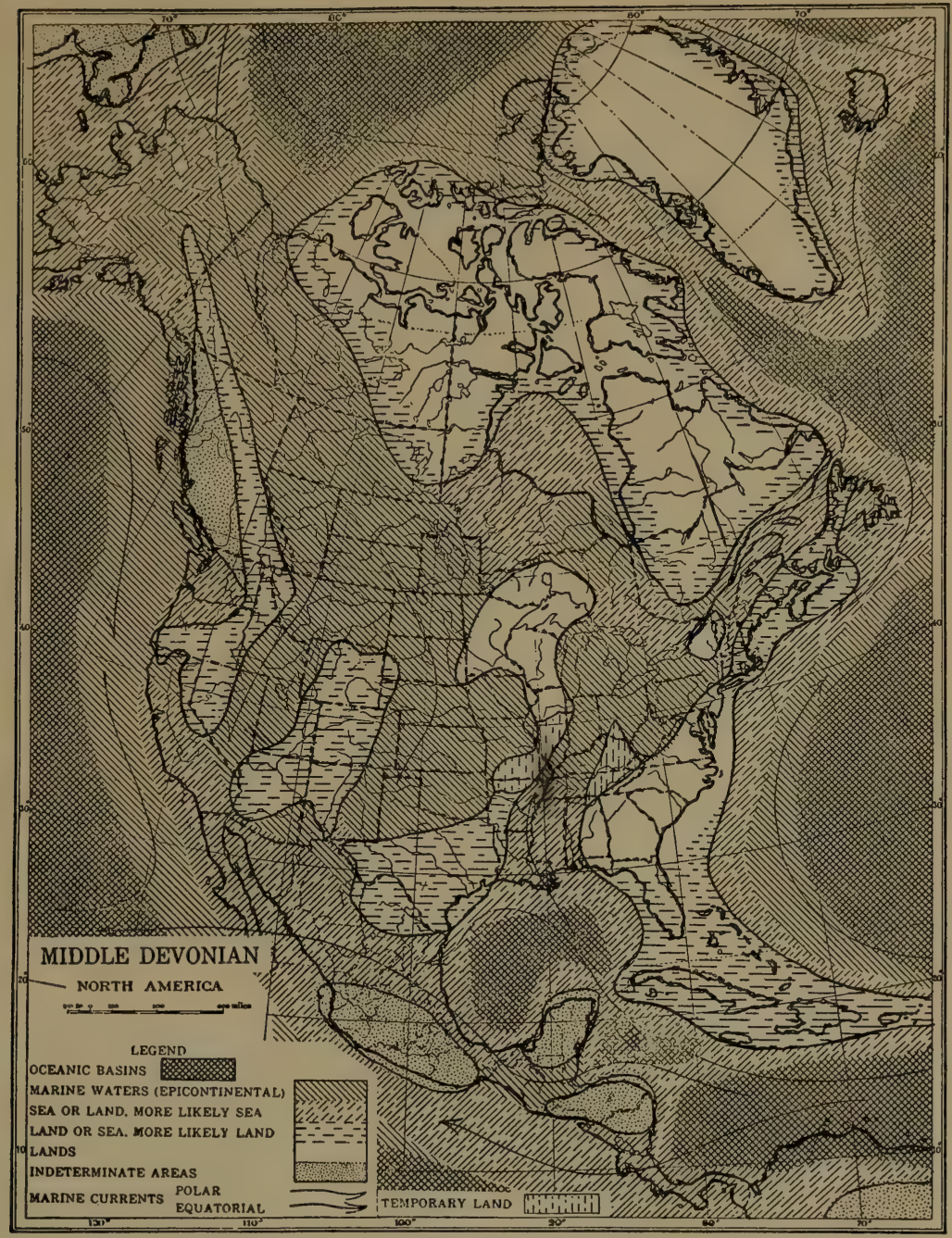

Fig. 70

Paleogeographic map of North America during Middle Devonian time. (Slightly modified after Bailey Willis, courtesy of The Journal of Geology.) 
coarse, clastic sediments argues for considerable land rejuvenation, or much more rapid erosion, or both. The sediments are of distinctly shallow-water character, and the fossils show the fauna to have been suited to such conditions. The fossils are remarkably similar to those of the same age (Coblenzian) in Europe from which region they appear to have migrated. "The evidence then is fairly conclusive that during the period represented by the Coblenzian Oriskany, the arenaceous epicontinental sediment was the ground traversed by the Coblenz fauna westward along the North Atlantic continent" (J. M. Clarke). In other words, there must have been a land connection between Europe and North America.

Middle Devonian. - During Ulsterian time (neglecting the slight deposition of Schoharie grit in eastern New York) important geographic changes took place. The Appalachian Basin from Pennsylvania southward was raised into land, but the sea continued from eastern New York and Pennsylvania across the Upper Mississippi Basin to northern Michigan and southern Illinois, except probably around the Cincinnati anticline area. Much of New Brunswick and the region at the southern end of Hudson Bay were submerged, as well as the Rocky Mountain district from Alaska to western Colorado, northern Arizona, and Nevada. Marine waters covered the areas much as shown on the map (Fig. 70) except for the absence of the sea from the northern Appalachian district and the large area from the Mississippi River to the Rocky Mountains. This was the great Onondaga sea, which must have been mostly clear, shallow, and comparatively warm as indicated by the widespread accumulation of largely coralline limestone already mentioned. Evidently there were no rapidly eroding land areas.

Late middle Devonian (Erian) time witnessed another important physical change probably due to a very considerable rejuvenation of northern Appalachia, resulting in renewed erosion and deposition of vast quantities of muds in the eastern part of the interior sea. These muds are now hardened and called the Marcellus and Hamilton shales. Farther westward in the Mississippi Basin, however, much limestone still formed in the clearer sea. The relations of land and water during this (Erian) time are depicted on the paleogeographic map (Fig. 70). One feature to be especially noted is the long, narrow, land-bridge from Wisconsin to Texas, separating the eastern from the western interior seas. 


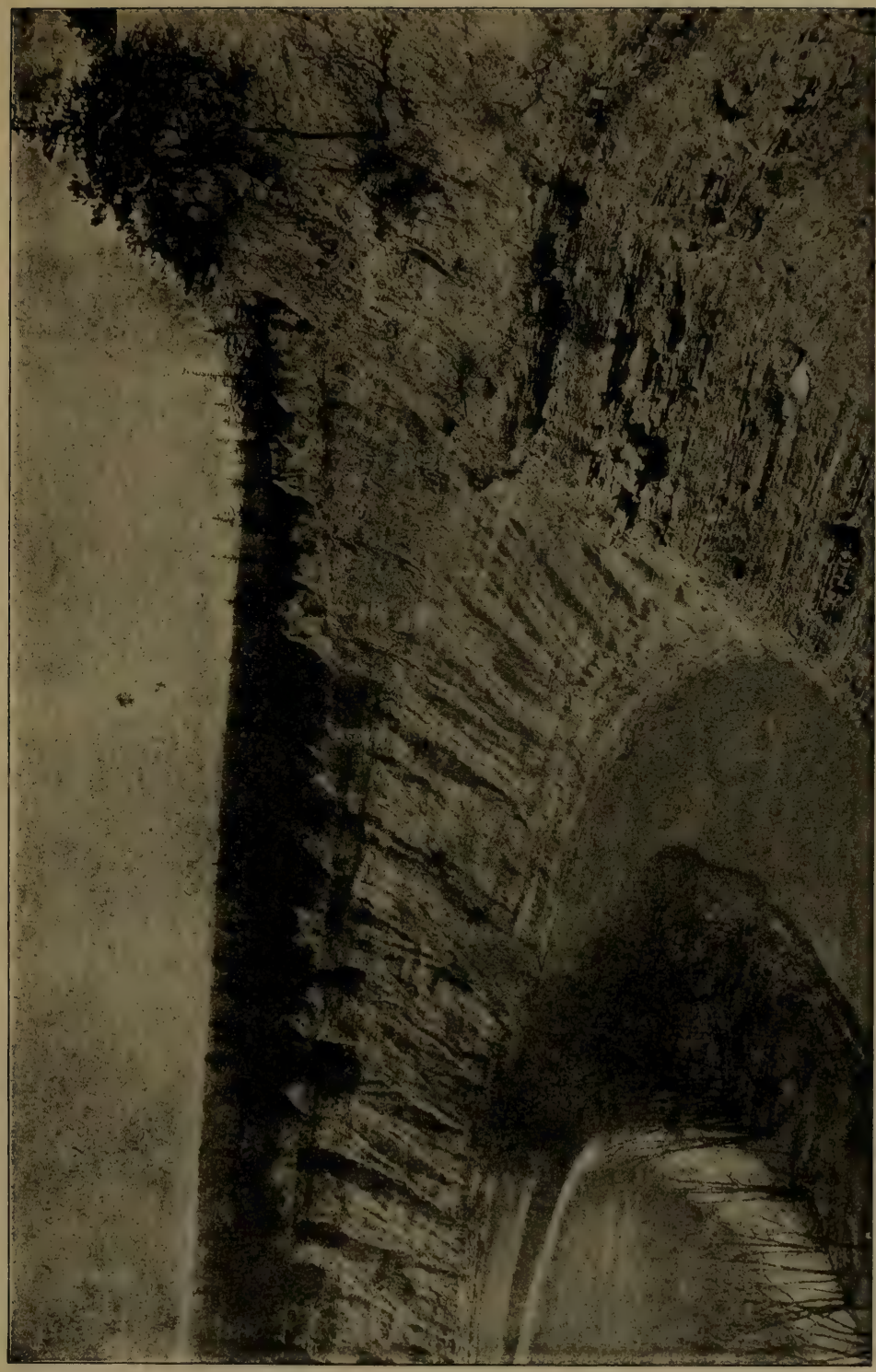

$\frac{0}{v}$

A

$<$

章

志

造

党

든

$\dot{0} \frac{0}{0}$

济

$\Xi$

๘)

$\frac{1}{2}$

๖ं

욤

อิ

을

ํี๊

เू็ 
The eastern interior sea was probably connected with the Gulf on the south, and with the Atlantic, through the St. Lawrence Basin, on the north.

Late Devonian. - During late Devonian (Senecan and Chautauquan) time the relations of land and water were much the same as during middle Devonian, with the following principal differences: The eastern and western interior seas became connected; the southern Appalachian region became submerged; and the connection with the Gulf of Mexico appears to have been closed. In New York and the northern Appalachian region, there was a tremendous accumulation of sandstone together with more or less shale and conglomerate. The Chemung-Catskill formation, as already stated, is largely a shallow-water, non-marine deposit from 1500 to 8000 feet thick in New York and Pennsylvania. The few known fossils are non-marine types. This, together with the common occurrence of red shales and sandstones, and the great thickness of the beds, all point to the origin of this remarkable formation as either a great delta deposit pushed out into the shallow interior sea, or as an estuarine or lagoon deposit. Notable thinning toward the west proves the material to have come from the east, doubtless from greatly rejuvenated Appalachia. Farther westward, over Michigan, Indiana, and Tennessee, the deposits formed at the same time were mostly shales, usually not over a few hundred feet thick.

Close of the Devonian. - Throughout most of North America there was a quiet transition from the Devonian to the succeeding Mississippian, therefore the two systems are not sharply separated. In Maine, Nova Scotia, and New Brunswick, however, the strata were considerably upturned and eroded toward the close of the Devonian, and Mississippian rocks rest upon them by unconformity.

\section{Foreign Devonian}

Europe. - It may be said in general that the Devonian of Europe began with a progressive transgression of the sea, continuing till near the close of the period when much of the continent was submerged as shown in Fig. 72. This extensive sea spread over the barrier which, since Cambrian time, had quite effectually kept Europe divided into two provinces (a northern and a southern) or basins of deposition. 
In the southern British Isles there are thick marine strata containing much contemporaneous igneous rock (lava sheets), while in the northern portion occurs the famous "Old Red Sandstone" which is largely of continental origin. This sandstone attains a greatest thickness of fully 20,000 feet, of which 6000 feet are interbedded lavas and tuffs. Deposition of the sandstone appears to have taken place, probably partly as delta and partly as wind-blown

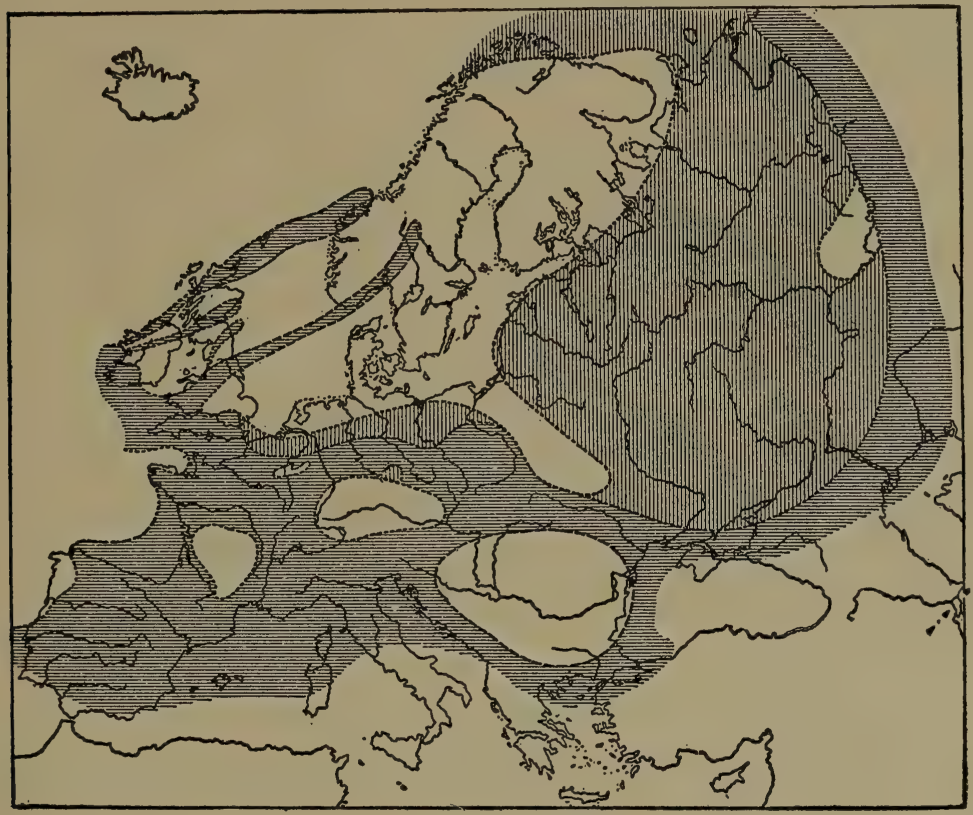

Fig. 72

Sketch map showing the general relations of land and water in Europe during the Devonian. Horizontal lines = Early Devonian; vertical lines = additional areas of Middle Devonian. (After De Lapparent, from Chamberlin and Salisbury's "Geology," courtesy of Henry Holt and Company.)

deposits, in basins or lagoons more or less cut off from the open sea, or at times in fresh-water lakes. Fossils are not abundant, but they constitute a remarkable assemblage of land, fresh water, and marine species scattered through various horizons. In many 
respects the "Old Red Sandstone" is much like the ChemungCatskill formation of America.

The typical marine strata of Germany also contain many beds of lava, thus indicating much igneous activity during the period.

In west-central Europe much of the Devonian has been metamorphosed.

Typical marine limestones, shales, and sandstones were extensively deposited in Spain, France, Switzerland, much of Austria, and Russia, but with Lower Devonian mostly absent from Russia. Coralline limestones are prominent in the Alps.

Other Continents. - The Devonian sea spread over most of Siberia and into central Asia and China. Rocks of this age are also known in various parts of southern Asia, northern and southern Africa, Australia, New Zealand, and in South America they appear to be more widespread than the rocks of any other Paleozoic system. Most of South America must have been submerged under a transgressing sea.

\section{Climate}

The general distribution and character of the fossils, as for example the Corals of the Onondaga sea, indicate rather mild and uniform climatic conditions. Possibly such red formations as the Catskill and the "Old Red Sandstone" were formed under arid or semi-arid conditions. What appears to be boulder clay with striated pebbles, implies at least local glaciation in South Africa.

\section{Economic Products}

Oil and gas are principally derived from Devonian strata in the great fields of western Pennsylvania, West Virginia, and western New York.

Flagstones of Devonian age are extensively quarried in southern New York and in Pennsylvania.

Black phosphate deposits occur in the Upper Devonian shales of central Tennessee.

\section{Life of the Devonian}

Plants. - Of the Algce, both Sea-weeds and Diatoms are known in fossil form, though they are not abundant. Certain forms regarded as tree-like Sea-weeds were remarkable for their 
size, having attained a diameter of two or three feet. Diatoms are unicellular, aquatic plants of microscopic size which secrete shells of silica, and some of Devonian age are known. In some of the later periods these tiny plants were of considerable importance. No Bryophytes (Mosses) have yet been discovered. Spores and spore-cases of certain aquatic plants (Rhizocarps), probably related to very simple Pteridophytes, are very abundant in the black shales, especially those of Marcellus and Hamilton ages. According to Dawson they are "dispersed in countless millions of tons through the Devonian shales," and by their decomposition much oil has been produced.

Our knowledge of land plants prior to the Devonian is very scant as we have seen, but the records are sufficient to make it certain that the Devonian lands were covered with a rich and diversified vegetation, often even with luxuriant forests. The forests were, however, far different in appearance from those of the present because the trees were all of very simple or low organization types. Thus they were largely represented by all the main subdivisions of the non-flowering Pteridophytes such as Lycopods, Equiseto, Ferns, and Seed-ferns, and some simple types of the lower order of flowering plants (i.e. Gymnosperms) were also present. Since these important and remarkable land plants reached their climax of development in the Pennsylvanian (great coal period), it will serve our purpose best to discuss these plants in connection with the flora of the Pennsylvanian.

Protozoans. - Foraminifers and Radiolarians no doubt existed because they are known from the immediately preceding and succeeding periods, but fossil forms have not been found.

Porifers. - Sponges were common but they require no special description.

Cœlenterates. - The Graptolites which are so abundant and important for correlation purposes in the three preceding systems, are comparatively rare in the Devonian, and they became almost extinct before the close of the period.

Corals displayed a very marked increase in numbers, species, and size. They must have grown in profusion, especially in the clear Onondaga sea, as proved by the many great fossil Coral reefs. From near Louisville, Kentucky, alone more than 200 species are known, and these are only a fraction of all described Devonian species. They were almost all of the cup and honeycomb types, 
the Chain Corals having become rare and extinct in the early Devonian. The solitary Cup Corals probably reached their culmination in size, some of them being 12 to 18 inches long and several inches in diameter.

Echinoderms. - Cystoids were rare and became extinct during this period. Blastoids still continued to assume a minor rôle.

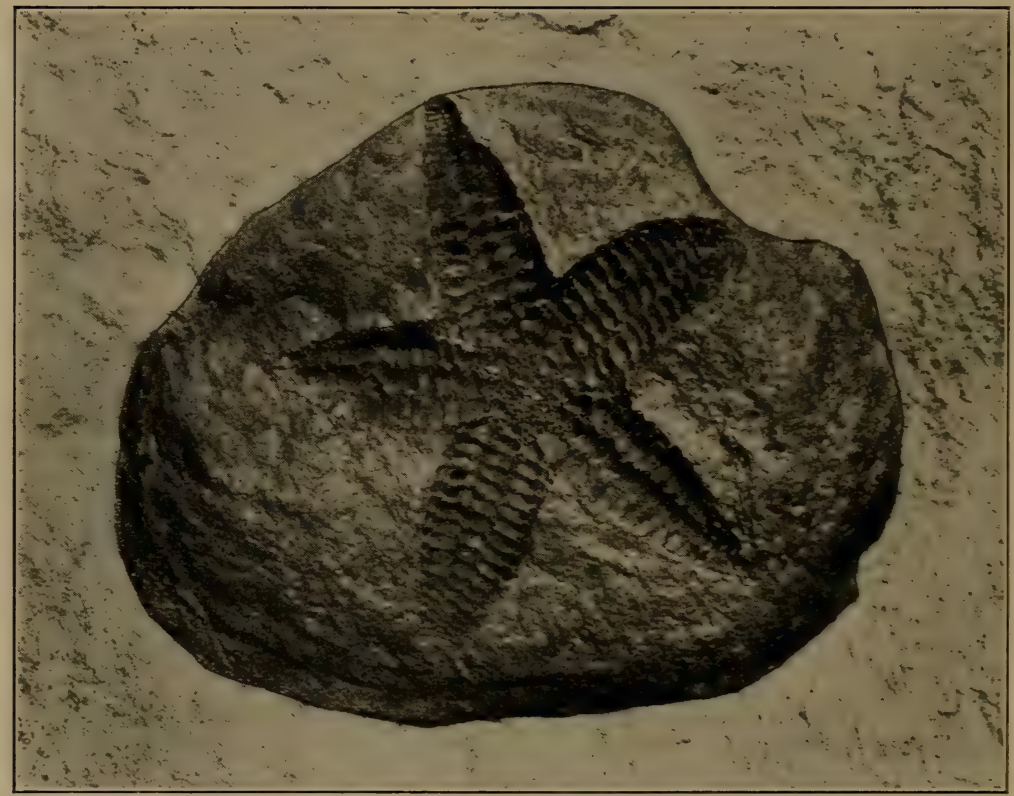

Fig. 73

A Devonian Asterozoan, Paleaster eucharis, on a Pelecypod shell. (After Clarke, N. Y. State Mus. Bul. 158.)

Crinoids continued to increase and diversify. Asterozoans (Starfishes) notably increased (Fig. 73), while the Echinozoans (e.g. Sea-urchins) were only moderately represented.

Molluscoids. - Bryozoans were present, but not conspicuous as reef builders.

Brachiopods reached their culmination as regards numbers of species and abundance (Fig. 74). Here, as in the three preceding periods, Brachiopods were the most numerous fossils, and most 
of them still had straight hinge lines. Many Spirifers, particularly the wide "butterfly" genera (Fig. 74a) were common and characteristic.

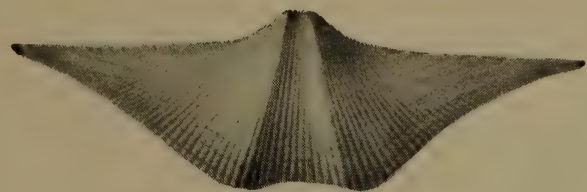

$a$

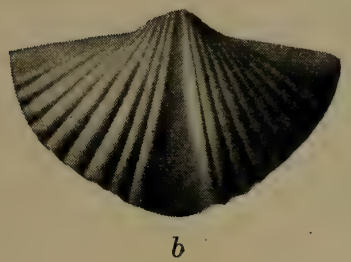

Fig. 74

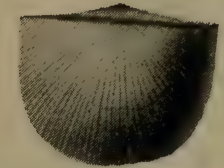

C

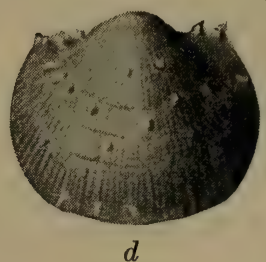

Devonian Brachiopods: $a$, Spirifer disjunctus; $b$, Spirifer intermedius; c, Stropheodonta demissa; d, Productus Hallanus. (All from Md. Geol. Survey, "Devonian.")

Mollusks. - Pelecypods and Gastropods were much like those of the Silurian, though with various genera and species changes (Figs. 75, 76).

Among the chambered Cephalopods, a significant change took place with the introduction of the Ammonoids (e.g. Goniatite, Fig. 77) in which the septa or partition junctions were angular or irregular instead of simple or straight as in all previous forms (Nautiloids). As we shall see, this irregularity of partition structure gradually evolved into more and more complex forms, reaching a maximum in the Mesozoic era. (See table

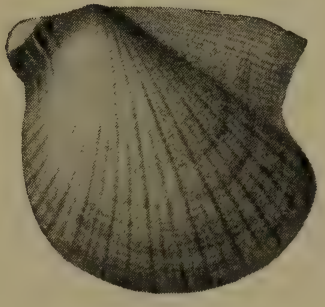

$a$

Fig. 75

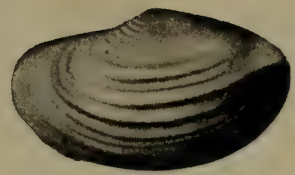

$b$

Devonian Pelecypods: a, Actinopteriate textilis; $b$, Grammysia arcuata. (From Md. Geol. Survey, "Devonian.") 
on page 99.) Most of the common Nautiloid types still persisted, though the simpler forms (straight and slightly curved) were
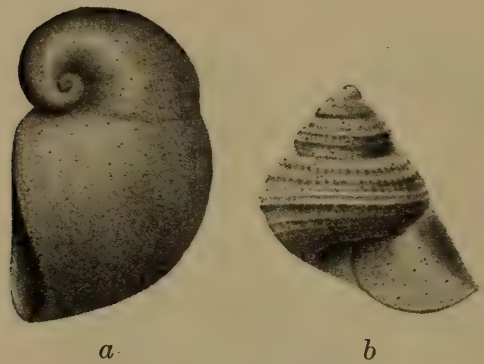

Fig. 76 notably diminished in prominence.

Arthropods. Trilobites showed a marked decline in numbers and species, though they were not uncommon, and were still often fantastically decorated.

Eucrustaceans were fairly represented by several types.

Arachnids were represented by Scorpions and Eurypterids, and the Myriapods made their first known appearance. Eurypterids probably culminated in the preceding period, but they were still prominent and notable for great size, one type having attained a length of eight feet.

Insects are not known from the Devonian.

Simplest Vertebrates. - Perhaps the most interesting and important feature of Devonian life was the profusion and development of the simple Vertebrates, particularly the $F$ ishes. These simple or primitive Vertebrates are of unusual significance because they were the progenitors of the great groups of higher Vertebrates, which gradually became more complex and diversified, and finally culminated in Man himself. All known Devonian Vertebrates were aquatic.

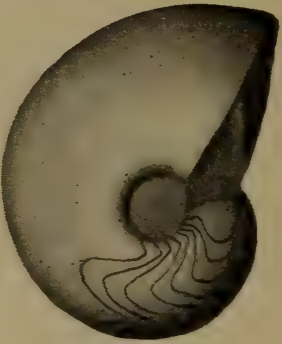

Fig. 77

A Devonian Goniatite, Manticoceras patersoni. (After Hall.)

Paleospondylus. - This remarkable creature was an exceedingly simple and primitive type of Vertebrate. Its appearance is well shown in Fig. 79. The animal, one or two inches long, possessed a distinct, slender, segmented, cartilaginous vertebral column supplied at one end with a rather symmetrical tail fin 
structure, and at the other with a head. The head had a circular mouth but no jaws. Its lack of jaws and paired fins cause it to rank below the true Fishes, and it is probably to be classed with the Lamprey Eels.

Ostracoderms.-These curious and bizarre forms also represent a very simple class of the Vertebrates. For a long time they were classed as simple Fishes, but recent study has led some to believe that they are really transition forms between the highest invertebrates (Arthropods) and the Fishes which rank very low among the Vertebrates.

A characteristic feature is the cover or armor of

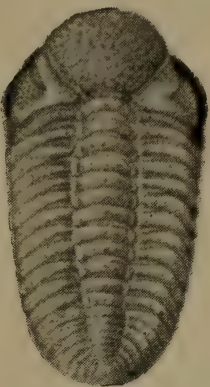

$a$

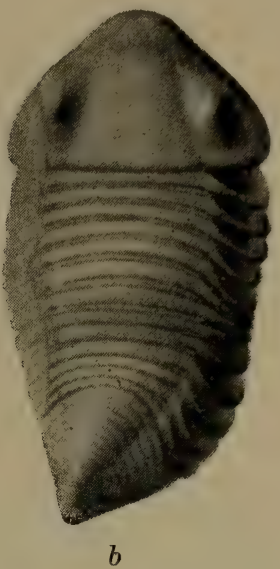

Fig. 78

Devonian Trilobites: a, Phacops logani (Hall); b, Homalonotus noticus (Clarke). bony plates developed in the skin over the head and fore part of the body, hence the name, which literally means "shell-skin." The rear part of the body was generally covered with scales. Some

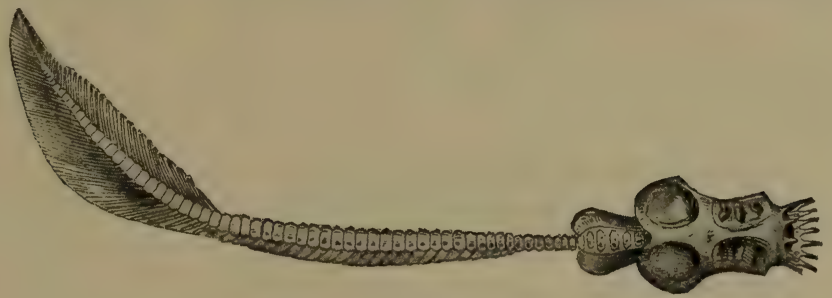

Fig. 79

A very simple Devonian Vertebrate, Paleospondylus gunni. (After Dean, restored by Traquair, from Chamberlin and Salisbury's "Geology," courtesy of Henry Holt and Company.)

had vertebrated tail fins and were fish-like in appearance (Fig. 80a), while others looked much like Trilobites or King-crabs. Some had a pair of jointed flappers or swimming paddles extending out from 
the fore part of the body, but none had true paired fins like the Fishes. The vertebral column was of cartilage (gristle). The eyes were close together near the top of the head. They did not possess true jaws in the Vertebrate sense of that term, but rather the simple
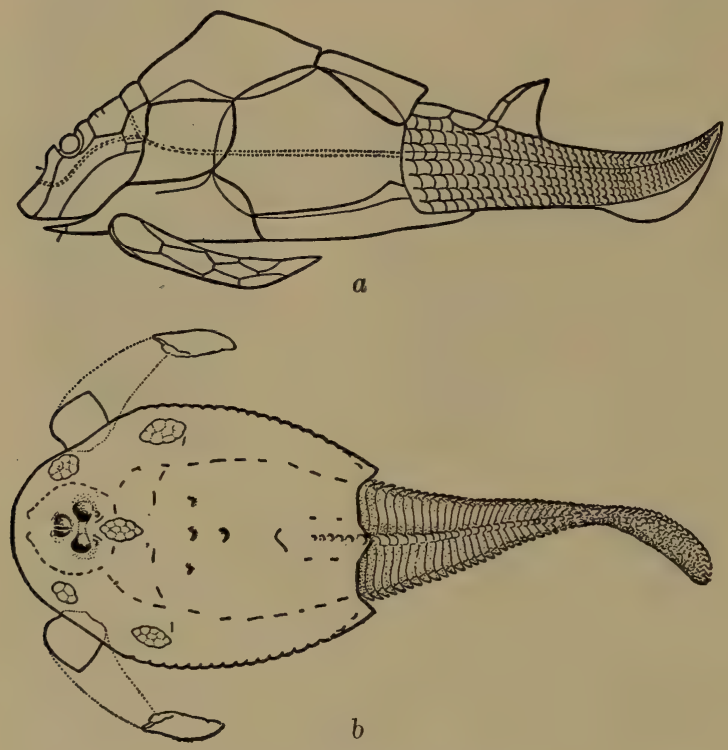

Fig. 80

Devonian Ostracoderms: a, Pterichthys testudinarius, restored (Dean after Woodward); b, Tremataspis, restored (after Patten). jaw-like portions moved over each other laterally as in many Arthropods (e.g. Beetles).

Ostracoderms reached the zenith of their development in the Devonian, and, so far as known, they became extinct during the same period.

Fishes.-Because of the profusion of Fishes, the Devonian is often called the "Age of Fishes." Their abundance, together with their importance as bearing upon the evolution of the Vertebrates, requires that considerable attention be devoted to the Fishes here. In all of our discussion of the geological history of Fishes, the following important groups only will be recognized: (1) Selachians ("Cartilage"-fishes), now uncommon, but e.g. Sharks; (2) Dipnoans ("lung"-fishes), now rare, but e.g. Ceratodus of Australian rivers; (3) Arthrodirans (e.g. Fig. 82b), now wholly extinct; (4) Ganoids ("lustre"-fishes), now uncommon, but e.g. Gar-pike and Sturgeon; and (5) Teleosts ("perfect bone"-fishes), now the most abundant of all Fishes, e.g. Trout, Salmon, Cod.

Selachians are the simplest of all true Fishes, and they comprise the oldest group of living Fishes, dating back at least to the 
Silurian. Their skeletons are wholly cartilaginous, the only hard parts being the teeth and fin spines which are commonly preserved

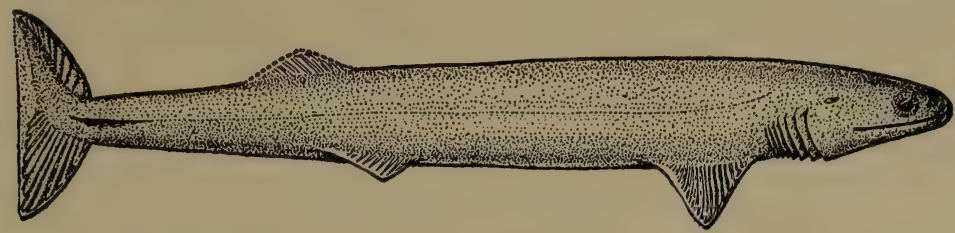

Fig. 81

A Paleozoic (early Mississippian) Selachian or Shark, Cladoselache fyleri. (Restored by Dean.)

as fossils. The arrangement of separate gill slits in the throat wall is a more eel-like than fish-like feature. Simple, paired fins are present, but scales or plates are absent. They were common in the Devonian seas, and also probably in lakes and lagoons. Fig. 81 exhibits a typical Paleozoic species which is very similar to living forms.

Dipnoans are remarkable in being able to breathe both in water and air, since they have both gills and lungs, the airbladder being more or less used

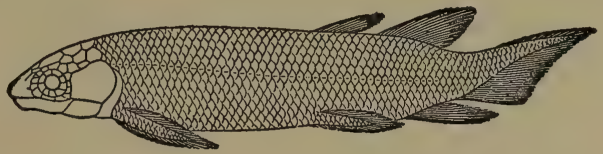

$a$
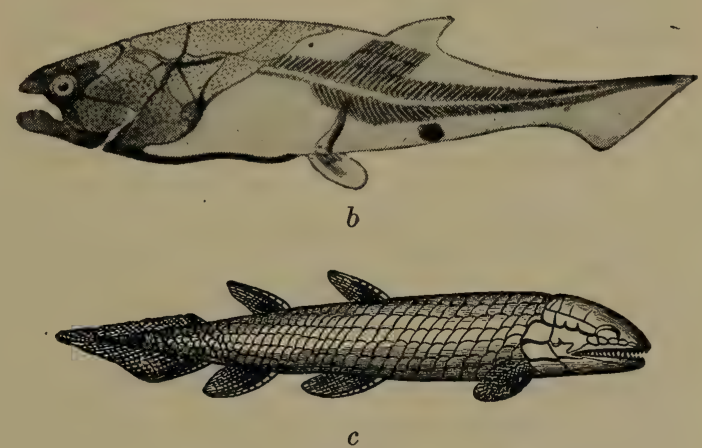

Fig. 82

Devonian Fishes: a, Dipnoan, Dipterus valenciennesi, (restored by Traquair); $b$, Arthrodiran, Coccosteus decipiens (restored by Woodward); c, Ganoid, Osteolepis (restored by Nicholson).

as a lung. They were abundant during Devonian time. Fig. 82a shows a common Devonian species which is remarkably similar to the modern Ceratodus. Note the paddle-shaped paired fins, 
almost like legs, and the covering of scales. Their skeletons were cartilaginous. Their limb-like fins and peculiar lung-like air sacs were more amphibian-like than fish-like characters and they strongly suggest that the Dipnoans may have been the progenitors of the Amphibians.

Arthrodirans comprise a remarkable group of Fishes now wholly extinct, but they were common in Devonian time. Fig. $82 \mathrm{~b}$ shows an example of a well-known genus (Coccosteus) from the Old Red Sandstone. Note the bony armor covering the fore part of the body, thus suggesting the Ostracoderms, though the paired fins and true jaws supplied with teeth place them with the Fishes. The backbone was of unsegmented cartilage. Other forms closely related to Coccosteus were remarkable for size, some having attained lengths up to 20 or 25 feet. Arthrodirans were probably the most formidable denizens of the Devonian seas.

Ganoids were the most highly organized and abundant Fishes of the time. These were characterized by a covering of small

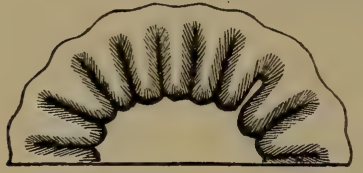

Fig. 83

Structure of a Ganoid tooth. (After Agassiz.) lustrous plates or bony scales, usually rhomboid and set together like tile, rather than by overlapping as in typical modern Fishes. The skeletons were of cartilage, though in later periods they were more or less ossified as in the few modern representatives. Their internal tooth structure was often labyrinthine (Fig. 83) or much like that of Amphibians of later Paleozoic periods. A typical Devonian Ganoid is shown in Fig. 82c. The so-called fringe-finned Ganoids were externally rather similar to the Dipnoans, especially as regards the paired, lobate, limb-like fins. Their intricate (labyrinthine) tooth structure, character of the skull bones, and limb-like fins, suggest strong affinities with the Amphibians of the later Paleozoic.

Teleosts, which are the most common and typical modern Fishes, were entirely absent from the Devonian. In these the skeletons are completely ossified and the body is nearly always covered with overlapping scales. In marked contrast with the Devonian Fishes, Teleosts always have non-vertebrated tail fins.

General Observations on Devonian Fishes. - (1) All were of simple types. The most typical and highly organized Fishes so 
common today, did not exist in the Devonian, and even the Ganoids were of primitive types.

(2) All had cartilaginous skeletons. The vertebral column and other portions of the skeleton were not ossified (i.e. changed to bone).

(3) All had vertebrated tail fins. The vertebral column extended through the tail fin and gave off fin rays to support a lobe above and below. Sometimes this tail fin was symmetric and sometimes asymmetric. The asymmetric form is regarded as the more primitive. Most modern Fishes (Teleosts) have non-vertebrated tail fins, the fin rays being sent out from a plate at the end of the vertebral column.

(4) They were generalized types. "Along with their distinctive fish-characters, they combined others which connect them with higher Vertebrates, especially Amphibians, and still others which are found in the embryos of Teleosts. The most important connecting characters ... are: (a) An external protective armor of thick bony plates or scales, such as were possessed by early Amphibians, and by many Reptiles of the present time; (b) Large conical
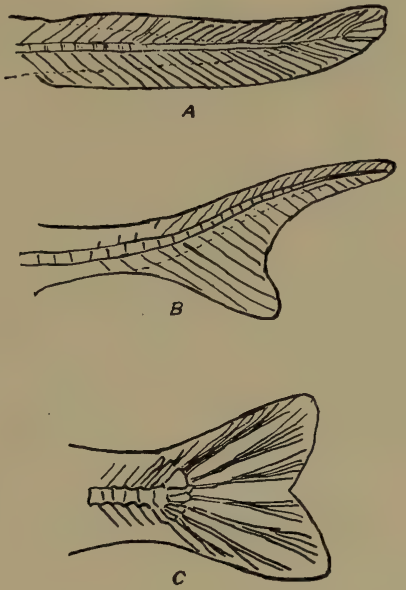

Fig. 84

Types of Fish tails: $a$, vertebrated symmetric; $b$, vertebrated nonsymmetric; $c$, non-vertebrated symmetric. (Redrawn after Le Conte.) teeth channelled at the base, and of labyrinthine structure on section. This structure was very marked in early Amphibians; (c) A cellular air-bladder . . . capable of being used to some extent as a lung; (d) In many cases paired fins which had something like jointed legs running through them; (e) The Tail fin vertebrated as in Reptiles." 1 The most prominent embryonic characters were the cartilaginous skeleton found only in the embryonic

1 J. Le Conte: Elements of Geology, p. 356. 
stage of the typical modern Fishes (Teleosts), and the vertebrated character of the tail fin, the tail of the modern Teleost successively passing from the asymmetric vertebrated stage, to symmetric vertebrated, and finally to symmetric non-vertebrated (Fig. 84).

Generalized or synthetic types, so well illustrated by Devonian Fishes, are of great importance in considering the evolution and geological history of organisms.

Amphibians. - Footprints, considered to be those of Amphibians, have been found in the Upper Devonian strata of Pennsylvania, but remains or impressions of the animals are not known. At any rate it seems certain that terrestrial Vertebrates existed as early as the Devonian. 


\section{CHAPTER X}

\section{THE MISSISSIPPIAN (LOWER CARBONIFEROUS) PERIOD}

Origin of Name, Subdivisions, etc.

Formerly the Carboniferous period included all of what, in America at least, we now call the Mississippian, Pennsylvanian, and Permian periods. ${ }^{1}$ In Europe the term Carboniferous is still employed; though the Permian has been separated from it. The name "Carboniferous" was given about one hundred years ago because it was supposed that workable coal beds were almost, if not wholly, confined to that system. Although workable coal beds are known to occur in most later systems, nevertheless what was long known as Carboniferous, particularly that portion now called Pennsylvanian, does contain the world's greatest coal deposits. The name "Mississippian" was given because of important outcrops of its formations in the eastern Mississippi Basin, especially along the river.

Some idea of the system in three well-known regions may be gained from the following table:

\begin{tabular}{|c|c|c|c|}
\hline & Mississippi River States & Pennsylvania & Maryland \\
\hline $\begin{array}{l}\text { Mississippian } \\
\text { System }\end{array}$ & $\begin{array}{l}\text { 4. Chester or Kaskaskia } \\
\text { series (Limestones, } \\
\text { sandstones and shales). } \\
\text { 3. St. Louis series } \\
\text { (Limestones). } \\
\text { 2. Osage or Augusta series } \\
\text { (Limestones and shales). } \\
\text { 1. Kinderhook or Chouteau } \\
\text { series (Limestones, } \\
\text { shales, and sandstones). }\end{array}$ & $\begin{array}{l}\text { 2. Mauch Chunk } \\
\text { (Shales) } \\
\text { 1. Pocono } \\
\text { (Sandstone). }\end{array}$ & $\begin{array}{l}\text { 3. Mauch Chunk } \\
\text { (Shales). } \\
\text { 2. Greenbrier } \\
\text { (Limestone). } \\
\text { 1. Pocono } \\
\text { (Sandstone). }\end{array}$ \\
\hline
\end{tabular}

1 In its geologic folios the U.S. G. S. still uses the term Carboniferous. 
It will be seen that, in the Appalachian region, the rocks are almost wholly clastic, while limestones are prominent in the Mississippi River region. Also the system in the east has not been so much subdivided, and detailed correlations with the subdivisions farther west have not been made. Regarding the detailed classification of subdivisions in America, much difference of opinion still exists, and more or less local names are used in different regions.

\section{Distribution and Character of the Rocks}

General Distribution. - The accompanying map (Fig. 85) shows the surface distribution of the Mississippian and Pennsylvanian rocks together. In the western part of the continent these two systems have not yet been satisfactorily separated, hence it is impossible to delimit them separately upon the map. Also it must be borne in mind that the large areas in British Columbia and Alaska contain considerable amounts of other Paleozoic rock as well as early Mesozoic rock, though the Mississippian and Pennsylvanian are abundantly represented. In the eastern part of the continent, the two systems have been clearly separated, and map Fig. 86 shows the surface distribution of Mississippian strata there. A comparison with the Devonian surface distribution map (Fig. 68) shows that the Mississippian has a very similar distribution in eastern North America, and that the Mississippian generally borders the Devonian areas. This is because the Devonian usually passed so quietly into the Mississippian with continuous deposition. A distribution feature of special importance as compared with the Ordovician and Silurian, and to some extent with the Devonian, is the complete absence of Mississippian strata from all of northern North America east of the Rocky Mountains except around the mouth of the St. Lawrence River.

In the Appalachians, Rockies, and mountains still farther west, the outcropping strata form long and short, narrow belts because the rocks have been highly folded and only the eroded edges of upturned strata are visible (Fig. 113). The eastern Mississippi Basin shows a different type of distribution because the rocks are there in nearly horizontal position and outcrop where the later (overlying) Paleozoic strata have been removed from them by erosion, or where later sediments were never deposited upon them. The character of the rocks and distribution of outcrops, supple- 
mented by many deep well sections, proves that Mississippian strata underlie nearly the whole Mississippi Basin except the Gulf border, and Wisconsin and Minnesota.

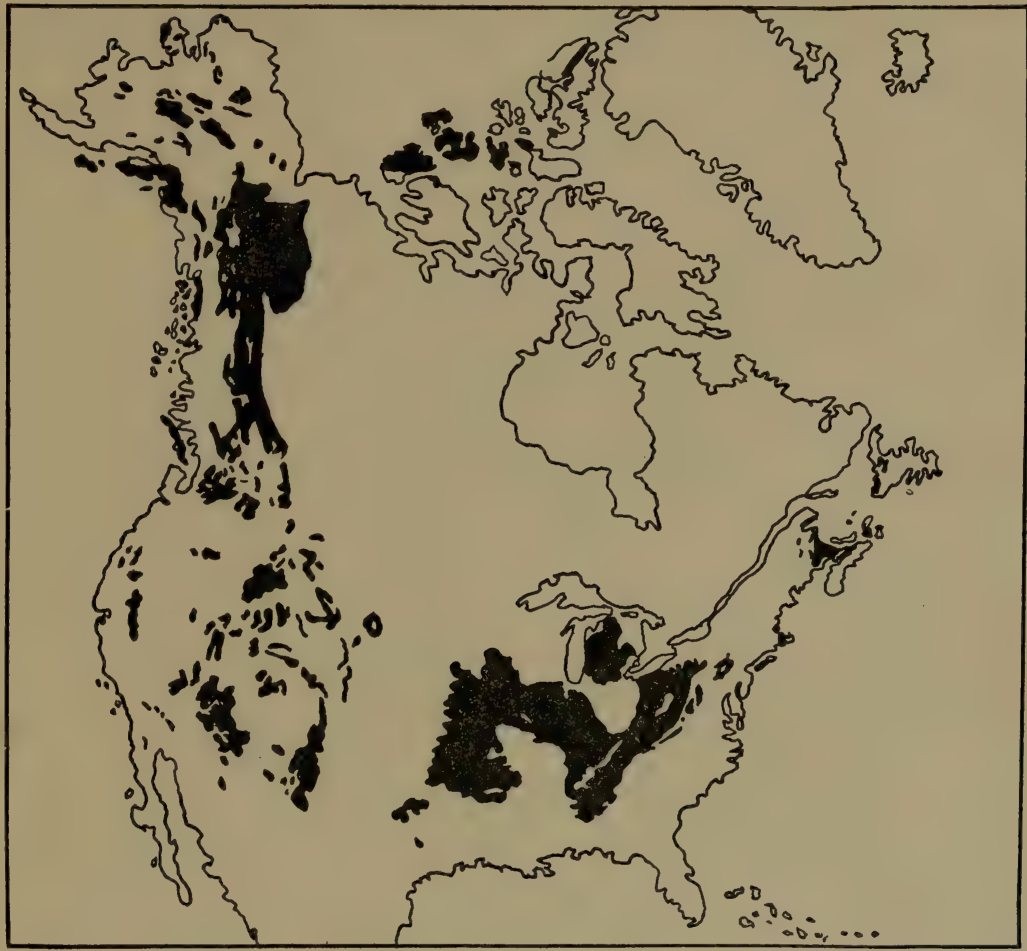

Fig. 85

Map showing the surface distribution (areas of outcrops) of Mississippian and Pennsylvanian strata in North America. The areas in British Columbia include some other Paleozoic rocks as well as some early Mesozoic rocks. (By W. J. M., data from Willis, U. S. Geological Survey.)

Lower Mississippian Rocks in the East. - The Pocono sandstone, also including some conglomerate, shale, and thin beds of coal, extends from northern Pennsylvania to Virginia in the Appalachian district. Its thickness varies from about 2000 feet in Pennsylvania to about 100 feet in the south. As judged by numerous terrestrial fossils, the Pocono appears not to be a typical marine 
deposit. Just west of the Appalachians considerable shale is associated with the sandstone of this same age, while in the Mississippi River states the Lower Mississippian is represented by the Kinderhook and Osage series, which contain much limestone. The Kinderhook consists of sandstone, shale, and limestone, but

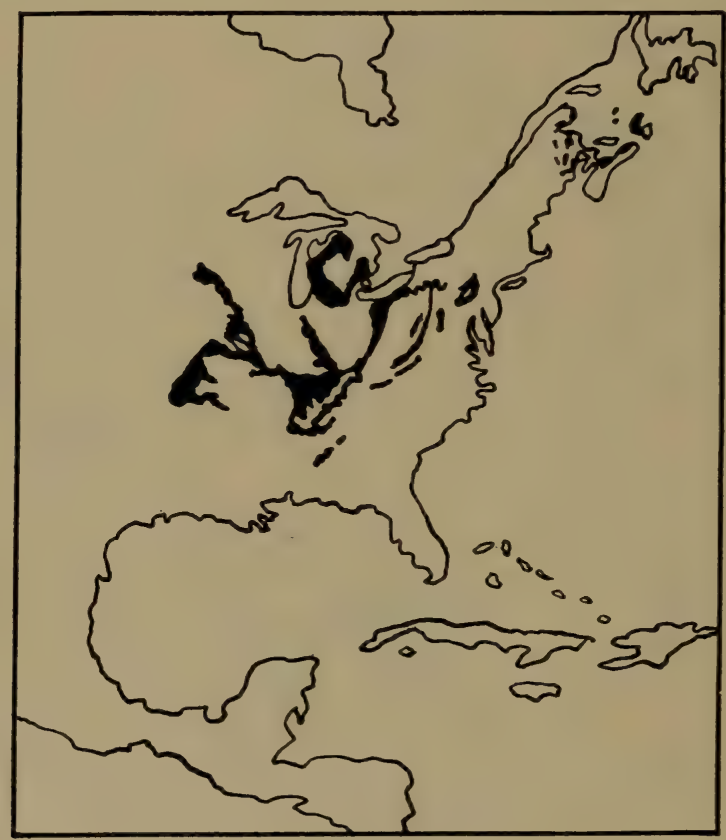

Fig. 86

Map showing the surface distribution (areas of outcrops) of Mississippian strata in eastern North America. (Modified by W. J. M. after Willis, U. S. Geological Survey.)

varies greatly in lithologic character from place to place. The Osage series directly overlies the Kinderhook, and is dominantly limestone, though with some shale. Both Kinderhook and Osage are chiefly true marine deposits. Lower Mississippian strata in southern Michigan are mostly sandstones and shales (often red), with some interbedded salt and gypsum deposits. 
Upper Mississippian Rocks in the East. - In the northern Appalachian district, the Mauch Chunk formation, consisting mostly of red sandy shales, directly overlies the Pocono, while in Maryland and West Virginia the lower portion of the Mauch Chunk gives way to the Greenbrier limestone. The Mauch Chunk shows a maximum thickness of 3000 feet in eastern Pennsylvania, but this diminishes notably to the north, west, and south. It is considered to be either a great flood-plain or a delta deposit. Farther west, in the Mississippi River states, the Upper Mississippian is represented by the St. Louis and Chester series. The former is made up almost wholly of limestone of very widespread extent, while the latter is rather variable lithologically, and is more restricted in distribution.

The Mississippian of Nova Scotia and New Brunswick has not been so carefully subdivided, but it is largely sandstone below and limestone, with some red beds and gypsum, above. Its thickness is about 2500 feet.

Mississippian of the West. - This system is very widely distributed in the West as proved by the numerous exposures, but it has not been carefully studied and subdivided as in the east. Throughout the system, which is commonly several thousand feet thick, limestone greatly predominates. Thus in the Canadian Rockies the system measures over 6000 feet thick with over 5000 feet of limestone.

Thickness of the Mississippian. - The Mississippian system in eastern North America ranges in thickness from about 5000 feet in eastern Pennsylvania to only some hundreds of feet in the western part of the same state. In the Mississippi River states the maximum thickness is 1500 feet, though it is generally less than 1000 feet. In the western part of the continent thicknesses of several thousand feet (maximum over 6000 feet) have been observed at several places, while in other localities, as in the Black Hills and parts of Colorado, it measures only a few hundred feet thick. Eighteen hundred feet are known in the Grand Canyon of the Colorado River.

Igneous Rocks. - Igneous activity appears to have been wholly confined to the region from Alaska to northern California, where vulcanism occurred on a large scale. Mississippian rocks are there often largely made up of igneous materials. 


\section{Physical History}

Earlier Mississippian. - This time was marked by a still further expansion or transgression of the epicontinental sea which had already become pretty extensive in the late Devonian. By the close of the Osage epoch of the Mississippian, most of the Mississippi Basin and Appalachian region, as well as much of the Rocky Mountain region, had become submerged, though with considerable islands like the Cincinnati anticline area, Ozark Mountain area, and others in the Rocky Mountain district. During this time coarse, clastic sediment (Pocono sandstone) accumulated along the western shore of Appalachia; red beds, with interbedded salt and gypsum, deposited in Michigan in lagoons bordering the Canadian land; and chiefly limestone, with some clastic sediment, were laid down in the great interior sea.

Later Mississippian. - During the St. Louis epoch the Mississippian sea reached its maximum extent, when even the islands of the Osage epoch were submerged, and all of North America was covered by the sea except the northeastern part of the continent, Appalachia, and probably some lands on the Pacific Coast. Map Fig. 87 shows the geography of the continent during that time. A comparison with the map (Fig. 45) of the mid-Ordovician shows the Ordovician sea to have been more interrupted with islands from Appalachia westward across the continent than the Mississippian (St. Louis) sea, but, because of the extensive arm of the Ordovician sea over the Hudson Bay region, more of North America was then submerged than during the Mississippian.

In the east vast quantities of clastic sediments continued to deposit as muds (now Mauch Chunk shales) above the Pocono sands along the western shore of Appalachia. Locally conditions were right for coal formation as proved by some coal beds in the Mauch Chunk. The interior sea, however, had clearer waters than at any time since the Onondaga epoch of the Devonian, and limestone deposition greatly prevailed. This clear sea extended westward even across the site of the Rocky Mountains. More red beds with associated salt and gypsum continued to form in southern Michigan lagoons. Also red beds and gypsum were formed in Nova Scotia.

Later in the period (Chester epoch) there was considerable withdrawing and shoaling of the sea, as indicated by sandstones 


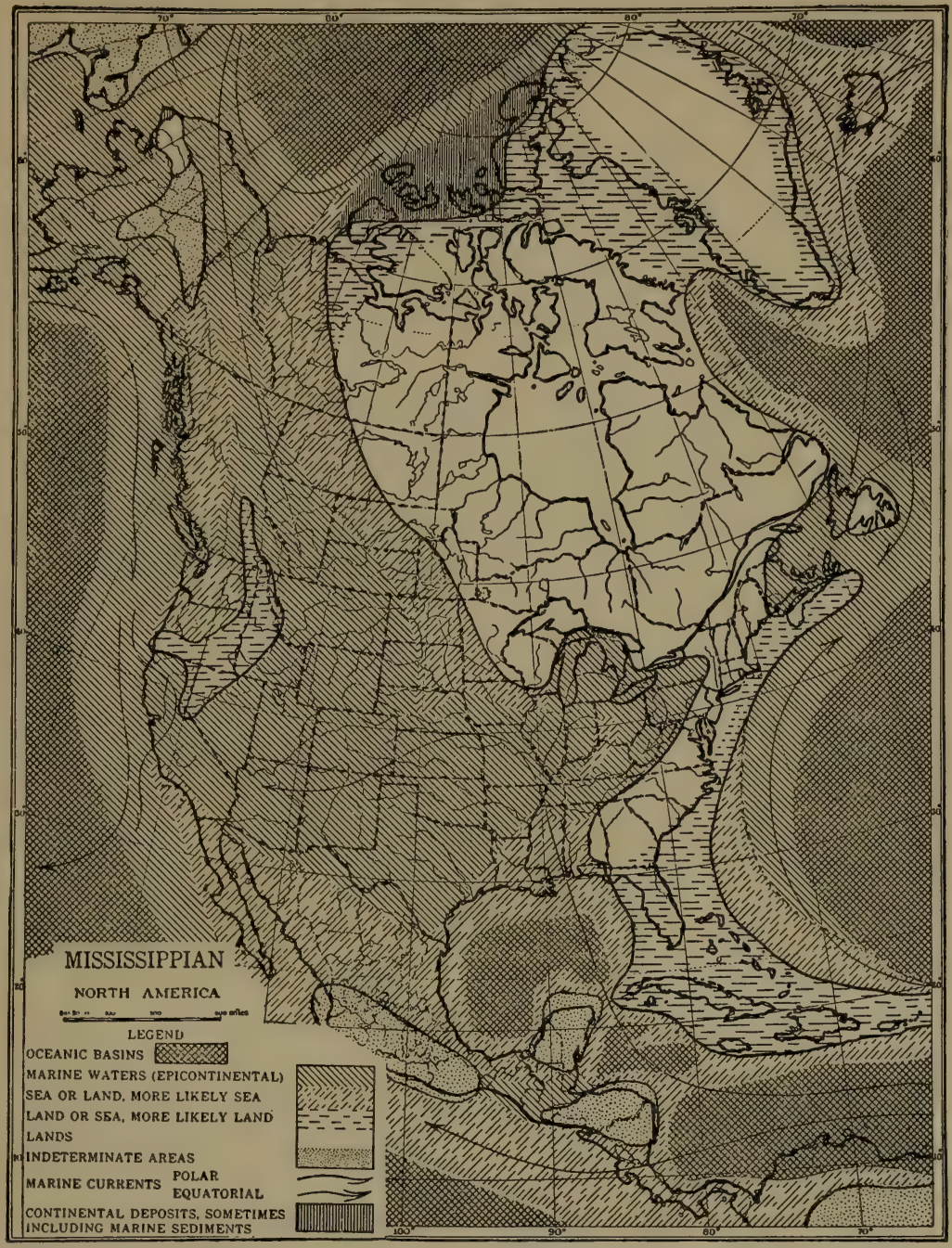

Fig. 87

Paleogeographic map of North America in Mississippian time. (Slightly modified after Bailey Willis, courtesy of The Journal of Geology.) 
and shales which make up a good percentage of the rocks along with limestones. Also the fact that the rocks of the Chester series are not so widespread as those of the St. Louis proves the lesser extent of the Chester sea.

Close of the Mississippian. - A significant geographic change marked the slose of the Mississippian period. Much, if not practically all, of the great area covered by the eastern interior sea was converted into land by retrogression of the sea. Recent studies in the western part of the continent point to emergence of lands in various places at the same time, though the extent of the emergence

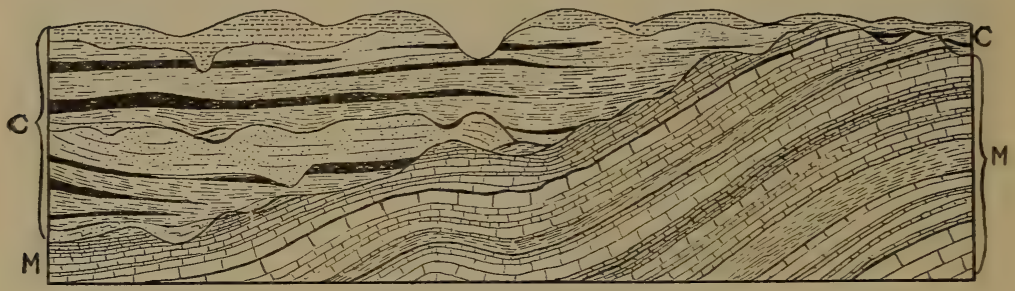

Fig. 88

Generalized section in Iowa, showing how the Pennsylvanian system $(C)$ rests unconformably upon the Mississippian $(M)$. (After Keyes, from Chamberlin and Salisbury's "Geology," courtesy of Henry Holt and Company.)

there is not so well known. This extensive emergence was largely accomplished without very appreciable folding or tilting of the strata, though in some regions moderate folding or tilting did occur, as in Iowa (Fig. 88), Arbuckle Mountains of Oklahoma, and northeastern Pennsylvania. The newly exposed lands were notably eroded, and the Mississippian and Pennsylvanian systems are separated by one of the most extensive and distinct unconformities in the whole Paleozoic group of rocks. For this reason the Mississippian and Pennsylvanian should be regarded as separate systems rather than as merely subdivisions of the old Carboniferous.

Comparisons with Preceding Systems. - The comparison of the Ordovician, Silurian, and Devonian systems given in the preceding chapter (page 124) to show a certain rhythmic recurrence of events might also fairly include the Mississippian, because this period, like the others, began with a sea transgression which reached a maximum (accompanied by much limestone making) about the 
middle of the period, followed by widespread withdrawal and shoaling of the sea, and deposition of clastic sediments toward the close of the period.

\section{Foreign (Lower Carboniferous) Mississippian ${ }^{1}$}

Europe. - As in North America, there was considerable encroachment of the sea so that much of the non-marine Old Red Sandstone became covered with true marine sediments. Map

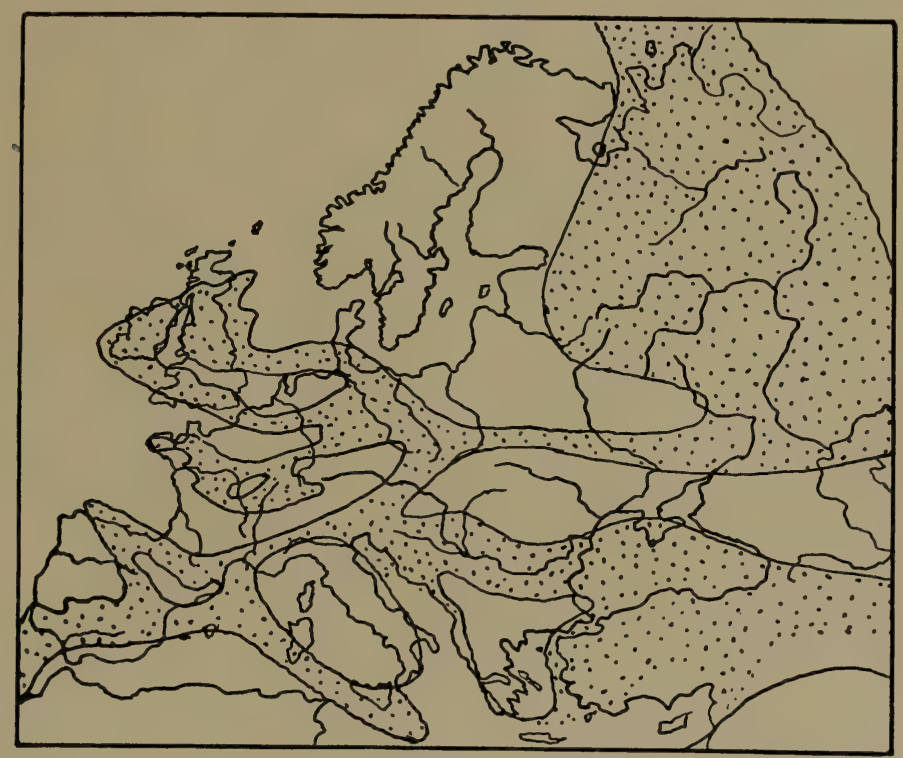

Fig. 89

Sketch map showing the relations of land and water in Europe during Mississippian (Lower Carboniferous) tinte. (Slightly modified after De Lapparent.)

Fig. 89 gives a general idea of the relations of land and water in Europe in early Mississippian time. In western Europe limestone predominates. Marine waters, mostly free from land-derived sediments, extended from the western British Isles to central Europe.

${ }^{1}$ It should be remembered that the term "Mississippian" is not used in 
Germany. In these waters there lived vast numbers of organisms such as Crinoids, Corals, etc., the remains of which accumulated to build a great mass of limestone said to attain a thickness of 6000 feet in England, and over 2000 feet in Belgium. Farther eastward, in central Europe, shales and sandstones were laid down. In Scotland and southern England also shallow water deposits were formed. Throughout much of central, southern, and eastern Russia, chiefly non-marine materials were deposited as proved by the many coal beds and associated deposits. The rocks of Mississippian age in southern Europe are much like those of central Europe, and also the similarity of fossils shows that northern and southern Europe were not separate provinces as during most of earlier Paleozoic time.

Rather widespread crustal disturbances marked the close of the period in western Europe. As a result of the upturning and folding of the rocks, great mountains were formed principally as two chains - one extending from Ireland to central Germany, and the other from Bohemia to southern France. The structure of the remnants of these mountains, as seen in the Vosges, Harz, Black Forest, and Cornwall hills or low mountains, implies deformation intense enough to have produced high altitudes. Accompanying this deformation there were abundant intrusions and extrusions of igneous rocks. In many other parts of Europe there were relative changes of level between land and sea without very appreciable folding or tilting of the strata. Thus, the reason for separating the old Carboniferous into two systems applies with great force to Europe as well as to North America.

Other Countries. - In South America Mississippian rocks are known in Argentina where they contain some coal, in Chili, and in other parts of the continent where they have not been carefully separated from the Pennsylvanian (Upper Carboniferous).

Eastern Australia, New Zealand, and Tasmania contain marine strata of Mississippian age which were generally highly deformed toward the close of the period, and injected with igneous rocks. Salt and gypsum occur in the system in western Australia.

In northern Africa the system is extensively represented, especially by limestone. Non-marine formations occur in southern Africa.

Rocks of Mississippian age are also known to be widely developed in Asia. 


\section{Climate}

As for the earlier Paleozoic periods, the character and distribution of Mississippian fossils pretty clearly prove absence of climatic zones like those of today. A mild, uniform climate appears to have prevailed. Salt and gypsum beds more or less associated with red beds point to arid climate in Michigan, Montana, Nova Scotia, and Australia, but these were probably local conditions. Evidence of glaciation toward the close of the period has been reported from Oklahoma.

\section{Economic Products}

Much oil is obtained from Mississippian sandstones in western Pennsylvania, West Virginia, Illinois, and Oklahoma.

Some gas is obtained from the Chester sandstone of Illinois, and some coal from the Pocono sandstone of West Virginia.

Building stones of Mississippian age are considerably quarried, especially the oölitic Bedford limestone of Indiana, which is perhaps the most widely used limestone for building stone in the United States.

Vast quantities of salt are produced by pumping out and evaporating the natural brines from the Mississippian sandstones of Michigan, and smaller quantities from the sandstones, or limestones of Ohio, West Virginia, and Virginia.

Certain important zinc ore deposits occur in the Lower Mississippian limestones of Missouri and Kansas though the deposition of the ore was post-Mississippian.

\section{Life of the Mississippian}

Plants. - In general the flora of the Mississippian may be said to have been very much like that of the Devonian, though the former showed greater diversity and various minor changes. Because of the prevalence of marine waters during much of the time, the records of land plants are perhaps not as full as those of the preceding period. Fossil plants are most numerous in early Mississippian rocks.

The simplest plants, such as Thallophytes and Bryophytes, were present but their fossil forms are not known to be common. 
The flora of the period consists almost entirely of the highest Cryptogams (i.e. Pteridophytes) and the simpler Phanerogams (i.e. Gymnosperms). As in the Devonian, all the principal groups of the Pteridophytes - Lycopods, Equiseto, and Ferns - as well as the still higher Seed-ferns and simpler types of Gymnosperms were represented. All of these plant types are of unusual interest and importance but, because of their vastly greater abundance

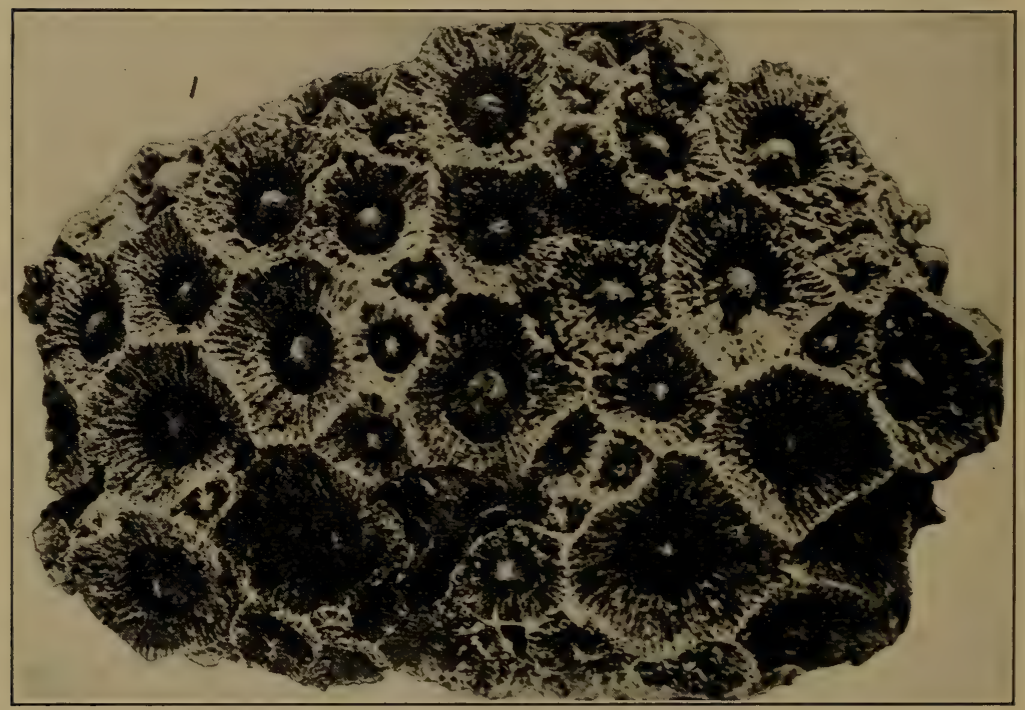

Fig. 90

Mississippian Cup-corals, Lonsdaleia canadense, forming a compact mass or colony. (After Ulrich, U. S. Geological Survey, Folio 95.)

and better state of preservation in the Pennsylvanian rocks, it will be best to postpone their somewhat detailed discussion to the next chapter.

Protozoans. - Foraminifers were exceedingly abundant, especially in the Mid-Mississippian (St. Louis) sea. The famous Bedford limestone of Indiana, for example, is very largely made up of the tiny calcareous shells of these Protozoans. Radiolarian (siliceous) shells are very abundant in some formations where they make up layers of chert. 
Porifers. - Sponges continued to be common.

Cœlenterates. - Graptolites were very rare and became extinct. Corals showed a notable decline as compared with their remarkable development in the Devonian, though Cup-corals especially were locally numerous in the Mississippian seas (Fig. 90).

Echinoderms. - Cystoids were absent, having become extinct in the Devonian.

Blastoids, which, during several preceding periods, assumed a minor rôle, showed a wonderful development in the Mississippian when they appear to have reached their culmination both as regards numbers of individuals and diversity of forms. Fig. 91 shows one of the most common types, known as Pentremites, which largely constitutes beds of limestone in some places. At certain localities even the most delicate of the hard parts of the organisms are nearly

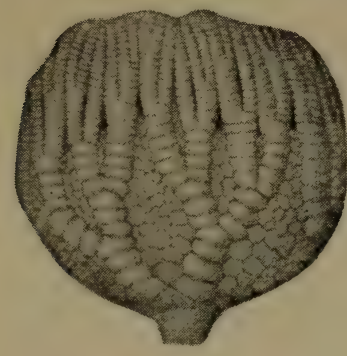

Fig. 92

A Mississippian Crinoid head, Forbesiocrinus wortheni. (After Hall.) perfectly preserved. It is a remarkable fact that this

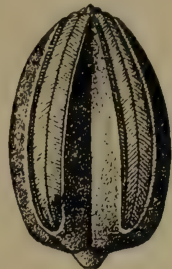

Fig. 91

A Mississippian Blastoid head, Pentrimites elongatus. (After Shumard.) class of animals, which attained such prominence during this period, also became nearly extinct by the close of the same period.

Crinoids also culminated during this period. Hundreds of species are known, and some localities such as Crawfordsville, Indiana, and Burlington, Iowa, are well known for the remarkable preservation of vast numbers of these beautiful forms (fossil "sea-lilies"). "The Crinoid remains occur in such multitudes that in many places the limestones are principally composed of them; in such places they must have covered the sea-bottom like miniature forests" (W. B. Scott). It is noteworthy that all of this wealth of forms belonged to a single subclass or order of Crinoids (Fig. 92), not one of which is known to have lived on into the Mesozoic. "The rapid decline (of Crinoids) after this epoch (Osage) is one of the most remarkable incidents in the life-history of the invertebrates. . . The ornamentation of the Crinoids at this time was notable, and as in the case of the Trilobites, preceded the decline 
of the group. The repetition of this singular phenomenon at different times, and in quite different groups of organisms, is worthy of notice, though its meaning is not altogether clear." ${ }^{1}$

Asterozoans are not known to have been common.

Echinoids considerably increased in numbers, size, and diversity, and, as in the preceding period, all belonged to a now extinct subclass.

Molluscoids. - Bryozoans, in marked contrast with the Devonian, were very abundant, and in some cases the calcareous skeletons of the colonies contributed much material to the building of limestone. For the first time the delicate moss-like colony supports were partly replaced by thicker and heavier supports, a good example being called Archimedes because of some resemblance to the familiar screw of the same name.

Brachiopods in general diminished notably, though they were by no means uncommon. Certain important earlier Paleozoic genera (e.g. Pentamerus) were entirely gone. The important genus Spirifer greatly diminished in numbers and size of individuals. Perhaps the most important Mississippian genus was Productus with many species and some of the largest known individual Brachiopods. Straight-hinge line types still prevailed.

A very fine illustration of the production of a dwarfed fauna due to unfavorable environmental influences is afforded by the diminutive Brachiopods and associated shells of the Bedford limestone of Indiana. Since the species of these dwarfed forms are the same as those which grew to normal size elsewhere, it is evident that they must have lived in an unfavorable environment.

Mollusks. - Pelecypods were more common than ever before, and for the first time they appear to have been more numerous than the Brachiopods. The genera were much like those of the Devonian.

Gastropods continued to be common with most of the prominent Silurian and Devonian genera still present.

Cephalopods were much like those of the Devonian. All common groups of Nautiloids persisted but with the simpler forms still more diminished. The coiled forms, however, probably reached their climax of development both as regards numbers and diversity of forms. The Ammonoids were still represented by the Goniatites, though the sutures were appreciably more complex

${ }^{1}$ Chamberlin and Salisbury: College Geology, pp. 607-609. 
in accordance with the evolutionary principle already given in connection with this group (see page 99).

Arthropods. - Among Crustaceans, the Trilobites, which were approaching the period of their extinction, were few in number, comparatively small, and usually not highly decorated. Eucrustaceans must have been present but the records are scant.

Among Arachnids, the remarkable group of Eurypterids had notably fallen off both in numbers and size as compared with the Devonian.

Myriapods must also have been present because of their existence in the Devonian and their abundance in the succeeding Pennsylvanian, but fossil forms in the Mississippian are relatively scant.

Fossil Insects are not known from the Mississippian.

Vertebrates. - Ostracoderms became extinct with the Devonian.

Fishes. - The Selachians (Sharks), as compared with the Devonian, showed an extraordinary development in numbers and species. They were doubtless the most prominent of all Fishes of the time, many hundreds of species being known. Teeth and spines are the most numerous fossils. In sharp contrast with most modern forms, many species had the mouths lined or paved with rough plate-like teeth probably suitable for grinding such shelled animals as Brachiopods, Pelecypods, etc. The spines were doubtless provided for defence against more predaceous Fishes. Dipnoans and Arthrodirans still continued though notably diminished. Ganoids were still prominent, probably having been more abundant than in the Devonian, with many new genera and species.

Amphibians. - As we have learned, there is good reason to think that Amphibians lived in Devonian time, though actual remains are not known. In the Mississippian rocks of Scotland good specimens of Amphibians have been found. These all belong to the long extinct and remarkable group of Stegocephalians which will be described in the next chapter because of their much more satisfactory preservation in the Pennsylvanian rocks. As already suggested in our discussion of Devonian Fishes, it is well-nigh certain that the earliest Amphibians were derived from certain types of Fishes (Dipnoans). In fact the larval forms of Amphibians are true water animals breathing through gills and swimming like Fishes. 


\section{CHAPTER XI}

\section{THE PENNSYLVANIAN (UPPER CARBONIFEROUS) PERIOD}

\section{Origin of Name, Subdivisions, etc.}

As stated in the preceding chapter, the Pennsylvanian system represents a part of what was formerly known as the Carboniferous system in America. In other continents, strata equivalent to the Pennsylvanian are usually called Upper Carboniferous. Rocks of Pennsylvanian age include the Coal Measures proper of the old Carboniferous, and they contain a far greater supply of workable coal than the rocks of any other system. The name has been given because of the typical development of the system with its coal in Pennsylvania where it shows the following subdivisions generally recognized in the eastern United States:

\section{Pennsylvanian SYsTEM \\ (4. Monongahela series (Upper Productive Coal Measures) (Shales, sandstones, and limestones with much coal). \\ 3. Conemaugh series (Lower Barren Coal Measures) \\ (Sandstones, conglomerates, shales, and limestones with some coal). \\ 2. Allegheny series (Lower Productive Coal Measures) (Sandstones, shales, and limestones with much coal and iron ore). \\ 1. Pottsville series \\ (Sandstones and conglomerates with some clays, lime- stones, and coal).}

In the interior of the United States these four subdivisions have scarcely been recognized as such. For example, in Iowa the whole system is divided into two series: (1) Des Moines and (2) Missourian. Local names are often employed in other portions of the Mississippi Basin. In the western United States little has been done toward subdividing the system.

\section{Distribution and Character of the Rocks}

General Distribution. - Only in the eastern part of the continent have the Mississippian and Pennsylvanian rocks been 
satisfactorily separated. The accompanying map (Fig. 93) shows the surface distribution of the Pennsylvanian in eastern North America. Two points of difference as compared with the older systems in this portion of the continent are worthy of mention as follows: (1) The Pennsylvanian rocks occupy distinctly larger

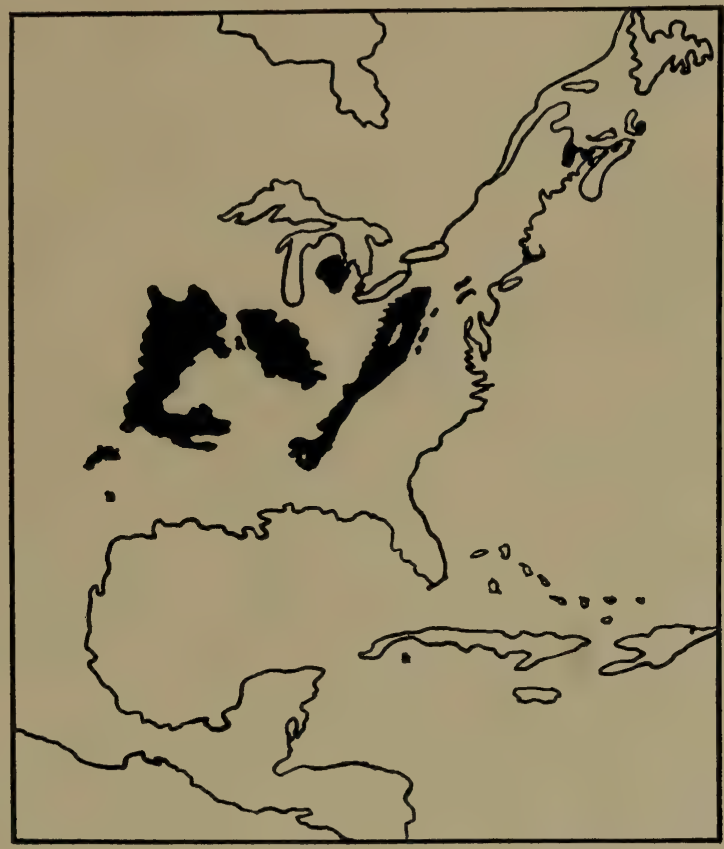

Fig. 93

Map showing the surface distribution (areas of outcrops) of Pennsylvanian rocks in eastern North America. These are also essentially the great areas of Pennsylvanian coal. (By W. J. M., data after Willis, U. S. Geological Survey.)

(surface) areas than the rocks of any older Paleozoic system, and (2) "the commonest position for the outcrops of the preceding Paleozoic systems severally is around the outcrops of the older systems. But the outcrops of the Pennsylvanian exhibit no tendency to a similar concentric distribution. Rather do they seem to cover areas between the outcrops of the older systems" (Chamberlin 


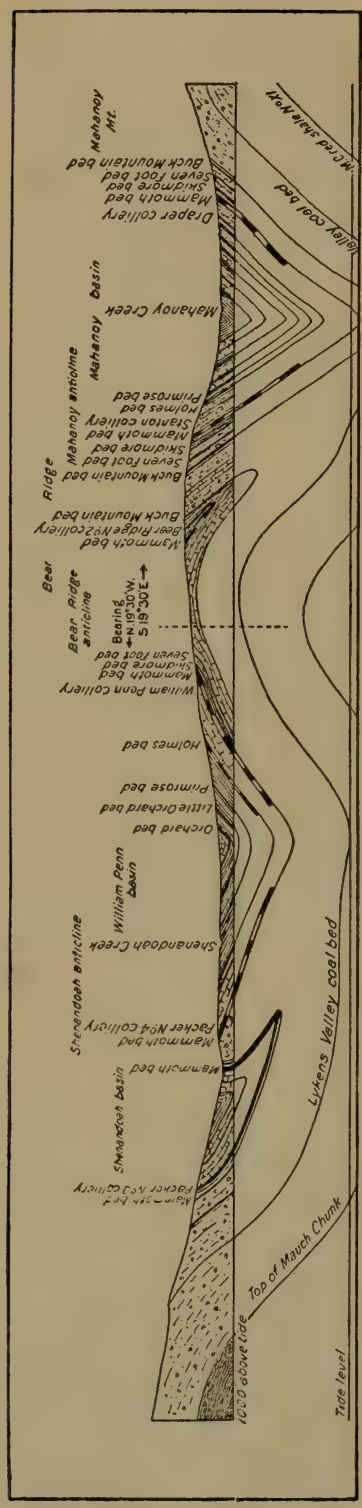

-

สี

है

언-

임

4 通

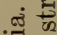

플

तथ

है

들 글

듕

인

कै.

एँ

पै ढี क

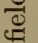

¿゙

sio
\& है

政

$\pm$

莺

离

논

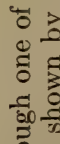

혛

를 응

들

过

ठ

를 and Salisbury). The reason for such differences is not far to seek. For instance, Ordovician rocks are actually more widespread than the Pennsylvanian, but they are largely concealed under later rocks, while the Pennsylvanian rocks were never extensively covered by later deposits (except Glacial drift and to a small extent by Permian strata in the Appalachian district). Shortly after their deposition, toward the close of the Paleozoic, the region was elevated and has remained a land area ever since. Post-Paleozoic erosion has been sufficient to remove much of the Permian and some of the Pennsylvanian, though large areas of the latter rocks still remain as shown on the accompanying map.

Pennsylvanian rocks are extensively developed in the western United States except in Montana, Idaho, Washington, and Oregon. They probably underlie much of the Great Plains just east of the Rockies from Wyoming to Texas. They are also pretty widespread in Alaska.

In the Appalachians (Fig. 94), Nova Scotia, and New Brunswick, and in the mountains of the west, the rocks are highly folded or tilted, but 
in the Mississippi Basin they have remained in almost horizontal position.

Pennsylvanian Rocks in the East. - Rocks comprising this system in the eastern part of North America are partly of marine and partly of non-marine origin with the latter (including coal) unusually prominently developed.

The following extracts from a paper by D. White concisely describe the Pennsylvanian rocks of the Appalachian province (also see Fig. 95): "The Pottsville, like the succeeding formations, is composed of sandstones, shales, and clays (including fire clays, coals, and limestones), but it contains a larger proportion of sandstones and arenaceous shales than the later formations ... The Pottsville is thickest in the southern exposures, where, near the eastern outcrops, it probably exceeds 7500 feet. In the northwestern bituminous area ... it measures locally less than 200 feet. . . . The Pottsville contains all the workable coals south of the Kentucky-Tennessee state line.

The Allegheny, next succeeding the Potisville, is a thin formation characterized by a larger proportion of coal, shale, limestone, and iron ore. In the bituminous districts . . . the Allegheny ranges generally between 250 and 350 feet in thickness near the northern outcrop, though it thins southwestward to 160 feet in northeastern Kentucky.

The Conemaugh, which succeeds the Allegheny, is generally marked at its base by sandstone or conglomerate. It is especially characterized by sandstones, shales, and limestones, intermingled, particularly in the western area, with red and green shales, clays, and sandstones. It contains less coal than any of the other Pennsylvanian formations of the Appalachian trough. ${ }^{1}$

The Monongahela is distinguished by its relatively large proportion of coal and limestone, the latter composing over onethird in some districts. The formation . . . averages about 325 feet or less in thickness. Its coals, including the great Pittsburg coal at its base, are of notable thickness and value." 2

The four distinct subdivisions of the system above described are generally not recognized as such in the Mississippi Basin, but various local names are there given to the subdivisions of the

${ }^{1}$ A maximum thickness of 800 to 900 feet for the Conemaugh is shown in western Pennsylvania and Maryland.

${ }^{2}$ D. White: U. S. G. S., Professional Paper 71, pp. 431-432. 


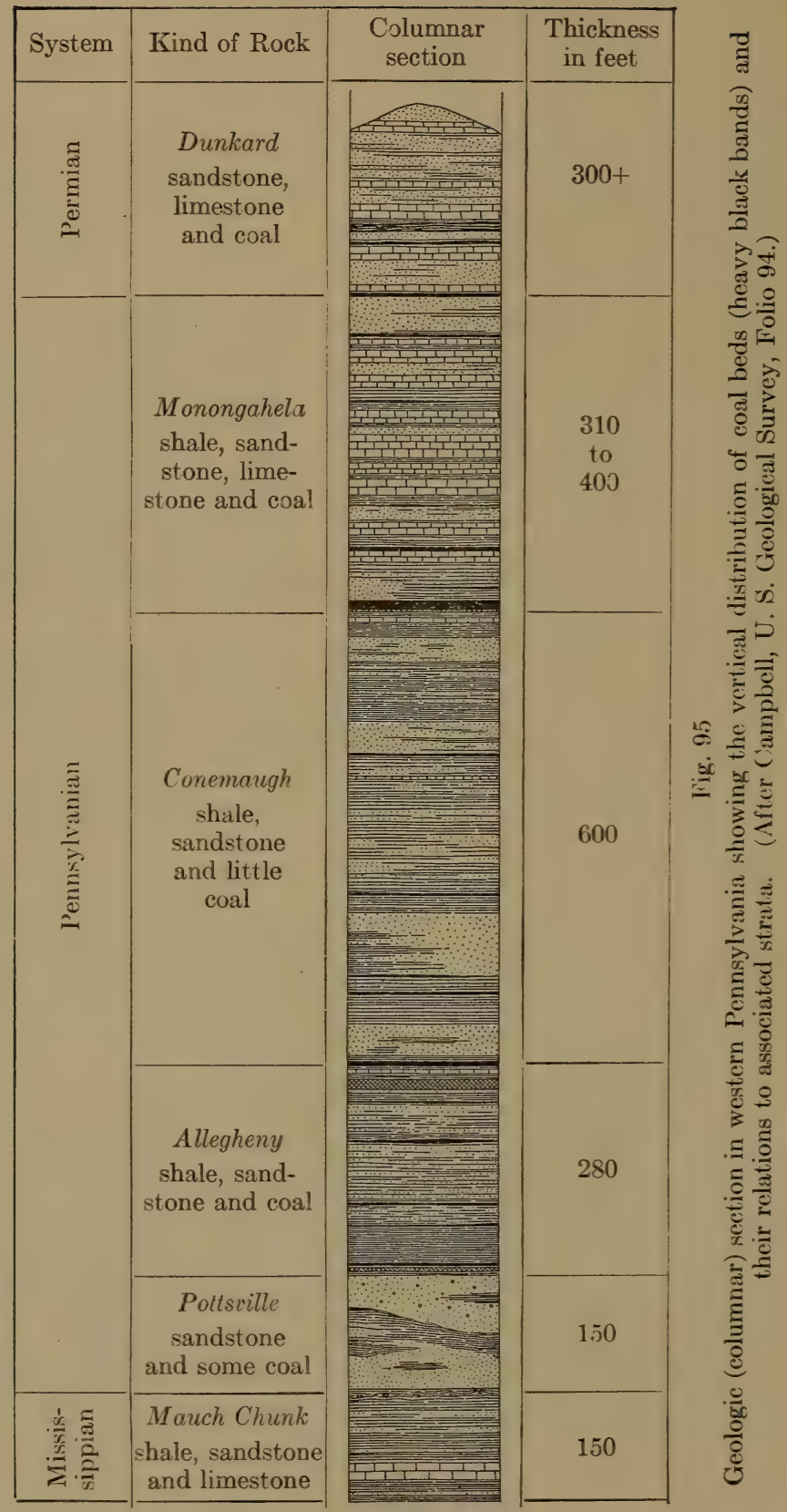


system which is usually thinner and less arenaceous than in the Appalachian district.

Small areas of Pennsylvanian igneous and metamorphosed sedimentary rocks, together with some graphitic coal, occur in Rhode Island and Massachusetts.

Coal-bearing strata of this age attain a thickness of thousands of feet in New Brunswick and Nova Scotia.

Pennsylvanian Rocks in the West. - From the Rocky Mountains westward in the United States, the Pennsylvanian rocks are practically all of true marine character and consist largely of limestone and sandstone but entirely without coal, thus being in marked contrast with the rocks of the system in eastern North America.

Thickness of the Pennsylvanian. - In the Appalachian district, the system ranges in thickness from about 1000 feet to fully 7000 or 8000 feet. A maximum thickness of 13,000 feet is known in Nova Scotia, and 12,000 feet in Rhode Island. Through the Mississippi Basin the thickness is usually not more than 1000 to 2000 feet, though in Arkansas a thickness of over 18,000 feet has been claimed. In the western United States the thickness varies much, though it is usually at least several thousand feet.

Igneous Rocks. - Considerable amounts of granite are intruded into the Pennsylvanian and other rocks of Massachusetts, but these may really be of Post-Pennsylvanian age. Also in the Cordilleran region from northern California to Alaska we learned that vulcanism occurred on a large scale in Mississippian time, and it is probable that it continued into Pennsylvanian time.

\section{Physical History}

Early Pennsylvanian. - As we learned in the preceding chapter, the Mississippian period closed with a widespread emergence of all (or nearly all) of the submerged areas in eastern North America. Very early in the Pennsylvanian the sea began to transgress over the land by extending a long, narrow estuary northward through the Appalachian district as far as Pennsylvania. The Pottsville sandstones and conglomerates, derived by erosion from Appalachia immediately to the east, were accumulated to great thickness in this estuary, and it is thus readily seen why the Pottsville should be thickest on the east side. Gradually the early 
Pottsville basin of deposition expanded and extended over much of the interior coal fields region. Though not so well known, the best evidence also points to considerable submergence of the western United States in the early part of the period.

Middle and Late Pennsylvanian. - During the middle Pennsylvanian the geographic conditions were essentially as shown on the paleogeographic map (Fig. 96), except that true marine waters then also covered the temporary land area in Wyoming, Colorado, and New Mexico. In the west, marine conditions prevailed till the close of the period, while in the east true marine, estuarine, lacustrine, marsh or bog, and possibly even land conditions alternated repeatedly and more or less locally in the basins of deposition. Since such remarkable physical geography conditions favored the accumulation of the world's greatest coal beds, they deserve more detailed discussion. "Perhaps the most perfect resemblance to coal-forming condition is that now found on such coastal plains as that of southern Florida and the Dismal Swamp of Virginia and North Carolina. Both of these areas are very level, though with slight depressions in which there is either standing water or swamp conditions. In both regions there is such general interference with free drainage that there are extensive areas of swamp, and in both there are beds of vegetable accumulations. In each of these areas there is a general absence of sediment and therefore a marked variety of vegetable deposit. If either of these areas were submerged beneath the sea, the vegetable remains would be buried and a further step made toward the formation of a coal bed. Reëlevation, making a coastal plain, would permit the accumulation of another coal bed above the first, and this process might be continued again and again." 1 It is, however, not necessary to assume repeated elevation and subsidence of swamp areas in order to account for numerous coal beds one above another in a given region. A general subsidence, often intermittent (with possibly some upward movements), would occasionally cause the luxuriant vegetation of a great swamp area to be killed and allow the deposition of sediment over the site. Then the filling of the shallow water with sediment would allow another bog to be formed, etc. In the coal field of Nova Scotia there are 76 distinct coal beds; in Alabama 35; in Pennsylvania at least 20; and in Illinois 9. Each of these coal beds represents an ancient swamp in which grew a

${ }^{1}$ H. Ries: Economic Geology, 1910, p. $\theta$. 


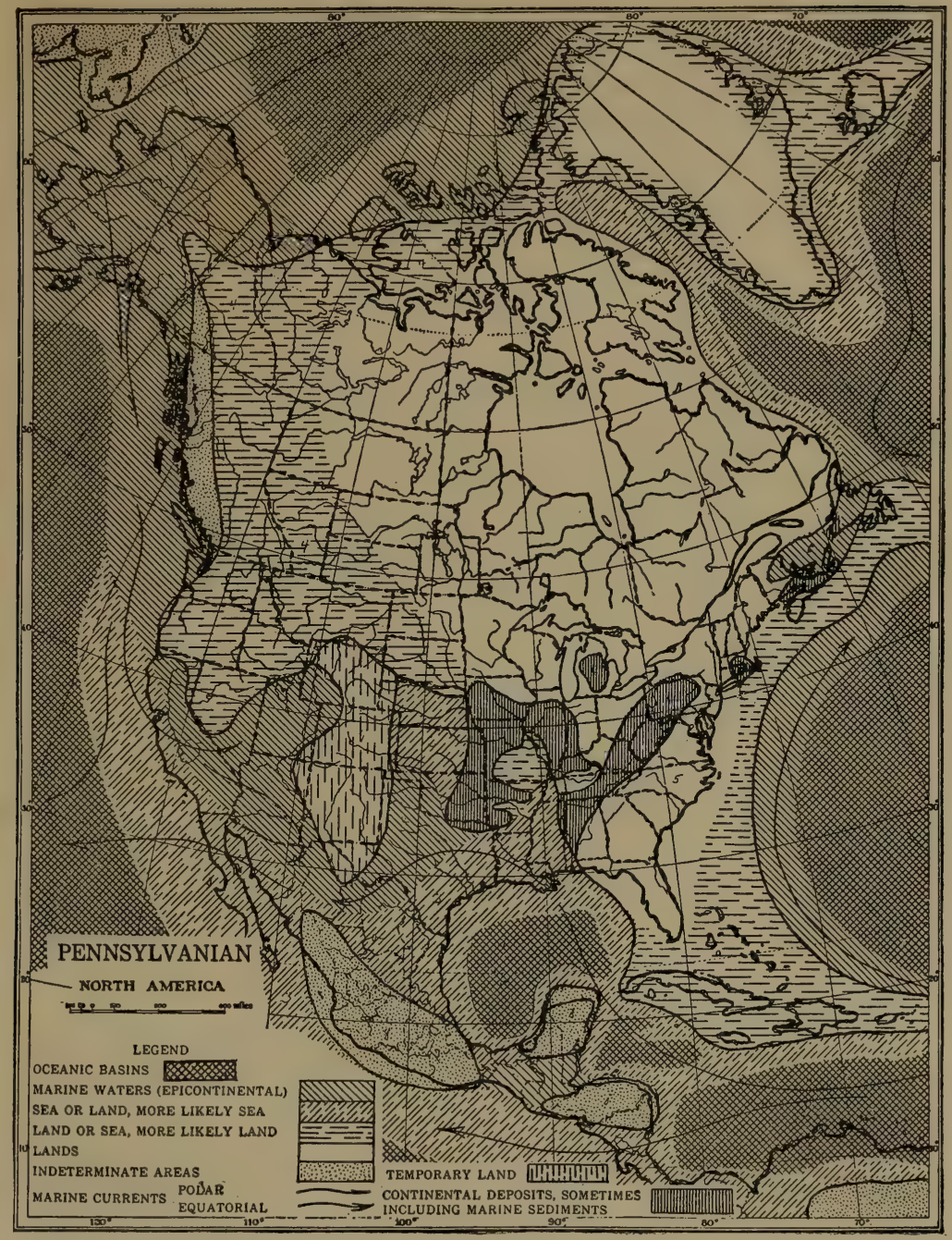

Fig. 96

Paleogeographic map of North America during Pennsylvanian time. (Slightly modified after Bailey Willis, courtesy of The Journal of Geology.) 
luxuriant vegetation. It should be borne in mind that workable coal seams constitute only about 2 per cent of the containing strata which are sandstones, shales, clays, and, in some localities, limestones.

1 Perhaps no single coal seam in the world underlies such a large area (12,000 to 15,000 square miles) as the famous Pittsburg coal bed. It is worked over an area of about 6000 square miles, and for 2000 square miles it averages 7 feet in thickness. Most of the swamps or bogs of Pennsylvanian time were much smaller than this.

In the anthracite coal district of eastern Pennsylvania, the famous "Mammoth" coal bed is remarkable for its great thickness up to 50 or more feet.

It may be of interest to consider the length of time necessary for the accumulation of so many coal beds one above the other. A vigorous growth of vegetable matter on an acre has been estimated to produce the equivalent of 100 tons of dried organic matter per century. This amount compressed to the specific gravity (1.4) of coal would cover an acre less than two-thirds of an inch deep. Considering that four-fifths of the organic matter escapes as gases in the process of coal making, we find that it would take nearly 10,000 years to make one foot of coal. Now, since the total thickness of coal beds in the Pennsylvanian system is often from 100 to 250 feet, it is readily seen, on this basis, that the time necessary for the accumulation of the coal deposits was from $1,000,000$ to $2,500,000$ years. On a conservative basis, the time necessary for the deposition of the sediments was fully as long, so that the Pennsylvanian period appears to have had a duration of no less than $2,000,000$ to $5,000,000$ years.

Close of the Pennsylvanian. - At the end of the period the remarkable, near sea-level, coal-swamp geographic conditions in the eastern United States were largely brought to a close by emergence of the lands distinctly above sea level, except in a narrow trough lying along the western side of the Appalachian Mountain axis and in which Permian deposits accumulated. From the Great Plains westward also the marine waters were notably restricted. In the east, at least, the emergence was probably due to a beginning of the great orogenic movements which culminated in the Appalachian Mountain Revolution at the close of the Paleozoic era. 


\section{Foreign Pennsyluanian}

Europe. - Viewed in a broad way, the Pennsylvanian of Europe presents certain interesting parallels with North America. Thus in Europe, sandstone or conglomerate, corresponding to our Pottsville, often lies at the base of the system. Above this, in

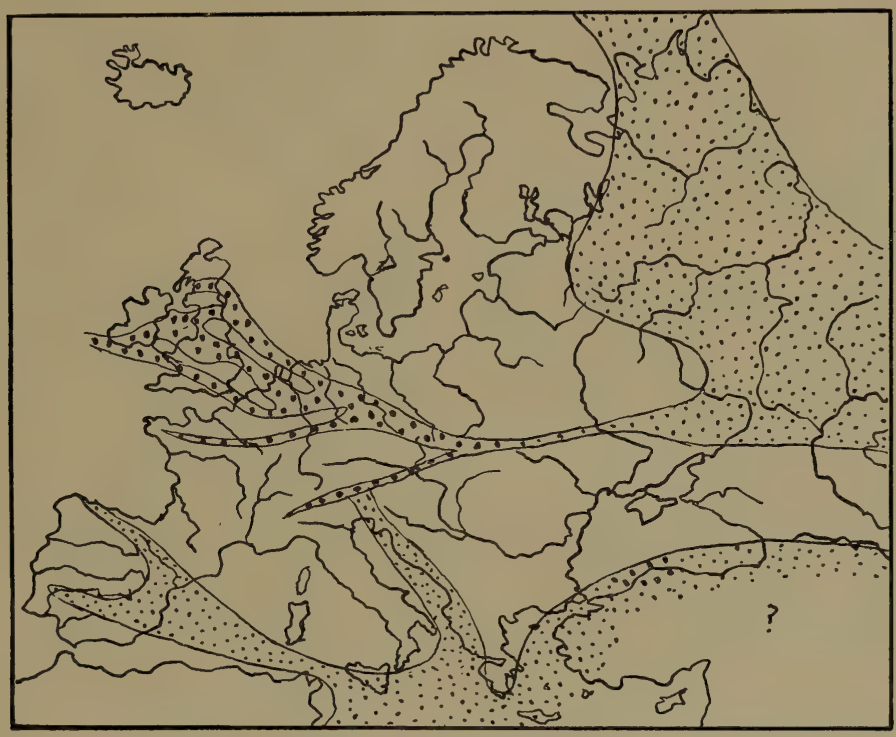

Fig. 97

Sketch map showing the relations of land and water in Europe during Pennsylvanian (Upper Carboniferous) time. Finer dotted areas were covered by marine water, and coarser dotted areas represent lagoons or basins of continental deposition. (Slightly modified after De Lapparent.)

western Europe, are the Coal Measures consisting of shales, sandstones, and some limestones together with numerous beds of coal, and in every way much like the Coal Measures of eastern North America (Fig. 95). In western and southern Europe the rocks are largely true marine limestones and free from coal, though some coal does exist in southern Russia.

Igneous rocks were intruded into the strata of western Europe 
during the Pennsylvanian, the vulcanism probably being a continuation of that begun in the preceding period.

Other Continents. - Much rock of Pennsylvanian age, both of marine and non-marine origin, occurs in Asia, with coal beds in Asia Minor, the east side of the Ural Mountains, and in northern China. The coal beds of China are said to be extensive and important.

Marine strata without coal occur in northern Africa. In the Zambesi district of southern Africa a coal field is known.

In Australia and South America marine and non-marine strata of this age are also pretty widespread. Much coal occurs in southern Brazil.

\section{Climate}

Until comparatively recently the plant life of the great coal period was thought to imply a warm to tropical, very moist, uniform climate. More careful study, however, clearly points to a temperate, only relatively humid, but remarkably uniform climate. Some of the criteria favoring this latter view may be stated as follows: ${ }^{1}$ The great size and height of the plants together with their frequent succulent nature and spongy leaves indicate luxuriant growth in a moist, mild climate; absence of annual rings of growth shows absence of distinct change of seasons; the presence of aërial roots, by analogy with similar modern plants, implies a moist and warm climate; the nearest present-day allies of the coal plants attain greatest growth in warm and humid climates; at present the greatest accumulations of vegetable matter in bogs and marshes take place in temperate climates where decay is not too rapid and thus suggests a similar climate for the accumulation of the coal deposits; and the remarkable distribution of almost identical plant types in Pennsylvanian rocks from Arctic to tropical regions clearly shows a pronounced uniformity of climate over the earth.

\section{Economic Products}

As already suggested, the principal economic product of Pennsylvanian age is coal, the richest and most extensive coal deposits in the world being of this age. Eastern North America, western

1 Based upon the work of D. White: Jour. Geol., Vol. 17, 1909, p. 338. 
Europe, and northern China contain the most important coal fields. The map (Fig. 93) gives a general idea of the locations of the coal fields of eastern North America, though several of the areas of coal-bearing Pennsylvanian rocks are really somewhat larger than this surface distribution (or outcrop) map shows. These areas, largely underlain with workable coal, are as follows: (1) Anthracite field of eastern Pennsylvania - 484 square miles; (2) Appalachian field from western Pennsylvania to Alabama70,000 square miles; (3) Eastern Interior field in Indiana, Illinois, and Kentucky - 50,000 square miles; (4) Northern Interior field in Michigan - 11,000 square miles; (5) Western Interior field from Iowa to Oklahoma - 72,000 square miles; (6) Texas field - 13,000 square miles; and (7) Nova ScotiaNew Brunswick field $-18,000$ square miles. Thus in eastern North America a total of about 235,000 square miles is mostly underlain with workable coal of Pennsylvanian age. Considerable coal of this age also occurs in Alaska.

Iron ores of some importance are found in the carbonate and oxide forms as bedded deposits in Pennsylvanian rocks. Such deposits were formed by precipitation, in the marshes and swamps, of the iron brought down from the lands in soluble form. The principal deposits occur in western Pennsylvania, eastern Ohio, and northern West Virginia.

Pennsylvanian rocks also yield considerable oil and gas especially in Illinois, Kansas, and Oklahoma.

\section{Life of the Pennsylvanian}

IN all of the preceding periods, our studies of organisms have been chiefly confined to marine forms because either they only existed, or predominated, or because they have left us the most abundant records. Rocks of the Pennsylvanian system are the earliest to carry abundant records of land plants and animals (Amphibians), and for the first time our principal discussion of the life of a period will deal with such forms. The Coal Measures and their enclosed organic remains have been studied in unusual detail because of the economic value of the coal.

Plants. - The plant life of Pennsylvanian time was very prolific and the records for this period are far more abundant than for any other Paleozoic period, one reason for this unusually full 
record doubtless being the very favorable conditions for preservation of the flora of the time. Several thousand species of now extinct plants are known from the Coal Measures alone. It must be remembered that most of the important classes of Pennsylvanian plants existed as early as in the Devonian, but these earlier records are much more scant. The known Coal Measures flora consists almost entirely of the higher Cryptogams (Pteridophytes) and the lower Phanerogams (Gymnosperms), though Thallophytes (e.g. Algæ) certainly, and Bryophytes probably, also existed.

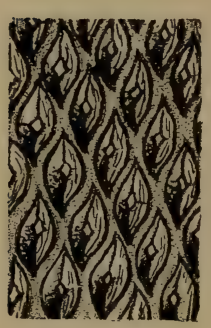

$a$

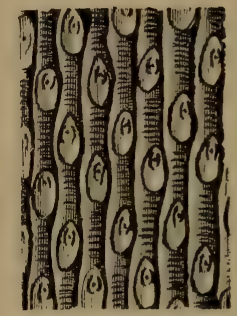

$b$
Fig. 98

Lepidodendron bark $(a)$ and Sigillarian bark (b), showing arrangement of leaf scars.

From the negative standpoint, the most significant feature was the complete absence of the typical flowering plants (Angiosperms) which are today the most common and the most advanced of all plants.

Lycopods (giant Club-mosses) were the largest, most abundant, and conspicuous of the forest trees, and they appear to have culminated during this same period. In marked contrast to such a high position, their descendants of today are represented only by a few, small, delicate, trailing so-called Club-mosses and Ground-pines in our forests. Two of the most prominent of the Pennsylvanian Lycopods were the Lepidodendrons and the Sigillarians. The Lepidodendrons ("scale-trees") had leafscars or scales arranged spirally around the trunks of the trees (Fig. 98a). They generally attained a height of 50 to 100 feet and a diameter of 2 to 4 feet. The tall trunks were slender and they branched dichotomously (by twos) only at a considerable height. Long, stiff, needle-shaped leaves were thickly set on the branches. The dropping of the leaves from the older (trunk) portions caused the leaf-scars or scales above mentioned. Inside of the outer bark, the stem consisted of pithy or loose cellular tissue. Over 100 species of the Lepidodendron are known. The Sigillarians ("sealtrees") are so called because of seal-like markings (Fig. 98b) which were arranged vertically on the tree trunk. They were even larger than the Lepidodendrons, having attained a height of 100 
feet or more and a diameter of 5 or 6 feet. The trunk seldom branched and it ended with a rounded tip. In other respects these trees were much like the Lepidodendrons.

Equisetce ("Horse-tail" plants) were also common in the Pennsylvanian forests. These plants had long, slender, segmented stems which were either hollow or filled with a large, soft pith

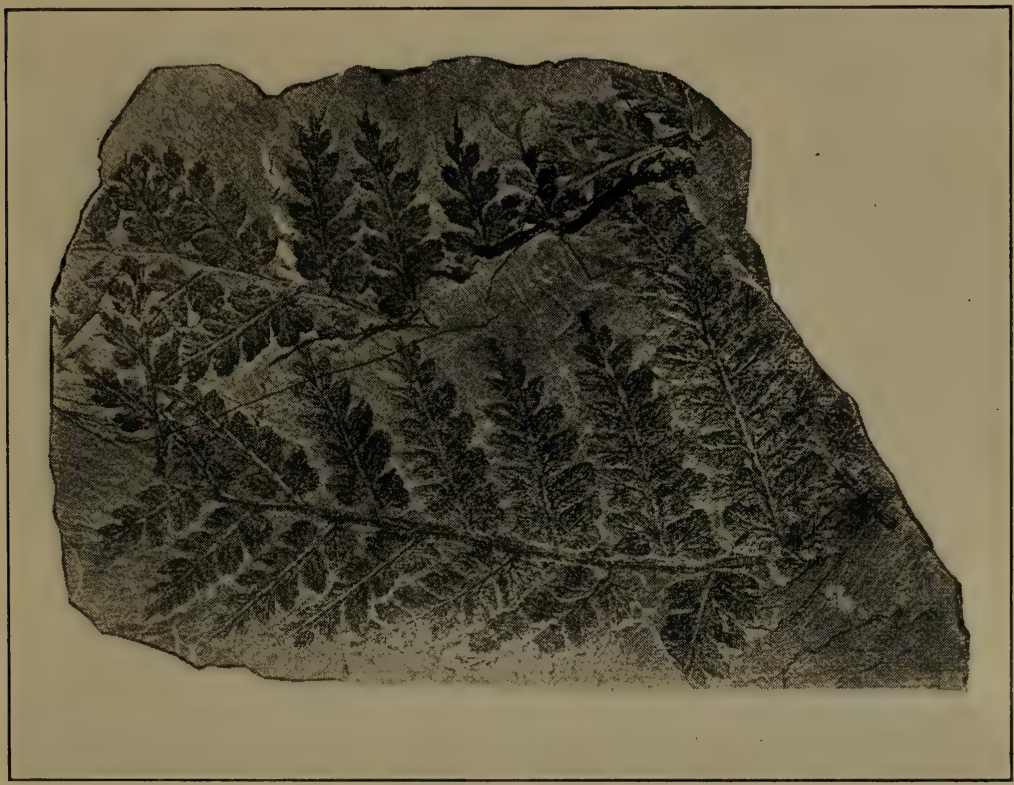

Fig. 99

Fronds of a Pennsylvanian Fern, Mariopteris. (After D. White, U. S. Geological Survey, Monograph 37.)

(Fig. 101). The leaves, which were arranged in whorls around the stems at the joints, were of variable shapes and sizes, usually either needle-like, scale-like, or strap-like. The outside of the stem had a sort of finely fluted structure but without scars and not continuous as in the Sigillarians. They reached heights of 60 to 90 feet and diameters of 1 or 2 feet. Equisetæ are today chiefly represented by only a few species of rush-like forms not over a few feet high, though in South America some very slender forms grow to heights of 30 or 40 feet. 
Fitices (true Ferns) were very abundant and diversified, both as tree-like forms and as small, herbaceous forms. Both forms were very similar in appearance to those now living in tropical and temperate climates (Figs. 99-100).

Cycadofilices ("Seed-ferns"), which were common in the Pennsylvanian, comprise a remarkable group of plants recently regarded as transitional between the Cryptogams and Phanerogams. They possessed seeds but not flowers and showed many features which seem to make them the connecting link between the Filices and the

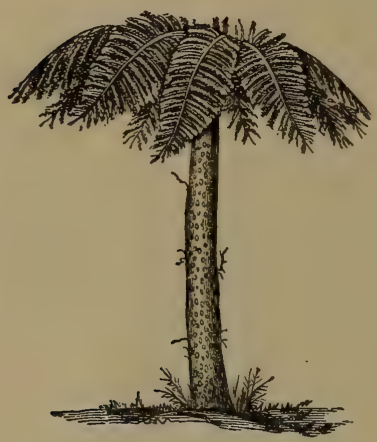

Fig. 100

A Living Tree-fern. (From Le Conte's "Geology," permission of D. Appleton and Company.) Cycads, hence the name "Cycadofilices." The seeds were arranged on the leaves. There is considerable difference of opinion concerning the relations and affinities of this remarkable group of plants, now long extinct (Fig. 102).

Gymnosperms.-Of these the most abundant representatives were the Cordaites. They were comparatively slender trees which attained a diameter of 2 or 3 feet and a height of 90 feet or more (see Fig. 103). The branches, which were given off only toward the top of the trunk, were supplied with numerous, long, very simple, parallel-veined, strap-shaped leaves notable for great size, sometimes 5 or 6 feet long and 5 or 6 inches wide. The trunks were covered with thick bark, while inside there was much pith. Many specimens have been well preserved. They were important contributors to the formation of some coal beds. They possessed certain features or structures of the Seed-ferns, Conifers, Cycads, and Ginkgos in addition to their own characteristics. Cordaites thus afford a fine illustration of a generalized type of plant, that is to say one which combined the characters of several distinct (some later) forms.

True Cycads and Conifers are not certainly known to have existed in the Pennsylvanian period, though some paleobotanists claim their existence.

Protozoans. - Foraminifers were very abundant as proved by the vast numbers of tiny wheat-like shells which contributed much 
to building up certain Pennsylvanian limestones in America, Europe, and other continents.

Porifers. - Sponges were present but they require no special mention.

Cœlenterates. - Among these the Corals only have left records, and even these do not appear to have been abundant. In

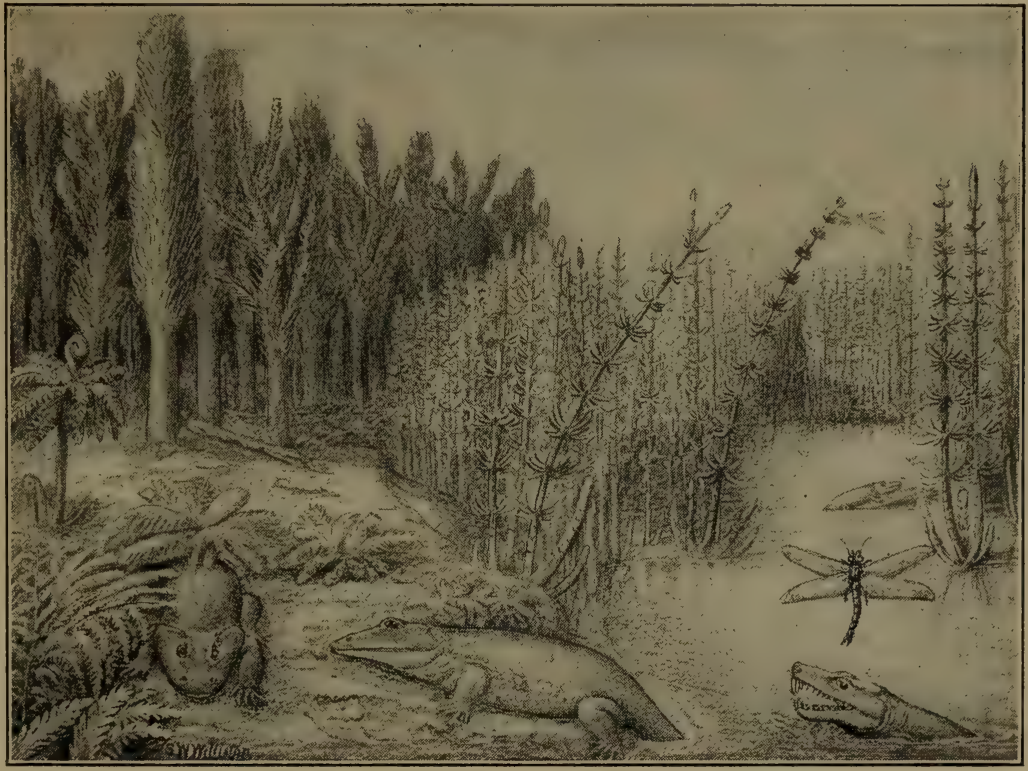

Fig. 101

A Permo-Carboniferous landscape, showing some of the most conspicuous plants of the great Coal Age. Lepidodendrons (with branches) and Sigillarians (without branches) in the left background; Equisetæ (segmented) on the right; Seed-ferns in the left foreground; two Amphibians (Eryops) on the land; a primitive Reptile (Limnoscelis) in the water; and a great Insect (Dragon-fly) in the air. (From a drawing by Prof. S. W. Williston.)

eastern North America and western Europe the physical geography conditions were distinctly unfavorable to them.

Echinoderms. - Of the Pelmatozoans (stemmed Echinoderms) only the Blastoids and Crinoids remained, the former having become extinct during the period. The Crinoids showed a remark- 
able falling off after their culmination in the Mississippian, but in the Mesozoic they regained prominence.

Asterozoans of this age have not been found in fossil form, but, judging by their previous and subsequent history, they must have existed.

Echinoids were much like the Mississippian forms though rare.

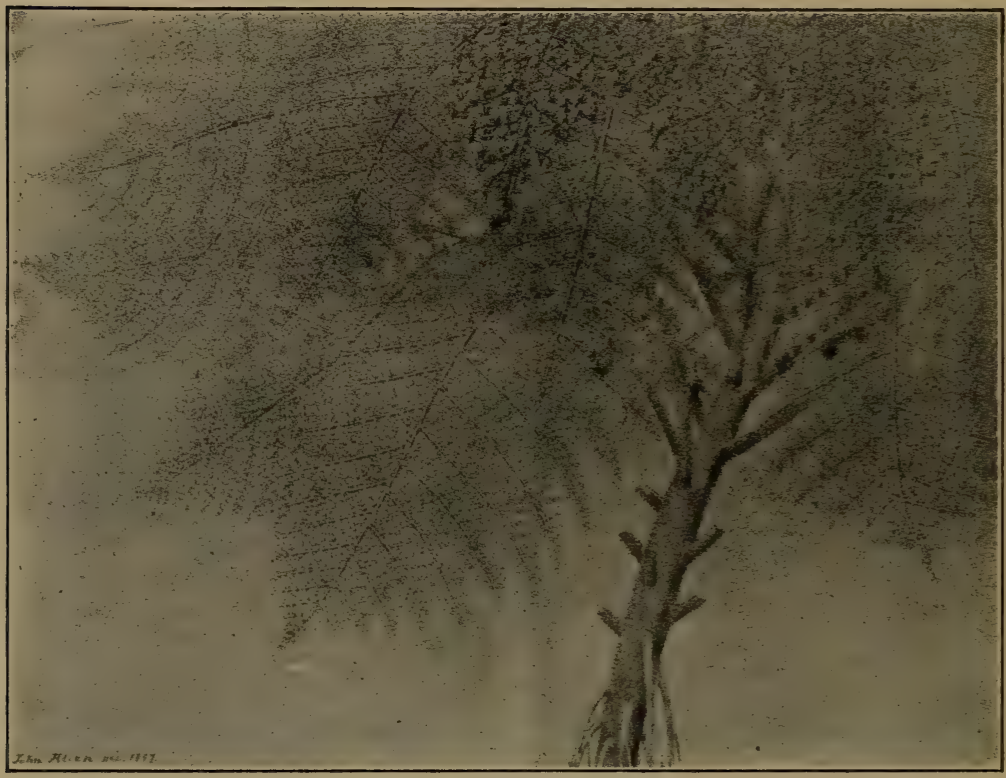

Fig. 102

A Cycadofilices or Seed-fern. Restored by D. H. Scott and J. Allen. (From Chamberlin and Salisbury's "Geology," courtesy of Henry Holt and Company.)

Molluscoids. - Bryozoans continued to be common, though the peculiar spiral forms (Archimedes) disappeared.

Brachiopods were still common but by no means as prominent as in earlier Paleozoic periods. They were much like the Mississippian forms. A noteworthy fact was the almost world-wide distribution of some of the species, which indicates either actual land bridges or at least shallow water areas connecting all the continents. 
Mollusks. - Pelecypods showed advancement in numbers and species and closer approach to modern species in appearance.

Gastropods continued to be much like those of earlier periods. It is important to note that several species of the earliest known land (air-breathing) Gastropods (Snails) have been found.

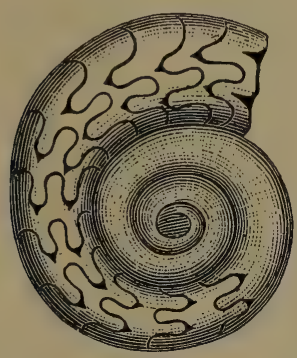

Fig. 104

A Pennsylvanian Goniatite. (Goniatites lyoni. After Meek.)

Cephalopods, both Nautiloids and Ammonoids were much as in the Mississippian, though the former had somewhat diminished and the latter showed gradually increasing complexity of suture structure (Fig. 104).

Arthropods. - Trilo-

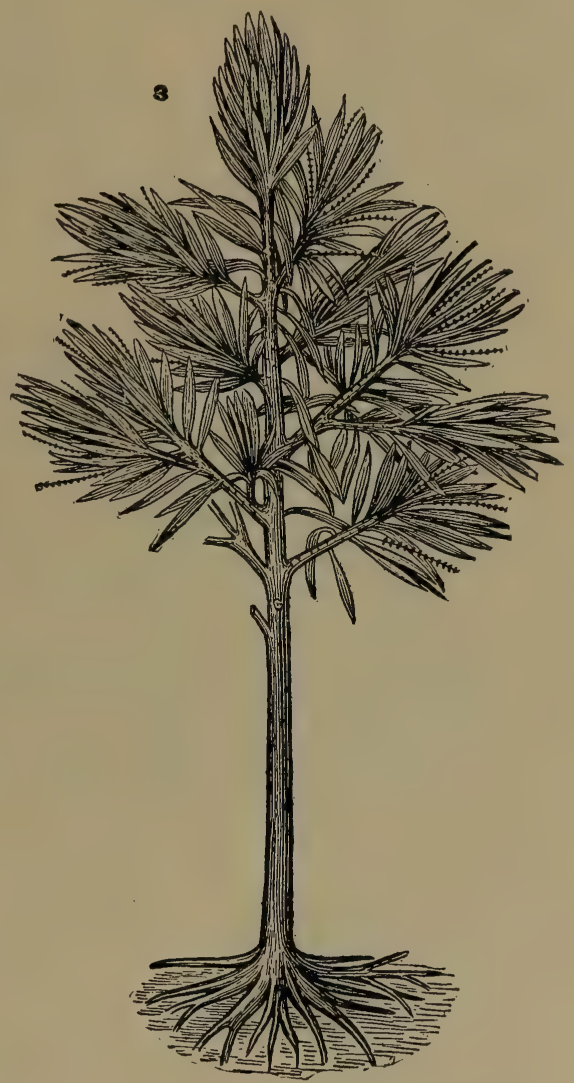

Fig. 103

Cordaites restored. (From Schuchert's

"Historical Geology," courtesy of John Wiley and Sons.)

bites were few and unimportant and close to the period of their extinction.

Eucrustaceans of Shrimp-like and Crayfish-like forms were present but not common (Fig. 105).

Arachnids were well represented by both Spiders and Scorpions, 

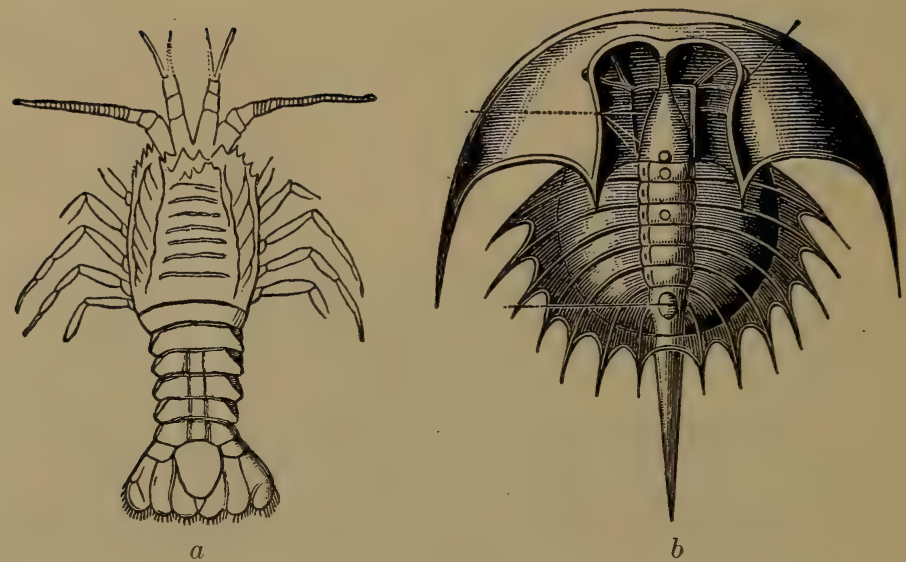

Fig. 105

Pennsylvanian Eucrustaceans: a, Anthrapalcemon gracilis (Meek and Worthen); b, Euproöps dance (Meek and Worthen). (From Le Conte's "Geology," permission of D. Appleton and Company.)

the former having made their first known appearance. They looked much like existing forms (Fig. 106). Eurypterids still continued

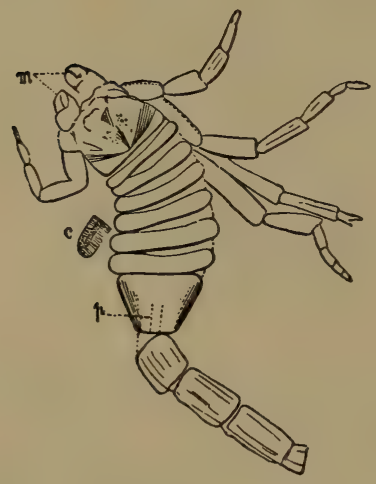

$a$

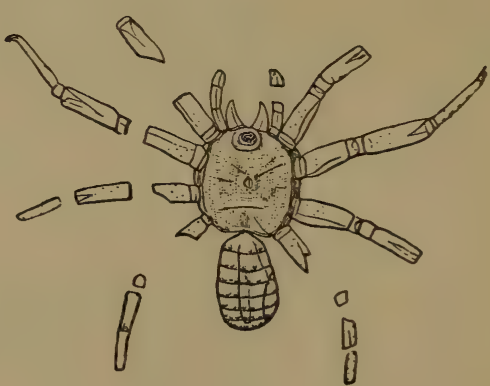

$b$

Fig. 106

Pennsylvanian Arachnids: a, Scorpion, Eoscorpius carbonarius (Meek and Worthen); b, Spider, Anthrolycosa antiqua (Beecher). (From Le Conte's "Geology," permission of D. Appleton and Company.) 
though not in abundance. Their common associations with land and fresh-water plants and animals clearly proves many at least to have been fresh-water dwellers.

\section{Myriapods were plentiful.}

Insects. - As would be expected in accordance with the abundant and favorable plant environment, the Insects showed a notable development. Hundreds of species are known from the Coal Measures of America alone. Nearly all were of simple types belonging to the Orthopters and Neuropters, which orders

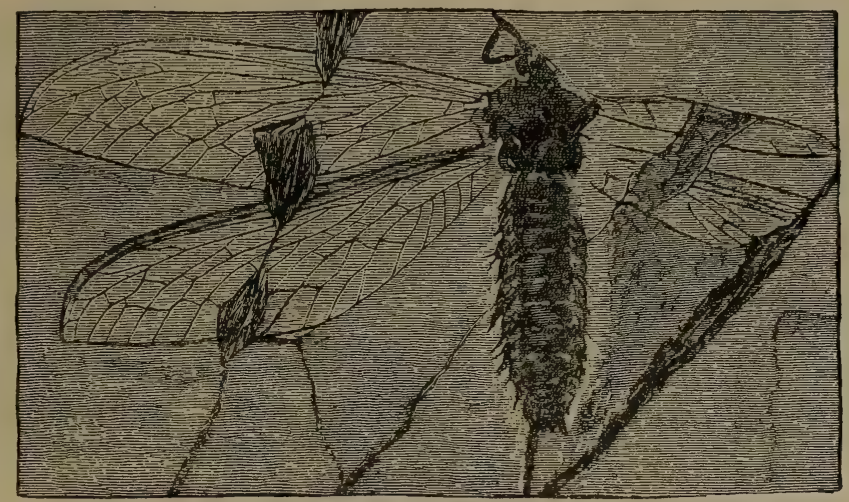

Fig. 107

A Pennsylvanian Insect, Corydaloides scudderi (Brongniart). This Insect had a spread of wing of 18 inches. (From Le Conte's "Geology," permission of D. Appleton and Company.)

are represented by modern Grasshoppers, Cockroaches, Caddisflies, etc. Somewhat higher types may possibly have been present, but the highest Insects, such as Butterflies, Bees, Ants, etc., are not known to have existed. Two other noteworthy facts regarding Pennsylvanian Insects are: (1) Their great size, some having had a spread of wing of from 1 to $2 \frac{1}{2}$ feet (Fig. 107); and (2) the existence of three pairs of wings on some species.

Vertebrates. - Fishes continued much the same as in the Mississippian and they require no special mention here.

Amphibians for the first time left abundant records in the Pennsylvanian rocks, and they merit special discussion here. This was probably the culminating period of the Amphibians, and from 
the standpoint of the evolution of the air-breathing Vertebrates the Pennsylvanian is regarded as the most important period in geological history. It is to be remembered that the earliest Amphibians almost certainly evolved from certain types of Fishes. All Mississippian and Pennsylvanian Amphibians are often classed together as Stegocephalians, so-called because of the relatively large, bony, roof-like plates of the skulls.

As regards the principal forms of Amphibians of Pennsylvanian time, the writer can do no better than to quote an excellent sum-

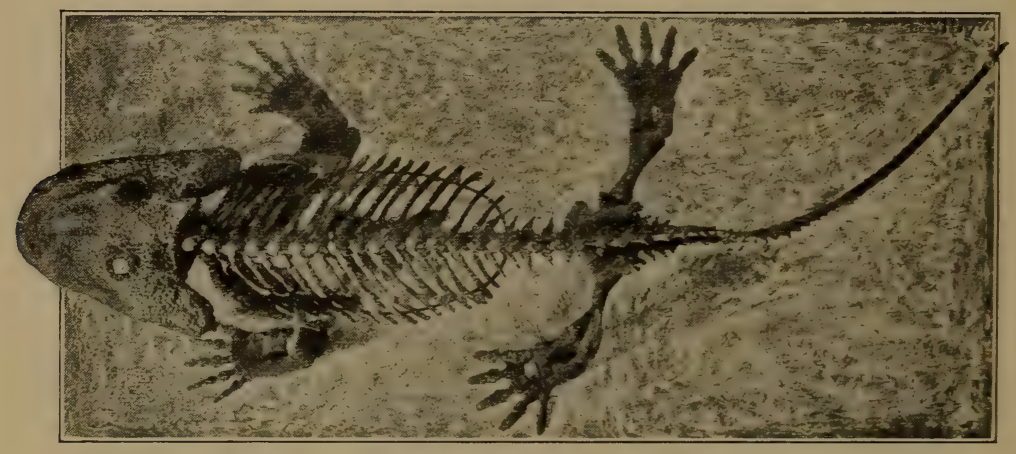

Fig. 108

A Pennsylvanian Amphibian (Labyrinthodont), Eryops. This creature attained a length of 6 or 8 feet. (Courtesy of the American Museum of Natural History.)

mary by S. W. Williston: ${ }^{1}$ "The predominating types of the Pennsylvanian were what we usually call the Branchiosaurs and the Microsaurs, for the most part small or very small creatures, at least as small as their nearest living relatives of the present time, the Salamanders. We are quite justified in the belief that their habits in general were not greatly unlike these descendants, rather sluggish creatures living about or in the water, for the Branchiosaurs at least passed through larval stages. They were more or less protected by an external bodily armor against their enemies, whether of their own or other kinds, in all probability terminating their existence as distinctive types long before the close of the Paleozoic. But among them there were some classed with the

1 Outlines of Geologic History, 1910, p. 164. 
heterogeneous group which we call Microsaurs, which had made a very distinct advance, both toward a higher existence and away from the water. ... Some lost the dermal armor completely and became fleet of movement, as is evidenced by the structure of the limbs, limbs mimicking in form and structure so closely those of modern quick-running Lizards as to be practically indistinguishable."

The Labyrinthodonts, and certain other closely related forms, comprised another important group of Pennsylvanian Amphibians. They are so named because of the peculiar, labyrinthine, internal tooth-structure (Fig. 109). They were the gigantic land Vertebrates of the period, some having reached a length of 7 or 8

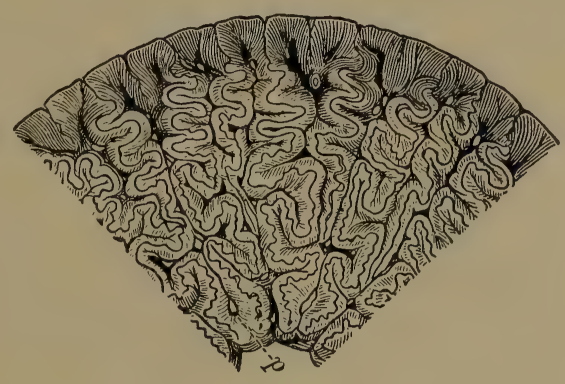

Fig. 109

Transverse section of a Labyrinthodont tooth. (After Owen from Norton's "Elements of Geology," by permission of Ginn and Company, Publishers.) feet (Fig. 108).

Reptiles. - Whether or not true Reptiles existed in this period depends largely upon the classification of the primitive land Vertebrates. The abundance of true Reptiles in the succeeding (Permian) period strongly suggests their earlier differentiation from the Amphibians. According to Williston: "We may be assured that some of them (Amphibians), before the close of the Pennsylvanian, were inhabitants of high-and-dry land regions where fleetness of movement, rather than obscurity, preserved them from their enemies, crawling Reptiles in everything save some insignificant technical details of their plates." 


\section{CHAPTER XII}

\section{THE PERMIAN PERIOD}

\section{Origin of Name, Subdivisions, etc.}

THIs period was so named by Murchison in 1841 because of the widespread development of rocks of this age in the Russian province of Perm. It is pretty distinctly a transition period between the Paleozoic and Mesozoic eras. In both the eastern and western United States the Pennsylvanian rocks usually grade upward into the Permian, while in the western regions the Permian strata nearly always grade upward into the Triassic. Thus it is well-nigh impossible to sharply separate the Permian from the systems immediately above and below it, and the delimitation of the Permian system in western America is by no means a settled matter at the present time. The scarcity or absence of fossils in many of the western areas adds to the difficulty.

The following table will give a general idea of the subdivisions now recognized in some of the better known regions, though it must be clearly understood that precise correlations are not meant to be implied.

\begin{tabular}{|c|c|c|c|}
\hline & Texas & Kansas & Pennsylvania \\
\hline $\begin{array}{r}\text { Permian } \\
\text { System }\end{array}$ & $\begin{array}{l}\text { Double Mountain series } \\
\text { (Salt, gypsum, and } \\
\text { limestone). } \\
\text { Clear Fork series } \\
\text { (Limestone and red } \\
\text { clay). } \\
\text { Wichita series } \\
\text { (Red clay, sandstone, } \\
\text { and limestone). }\end{array}$ & $\begin{array}{l}\text { Cimarron (Red Beds) series } \\
\text { (Sandstones, shales, dolo- } \\
\text { mites, and gypsum). } \\
\text { Big Blue series } \\
\text { (Shales and limestones). }\end{array}$ & $\begin{array}{l}\text { Dunkard } \\
\text { series } \\
\text { (Sandstones, } \\
\text { shales, lime- } \\
\text { stones, and } \\
\text { some coal.) }\end{array}$ \\
\hline
\end{tabular}




\section{Distribution and Character of the Rocks}

General Distribution. - Compared with the preceding Paleozoic systems, the Permian rocks have a rather limited distribution. There are small areas in Nova Scotia and New Brunswick; a small area in Pennsylvania, Ohio, and West Virginia; large areas in Texas, Oklahoma, Kansas, Colorado, Nebraska, and Iowa; smaller areas in South Dakota and Wyoming; and some rather poorly known areas in New Mexico, Utah, northern Arizona, northern California, and the Pacific border of Alaska. All of these surface exposures are within the areas represented on the map (Fig. 111) either as occupied by marine waters or receiving continental deposits.

In the western United States the Permian strata are considerably more extensive than their surface distribution because they are concealed under Mesozoic or Cenozoic rocks over large areas. Also there is some reason to think that the Permian strata formerly extended over much of the Great Basin region, but have been removed by erosion, leaving much Pennsylvanian or Mississippian rock now at the surface. In the eastern United States, however, the one small area in the northern Appalachian district comprises all of the Permian except possibly some in the lower Mississippi Valley where Mesozoic and later rocks effectually conceal the older rocks.

Character of the Rocks. - The Permian strata (Dunkard series) in the small area of the northern Appalachian district are sandstones and shales, together with some limestone and coal beds. They are in every way much like the Coal Measures just below.

In Kansas the Permian rocks are divisible into two rather distinct series, the lower or Big Blue series of shales and limestones being largely marine, while the upper or Cimarron series of sandstones, shales, dolomitic limestones, and gypsum are mostly not truly marine and they are characterized by a prevailing red color.

The Texas Permian strata are chiefly red beds of mostly nonmarine origin and divisible into three series as shown above. Red clays, limestones, and sandstones constitute the two lower series, while limestone, salt, and gypsum chiefly make up the upper series.

Marine Permian strata of considerable thickness have been reported from the Wasatch Mountains of Utah, and from northern California. 
Strata, mostly of non-marine origin and containing much red materials like those of Texas and Kansas, are also found in the other western states where Permian rocks occur (see above, also Fig. 110).

True marine strata, some thousands of feet thick, are known in Alaska, especially in the Copper River region.

In Nova Scotia and New Brunswick the Permian also consists mostly of red beds including conglomerates, sandstones, and shales.

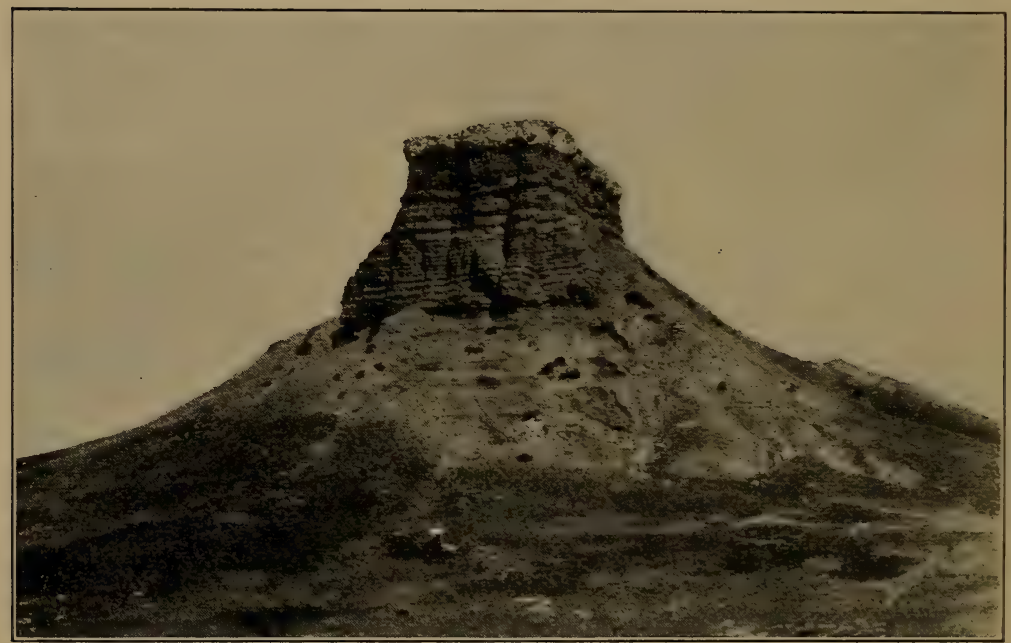

Fig. 110

Late Permian or early Triassic "Red Beds" in Red Butte, eastern Wyoming. The bright red strata are capped by a 30-foot layer of white gypsum. (After Darton, U. S. Geological Survey, Folio 127.)

Thickness of the Permian. - In Pennsylvania and Ohio the Dunkard series (Lower Permian only) shows a thickness of about 1000 feet. A thickness of 2000 feet for the whole system is reported from Kansas; 5000 to 7000 feet in Texas; and 3800 feet in Utah. In Nova Scotia and New Brunswick Permian strata attain a maximum thickness of 8000 feet.

Igneous Rocks. - Evidence of vulcanism during the Permian period in North America is practically absent. 


\section{Physical History}

During the Period. - Combining the above descriptions of rock distribution and characters with an examination of the paleogeographic map, the physical history of North America during the Permian may be readily comprehended. True marine conditions are definitely known to have prevailed during the whole period only in southern Alaska, northern California, Utah, and possibly southern New Mexico. The visible Permian strata in most of the other western states are of such character as to indicate deposition in great salt lakes or more or less cut off basins or arms of the sea. Conditions of aridity must have prevailed. Interbedded with these deposits, however, in some areas are marine strata, thus proving at least occasional incursions of the sea. In Kansas the character of the rocks shows the prevalence of marine waters during much of the earlier Permian. The best evidence seems to indicate that these interior basins had their connections with the sea across the Great Basin region (as indicated by true marine strata in the Wasatch Mountains) on one side, and through southern New Mexico and northern Mexico on the other, with an island between as shown on the map (Fig. 111).

The rocks of the northern Appalachian district clearly prove a continuation of the Coal Measures conditions, that is great fresh-water lagoons or basins, with occasional sea incursions.

The Nova Scotia and New Brunswick Permian rocks are also chiefly of continental origin, suggesting conditions of deposition similar to those in the western states, except that salt and gypsum are practically absent.

Close of the Permian (Appalachian Revolution) - The Paleozoic era was brought to a close by one of the most profound physical disturbances in the history of North America. It has been called the Appalachian Revolution because at that time the Appalachian Mountain Range was born out of the sea by upheaval and folding of the strata. Perhaps it would be better to say that the revolution reached its climax at about the close of the Paleozoic because the evidence is clear that the upward movement began at least as early as the close of the Mississippian and slowly increased to the close of the era. Since Permian strata are involved in the folding along the western side of the Appalachians, we know 


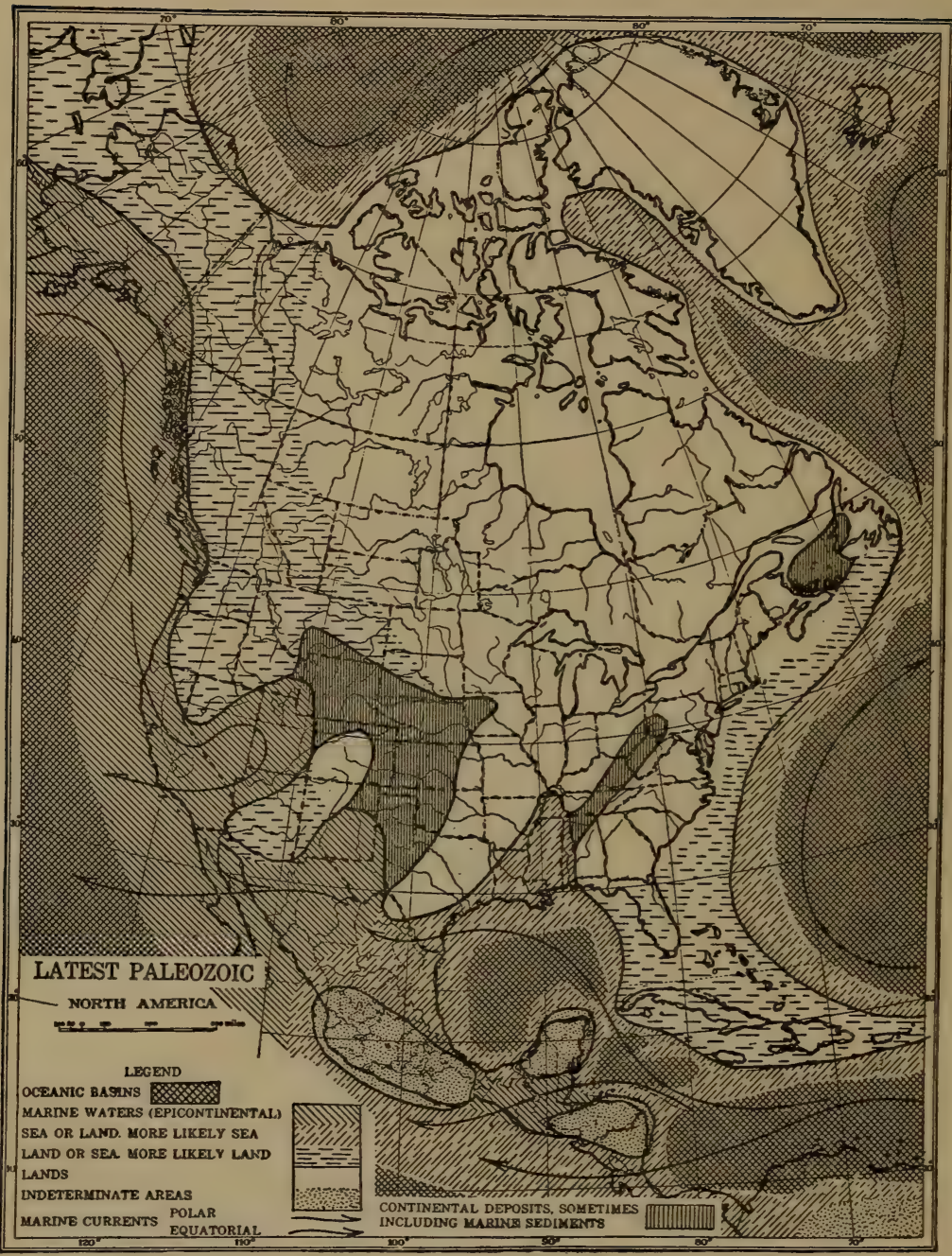

Fig. 111

Paleogeographic map of North America during latest Paleozoic (Permian) time. Outcrops of Permian strata are confined to the vertical and obliquelines areas, and in this way the map may also be regarded as a Permian surface distribution map. (Slightly modified after Bailey Willis, courtesy of The Journal of Geology.) 
that much of the disturbance must have occurred after the deposition of those strata.

All through the vast time (at least 10,000,000 years) of the Paleozoic era, a great land-mass (Appalachia) existed along what is now the eastern coast of the United States. Its western boundary was, most of the time, just east of the present Appalachians, while it must have extended eastward at least as far as the border of the continental shelf. Concerning the altitude and the character of the topography of Appalachia we know almost nothing, but we do know that it consisted of rock of pre-Cambrian age. The enormous amount of sediment derived from it shows that Appalachia was high enough during nearly all of its history to undergo vigorous erosion. Although oscillations of level more than likely affected the land-mass, and its western shore line was quite certainly shifted at various times, nevertheless it persisted as a great land area with approximately the same position during all of its long history. Its general position is well shown on the various Paleozoic paleogeographic maps.

Barring certain minor oscillations of level, all of the region just west of Appalachia was occupied by sea water during the whole Paleozoic era, and sediments derived from the erosion of Appalachia were laid down layer upon layer upon that sea bottom. The coarsest and greatest thickness of sediments deposited nearest the land, that is along what we might call the marginal sea bottom. At the same time, finer sediments and limestones in thinner sheets were being deposited over much of the Mississippi Valley region. By actual measurement, in the present Appalachians, we know that the maximum thickness of these sediments was at least 25,000 feet. Now, since these are all of comparatively shallow water origin, as proved by the coarseness of sediments, ripplemarks, fossil Coral reefs, etc., we are forced to conclude that this marginal sea bottom gradually sank during the process of sedimentation, thus producing what is called a great geosynclinal trough. Perhaps the very weight of accumulating sediments caused this sinking. Finally, toward the close of the Paleozoic era, sinking of the marginal sea bottom and deposition of sediments ceased, and a tremendous force of lateral compression was brought to bear, causing the strata to become folded and more or less fractured. Thus arose the great Appalachian Mountain range which, in its prime, was doubtless much loftier than it is today (see Fig. 112). 
This tremendous deformation took place very slowly, though during a short time as compared with the length of the Paleozoic era. As soon as the folds appeared well above sea-level, irregu-
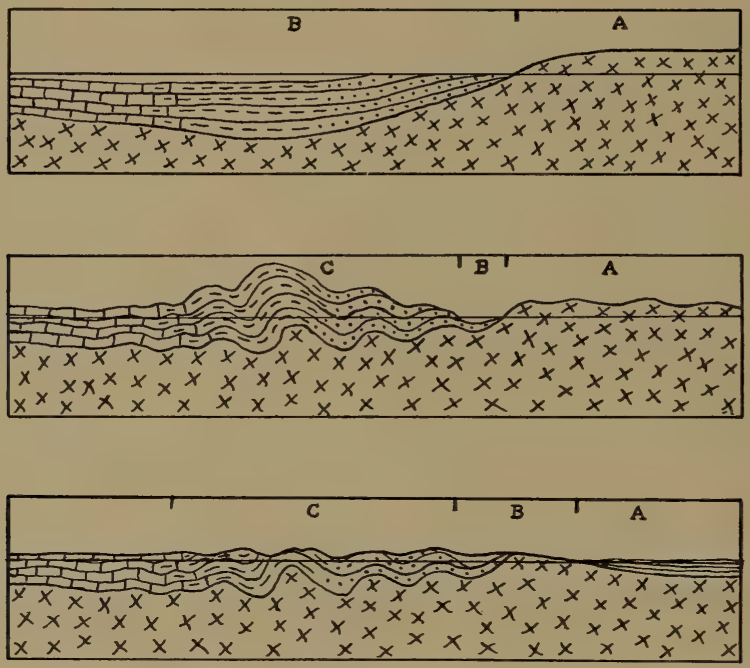

Fig. 112

Highly generalized structure sections across the Appalachian Mountains and adjoining districts to illustrate certain important features in the history of the region.

Upper figure: $A$, Appalachia; $B$, marginal sea-bottom (Appalachian geosyncline) mostly filled with sediments derived from Appalachia during Paleozoic time.

Middle figure: The same region with the strata folded into mountains as they would have appeared, if unaffected by erosion, toward the close of the Paleozoic era. $A$, Appalachia; $B$, Triassic basin or downwarp; $C$, Appalachian Mountains.

Lower figure: The same region as it now appears after much erosion, the submergence of Appalachia, and the deposition of the Coastal Plain beds. A, Coastal Plain; $B$, Piedmont Plateau; $C$, Appalachian Mountains. (By W. J. Miller.)

larities began to be carved out by the work of erosion so that even from early youth the mountains presented a rugged surface. Mountains now in process of growth, like the Coast Ranges of 
California, show such ruggedness. The great thrust faults, especially of the southern Appalachians where certain great rock masses have been pushed for miles over others, were not produced by single movements but rather by many repeated movements along the same thrust planes (see Fig. 113).

Important orogenic movements from Newfoundland to Rhode Island, and also in the Ouachita Mountains of Arkansas, are regarded as having taken place at the same time. Accordingly the whole eastern side of the continent was profoundly affected by mountain-making disturbances.

Other important geographic changes in addition to the above were (1) the warping of the surface of Appalachia as we shall show in our discussion of the Triassic period; (2) the uplift of the Mississippi Basin, mostly without folding of the strata, east of the Great Plains never again to become submerged to the present time except along the Gulf Coast; and (3) the elevation and erosion of most of the Permian areas west of the Rocky Mountains in the United States, which thus accounts for a pretty widespread unconformity between the Permian and Triassic in those areas.

\section{Foreign Permian}

Europe. - The Permian of Europe also shows two rather distinct phases marine and non-marine - but the system in central and western Europe is usually separated from the underlying Upper Carboniferous (Pennsylvanian) by unconformity, thus presenting a contrast to

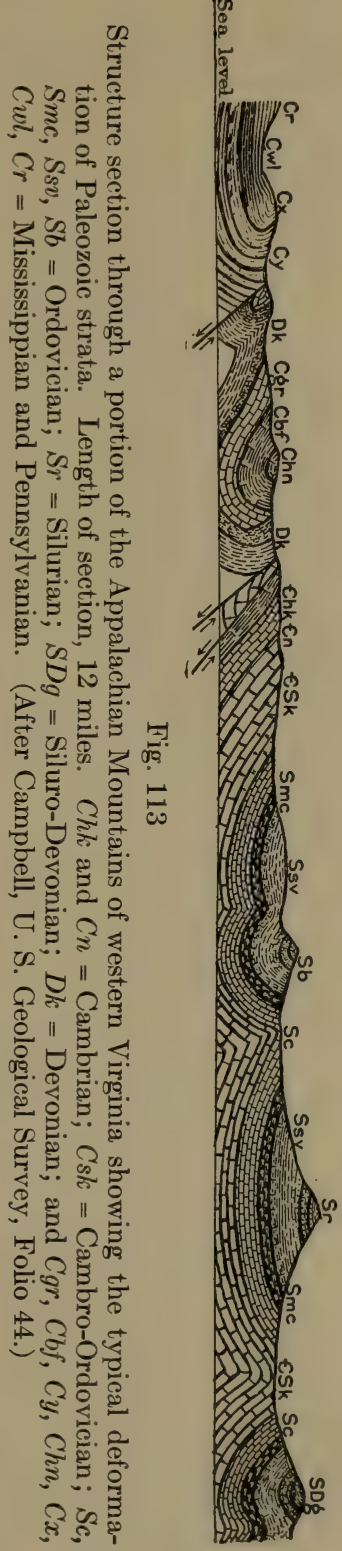


North America. Early in the Permian a great salt lake (or series of lakes), sometimes with local fresh-water conditions, extended over western to central Europe from Ireland to central Germany. Red beds, consisting of sandstones, shales, marls, salt and gypsum, together with some coal beds, were formed in these inland water bodies. Fossils prove that marine waters sometimes spread over at least portions of this inland basin. Glacial deposits have recently been discovered toward the base of the Permian in Germany. Another feature of special interest is the large amount of igneous rock in the form of lava flows, dikes, and tuffs in the Lower Permian, particularly in the British Isles, Germany, France, and the Alps.

Where the Lower Permian occurs in southern Europe, it is mostly of marine origin.

About the beginning of the Upper Permian, marine waters appear to have prevailed over the enclosed basin areas of central and western Europe, but soon again those waters withdrew to restore salt lake conditions (Fig. 114). Neither coal nor igneous rock occurs in the Upper Permian, but the greatest salt beds in the world were deposited in northern Germany during late Permian time. Some layers of magnesium and potassium salts were deposited with the common salt, one well having penetrated the deposit near Berlin to a depth of 4000 feet without reaching the bottom.

Upper Permian rocks do not occur in France, and where found in southern Europe they are largely marine.

In Russia, the type region for the Permian, rocks of this age underlie much of the country and appear at the surface over a wide area in the eastern part, just east of the Ural Mountains. These rocks are usually conformable upon the Upper Carboniferous (Pennsylvanian). Non-marine deposits, including red beds with salt and gypsum, are common, though at some horizons true marine strata prove incursions of the sea.

Other Continents. - In many other parts of the world Permian rocks are extensively developed, particularly in northern Asia, China, Persia, northern India (including the Himalayas), South Africa, Australia, Tasmania, New Zealand, Argentina, and Brazil. Continental deposits are common. A most remarkable feature is the widespread occurrence of thick (sometimes from 1000 to 2000 feet) glacial deposits in the Permian system in low-latitude countries such as India, South Africa, southern Brazil, and Australia. 
Furthermore, the plain inference from the close association of certain of these glacial deposits with marine strata is that glaciers near the equator came down near or actually to sea-level.

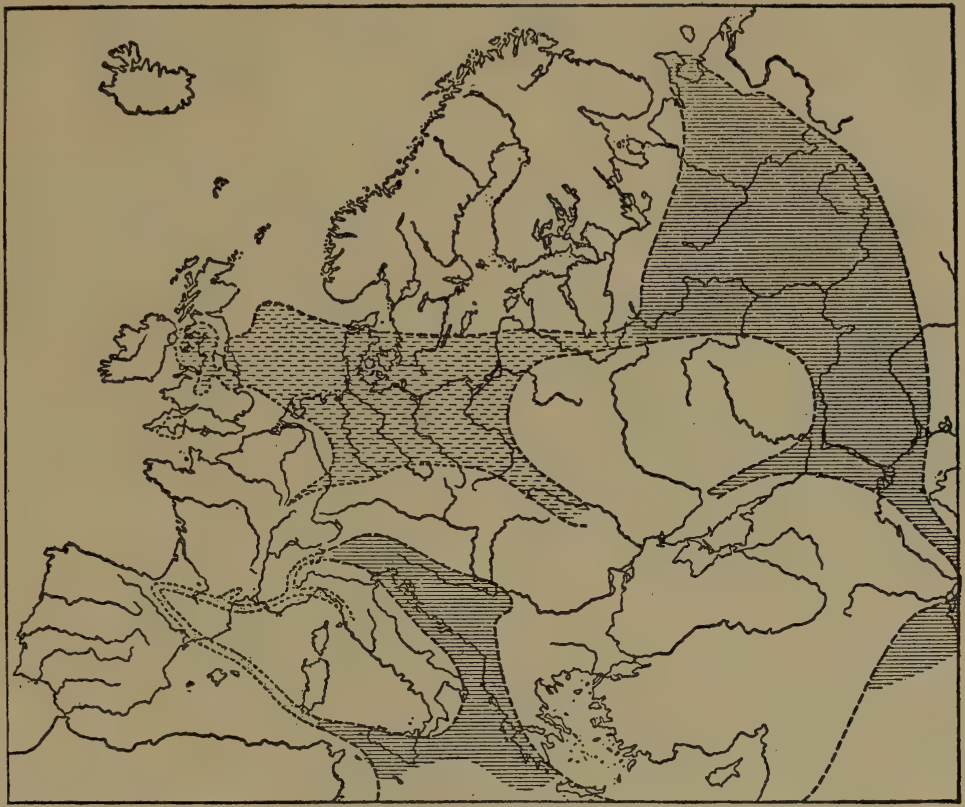

Fig. 114

Sketch map showing the relations of land and water in Europe during later Permian time. The lighter shading represents chiefly lagoon areas, while the heavier shading shows areas of marine water. (After De Lapparent, from Chamberlin and Salisburv's "Geology," courtesy of Henry Holt and Company.)

In some countries, as South Africa, Brazil, and Australia, coal beds also occur within the Permian.

\section{Climate}

From the above descriptions it is evident that the Permian presents a remarkable combination of climatic conditions, including extensive glaciation, widespread aridity, and conditions favorable for prolific growth of coal-forming plants, all in a single 
period. Thus the climate of the Permian stands out in striking contrast against the mild and uniform climate of the immediately preceding period. The concentration of the extensive glaciation over low-latitude countries, instead of high-latitude regions, is at present without adequate explanation. It must be confessed that the perplexing problems of Permian climate are as yet far from solved.

\section{Economic Products}

As already suggested, coal beds of considerable economic importance occur in the Permian of the northern Appalachian belt, France, Germany, Bohemia, Australia, Transvaal, and Brazil.

Salt is obtained from the Permian strata of Kansas, Oklahoma, and central Europe.

Gypsum deposits, which are so widespread in rocks of Permian age, are quarried in many states as Iowa, Kansas, Oklahoma, Texas, New Mexico, South Dakota, and Colorado. There are also important gypsum and potash deposits in Europe.

\section{Life of the Permian}

As compared with the preceding Paleozoic periods, the Permian shows a decided decrease in numbers and diversity of organisms. The known animal species of the period are to be reckoned by hundreds only. The organisms of the Permian were in several ways distinctly transitional in character between those of the Paleozoic and Mesozoic eras.

Plants. - All the principal groups of Cryptogams were represented much as in the Pennsylvanian, except that the Lycopods were very greatly reduced. In fact the Lepidodendrons became wholly extinct by the close of the period. The Equisetie and Ferns continued to be prominent, the Tree-ferns particularly becoming more common.

From the standpoint of evolution, the most interesting changes or advances occurred among the Gymnosperms. In addition to the Cordaites, which continued from the Pennsylvanian, Cycads and Conifers are known for the first time, thus giving the flora a decided Mesozoic aspect.

Protozoans. - Foraminifers continued to be very abundant as shown by their presence in marine limestones. Radiolarians were present though they are not well known as fossils. 
Porifers were present though they are not common in fossil form.

Cœlenterates. - An important change took place in the evolution of the Corals because of the first appearance of more modern Hexacoralla, or forms whose septa or dividing walls were six in number or multiples of six. The Paleozoic Tetracoralla, however, still continued to be common.

Echinoderms. - So far as the records show, this sub-kingdom diminished in an extraordinary manner, though Crinoids, Asterozoans, and Echinoids were present.

Molluscoids. - Bryozoans were abundant.

Brachiopods continued to be common with straight-hinged types, so abundant through the Paleozoic era, still prevalent for the last time.

Mollusks. - Pelecypods continued to increase in numbers and species, while Gastropods much like the older Paleozoic forms were still common.

Cephalopods. — Some early Paleozoic types of Nautiloids (e.g. Orthoceras and Gyroceras) still persisted and various species of the modern genus Nautilus were added. The Ammonoids show the most interesting evolutionary

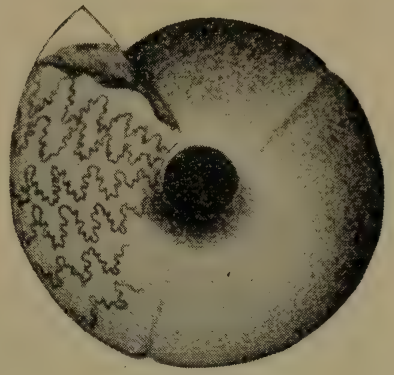

Fig. 115

A Permian chambered Cephalopod, Waagenoceras cumminsi (White) showing highly folded suture (partition) lines. changes, because of the notably increased complexity of their partition or suture structures. A good example is shown in Fig. 115 which is really more suggestive of Mesozoic Ammonites than of Paleozoic Nautiloids.

Arthropods. - Among the Crustaceans and Arachnids the groups of Trilobites and Eurypterids became extinct. In fact they had but few representatives in the Permian.

Insects have been found in abundance, especially in the Permian of Kansas and, though the species are different, they were much like those of the Pennsylvanian.

Vertebrates. - Fishes were in general very similar to those of the Mississippian and Pennsylvanian, though there were various species and genera changes.

Amphibians. - In general it may be said that the Permian 


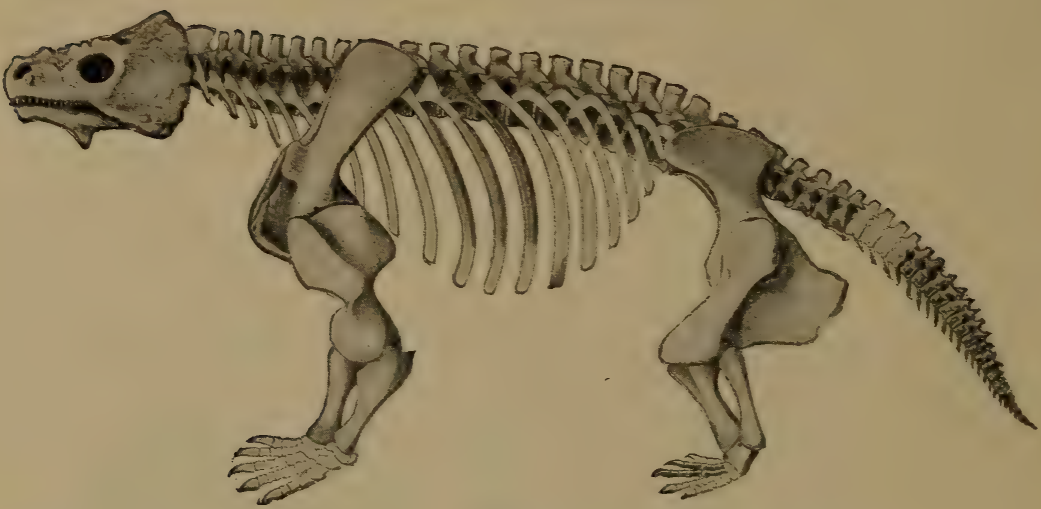

Fig. 116

A Permian Reptile, Pareiasaurus serrideus. This creature reached a length of over 8 feet. (After Broom, from Chamberlin and Salisbury's "Geology," courtesy of Henry Holt and Company.)

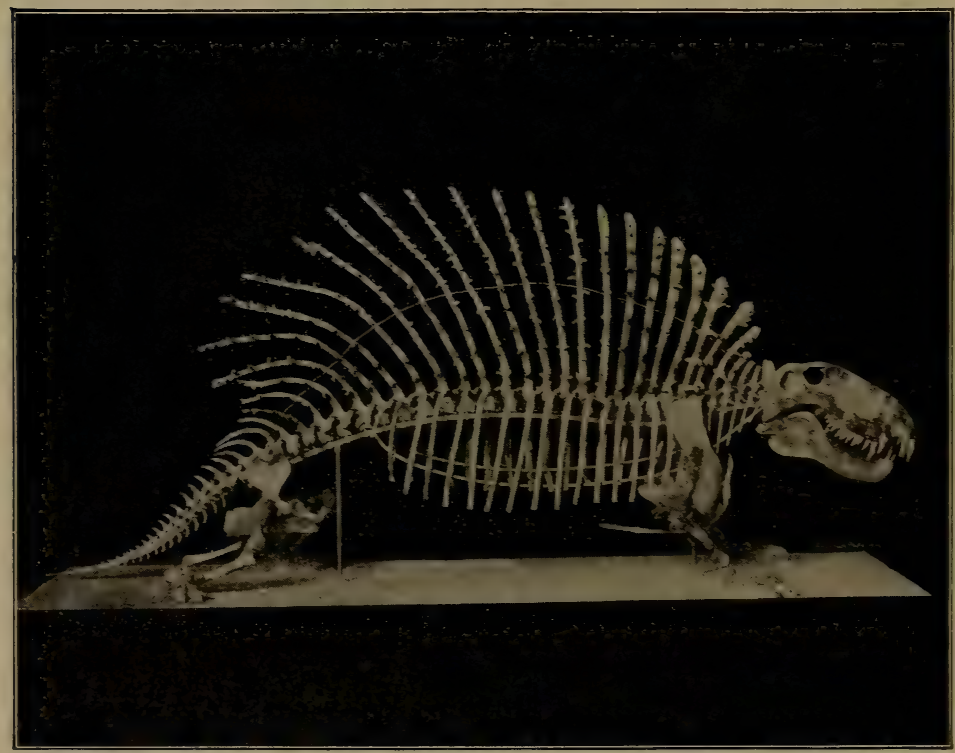

Fig. 117

A Permian Reptile (Pelycosaurian), Naosaurus clariger. (After Osborn, from Scott's "Geology," permission of The Macmillan Company.) 
Amphibians were much like those of the Pennsylvanian, except that some were even larger, new species were added, and even more reptilian features were developed in some.

Reptiles. - Any possible doubt about the existence of true Reptiles in the Pennsylvanian is completely removed when we consider the abundant reptilian records of the Permian. They developed in a remarkable manner, so that before the close of the period several important subclasses or orders, represented by many individuals, were evolved. Some of the Reptiles already began to show pretty distinct mammalian characteristics. The accompanying figures will give a good idea of two important Permian forms. 


\section{CHAPTER XIII}

\section{SUMMARY OF PALEOZOIC HISTORY}

"WE have defined geology as the history of the evolution of the earth. Evolution, therefore, is the central idea of geology. It is this idea alone which makes geology a distinct science. This is the coherent principle which unites and gives significance to all the scattered facts of geology - which cements what would otherwise be a mere incoherent pile of rubbish into a solid and symmetrical edifice. It seems appropriate, therefore, that at the end of the long and eventful Paleozoic era we should glance backward and briefly recapitulate the evidences of progressive change (evolution)." 1

\section{PaLeOzoIC Rocks}

Paleozoic rocks are dominantly sandstones, conglomerates, shales, and limestones of typical, marine, sedimentary character, though continental deposits also are common, such as fresh-water, swamp, or lagoon deposits of the Pennsylvanian in the eastern Mississippi Basin and the "Red Beds" formed in great salt lakes of Permian age in the southwestern United States.

The marine strata furnish abundant evidence, by the presence of ripple and wave-marks, the coarseness of the clastic materials (conglomerates and sandstones), etc., that they were deposited in shallow (epicontinental) seas, and never in really deep ocean water. Continental deposits are also abundantly represented.

In Europe the estimated maximum thickness of Paleozoic strata is 75,000 to 100,000 feet. It must be remembered, however, that this does not mean that such a great thickness of strata is present in any one locality, but rather that this represents the sum-total of the greatest thicknesses of the different formations of the continent.

A thickness of more than 25,000 feet of strata (largely clastic) actually piled layer upon layer may now be seen exposed in the

1 J. LeConte: Elements of Geology, 5th Ed., p. 421. 
highly folded and eroded Appalachians, while the maximum thickness of strata there must be between 40,000 and 50,000 feet.

The Paleozoic group of rocks in the interior of the Mississippi Basin measures only a few thousand feet in thickness, and limestones are there relatively more abundant than clastic deposits, because of the generally greater distance from the eroding lands.

In the western United States, Paleozoic strata usually show a thickness of many thousands of feet, and limestones are there also prominently developed.

The only large masses of igneous rocks of Paleozoic age are Mississippian or Pennsylvanian or both in the northern Cordilleras and in parts of New England.

\section{Physical History}

Relations of Land and Sea.-Throughout the Paleozoic era the most persistent lands were large portions of northeastern North America; Appalachia, the large area which occupied the eastern side of the United States; and islands and land areas of varying positions and sizes in the Cordilleran region. Most of the Mississippi Basin and much of the western side of the continent were submerged under epicontinental seas during the greater portion of the time. There were many oscillations of level of the land, or rising or falling of the sea-level, or both, causing repeated emergence and submergence of small and large areas. In this summary only the most salient geographic changes will be mentioned. The paleogeographic maps should be reviewed. Also the accompanying generalized map (Fig. 118) should be studied.

The era opened with much of North America a land area, but early in the Cambrian marine waters extended across the southern portion of the United States and northward by estuaries through both the Appalachian and Rocky Mountain districts. Throughout Cambrian time and to mid-Ordovician, a progressive submergence took place reaching a climax with all the continent submerged except two or three land areas around Hudson Bay, Appalachia, and some islands in the west. In late Ordovician time came emergence of considerable areas followed by extensive submergence which reached a climax toward the middle of the Silurian with nearly as much of the continent under water as during the midOrdovician. Similar extensive emergence at the beginning, and 
widespread submergence toward the end of the period, characterized both the succeeding Devonian and Mississippian. The

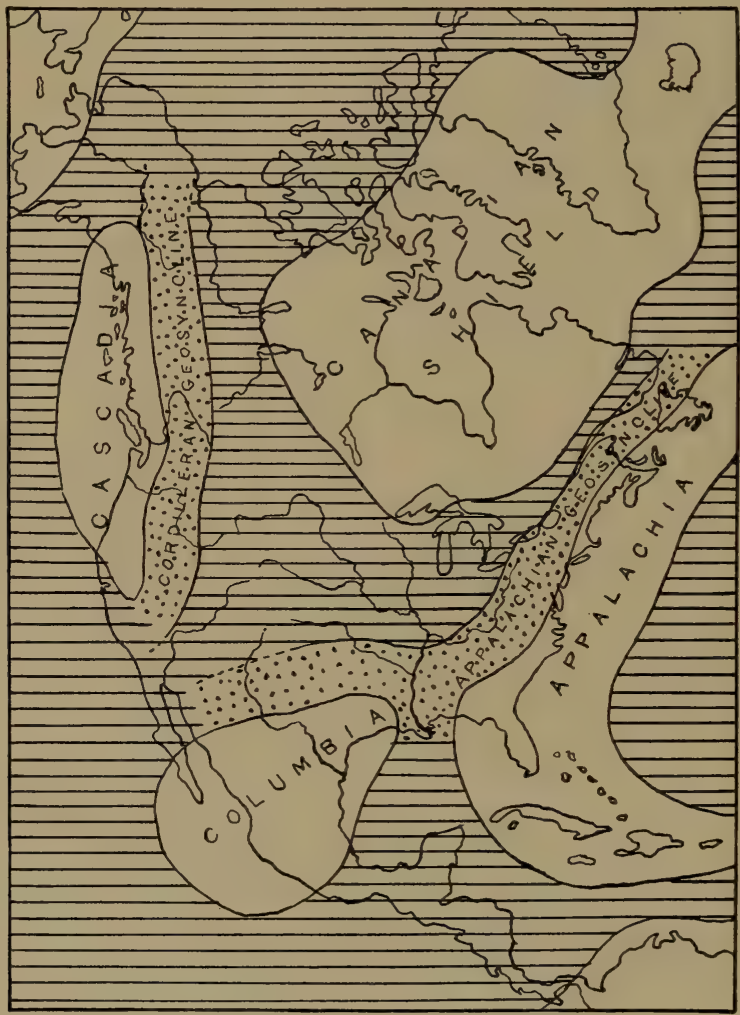

Fig. 118

Highly generalized paleogeographic map of North America during the Paleozoic era. White areas were the more persistent lands (positive elements); lined and dotted areas were the more persistent waters; dotted areas were the principal geosynclines. (Somewhat modified by W. J. M. after Charles Schuchert.)

Pennsylvanian was characterized by marine conditions in the west and low-lying, swampy lands in the east. During Permian time nearly all of eastern North America was dry land, and alternating 
salt-like, lagoon, and marine conditions prevailed in the southeastern United States.

Through the era the emergences and submergences of great areas affected the western part of the continent less than the eastern, as proved by the fact that the strata there show fewer unconformities and are rich in limestone, thus indicating greater persistence of oceanic conditions, especially from the Ordovician to the Mississippian inclusive. Of all the west, the Great Basin region appears to have been the most continuously submerged.

Mountain Making. - During the era there were only two times of great orogenic movements in North America when thick masses of strata were subjected to lateral compression and upraised into mountain ranges. The first of these was toward the close of the Ordovician when the Taconic Mountain range was formed along the eastern border of the continent just east of the present site of the Appalachians. The second was toward the close of the era (Permian) when one of the greatest post-Algonkian physical disturbances in the history of North America resulted in the formation of the Appalachian Mountains by folding and faulting of the strata.

Vulcanism. - The long Paleozoic era was remarkably free from igneous activity in North America, the only extensive intrusions and extrusions of igneous rocks having taken place during the Mississippian (and probably Pennsylvanian) in the northern Cordillera. Some intrusions occurred in eastern Canada during Silurian and probably Devonian time. Other intrusions, usually regarded as of Carboniferous age (either Mississippian or Pennsylvanian), occurred in Massachusetts.

In Europe, however, igneous activity was more frequent and widespread during the era.

\section{Climate}

The strongest evidence from the character and distribution of the organisms points to a temperate and pretty uniform climate for most part over the globe during Paleozoic time.

Typical glacial deposits show that extensive areas were glaciated about the beginning of the early Cambrian and again toward the close of the era (Permian).

Certain deposits such as the "Red Beds," salt, and gypsum indicate at least local arid climate conditions, as for example in 
TABULAR SUMMARY OF PALEOZOIC LIFE

\begin{tabular}{|c|c|c|c|c|}
\hline & Plants & Protozoans & $\begin{array}{l}\text { Porifers and } \\
\text { Calenterates }\end{array}$ & Echinoderms \\
\hline Permian & $\begin{array}{l}\text { Thallophytes. } \\
\text { Bryophytes. } \\
\text { Pteridophytes: Ly- } \\
\text { copods reduced; } \\
\text { Equisetæ and Ferns } \\
\text { prominent. } \\
\text { Gymnosperms: Com- } \\
\text { mon, e.g. Cycads, } \\
\text { Cordiates, Conifers. }\end{array}$ & $\begin{array}{l}\text { Foraminifers: } \\
\text { Very common. } \\
\text { Radiolarians: } \\
\text { Present. } \\
\text { Fumel }\end{array}$ & $\begin{array}{l}\text { Sponges: Present. } \\
\text { Corals: Ancient Te- } \\
\text { tracoralla still com- } \\
\text { mon, but first Hex- } \\
\text { acoralla appear. }\end{array}$ & $\begin{array}{l}\text { Crinoids: Greatly di- } \\
\text { minished. } \\
\text { Asterozoans: Pres- } \\
\text { ent. } \\
\text { Echinoids: Present. }\end{array}$ \\
\hline $\begin{array}{l}\text { Pennsyl- } \\
\text { Vanian }\end{array}$ & $\begin{array}{l}\text { Thallophytes. } \\
\text { Bryophytes. } \\
\text { Pteridophytes: Cul- } \\
\text { minate, e.g. Lyco- } \\
\text { pods, Equisetae and } \\
\text { Ferns. } \\
\text { (Seed-ferns). } \\
\text { Gymnosperms: Sim- } \\
\text { ple ones common } \\
\text { e.g. Cordaites. } \\
\end{array}$ & $\begin{array}{l}\text { Foraminifers: } \\
\text { Very abun- } \\
\text { dant. } \\
\text { Radiolarians: } \\
\text { Present. } \\
\end{array}$ & $\begin{array}{l}\text { Sponges: Present. } \\
\text { Corals: Similar to } \\
\text { Mississippian but } \\
\text { less common. }\end{array}$ & $\begin{array}{l}\text { Blastoids: Become } \\
\text { extinct. } \\
\text { Crinoids: Declining. } \\
\text { Asterozoans: Pres- } \\
\text { ent. } \\
\text { Echinoids: Rare. }\end{array}$ \\
\hline $\begin{array}{l}\text { Mississip- } \\
\text { PIAN }\end{array}$ & \begin{tabular}{|l} 
Thallophytes. \\
Bryophytes. \\
Pteridophytes: Com- \\
mon and much like \\
Devonian. \\
(Seed-ferns). \\
Gymnosperms: Simple \\
types only present. \\
\end{tabular} & $\begin{array}{l}\text { Foraminifers: } \\
\text { Very bun- } \\
\text { dant fuention } \\
\text { Radiolarians: } \\
\text { Common. }\end{array}$ & $\begin{array}{l}\text { Sponges: Common. } \\
\text { Graptolites: Very } \\
\text { rare and become ex- } \\
\text { tinct. } \\
\text { Corals: Cup and } \\
\text { Honey-comb forms } \\
\text { only, and less prom- } \\
\text { inent than in the } \\
\text { Devonians. }\end{array}$ & $\begin{array}{l}\text { Blastoids: Culminate } \\
\text { and become nearly } \\
\text { extinct. } \\
\text { Crinoids: Culminate } \\
\text { in numbers and spe- } \\
\text { cies. } \\
\text { Asterozoans: Not } \\
\text { common. } \\
\text { Echinoids: Common. }\end{array}$ \\
\hline DEVONIAN & $\begin{array}{l}\text { Thallophytes: Sea- } \\
\text { weeds and Diatoms. } \\
\text { Bryophytes? } \\
\text { Pteridophytes: Lyco- } \\
\text { pods, Equisetæ, and } \\
\text { Ferns. } \\
\text { (Seed-ferns). } \\
\text { Gymnosperms: Sim- } \\
\text { ple types only. }\end{array}$ & $\begin{array}{l}\text { Foraminifers: } \\
\text { Present. } \\
\text { Radiolarians: } \\
\text { Present. }\end{array}$ & $\begin{array}{l}\text { Sponges: Common. } \\
\text { Graptolites:- Decline } \\
\text { almost to extinction. } \\
\text { Corals: Cup and } \\
\text { Honey-comb forms } \\
\text { greatly increased in } \\
\text { numbers and size; } \\
\text { Chain corals rare } \\
\text { and become extinct. }\end{array}$ & $\begin{array}{l}\text { Cystoids: Rare and } \\
\text { become extinct. } \\
\text { Blastoids: Still un- } \\
\text { common. Still in- } \\
\text { Crinoids: Sr. } \\
\text { creasing. } \\
\text { Asterozoans: Abun- } \\
\text { dant. } \\
\text { Echinoids: Present. }\end{array}$ \\
\hline SildRIAN & $\begin{array}{l}\text { Thallophytes: Sea- } \\
\text { weeds. } \\
\text { Bryophytes? } \\
\text { Pteridophytes: } \\
\text { Ferns, but rare. }\end{array}$ & $\begin{array}{l}\text { Foraminifers: } \\
\text { Present. } \\
\text { Radiolarians: } \\
\text { Present. }\end{array}$ & $\begin{array}{l}\text { Sponges: Common. } \\
\text { Graptolites: Dimin- } \\
\text { ished in numbers } \\
\text { and species. Thow } \\
\text { Corals: Increase in } \\
\text { prominence and } \\
\text { Chain-corals be- } \\
\text { come nearly extinct. }\end{array}$ & $\begin{array}{l}\text { Cystoids: Prominent. } \\
\text { Blastoids: Still rare. } \\
\text { Crinoids: Increase in } \\
\text { numbers and species. } \\
\text { Asterozoans and } \\
\text { Echinoids: Increase. }\end{array}$ \\
\hline ORDOVICTAN & $\begin{array}{l}\text { Thallophytes: } \\
\text { Sea-weeds. } \\
\text { Higher Cryptogams? }\end{array}$ & $\begin{array}{l}\text { Foraminifers: } \\
\text { Abundant. } \\
\text { Radiolarians: } \\
\text { Abundant. }\end{array}$ & $\begin{array}{l}\text { Sponges: Very com- } \\
\text { mon. } \\
\text { Graptolites: Reach } \\
\text { climax in numbers } \\
\text { and species. } \\
\text { Corals: Common e.g. } \\
\text { Cup, Honey-comb, } \\
\text { and Chain forms. }\end{array}$ & $\begin{array}{l}\text { Cystoids: Culminate. } \\
\text { Blastoids: First ap- } \\
\text { pear and rare. } \\
\text { Crinoids: First ap- } \\
\text { pear and common. } \\
\text { Asterozoans and } \\
\text { Echinoids: First ap- } \\
\text { pear and rare. }\end{array}$ \\
\hline Cambrian & $\begin{array}{l}\text { Thallophytes: } \\
\text { Algæ. }\end{array}$ & $\begin{array}{l}\text { Foraminifers: } \\
\text { Present. }\end{array}$ & $\begin{array}{l}\text { Spoifges: Commito } \\
\text { Hydrozoans: Grap- } \\
\text { tolites and Jelly- } \\
\text { fishes, both com- } \\
\text { mon. } \\
\text { Corals: Present? }\end{array}$ & $\begin{array}{l}\text { Cystoids: Primitive } \\
\text { forms and rare. }\end{array}$ \\
\hline
\end{tabular}




\section{TABULAR SUMMARY OF PALEOZOIC LIFE-Continued}

\begin{tabular}{l}
\hline Molluscoids \\
\hline Bryozoans;- \\
Abundant. \\
Brachiopods: Still \\
common, with new \\
species; straight- \\
hinged forms still \\
prevail.
\end{tabular}

\section{Bryozoans: \\ Common.}

Brachiopods: Still declining, but fairly common; straight-hinged forms prevail.

Bryozoans: More abundant than in the Devonian.

Brachiopods: Declining but still common and with many new species; mostly straighthinged forms.

\section{Bryozoans: Present.}

Brachiopods: Culminate in numbers and species; many new forms added; mostly straighthinged forms.

Bryozoans: Abundant.

Brachiopods: Prominent in numbers and species; nearly all straight-hinged forms.

\section{Bryozoans:}

Abundant. complex, larger, and Cephalopods: Very promabundant; Articulates prevail; and nearly all are straight-hinged forms.

Bryozoans: Absent.

Brachiopods: Small, thin-shelled; Inarticulates prevail; some Articulates in the Upper Cambrian.

Mollusks

Pelecypods: Greatly inspecies. and more complex.

Pelecypods: Still increasing.

Gastropods: Common and first land forms appear. Cephalopods: Similar to Mississippian, but Nautiloids declining and Ammongids more complex.

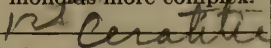

Pelecypods: More common than before.

Gastropods: Common.

Cephalopods: Much like the Devonian, but coiled Nautiloids culminate and Ammonoids are more complex.

Pelecypods and Gastropods: Much like the Silurian.

Cephalopods: Most earlier forms persist, but Ammonoids first appear, e.g. Goniatite.

$\underline{=}$

Pelecypods and Gastropods: Common and much like Ordovician.

Cephalopods: Common and much like Ordovician, but coiled Nautiloids predominate.

Pelecypods: Larger and inent and all are Nautiloids, e.g. Orthoceras, and Trocholites.

Pelecypods: Very stnall and rare. creased in numbers and Trilobites: Very rare and

Gastropods: Common: Eurypterids:

Aminonofan e.g. Waag-Insects: Much like the enoceras) now iebmmon Pennsylvanian.

Cyrtoceras, Trochoceras Eurypterids: Present.

Gastropods: Rare, simple Crustaceans: Trilobites and mostly in the Upper common and usually Cambrian limnif highly segmented and Cephalopods: Rare, small with small tail plates; and simple; all Naut - some very simple forms. loids e.g., Orthoceras and Eurypterids: Rare.

Decline markedly. become extinct.

Trilobites: Rare.

Eucrustaceans: Present. Fishes: Much like Arachnids: Eurypterids Mississippian.

still declining; first Spi- Amphibians: Culminders appear.

Myriapods: Common.

Insects: Common and large; simpler types Reptiles: Present? only.

Trilobites: Rare.

Eucrustaceans?

Arachnids: Eurypterids

Myriapods: Present.

Insects: No fossils.

Trilobites:

Vertebrate8

Fishes and Amphibians: Much like the Pennsylvanian, but with new species.

Reptiles: Many representatives of the lower orders. ate, e:g. Stegocephalans. Arachnids: Eurypterids Fishes: Very profuse, declining, but still not- e.g. Selachians, able for size.

Myriapods: First known. Insects: Unknown.

Dipnoans, Arthrodirans and Ganoids. Amphibians?

Trilobites: Diminished but still common.
Eucrustaceans: Similar to Ordovician.

Arachnids: First Scorp-Fishes: Selachians ions; Eurypterids culmi- of primitive characnate in numbers, species ter and rare. and size (?).

Trilobites: Culminate in numbers and species.

Eucrustaceans: Few and simple.

Ostracoderms: Rare, small and primitive.

Ostracoderms: Marking first appearance of Vertebrates; specimens rare and very fragmentary.

None. 
northern Siberia (Ordovician); New York (Salina epoch of the Silurian); Michigan, Montana, Nova Scotia, and Australia (Mississippian); and southwestern United States, western and central Europe, and other parts of the world (Permian).

\section{Organic History}

Viewed in a broad way, the life of the Paleozoic is distinctly different from that of the succeeding Mesozoic or Cenozoic. Very few species and not many genera passed from the Paleozoic to the Mesozoic, and even the larger groups of organisms which did continue usually underwent important structural changes. Paleozoic organisms were the more primitive in structure, and it has been aptly said that they bear somewhat the same relation to the succeeding forms that the embryo does to the adult.

Of plants in the early Paleozoic only the simplest Cryptogams are known, while in the later Paleozoic periods there are abundant records of the higher Cryptogams such as Lycopods, Equisetæ, and Ferns, as well as of the Gymnosperms. Angiosperms (typical flowering plants) are wholly unknown from the Paleozoic, and even the later forests and foliage of the era must have presented a gloomy appearance because of the lack of true flowering plants as compared with today.

The animals of the Paleozoic were predominantly invertebrates, though Fishes were common in the Devonian and later periods, and Amphibians and Reptiles appeared in the later periods. Among the most common and characteristic types of invertebrates were Graptolites, Corals, stemmed Echinoderms (Pelmatozoans), Bryozoans, Brachiopods, Tetrabranch Cephalopods (Nautiloids especially), Trilobites, and Eurypterids. Certain of the higher Arthropods such as Spiders, Myriapods (Centepedes), and Insects did not appear till the era was pretty well advanced.

The accompanying chart has been devised by the writer for the purpose of bringing together the salient facts in the organic history of the Paleozoic era. Period by period the principal evolutionary changes in the subkingdoms and classes of plants and animals are graphically represented. 


\section{THE MESOZOIC ERA}

\section{CHAPTER XIV \\ THE TRIASSIC PERIOD}

Origin of Name, Subdivisions, etc.

The name "Triassic" was given because of the threefold, extensive development of the rocks of the system where first studied in Germany. It so happens, however, that the German Triassic strata are not typical of the system, as shown by later studies in other parts of the world.

The following table gives a general idea of the main subdivisions in North America and Europe:

\begin{tabular}{|c|c|c|c|}
\hline & $\begin{array}{c}\text { Pacific Coast } \\
\text { (Various formations) }\end{array}$ & Atlantic Coast & Germany \\
\hline $\begin{array}{r}\text { TriassiC } \\
\text { System }\end{array}$ & $\begin{array}{l}\text { Upper Triassic series. } \\
\text { Middle Triassic series. } \\
\text { Lower Triassic series. }\end{array}$ & $\begin{array}{l}\text { Newark series. } \\
\ldots \ldots \ldots \ldots \ldots \\
\ldots \ldots \ldots \ldots \ldots\end{array}$ & $\begin{array}{l}\text { Keuper series. } \\
\text { Muschelkalk series. } \\
\text { Bunter series. }\end{array}$ \\
\hline
\end{tabular}

\section{Distribution and Character of the Rocks}

General Distribution. - The accompanying map (Fig. 119) shows the surface distribution of both the Triassic and Jurassic rocks in North America. The Atlantic Coast areas are wholly Triassic; the California areas are mostly Jurassic; and the remaining areas include both Triassic and Jurassic rocks which have usually not been carefully separated. There is no reason whatever to believe that Triassic rocks were ever deposited over Canada except along the western coast and to a slight extent in Nova Srotia. Likewise it is not known that Triassic rocks ever occurred in the Mississippi Basin except immediately west of the Rocky 


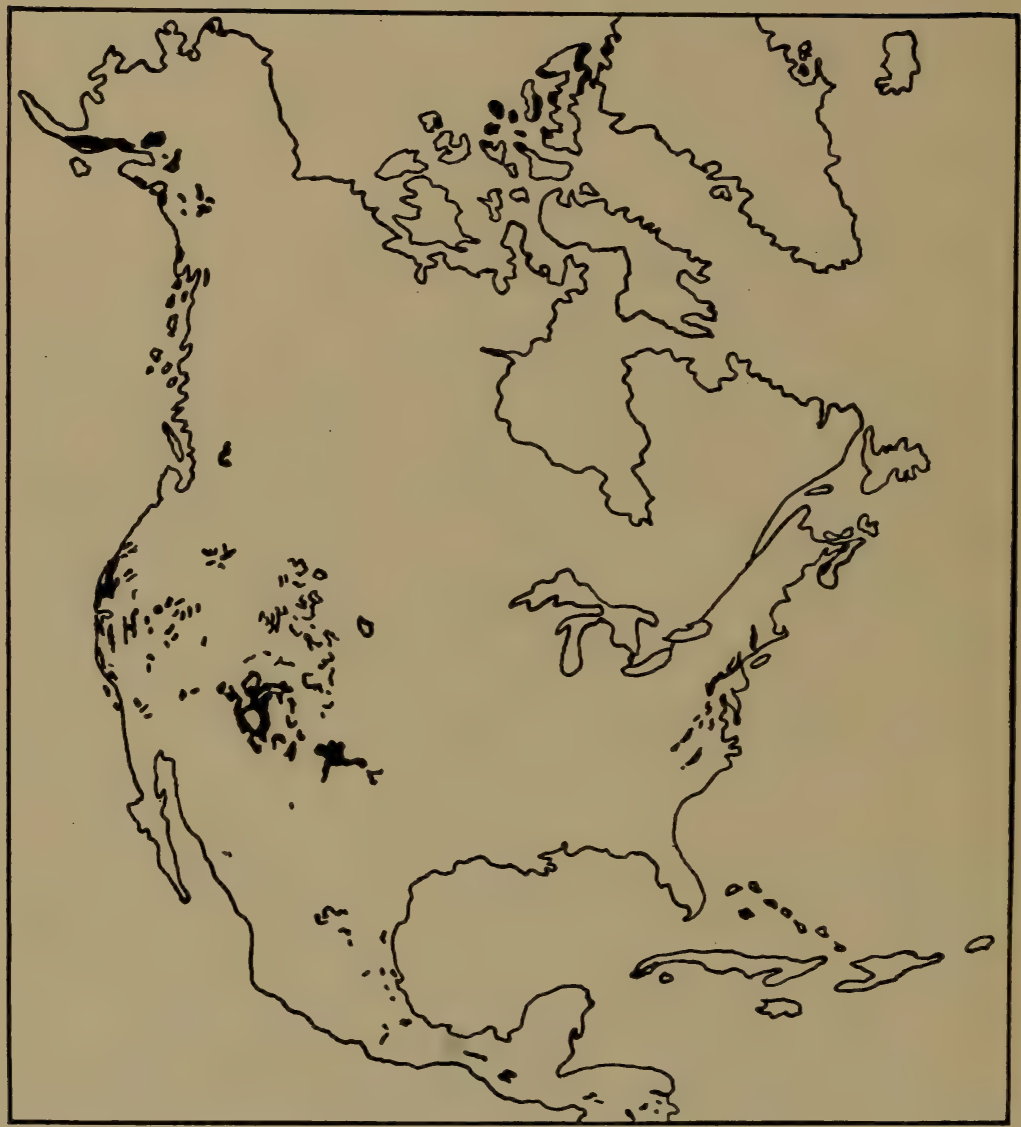

Fig. 119

Map showing the surface distribution (areas of outcrops) of Triassic and Jurassic strata in North America. Some areas of doubtful age and extent not shown in British Columbia. All Atlantic Coast areas are Triassic. In much of the western United States the Triassic and Jurassic have not yet been satisfactorily separated. (By W. J. M., data from two maps by Bailey Willis, U. S. Geological Survey.) 
Mountains. This is in marked contrast with the Paleozoic systems. Accordingly, the present concealed Triassic rocks and areas of their former presence are pretty largely confined to the immediate regions of existing outcrops.

Rocks of the Atlantic Coast. - These rocks (Newark series) are seen on the map to occupy comparatively small, narrow areas just east of and parallel to the Appalachian Mountain range from southeastern New York to South Carolina, and farther northward in the Connecticut River Valley and in Nova Scotia. In the northern areas the rocks are sandstones and shales, with some coarse conglomerates, especially at the base. Because of their prevailing red color and general resemblances to the "Old Red Sandstone" (Devonian) of Scotland, they have been called the "New Red Sandstone." Many of the beds show sun-cracks, raindrop pits, ripple-marks, and foot-prints, and remains of land Reptiles (Dinosaurs). In Virginia and the Carolinas the rocks have a similar lithologic character, though the red color is not so common, and some workable coal beds occur. The fossils, which are mostly plants in the dark shales, point to the Upper Triassic age of the Newark series.

The rocks of the series are nearly everywhere somewhat folded, tilted, and extensively fractured by normal faults, and they also contain numerous lava flows, intrusive sheets, and dikes of so-called trap rock (diabase) (Figs. 120, 121). A remarkable feature is the great thickness of the rocks in these narrow belts, fully 3000 feet in Virginia; 7000 to 10,000 feet in the Connecticut Valley; and 10,000 to 15,000 feet in New Jersey.

Rocks of the Western Interior. - The Triassic strata of the western interior region are distributed over nearly the same areas

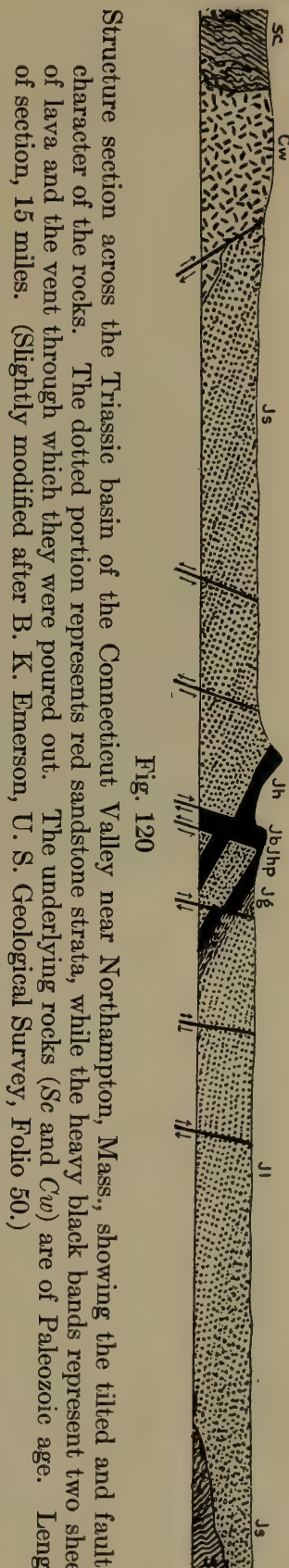


of these two systems are not at all sharply separated. All the known Triassic rocks of the western interior are located within the shaded area, indicating continental deposits on map Fig. 123. Red Beds (sandstones and shales), similar to those of the underlying Permian and often with salt and gypsum beds, are the most common rocks (Fig. 122). They are certainly very largely of continental origin. Their thickness varies from 100 to 200 feet in the

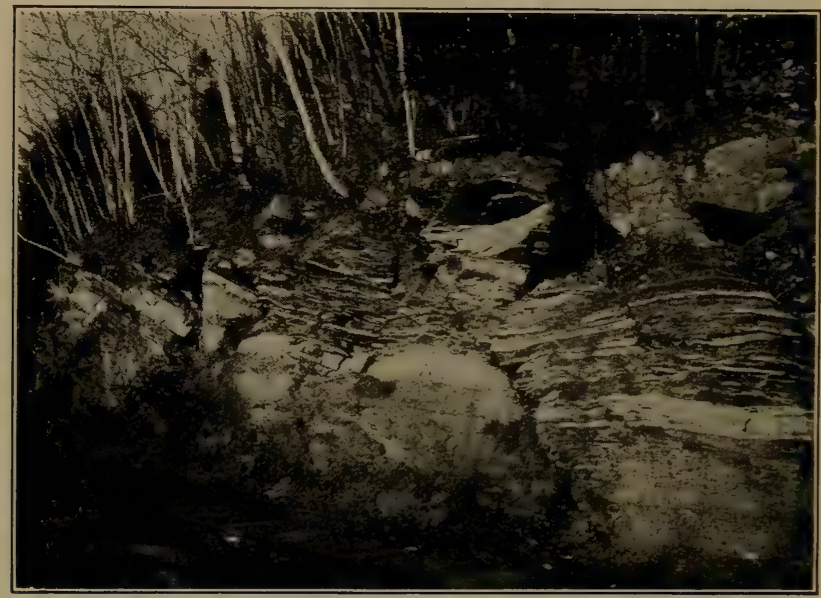

Fig. 121

Tilted and faulted Triassic sandstone in the Connecticut Valley near Northampton, Mass. (W. J. Miller, photo.)

eastern part of the western interior to 2000 or more feet in Utah. In the Rocky Mountains the strata of this age are often highly tilted or folded, while just east of the Rockies they are generally nearly horizontal.

Rocks of the Pacific Coast. - These are the only true Marine Triassic rocks of North America, and they are there extensively developed with practically all portions of the system from oldest to youngest well represented, particularly in California and Nevada. The rocks consist mostly of shales, slates, limestones, conglomerates, and sandstones, usually several thousand feet thick and with a maximum thickness of 17,000 feet in Nevada and 13,000 feet in British Columbia. In Alaska and British Columbia the system contains much igneous material. 


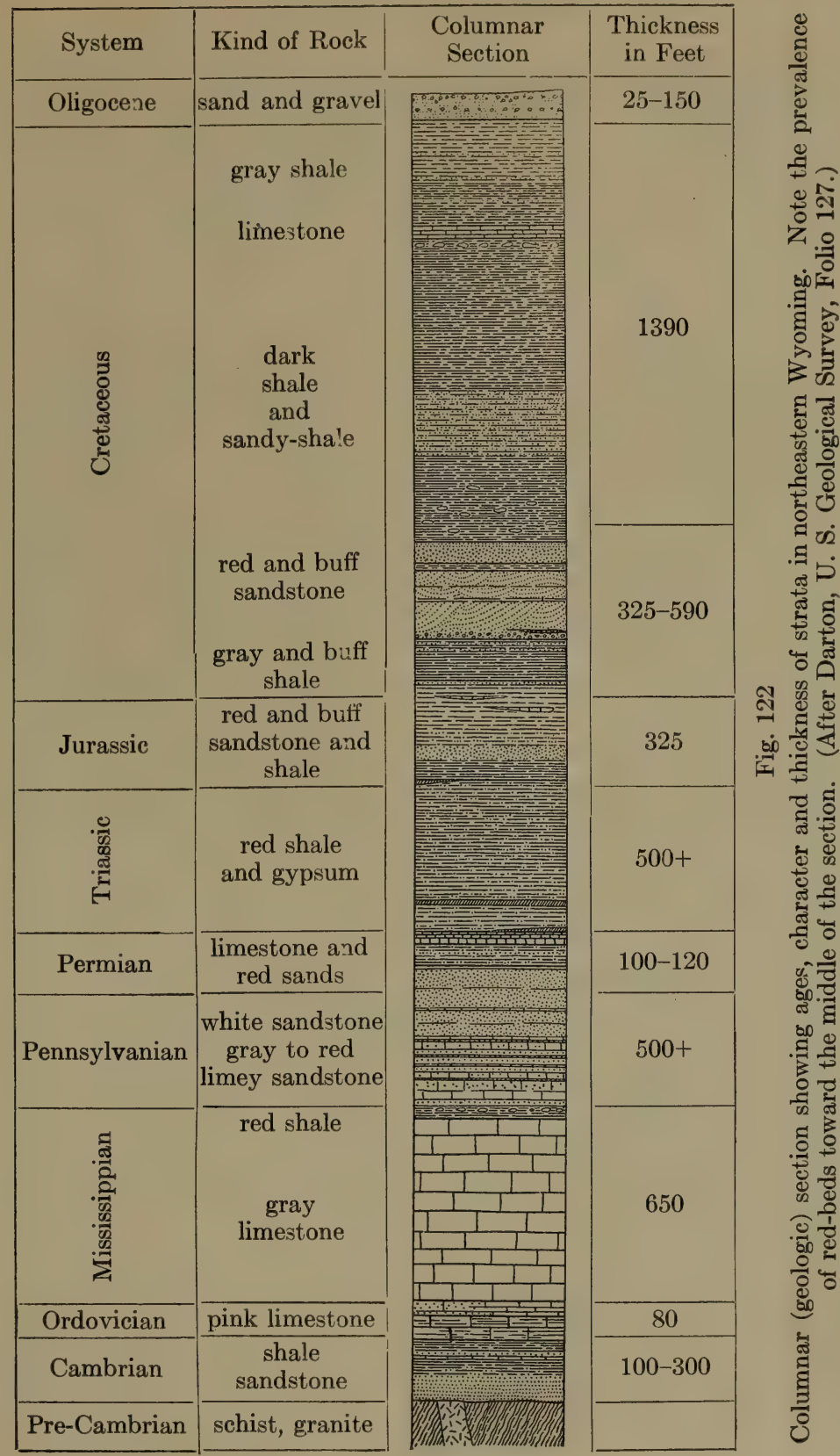


Thickness of the System and Igneous Rocks. - Figures showing the thickness of the system in different parts of the continent have already been given. Igneous rocks are abundant only in British Columbia, Alaska, and also in the Newark series of the Atlantic Coast, the last named being again referred to below.

\section{Physical History}

Atlantic Coast. - Accompanying map Fig. 123 shows the geography of the continent during Triassic time, though it must be borne in mind that the areas of deposition along the Atlantic Coast were such only in the latter part of the period.

The non-marine strata (Newark series) of Upper Triassic age clearly show by their present distribution and mode of occurrence that they were deposited in a series of long, trough-like depressions whose trend was parallel to that of the main axis of the Appalachian range. These troughs lay between the Appalachians proper and old Appalachia, which latter was then also, in part, made up of the greatly worn down Taconic Mountains. The fact that these troughs are true downwarps, and that they so perfectly follow the trend of the Appalachian folds, makes it certain that they were formed by a great lateral pressure which was a continuation of the Appalachian disturbance. Thus the Appalachian Mountains still seem to have been growing well into the Triassic period and, while the Paleozoic strata were being folded, the surface of old Appalachia, including part of the Taconic region, was also more or less warped, the downwarps forming the troughs in which the Triassic beds were deposited. These depressions or troughs were most favorably situated for rapid accumulation of thick deposits because of their position immediately between the two great land masses which were being eroded. The sediments derived from the erosion of the young Appalachians were especially abundant because of the vigorous wearing down of these newly formed mountains. Thus the great thickness of the Newark series is accounted for. Their thickness strongly argues for a gradual downwarping of the basins as the deposition of sediments went on. It is often stated that these strata were formed in estuaries, but the presence of sun-cracks, ripple-marks, Reptile tracks, etc., show that, in part at least, the beds may have formed in very shallow 


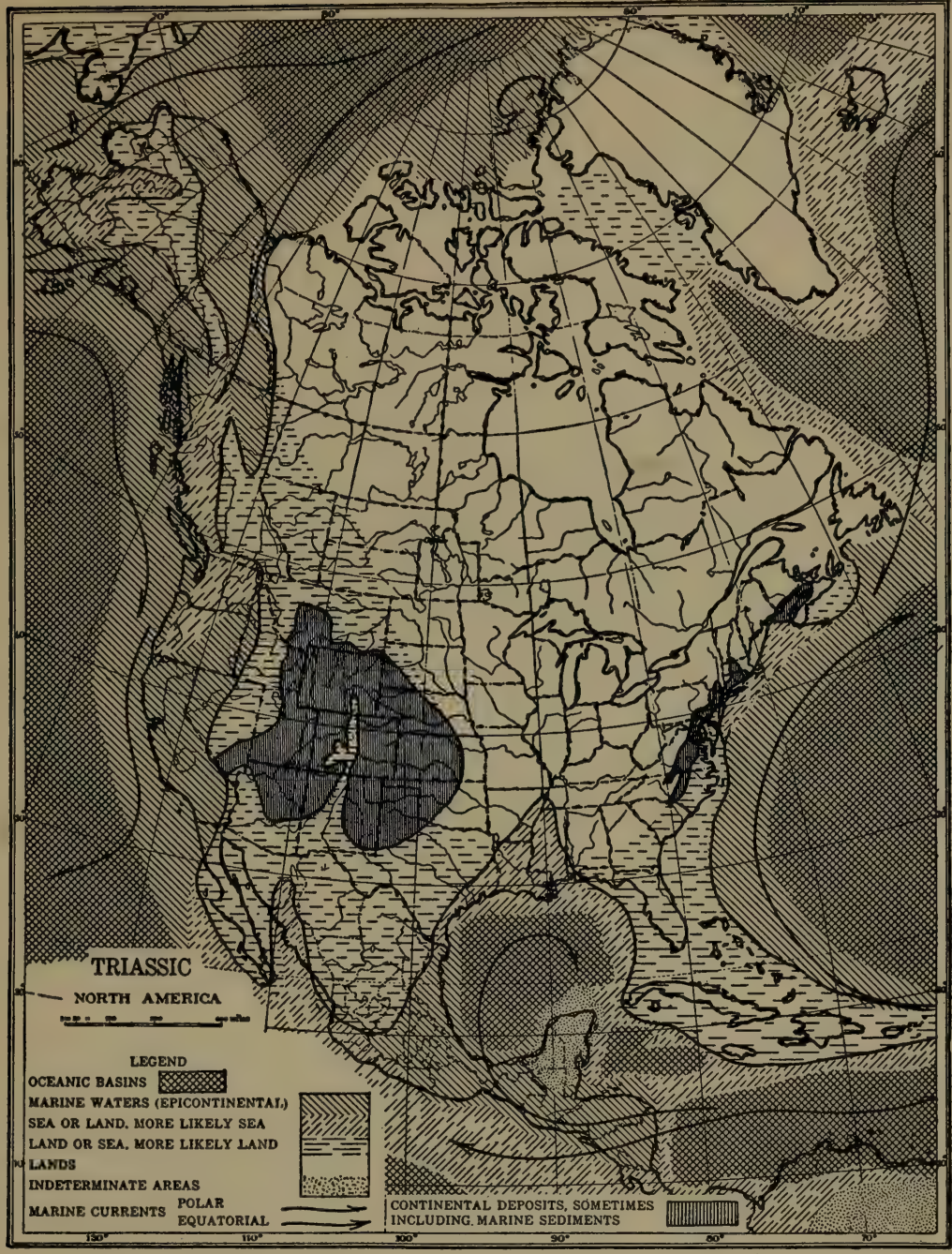

Fig. 123

Paleogeographic map of North America during Triassic time. Note the extensive areas of continental deposition. (Slightly modified after Bailey Willis, courtesy of The Journal of Geology.) 
water, such as flood-plains or lakes, where changing condition frequently allowed the surface layers to lie exposed to the sun.

"The curiously shaped and often huge Reptiles of that age (Triassic) wandered over the mud exposed at low tide, and their foot-prints, being covered by the deposit of the next flood tide, constitute the so-called 'Bird tracks' which have been found in such great numbers and perfection." 1

During the time of the formation of the Newark beds, there was considerable igneous activity, as shown by the occurrence of sheets of igneous rocks within the mass of sediments. In some cases true lava flows with cindery tops were poured out on the surface and then became buried under later sediments, while in other cases the sheets of molten rock were forced up either between the strata or obliquely through them, thus proving their intrusive character. As a result of subsequent erosion, these igneous rock masses often stand out conspicuously as topographic features. Perhaps the most noteworthy of these is the great igneous rock sheet, part of which outcrops to form the Palisades of the Hudson River, and which altogether outcrops for a distance of 70 miles. The molten rock first broke through the strata and then crowded its way along parallel to them. Another fine example is the so-called Holyoke Range of Massachusetts (Fig. 124) regarding which Emerson says: "The accumulation of sediments was interrupted by an eruption of lava through a fissure in the earth's crust, which opened along the bottom of the basin. The lava flowed east and west on the bottom of the bay, as tar oozes and spreads from a crack, and solidified in a sheet which may have been 2 or 3 miles wide and about 400 feet thick in its central part. This is the main sheet or Holyoke diabase. The sheet was soon covered with sand layers, but its thickness was such that it had shallowed the waters to near tide level, and thus occasioned extensive mud flats." ${ }_{2}$ In both regions just mentioned, the contraction of the cooling masses often expressed itself by breaking the rock into great and small, crude, nearly vertical columns, and hence the application of the term "palisades." The steep mountain sides or cliffs are due to the fact that the hard igneous rock is much more resistant to weathering and erosion than the sandstone above and below it (Fig. 124).

${ }^{1}$ B. K. Emerson: U. S. G. S., Holyoke folio No. 50, p. 3.

2 Ibid., Folio No. 59, p. 3. 
Western Interior. - The large area of sedimentation in this part of the continent had little or no connection with marine waters. Conditions of deposition of later Permian time appear to have been continued through Triassic time, that is, continental deposits were formed mostly in salt lakes, fresh lakes, and along stream courses, while some may even have been wind-blown.

Pacific Coast. - Since fossils show the strata of the Pacific Coast to be chiefly of marine origin, it is evident that sea water

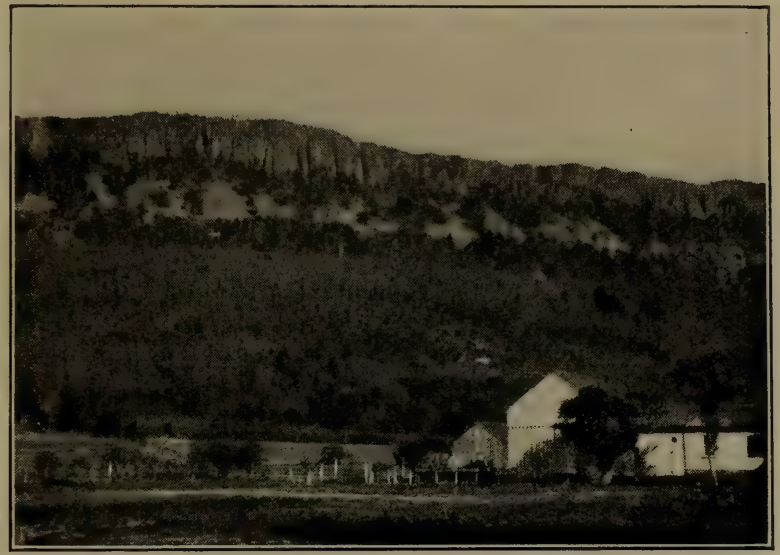

Fig. 124

The steep western front of the Holyoke Range as seen from Easthampton, Massachusetts. The upper portion is columnar lava of Triassic age, and this rests upon Triassic red sandstone. (W. J. Miller, photo.)

spread over the areas where these strata now occur (see map Fig. 123). Igneous rocks in the Triassic of British Columbia prove that there was considerable vulcanism there during the period.

Close of the Triassic. - The Triassic closed in eastern North America with crustal disturbances which raised the basins of deposition of the Newark series into dry land, thus leaving all of the eastern half or two-thirds of the continent dry land and undergoing erosion for the first time since the beginning of the Paleozoic era.

On the Pacific Coast the evidence is pretty clear that marine conditions continued as during the period, while in the western interior the geographic conditions toward the close of the Triassic 
are as yet more doubtful because scarcity of fossils renders a separation of possible Jurassic strata from Triassic uncertain. The best evidence, however, points to continual deposition of "Red Beds" over some of the region at least.

\section{Foreign Triassic}

Europe. - As in America, so in Europe, the Triassic shows considerable development of both continental and marine facies. The Bunter series (1600 to 1800 feet thick) of Germany consists chiefly of red beds, such as sandstones and shales, with some salt and gypsum, clearly indicating deposition under arid climate conditions much like the western interior of the United States at the same time. The Muschelkalk of Germany is mostly a marine limestone formation up to 1000 feet thick, thus showing the presence of marine waters over the region, probably as an arm of the sea, similar to the Baltic Sea, as the fossils suggest. During part of this time, at least, salt lake conditions were restored as indicated by gypsum and salt in the midst of the series. During Keuper time conditions of deposition were much as during the Bunter, though marine waters again transgressed the area toward the close of the Triassic.

In England, much of eastern Russia, and western and southern Spain, Triassic strata essentially like those of Germany are well developed.

In middle southern Europe the marine facies is widely developed, being mostly limestone (often dolomitic) and shales. The rugged peaks of the famous "Dolomites" or Tyrolean Alps have been carved out of this comparatively resistant dolomitic limestone, much of which was of Coral-reef origin.

Map Fig. 125 gives a good idea of the relations of land and water in Europe during earlier Triassic time.

Other Continents. - The marine facies of the European Triassic continues eastward through much of southern Asia, there being an unusually fine development of the system in the Himalayas. Triassic rocks, sometimes of continental origin, also occur in other parts of Asia as in Japan and eastern Siberia.

Triassic rocks are also known in Australia, New Zealand, north and south Africa, and South America, with coal-bearing strata in Argentina and Chile, and marine strata in the Andes. 


\section{Climate}

The extensive areas of "Red Beds," often accompanied by salt and gypsum, in the western interior and eastern North America, northern and western Europe, and northern Africa show widespread aridity of climate in the northern hemisphere during the

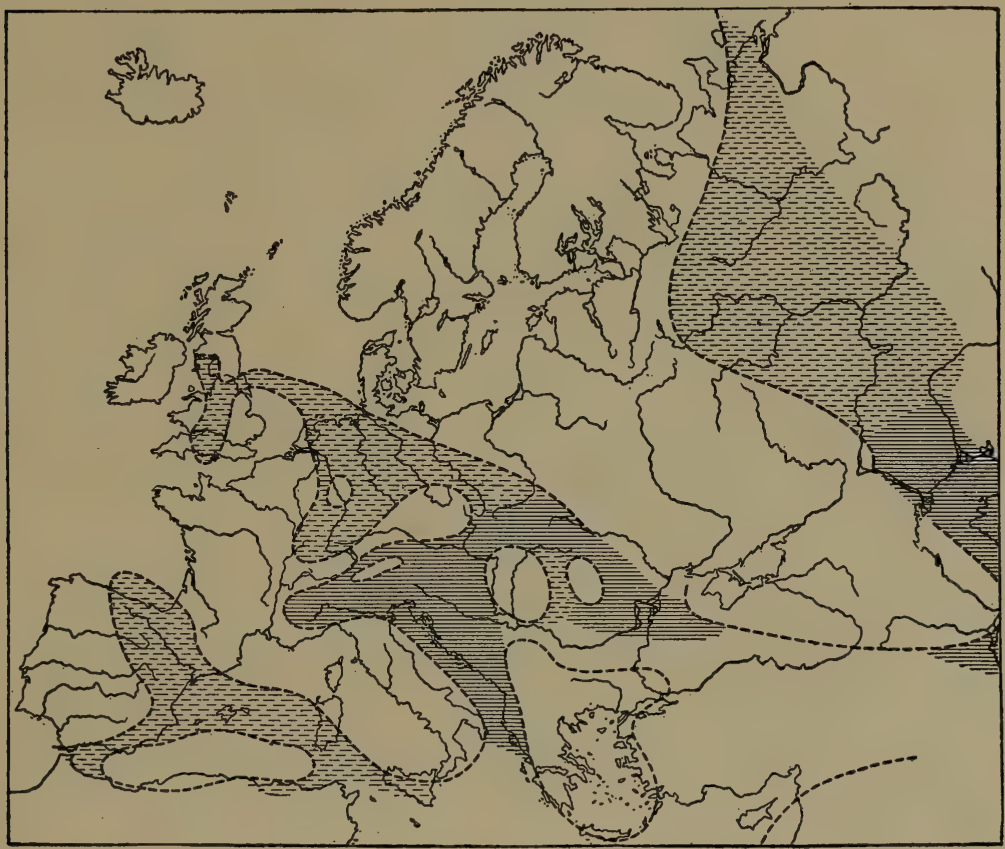

Fig. 125

Sketch map showing the relations of land and water in Europe in the early Triassic. Full lines = marine waters; broken lines = areas of non-marine deposition. (After De Lapparent, from Chamberlin and Salisbury's "Geology," courtesy of Henry Holt and Company.)

period. There is no evidence of glaciation, and the fossils indicate mildness of climate. Judging by the character and distribution of the fossils, the water of the Arctic Sea was appreciably cooler than that of lower latitudes, so that climatic zones must have been defined to some extent at least. 


\section{Economic Products}

Coal beds of some commercial value occur in the Triassic rocks of Virginia and North Carolina.

Enormous quantities of sandstone (the so-called "Triassic Brownstone") for building purposes have been quarried from the Newark series, especially in the Connecticut River Valley.

Gypsum of Triassic age is quarried in some of the western states.

Some copper deposits occur in Triassic rocks of California and Alaska.

\section{Life of the Triassic}

The physical revolution which closed the Paleozoic era was accompanied by one of the most profound changes in organisms in the earth's history, and hence we may expect the life of the Triassic to have been very notably different from that of preceding time. Some types of animals and various types of plants continued from the late Paleozoic, but the general aspect of Triassic life was distinctly more modern than that of the Paleozoic. In spite of this comparatively rapid evolutionary change in both fauna and flora, enough connecting links are known to make sure that the Mesozoic animals and plants were derived from the Paleozoic.

Plants. - Triassic plants have not left us a very abundant record. In fact the rather widespread aridity of climate doubtless hindered a luxuriant growth, over wide areas at least.

Among the simple plants (Thallophytes) the calcareous Seaweeds, that is those which had the power to secrete limey skeletons, were especially common.

Among Pteridophytes the Ferns and their allies were still important; the Equisetoe were fairly common, though much more like the existing forms except for their greater size; and the Lycopods were reduced almost to extinction, even the few lingering Sigillarians having finally disappeared with this period, so that the Lycopods will not again call for special mention.

Gymnosperms were the dominant types of plants of the Triassic, just as Pteridophytes had been the dominant plants of the later Paleozoic. The Cordaites were greatly reduced and they became extinct during this period. Cycads and their allies and the Conifers (Fig. 126), however, were the most common elements of 
the flora. Fig. 135 gives a good idea of a modern Cycad, though it must be understood that such plants are today relatively unimportant.

It is generally stated that the plants of the Triassic, except toward the close of the period, in both Europe and America presented a stunted or dwarfed appearance on account of unfavorable (chiefly climatic) environment. Such an impoverished condition of Triassic plants was at least not universal, for as Knowlton says: "In North Carolina, Virginia, and Arizona there are trunks of trees preserved, some of which are 8 feet in diameter and at least 120 feet long, while hundreds are from 2 to 4 feet in diameter. Many of the Ferns are of large size, indicating luxuriant growth." 1

Protozoans and Porifers were present, though their records are neither very abundant nor of special interest.

Cœlenterates. - For the first time the Hexacoralla, or forms of mod-

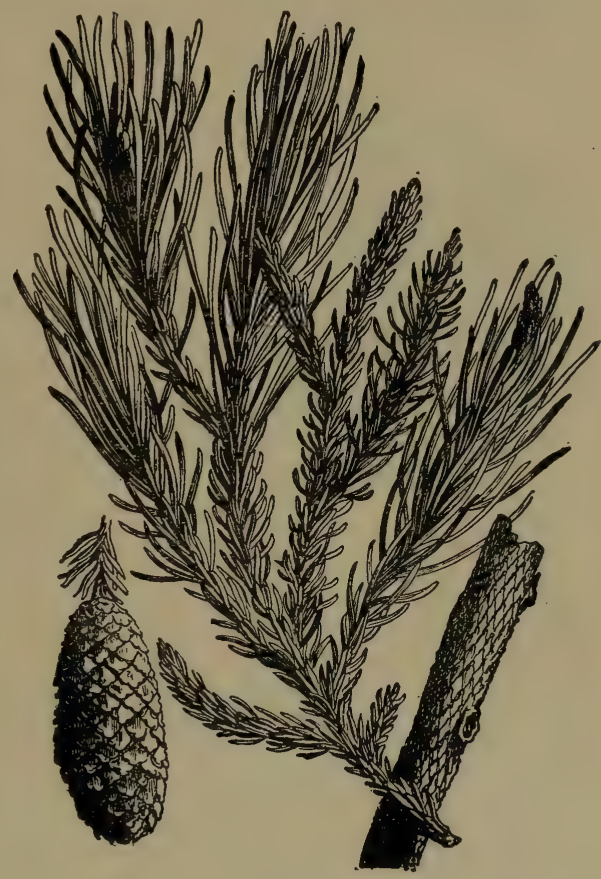

Fig. 126

Parts of a Triassic Conifer, Voltzia heterophylla. (After Fraas from Scott's "Geology," courtesy of The Macmillan Company.)

ern aspect, became abundant, while the ancient (Paleozoic) Tetracoralla dwindled away to extinction.

Echinoderms. - Crinoids were common, the more ancient types having given way to those of more modern aspect.

Asterozoans were present.

Echinoids (Sea-urchins) were common, though most of the ${ }^{1}$ F. H. Knowlton: Jour. Geol., Vol. 18, 1910, p. 106. 
dominant Paleozoic types were gone and all were forms of regular shape. For the first time the Echinoids were more prominent than the Crinoids.

Molluscoids. - Bryozoans continued, but with certain important genera changes.

Brachiopods showed two important changes, namely (1) a great reduction in number of species and of individuals, and (2) the shells

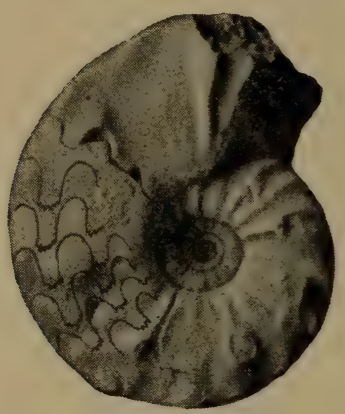

Fig. 127

A Triassic Ceratite, Ceratites trojanus, with part of shell removed to show suture structure. (After J. P. Smith, slightly modified by accentuation of sutures.) with straight-hinge lines becoming subordinate to those with curved-hinge lines for the first time, a common genus (Terebratula) of the latter being represented by a Cretaceous form in Fig. 159. To the present day the Brachiopods never again became conspicuous elements of the fauna. In spite of the important changes, a few of the Paleozoic genera survived the transition to the Mesozoic.

Mollusks.-This subkingdom included all of the most abundant invertebrate animals of the period, all of the wellknown classes having been prominently represented.

Pelecypods were more numerous and diversified than ever before. They vastly outnumbered the Brachiopod bivalves. Certain still existing genera were introduced so that many forms were of decided modern appearance. Gastropods. Several Paleozoic genera existed for the last time, and certain more modern types appeared.

Cephalopods. Among the Nautiloids the straight-shelled form (Orthoceras), known from the very early Paleozoic, became extinct in the Triassic, while the coiled forms were still common and much like those of later Paleozoic time.

Among the Ammonoids an evolutionary feature of particular interest was the development of still greater complexity of shell structure. Goniatite-like forms still persisted, but, even early in the Triassic, forms with slightly serrated sutures or partition structures (e.g. Ceratites, Fig. 127) appeared. Later in the period representatives of the most complex of all known chambered Cephalopods, that is the Ammonites, appeared (see Fig. 141). 
Another important advance among the Cephalopods was the first appearance of the Dibranchs, which include the highest of all Mollusks. Of these Dibranchs perhaps the most characteristic belonged to a group known as Belemnites (see Fig. 143), though these were not abundant. A fuller discussion of the Dibranchs will be given in the next chapter.

Arthropods. - Among Crustaceans neither Trilobites nor Eurypterids, so impo tant in the Paleozoic, continued into the Mesozoic, but the Eucrustaceans showed a notable advance by the first appearance of the so-called long-tailed Decapods (Macrura) or Lobster family, which rank among the highest of all Crustaceans (Fig. 128).

Insects also showed distinct progress by the addition of the Beetle tribe, which ranks next to the highest of all insects.

Fishes.-Selachians, Dipnoans, and Ganoids (Fig. 129) all continued with the Ganoids predominant. Teleosts had not yet appeared.

Amphibians. - Though somewhat diminished as compared with the later Paleozoic, the Amphibians were still numerous and often notable for their great size. In general they were much like the late Paleozoic forms. Mastodonsaurus attained a length of 15 or 20 feet and had a skull 4 feet long. The Bunter series of Germany is particularly rich in fine fossil Amphibians. By the close of the Triassic the Amphibians had declined remarkably, so that

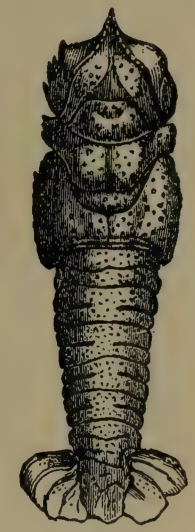

Fig. 128

A Triassic longtailed Macruran Decapod, Pemphix Sueurii. (From Naumann.) among the land Vertebrates, of which they were the ancestors, they never again assumed a position of importance.

Reptiles. - Because of the great abundance, size, and variety of Reptiles, the Mesozoic era is often called the "Age of Reptiles." Even in the Triassic most of the more important and interesting now extinct groups had appeared, such as the swimming Reptiles (e.g. Enaliosaurs); walking Reptiles (e.g. Dinosaurs); and flying Reptiles (e.g. Pterosaurs). Since these remarkable reptilian forms reached their climax of development later in the Mesozoic, a fuller discussion will be reserved for a subsequent chapter. In passing, however, it may be mentioned that Dinosaurs, often of great size, 


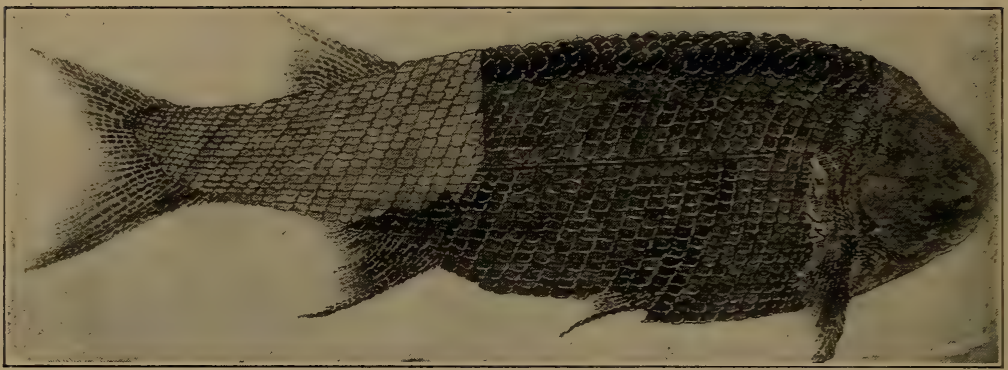

Fig. 129

A Ganoid, Catopterus redfieldi, from the Triassic sandstone of Connecticut. (After Newberry, U. S. Geological Survey, Monograph 14.)

were the creatures which left the numerous foot-prints up to 15 or 18 inches in length in the Newark sandstone of the Connecticut Valley (Figs. 130, 131).

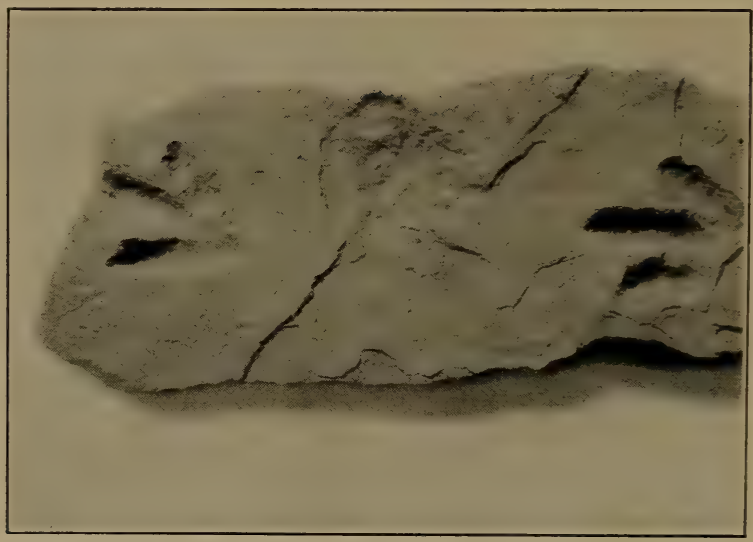

Fig. 130

Tracks of a small two-legged Dinosaur on a slab of Triassic sandstone from the Connecticut Valley. The tracks are about 4 inches long. (W. J. Miller, photo.)

Of the more modern reptilian forms, the Turtles and Lizards made their first appearance, the latter only in late Triassic time, but none of them became common. 
Mammals. - Another very important step in the development of animal life was the introduction of Mammals in the Triassic

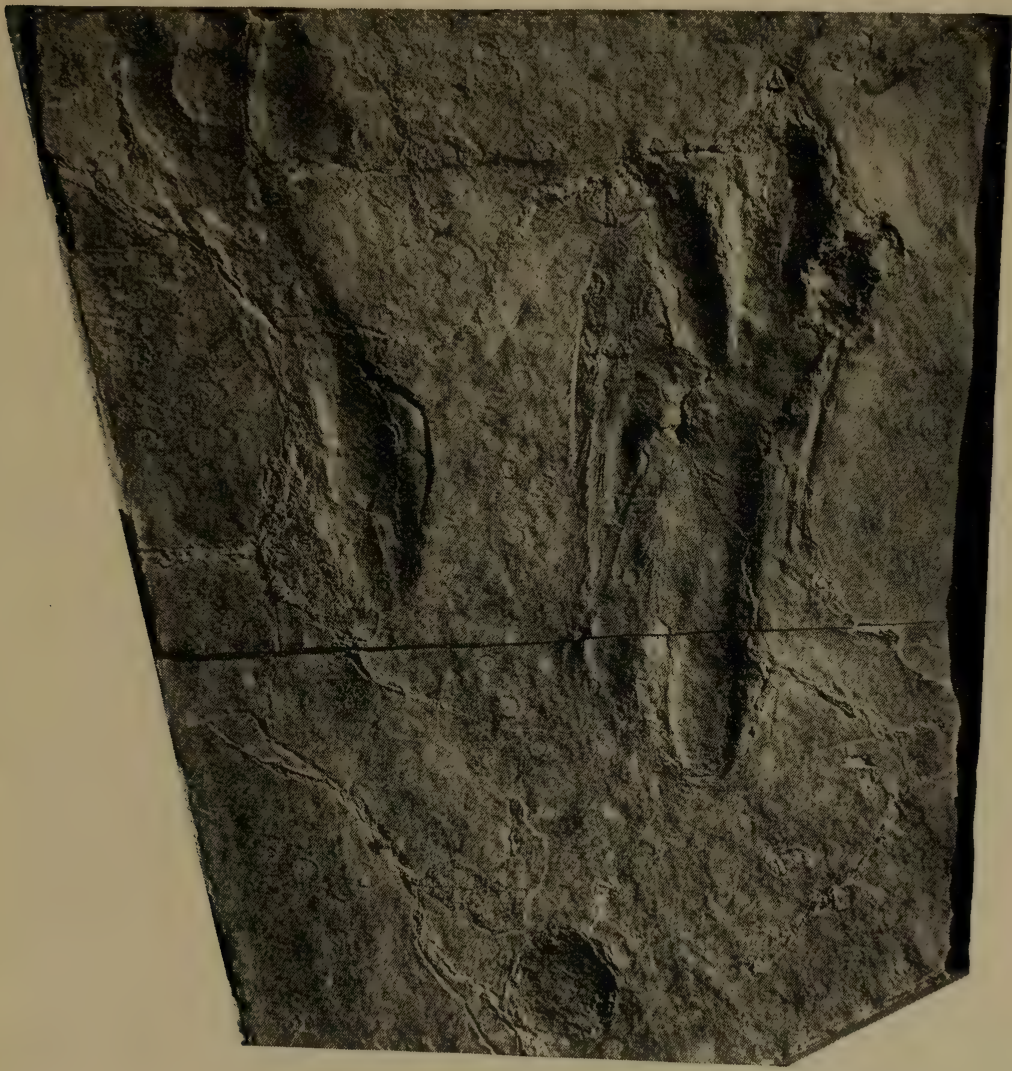

Fig. 131

Tracks of a large two-legged Dinosaur on Triassic sandstone from the Connecticut Valley, showing how both feet slid some distance in the soft material after which the creature suddenly sat down, the end of the backbone having left a distinct impression. (After Edward Hitchcock.)

period. Although Mammals include the most highly developed of all animals, their earliest representatives (in the Triassic) were very small, primitive types, apparently not very numerous, thus 
scarcely suggesting their later (Cenozoic) development into the manifold and most powerful and intelligent creatures of the earth. Only a few genera are known from the Triassic, and in fact Mammals continued to occupy a very subordinate position throughout the Mesozoic era. 


\section{CHAPTER XV}

\section{THE JURASSIC PERIOD}

\section{Origin of Name, Subdivisions, ETc.}

THE rocks of Jurassic age are of peculiar interest because they comprise one of the very first systems whose subdivisions were carefully determined by the use of fossils, this work having been done in England about one hundred years ago by William Smith, who is often called the father of historical geology. Smith applied the name "Oölitic" to the system because of the common occurrence of so much oölitic limestone, but this term later gave way to the term "Jurassic," so-called from the Jura Mountains, between France and Switzerland, where the rocks of the system are unusually well exhibited and have been much studied. In Germany, too, much study has been devoted to this system, largely because of the abundance of well-preserved and interesting fossils.

In western North America, where the only undoubted Jurassic strata occur on this continent, the subdivisions of the system are not so well known and correlated, so that various more or less local formation names are still employed. The following table gives a summary of the principal subdivisions for three important regions:

\begin{tabular}{l|l|l}
\hline $\begin{array}{l}\text { Pacific Coast of } \\
\text { North America }\end{array}$ & England & \multicolumn{1}{c}{ Germany } \\
\hline JuRAssic \\
System $\left\{\begin{array}{l}\text { Upper Jurassic. } \\
\text { Middle Jurassic. } \\
\text { Lower Jurassic. }\end{array}\right.$ & $\begin{array}{l}\text { Upper Oölite. } \\
\text { Middle Oölite. } \\
\text { Lower Oölite. } \\
\text { Lias. }\end{array}$ & $\begin{array}{l}\text { Malm (or White Jura). } \\
\text { Dogger (or Brown Jura). } \\
\text { Lias (or Black Jura). }\end{array}$ \\
\hline
\end{tabular}

Distribution and Character of the Rocks

General Distribution. - Except in Mexico and western Texas, rocks of undoubted Jurassic age are wholly confined to the western 
part of the continent. ${ }^{1}$ On map Fig. 119 the considerable areas shown in California and western Nevada are mostly Jurassic rocks.

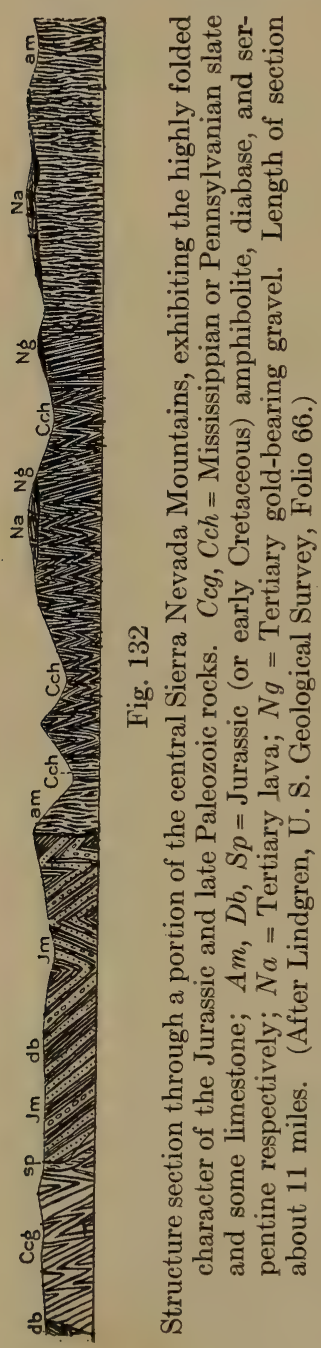
Some areas are also definitely known in southern Alaska and in western Oregon. In the western interior numerous small areas of mostly late Jurassic rocks only are known from northern Arizona and northwestern Colorado northward through Idaho, Wyoming, western South Dakota, and Montana. Rocks of late Jurassic age also quite certainly occur in western British Columbia east of the Cascade Mountains.

As compared with all preceding systems since the early Paleozoic, rocks of the Jurassic system are the least extensively developed on the continent.

Character of the Rocks. - The Jurassic rocks of California and Nevada, and the southern coast of Alaska, are chiefly of marine origin representing much or all of the period. In the Sierras and Coast Ranges the strata are usually metamorphosed and highly folded (e.g. Mariposa slates of the Sierras, Fig. 132).

In the western interior Triassic and Jurassic strata have often not been satisfactorily separated, and some "Red Beds" (with gypsum) of continental origin, like those of the Permian period, are probably of Jurassic age. At any rate, the only known true marine (Jurassic) strata in that whole region are of late Jurassic age. These rocks, which comprise all types of ordinary sediments, especially limestones and slates, are usually highly folded or tilted in the Rockies, Wasatch Mountains, Black Hills, etc., and hence are generally exposed only in narrow belts.

1 Certain non-marine deposits exposed along the Potomac River in Maryland have sometimes been called Jurassic, but the best evidence, as presented by W. B. Clark, points to their Comanchean (Lower Cretaceous) age. 
Thickness of the Jurassic. - The thickness of the system in California does not appear to be over 2000 feet, while in western Nevada 5000 to 6000 feet of limestones, and slates are reported. In Alaska a maximum thickness of 10,000 feet has been found. Throughout the western interior the thickness never appears to be great, usually not more than a few hundred feet.

Igneous Rocks. - Tremendous bodies of granite have been intruded into rocks as young as the late Jurassic (Mariposa) slates, and though the date of the intrusion is not certainly known, it very likely occurred toward the close of the Jurassic period and as an accompaniment of the Sierra Nevada Revolution (see below).

\section{Physical History}

Earlier Jurassic in the West. - During this time nearly all of North America north of Mexico was a land area. Marine waters spread over western Nevada, most of California, the western coast of Oregon, and southern Alaska. The western interior region received only continental deposits, probably including some "Red Beds" and gypsum in moderate amounts.

Later Jurassic in the West. - In the latter part of the period western Nevada probably was not covered by marine waters, but the other Pacific Coast regions above mentioned were. At this same time an important change took place in the western interior region by a transgression of the sea from British Columbia southward over the Rocky Mountain district to northern Arizona. The accompanying map (Fig. 133) shows the condition of the continent at that time. Eastern Mexico appears to have been largely submerged also.

Eastern North America in the Jurassic. - No Jurassic strata now occur in the eastern two-thirds of North America and we have no evidence that any ever were deposited there, hence that vast area was dry land undergoing erosion during the whole period. The period was ushered in by a slight upwarping of the Atlantic border accompanied by some faulting and tilting, particularly of the Triassic (Newark) rocks, as shown in Fig. 120. That this uplift actually occurred, and that the Jurassic period in the eastern United States was a time of extensive erosion, is well established, because the whole Atlantic seaboard, including the tilted and faulted Triassic strata, was worn down toward the condition of a 


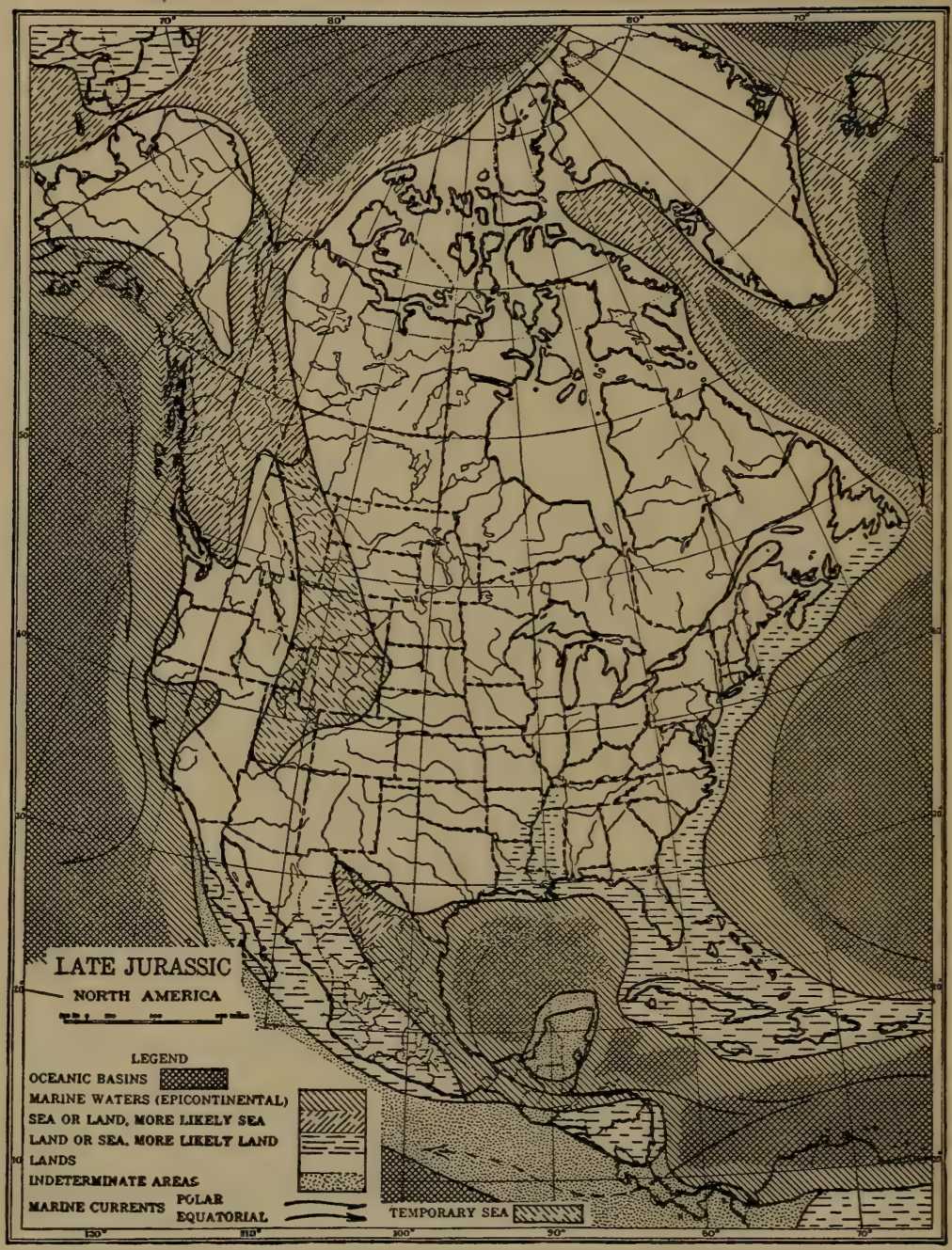

Fig. 133

Paleogeographic map of North America during late Jurassic time. (Slightly modified after Bailey Willis, courtesy of The Journal of Geology.) 
peneplain and the next sediments (Comanchean) were deposited upon the eastern portion of that worn-down surface. For instance, on Staten Island and in northern New Jersey, the Comanchean beds may be seen resting directly upon the deeply eroded Triassic rocks, and hence the proof is conclusive that during much, if not all, of the Jurassic period active erosion was taking place, and this in turn implies that the Triassic beds were well elevated in the early Jurassic.

Close of the Jurassic (Sierra Nevada Revolution). - The close of the period witnessed profound geographic changes in the western part of the continent. During both the Triassic and Jurassic periods, as well as throughout much of Paleozoic time, there had been more or less continuous deposition of sediments on the Pacific slope over the sites of the present Sierra, Cascade, and Coast Range Mountains. Toward the close of the Jurassic period these thick sediments, particularly in the Sierra region, were subjected to a tremendous force of lateral compression, the strata being upheaved, folded, and crumpled (Fig. 132). Thus the Sierra Nevada Mountains of California were borne out of the ocean and the Pacific shore line was transferred to the western base of the newly formed range. The Sierras, in this their youth, were most likely a lofty range, but were later much worn down by erosion, their present great altitude having been produced by later (Tertiary) movements. Accompanying the orogenic movements, the deeply buried sediments were metamorphosed and the vast quantities of granite were probably intruded at the same time, this granite being now exposed to view only because of profound subsequent erosion. As a result of the metamorphism the thick Mesozoic shales were converted into the hard (Mariposa) slates.

The best evidence indicates that this orogenic disturbance also affected the strata of the Klamath Mountains in northwestern California and the Cascade Mountain region through Oregon, Washington, and even British Columbia.

The strata then occupying the site of the present Coast Ranges were somewhat deformed, but probably only enough to form a chain of islands or a very low mountain range. This is proved by the fact that Lower Cretaceous strata are found resting unconformably upon the deformed Jurassic rocks. The orogenic movements which produced the Coast Range Mountains as we now see them came later. Some other mountains of the west, such as the 
Humboldt Range of western Nevada, were also probably upraised toward the close of the Jurassic.

The great arm of the sea or gulf which spread over the western interior region late in the Jurassic was drained as a result of these crustal disturbances. Hence we learn that all of North America except much of the western margin was dry land at the close of the Jurassic period.

\section{Foreign Jurassic}

Europe. - The marine transgression which, in late Triassic time, resulted in the submergence of the great salt lakes and other

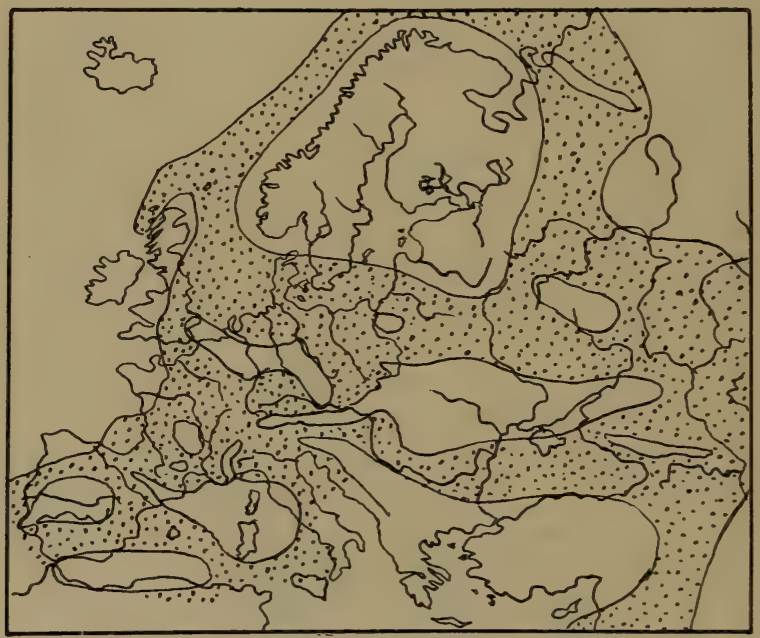

Fig. 134

Sketch map showing the relations of land and water in Europe during late Jurassic time. (Slightly modified after De Lapparent.)

basins of central and western Europe, continued into the Jurassic. Even in the early (Lias) part of the period the sea covered considerable areas in western, central, and southern portions of the continent. The strata are mostly typical shallow sea sediments, though some coal-forming swamps existed around the sea borders in central Europe. These early Jurassic strata are usually conformable upon and not sharply separated from the underlying Triassic. 
A progressive marine transgression continued through the middle of the period and well toward its close, extending farther and farther eastward, till much of the continent was submerged, as shown by Fig. 134. This was one of the greatest marine transgressions in the known geological history of Europe. As would be expected, the strata of later Jurassic age contain much more limestone than those of the earlier part of the period, because of the more widespread clear water areas. During all this time the great series of oölites were forming in England and the famous Solenhofen lithographic limestone was being deposited in southern Germany.

Just before the close of the period a considerable retrogression of the sea set in, draining certain areas and leaving lakes or estuaries in certain other places.

Other Continents. - Jurassic marine strata are known in many places in Arctic lands, thus showing extensive sea waters of that time there.

A great marine transgression also affected Asia, so that extensive areas of the continent became submerged, except mostly in the central portion. Widespread Jurassic deposits are known in Asia Minor, Siberia, India (especially the Himalayas), Persia, Turkestan, and Japan.

Jurassic rocks are also known in northern and eastern Africa, western South America, Australia, and New Zealand.

\section{Climate}

In general the evidence from the character and distribution of the organisms shows that the climate was comparatively mild. Corals, for example, had a range several thousand miles farther northward than they do today. A careful study of the migrations of certain animals has, however, pretty well established the fact that the Arctic Sea was notably colder than the Atlantic and Pacific, but it is perhaps too much to say that the northern sea was as cold as it is now. There was quite certainly some definition of climatic zones, especially in later Jurassic time.

\section{Economic Products}

Considerable crude oil is obtained from Jurassic strata in southern California.

The great gold-bearing veins or lodes of the famous "Mother 


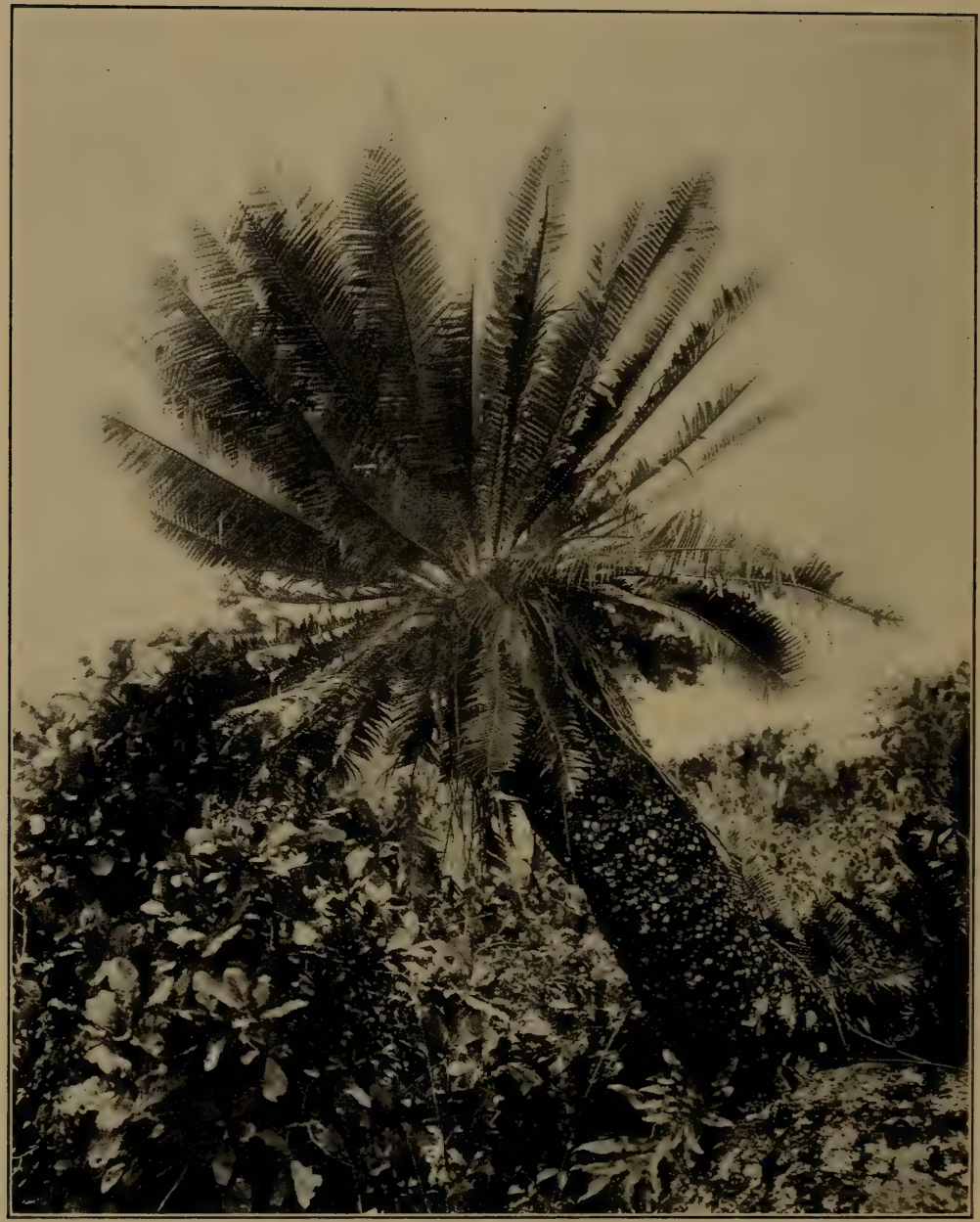

Fig. 135

A living Cycad, Dioon eduie, of Mexico. (From a photograph by Prof. C. J. Chamberlain.) 
Lode Belt" of the Sierra Nevada occur in Jurassic and older slates.

In California, also, important quicksilver deposits occur in metamorphosed Jurassic and later rocks.

Coal beds of some importance are found, mostly in the Lower Jurassic, in Hungary, various parts of Asia, and Australia.

As already mentioned, the famous Solenhofen lithographic stone of Bavaria is of Jurassic age.

\section{LIFE OF THE JURASSIC}

In Europe, as would be expected because of the great sea transgression, the marine life was prolific, and a wonderfully rich record has been left and carefully studied by many paleontologists. Some idea of the profusion of marine organisms may be gained from the fact that more than 4000 species are known from the British Isles alone. The far less complete American marine record is in harmony with the adverse physical conditions.

Beside the marine fossils, the wonderful records of land animals, especially the remark-

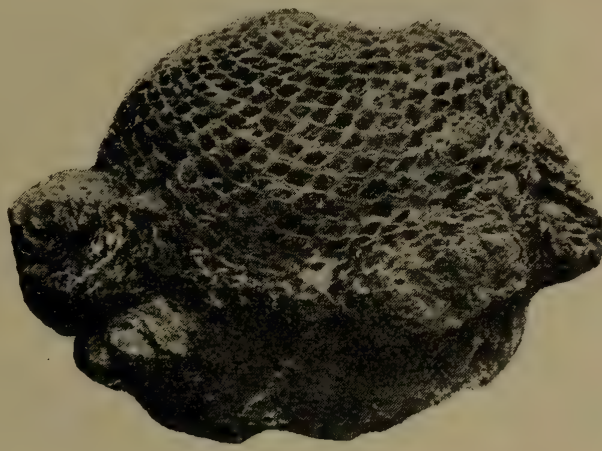

Fig. 136

A fossil Cycad tree trunk, Cycadeoidea pulcherrima. This is a Lower Cretaceous species. (After Darton and W. S. Smith, U. S. Geological Survey, Folio 108.)

able and now extinct Mesozoic Reptiles, are worthy of particular mention.

Plants. - Viewed in a broad way, the plants of the Jurassic were much like those of the preceding period, though some progressive evolutionary changes took place. Ferns, Equisetoe, Cycads (Figs. 135, 136, 137), and Conifers continued to be the dominant forms, with the Cycads attaining their culmination in both number of individuals and species. The Conifers took on a more modern aspect. The flora appears to have been remarkably uniform over wide portions of the world. 
Angiosperms are reported to have been represented by the Monocotyledons, though the evidence is not very conclusive.

Protozoans. - Foraminifers and Radiolarians were both very abundant and highly diversified. Foraminifers are particularly

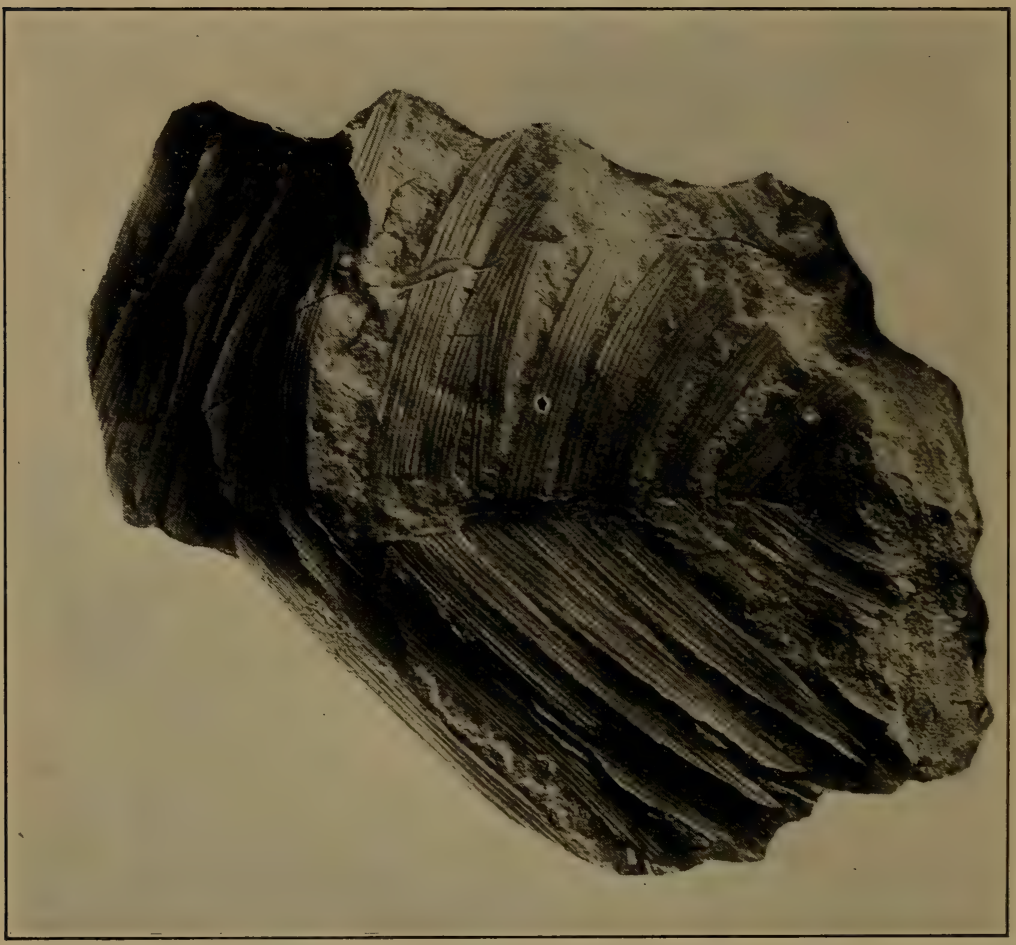

Fig. 137

Jurassic Cycad leaves. (After Ward, U. S. Geological Survey, Monograph 48.)

numerous in certain Jurassic clays, while certain other beds of chert or jasper are almost wholly made up of Radiolarian shells.

Porifers. - Sponges were very abundant and diversified. They are often beautifully preserved, even to the minutest details.

Cœlenterates. - Anthozoans (Corals) continued to be common, and all were of the modern Hexacoralla types. 
Echinoderms. - After their culmination in the Mississippian, the Crinoids remained in a comparatively subordinate position during the Permian and Triassic periods. During the Jurassic they again became profuse. As regards both abundance and size they probably even surpassed those of the Mississippian, though not in diversity of species. Their general structure was more like modern forms than like Paleozoic, and also there is good evidence that the shallow-water forms so common in the Paleozoic began to give way to deeperwater forms similar to those so prevalent today. Fig. 138 gives a good idea of one of the Jurassic Crinoids, the highly segmented and delicately branching arms being well exhibited. It scarcely seems credible that fully 600,000 segments have been counted in a single individual.

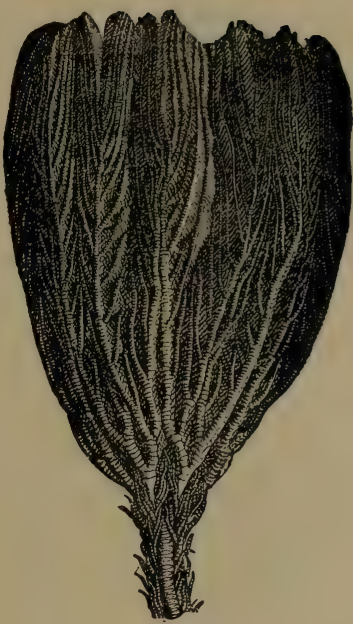

Fig. 138

A Jurassic Crinoid, Pentacrinus fossilis. (After Goldfuss.)

Asterozoans were moderately represented and they had already assumed a distinctly modern structure.

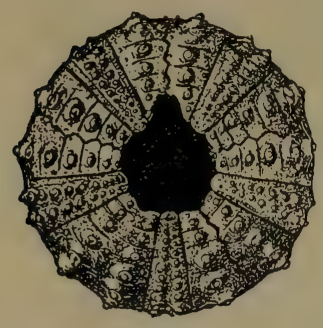

Fig. 139

A regular or radially symmetrical Echinoid, Pseudodiadema texanum, of Lower Cretaceous age. (After Hill and Vaughn, U. S. Geological Survey, Folio 76.)

Echinoids. - These forms, which first attained much prominence in the Triassic, continued to increase in abundance and variety in the Jurassic. Early in the period regular forms only existed, but later in the period the irregular forms made their first appearance. The regular forms were radially symmetrical, while the irregular ones were only bilaterally symmetrical (see Figs. 139, 140). Since the latter are distinctly more modern in structure, we have here another good illustration of progressive evolution toward modern forms.

Molluscoids. - Bryozoans were present, but apparently not very important.

Brachiopods were still fairly common, though the numbers of genera and species 


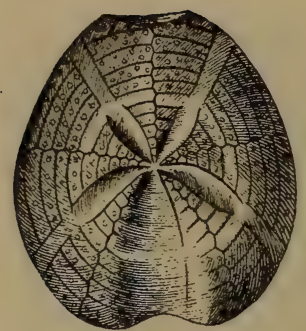

Fig. 140

An irregular or bilaterally symmetrical Eshinoid, Hemiaster texanus, of Cretaceous age. (After Hill and Vaughn, U. S. Geological Survey, Folio 76.) were reduced to only a few. Most of these genera have continued to the present day, so that in the succeeding periods the evolution of these creatures, so very prominent in all of the earlier fossiliferous periods, has but little interest.

Mollusks. - Pelecypods were even more abundant than in any preceding period, their shells often largely constituting whole strata or thick beds. They were quite modern in appearance, many genera being those which still exist. The members of the Oyster family were most common, being represented by such genera as Ostrea, Exogyra, Gryphea.

Gastropods, including various existing genera, were usually common.

Among Cephalopods the ancient and important straight-shelled Orthoceras had disappeared with the preceding period, but coiled Nautiloids still were common. The Ammonoids reached the very height of their development in the Jurassic. Among these, the most characteristic and abundant were the Ammonites, in which the sutures or partition structures reached the highest degree of complexity (see Fig. 141). Many hundreds of species are known, and often Jurassic strata are chiefly composed of them. Of all coiled Cephalopods, the largest were of this age, some Ammonites having attained a diameter of several feet. In many cases "erratic and degenerate developments showed themselves by uncoiling and strange coiling, presaging a stage of 'sport-

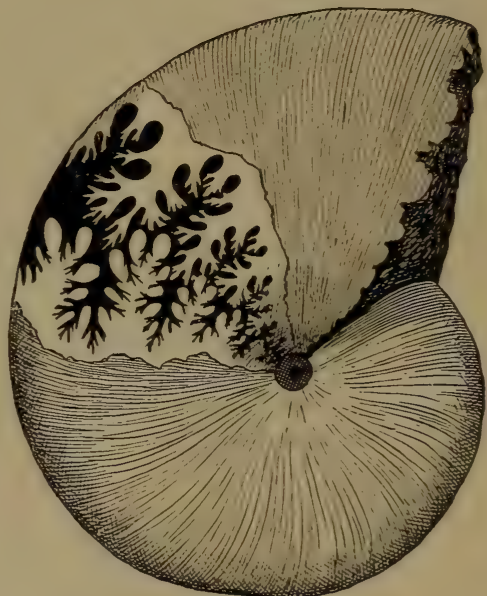

Fig. 141

An Ammonite with part of shell removed to show the very complicated (frilled) sutures. (From Norton's "Elements of Geology," by permission of Ginn and Company, Publishers.) 
ing' and retrogression in the next period, followed by extinction" (Chamberlin and Salisbury). The reader is again referred to the table on page 99 which outlines the evolution of the chambered-shell Cephalopods.

We learned that the Dibranch Cephalopods made their first appearance in the Triassic period. In the Jurassic these forms were exceedingly abundant both in numbers of species and of individuals. Most characteristic of these were the Belemnites, so-called because of the long, conical, or dart-shaped, internal shells which are generally the only portions preserved

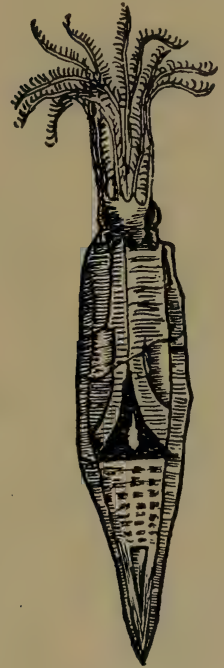

Fig. 143

A Jurassic Belemnite, Belemnoteuthis antiqua. (Modified after Mantell.) in the fossil state (see Fig. 142). They were similar in appearance to the modern Squids or Cuttle-fishes. Some Jurassic forms reached a length of over two feet. A few specimens from the English Oölite show almost perfect preservation of the original creature (see Fig. 143). Ink-bags, like those found in modern Squids, are sometimes so well preserved that drawings of the fossils have actually been made with ink taken from their own ink-bags.

Arthropods. - Among the Crustaceans the familiar Paleozoic Trilobites and Eurypterids were, of course, gone, and forms

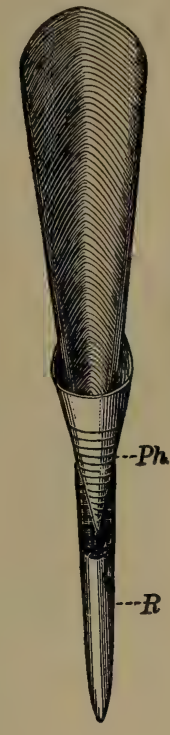

Fig. 142

Internal shell of a Belemnite, restored. (Frum Norton's "Elements of Geology," by permission of Ginn and Company, Publishers.) much higher in structure had become abundant and of pretty modern aspect. Thus, among Eucrustaceans, the long-tailed Decapods (Macrurans) or Lobster forms showed many genera and species (Fig. 144), while the short-tailed Decapods (Brachyura) or Crab forms made their first appearance, though they were not numerous. Many types intermediate between the long-tailed and short-tailed Decapods were very common, these connecting forms being of special evolutionary 
interest because, in the embryonic development of the modern Crab, the long tail of the early stage gradually becomes shorter and practically absent in the adult stage. This is an excellent example of the so-called "Law of Recapitulation" (see Fig. 145).

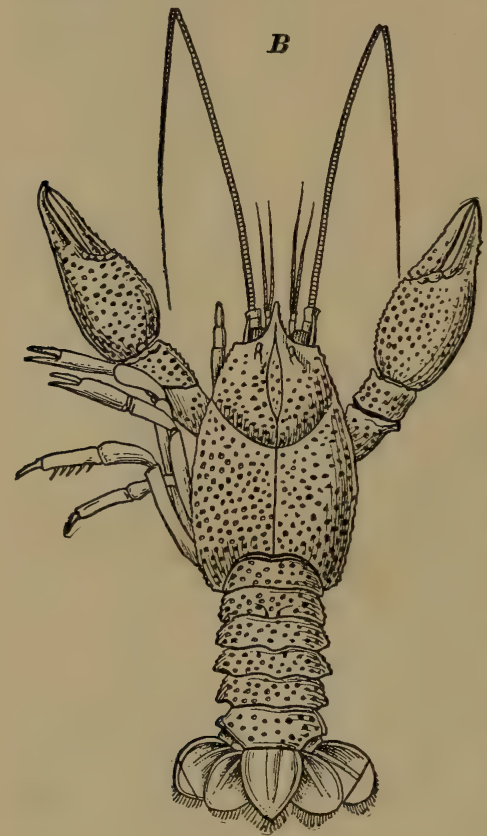

Fig. 144

A Jurassic long-tailed Decapod (Macruran). (After Neumayr's "Erdgeschichte," from Schuchert's "Historical Geology," courtesy of John Wiley and Sons.)

quently on the border between true Ganoids and true Teleosts (Fig. 146).

Amphibians. - Little or nothing is known concerning Jurassic Amphibians. This is in marked contrast with their prominent development in several immediately preceding periods. By the close of the Triassic they are known to have greatly diminished, never again to rise to prominence. Only a few small forms, such as Frogs, Newts, and Salamanders, represent this once great class at the present time. 
Reptiles. - Viewed in the broadest way, the Reptiles of the Jurassic were much like those of the Triassic, except that they

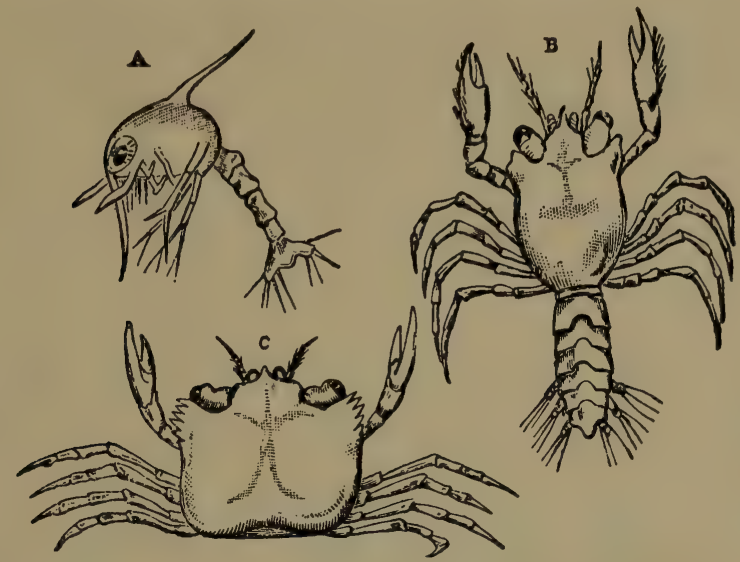

Fig. 145

Three stages in the life history of a modern Crab. The larval stage $B$ is very similar to the adult Jurassic form shown in figure 144. (After Couch, from Le Conte's "Geology," permission of D. Appleton and Company.)

became more numerous and diversified. By some, this period is regarded as the culminating time of the Reptiles. As compared

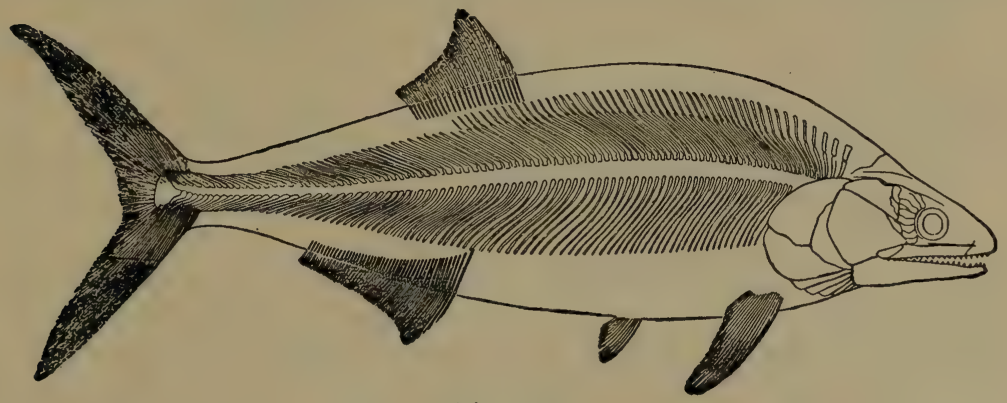

Fig. 146

A primitive or ancestral Jurassic Teleost, Hypsocormus insignis. (From Scott's "Geology," courtesy of The Macmillan Company.)

with the Triassic all the same principal groups were still represented, though with many genera and species changes. The more 
modern forms, such as Turtles, greatly increased, but Lizards were still very subordinate. Crocodiles made their first appearance. As with all the Mesozoic periods, the principal interest surrounds the great groups of remarkable extinct Reptiles such as Enaliosaurs, Dinosaurs, and Pterosaurs. It will be more convenient, however, to describe Mesozoic Reptiles together in a subsequent chapter.

Birds. - A very important feature from the standpoint of evolution was the introduction of the feathered creatures in the

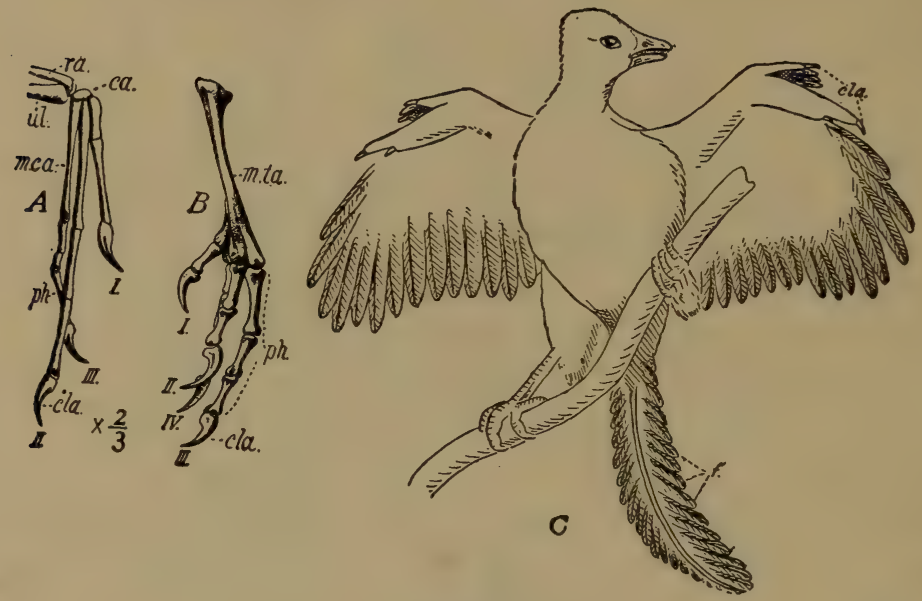

Fig. 147

The earliest known Bird, Archeopteryx macrura, from the Jurassic. $A$, right hand; $B$, right foot; $C$, restoration modified after Pycraft. (From Shimer's "Introduction to the Study of Fossils," courtesy of The Macmillan Company.)

Jurassic. "The class of Birds is now so distinctly separated from all others and the connecting links obliterated, that the earliest Birds are of especial interest as throwing light on the evolution of this class. Until 1862 Birds had been found only in the Tertiary, and these were already distinctly differentiated as typical Birds. But in that year there was found in the Solenhofen (Bavaria) limestone, so celebrated for its marvelous preservations of organisms, a flying feathered biped, and therefore presumably a Bird. But how different from our usual conceptions of this class! Along with 
its distinctive Bird-characters of feet, limb-bones, beak, and especially of feathered wings, it had the long tail and toothed jaws (see Fig. 147) of a Reptile. The structure of the tail is especially significant. In ordinary Birds the tail proper is shortened up to a rudiment and ends in a large bone, from which radiate the feathers of the tail-fan. In this earliest Bird, on the contrary, the tail proper is as long as all the rest of the vertebral column put together, consisting, as seen in the figure, of twenty-one joints from which the fan feathers come off in pairs on each side. The tail-fan of this Bird differs from that of typical Birds precisely as the tail-fin of the earliest Fishes differs from that of typical Fishes. The tail-fan of this earliest Bird, like the tail-fin of the earliest Fishes, was vertebrated. This wonderful reptilian Bird was called Archeopteryx ('primordial winged creature'), and the species macrura ('long-tailed'). ... . So complete is the mixture of the two kinds of characters that some zoölogists believe that the reptilian characters predominate, and that it should be called a Bird-like Reptile. Most agree, however, that it is a reptilian Bird." ${ }^{1}$ Thus, while the evidence seems conclusive that Birds were evolved from Reptiles, there is no conclusive evidence that they were derived from the flying Reptiles (Pterosaurs). Rather there appears to have been a development of these two remarkable groups of flying creatures alongside each other.

Mammals. - This important class, first known from the Triassic, continued to be represented by only comparatively few small, very primitive forms in the Jurassic. The scant records show these creatures to have been no larger than Mice or Rats and low in organization (i.e. Monotremes or Marsupials). As already stated, Mammals remained very subordinate throughout the Mesozoic era.

1 J. LeConte: Elements of Geology, Ed., pp. 462-463. 


\section{CHAPTER XVI}

\section{THE CRETACEOUS PERIOD}

Origin of Name, Subdivisions, etc.

The term Cretaceous, from the Latin "Creta" for chalk, was given to the period because of the prominence of chalk beds in the rocks of this age, especially in England and France. In fact, one of the most striking features of the landscape in southern England and northern France consists in the frequent exposures of beds of white or very light colored chalk. Perhaps the most famous are the Dover Cliffs of England. In many parts of the world, however, the Cretaceous system is not rich in chalk deposits. In the United States, chalk is extensively developed in the Cretaceous of Alabama and Texas. The system was first carefully studied in England, but the names of the French subdivisions are now more widely employed.

For a long time the Cretaceous system has been known to be divisible into two portions - a Lower and an Upper - often separable by unconformity, and, during the past ten or twelve years, some authors have regarded the Lower Cretaceous as a separate system called "Comanchean" from a locality in Texas. Recent work has, however, shown that the Lower and Upper Cretaceous are not so sharply and widely separated as was formerly supposed, particularly in the type region of Texas. Hence the use of "Comanchean" as a distinct system and period name seems inadvisable at the present time.

Following are the principal subdivisions of the Cretaceous as now recognized in Europe and North America, though exact correlations are not implied (see page 237).

\section{Distribution and Character of the Rocks}

General Distribution. - Lower Cretaceous. The surface distribution of rocks of known Lower Cretaceous age is shown on the accompanying map (Fig. 148). With the exception of part of 


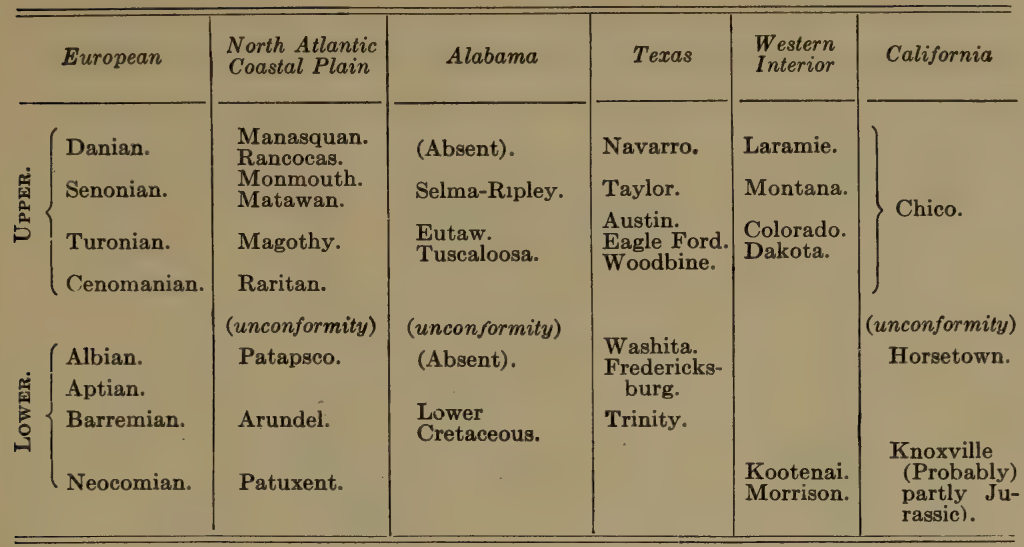

Virginia, ${ }^{1}$ these rocks are seen to form a narrow outcropping belt at the western margin of the Atlantic Coastal Plain from New Jersey to Alabama. Passing eastward from the exposed belt, well borings show that much at least of the whole Coastal Plain is underlain with Lower Cretaceous rocks. "The sediments (of the Coastal Plain) in general form a series of thin sheets which are inclined seaward (Fig. 155), so that successively later formations are encountered in a journey from the inland border of the region toward the Coast" (W. B. Clark).

As the map shows, the most extensive surface distribution of Lower Cretaceous rocks is in Mexico and Texas. Here, too, in passing toward the (Gulf) Coast these strata are known to be extensively developed under cover of later formations. In general, therefore, the actual extent of Lower Cretaceous strata in the Atlantic and Gulf Coastal Plain is much greater than the surface exposures.

Several small areas are known in the western United States in the Rocky Mountains and in the Coast Range of northern California. Large surface areas occur in British Columbia and Alaska. In most of these western regions the Lower Cretaceous strata are notably folded or tilted, so that their full extent is not shown by the outcrops.

${ }^{1}$ In this part of Virginia the Lower Cretaceous strata are completely concealed under Tertiary strata. 
Upper Cretaceous. As seen on map Fig. 149, the rocks of Upper Cretaceous age are widely exposed at the surface - much

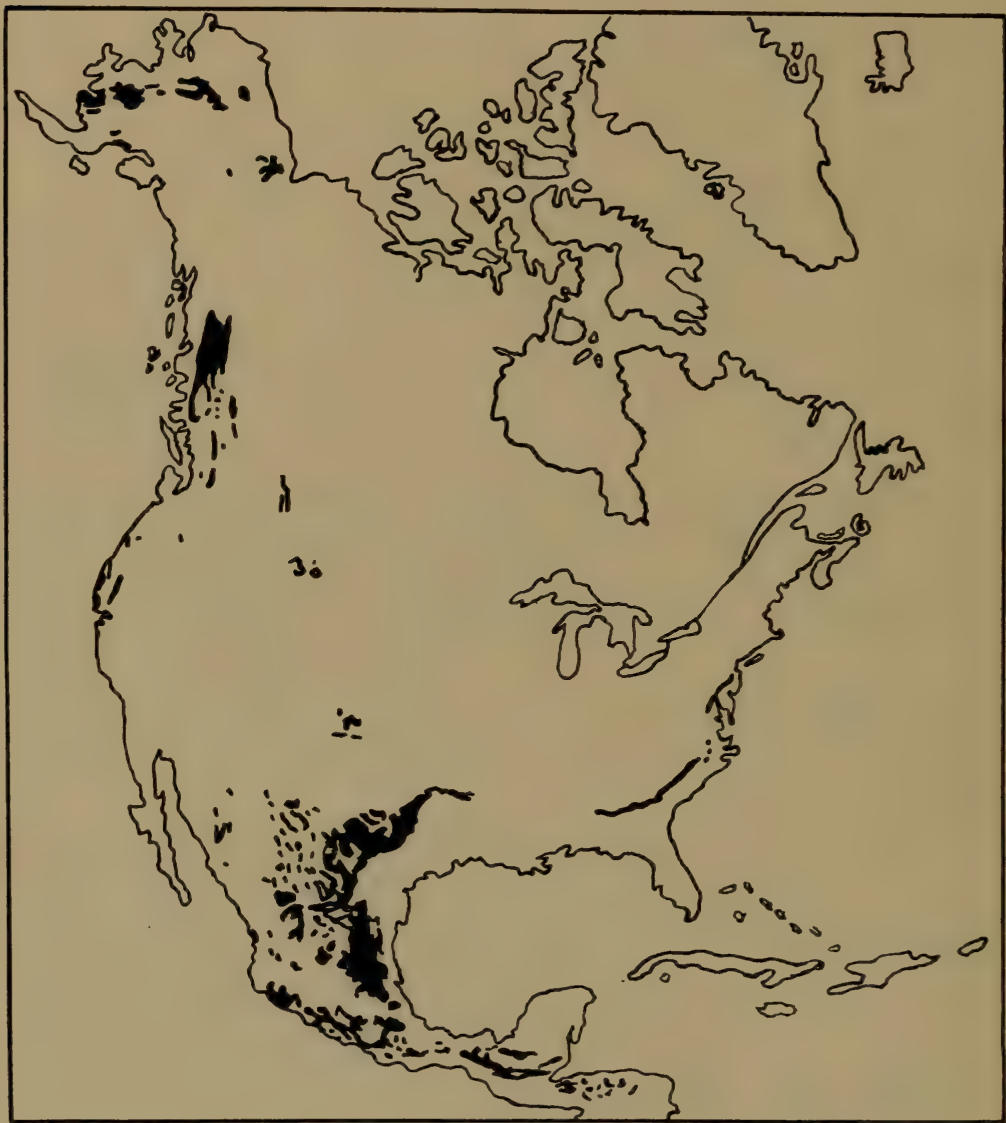

Fig. 148

Map showing the surface distribution (areas of outcrops) of Lower Cretaceous strata in North America. (Modified by W. J. M. after Willis, U. S. Geological Survey.)

more so than those of Lower Cretaceous age. In the eastern and southern United States, Upper Cretaceous strata outcrop as comparatively long, narrow belts at or near the western and northern 
margin of the Atlantic and Gulf Coastal Plain. The northernmost exposures are on Martha's Vineyard. The occasional gaps shown

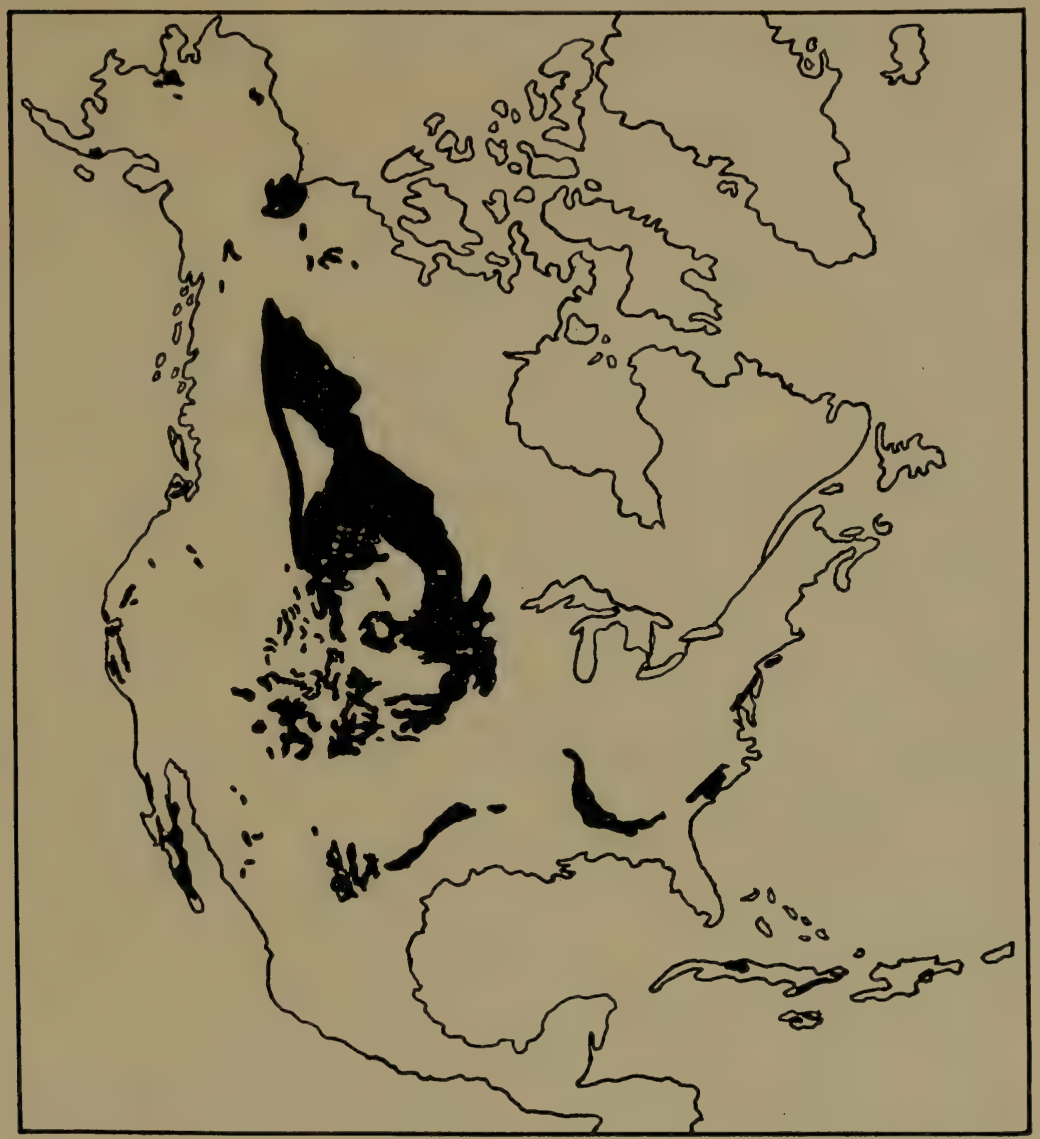

Fig. 149

Map showing the surface distribution (areas of outcrops) of Upper Cretaceous strata in North America. (Modified by W. J. M. after Willis, U. S. Geological Survey.)

on the map are due to the fact that the Upper Cretaceous beds are there concealed under later deposits. From the outcropping belts oceanward or gulfward, the Cretaceous strata dip gently under the 
later (Cenozoic) deposits and they there underlie much, if not all, of the Coastal Plain (Fig. 155).

A large part of the western interior shows Upper Cretaceous rocks at the surface. Because of the usual only slightly deformed character of the strata just west of the main axis of the Rocky Mountains, there is a large, practically solid outcropping area, while within the Rockies, where much deformation has affected the rocks, the outcrops are much more patchy in distribution. Large areas of Upper Cretaceous strata are also concealed under later rocks in this western interior region (Fig. 149).

On the Pacific Coast and in Alaska only small areas of Upper Cretaceous strata show at the surface, but since the rocks there are usually in a highly deformed condition, they are really considerably more extensive than the surface exposures seem to indicate.

Character of the Rocks. - Atlantic Coastal Plain. Three wellknown Lower Cretaceous formations (Patuxent, Arundel, and Patapsco) of the Atlantic Coast have long been called the Potomac series. They are all of continental origin. Describing these formations in Maryland and Delaware, W. B. Clark says: "The Patuxent formation consists mainly of sand, generally arkosic and in many places crossbedded, with small masses of clay scattered through it. The formation attains a thickness of 350 feet. It has a well-defined early Cretaceous flora. The Arundel formation consists chiefly of clays, which in places carry iron ore and are commonly lignitic. It has a thickness of about 125 feet. It is unconformable to the Patuxent. . . The Patapsco formation consists of highly colored and variegated clays and lighter colored sandy clays and sands. It has a thickness of 200 feet and is unconformable to the Arundel." 1

The Upper Cretaceous deposits rest unconformably upon the Lower Cretaceous. According to Clark the Upper Cretaceous formations of New Jersey are typical of the North Atlantic Coastal Plain and are constituted as follows: "The Raritan formation . . . consists of clays, sands, and gravels. It has been estimated to have a maximum thickness of about 300 feet at the outcrop. . . . The Magothy formation unconformably overlies the Raritan formation and consists of dark clays and light sands. The clays are

${ }^{1}$ W. B. Clark: in Index to The Stratigraphy of North America, U. S. G. S., Professional Paper 71, p. 610. 
commonly lignitic. The deposits attain a maximum thickness of about 100 feet. . . . The Matawan consists chiefly of dark-colored clays, in some places micaceous and glauconitic, in its lower part, and of sands, with an interbedded clayey member, locally highly glauconitic, in its upper part. It attains a thickness of about 275 feet, although a thickness of 400 feet has been found in deep well borings east of its outcrop. It lies unconformably on the Magothy. . . . The Monmouth group consists of sands and clays, with an interbedded glauconitic division in the northern part of the area. Toward the south the upper sandy formation disappears. The greatest thickness of the group is about 150 feet. The Monmouth is conformable to the Matawan. . . . The Rancocas consists largely of greensand marls and sandy calcareous beds which have a maximum thickness in southern New Jersey of about 125 feet. It is conformable to the Monmouth. . . . The Manasquan formation consists of greensand marls and attains a thickness of about 50 feet. It is conformable to the Rancocas." 1

Alabama. Lower Cretaceous strata (unnamed) of Alabama, according to Stephenson, consist of "irregular bedded, coarse, arkosic, more or less micaceous sand, with subordinate lenses of usually massive clay of greater or lesser purity. The terrane rests upon a basement of crystalline rocks and is separated from the overlying Eutaw and other Upper Cretaceous and Tertiary formations by an unconformity." 2

According to Stephenson "the Tuscaloosa formation consists of irregularly bedded sands, clays, and gravels having an estimated total thickness of 1000 feet. . . . The Eutaw formation consists predominantly of more or less glauconitic sand, massive to crossbedded in structure, with, in parts of the terrane, irregularly interbedded fine laminæ and laminated layers of dark clay.... The total thickness of the formation is estimated to be from 400 to 500 feet. . . . The Selma chalk consists in the main of more or less argillaceous and sandy limestones rendered chalky by their large content of Foraminiferal remains, with interbedded layers of nearly pure, hard limestone at wide intervals. In western Alabama the terrane has a measured thickness of 930 feet. . . . The typical beds of the Ripley formation consist of more or less calcareous and glauconitic sands, sandy clays, impure limestones, and

1 W. B. Clark: U. S. G. S., Professional Paper 71, pp. 609-610.

${ }^{2}$ L. W. Stephenson: U. S. G. S., Professional Paper 81, p. 20. 
marls, of marine origin, reaching an estimated thickness in this region of 250 to 350 feet." 1

From the above descriptions, the Atlantic and eastern Gulf Coastal Plain Cretaceous deposits are seen to be largely unconsolidated and only slightly tilted sediments.

Texas. In the Texas region the Trinity formation consists mostly of light colored sands, with some alternating marls, clays, and limestones. Its lower portion is of continental origin, while its upper portion is marine. The whole formation attains a maximum thickness of about 2000 feet. The Fredericksburg formation is typically almost entirely chalky limestone of marine origin from 1000 to 5000 feet thick. It covers wide areas in Mexico and Texas. The Washita formation ${ }^{2}$ comprises chiefly alternations of light and dark colored marly clays, limestones, and sandy limestones whose thickness is from 200 to 400 feet. This formation extends across much of Mexico, Texas, and northward into Oklahoma, southeastern Kansas, eastern Colorado, and possibly into Wyoming.

The Woodbine formation, according to Hill, ${ }^{3}$ is made up of ferruginous sands and clays $(600 \pm$ feet thick); the Eagle Ford formation is essentially bituminous clay with some limestone ( $600 \pm$ feet thick); the Austin formation is largely impure chalk with some softer beds of marl $(600 \pm$ feet thick); the Taylor formation is calcareous clay marl (several hundred feet thick); and the Navarro formation is mostly made up of sands, chalks, and clays with some glauconite (thickness?).

Western Interior. In the western interior region mostly just east of the main axis of the Rocky Mountains from Colorado northward, there occur certain formations - Morrison, Kootenai, etc. - of rather doubtful age and origin. They consist mostly of shales, sandstones, and limestones, and, in part at least, they are Lower Cretaceous deposits of continental origin.

The Dakota formation is chiefly sandstone, mostly of marine origin, and up to 100 feet thick. The Colorado formation is very largely of marine origin and comprises mostly clastic sediments but with considerable chalk. The Montana formation comprises mostly clastic sediments of marine origin, though with some continental deposits, as, for example, local coal beds. It shows a

${ }^{1}$ L. W. Stephenson, U. S. G. S., Professional Paper 81, pp. 20-21.

2 Recent work has shown the Washita to be partly Upper Cretaceous.

3 U. S. G. S., Professional Paper 71, pp. 20-21. 
remarkable variation in thickness of from 8700 feet in Colorado to only 200 feet in the Black Hills of South Dakota. The Laramie formation is quite certainly mostly of non-marine origin, with fresh-water and land deposits (including much coal) common. The formation shows a variable thickness possibly up to several thousand feet, and it occurs only in the western interior region.

Pacific Coast. - On the Pacific Coast, the Lower Cretaceous is remarkably developed, where it shows a maximum thickness. According to Diller, the older or Knoxville ${ }^{1}$ series, comprising nearly 20,000 feet of shales with some interbedded sandstones and limestones, is overlain conformably by the Horsetown series of sandstones and shales about 6000 feet thick. This enormous thickness of sediments is clearly of shallow-water origin, the rocks now nearly always being distinctly folded or tilted. In southern California, too, the system is pretty thick and there contains some volcanic rocks. Lower Cretaceous strata, usually folded and sometimes metamorphosed, also are widely developed in British Columbia and Alaska with some coal in both regions and some volcanic rock in the former.

The Upper Cretaceous on the Pacific Coast is represented by the single great Chico formation, but both the oldest and the youngest portions of the series are often not represented at all. The Chico is a marine deposit from a few hundred to several thousand feet thick. It is prominently developed in the Coast Range Mountains from Lower California to British Columbia. It consists mostly of sandstones, shales, and conglomerates, and is, in some places, conformable, and in others unconformable, upon the Lower Cretaceous.

Thickness of the Cretaceous. - The system shows a maximum thickness of fully 1700 feet on the north Atlantic Coast; $3000+$ feet in the eastern Gulf region; 3500 to 7500 feet in the western Gulf region; 10,000 to 15,000 feet in the western interior region, though usually much less in any one locality; and 26,000 feet on the Pacific Coast.

Igneous Rocks. - Volcanic rocks in the Lower Cretaceous are known only in British Columbia and in the Coast Range of southern California. Igneous rocks (chiefly lavas) of late Cretaceous and Tertiary ages occur in vast quantities over great areas in

${ }_{1}$ According to some workers the Knoxville is now regarded as partly Jurassic in age. 
central western North America. The igneous activity represented by these rocks is more fully described in succeeding pages.

\section{Physical History}

Atlantic and Eastern Gulf Coasts. - The Cretaceous period opened with the coast line of the eastern United States somewhat farther out than it now is, but, early in the period, there was enough subsidence, or possibly warping, of the coastal lands to allow deposition of sediments over much of what is now known as the Atlantic and eastern Gulf Coastal Plain. That but little downwarping of the surface was necessary in order to produce proper conditions for this sedimentation is evident, because the coastal lands just prior to the Cretaceous were already low-lying as a result of the long Jurassic erosion interval. There was just enough warping of the low coastal lands to produce wide flats, flood-plains, shallow lakes, and marshes back from the real coast line. Over such areas were deposited the sediments derived from the Piedmont Plateau and Appalachian areas. The very irregular arrangement of the deposits (Potomac) and their rich content of fossil land plants afford conclusive evidence that the sediments were accumulated under continental conditions.

The pretty widespread unconformity between the Lower and Upper Cretaceous in these regions proves that, about the close of the Lower Cretaceous, there must have been enough emergence of the lands to convert the basins of deposition into areas of erosion. Early in the Upper Cretaceous, however, a submergence of the coastal lands took place, inaugurating the deposition of the Upper Cretaceous strata. The general character, mostly marine ${ }^{1}$ origin, and present extent of these deposits prove that the submergence allowed a shallow sea to spread over much of what is now called the Atlantic and eastern Gulf Coastal Plain. ${ }^{2}$ In this connection it is very important to note that Appalachia, the great land-mass which had persisted through the many millions of years of the Paleozoic era as well as most of the Mesozoic era, disappeared under the Cretaceous sea not again to reappear.

Texas. - Early in Trinity time continental deposits (sands) only were forming over the Texas region, but later in the epoch

${ }^{1}$ Some beds of continental origin occur in the Upper Cretaceous of Maryland and New Jersey.

${ }_{2}^{2}$ Certain minor oscillations of level are here disregarded. 


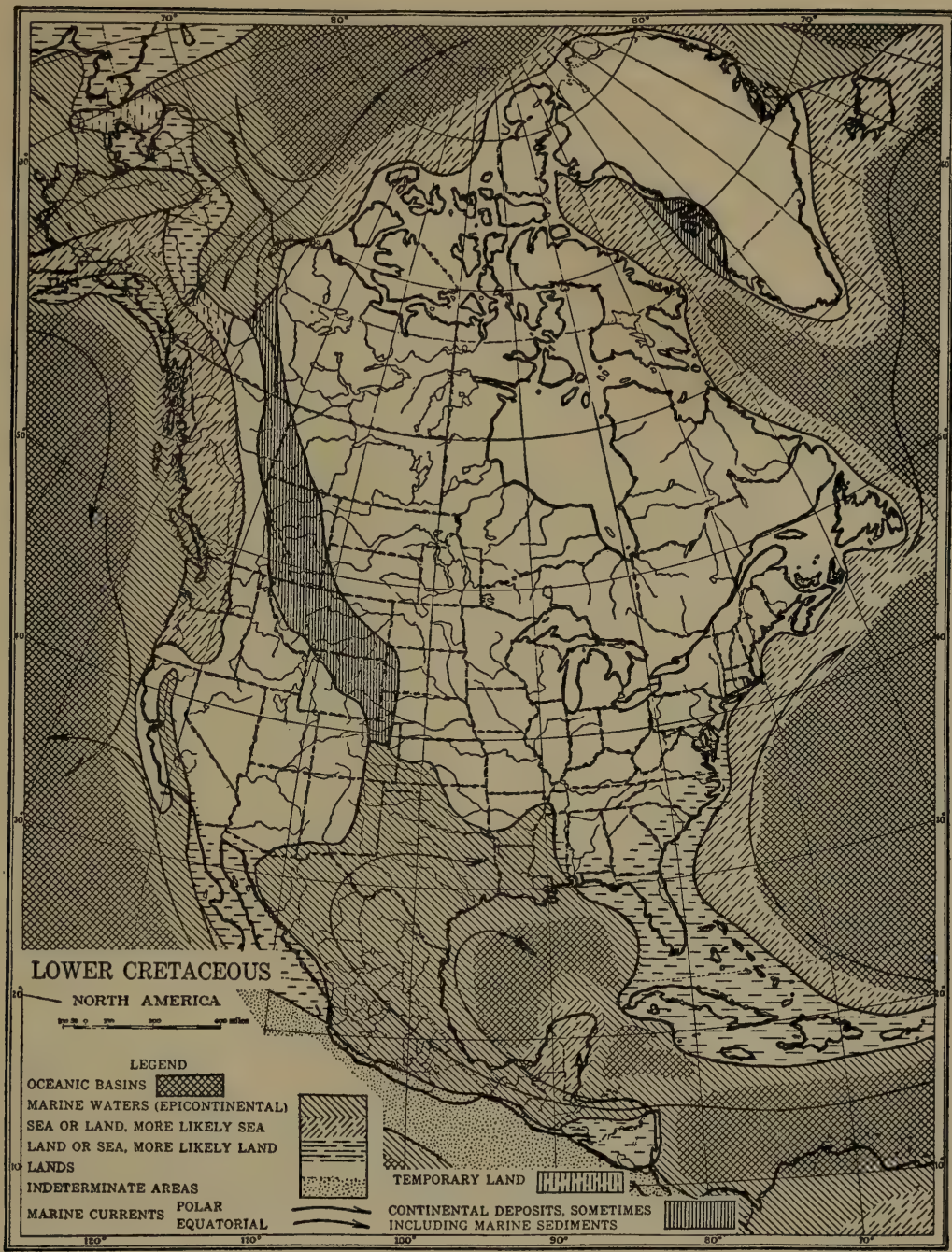

Fig. 150

Paleogeographic map of North America during Lower Cretaceous time. (Slightly modified after Bailey Willis, courtesy of The Journal of Geology.) 
marine waters spread over the region. During all of Fredericksburg time a clear and unusually deep epicontinental sea occupied much of Mexico and Texas and immediately adjoining regions. Great chalk deposits were formed in this clear sea. Perhaps the maximum northward extension of the Lower Cretaceous sea took place during Washita time, when marine waters probably reached as far northward as Colorado (see map Fig. 150).

Throughout Upper Cretaceous time, from Woodbine to Navarro inclusive, marine waters appear to have persisted over the Texas area, having been particularly clear during the deposition of the Austin chalk.

Western Interior Region. - The physical history of this area during Lower Cretaceous time is still somewhat problematical, but the best evidence seems to show that, just east of the site of the Rockies, deposits of continental origin (Morrison and Kootenai) were forming very much like those of the Potomac on the Atlantic Coast.

Pretty early in the Upper Cretaceous, the western interior region witnessed a very extensive marine transgression beginning during Dakota time and probably reaching a maximum during Colorado time. In the comparatively clear waters of this Colorado sea were accumulated the chalk and other marine deposits. This great marine invasion must take rank as one of the most extensive in the history of the continent, the marine waters having spread from the Gulf of Mexico northward over the western interior region to the Arctic Ocean by way of what is now the Mackenzie River Valley (see map Fig. 151). There is no good evidence that this vast western interior sea had direct connection with the Pacific Ocean. In the latter portion of the period (Laramie) marine waters did not prevail over the immediate Rocky Mountain district through the United States and Alberta. Sufficient emergence "formed a coastal plain, extensive marshes prevailed, and the marsh deposits became coal beds. Sea, marshes, and river plains alternated in sequence till near the close of the Cretaceous period" (Bailey Willis).

Pacific Coast. - Rather remarkable physical conditions must have obtained in California, especially in the north, to give rise to such a phenomenal thickness of sediments during this one period. Apparently the explanation is not far to seek, because the newly upraised Sierras must have undergone vigorous erosion with rapid 


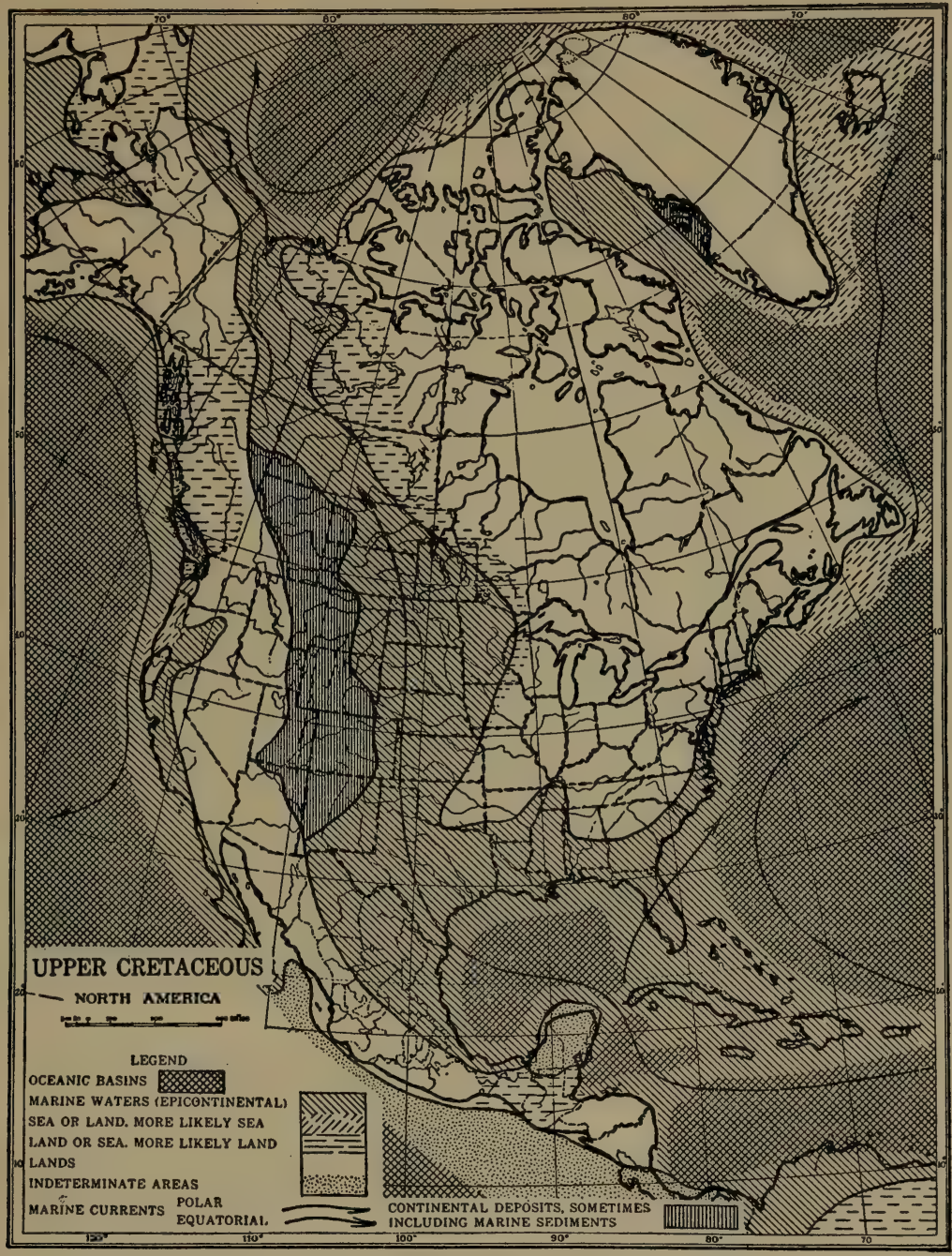

Fig. 151

Paleogeographic map of North America during Upper Cretaceous time. (Slightly modified after Bailey Willis, courtesy of The Journal of Geology.) 
accumulation of materials in the marine waters which then occupied the sites of the present Great Valley and Coast Range of California. According to Bailey Willis, "a bold peninsula developed from Oregon south to Santa Barbara (California)" during Lower Cretaceous time, as shown on the map Fig. 150, but according to certain others marine waters spread over most of the Coast Range district during both Lower and Upper Cretaceous times.

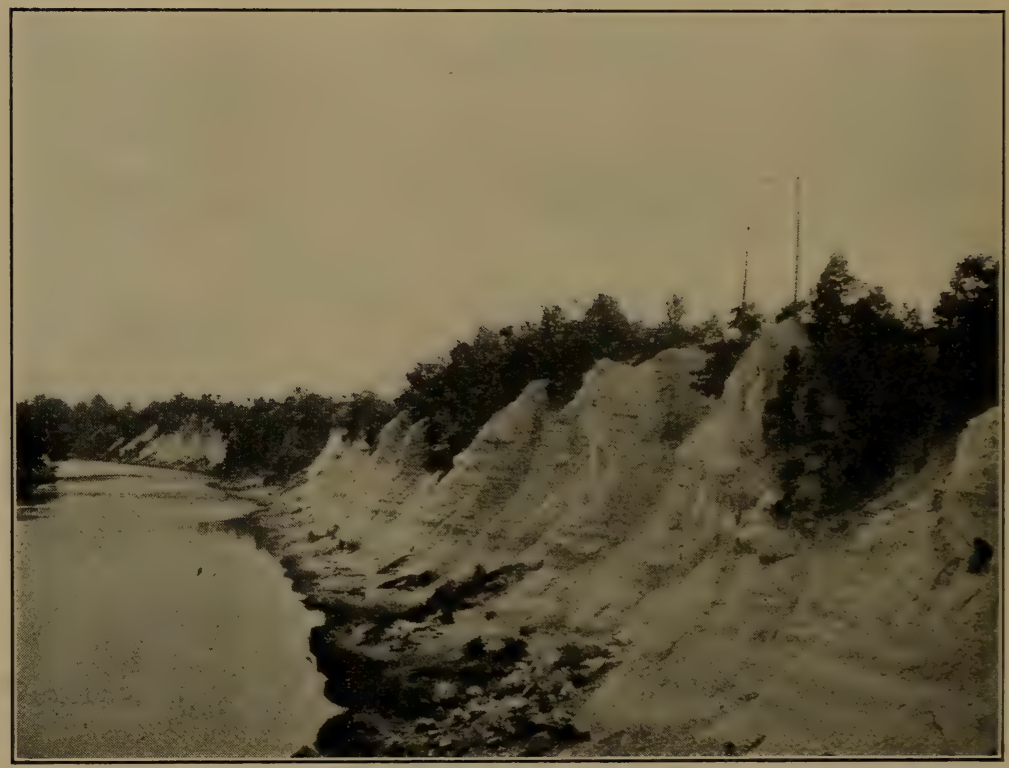

Fig. 152

Typical exposure of Upper Cretaceous (Selma) chalk in Alabama. (After L. W. Stephenson, U. S. Geological Survey, Prof. Paper 81.)

In British Columbia and Alaska the presence of marine strata proves the existence of sea water over the areas indicated on the accompanying maps, though the coal beds show that great swamps or lagoons must have existed locally.

Close of the Period in the West (Rocky Mountain Revolution). - The close of the Cretaceous period, or, what is the same thing, the close of the Mesozoic era, was marked by one of the most profound and widespread physical disturbances in the history of 
North America since pre-Cambrian time. Over the Rocky Mountain district there had been more or less deposition of sediments (both marine and continental) throughout Paleozoic and Mesozoic times. Toward the close of the Cretaceous, there was vigorous deformation, including both folding and dislocations of the strata, not only throughout the Rocky Mountain district in North America from the Arctic Ocean to Central America, but also even along the line of the Andes Mountains to Cape Horn - altogether more than onefourth of the way around the earth. This great crustal disturbance has been called the "Rocky Mountain Revolution." While the folding was usually not nearly as intense as at the time of the "Appalachian Revolution," nevertheless there were very considerable uplifts accompanied by moderate folding of the strata in many parts of the district (Fig. 154). That portion of the Rockies north of the United States (so-called Laramide Range) suffered the severest deformation where strata estimated at 40,000 to 50,000 feet thick were folded and faulted into a range which was probably no less than 20,000 feet high. The Rocky Mountains

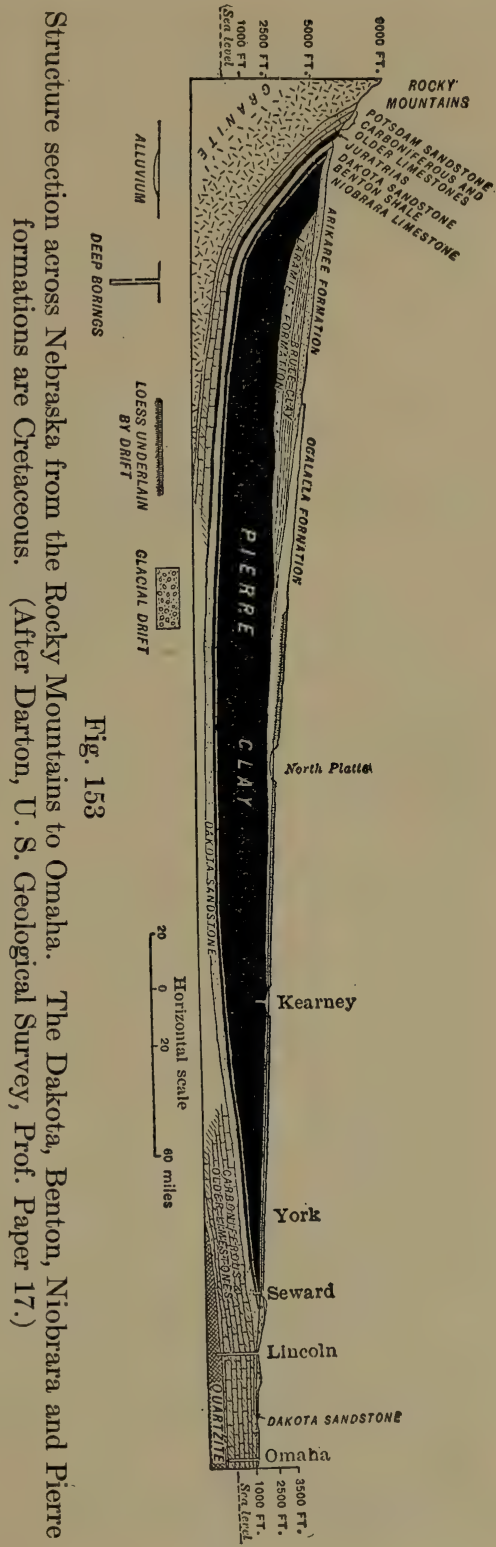


may be truly said to have had their beginning at that time, although their existing altitude and relief features are largely due to later movements and erosion. Instead of folds, great thrust faults were sometimes developed, a fine example being near the Canadian boundary, where Algonkian rocks were pushed about 7 miles over Cretaceous rocks. ${ }^{1}$

Another very important physical disturbance, accompanying the "Rocky Mountain Revolution" in the northwestern United States and southern British Columbia, was the inauguration of vast igneous (chiefly volcanic) activity, which continued almost unabated through the immediately succeeding Tertiary period.

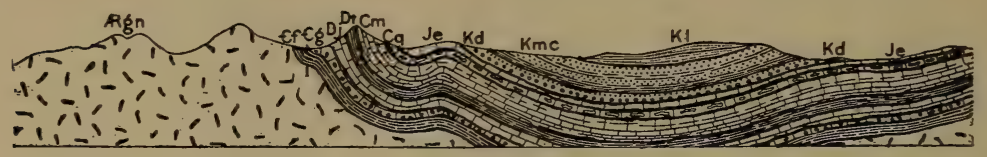

Fig. 154

Structure section in the Rocky Mountains of western Montana showing moderate folding of Cretaceous and older rocks. Argn, Archean; $C g, C f$, Cambrian; $D t, D j$, Devonian; $C q, C n$, Carboniferous; $K l, K m c, K d$, Cretaceous. (After Peale, U. S. Geological Survey, Folio 24.)

Volcanic and fissure eruptions took place on a grand scale, and lava-flows accumulated to a thickness of several thousand feet over an area of about 200,000 square miles. This was the time of greatest igneous activity in North America since pre-Cambrian days.

Close of the Period in the East. The Cretaceous Peneplain and its Uplift. - Turning our attention to the eastern part of the continent, we find that significant changes took place there also. In fact the area of the eastern United States was subjected to the greatest crustal disturbance since the "Appalachian Revolution" toward the close of the Paleozoic.

During all of the Mesozoic era most of the eastern portion of the United States, except the Coastal Plains during part of the time, was above sea water and undergoing erosion, so that, as a result of this very long time of wear, the region was reduced to the condition of a more or less perfect peneplain. It is known as the

1 It is possible that this fault was developed a little later, that is in early or middle Tertiary time. 
"Cretaceous Peneplain," because of its best development during the Cretaceous period (Fig. 155). This vast plain extended over the areas of the Appalachian Mountains, Piedmont Plateau, all of New York state, the Berkshire Hills, and the Green and White Mountains. Its most perfect development was in the northern Appalachians as, for example, from east-central Pennsylvania to Virginia, where hard and soft rocks alike had been so thoroughly

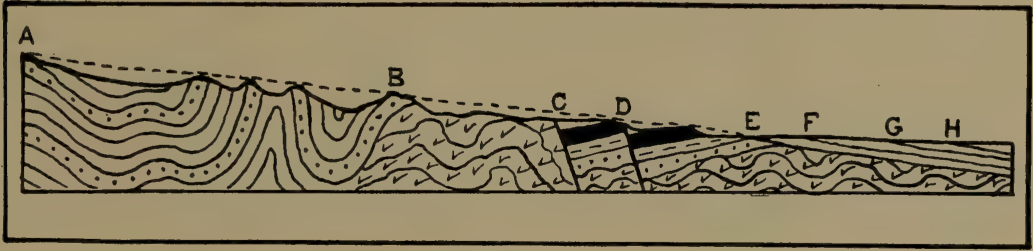

Fig. 155

Diagrammatic section through the Atlantic slope at about the latitude of northern New Jersey, showing the structures and relations of the various physiographic provinces as they now exist.

$A$ to $B$, folded Paleozoic strata of the Appalachian Mountains, with hard strata standing out to form the ridges; $B$ to $C$, Piedmont Plateau, consisting of highly folded and metamorphosed rocks of pre-Cambrian and early Paleozoic ages; $C$ to $E$, Triassic strata, showing tilting and faulting of the beds and mode of occurrence of a sheet of igneous rock $(D)$ which outcrops to form low ridges; $E$ to $H$, Coastal Plain, consisting of comparatively thin sheets of unconsolidated sediments; $E$ to $F$, Cretaceous beds; $F$ to $G$, Tertiary beds; $G$ to $H$, Quaternary beds; $H$, present coast line.

The dotted line represents the peneplain character of the surface, except for the tilting, toward the close of the Mesozoic era. (After W. J. Miller, N.Y. State Mus. Bul. 168.)

cut down that no masses projected notably above the level of the low-lying plain.

Farther northward, however, over New York and western New England, its development was less perfect, so that certain masses of harder rock stood out more or less prominently above the general level of the plain.

As Berkey says: "The continent stood much lower than now. Portions that are now mountain tops anu'tede crests of ridges were then constituent parts of the rock floor of the peneplain not much above sea level. . . . The ridges and valleys, the hills, mountains, and gorges of the present were not in existence, 
except potentially in the hidden differences of hardness or rock structure. Such conditions prevailed over a very large region certainly all of the eastern portion of the United States." 1

The Cretaceous period was closed in eastern North America by a disturbance which produced an upwarp of this vast Cretaceous peneplain with maximum uplift of from 2000 to 3000 feet, following the general trend of the Appalachians and thence through northern New York and western New England. This upward movement was unaccompanied by any renewed intense folding of the strata, the effect having been to produce a broad dome sloping eastward and westward, and northward to the Gulf of St. Lawrence and southward to the Gulf of Mexico. The upward movement was, however, accompanied by the retreat of the sea from the Coastal Plain area, which thus accounts for the widespread unconformity there between the Cretaceous and the overlying Tertiary strata.

Another prominent effect of this great uplift was to revive the activity of the streams so that they once more became active agents of erosion, and the present major topographic features of the eastern United States have been largely produced by the erosion and dissection of this upraised Cretaceous peneplain. Where the peneplain was best developed, the typical Appalachian ridges and valleys, running parallel to the trend of the mountain range, are now beautifully shown. These valleys are the trenches of the upraised peneplain, while the ridges have developed along the belts of hard rock, their summits actually representing portions of the old peneplain surface (Fig. 155). These ridges all rise to the same general level for miles around, and as viewed from the summit of any one of them, the concordant altitudes give rise to what is called the "even sky-line," which is a most striking feature of the landscape. In New York state and western New England remnants of the upraised peneplain surface are also distinctly shown.

\section{Foreign Cretaceous}

Europe. - Toward the close of the Jurassic and about the beginning of the Crettiaceous, continental deposits were forming in parts of central and western Europe. Often these deposits grade from the Jurassic into the earliest Cretaceous. The Alpine 1 C. P. Berkey: N. Y. State Mus. Bull. 146, p. 67. 
region continued to be submerged under sea water. Soon after the beginning of the Cretaceous, a more or less interrupted marine transgression caused considerable areas of western and central Europe to become submerged, the deposits including both marine and non-marine beds. At the same time marine waters were more extended over the southern part of the continent. Map

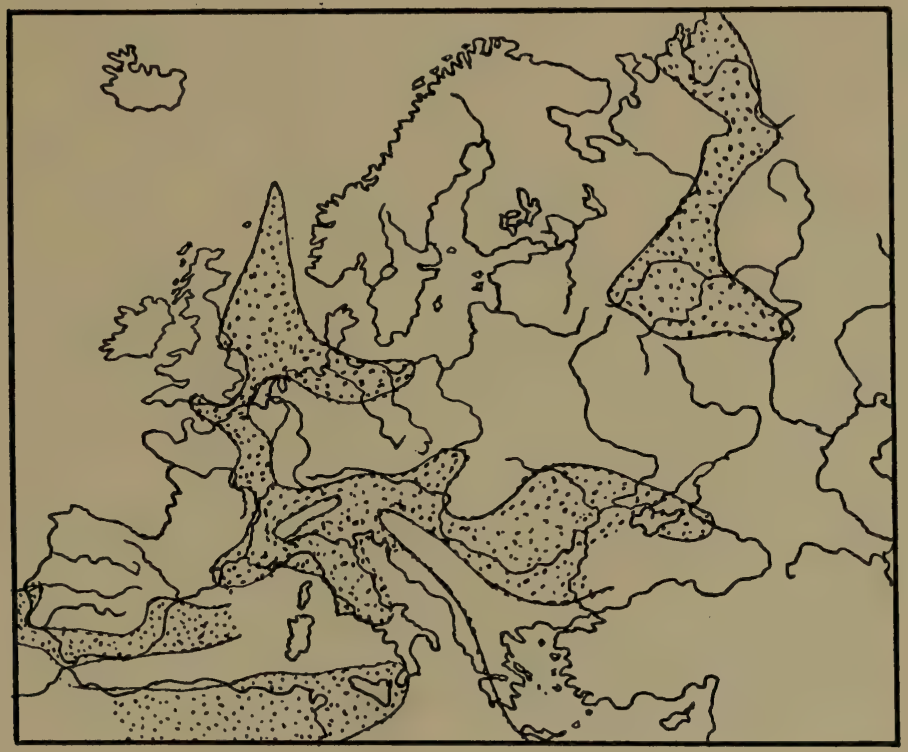

Fig. 156

Sketch map showing the relations of land and water in Europe during Lower Cretaceous time. (Slightly modified after De Lapparent.)

Fig. 156 affords a general picture of the relations of land and water at that time. In western and central Europe all types of common sedimentary rocks were formed, as well as some beds of coal in Germany. As would be expected, because of the more prevalent marine conditions in southern Europe, limestone was more commonly formed there. The conditions just described continued essentially till the close of the Lower Cretaceous, when only comparatively slight sea retrogressions took place, as proved by the fact that the Upper Cretaceous rocks usually rest conformably 
upon the Lower Cretaceous. Thus in Europe there is not such a sharp break between the Lower and Upper Cretaceous as in North America.

As in North America, so in Europe, Upper Cretaceous time was marked by a great transgression of the sea. This marine invasion, which started in the Lower Cretaceous, continued with

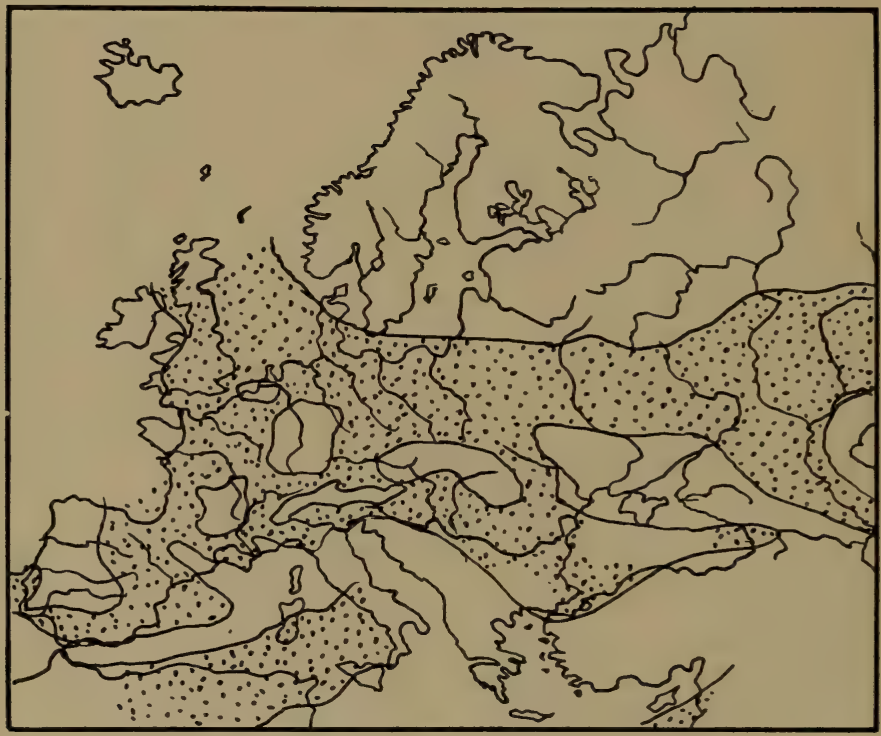

Fig. 157

Sketch map showing the relations of land and water in Europe during early Upper Cretaceous time. (Slightly modified after De Lapparent.)

only slight interruptions well into the Upper Cretaceous, when much of Europe, except Seandinavia and Russia, was submerged, as shown by map Fig. 157. As in the Lower Cretaceous, the most common rock to form in southern Europe was limestone. In central-western Europe all types of ordinary sediments are represented, but, as already stated, in northern France and southern England, the Cretaceous contains much chalk (e.g. Dover Cliffs) which is made up of Foraminiferal shells and which implies clear, 
if not fairly deep, sea water for its accumulation. Considerable greensand also occurs in the European Upper Cretaceous.

Toward the close of the period (Danian time) there were upward movements sufficient to increase the land areas and establish basins of non-marine sedimentation from Spain to and across the Alpine region as shown by the Cretaceous fresh-water deposits there.

Other Continents. - Rather extensive areas of Cretaceous occur in New Zealand and Australia, where the rocks are frequently coal bearing and an unconformity often separates the Lower and Upper portions of the system.

Southwestern Asia, India (in the Himalayas), China, Japan, and Siberia all show more or less extensive development of Cretaceous strata. Over northern Africa extensive areas of marine Cretaceous rocks show much of that region to have been submerged during the period. In South Africa Cretaceous rocks (especially the Lower) are considerably developed. A feature of special importance in India was the inauguration, late in the period, of one of the greatest times of vulcanism since the pre-Cambrian and quite comparable to that of western North America already referred to. This is known as the Deccan lava region where some 200,000 square miles are covered by lava flows whose aggregate thickness reaches several thousand feet.

In South America Cretaceous rocks are widely distributed, especially in Brazil, where a notable marine invasion occurred in the Upper Cretaceous, though in places only continental deposits were formed. East of the Andes the Lower Cretaceous rocks are mostly non-marine. High in the eastern Andes and in southern Patagonia marine Upper Cretaceous strata are known. Toward the close of the period came the great orogenic disturbance, accompanied by much volcanic activity, in the Andes Mountains district.

\section{Climate}

As would be expected because of the unusually extensive epicontinental seas, the climate of the period seems to have been mild to warm and pretty uniform but with some distinction of climatic zones. The fossil evidence (e.g. plants in the Cretaceous of Greenland) indicates mildness of climate even within the Arctic circle. 


\section{Economic Products}

Coal beds of moderate extent and value are known in the Lower Cretaceous rocks of Alaska, British Columbia, Australia, and Germany.

Coal is extensively developed in the later Cretaceous of the western interior region of the United States. It is estimated that fully 100,000 square miles are underlain with chiefly lignitic and bituminous coals as well as a little anthracite coal. Considerable Cretaceous coal also occurs in Australia and New Zealand.

The greensands (glauconitic) of the Atlantic Coastal Plain, especially in New Jersey and Virginia, were formerly extensively used as land fertilizers on account of their phosphoric acid content.

A heavy production of petroleum has been obtained from the Cretaceous strata of Texas, particularly in the vicinity of Beaumont. Both oil and gas are obtained from the Cretaceous in Louisiana and Wyoming.

Cretaceous limestones are quarried in Kansas, Nebraska, and Iowa for building stone.

The most important sulphur deposits in the United States occur in rocks of Cretaceous age in Louisiana.

The vast supply of underground water obtained from the Cretaceous (Dakota) sandstone in the Great Plains region is worthy of special mention. Much artesian water is also derived from Cretaceous beds in the Atlantic and Gulf Coastal Plain. In the regions just mentioned the water is held under pressure in porous sandstone by overlying impervious clay or shale.

\section{Life of the Cretaceous}

Plants. - Early in the period the plants were very much like those of the preceding Mesozoic periods, the dominant types still having been Ferns, Equiseto, Cycads, and Conifers.

Among the Gymnosperms, which were distinctly subordinate and a good deal like those of the present day, a feature of special interest was a considerable development of the genus Sequoia which is still represented by the so-called "Big Trees" and giant Redwoods of California.

Before the Cretaceous, Angiosperms are not definitely known to have existed, but in North America there can be no possible 
doubt of their presence - both Monocotyledons and Dicotyledons - even in late Lower Cretaceous time. By the close of the period the Angiosperms had developed so phenomenally as to attain a position of supremacy among plants, which position they have maintained ever since. This comparatively sudden appearance and remarkable development of the Angiosperms "was one of the most important and far-reaching biologic events the world has known. ... So far as we know, this flora appears to have

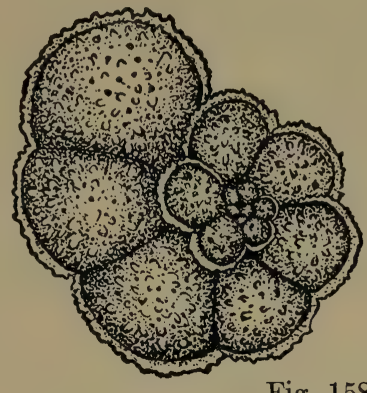

Fig. 158

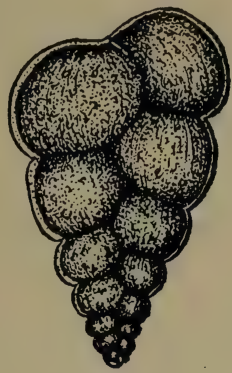

Cretaceous Foraminifers, greatly enlarged. (After Calvin, from Le Conte's "Geology," permission of D. Appleton and Company.) had its origin in eastern or northeastern North America, in the Patapsco division of the Potomac series. Although the great ma-

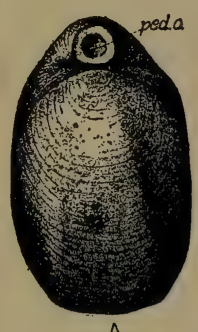

A

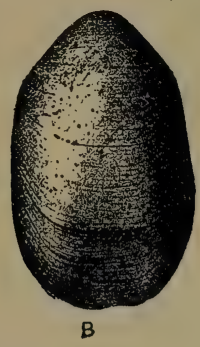

Fig. 159

A Cretaceous Brachiopod, Terebratula harlani. Note the curved hinge line. (From Shimer's "Introduction to the Study of Fossils," courtesy of The Macmillan Company.)

jority of the plants found in association in these beds, both as regards species and individuals, still belonged to lower Mesozoic types, such as Ferns, Cycads, and Conifers, we find ancient if not really ancestral Angiosperms. . . . No sooner were they (Angiosperms) fairly introduced than they multiplied with astonishing rapidity and in the ... Raritan they had become dominant, the Ferns and Cycads having mostly disappeared and the Conifers having taken a subordinate position." 1 No present-day species existed, but, among the more modern genera were Oaks, Elms, Magnolias, Maples, Figs, Laurels, Palms, Grasses, etc.

1 F. H. Knowlton: In Outlines of Geologic History, by Willis and Salisbury, pp. 205-206. 
Later Cretaceous Angiosperms were remarkably uniform and widespread over the earth.

Protozoans. - The Foraminifers were perhaps more prolific than during any other period. Their tiny shells practically make up the great chalk beds, especially those of England, France, and the Gulf Coast of the United States.

Porifers, Cœlenterates, and Echinoderms. - Among these the Sponges were common; the Corals and Crinoids were not so common; while the Echinoids were abundant and diversified, including both the regular and the irregular forms. All these forms were quite modern in aspect.

Molluscoids. - Since these organisms had previously attained very much their present-day structures and subordinate position among the invertebrates, they require no special mention here.

Mollusks. - Pelecypods continued to be very abundant, with the same genera of the Oyster (Ostrea) family of the two preceding periods still prominent. In addition to these were many species of the characteristic genera Exogyra and Inoceramus (see Fig. 160). Many of the other genera, often of modern aspect, were also present.

Gastropods were enriched by the appearance of many modern genera.

Cephalopods. The Nautiloids had before this become greatly reduced, with only a comparatively few coiled forms of rather modern aspect left. Ammonoids continued to be very prominently represented as regards both numbers of species and individuals, especially by the Ammonites, of which more than 2000 species are known from the Mesozoic alone. Some Cretaceous Ammonites attained a diameter of several feet. During the Cretaceous many of the Ammonites showed a remarkable tendency to assume strange forms (Fig. 161). Some developed uncoiled shells; others spiral shapes; while still others were curved or actually straight (e.g. Baculites). Thus, externally at least, there was a reversion to the early Paleozoic forms, but in all cases they retained their complicated suture or partition structure. "These strange forms have been likened by Agassiz to death-contortions of the Ammonite family; and such they really seem to be..... From the point of view of evolution, it is natural to suppose that under the gradually changing conditions which evidently prevailed in Cretaceous times, this vigorous Mesozoic type would be com- 

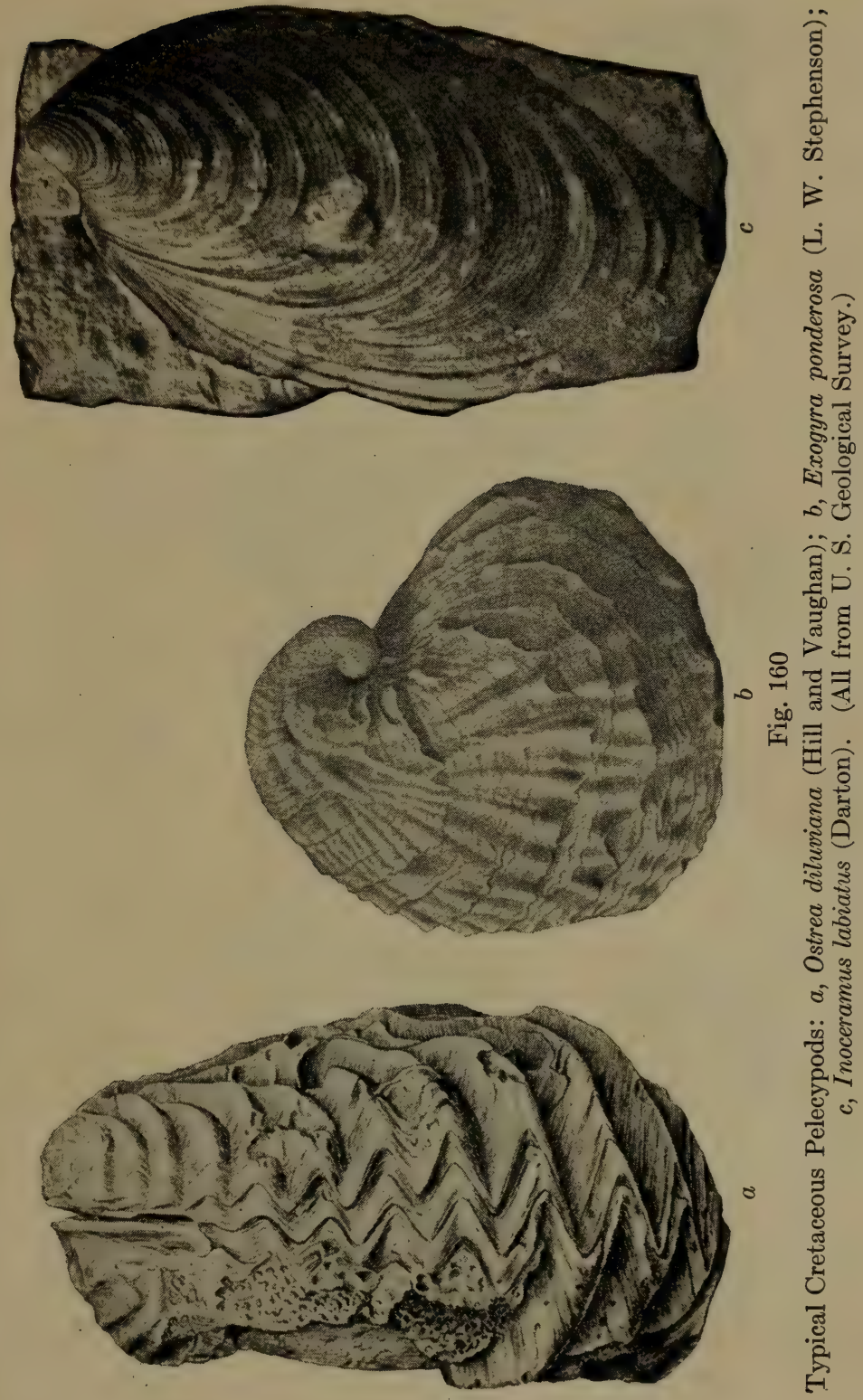

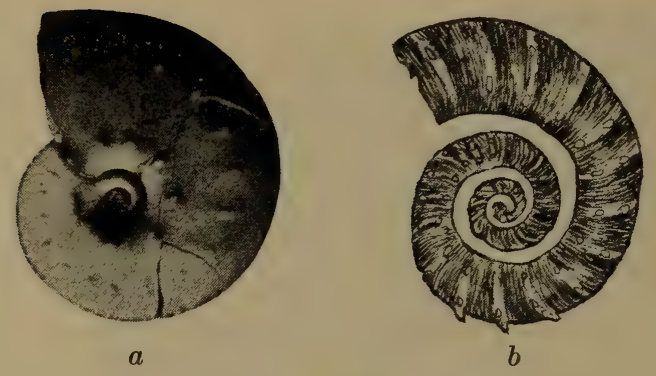

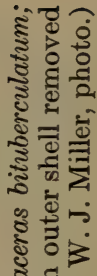

本武

स

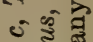

$\therefore$ 능
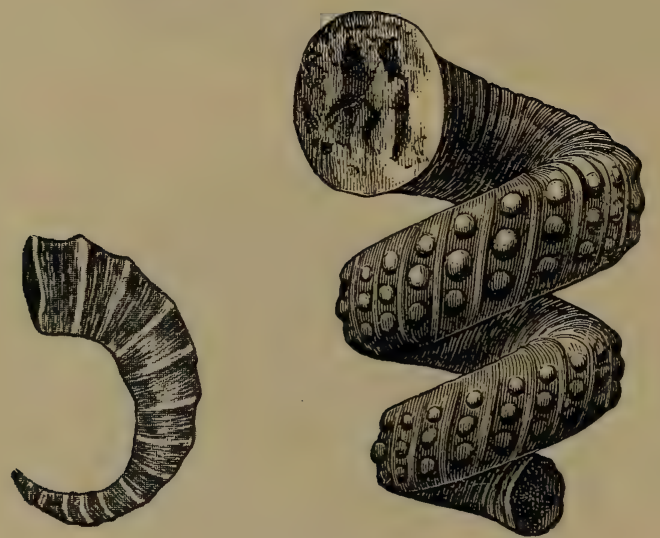

สิ

ริ

उ స్

ङ

ปู่

कहे द्रे

…

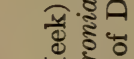

$-0 \sum_{0} \frac{\vec{s}}{\vec{s}}$

म० हु है

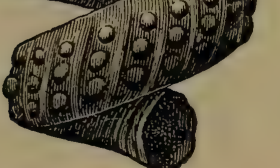

$d$
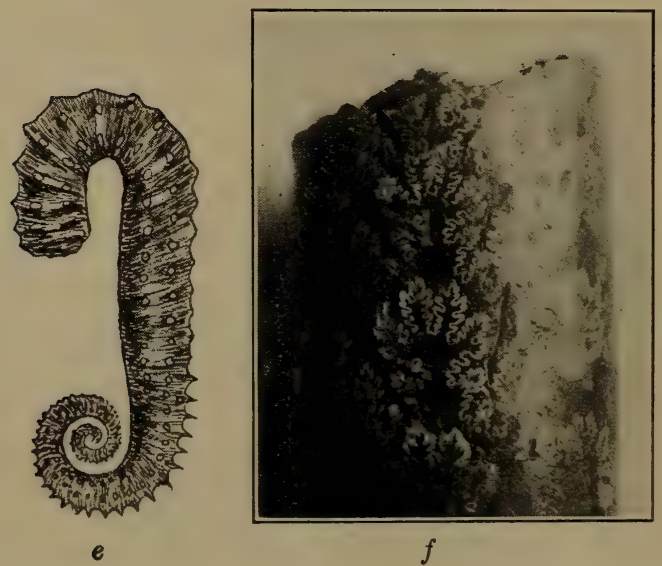

8.

ఫ్ త్ =

. స్

ॐ इ

ङ 0

है...

ర్తి

․․ㅇ

ㅎํ요

iि $\frac{\Phi}{5}$

류

हี స్తి

ह

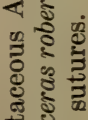

บั้

कु

है 
pelled to assume a great variety of forms, in the vain attempt to adapt itself to the new environment, and thus to escape its inevitable destiny. The curve of its rise, culmination, and decline reached its highest point just before it was destroyed. The wave of its evolution crested and broke into strange forms at the moment of its dissolution." 1 Very few if any Ammonites crossed the line into the early Cenozoic, and such an abrupt termination of so abundant and diversified a group of animals has rarely been equaled in the history of the animal kingdom. Belemnites still were abun-

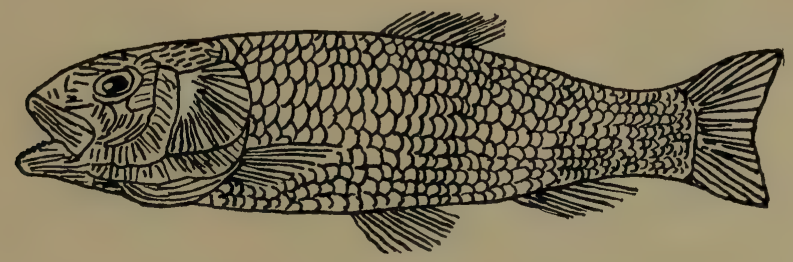

Fig. 162

A Cretaceous Teleost Fish, Osmeroides Lewesiensis, restored.

dant and these, too, showed a remarkable decline by the close of the Cretaceous.

Arthropods. - Broadly considered, the Cretaceous Arthropods were much like those of the Jurassic, though the short-tailed Decapods (Crabs) increased notably. Most of the Arthropods were of pretty modern aspect, though the species were quite different from those of today.

Fishes. - From the standpoint of evolution, a very important change took place among the Fishes. Sharks were common, having left an almost incredible number of fossil teeth. For the first time the Teleosts (typical bony Fishes), which were introduced in a small and primitive way in the Jurassic, predominated over the Ganoids. Many Cretaceous Teleosts belonged to families or genera which still exist, such as Salmon, Herring, Bass, Cod, etc. Other types were more characteristic of the time.

Amphibians. - These were of quite modern appearance and they occupied much the same relatively subordinate position that they do today.

1 J. Le Conte: Elements of Geology, 5th ed., pp. 499-500. 
Reptiles. - Most of the great characteristic groups of Jurassic Reptiles continued into the Cretaceous, while certain new forms, such as Mosasaurs, Triceratops, and Snakes, were added. Mesozoic Reptiles are discussed at the end of this chapter.

Birds. - During the long time between the Jurassic, when the first known Birds appeared, and the Upper Cretaceous, important evolutionary changes took place in this class of animals, though fossils of the interval are almost, if not wholly, absent. Cretaceous Birds were distinctly more advanced and modern in appear-

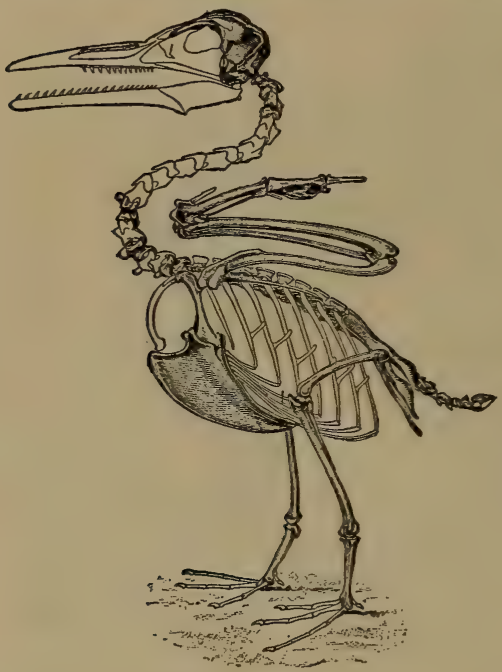

Fig. 163

A Cretaceous toothed Bird, Ichthyornis victor. Height, about 9 inches. (After Marsh.) ance than were those of the Jurassic. Thus the long, vertebrated tail of the earlier forms had become greatly shortened, and the only important primitive characteristic which they retained was the possession of teeth. Compared with modern Birds, they had much smaller brain cavities.

At least 30 species of Cretaceous Birds are known, all of these belonging to two great, though very different, groups (orders) e.g. Ichthyornis and Hesperornis. All appear to have been aquatic forms. The Ichthyornis types were powerful fliers, as proved by the strongly developed keel and wing bones. The teeth were set in distinct sockets. The structure (biconcave) of their vertebræ was quite distinctly reptilian. They averaged about the size of a pigeon (see Fig. 163).

Hesperornis comprised forms incapable of flight, but often of great size - five to six feet in length. In marked contrast with the Ichthyornis, these forms had powerfully developed legs which served as swimming paddles in these almost wholly aquatic forms. In every way they were adapted to rapid swimming. Their teeth were set in grooves instead of sockets. 
Mammals. - As in the earlier Mesozoic periods, the Cretaceous Mammals were small, primitive forms which still occupied a very subordinate position among the animals of the time.

\section{Mesozoic Reptiles}

The Mesozoic era has been appropriately called the "Age of Reptiles," since those animals were at once the most characteristic and powerful creatures of the time. So far as known, the first true Reptiles appeared in the Permian. During the Mesozoic they rose to great prominence, both in number of individuals and diversity and size of forms; reached their culmination in the midst of the era; and declined in a most remarkable manner toward the close of the era. During the Mesozoic the Reptiles ruled all fields - sea, land, and air.

"The advance from the Amphibian to the Reptile was a long forward step in the evolution of the Vertebrates. ... Yet in advancing from the Amphibian to the Reptile the evolution of the Vertebrate was far from finished. The cold-blooded, clumsy and sluggish, small-brained and unintelligent Reptile is as far inferior to the higher Mammals, whose day was still to come, as it is superior to the Amphibian and the Fish" (W. H. Norton).

\section{The Principal Extinct Mesozoic Reptile Groups}

The following grouping of the more characteristic, extinct Mesozoic Reptiles is not meant to be an exact scientific classi-
1. Enaliosaurs ("Sea-lizards")
(Swimming Reptiles).
1. Ichthyosaur ("Fish-lizard").
2. Plesiosaur ("Lizard-like").
3. Mosasaur ("Meuse River lizard")
(Later Mesozoic only).

1. Sauropod ("Lizard-footed")

(Not known from the Triassic).

2. Stegosaur ("Plated-lizard")

2. Dinosaurs ("Terrible-lizards")

(Walking Reptiles). e.g.

3. Pterosaurs ("Winged-lizards")

(Flying Reptiles).
(Not known from the Triassic).

3. Triceratops ("Three-horned face")

(Later Mesozoic only).

4. Theropod ("Beast-footed").

5. Ornithopod ("Bird-footed")

(Not known from the Triassic).

1. Pterodactyl ("Winged-finger").

2. Ramphorhyncus ("Beaked-snout"). 


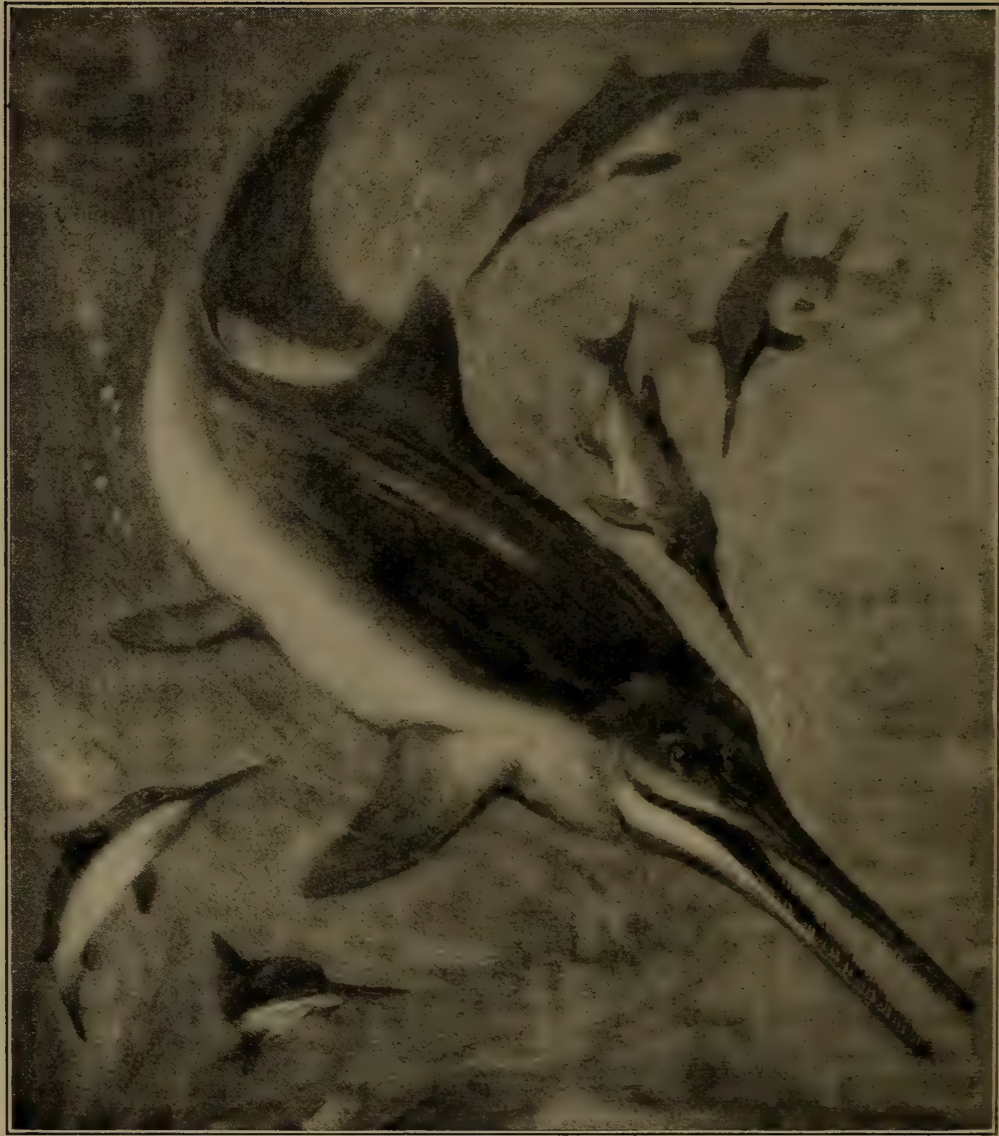

Fig. 164

A group of Ichthyosaurs, Ichthyosaurus quadricissus, of the Enaliosaur division of Mesozoic Reptiles. Maximum length 25 to 30 feet. Restoration by C. R. Knight, under the direction of H. F. Osborn. (By permission of the American Museum of Natural History.) 
fication, but rather it is a simple arrangement for convenience of elementary discussion. Unless otherwise stated the types mentioned ranged through the whole Mesozoic.

Enaliosaurs. - There are many known types of these swimming Reptiles, but only a few of the most typical and characteristic forms are chosen for description.

The Ichthyosaurs were Fish-like forms which ranged in length up to 25 or 30 feet. They had stout body, very short neck, and very large head (see Fig. 164). The head, sometimes 4 or 5 feet long, had an elongate snout in which as many as 200 large sharp teeth were set in grooves (not in sockets). Enormous eyes, sometimes over a foot in diameter, were protected by bony plates. A powerful tail with two lobes set vertically had the vertebral column extending through the lower lobe. The four limbs were perfectly converted into swimming paddles, thus strongly suggesting

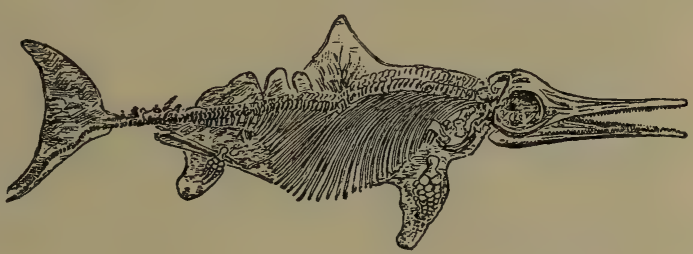

Fig. 165

A well-preserved Ichthyosaur found in Germany. (After Fraas.)

that these, as well as other Enaliosaurs, represent former land Reptiles which adapted themselves to a water environment much like certain Mammals of today, such as Whales and Dolphins. Fishes and Cephalopods were largely their prey, as proved by the fossil contents of their stomachs, no less than 200 Belemnite remains having been found in one specimen alone. Many remarkably preserved specimens of Ichthyosaurs have been discovered (Fig. 165), some with even the embryos plainly visible within the bodies. Ichthyosaurs ranged through the whole Mesozoic.

Plesiosaurs were less powerful forms than Ichthyosaurs, though they were usually longer, some having attained a maximum length of 40 to 50 feet (Fig. 166). A stout body, long slender neck, small head, short tail, and four powerful paddles were characteristic features. Sharp teeth were set in sockets (not grooves) in the jaws. With their slender, serpent-like necks, often 10 to 20 feet long, "the Plesiosaurs could lie motionless far below the surface, occasionally raising their heads above the water to breathe, 
or darting them to the bottom after their prey, which consisted chiefly of Fish" (W. B. Scott). Plesiosaurs ranged through the whole Mesozoic.

Mosasaurs were literal "sea-serpents" or carnivorous marine Reptiles which often reached a length of from 40 to 75 feet (Fig. 167). Though now wholly extinct, they were closely related to Snakes and Lizards in structure. The four limbs were converted

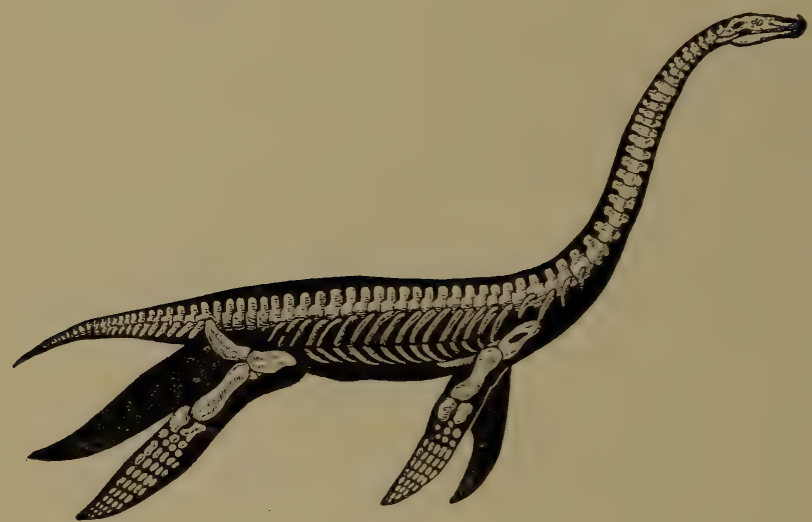

Fig. 166

A restored Plesiosaur, Plesiosaurus dolichodeirus, of the Enaliosaur division of Mesozoic Reptiles. Maximum length 40 to 50 feet. (From Le Conte's "Geology," courtesy of D. Appleton and Company.)

into short, stout, swimming paddles, and their jaws were set with sharp teeth. The relatively smaller head, long, slender body, and different tail structure distinguish the Mosasaurs from the Ichthyosaurs, as a comparison of the accompanying pictures will show. Mosasaurs existed during the latter portion only of the Mesozoic.

Dinosaurs. - These Mesozoic Reptiles comprised a great variety of forms both as regards shape and size. Only five of the more common and characteristic types have been selected for description.

The Sauropods were the largest of all Mesozoic Reptiles, and in fact they included the largest animals which ever trod the earth. Well-preserved specimens are known whose lengths are from 75 to 90 feet, and recently one has been discovered in Utah which it is 
thought will, when mounted, show a length of over 100 feet. It has been estimated that one of these large brutes must have weighed about 40 tons. Note the extremely long neck and tail, very small head, and strong bones of the four great legs. Thigh bones 7 feet long are known. They were five-toed and plantigrade, and doubtless walked with body well above ground (Fig. 168).

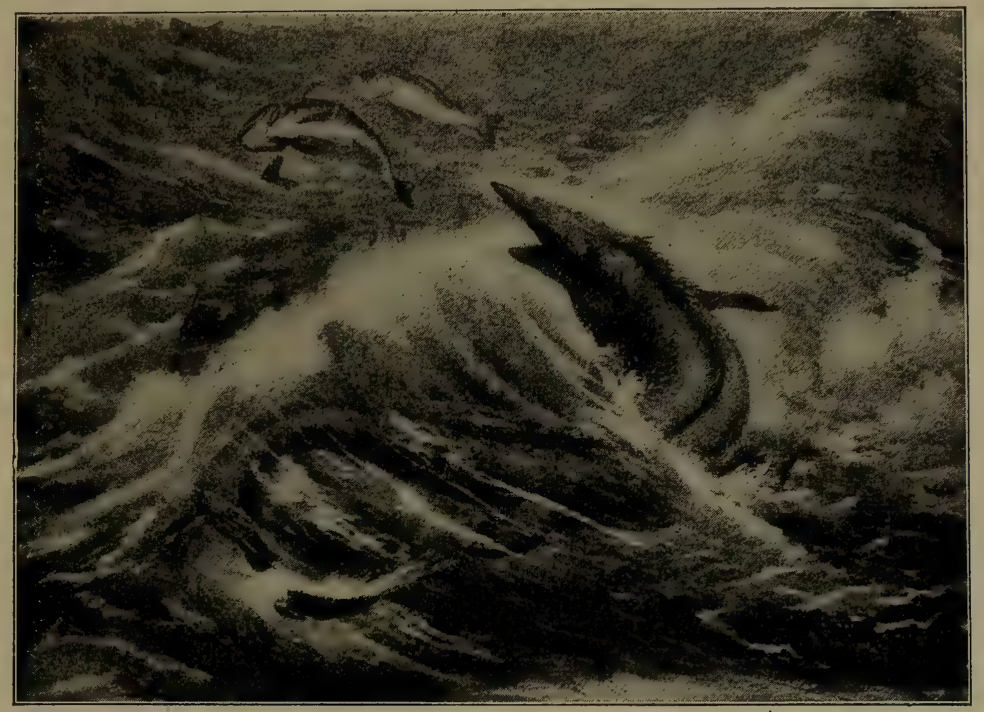

Fig. 167

A Mosasaur, Tylosaurus dyspelor, of the Enaliosaur division of Mesozoic Reptiles. Maximum length about 75 feet. Restoration by C. R. Knight under the direction of H. F. Osborn. (Courtesy of the American Museum of Natural History, from Scott's "Geology," by permission of The Macmillan Company.)

All were plant-eaters and provided with grinding teeth. Sauropods ranged through all the Mesozoic except the Triassic.

The Stegosaurs are so named because of the double row of great bony plates on the back of each of these most remarkable brutes (Fig. 169) which attained a maximum length of 30 to 40 feet. The long, powerful tail had several pairs of long spines toward the end instead of plates. As compared with the Sauropods the neck was short. They were quadrupedal, four-toed in front, and three-toed 
in the rear. All were plant-eaters. The brains of all Dinosaurs were almost incredibly small, even as compared with modern Reptiles, and "this was especially true of Stegosaurs. To make up for this deficiency they had an enormous enlargement of the spinal cord in the sacral region (i.e. over the hind legs). This sacral brain - if we may so call it - was ten to twenty times

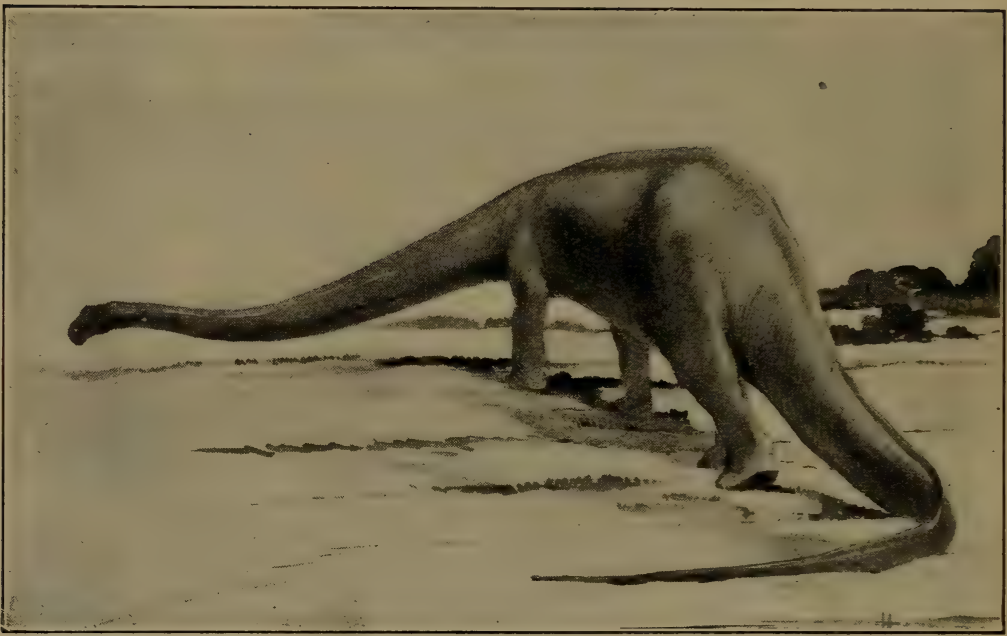

Fig. 168

The hugest of all known Dinosaurs, a Sauropod, Diplodocus. A mounted skeleton in the Carnegie Museum of Pittsburg measures 87 feet long. Restored by C. R. Knight under the direction of H. F. Osborn. (Courtesy of the American Museum of Natural History.)

bigger than the cranial brain. It was necessary in order to work the powerful hind-legs and tail" (J. LeConte). Stegosaurs existed through all of the Mesozoic except the Triassic.

Triceratops was another strange-looking creature, so named because of its three horns - two of great size just back of the eyes and a smaller one on the nose (see Fig. 170). The enormous flattened skull had a sharp beak in front. The skull extended backward into an immense hood or cape-like structure. According to Marsh they (Triceratops) had the largest heads and smallest brains of the Reptiles, and hence they must have been exceedingly stupid. Skulls 6 or 8 feet long have been found. The four legs 


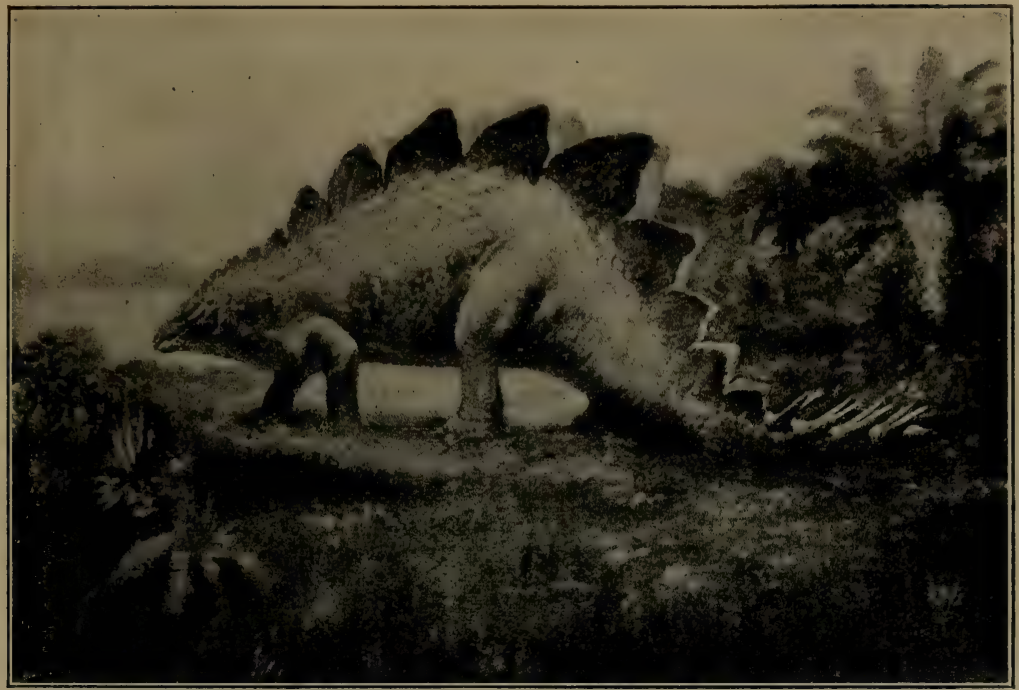

Fig. 169

A Stegosaur, an armored Dinosaur. Maximum length 30 to 40 feet. Restored by C. R. Knight. (By permission of F. A. Lucas and Doubleday, Page and Company, and courtesy of Henry Holt and Company.)

and the tail were massive and powerful. This creature attained a length of fully 25 feet, and it had a bulk about twice that of an

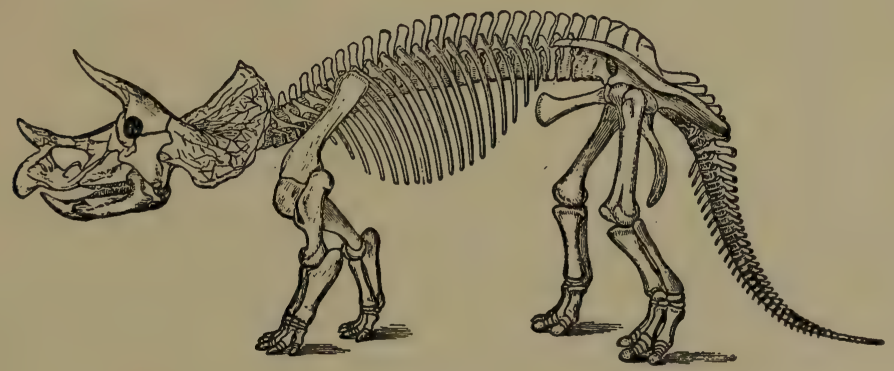

Fig. 170

A Triceratops, Triceratops prorsus, of the Dinosaur division of Mesozjic Reptiles. Maximum length 25 feet. (Skeleton restored by Marsh.) 
Elephant. It was a plant-eater and probably not as ferocious as it looked. Good specimens have been found in the western interior of the United States. Triceratops existed only during the Cretaceous period.

Theropods were carnivorous Dinosaurs, as proved by their numerous sharp teeth set in comparatively large heads (see Fig.

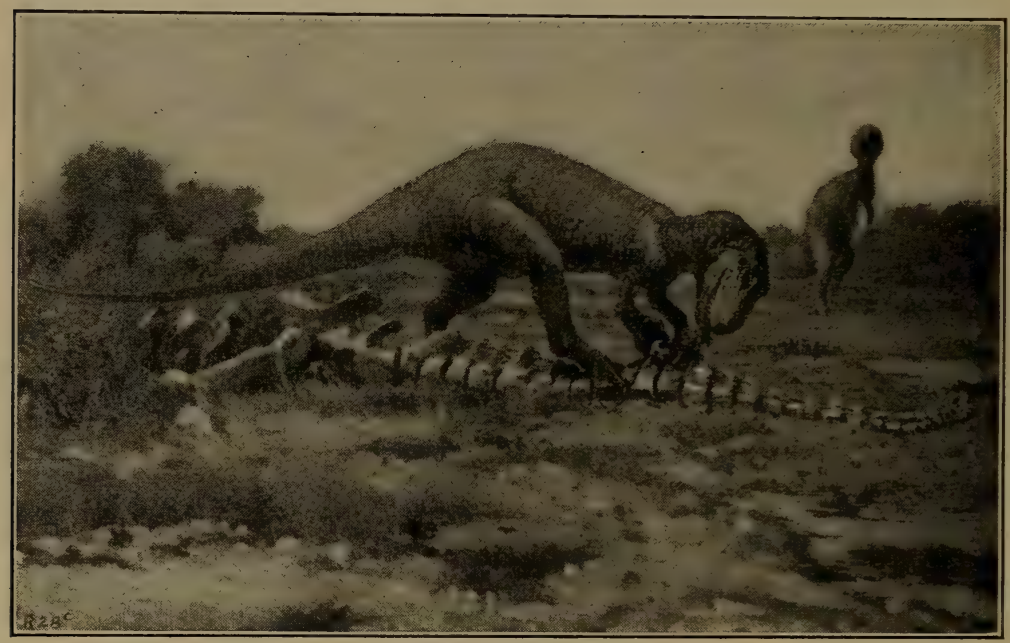

Fig. 171

Theropods, Allosaurus agilis, of the Dinosaur division of Mesozoic Reptiles. Restored by C. R. Knight, under the direction of H. F. Osborn. (Courtesy of the American Museum of Natural History.)

171). They were bipedal, that is they walked on two legs, the front limbs having been very small and used only for grasping. The toes were armed with sharp claws. The bipedal habit combined with the long, ponderous tail gave them a sort of Kangaroo aspect. The limb bones were hollow, thus suggesting a bird-like structure. In fact before it was known that the numerous tracks in the Newark sandstone of the Connecticut Valley were made by creatures of this sort, they were called "Bird-tracks." Theropods reached a length of fully 15 feet, and though much smaller than many other Dinosaurs, they were probably the most ferocious of all and more than likely preyed upon even the much larger plant- 
eaters. The Theropods lived through the whole Mesozoic, and they have been found in many parts of the world.

Ornithopods were in general appearance much like the Theropods, but they were certainly plant-eaters, as shown by the tooth structure (see Fig. 173). They were bipedal, the hind limbs having only three functional toes, giving a sort of bird-like track. The largest of these creatures measured 30 feet in length, and when walking they must have stood 15 or 20 feet high. Ornithopods ranged through all the Mesozoic except the Triassic.

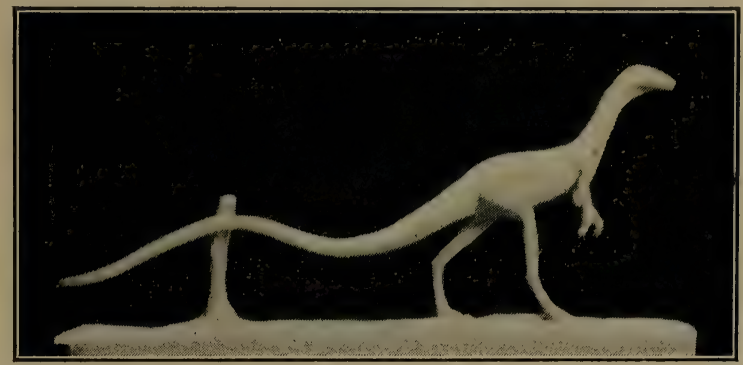

Fig. 172

A small two-legged Dinosaur, Podokesaurus holyokensis (Talbot), from the Triassic of Massachusetts. Length, less than 4 feet. Restored by Lull. (From a photograph by Mrs. E. H. Terry of the model at Mount Holyoke College.)

Pterosaurs. - These were literal "flying-dragons" in Mesozoic time. They varied greatly in size from about that of a sparrow to others with a spread of wing of 25 feet, which is about twice that of any modern Bird. Not only did they include the largest creatures which ever flew but, on account of their hollow bones, their skeletons were wonderfully light. One finger of each front limb was enormously lengthened to support the flying membrane, as shown in Fig. 174. The other fingers were armed with sharp claws. In general we may recognize two groups. One group was typified by the Pterodactyl, which had a short, stout body, short tail, and moderately long neck. The earlier Mesozoic forms were supplied with sharp teeth, while the Cretaceous-forms were mostly toothless. The other group, typified by the Rhamphorhyncus (Fig. 174), had long tail, and in one species at least 
the end of the tail was expanded into a sort of rudder. Many wonderfully preserved specimens of Pterosaurs have been found,

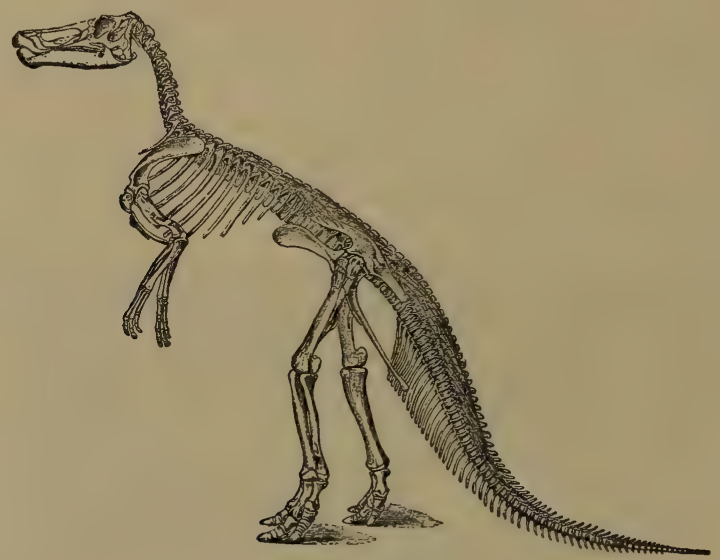

Fig: 173

An Ornithopod, Claosaurus annectens, of the Dinosaur division of Mesozoic Reptiles. Length over 20 feet. (Skeleton restored by March.)

some with even the wing membranes preserved. Pterosaurs ranged from the late Triassic to the close of the Mesozoic.

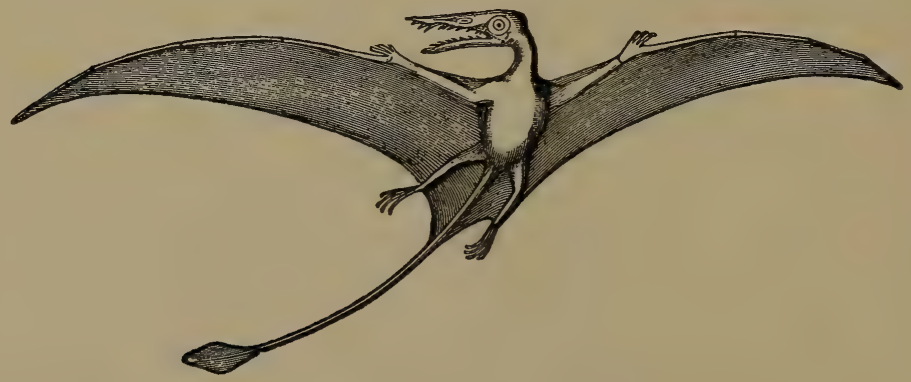

Fig. 174

A Rhamphorhynchus of the Pterosaur division of Mesozoic Reptiles.

Spread of wing about 2 feet. (Restored by Marsh.) 


\section{The Principal Surviving Mesozoic Reptile Groups}

Though overwhelmed by the Reptiles above described and of less peculiar interest because they represent groups still living, certain other Mesozoic Reptiles deserve brief mention.

Turtles date back at least to the middle Triassic, and even those very early forms clearly showed the familiar structure which easily separates them from other Reptiles.

Lizards are known even from the Triassic, and, though they ranged through the Mesozoic, they were always small and comparatively rare.

Crocodiles made their first appearance in the Jurassic, and some were marine forms. In appearance they resembled the modern Gavial of India, particularly as regards the long, slender snout. Crocodiles were numerous from the Jurassic to the end of the Mesozoic.

Snakes are not known to have appeared till late in the Cretaceous, and those early forms were small and comparatively rare. 


\section{CHAPTER XVII}

\section{SUMMARY OF MESOZOIC HISTORY}

Although the Mesozoic was quite certainly shorter than the Paleozoic, it must, nevertheless, have had a duration of at least some millions of years. As the name indicates, the Mesozoic was the era of transition between the Paleozoic and the Cenozoic. Eastern North America had been to a large degree completed at the time of the Appalachian Revolution, except for the addition of the Atlantic and Gulf Coastal Plain belts. In western North America, however, profound physical geography changes took place, bringing that part of the continent almost to its present condition, as regards relations of land and sea, only near the close of the Mesozoic. The life of the Mesozoic, too, was distinctly intermediate in character, those of the great groups of characteristic Paleozoic organisms which did continue into the Mesozoic having become extinct during the era, while many more modern groups showed great development during the era. Certain other important groups of organisms like the Cycads, Ammonites, and Reptiles, were eminently characteristic of the Mesozoic and reached their culmination during the era.

\section{Mesozoic Rocks}

The late Triassic stratified rocks of the Atlantic Coast are sandstones, conglomerates, and shales, mostly of continental origin, though in part at least probably of estuarine origin. Rocks of the Triassic in the western interior are chiefly the Red Beds (shales, sandstones, and limestones), with more or less salt and gypsum, of terrestrial or lacustrine origin. On the Pacific Coast the strata are of true marine origin and they consist of all sorts of typical sediments.

Jurassic strata are wholly confined to the western interior and Pacific borders, where they are all typical marine sediments, except the earlier Jurassic beds of the western interior, which are of continental origin and probably also include some Red Beds. 
Lower Cretaceous strata occur on the Atlantic and eastern Gulf coasts, where they consist almost entirely of unconsolidated sands and clays of continental origin. The Lower Cretaceous strata in the Texan region are made up chiefly of more or less consolidated sands, sandstones, and chalky limestones of marine origin, with continental deposits at the base. In the western interior regions of both the United States and Canada, the strata rather doubtfully of this age are probably of continental origin. On the Pacific Coast there are great thicknesses of marine Lower Cretaceous strata of rather restricted occurrence.

Upper Cretaceous deposits of the Atlantic and eastern Gulf regions are mostly sands, clays, marls, and greensands, with some chalky limestones toward the south. These are very largely of marine origin. In Texas and the western interior the Upper Cretaceous beds are there mostly marine sandstones, shales, and chalky limestones, though some continental deposits (including coal) also occur, especially in the latest Cretaceous. On the Pacific Coast typical marine beds occur.

Some igneous rocks of Triassic age occur on the Atlantic Coast, while great quantities of Cretaceous igneous rocks occur in the Pacific northwest.

In general the thickness of the Mesozoic group of rocks is not nearly as great as that of the Paleozoic, but more locally remarkable thicknesses of strata are represented in even single systems, as in the case of the Triassic beds of the Atlantic border $(10,000$ to 15,000 feet thick), or the Lower Cretaceous beds of the Pacific border (fully 26,000 feet thick).

\section{Physical History}

Relations of Land and Sea. - Throughout the era, except during the Cretaceous, North America was mostly dry land, thus being in marked contrast with the Paleozoic condition of the continent. The eastern half or two-thirds of the continent, except the Atlantic and Gulf borders, was continually dry land, while the western side of the continent was subject to varying marine, estuarine, and lacustrine conditions. The reader should review the paleogeographic maps.

At the opening of the Mesozoic era, or Triassic period, eastern North America was all dry land; continental (partly lacustrine) 
deposits were forming in the western interior of the United States; and the Pacific border was mostly occupied by marine waters. Later in the Triassic the same conditions prevailed in the west, but long, narrow troughs were formed along the Atlantic side in which were accumulated the thick continental and estuarine (Newark) deposits. Map figure 123 shows the condition of the continent at that time. At the close of the Triassic, or beginning of the Jurassic, there was enough crustal movement to convert the basins (Newark) of deposition in the east into dry land, while in the west the conditions appear to have continued as during the period.

During the earlier Jurassic the conditions just described in the west still prevailed, but in the later Jurassic a transgression of the sea took place from British Columbia southward over the Rocky Mountain region as far as northern Arizona (see map Fig. 133). During the whole Jurassic eastern North America was land undergoing erosion toward the peneplain condition.

During the Lower Cretaceous there was enough subsidence of the Atlantic and eastern Gulf borders to produce flood-plains, lakes, and marshes in which were deposited the Potomac series of sands, gravels, clays, etc. About the same time the continental (Trinity) deposits, followed by the marine Fredericksburg and Washita beds, were accumulating over the western Gulf (Texan) regions and southern western interior regions, and continental deposits were forming over the northern western interior region just west of the site of the Rockies. During the Lower Cretaceous on the Pacific border there were accumulated very thick marine deposits just west of the newly formed Sierras, especially in the Great Valley of California. Marine deposition also took place along some of the coast north of California.

The Lower Cretaceous closed, or the Upper Cretaceous opened, with the eastern part of the continent all undergoing erosion; a continuance of marine waters over the western Gulf (Texan) and southern western interior regions; and some deformation (folding and faulting) of the strata in parts of the Coast Range district.

At the opening of the Upper Cretaceous the condition of the continent was essentially that just described for the close of the Lower Cretaceous. Early in the Upper Cretaceous, marine waters spread over practically all of the Atlantic and eastern Gulf Coastal Plain areas. At the same time "Appalachia," which had been so long persistent, became submerged, not again to reappear. The 
Texan and western interior areas were marked by the deposition of the largely continental (Dakota) sandstone early in the period. At the same time the western edge of the continent was submerged under the sea.

In later Upper Cretaceous time, the Atlantic Coast and eastern Gulf districts continued much as in the earlier Upper Cretaceous. The western Gulf and western interior districts, however, were marked by a vast transgression of the sea from the Gulf to the Arctic, while the Pacific border continued as earlier in the Upper Cretaceous. Map Fig. 151 shows the condition of the continent in this later Cretaceous time.

Mountain Making. - The Jurassic period was closed in the west by the "Sierra Nevada Revolution," when strata of great thickness were folded into mountains along the present site of the Sierras and probably also the Cascades. There was also some deformation in the region of the Coast Ranges.

The Mesozoic era was closed by one of the most profound physical disturbances in the post-Algonkian history of North America, if not in the world, - the "Rocky Mountain Revolution," - when strata were more or less deformed by folding and faulting throughout much of the Rocky Mountain system. At the same time the whole eastern side of the United States, including the Appalachians, which had been worn down to a peneplain, was distinctly upraised without renewed folding of the rocks.

Vulcanism. - While the later Triassic (Newark) sandstones were forming on the Atlantic Coast, there were considerable intrusions and extrusions of igneous rocks, now represented by such masses as the Palisades of the Hudson and the Holyoke Range of Massachusetts.

Accompanying the Rocky Mountain Revolution there were tremendous outpourings of lava in the northwestern portion of the United States.

\section{Climate}

The character and distribution of organic remains, both plant and animal, pretty clearly prove the climate of the Mesozoic to have been mild to possibly even warm temperate, with an appreciable distinction of climatic zones, though not at all comparable to those of the present. Warm temperate plants of the Cretaceous are found even within the Arctic circle. 
TABULAR SUMMARY OF MESOZOIC LIFE

\begin{tabular}{|c|c|c|c|c|}
\hline & Plants & Protozoans & $\begin{array}{l}\text { Porifers and } \\
\text { Calenterates }\end{array}$ & Echinoderms \\
\hline Cretaceous & $\begin{array}{l}\text { Cryptogams and } \\
\text { Gymnosperms: } \\
\text { Much like earlier } \\
\text { Mesozoic. } \\
\text { Angiosperms: Mono- } \\
\text { cotyledons and Di- } \\
\text { cotyledons attain } \\
\text { supremacy among } \\
\text { plants. }\end{array}$ & $\begin{array}{l}\text { Foraminifers } \\
\text { and Radiolari- } \\
\text { ans: Profuse. }\end{array}$ & $\begin{array}{l}\text { Sponges and Corals: } \\
\text { Abundant and } \\
\text { much like those of } \\
\text { the Jurassic. }\end{array}$ & $\begin{array}{l}\text { Crinoids: Greatly } \\
\text { reduced. } \\
\text { Asterozoans: Pres- } \\
\text { ent. } \\
\text { Echinoids: Both } \\
\text { regular and irregu- } \\
\text { lar forms common. }\end{array}$ \\
\hline JuRassic & $\begin{array}{l}\text { Cryptogams: Much } \\
\text { like Triassic. } \\
\text { Gymnosperms: Cy- } \\
\text { cads culminate; } \\
\text { Conifers more mod- } \\
\text { ern in aspect. } \\
\text { Angiosperms: } \\
\text { Monocotyledons? }\end{array}$ & $\begin{array}{l}\text { Foraminifers } \\
\text { and } \\
\text { Radiolarians: } \\
\text { Very abundant } \\
\text { and highly di- } \\
\text { versified. }\end{array}$ & $\begin{array}{l}\text { Sponges: Very } \\
\text { abundant. } \\
\text { Corals: Abundant } \\
\text { and all are Hexa- } \\
\text { coralla of modern } \\
\text { appearance. }\end{array}$ & $\begin{array}{l}\text { Crinoids: Very pro-- } \\
\text { fuse and notably } \\
\text { large. } \\
\text { Asterozoans: Pres- } \\
\text { ent and of modern } \\
\text { appearance. } \\
\text { Echinoids: Abun- } \\
\text { dant, with first ir- } \\
\text { regular, more mod- } \\
\text { ern forms. }\end{array}$ \\
\hline Triassic & $\begin{array}{l}\text { Thallophytes. } \\
\text { Bryophytes. } \\
\text { Pteridophytes: Ly- } \\
\text { copods almost ex- } \\
\text { tinct; Ferns and } \\
\text { Equisetæ common. } \\
\text { Gymnosperms: Cor- } \\
\text { daites become ex- } \\
\text { tinct; Cycads and } \\
\text { Conifers prominent. }\end{array}$ & $\begin{array}{l}\text { Foraminifers } \\
\text { and } \\
\text { Radiolarians: } \\
\text { Present. }\end{array}$ & $\begin{array}{l}\text { Sponges: Present. } \\
\text { Corals: Very abun- } \\
\text { dant, especially the } \\
\text { more modern Hexa- } \\
\text { coralla; ancient } \\
\text { Tetracoralla be- } \\
\text { come extinct. }\end{array}$ & $\begin{array}{l}\text { Crinoids: Common. } \\
\text { Asterozoans: } \\
\text { Present. } \\
\text { Echinoids: Common } \\
\text { and all are regular } \\
\text { forms of ancient as- } \\
\text { pect. }\end{array}$ \\
\hline
\end{tabular}

In early Mesozoic time arid climate conditions must have prevailed over the western interior of the United States, as shown by the Red Beds with some salt and gypsum.

There is no good evidence of glaciation in the Mesozoic.

\section{Organic History}

"The life of the Mesozoic constitutes a very distinctly marked assemblage of types, differing both from their predecessors of the Paleozoic and their successors of the Cenozoic. In the course of the era the plants and marine invertebrates remain throughout the era very different from later ones. Even in the Vertebrates, however, the beginning of the newer order of things may be traced." ${ }^{1}$

${ }^{1}$ W. B. Scott: Introduction to Geology, 2nd ed., p. 655. 


\section{TABULAR SUMMARY OF MESOZOIC LIFE-Continued}

\begin{tabular}{|c|c|c|c|}
\hline Molluscoids & Mollusks & Arthropods & Vertebrates \\
\hline $\begin{array}{l}\text { Bryozoans: } \\
\text { Present. } \\
\text { Brachiopods: Only } \\
\text { a few genera and } \\
\text { species remain, } \\
\text { and these are of } \\
\text { pretty modern as- } \\
\text { pect. }\end{array}$ & $\begin{array}{l}\text { Pelecypods and Gastro- } \\
\text { pods: Abundant and sim- } \\
\text { ilar to Jurassic, but more } \\
\text { modern. } \\
\text { Cephalopods: Still very } \\
\text { abundant and mueh like } \\
\text { those of the Jurassic with } \\
\text { uncoiled to even straight } \\
\text { Ammonoids (e.g. Bacu- } \\
\text { lites) common. Ammo- } \\
\text { noids become nearly ex- } \\
\text { tinct. Dibranchs com- } \\
\text { mon. }\end{array}$ & $\begin{array}{l}\text { Eucrustaceans: Much } \\
\text { like Jurassic, but } \\
\text { Brachyurans (Crabs) } \\
\text { greatly increased. } \\
\text { Insects: Much like } \\
\text { Jurassic but even } \\
\text { more modern types } \\
\text { appear. }\end{array}$ & $\begin{array}{l}\text { Fishes: Selachians abun- } \\
\text { dant; Dipnoans rare; } \\
\text { Ganoids common; Tele- } \\
\text { osts predominate. } \\
\text { Amphibians: Very sub- } \\
\text { ordinate. Abundant and } \\
\text { Reptiles: Abund } \\
\text { much like Jurassic; first } \\
\text { Snakes. } \\
\text { Birds: Much increased. } \\
\text { Mammals: Simple, rare. }\end{array}$ \\
\hline $\begin{array}{l}\text { Brachiopods: Still } \\
\text { more diminished } \\
\text { and not many spe- } \\
\text { cies. }\end{array}$ & $\begin{array}{l}\text { Pelecypods: Similar to } \\
\text { Triassic, but increased. } \\
\text { Gastropods: Ditto. } \\
\text { Cephalopods: Nautiloids } \\
\text { of coiled forms only and } \\
\text { common; Ammonoids } \\
\text { (e.g. Ammonites) culmi- } \\
\text { nate, with development } \\
\text { of some uncoiled to even } \\
\text { straight forms; Di- } \\
\text { branchs become profuse } \\
\text { (e.g. Belemnites). }\end{array}$ & $\begin{array}{l}\text { Eucrustaceans: Ma- } \\
\text { crurans (e.g. Lob- } \\
\text { sters) common, and } \\
\text { Brachyurans (e.g. } \\
\text { Crabs) first appear, } \\
\text { though rare. } \\
\text { Insects: Abundant } \\
\text { and diversified; first } \\
\text { appearance of high- } \\
\text { est forms, e.g. Flies, } \\
\text { Ants and Bees. }\end{array}$ & $\begin{array}{l}\text { Fishes: Selachians com- } \\
\text { mon; Dipnoans rare; } \\
\text { Ganoids common; Tele- } \\
\text { osts first appear, but } \\
\text { rare. } \\
\text { Amphibians: Fossils? } \\
\text { Reptiles: Much like Tri- } \\
\text { assic, but more common } \\
\text { and varied. } \\
\text { Birds: First appear (e.g. } \\
\text { Archeopteryx). Mam- } \\
\text { mals: Simple, rare. }\end{array}$ \\
\hline $\begin{array}{l}\text { Bryozoans: } \\
\text { Present. } \\
\text { Brachiopods: } \\
\text { Greatly dimin- } \\
\text { ished and those } \\
\text { with curved-hinge } \\
\text { lines prevail for } \\
\text { the first time. }\end{array}$ & $\begin{array}{l}\text { Pelecypods and Gastro- } \\
\text { pods: Prominent and as- } \\
\text { sume more distinctly } \\
\text { modern aspect. } \\
\text { Cephalopods: Nautiloids } \\
\text { common, with straight } \\
\text { forms (Orthoceras) be- } \\
\text { coming extinct; Ammo- } \\
\text { noids common, with com- } \\
\text { plex sutures (e.g. Cera- } \\
\text { tites and Ammonites); } \\
\text { Dibranchs first appear. }\end{array}$ & $\begin{array}{l}\text { Eucrustaceans: Ma- } \\
\text { crurans (e.g. Lob- } \\
\text { sters) first appear. } \\
\text { Insects: Common } \\
\text { and mostly simpler } \\
\text { forms but first Bee- } \\
\text { tles appear. }\end{array}$ & $\begin{array}{l}\text { Fishes: Selachians, Dip- } \\
\text { noans and Ganoids much } \\
\text { as in late Paleozoic time. } \\
\text { Amphibians: Declining } \\
\text { but large. } \\
\text { Reptiles: Abundant and } \\
\text { varied, e.g. Enaliosaurs, } \\
\text { Dinosaurs, and Ptero- } \\
\text { saurs; first Turtles and } \\
\text { Lizards. } \\
\text { Mammals: First and rare. }\end{array}$ \\
\hline
\end{tabular}

Among plants the Ferns, Cycads, and Conifers predominated during the earlier Mesozoic, but later in the era the Angiosperms, including both Monocotyledons and Dicotyledons, first appeared and very soon predominated.

Among animals the absence of certain characteristic Paleozoic groups should be noted, such as Cystoids, Blastoids, Trilobites, and Eurypterids. Other Paleozoic groups continued into the early Mesozoic and then either became extinct or very greatly diminished such as the ancient Corals (Tetracoralla), Brachiopods, Orthoceras, and Amphibians. Some of the more important groups which made their first appearance in the Mesozoic were modern Corals (Hexacoralla), modern Echinoids (e.g. Sea-urchins), modern Eucrustaceans (e.g. Lobsters and Crabs), highest Insects, Teleost Fishes, 
primitive Birds, and small, primitive Mammals. Reptiles, which began in the very late Paleozoic, developed marvellously during the era, thus justifying the application of the term "Age of Reptiles" to the Mesozoic.

On the accompanying chart the author has brought together in concise form the salient facts regarding the life of the Mesozoic. In regular order, the principal successive changes in the subkingdoms and classes of plants and animals are graphically represented. 


\section{CENOZOIC ERA}

\section{CHAPTER XVIII}

\section{THE TERTIARY PERIOD}

\section{Origin of Name, Subdivisions, etc.}

The Cenozoic era is often called the "Age of Mammals" because, for the first time, these most highly organized of all animals became abundant and diversified and were masters of the land. Plants and animals both took on a decidedly modern aspect, with species of living organisms represented for the first time, some even in the early Cenozoic and many during the later portion of the era.

The name "Tertiary" has entirely lost its original significance, but has, nevertheless, become thoroughly fixed in the literature of geology. In the early days of the science, the whole known geological column was divided into three groups of rocks, and later into four groups, namely: Primary, Secondary, Tertiary, and Quaternary. After the discovery of rocks still older than these, the term Primary was replaced by Paleozoic; Secondary by Mesozoic; while Tertiary and Quaternary have been retained as subdivisions of the Cenozoic.

Following are the subdivisions of the Tertiary system now recognized as world-wide in application:

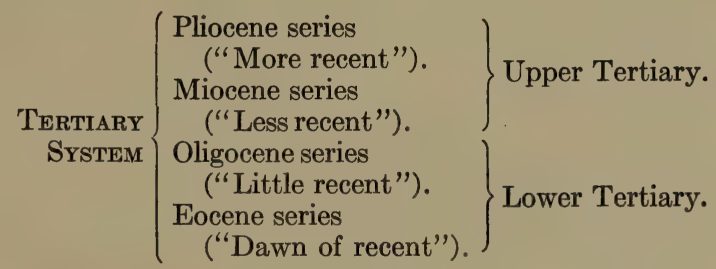

Sir Charles Lyell first divided the Tertiary into Eocene, Miocene, and Pliocene on the basis of percentage of living species represented in each series, there being very few in the earliest and a 
very large percentage in the latest series. Later the Oligocene was added by combining some of the uppermost Eocene with some of the lowermost Miocene, though in North America the term Oligocene has been but little used till very recently, and even now such strata are not always separately differentiated.

Following are the principal subdivisions of the Tertiary as now recognized in various parts of the United States:

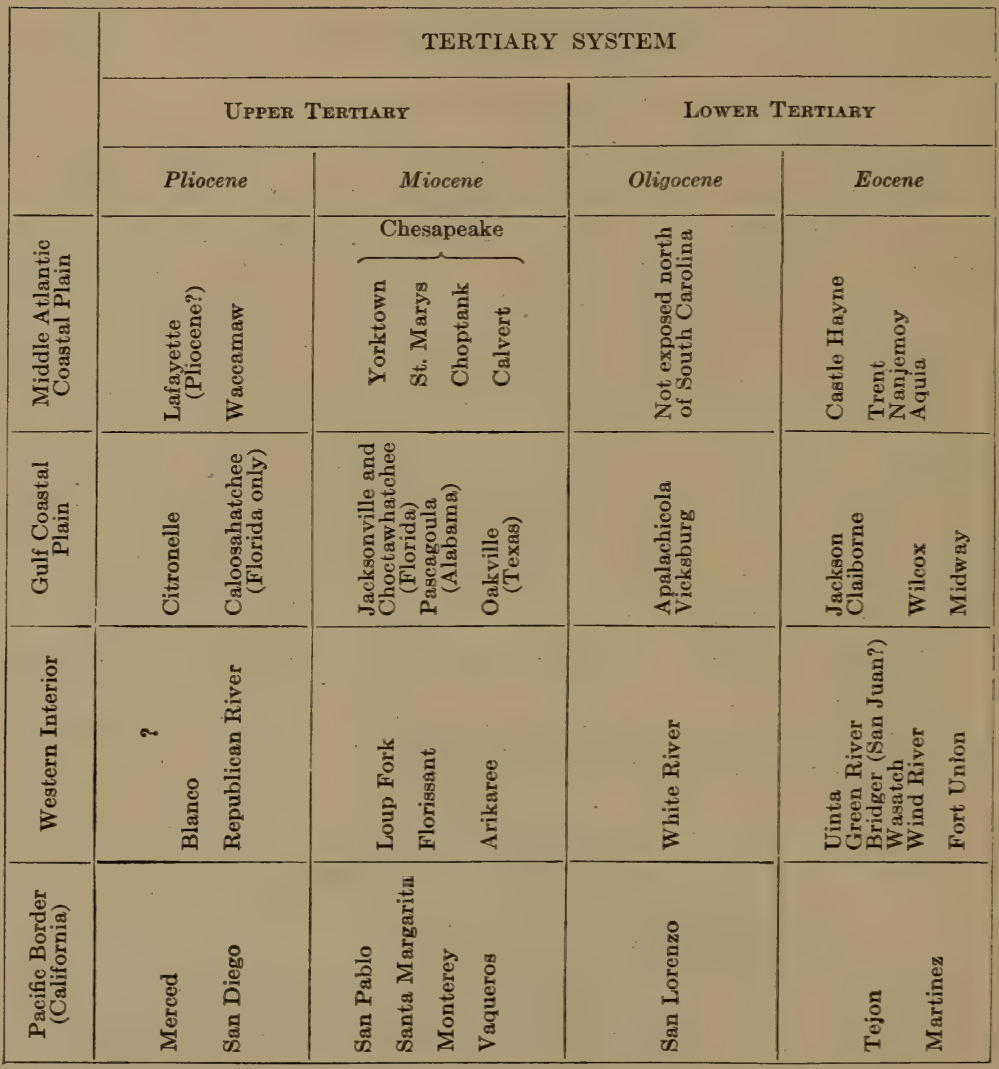

It should be distinctly understood that exact correlations of the various formations in these widely separated regions are not meant to be implied in the above table. 


\section{Distribution and Character of the Rocks}

General Distribution. - Lower Tertiary (Eocene and Oligocene) strata appear at the surface in North America over the areas indicated on map Fig. 175. Disregarding the countries south of

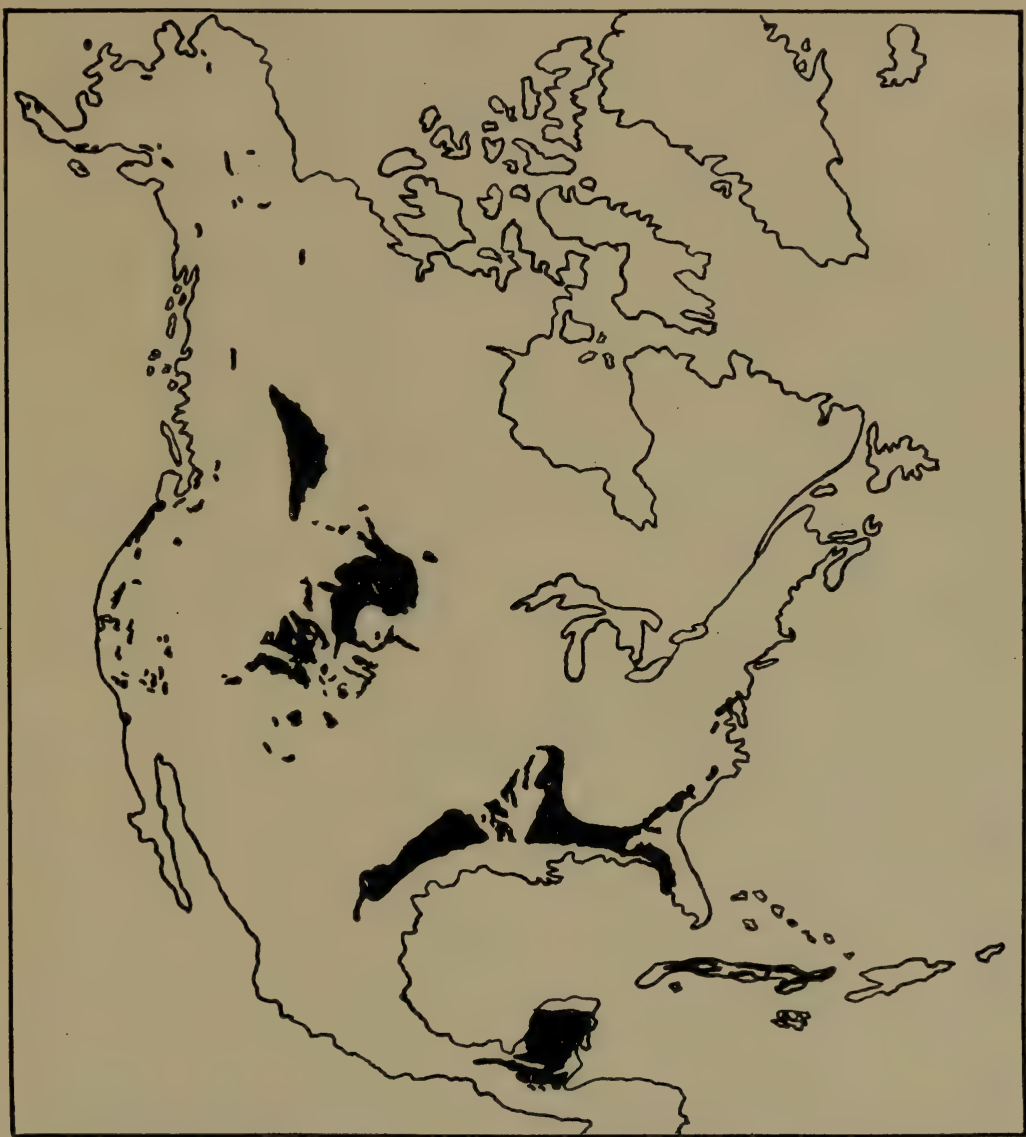

Fig. 175

Map showing the surface distribution (areas of outcrops) of Lower Tertiary (Eocene and Oligocene) strata in North America. Tertiary lavas are separately shown on map figure 184. (Modified by W. J. M. after Willis, U. S. Geological Survey.) 
the United States, there are, in general, four regions: Atlantic and Gulf Coastal Plain; western interior; Pacific Coast; and Alaska. The discontinuity of the areas on the Atlantic and Gulf Plain, especially the former, is due to the fact that later deposits overlap and conceal the Lower Tertiary strata in places. The Lower Tertiary strata extend oceanward or Gulfward under much or all of the Coastal Plain. In the western interior the numerous disconnected areas are chiefly due either to deposition in separate basins or removal of the strata from some places by erosion. On the Pacific Coast, Lower Tertiary strata appear mostly as small, narrow belts, because only the eroded edges of the upturned and folded rocks are visible in the mountains. Such strata are in reality much more extensively developed than these surface areas seem to indicate. There is no evidence that Lower Tertiary strata were deposited over any other parts of the continent than those above mentioned.

Upper Tertiary (Miocene and Pliocene) strata show a surface distribution as indicated on map Fig. 176. In general this distribution is much like that of the Lower Tertiary. On the Atlantic and Gulf Coastal Plain, it is quite the rule that the Upper Tertiary beds form a somewhat discontinuous belt between the continental margin and the belt of Lower Tertiary beds. Upper Tertiary strata are more extensive at the surface than Lower Tertiary on the Atlantic Coast and less extensive on the Gulf Coast. The margin of the continent, as well as much of Florida, are occupied by Quaternary deposits which are, mostly at least, underlain by the Upper Tertiary. In the western interior a large, nearly continuous area extends from northern Texas into South Dakota. The comparatively small, disconnected areas in the northwestern United States mostly represent deposition in separate basins. On the Pacific border of the United States the Upper Tertiary outcrops extensively as long, narrow bands, due to the fact that usually only the edges of the upturned strata are exposed. In British Columbia and Alaska Upper Tertiary rocks are only slightly developed. It is not known that late Tertiary strata ever occupied any other portions of the United States or Canada than those akiticis mentioned.

Atlantic Coastal Plain Strata. - Lower Tertiary (Eocene) strata are only slightly exposed to view, while those of Upper Tertiary (Miocene and Pliocene) age are extensively exposed in the 
Atlantic Coastal Plain. All the formations, except possibly the Lafayette, are there of marine origin and usually very fossiliferous.

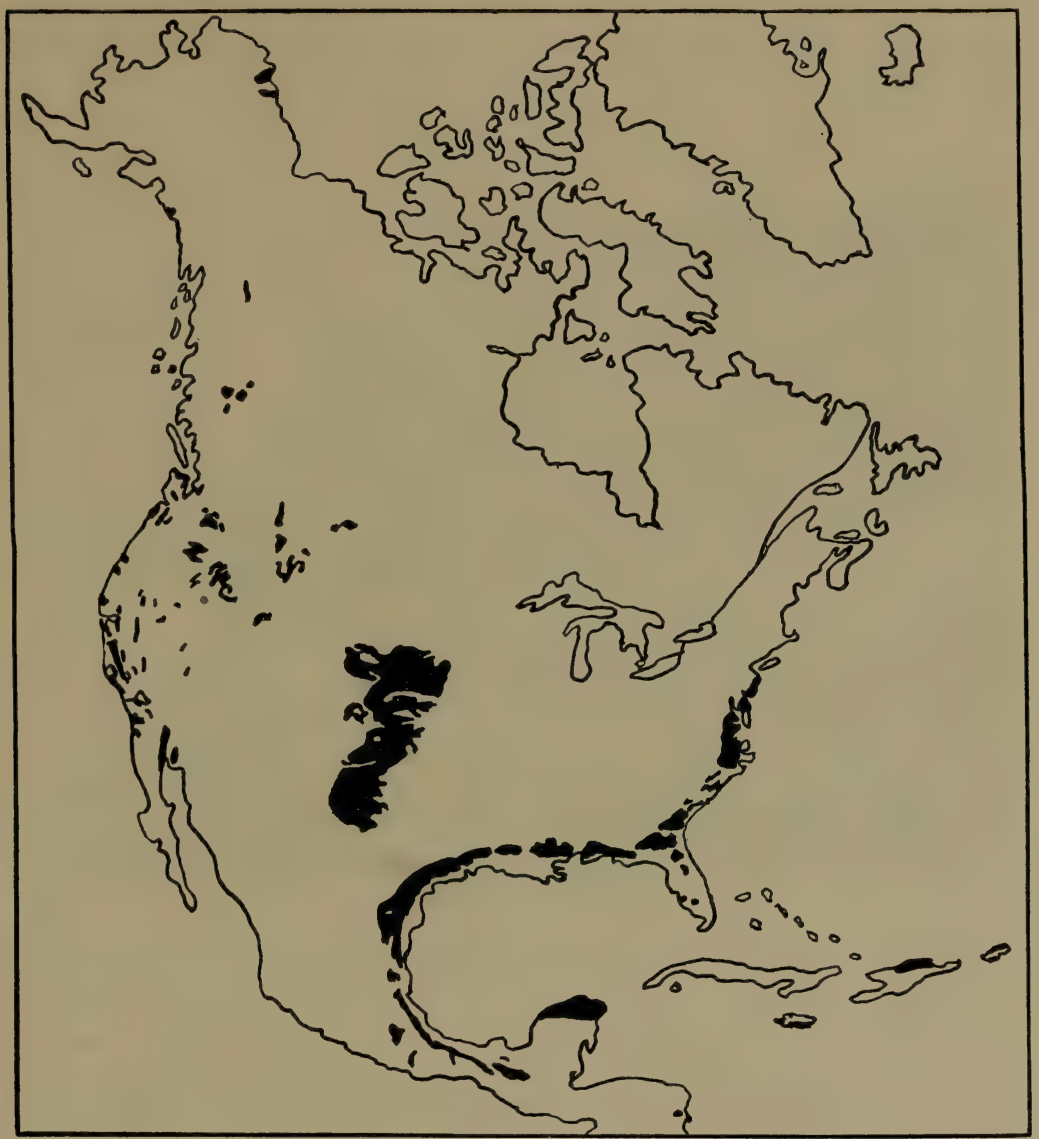

Fig. 176

Map showing the surface distribution (areas of outcrops) of Upper Tertiary (Miocene and Pliocene) strata in North America. (Modified by W. J. M. after Willis, U. S. Geological Survey.)

The Eocene formations consist very largely of greensand marls and some clays. They show a maximum thickness of about 250 feet in Maryland and rest unconformably upon the older de- 
posits. Oligocene strata have not been recognized north of South Carolina.

The Miocene beds are well developed, with a maximum thickness of nearly 500 feet. They are made up mostly of sands, clays, and marls.

The Pliocene is represented by the marine Waccamaw formation, which consists mostly of buff sands with some quartz pebbles

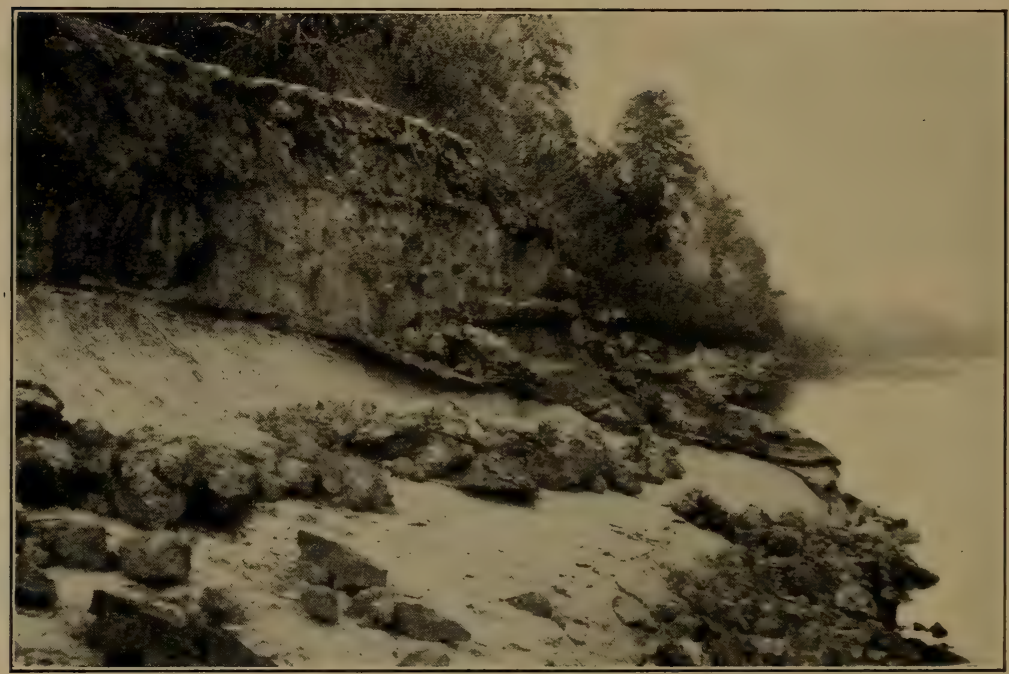

Fig. 177

Eocene sandstone resting by sharp contact upon Upper Cretaceous white chalk in Alabama. (After L. W. Stephenson, U. S. Geological Survey, Prof. Paper 90-J.)

and shell marls. The Pliocene is also thought to be represented by the problematical Lafayette formation (see below), which comprises sands, clays, loams, and gravels often rich in iron oxides. Its thickness seldom exceeds 50 feet. Lack of fossils makes it uncertain whether the formation is late Pliocene or early Pleistocene in age.

Gulf Coastal Plain Strata. - Here the Lower Tertiary (Eocene and Oligocene) strata are much more extensive at the surface than the Upper Tertiary. Both marine and non-marine deposits are present, with the former predominant. 
The Eocene formations are much thicker (1700 feet maximum) than on the Atlantic Coast. Also the deposits are quite distinctly hardened into sandstones, shales, and limestones, with much lignite in some places.

The Oligocene is well represented by the Vicksburg limestone formation and the Apalachicola formation, which latter is very variable but mostly made up of limestones, marls, sands, and clays. These two formations are usually only a few hundred feet thick.

Miocene strata are represented in Florida by the Jacksonville limestone and Choctawhatchee marl, in the Alabama region by the Pascagoula bluish clay formation, and in Texas by the Oakville limestone formation. A maximum thickness of fully 1500 feet is attained in Texas.

The Pliocene is represented in Florida by the marine Caloosahatchee marl formation, but throughout the rest of the Gulf Coast the Citronelle formation appears to be the only representative of the Pliocene.

Western Interior Strata. - All Tertiary strata of the western interior are of non-marine origin, and they comprise lake, river, alluvial-fan, and wind deposits, with some volcanic ash and tuff (Fig. 178).

Of the Eocene deposits, the Fort Union sands, clays, etc. (both lacustrine and subaërial), occur in North Dakota, Montana, and southwestern Canada, where they reach a maximum thickness of 2000 feet; the Wind River variegated shales, together with some sandstones and volcanic ash, are terrestrial (mostly fluviatile) deposits several hundred feet thick in Wyoming; the Wasatch variegated clays, shales, and sandstones, together with some coal, are very largely terrestrial deposits up to several thousand feet thick in Utah, western Colorado, and Wyoming; the Bridger beds, many hundreds of feet thick, are mostly volcanic dust, with some shales, etc., deposited partly on land and partly in shallow lakes in western Wyoming and northern Utah, while the San Juan formation, probably of the same age, is a great volcanic tuff deposit up to 2000 feet thick in Colorado; the Green River shales are lacustrine deposits just to the north and south of the Uinta Mountains; and the Uinta shales, sandstones, etc., are chiefly of terrestrial origin in western Wyoming, northeastern Utah, and northwestern Colorado.

Oligocene strata, represented by the White River formation of 
moderate thickness, occupy extensive areas in Wyoming, western South Dakota, western Nebraska, and eastern Colorado. The formation consists of clays and sandstones, with some limestone and volcanic ash, variously deposited in lakes, by rivers, by wind, etc.

The Miocene, far less thick than the Eocene, is represented toward the base by the Arikaree formation of chiefly soft sand-

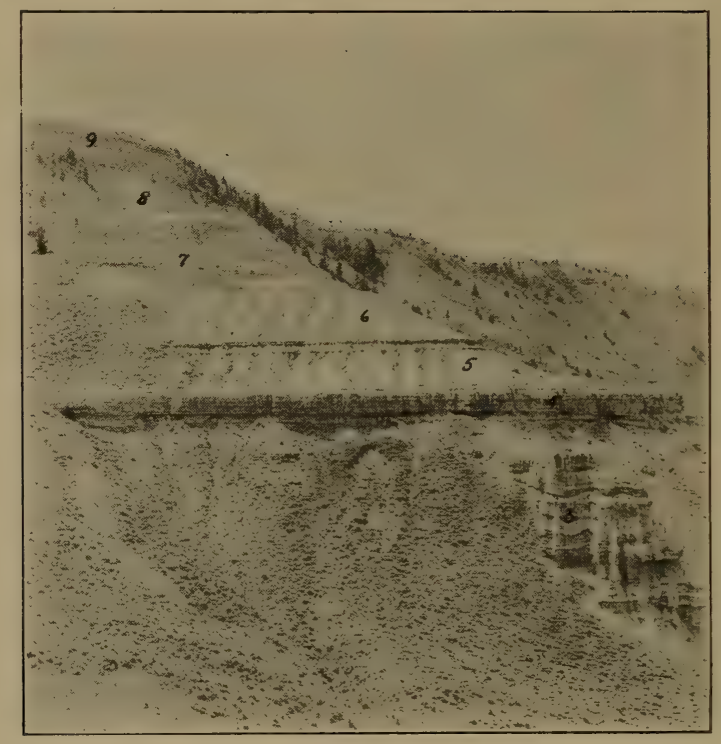

Fig. 178

Focene-Oligocene strata as seen in the Wind River Basin of Wyoming. 3, Eocene sandstone; 4, 5, 6, 7, Eocene sandstone and shale; 8, 9, Oligocene volcanic dust and marl. (After Sinclair and Granger, Amer. Mus. Nat. Hist., Bul. 30.)

stones some hundreds of feet thick in South Dakota, Nebraska, and Wyoming; toward the middle by the Florissant beds, which consist of laminated shales formed by deposition of fine volcanic ash in a small lake in Colorado and remarkable for the great number of insects and plants contained in it; and toward the top by the Loup Fork beds, which form thin deposits of fine sands and marls (both subaërial and lacustrine) over extensive areas from South Dakota to Mexico. 
Pliocene deposits formed in many parts of the western interior, but for most part they are difficult to separate from the later (Pleistocene) deposits. They are mostly of terrestrial origin, though probably with some lake deposits. Two formations which have been described as Pliocene east of the Rockies are the Republican River of Kansas and Nebraska, and the Blanco of northern Texas and Nebraska. Other Pliocene deposits quite certainly occur west of the main axis of the Rockies.

In addition to the Tertiary beds above described in the western interior, there are also many small to large deposits, especially of Miocene and Pliocene ages, in the northwestern United States and the Great Basin between the Rocky and Cascade Mountains (see map Fig. 176). For most part these formations have not been carefully studied, though it is known that they represent all types of continental deposits. Perhaps the best known area is the John Day basin of eastern Oregon, where various continental deposits, including volcanic ash, attain a thickness of several thousand feet and are particularly rich in Eocene and Oligocene fossils.

Pacific Coast Strata. - Tertiary marine strata, together with some brackish and fresh water deposits, are extensively developed west of the Sierras and Cascades and along the southern coast of Alaska.

Eocene strata are prominently developed in California, Oregon, Washington, and Alaska. They are mostly of marine and brackish water origin and very thick (maximum 8000 to 12,000 feet). They are chiefly sandstones and shales, but with locally developed tuffs, conglomerates, and diatomaceous shales. Some Eocene strata of Alaska and Washington are of palustrine origin and contain coal.

Oligocene strata are much less widely distributed than the Eocene. The deposits are mostly sandstones and shales of marine origin in western Washington and Oregon, and north of Los Angeles in California. Similar beds are known on the Alaskan coast.

Miocene marine strata are almost as prominently represented on the Pacific Coast as the Eocene, the beds being very largely sandstones and shales, often with much diatomaceous earth or shale, especially in the Monterey formation (Fig. 179). The Miocene strata exhibit a maximum thickness of from 14,000 to 16,000 feet, the Monterey alone reaching a thickness of 5000 feet. 
Pliocene marine strata are far less extensively developed on the Pacific Coast than the Miocene, the principal areas being in the Coast Ranges of California, and two or three small areas on the coast of Oregon. Pliocene fresh water beds are widely developed in the southern half of the Great Valley of California. The

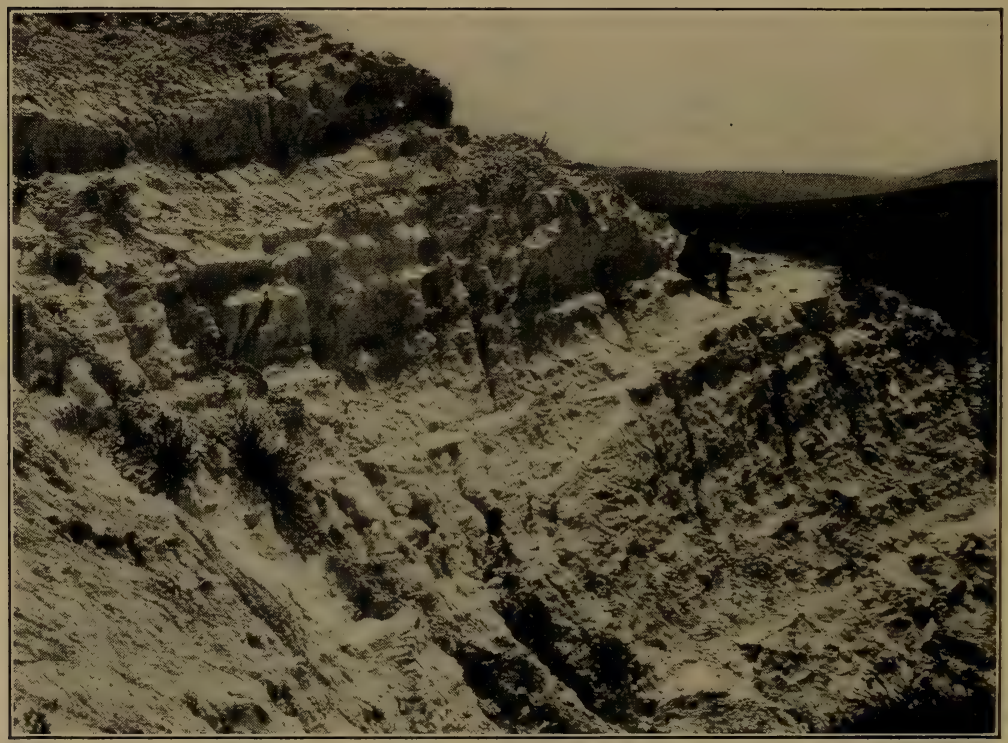

Fig. 179

Soft white diatomaceous Miocene shale in southern California. (After Arnold, U. S. Geological Survey, Bul. 322.)

maximum thickness of the marine Pliocene is at least 4000 to 5000 feet to the south of San Francisco.

Thickness of the Tertiary. - In the above descriptions some details have been given regarding the thickness of Tertiary formations. To summarize for the whole Tertiary, the maximum thickness of the whole system (not including igneous rocks) on the Atlantic Coast is less than 1000 feet; on the western Gulf Coast between 3000 and 4000 feet; in the western interior many thousands of feet, though usually not more than a few thousand feet occur in any one locality, because in no case are all the formations 
present; and on the Pacific Coast fully 30,000 feet, with a thickness of 10,000 to 20,000 feet shown in many districts. According to these figures it is seen that the thickness of the Tertiary system is quite comparable to that of ordinary Paleozoic or Mesozoic systems.

Igneous Rocks. - In the above descriptions, attention has been wholly given to a consideration of the sedimentary rocks (including some tuffs and volcanic ash deposits), but the igneous rocks of Tertiary age are also of very great extent and importance, particularly in the northwestern part of the United States. This igneous activity will be discussed below in connection with the Tertiary physical history of North America.

\section{Physical History}

In the interest of more clearly presenting an outline of our unusually detailed knowledge of the complicated physical history of this comparatively recent (Tertiary) period, we shall depart slightly from our ordinary method by considering first the relations of land and water, basins of deposition and character of sediments in different parts of the continent, etc., after which will follow a discussion of the development of relief features in the east and west, and mountain making and igneous activity in the west.

Atlantic Coast. - During most of the time from Eocene to Miocene inclusive, much of the Atlantic Coastal plain (including Florida) was occupied by marine water (see Figs. 180, 181). Certain unconformities, especially between the Eocene and Miocene, show that there were some retrogressions and transgressions of the sea. During Eocene time the newly added belt of Cretaceous deposits lay along the shore, and the Eocene strata are known to have been mostly derived from the Cretaceous and in part from the more inland older formations. In general, it may be said that, to and including the Miocene, there was a tendency to gradually push the shore line farther eastward by the addition of strips of land.

With the possible exception of the Lafayette, which is usually regarded as of Pliocene age, the only marine strata of Pliocene age comprise the comparatively thin Waccamaw formation on the middle Atlantic Coast.

The Lafayette deposits of North Carolina, according to Stephenson and Johnson, "are present as surficial coverings (10 to 40 
miles wide), probably at but few places exceeding 25 or 30 feet in thickness, along the northwestern border of the Coastal Plain province. They occur for the most part at elevations of from 200 to 500 feet and form mouth-like coverings which cap the tops of, and lap down over the slopes of, the pre-Lafayette hills. The materials consist of sandy loams and sands, as a rule coarse and in places arkosic, and having at their base at many places a bed of coarse gravel and cobbles." 1 In Maryland the Lafayette is quite distinctly terrace-like. According to one view it is of continental origin and was deposited as a result of "a comparatively rapid Pliocene uplift in the Appalachian region" (W. H. Dall), which, early in the Pliocene, had become mantled with deep residual soil so that the revived streams picked up and carried great loads of debris which were spread over the relatively flat lands near sea level. Another explanation is that the Lafayette was of marine origin, due to simultaneous depression of the Coastal Plain district and elevation of the Piedmont Plateau and Appalachian areas when "streams gorged with detritus from the decayed, uplifted Piedmont above rushed down to the sea and poured their contents into the ocean" (G. B. Shattuck). The most likely view is that the Lafayette is a normal marine terrace, much like the later ones below described, and that, "with the successive oscillations of the coast line, terraces have been formed at levels where the sea has stood for any considerable period of time". (W. B. Clark). Careful search has failed to produce any marine fossils from the formation.

Gulf Coast. - During Eocene-Oligocene time extensive sedimentation, both marine and non-marine, took place over the Gulf Coastal Plain area. The Mississippian embayment (see Fig. 180) extended northward (to the mouth of the Ohio River) as it did in the Cretaceous, and the unconformity between the Cretaceous and Eocene clearly shows a transgression of the sea over the area in Eocene time. Marine conditions in this embayment were, however, more or less interrupted as proved by the considerable development of non-marine deposits such as lignite beds. Over Florida, the Gulf Coast of Mexico, and much of the coast of Texas, true marine deposition went on during practically all of Eocene and Oligocene times.

During Miocene time the Mississippi embayment was greatly

1 The Coastal Plain of North Carolina: North Carolina Geological and Economic Survey, 1912, p. 359. 


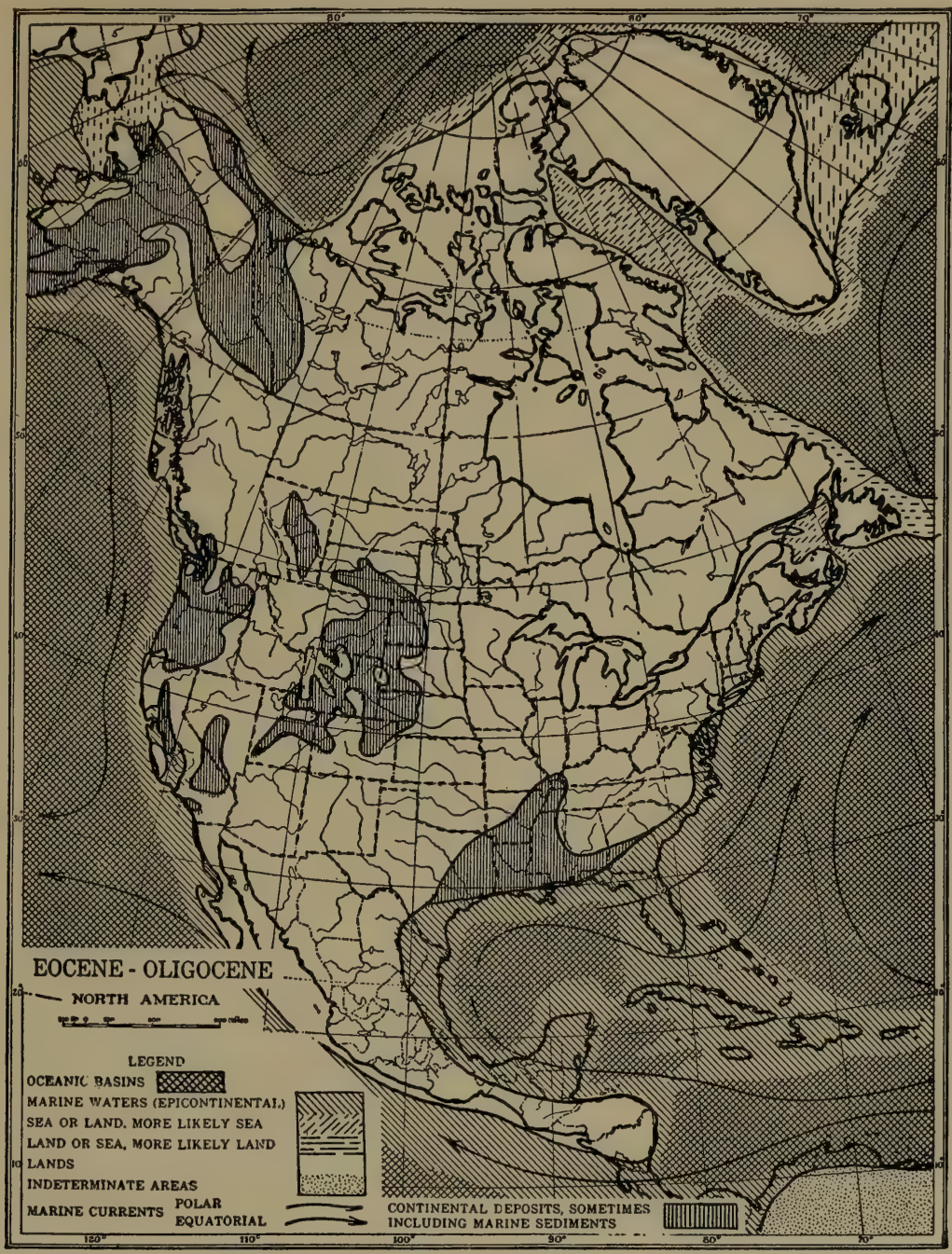

Fig. 180

Paleogeographic map of North America during Lower Tertiary (EoceneOligocene) time. (Slightly modified after Bailey Willis, courtesy of The Journal of Geology.) 
restricted, but marine waters spread over the whole Gulf Coast from Florida to southern Mexico, except for a small island in Florida (see Fig. 181).

The presence of some marine Pliocene strata in Florida and along the Gulf Coastal Plain border shows those areas to have been submerged during portions of Pliocene time at least.

Western Interior. - The extensive folding, faulting, and lava extrusions which marked the close of the Cretaceous period left the western interior topographically rugged with conditions favorable for rapid erosion of the mountains and deposition of sediments in the intermontane basins. As the character of the Tertiary sediments indicates, all sorts of continental deposits were formed, that is in lakes, on river flood-plains, as alluvial fans, as wind-blown deposits, and even as volcanic dust or tuff in many places. Marine deposition was wholly lacking. As shown by the above statements regarding the distribution of the various formations, it is apparent that the principal areas over which sediments were being deposited must have shifted more or less.

That there was very active vulcanism during Tertiary time in this western interior region is proved by the presence of so much volcanic dust and ash. Also in the great area between the Rockies and Sierra-Cascade Ranges, there was tremendous volcanic activity, but this will be described under a separate heading below.

Many of the Tertiary deposits of the western interior now lie at altitudes of from 5000 to 10,000 feet above the sea, and they have been somewhat deformed by tilting or warping.

Pacific Coast. - Summarizing the physical history of the Pacific Coast during Cenozoic time, Ralph Arnold says in part: "Following the period of elevation and erosion at the close of the Cretaceous, the Eocene was inaugurated by a subsidence below sea-level of the greater part of western Washington and Oregon and the western part of central and southern California. Volcanic activity was pronounced in the early and middle Eocene. Later in the Eocene brackish and freshwater conditions prevailed over the same area, and extended over much of Alaska.... The Oligocene was a period of elevation, with marine conditions restricted to a much smaller area than in the Eocene. ... The lower Miocene marked a widespread subsidence in the Coastal belt which was followed by a period of mountain building (Coast Ranges) and great local deformation, vulcanism, etc. ... The 


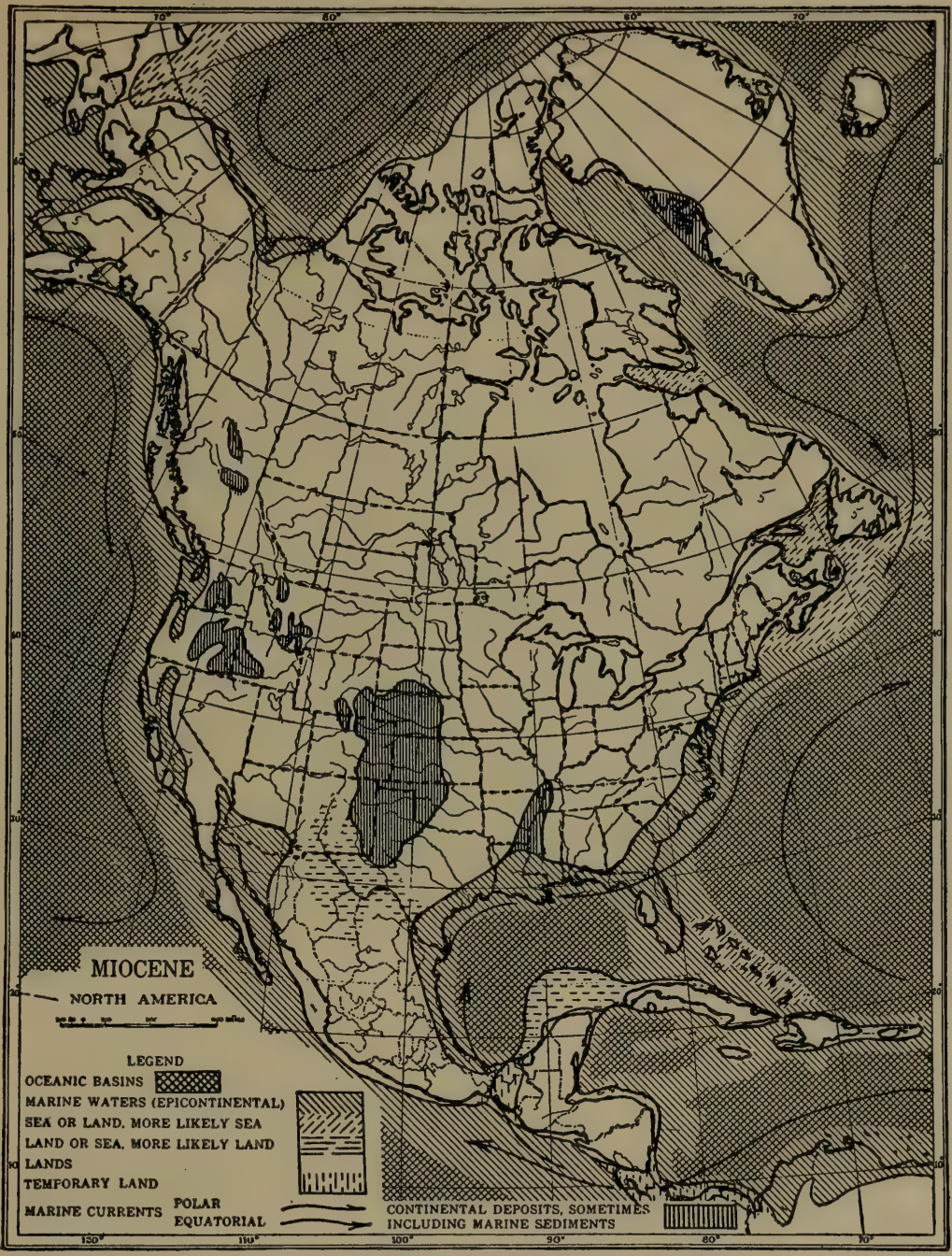

Fig. 181

Paleogeographic map of North America during Miocene time. (Slightly modified after Bailey Willis, courtesy of The Journal of Geology.) 
upper Miocene was a period of subsidence, with ideal conditions for maximum deposition of sediments in local basins. During Pliocene and early Pleistocene time there was a continuation of many of the upper Miocene conditions, except that marine environment gave way to freshwater. . . . A period of elevation

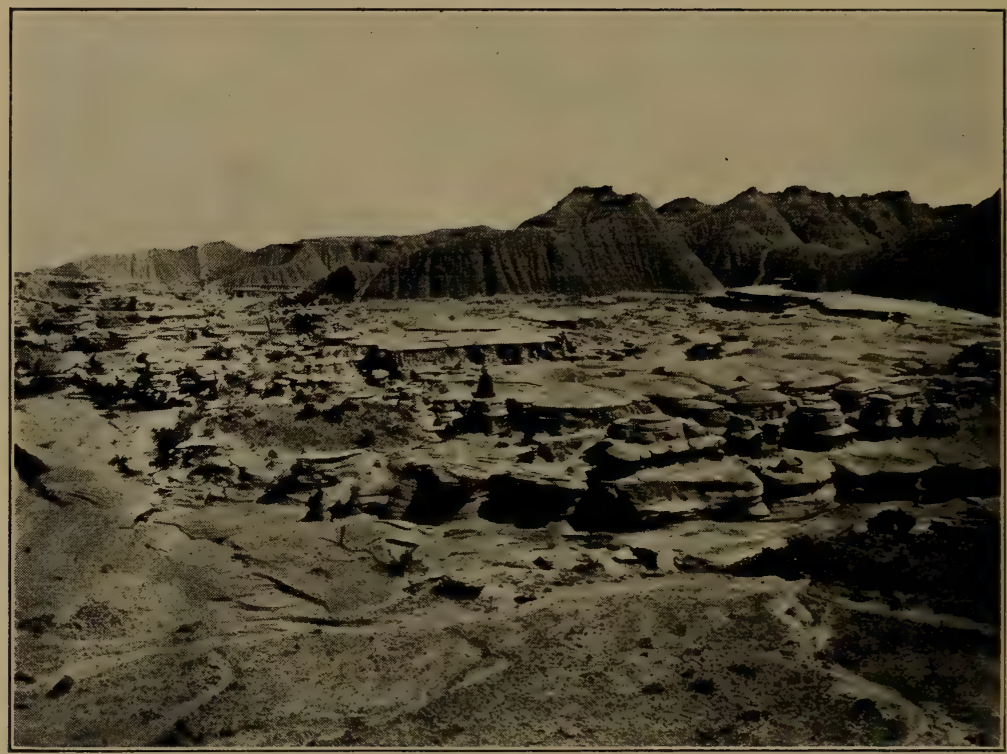

Fig. 182

"Toadstool Park": a view in the Bad Lands of western Nebraska. The rocks are of Oligocene age. (After Darton, U. S. Geological Survey, Prof. Paper 17.)

and considerable local deformation in the early Pleistocene inaugurated the present conditions on the Pacific Coast." 1

Development of Relief Features in the Eastern United States. - The uplift of the great Cretaceous peneplain was an event of prime importance for the eastern United States, because it literally furnishes us with the beginning of the history of most of the existing relief features of the Appalachian district as well as

1 Ralph Arnold: Outlines of Geologic History, by Willis and Salisbury, p. 248. 
New York and much of New England. Hence we assert, with emphasis, that all the principal topographic features of this region as we see them today date from the uplift of the Cretaceous peneplain, because they have been produced by the dissection of that upraised surface. This dissection was largely the work of erosion, though more locally (e.g. the eastern Adirondack Mountains) faulting has produced notable effects. All the valleys, great and small, such as the Champlain, Connecticut, Mohawk, Hudson, the Great Lakes valleys, and the valleys of the Appalachians, have been produced since the uplift of the peneplain.

The uplift greatly revived the activity of the streams, so that they became very active agents of erosion, first cutting channels through the alluvial deposits, and then into the underlying bed rock. Thus these large original streams had their courses determined in the overlying deposits, and when the underlying rocks were reached the same courses had to be pursued entirely without reference to the underlying rock character and structure. Fine examples of such (superimposed) streams, which are now entirely out of harmony with the structure of the regions through which they flow are the Susquehanna, Delaware, and Hudson. Thus the Susquehanna cuts across a whole succession of Appalachian

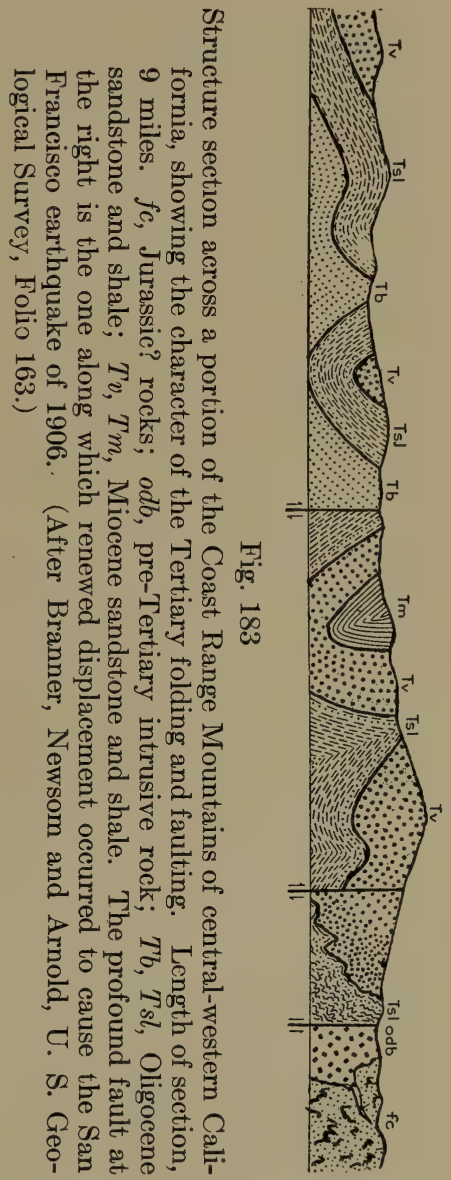
ridges, while, in accordance with the same explanation, the Delaware cuts through the Kittatinny ridge at the famous Delaware Water Gap. The lower Hudson pursues a course no less out of harmony with the country through which it passes. It flows at 
a considerable angle across the old Taconic folds above the Highlands, after which it passes through a deep gorge which it has cut through the hard granites and other rocks of the Highlands. The simple explanation is that the Hudson had its course determined upon the surface of the upraised Cretaceous peneplain, and that it has been able to keep that course in spite of the discordant structures of the underlying rocks. The seemingly anomalous courses of the Delaware, Potomac, Susquehanna, etc., are to be similarly explained.

But while the great master streams were thus cutting deep trenches in hard and soft rock alike, numerous side streams or tributaries came into existence and naturally developed along the belts of weak rock and in harmony with the geologic structures. This principle is especially well illustrated by all of the streams now occupying the valleys between the Appalachian ridges.

After the uplift of the peneplain, the larger streams cut down their channels most rapidly and were the first to reach "grade," that is a condition in which, because of low velocity, they could no longer cut down their channels, though the widening process could continue because of side cutting due to meandering of the streams back and forth from one side to the other of the channels. The commonly occurring, deep, broad-bottomed, stream-cut valleys, in the area under discussion, show that many of the streams had reached graded, or nearly graded, condition even by the close of the Tertiary. In the northern Appalachian district, at least, we have evidence to show that after the streams had reached grade there was an appreciable renewed uplift of the land which again revived the activity of the streams. Thus the broad Hudson Valley, with minor hills rising above its surface, was produced when the Hudson was well along toward a graded condition and then, as a result of this late Tertiary uplift of the land, the present narrow and fairly deep inner channel of the Hudson was formed. The Hudson did not reach grade in this inner channel, its work having been interrupted by both the subsidence of the land and the spreading of the great ice sheet over the region.

This inner channel of the Hudson has been traced for fully 100 miles eastward beyond the mouth of the present river. The Coast and Geodetic Survey has made a detailed map of the ocean bottom near New York City, and the submerged channel of the Hudson River is clearly shown as a distinct trench 
cut into the continental shelf. Even in the Hudson Valley above New York City, the narrow inner rock channel has a depth of hundreds of feet and is mostly submerged below tide water. Without question, this submerged Hudson channel was cut when the region was dry land, and thus we have positive proof that, late in the Tertiary and possibly extending into the early Quaternary, the region of southeastern New York was notably higher than it is today. Conservative estimates place the amount of elevation greater then than now at not less than 2000 feet because the end of the Hudson channel is submerged to that extent. ${ }^{1}$ The coast was then at what is now the edge of the continental shelf or platform about 100 miles east of the present coast line. That this greater altitude was before the Ice age is proved by the fact that the inner Hudson channel now contains much glacial debris filling.

By similar reasoning, based upon the drowned valleys of the Maine coast and the lower St. Lawrence, we know that all of the middle Atlantic sea-board region, at least, was notably higher in late Tertiary time than now.

The Mississippi Valley area also appears to have been notably elevated during late Tertiary time, and hence the major (erosion) relief features of that great area, as we now know them, have been produced by the dissection of that upraised area by streams.

Mountain Making and Development of Relief in the West. ${ }^{2}$ In North America, as well as other continents, the Tertiary was a period of unusual mountain-making activity. Many of the present great mountain ranges of the earth actually had their birth and principal development during this period, while others were rejuvenated and brought essentially to their present form and altitudes.

Coast Ranges. - This belt was somewhat affected by deformative movements toward the close of the Jurassic, as we have already

${ }^{1}$ It has been suggested by Chamberlin and Salisbury (Geology, Vol. 1, p. 529) that the very end of the Hudson, and other submerged channels, may have been deepened by tidal scouring and, if so, the figure (2000 feet) generally given may be too high. At any rate the Hudson channel at the Highlands is submerged nearly 800 feet, which certainly implies an altitude of more than 1000 feet greater than now when the river was there actively eroding.

2 The topographic influence of Tertiary vulcanism in the west will be described under another heading. 
seen, but probably not more than a chain of islands was then developed. Another time of moderate elevation occurred during the Eocene. The Oligocene was a time of considerable elevation and erosion in the Coast Range district, though the relief could not have been strong, as shown by the fine-grained sediment which was deposited during the Oligocene in the limited areas of southern California and western Oregon and Washington.

What may really be called the "Coast Range Revolution" took place in mid-Miocene time. According to Arnold, "one of the most widespread and important periods of diastrophism in the Tertiary history of the Pacific Coast was that immediately following the deposition of the Monterey or lower middle Miocene. Its effects are visible from Puget Sound to southern California. It is marked as much by readjustment, by local faulting and folding, as by general movements of elevation and subsidence. In some regions the folding and faulting were intense, the greatest disturbance accompanying the uplift of the mountain ranges to an altitude of thousands of feet (Fig. 183). In other regions low broad folds were formed during the post-Miocene disturbance, and the strata were not upheaved to a great altitude. Faulting on a most magnificent scale took place along the (San Francisco) earthquake rift (fault) and certain other fault-zones. . . . The postMonterey diastrophic movements in the Puget Sound province also produced sharp relief, as is evidenced by the coarse sediments deposited immediately following the disturbance." 1

Other important mountain-making movements took place during the Quaternary, with minor activity continuing to the present time. The combination of the various diastrophic movements and erosion in the Coast Range belt since early Tertiary time has given rise to the Pacific border mountains as we see them today.

Sierra Nevada and Cascade Ranges. - We have already seen that the Sierras were produced by crustal disturbance toward the close of the Jurassic period. From that time till late in the Miocene epoch the mountain mass had undergone profound erosion, so that it was reduced to a range of hills or low mountains with no great relief features. In other words, it approached the condition of a peneplain. Then, late in the Miocene or early in the Pliocene, p. 242 .

1 Ralph Arnold: Outlines of Geologic History, by Willis and Salisbury, 
there began a tremendous rejuvenation of the range, caused by the development of profound faulting along the eastern side. The vast earth-block was tilted westward with steep eastern front and long gradual slope toward the west, with the crest of the block forming the summit of the range. The maximum amount of displacement along this fault zone is no less than 15,000 feet and, in spite of subsequent erosion, the fault-scarp still stands out as a topographic feature usually several thousand feet high. That the faulting has not yet ceased is evidenced by the Inyo earthquake of 1872 , when a renewed displacement of 10 to 25 feet took place along the fault zone for many miles. The mighty canyons (e.g. Yosemite) and other relief features of the Sierras as we know them today have been sculptured out of the great tilted earth-block by weathering and erosion.

The Cascade Mountains, too, appear to have approached the peneplain condition by late Tertiary time, when a vigorous rejuvenation took place by an arching or bowing of the surface rather than by profound faulting.

Great Basin and Colorado Plateau. - About the same time (later Tertiary) the whole Great Basin region between the Sierras and the Wasatch Mountains of Utah was also notably affected by faulting. The steep western front of the Wasatch represents a profound fault, while many of the north-south Basin Ranges of Nevada are tilted earth-blocks.

The Cenozoic history of the Colorado Plateau region still presents important problems for future studies. According to Dutton the Plateau was raised, more or less periodically, fully 20,000 feet during Tertiary time, but its surface now shows an altitude of only 7000 to 8000 feet, because of deep erosion during its uplift. As a result of the rejuvenation of this region, the Colorado River was very actively revived and has carved out the Grand Canyon since the early Tertiary. Later investigations, however, seem to show that the rejuvenation was much later, probably late Pliocene, and that most, if not all of the Grand Canyon, is of post-Tertiary age.

Rocky Mountain and Western Interior Regions. - Late in the Tertiary much of the Rocky Mountain region was also greatly rejuvenated by an uplift or upwarp, unaccompanied by folding of the strata. That this upwarp amounted to some thousand of feet is distinctly proved by the fact that the Miocene beds east of the 
Rockies are so tilted that they are 3000 feet higher close to the mountains than they are farther east. Also the fact that many

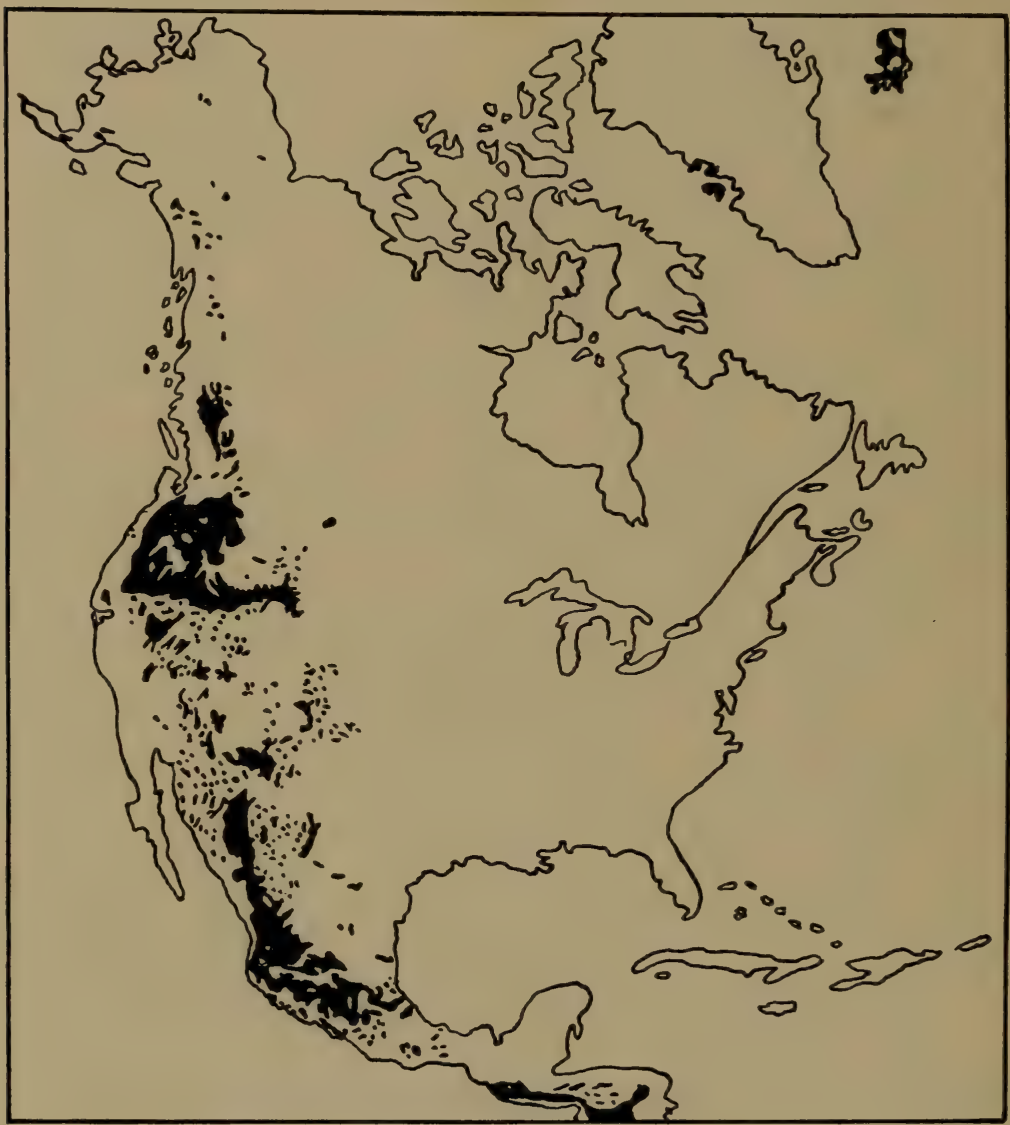

Fig. 184

Map showing the surface distribution (areas of outcrops) of Tertiary and later volcanic rocks in North America. (Modified by W. J. M. after Willis, U. S. Geological Survey.)

large areas of Tertiary deposits now lie from 5000 to even 10,000 feet above sea-level, pretty clearly indicate notable elevation since their deposition, because such deposits must have been formed in 
intermontane basins much nearer sealevel, like the recent deposits of the Great Valley of California.

The dissection by erosion of the usually comparatively soft and only moderately tilted deposits of Tertiary age in the western interior has given rise to much of the "Bad Lands" country, so called because of the difficulty early explorers had in travelling across that rugged region (Fig. 182).

Igneous Activity. - In connection with the discussion of the close of the Cretaceous period, we spoke of the inauguration of igneous activity which resulted in the building up of the vast lava plateau, occupying fully 200,000 square miles, between western Wyoming (including Yellowstone Park) and the Cascades and southward into northern Nevada and northeastern California (Fig. 184). Most of this lava was poured out in Tertiary time, particularly in the latter part. Norton has clearly and concisely stated the principal facts as follows: "For thousands of square miles the surface is a lava plain which meets the boundary mountains as a lake or sea meets a rugged and deeply indented coast.... The rivers which drain the plateau - the Snake, the Columbia, and their tributaries - have deeply trenched it, yet their canyons, which reach the depth of several thousand feet, have not been worn to the base of the lava except near the margin and where they cut the summits of mountains drowned beneath the flood. Here and there the plateau has been deformed. . . . The plateau has been built like that of Iceland, of innumerable overlapping sheets

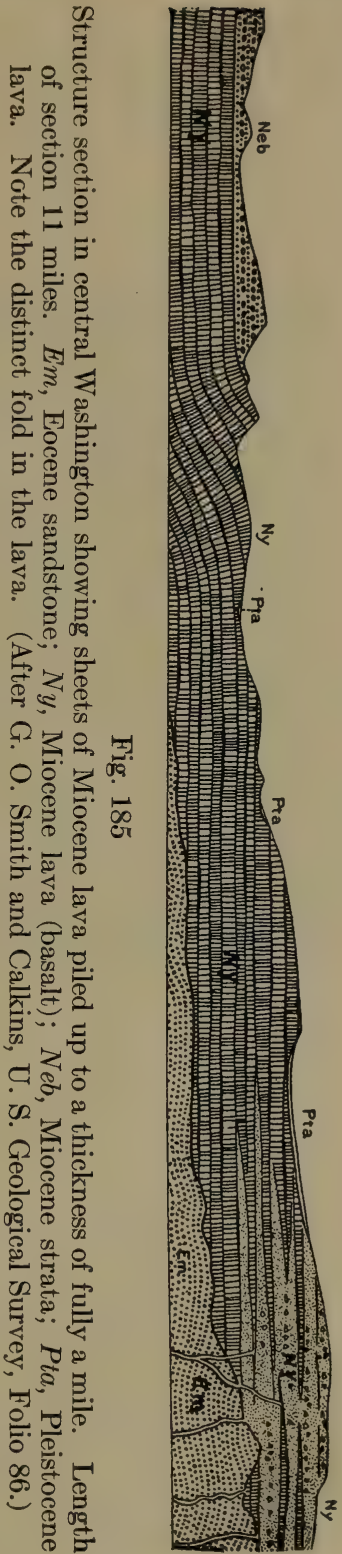


of lava (Fig. 185). . . . The average thickness of flows seems to be about seventy-five feet.

"The plateau was long in building. Between the layers are found in places old soil beds and forest grounds and the sediments of lakes. ... So ancient are the latest floods in the Columbia Basin that they have weathered to a residual yellow clay from

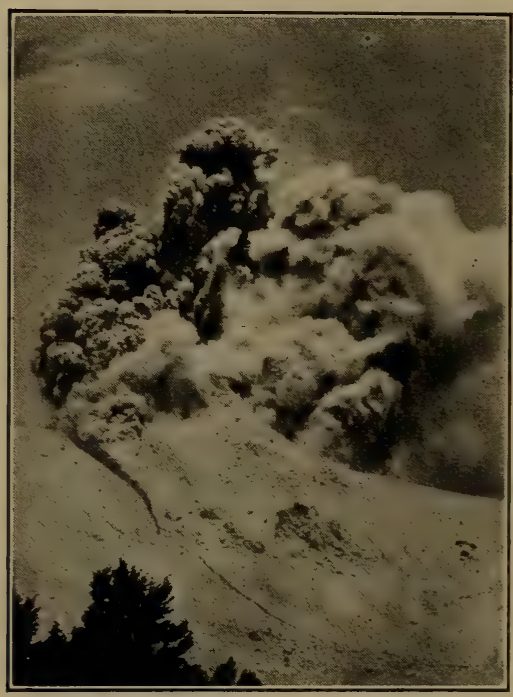

Fig. 186

Mount Lassen in northern California in eruption August 22, 1914. Smoke and volcanic ash rose to a height of 10,000 feet. (From a photograph by Restinson, Red Bluff, Cal.) thirty to sixty feet in depth and marvelously rich in the mineral substances on which plants feed. In the Snake River Valley the latest lavas are much younger. Their surfaces are so fresh and undecayed that here the effusive eruptions may have continued to within the period of human history." 1

Volcanic activity must have been very pronounced along the Rockies during the Tertiary, as shown by extensive and often very thick deposits of tuff or volcanic ash (e.g. San Juan and Florissant formations). Many volcanoes also broke forth on the Colorado Plateau of Utah, New Mexico, and Arizona, in the latter state especially there being cones exhibiting all stages of denudation from very recent cinder cones to others where only the merest remnants or "volcanic necks" are left.

In the northern Coast Range mountains of the United States there was considerable volcanic activity in the Eocene and much throughout the Range in the Miocene.

Very pronounced vulcanism occurred in the Cascade Mountain region during the Eocene and to the middle Miocene. During Pliocene time there was great volcanic activity with outpourings

${ }^{1}$ W. H. Norton: Elements of Geology, pp. 400-401. 
of lava in the Sierras and Cascades. At that time the Miocene gold-bearing stream gravels of California were buried under the lava. Many well-known volcanic mountains, such as Shasta, Hood, Rainier, etc., date from that time. In fact this period of vulcanism has not altogether ceased at the present day, as shown by a renewal of activity of Lassen Peak (altitude 10,437 feet) in northern California on May 30, 1914. At the present writing (October, 1915) there have been about 150 eruptions of the mountain, in all cases fragmental materials only having been ejected sometimes to a height of 5000 to 10,000 feet above the mountain (Fig. 186). The eruptions of cinders and lava at Cinder Cone, only 10 miles from Lassen Peak, occurred not over 200 years ago. Other quite recent cinder cones are known in southern California and Arizona.

\section{Foreign Tertiary}

Eocene. - Just after the emergence of much of Europe at the close of the Mesozoic, there were certain basins of deposition such as lakes, estuaries, etc. Early in the Eocene, however, a great submergence set in, allowing marine waters to spread over a considerable part of western and much of southern Europe. The southeastern British Isles, the northern border of France, Belgium, Holland, the northern border of Germany, the site of the Pyrenees, Italy, all but the axis of the Alps, much of southeastern Europe, and northern Africa were submerged (see Fig. 187). This greatly expanded mediterranean of Europe also extended eastward across southwestern Asia, except southern Arabia and southern India, to connect with the Indian Ocean through the Bay of Bengal. A narrow sound along the eastern side of the Urals connected this mediterranean with the Arctic. In this vastly expanded interior sea true marine deposition took place, the most characteristic formation being known as Nummulitic limestone, so called because it is chiefly made up of shells of a certain species (Nummulites) of unusually large Foraminifers. Perhaps no other single formation in the crust of the earth built up essentially of the remains of but one species of organism is so widespread and thick, its thickness at times reaching several thousand feet. This marine Nummulitic limestone now occurs at altitudes of 10,000 feet in the Alps, and fully 20,000 feet in Thibet. Limestone of this age was quarried for the building of the Egyptian pyramids. 
During Eocene time also the island region along the eastern coast of Asia was largely submerged as well as the eastern coasts of Australia and South America (in Argentina and Brazil). Land seems to have been continuous in the northern hemisphere except for the narrow strait or sound just east of the Ural Mountains.

Toward the close of the Eocene the Pyrenees Mountains were upraised by folding, while initial (though moderate) orogenic movements took place in the regions of the Apennines, Alps, and probably Himalayas as well as some other mountain districts.

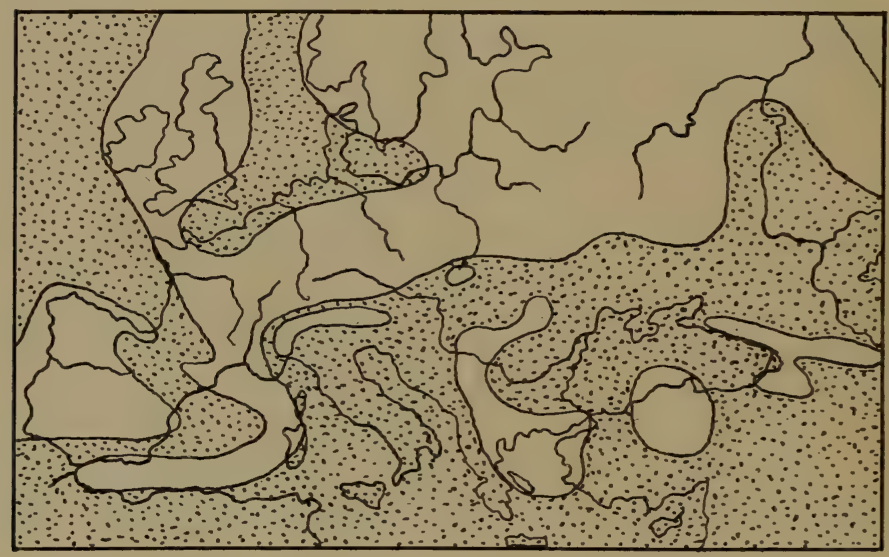

Fig. 187

Sketch map showing the relations of land and water in Europe during Middle Eocene time. (After Kayser.)

Oligocene. - The Oligocene is best known in Europe, while in many other parts of the world it has not yet been separated from the Eocene or Miocene. During the Oligocene a shallow sea transgressed over northern Germany. In many places there were lagoons, estuaries, and even basins in which terrestrial deposits were formed. Some beds of gypsum, salt, and brown coal (lignite) were formed. Oligocene strata are especially well developed throughout southern Europe. In Italy, marine deposits of this age have an estimated thickness of 12,000 feet. In southern Europe true marine conditions prevailed, though continental deposition also occurred. 
There was much igneous activity during this epoch, particularly in Bohemia, Ireland, Scotland, Iceland, and in the vicinity of Vienna.

More or less severe orogenic movements affected certain districts such as the Balkan and Carpathian Mountains toward the close of the epoch.

Oligocene rocks are also quite certainly present in the Caucasus Mountains, southwestern Asia, and northern Africa, but they have not been much studied in other countries.

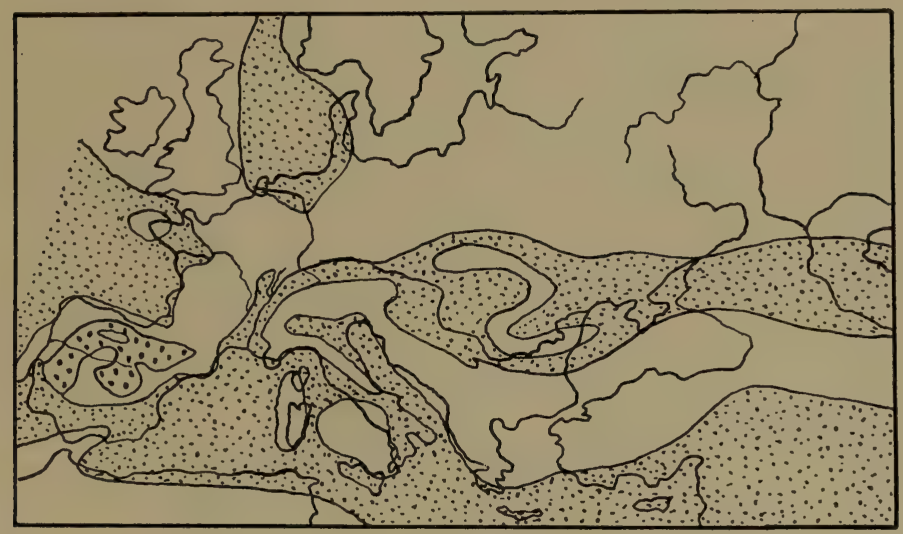

Fig. 188

Sketch map showing the relations of land and water in Europe during Middle Miocene time. Area of coarse dots, continental deposition; areas of small dots, marine waters. (After Kayser.)

Miocene. - Viewed in a broad way, the Miocene land and water areas of Europe were much as they had been in the Eocene, all but the northern coast of Germany again becoming dry land. Marine waters occupied parts of the Atlantic borders of France and the Iberian peninsula, while southern Europe was largely submerged as in the Eocene, except for considerable land masses occupying such areas as the interior of Spain and France, portions of the sites of the Alps, Pyrenees, Carpathians, Apennines, etc., which had been more or less affected by orogenic movements before the Miocene (see map Fig. 188). A remarkable formation, worthy of special mention, is an extensive conglomerate several thousand feet thick along the northern side of the present Alps. This con- 
glomerate has considerably controlled the topography, for instance in the vicinity of Lucerne.

The vast Eocene mediterranean across southwestern Asia was not continued into the Miocene. Eocene strata, both marine and non-marine, occur in northern Africa and Syria, but not in the Persian region. Though not yet well studied, Miocene strata are well developed in southern Asia, Japan, and northeastern Asia and Australia. In South America the Miocene is extensively

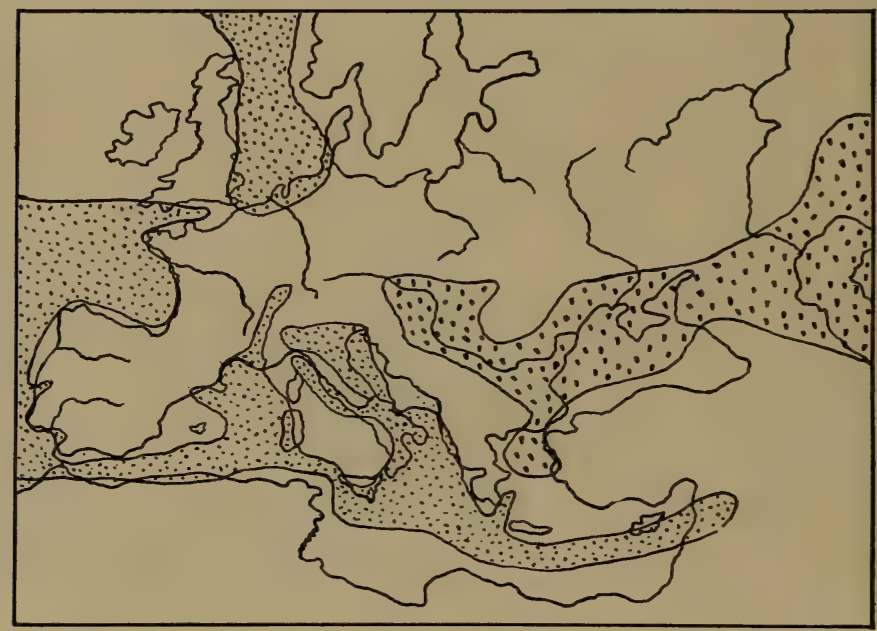

Fig. 189

Sketch map showing the relations of land and water in Europe during Middle Pliocene time. Small dots, marine waters; coarse dots, areas of continental deposition. (After Kayser.)

shown in Argentina and probably also on the western coast of the continent.

Important mountain building occurred in Europe and Asia in the middle and late Miocene. Though initial movements had affected the sites of the Alps, Apennines, and probably the Himalayas, these mountains were greatly elevated by tremendous orogenic movements in the Miocene. ${ }^{1}$ The Caucasus Mountains

1 There appears to be some doubt as to whether the principal orogenic movement in the Himalayas occurred at the close of the Eocene or in the Miocene. 
were also upraised not earlier than in late Miocene, since Miocene strata are there found about 7000 feet above sea-level.

Considerable igneous activity accompanied the late Miocene orogenic movements.

Pliocene. - The Pliocene opened with comparatively little of Europe under marine waters, only a little of southern England, Belgium, the northwestern border of Germany, a little of southern France, and much of Italy having been submerged (see map Fig. 189). Only in Italy are thick marine deposits known where the sediments washed from the newly built Apennines accumulated to a thickness of from 1000 to 3000 feet. Since some of these deposits now lie at altitudes of 2000 to 3000 feet, it is evident that the Apennines were again notably upraised after the deposition of the Pliocene sediments. Volcanoes were active in the Mediterranean region, especially in Italy and Sicily, where volcanoes like Vesuvius and Etna began their eruptions.

In southeastern Europe conditions were favorable for much deposition of continental material - lake, river, and terrestrial deposits.

Marine Pliocene extends up the Nile Valley for many miles. As a result of the erosion of the newly upraised Himalayas, a deposit of sandstones, conglomerates, clays, etc., several thousand feet thick, accumulated at the southern base of those mountains during Pliocene time.

In South America Pliocene deposition took place over much of southern Argentina, deposits of this age being upturned on the eastern flank of the southern Andes.

\section{Climate}

During the Eocene the existence of a subtropical climate well toward the northern boundary of the United States, and in Europe as far north as Germany and the British Isles, is abundantly proved by the character of the fossil plants and animals.

Over the Great Plains region of the United States the climate, now semiarid, was distinctly moister during the earlier Tertiary, because the great deposits of lignite prove the existence of prolific plant life in swamps. Fossil Figs, Palms, and Magnolias in the western interior indicate much warmer and moister climate than now. This was in harmony with what we know of the physical 
geography of the west, because there were no great mountains on the Pacific Coast to catch most of the moisture from the westerly winds.

Oligocene climate appears to have been somewhat cooler (perhaps warm-temperate) in western North America, and tropical in southeastern North America. In Europe the warm climate of the Eocene seems to have continued, for Palms lived in northern Germany.

During Miocene time the climate of the Pacific Coast was almost like that of today. On the Atlantic Coast a comparatively cool current, apparently from the north, drove out the warm water forms of the earlier Tertiary. In the western interior region of the United States, subtropical plants gave way to temperate climate plants. In Europe the warm climate of the earlier Tertiary continued into the earlier Miocene and became distinctly cooler (temperate) in the later Miocene.

The Pliocene was in general cooler than the Miocene, in fact, gradually increasing from temperate to sub-Arctic conditions in the waters along the California coast, and even to Arctic conditions in the British Isles region. Thus, passing upward in the British Pliocene series, the number of Arctic fossil forms increases from a few percent to 50 or 60 percent. An exception to the above general conditions appears to have been along the Atlantic Coast of the United States, where the marine water was rather warmer than it had been during the Miocene. As judged by the plants, the lands apparently had not become so correspondingly cold during the Pliocene.

\section{Economic Products}

The largest production of petroleum in the United States comes from southern California, where it is obtained mostly from Tertiary shales and sandstones. It seems certain that this petroleum originated from the decomposition of countless numbers of Diatoms in certain of the shales.

Lignite (or brown coal) underlies thousands of square miles of both the Gulf States and the western interior regions, as well as smaller areas on the Pacific Coast. There are also important lignite deposits in Europe, particularly in Germany.

Many important gold deposits of California occur in Tertiary 
river gravels, which are often capped by lava. The famous gold deposits of Cripple Creek, Colorado, and Tonopah, Nevada, and the copper deposits of Butte, Montana, all occur as veins in, or adjacent to, Tertiary igneous rocks.

Valuable phosphate deposits occur in the Tertiary limestones of Florida.

\section{Life OF THE Tertiary}

Taken as a whole, the life of the Cenozoic era was markedly different from that of the Mesozoic. Even in the Tertiary period the most important groups of plants and animals had a decidedly modern aspect. Most of the plants and the invertebrate animals of the Tertiary period belonged to genera which still exist, while the present-day species gradually increased from a small percentage in the Eocene to a large percentage in the Pliocene. Among the Vertebrates, the Fishes, Amphibians, Reptiles,${ }^{1}$ and Birds differed but little from those of today. The Mammals, however, which were small, primitive, and relatively rare throughout the Mesozoic, showed a wonderful development both in number of individuals and diversity of forms. The Mammals are, therefore, the most interesting and characteristic organisms of Tertiary time.

\section{Plants}

Vegetation had assumed a pretty distinctly modern aspect well before the opening of the Cenozoic era, the great revolution from ancient to modern types having taken place about the middle of the Mesozoic era. During the Tertiary, however, there was notable progress toward even more modern

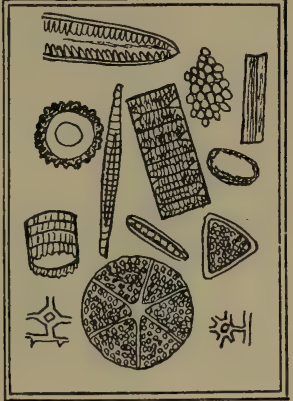

Fig. 190

Diatoms from diatomaceous earth of Tertiary age. Greatly enlarged. conditions, so that many genera became the same as now and gradually more and more present-day species were introduced.

Among the simplest or single-celled plants, the Diatoms deserve special mention. In certain times and places they swarmed in the

${ }_{1}^{1}$ Recently a few Dinosaur remains have been found in the earliest Tertiary rocks, but otherwise all of the characteristic Mesozoic Reptiles had become extinct, leaving representatives only of such modern groups as Lizards, Snakes, Turtles, Crocodiles, and a few other water forms. 
Tertiary waters. "The microscopic plants which form siiiceous shells, called Diatoms, make extensive deposits in some places (Fig. 190). One stratum near Richmond, Virginia, is 30 feet thick and is many miles in extent; another, near Monterey, California, is 50 feet thick, and the material is as white and fine as chalk, which it resembles in appearance; another, near Bilin in Bohemia,

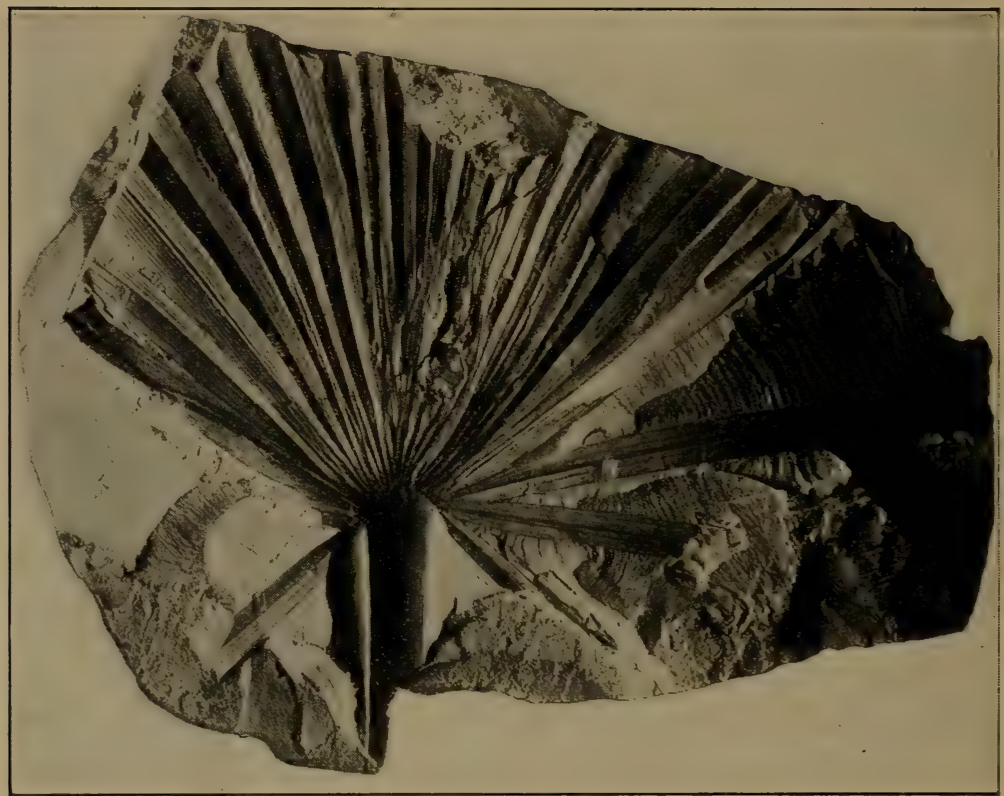

Fig. 191

A well-preserved fossil Palm, Thrimax eocenica, from the Eocene of Georgia. (After Berry, U. S. Geological Survey, Prof. Paper 84.)

is 14 feet thick. . . Ehrenberg has calculated that a cubic inch of the fine earthy rock contains about forty-one thousand millions of organisms. Such accumulations of Diatoms are made both in fresh waters and salt, and in those of the ocean at all depths." 1

During the earlier Tertiary, as we have learned, the climate of Europe and the northern United States was warm temperate to even subtropical and there flourished such trees as Paims (Fig.

1 J. D. Dana: Text-book of Geology, 5th ed., pp. 391-393. 
191), Laurels, Oaks, Willows, Chestnuts, etc., with the addition of Magnolias, Figs, Poplars, Ferns, etc., in the western interior of the United States and southern Canada. As far north as Greenland and Spitzbergen, there were forests with Maples, Camphor trees, Figs, Laurels, Cypresses, Poplars, and Sequoias. The Sequoias, which are of special interest, began in the late Jurassic; attained their culmination in numbers and species in the Tertiary; and are now represented by only two species, - the so-called Big Trees and the Redwoods, - which are wholly confined to California. During the Tertiary they ranged from Greenland on the north to New Zealand on the south, often in great forests.

In the later Tertiary the distinctly cooler climate in the higher latitudes caused a disappearance of the warm climate plants such as the Palms from Europe, and the Palms, Figs, Magnolias, etc., from the western interior of North America.

So far as known, the Cereals had not yet appeared in the Tertiary, but the Grasses became abundant and must have had an important influence in the development of the principal groups of herbivorous Mammals.

\section{ANIMALS}

Since the Tertiary invertebrates were in nearly every way so similar to those of today, we shall give special attention to only a few features of interest.

Among Protozoans, the Foraminifers were

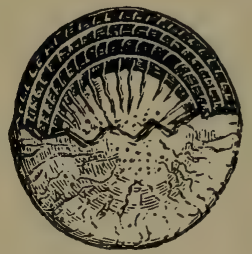

Fig. 192

An Eocene Foraminifer, Nummulina levigata. (From Le Conte's "Geology," courtesy of D. Appleton and Company.) exceedingly abundant and often remarkable for their great size. Of these the Nummulites, so called because coin-shaped, have already been referred to as making up great limestone deposits in the Old World Eocene. They attained a diameter as great as half an inch to an inch (Fig. 192).

Porifers, Cœlenterates, Echinoderms, and Molluscoids were almost wholly modern in character, with Crinoids and Brachiopods both rare.

Among Mollusks both Pelecypods (Figs. 193, 194) and Gastropods (Fig. 195) were exceedingly common, perhaps more so than ever before, and of very modern aspect. Oysters appear to have 
reached their culmination in size at least, some having grown to a length of ten to twenty inches and a width of six or eight inches (Fig. 193). Cephalopods, as we have learned, diminished remarkably at the close of the Cretaceous, a very few only of the Ammonites and Belemnites having straggled into the Tertiary, while the Nautiloids (e.g. Nautilus) were more diversified and widespread

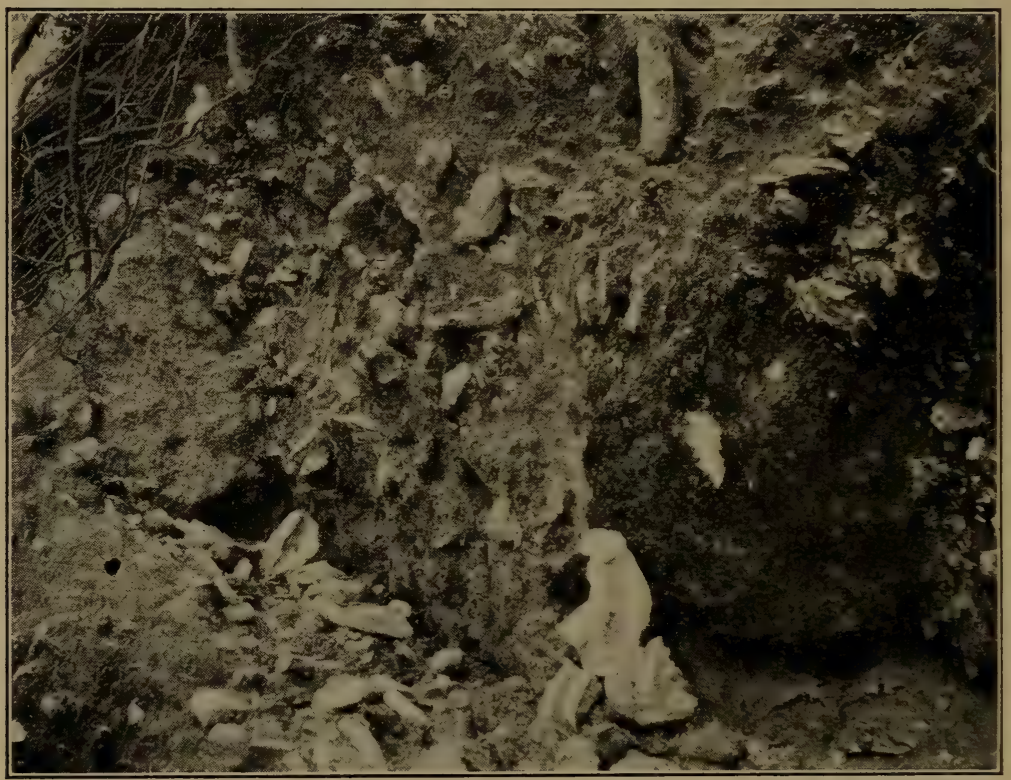

Fig. 193

Large Oyster shells, Ostrea georgiana, in Eocene strata of Georgia. (After L. W. Stephenson, Geol. Sur. Ga., Bul. 26.)

than now. The Dibranchs were of the modern Squid and Cuttlefish types.

Among Arthropods all the principal groups except the simplest (e.g. Trilobites and Eurypterids) were represented, the Crabs among the Crustaceans having become numerous and varied. Insects are known in far greater numbers and variety than from any preceding period. All the important groups or orders were represented, including the highest, such as Moths, Butterflies, 
Beetles, Bees, and Ants. The prolific vegetation of the period was of course very favorable for Insect development.

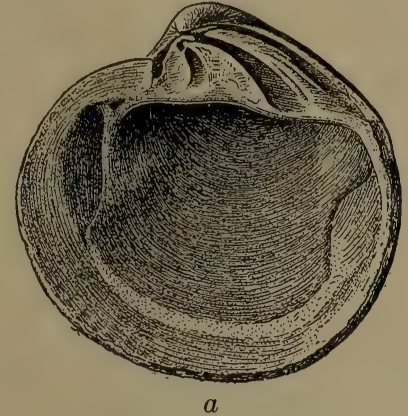

Fig. 194

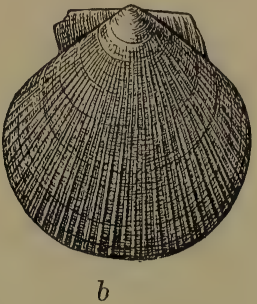

$b$

Tertiary Pelecypods: $a$, Venericardia marylandica (Clark and Martin); b, Pecten choctanensis (Aldrich). (After Maryland Geological Survey.)

In a single Miocene stratum a few feet thick at Oeningen, near the Swiss border, more than 900 species of Insects have been found. "In some places the stratum is black with the remains of Insects.

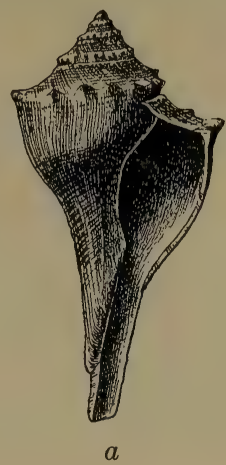
subcalarina; c, Turritella potomacensis. (All from Maryland Geological Survey.)

The same stratum is also full of leaves of Dicotyls, of which Heer has described 500 species. Mammalian remains and also Fishes 
are found. . . . Doubtless, at Oeningen, in Miocene times, there was an extensive lake surrounded by dense forests, through which ran a small river emptying into the lake; and the Insects drowned in its waters, and the leaves strewn by the winds on its surface, were cast ashore by the waves. . . . Over 500 of the Oeningen Insects were Beetles." 1

Another remarkable occurrence of fossil Insects is in the amber of northern Germany, especially on the shores of the Baltic Sea, where fully 2000 species have been obtained. The amber is a

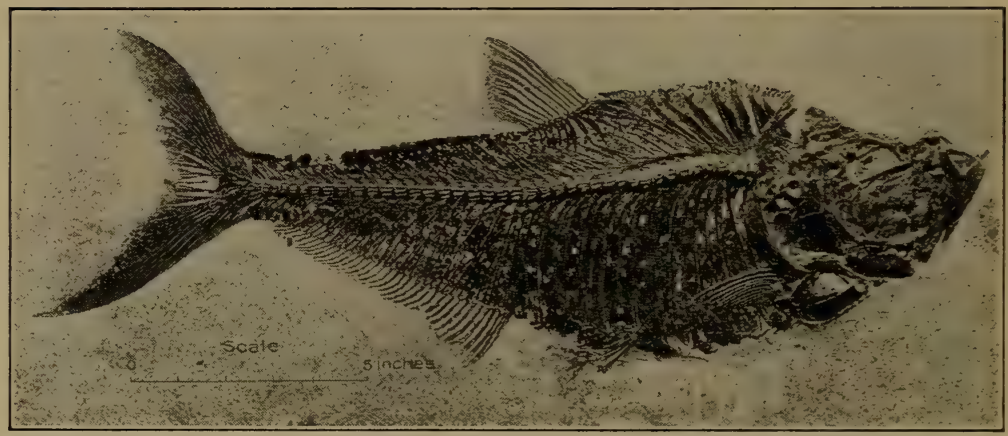

Fig. 196

A nearly perfect fossil Teleost Fish, Diplomystus densatus, from the Eocene of Wyoming. (After Veatch, U. S. Geological Survey, Prof. Paper 56.)

fossil resin of early Oligocene age derived from certain Conifers. The Insects were caught in the resin while it was still soft and sticky and they were thus literally embalmed and perfectly preserved to the present day in the often quite transparent amber.

At Florissant, Colorado, certain fresh water shales of Oligocene (?) age are said to be black with the remains of Insects. Over 2000 species are represented as well as various plants, Fishes, and even a Bird with well-preserved feathers.

Fishes. - These were in general much like those of the later Mesozoic, though even more modern in aspect. Teleosts (Fig. 196) predominated, but Sharks were abundant and of great size - 60 to 80 feet long - with fossil teeth up to 5 or 6 inches long occur-

1 J. Le Conte: Elements of Geology, 5th ed., p. 534. 
ring in immense numbers in some places as, for example, the Atlantic Coast of the United States (Fig. 197).

Amphibians. - After the culmination of their development in the Triassic, the Amphibians never again assumed much importance. In the Tertiary they were represented only by such modern types as Salamanders, Frogs, and Toads. A four-foot skeleton of a Salamander discovered at Oeningen, Switzerland, in 1728, attracted much attention for many years. It was called "Homo Diluvii Testis," because it was considered to be the skeleton of a human being killed during the great deluge of Noah.

Reptiles. - These, too, were quite modern in character, with Lizards, Snakes (all non-poisonous), Crocodiles, and Turtles all common and varied.

Birds. - These were much more advanced and numerous than in later Mesozoic time, and many of the modern groups had representatives. A few of the more primi-

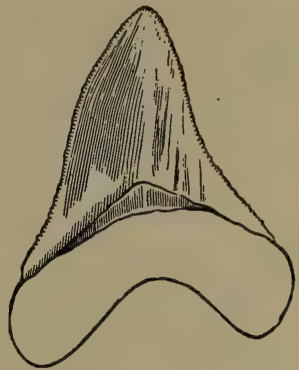

Fig. 197

A Shark's tooth from the Eocene of the Gulf Coastal Plain. Length of tooth, 6 inches. (After Gibbes.) tive or generalized types, however, still existed in the early Tertiary. Thus a toothed Bird has been found in the Eocene of England, though it is to be noted that the teeth were not set in sockets but were only dentations of the edge of the bill (Fig.

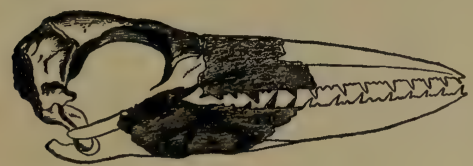

Fig. 198

Head of an Eocene Bird, Odontopteryx toliapicus, showing teeth. (After Owen.)

198). Another special feature was the existence of very large, flightless Ostrich-like forms which attained heights up to fully 10 feet.

Mammals. - All during the Mesozoic era Mammals existed, but they were represented only by comparatively few, small, primitive forms which always occupied a very subordinate position in the animal world. Very early in the Tertiary, however, there began a wonderful development of Mammals. Evolution of many of the higher groups went on rapidly, so that by the close of the period the Mammals had become differentiated into most of the principal modern types. One of the most significant features in 
the evolution of the Mammals during the Cenozoic was the gradual increase in the relative sizes of the brains. The accompanying
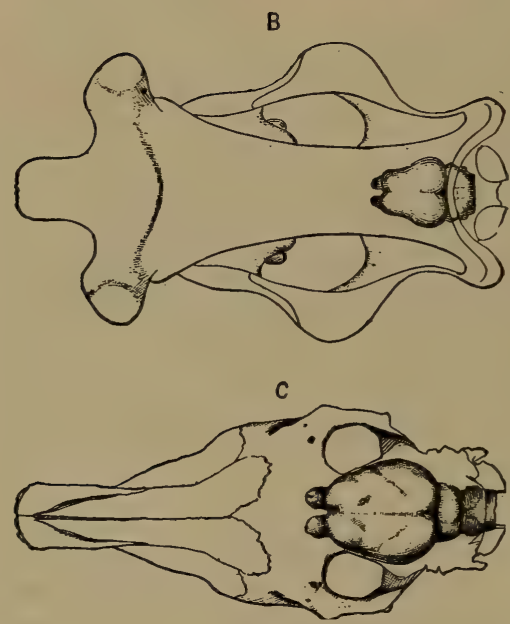

Fig. 199

Sketches to illustrate increase in size of brains of Mammals from the Eocene to the present. $A$, Eocene Uintatherium; $B$, Miocene Brontotherium; $C$, modern Horse, Equus. (After Marsh, from Shimer's "Introduction to the Study of Fossils," courtesy of The Macmillan Company.)

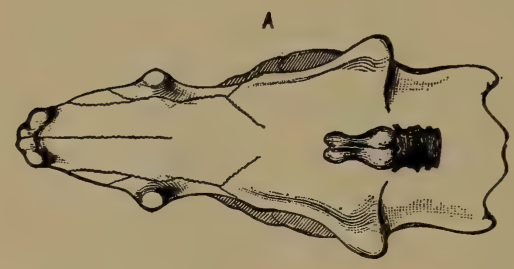

sketches graphically illustrate this fact (Fig. 199).

Mammals comprise the highest of all animals and are all characterized by suckling the young. For convenience of discussion, they may be divided into three groups as follows: (1) Monotremes or egglaying forms, such as the modern Spiny Ant-eater; (2) Marsupials (e.g. Opossum and Kangaroo) or those giving birth to imperfectly formed young, which are then carried by the mother in a pouch (marsupium); and (3) Placentals (e.g. Dog, Horse, and Man) or those giving birth to well-formed young which, in the prenatal condition, are attached to the mother by the placentum. So far as known, only Monotremes and Marsupials existed during the Mesozoic, but during the Tertiary they were very subordinate to the Placentals, and today they are comparatively rare. The Cenozoic was, (and is) therefore, very decidedly the "Age of Placental Mammals."

Because of the vast wealth of material concerning Tertiary Mammals, we can do no more, in our brief survey, than to refer to a few of the more interesting and better known evolutionary features.

Generalized Mammals of the Early Tertiary. - Although Mammals were the dominant animals even in the early Tertiary, 
nevertheless they were not then differentiated into the more or less clearly defined groups of today such as the Carnivores, or flesh eaters (e.g. Dogs, Bears, Tigers, etc.); Perissodactyls, or hoofed Mammals with an odd number of toes (e.g. Horses, Rhinoceroses, etc.); Artiodactyls, or hoofed Mammals with an even number of toes (e.g. Camels, Deer, Pigs, etc.); Proboscidians, or trunk-bearing hoofed Mammals (e.g. Elephants); Rodents, or gnawers (e.g. Rats, Squirrels, etc.); Insectivores (e.g. Moles, Hedgehogs, etc.); Cetaceans, or exclusively swimmers (e.g. Whales, Dolphins, etc.); Primates, or the very highest of all Mammals (e.g. Monkeys, Man, etc.); and many others. These groups, traced back toward the early Tertiary, gradually become less and less distinct until, in the Eocene, they cannot be at all distinguished as separate groups, but rather we find ancestral or generalized forms which show combinations of features of the later groups.

One of the most characteristic of these generalized types

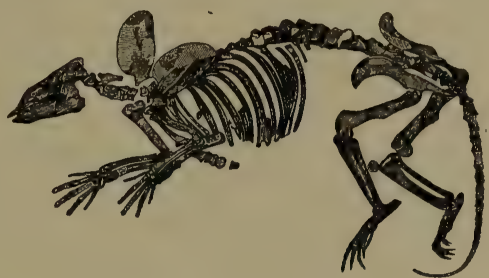

Fig. 200

A nearly perfect skeleton of the Eocene Phenacodus primaevus. (After Cope.)

of the early Eocene was Phenacodus (see Fig. 200). The various species of this genus showed about the same range in size as modern Dogs. Each foot had five toes which were supplied with nails rather between true claws and true hoofs in structure. The simple (primitive) teeth indicate that the animal was omnivorous, that is both plant and flesh eating. In harmony with other early Tertiary Mammals, the brain was relatively small and almost devoid of convolutions, thus pointing to a low grade of mental development.

Perissodactyls (e.g. Horse). As an example of the history of the odd-toed, hoofed, Mammals, we shall consider the well-known evolution of the Horse family. At least forty species of this family, ranging from early Eocene to the present, have been described, and practically every connecting link in the evolution of the family is known. Only a few of the most important changes can be noted in our brief description, which is, in fact, not much more than an explanation of the excellent chart shown in Fig. 201. The earliest form, called Eohippus, occurring in the lower Eocene, was 
about the size of a large cat (Fig. 202). On the forefoot it had four functional toes (one larger than the others) and a splint or imperfectly developed fifth toe. The hind foot had three functional toes and a splint. Doubtless this early member of the Horse family was derived from an original five-toed ancestor ${ }^{1}$ whose general structure was something like Phenacodus. In the later

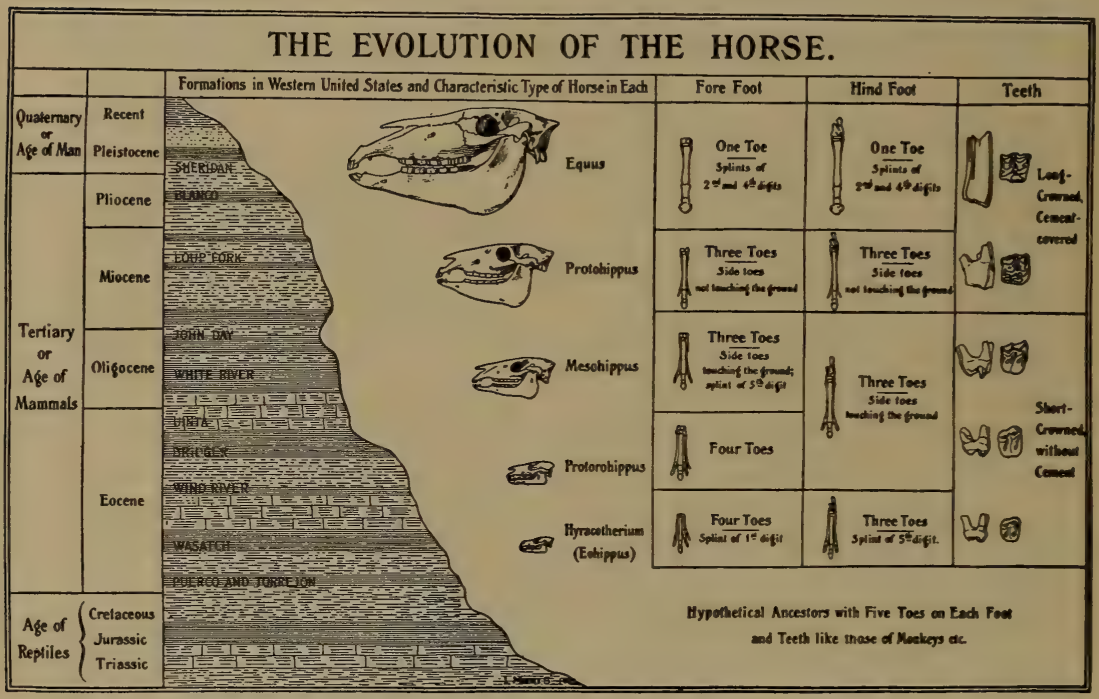

Fig. 201

Chart to illustrate the evolution of the Horse family. (After W. D. Matthew, Amer. Mus. Nat. Hist. Journal.)

Eocene Protorohippus had four distinct toes on the front foot and three on the hind foot, but with no sign of splints. This form was but little larger than Eohippus. During the Oligocene Mesohippus had three functional toes (the middle one being distinctly larger), with the former fourth toe reduced to a splint on the front foot, while the three functional toes continued on the hind foot. It was about the size of a sheep. In the Miocene Protohippus had three toes on both fore and hind feet, but in each case only one was

1 Very recently there has been reported the discovery of a still more primitive form, even more closely resembling the five-toed ancestor. 
large and functional, with the other two small toes not long enough to reach the ground. This form was about the size of a pony. During the Pliocene and Quaternary, Equus, or the modern Horse, had one toe only on front and hind feet with the two side toes of Protohippus reduced to splints (the fetlock of the present-day Horse). Thus we see that the middle toe of the original five-toed

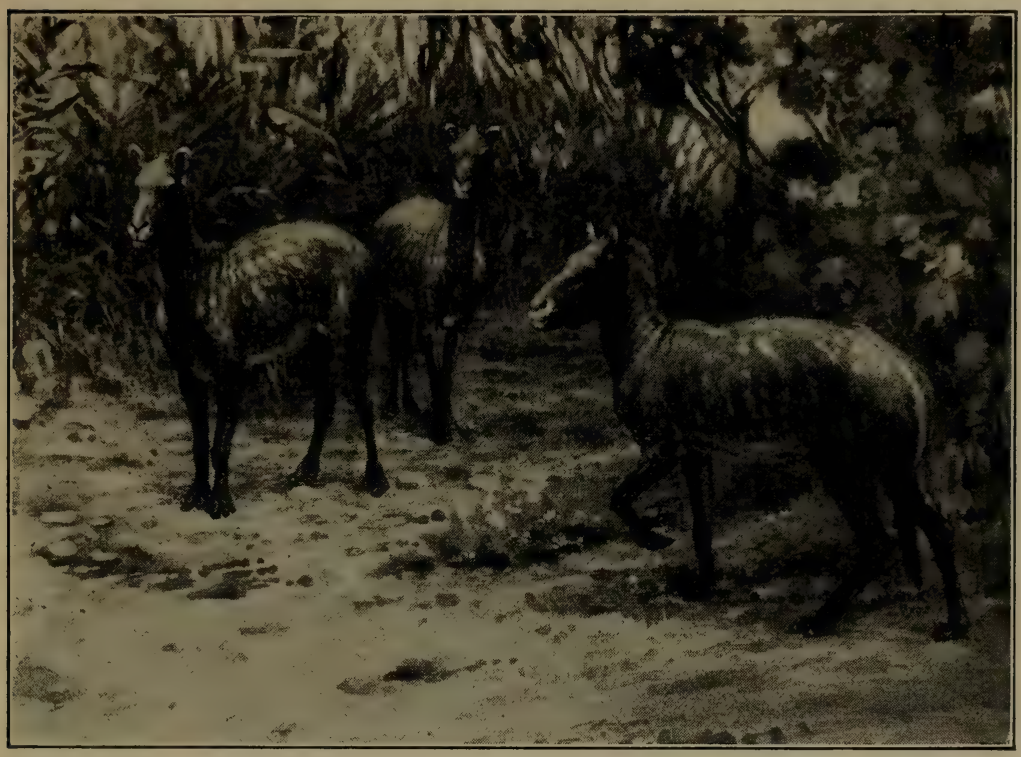

Fig. 202

Primitive or ancestral Horses, Eohippus, of the Eocene. Restored by C. R. Knight under the direction of H. F. Osborn. (Permission of American Museum of Natural History.)

ancestor has developed, to the exclusion of the others, and it is thought that this has tended toward greater fleetness of foot. While these evolutionary changes took place, there was also gradually developed longer and more complex teeth; the two entirely separate bones (radius and ulna) of the fore limb gradually became consolidated into a single strong bone; and the brain steadily increased in relative size.

Artiodactyls (e.g. Camel). These even-toed, hoofed Mam- 
mals (Fig. 203), like the odd-toed ones, were descended from a five-toed Eocene ancestor. In their development the first toe

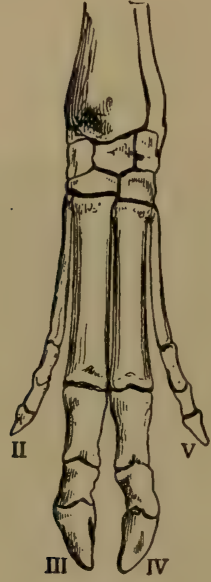

A

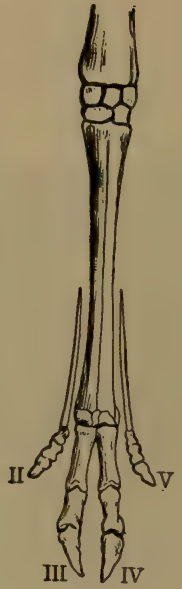

$B$

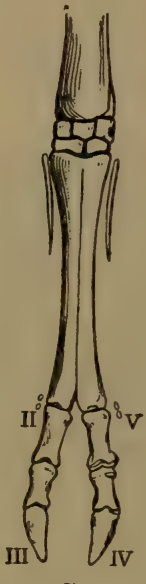

C

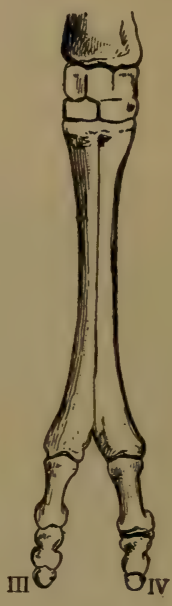

$D$

Fig. 203

Evolution of foot of even-toed (Artiodactyl) Mammals illustrated by existing forms. $A$, Pig; $B$, Roebuck; $C$, Camel. (From Norton's "Elements of Geology," by permission of Ginn and Company, Publishers.)

disappeared, while the middle pair of the remaining four became larger and the two side toes became smaller and smaller, having

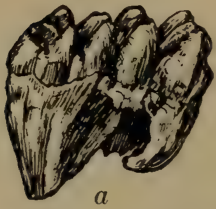

Fig. 204

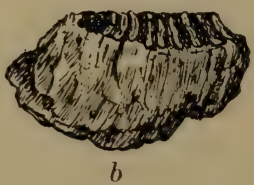

$a$, Mastodon tooth; $b$, Mammoth tooth.

Both viewed from the side. disappeared altogether in such a type as the modern Camel. This sort of evolution in the Camel family has been traced in almost as much detail as in the Horse family. Beside the Camel, other two-toed existing forms are Deer, Cattle, and Sheep. The two-toed Artiodactyls now predominate, while the four-toed forms (at present represented e.g. by Hogs and Hippopotami) culminated in the Tertiary.

Proboscidians (e.g. Elephant). This group of hoofed Mam- 
mals, characterized by the proboscis (trunk), has been traced through many intermediate forms back to primitive Eocene ancestry. Proboscidians culminated in the Pliocene, when they were the largest (up to 13 or 14 feet high), the most numerous, and widespread over much of the earth except Australia. Mastodons, now wholly extinct, are characterized by having knob-like promi-

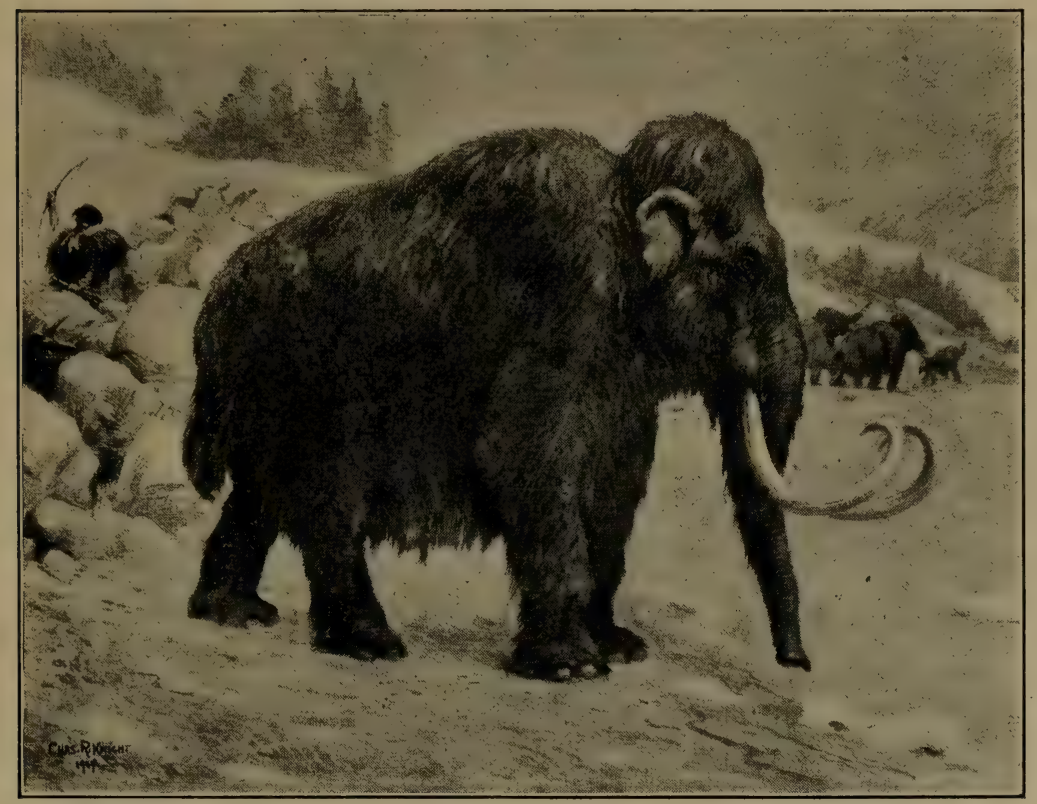

Fig. 205

A Mammoth Elephant, Elephas primigenius, restored by C. R. Knight. (Permission of American Museum of Natural History.)

nences on the chewing surfaces of their large teeth (Fig. 204a), while the true Elephants (including the extinct Mammoths) have large nearly flat grinding surfaces on their teeth (Fig. 204b). True Elephants also nearly always show greater curvature of the tusks. The Mammoth had long brown hair (Fig. 205).

The accompanying sketches (Fig. 206), together with the following excellent summary by Lull, will give a good idea of the evolution of the Proboscidians. "Increase in size and in the de- 

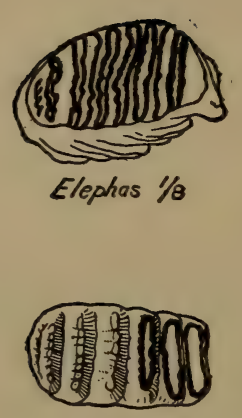

Stegodon $/ 8$

UPPERPLIOCENE)
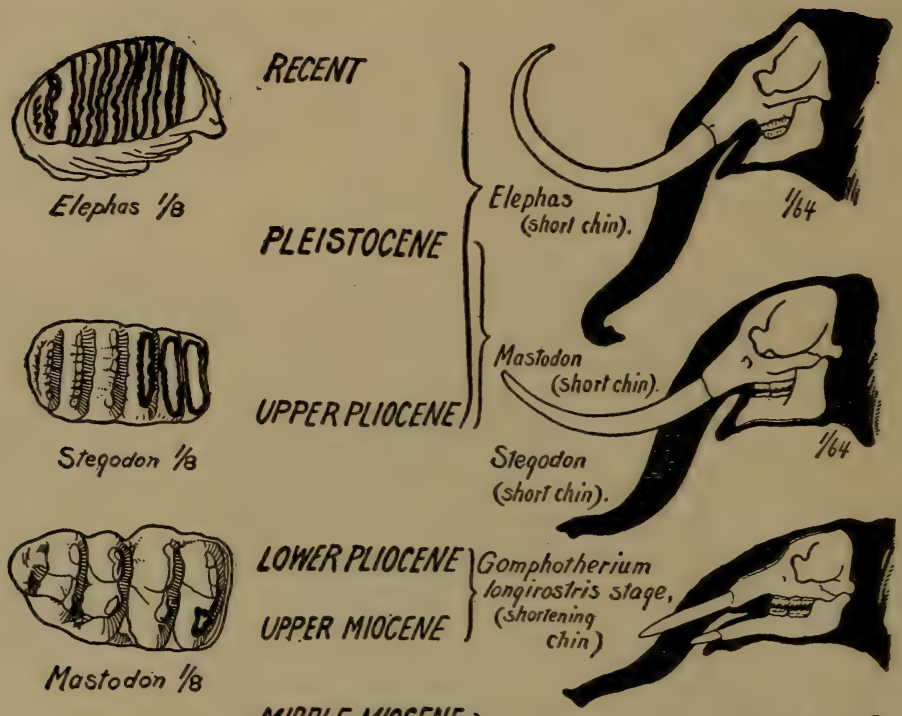

LOWER PLIOCENE

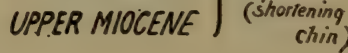

Mastodon $1 / 8$

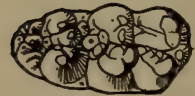

MIOOLE MIOCENE

Tetrabelodon $1 / 8$

Migration into

North America

LOWER MIOCENE)

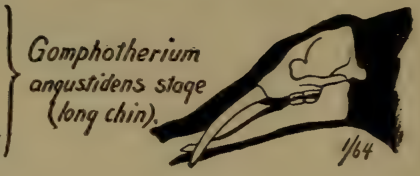

?

UPPER OLIGOCENE

?

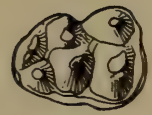

Poloeomastodon $1 / 4$

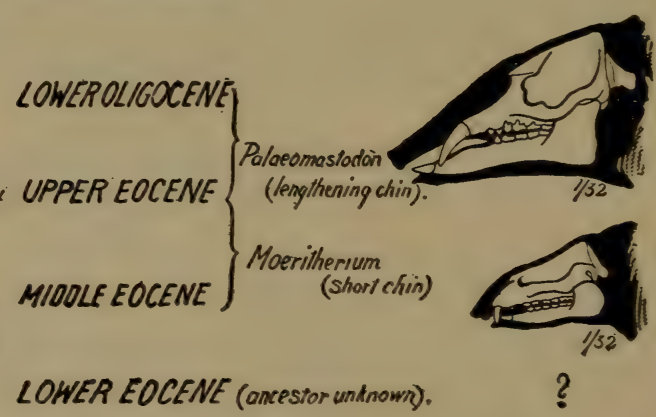

Fig. 203

Chart to illustrate the evolution of the Elephants. (From Scott, after Lull, modified by Sinclair, by courtesy of The Macmillan Company.) 
velopment of pillar-like limbs to support the enormous weight. Increase in size and complexity of the teeth and their consequent diminution in numbers and the development of the peculiar method of tooth succession. The loss of the canines and of all of the incisor teeth except the second pair in the upper and lower jaws and the development of these as tusks. The gradual elongation of the symphysis or union of the lower jaws to strengthen and support the lower tusks while digging, culminating in Tetrabeledon (or Gomphotherium) Angustidens. The apparently sudden shortening of this symphysis following the loss of the lower tusks and the compensating increase in size and the change in curvature of those of the upper jaw.

"The increase in bulk and height, together with the shortening of the neck necessitated by the increasing weight of the head with its great battery of tusks, necessitated the development of a prehensile upper lip which gradually evolved into a proboscis for food gathering. The elongation of the lower jaw implies a similar elongation of this proboscis in order that the latter may reach beyond the tusks. The trunk did not, however, reach maximum utility until the shortening jaw, removing the support from beneath, left it pendant, as in the living Elephant." 1

Carnivores (Tigers, Dogs, etc.). These modern flesh-eaters can be traced back to a generalized order or group (so-called Creodonts, Fig. 207) which had certain characters suggesting the Insect-eaters, hoofed Mammals, and Marsupials, as well as the Carnivores. These Creodonts or ancestral flesh-eaters had small, simple brains and many small teeth. In the course of evolution the existing carnivorous families have been derived from them.

Rodents (Rats, Porcupines, Squirrels, etc.). The Rodents (gnawers) can be traced back to the early Eocene, when the incisor teeth were just developing a structure suitable for gnawing. By the middle of the Eocene the Rodents were common and their incisors were highly specialized for gnawing. Primitive Squirrellike forms are known from the late Eocene.

Insectivores (e.g. Moles, Hedgehogs, etc.). These have also been traced back to the Eocene, and, like the Rodents, they still show many of their ancestral or primitive features. They have changed much less than most of the other classes of Mammals.

Cetaceans (e.g. Whales, Porpoises, etc.). In our study of ${ }^{1}$ R. S. Lull: Amer. Jour. Sci., Vol. 25, 1908, pp. 11-13. 


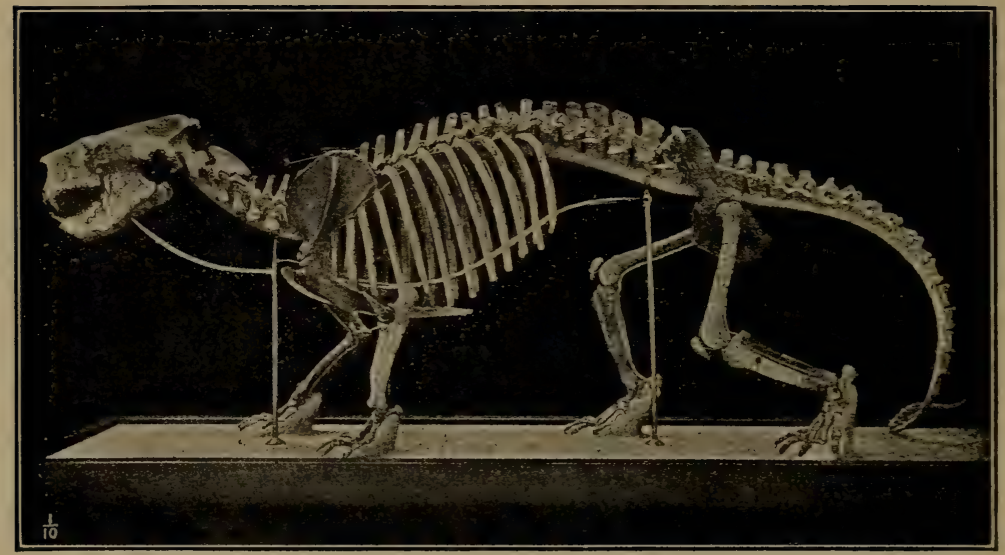

Fig. 207

Skeleton of an Eocene Creodont, Patriofelis. (After Osborn, from Chamberlin and Salisbury's "Geology," courtesy of Henry Holt and Company.)

Mesozoic Reptiles we found that certain forms took to the sea and became truly marine Fish-like creatures, such as the Ichthyo-

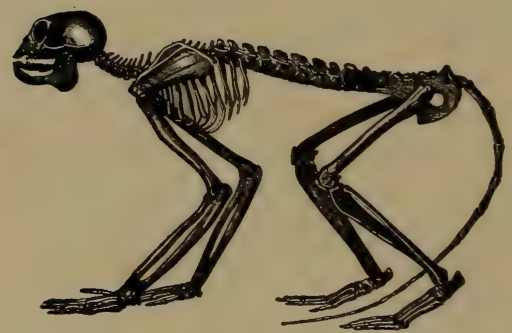

Fig. 208

One of the earliest Monkeys, Mesopithecus pentelici, from the Miocene of Europe, restored by Gaudry. Length of specimen, about 20 inches.

Eocene reached lengths up to 60 or 80 feet and must have been extremely abundant, their vertebræ often being found in great numbers in Alabama and other places. in the Tertiary (even in the Eocene) certain Mammals became so adapted to the water environment as to become Fish-like forms, such as Whales, Porpoises, etc., which are often popularly regarded as true Fishes. Apparently we have here an example of retrogression in evolution, because true land animals took to the water and their legs degenerated into swimming paddles. Certain Whale-like forms (Zeuglodons) of the

saur and the Mosasaur. So

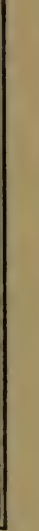

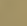


Lemuroids (e.g. Lemurs) and Primates (e.g. Monkeys, Apes, and Man). These two groups include the highest of all animals. During the Eocene "Numerous Lemuroids and primitive types of Monkeys swarmed in the trees" (W. B. Scott). True Monkeys and Apes, however, did not appear till in the Miocene (Fig. 208). A partial skeleton, known as Pithecanthropus erectus, discovered in Java (1891) in deposits possibly of Pliocene age, has been the cause of much discussion. This creature appears to have had characters intermediate between the lowest types of Men and the highest types of Apes, but the bones have elicited much difference of opinion. By some they are regarded as those of an ancestral type of Man; by others as those of an abnormal human being; and by still others as those of a large Ape.

So far as present knowledge goes, we have no positive evidence that Man appeared on the earth even late in the Tertiary, though future discoveries may trace his ancestry that far back. The antiquity of Man will be further discussed toward the close of the next chapter. 


\section{CHAPTER XIX}

\section{THE QUATERNARY PERIOD}

By the very nature of the case, our usual method of discussion cannot be applied to the Quaternary period without considerable modification, the characteristic feature having been vast sheets of ice covering much of the northern hemisphere. Otherwise the earth had reached essentially its present geological condition.

\section{Origin of Name, Subdivisions, etc.}

As pointed out toward the beginning of the last chapter, the terms "Tertiary" and "Quaternary" are both remnants of an old geological nomenclature, and both have entirely lost their original significance. The Quaternary is the last great period of earth history, the study of which leads us right up to present-day geographic and geologic conditions. During this period nearly all of the existing species of invertebrates and lower Vertebrates, as well as most of the existing species of Mammals, had appeared. Except in the glaciated regions, the line of separation between the Tertiary and the Quaternary is not at all clearly defined.

Following the usual method, we shall divide the Quaternary period into (1) the Pleistocene or Glacial epoch, which represents the time of ice occupation of northern North America and northern Europe, and (2) the Recent or post-Glacial epoch or time since the removal of the ice from those continents. We are living in the Recent epoch.

\section{The Fact of the Ice Age}

The Quaternary period was ushered in by the spreading of vast ice sheets over much of northern North America and northern Europe. This event must take rank as one of the most interesting and remarkable occurrences in geological time. On first thought, the existence of such vast ice sheets seems unbelievable, but the Ice age occurred so short a time ago that the records of the event are perfectly clear and conclusive. The fact of this great Ice age was discovered by Louis Agassiz in 1837, and fully announced 
before the British Scientific Association in 1840. For some years the idea was opposed, especially by advocates of the so-called iceberg theory. Now, however, no important event of earth history is more firmly established and no student of the subject ever questions the fact of the Quaternary Ice age.

Some of the proofs for the former presence of the great ice sheets are as follows: (1) Polished and striated rock surfaces which are precisely like those produced by existing glaciers, and which could not possibly have been produced by any other agency; (2) glacial boulders or "erratics," which are often somewhat rounded and scratched, and which have often been transported many miles from their parent rock ledges; (3) true glacial moraines, especially terminal moraines, like that which extends the full length of Long Island and marks the southernmost limit of the ice sheet there; (4) the generally widespread distribution, over most of the glaciated area, of heterogeneous glacial debris (so-called "drift") both unstratified and stratified, which is clearly transported material and typically rests upon the bed-rock by sharp contact. In regions which have not been glaciated, it is quite the rule to find that the underlying fresh rock grades upward through rotten rock into soil.

\section{Ice Extent and Centers of Accumulation}

The best known existing ice sheets are those of Greenland and Antaretica, particularly the former, which covers about 500,000 square miles. This glacier is so large and deep that only an occasional high rocky mountain projects above its surface, and the ice is known to be slowly moving outward in all directions from the interior to the margins of Greenland. Along the margins, where melting is more rapid, some land is exposed, but often the ice flows out into the ocean, where it breaks off to form large icebergs.

The accompanying map Fig. 209 shows the area of nearly $4,000,000$ square miles of North America covered by ice at the time of maximum glaciation, and also the three great centres of accumulation and dispersal of the ice. The directions of flow of the ice from these centres have been determined by the study of the directions of a very large number of glacial striæ, as well as the direction of transportation of the glacial debris. Greenland was also buried under ice during the Quaternary period. 
Two striking features regarding the distribution of the ice were (1) the failure of the ice to cover any of Alaska except its high southern mountain region, though that country is much farther north than most of the glaciated area; and (2) the failure of any-

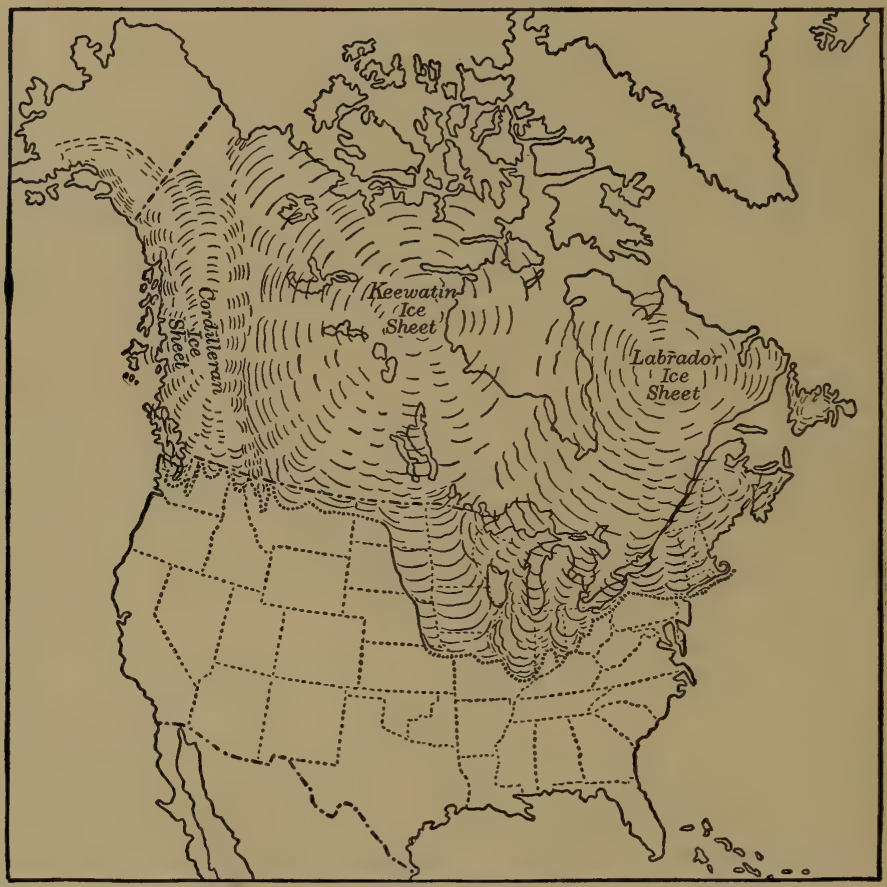

Fig. 209

Map showing the areas occupied by ice in North America at the time of maximum glaciation. The three great centres of dispersal are indicated. (After Salisbury, from Norton's "Elements of Geology," by permission of Ginn and Company, Publishers.)

thing like continuous ice sheets over the high plateaus of the western United States, while the great ice sheet spread over much of the low plains area of the upper Mississippi Basin.

From its centre of accumulation, the Labradorean ice sheet extended fully 1600 miles southwestward or to about the mouth of the Ohio River. The Kewatin sheet extended from its centre 
southward nearly as far, or into northern Missouri. These two great ice sheets practically merged. "One of the most marvelous features of the ice dispersion was the great extension of the Kewatin sheet from a low flat centre westward and southwestward over what is now a semiarid plain, rising in the direction in which the ice moved, while the mountain glaciers on the west, where now known, pushed eastward but little beyond the foothills" (Chamberlin and Salisbury).

The Cordilleran ice sheet appears to have been mostly made up of both plateau and typical mountain (Alpine) glaciers. Toward the south it extended only a little way over the high mountains of the northwestern United States.

Newfoundland, and possibly also Nova Scotia, had local centres of glaciation.

South of the ice sheets above described, the higher mountains of the United States, even as far south as southern California, Arizona, and New Mexico, bore numerous glaciers greatly varying in size. These were always of the typical valley or Alpine types instead of ice sheets. Some of these mountains, such as Shasta, Hood, Rainier, and those of the Glacier National Park in Montana, still have glaciers, the greatest being those of Mount Rainier, where they attain lengths of from 4 to 6 miles.

\section{Direction of Movement and Depth of Ice}

The fact that glacial ice flows as though it were a viscous substance is well known from studies of present-day glaciers in the Alps, Alaska, and Greenland. A common assumption, either that the land at the centre of accumulation must have been thousands of feet higher, or that the ice must have been immensely thick, in order to prevent flowage so far out from the centre, is not necessary. For instance, if one proceeds to pour viscous tar slowly in one place upon a perfectly smooth (level) surface, the substance will gradually flow out in all directions, and at no time will the tar at the centre of accumulation be very much thicker than at other places. The movement of the ice from each of the great centres was much like this, only in the case of the glacier the piling up of snow and ice was by no means confined to the centres of accumulation.

Some of the finest examples of the influence of topography upon the direction of movement of the ice are afforded by New 
York state on account of its peculiar relief features. When the Labradorean ice sheet spread southward as far as northern New York, the Adirondack Mountains stood out as a considerable obstacle in the path of the moving ice, and the tendency was for the current to divide into two portions, one of which passed southwestward up the low, broad St. Lawrence Valley, and the other due southward through the deep, narrow Champlain Valley. As the ice kept crowding from the rear, part of the St. Lawrence ice lobe pushed into the Ontario basin, while another portion worked its way up the broad, low Black River Valley and finally into the Mohawk Valley. At the same time the Champlain ice lobe found its way into the upper Hudson Valley, and sent a branch lobe westward up the broad, low Mohawk Valley. The two Mohawk lobes, the one from the west and the other from the east, met in the midst of the Mohawk Valley. As the ice sheet continued to push southward, all the lowlands of northern New York were filled; a tongue or lobe was sent down the Hudson Valley; and finally the whole state, except slight portions of the southern border, was buried under the ice. The general direction of flow at this time of maximum glaciation was southward to southwestward, with perhaps some undercurrents determined by the larger topographic features. Thus we learn that the major relief features of the state very largely determined the direction of ice currents, except at the time of maximum glaciation, when only the undercurrents were controlled. These ideas are abundantly borne out by the distribution of glacial striæ and boulders over the state.

Evidences of glaciation, such as striæ, boulders, lakes, etc., occur high up in the Adirondacks, the Catskills, the Green and the White Mountains, and the Berkshire Hills, so that the greatest depth of ice over New York and New England could not have been less than some thousands of feet. In fact we have every reason to believe that all of the mountains named, except possibly the Catskills, were completely buried. The reader may wonder how an ice sheet a mile thick in northern New York could have thinned out to disappearance at or near the southern border of the state, but observations on existing glaciers show that it is quite the habit of extensive ice bodies to thin out very rapidly near the margins, thus producing steep slopes along the ice fronts.

There is little reason to doubt that the vast ice sheet over the upper Mississippi Valley was also thousands of feet thick. The 
positions of the moraines there clearly prove that the ice front was more or less distinctly lobate.

\section{Successive ICe Invasions}

The front of the great ice sheet, like that of ordinary valley glaciers, must have shown many advances and retreats. In the northern Mississippi Valley, however, we have positive proof of several (perhaps five of six) important advances and retreats of the ice which gave rise to true interglacial stages. The strongest evidence is the presence of successive layers of glacial debris, a given

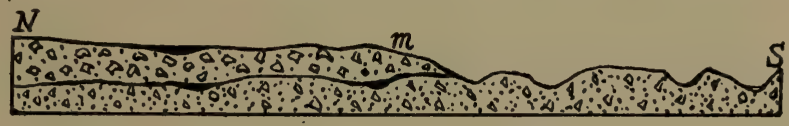

Fig. 210

Diagram to show how successive glacial drift sheets are distinguished. $N$ to $m$, younger drift; $m$ to $S$, surface of older drift. Surface of younger drift almost unaffected by erosion and weathering, while the older drift is notably dissected and its surface considerably weathered. A distinct terminal moraine at $m$ marks end of younger drift sheet. Heavy black bands represent deposits of organic matter.

layer often having been oxidized, eroded, and covered with vegetation before the next (overlying) layer was deposited (see Fig. 210). In drilling wells through the glacial deposits of Iowa, for example, two distinct layers of vegetation are often encountered at depths of from 100 to 200 feet. Near Toronto, Canada, plants which actually belong much farther south in a warm climate have been found between two layers of glacial debris. Thus we know that some, at least, of the ice retreats produced interglacial stages with warmer climate and were sufficient greatly to reduce the size of the continental ice sheet or possibly to cause its entire disappearance.

By applying the principles just laid down, at least five advances and retreats of the ice, with distinct interglacial intervals have been recognized in North America as follows: (1) Pre-Kansan or Jerseyan; (2) Kansan; (3) Illinoian; (4) Iowan; and (5) Wisconsin. ${ }^{1}$

1 The Wisconsin invasion is sometimes divided into two - an early and a late Wisconsin. 
In New York and New England no very positive evidence has as yet been found to prove truly multiple glaciation, though some phenomena as, for example, certain buried gorges, are difficult to account for except on the basis of more than one advance and retreat of the ice. At any rate there appears to be no good reason whatever to believe that there were more than two advances and retreats of the ice over this region.

For our purpose in considering only the general effects of glaciation, we may practically disregard the problem of multiple glaciation, because the final effects would have been essentially the same as a result of a single great glacial advance and retreat.

\section{The Driftless Areas}

In southwestern Wisconsin, and extending a little into Iowa and Illinois, there is a non-glaciated area of about 10,000 square miles which lies several hundred miles north of the southern limit of the ice sheets (see Fig. 209). This is called a "driftless area," because of the utter absence of glacial debris or any other evidence of glaciation within its boundary. In spite of several ice invasions on all sides, this small area was never ice covered. Residual soils and rotten rock are widespread; there are no lakes; and the streams are mostly graded and without waterfalls or rapids. This small region, therefore, gives an excellent idea of the kind of topography which the whole upper Mississippi Valley would have shown had it not been for the glaciation. At no time did the Labradorean ice sheet spread far enough eastward, or the Kewatin sheet far enough westward, to cover this driftless area. The highland district just south of Lake Superior doubtless served to deflect and weaken the flow of the Labradorean ice which otherwise might have spread far enough to have covered the driftless area.

A much smaller driftless area has more recently been discovered along the Mississippi River in Missouri. It is not difficult to understand why such an area so close to the southern limit of glaciation escaped all advances of the ice sheets.

\section{ICE ERosion}

Ice, like flowing water, has very little erosive effect unless it is properly supplied with tools. When flowing ice is shod with hard 
rock fragments the power to erode is often pronounced, because the work of abrasion is mostly accomplished by the rock fragments embedded in the ice rather than by the soft ice itself. For instance, when the great ice lobe moved up the St. Lawrence Valley it was shod with many pieces of hard pre-Cambrian rocks, and the effects of erosion are remarkably well shown in the Thousand Islands region, where successions of great grooves cut in the solid rock may often be seen. A little search will reveal polished and scratched or grooved rock surfaces in almost any part of the

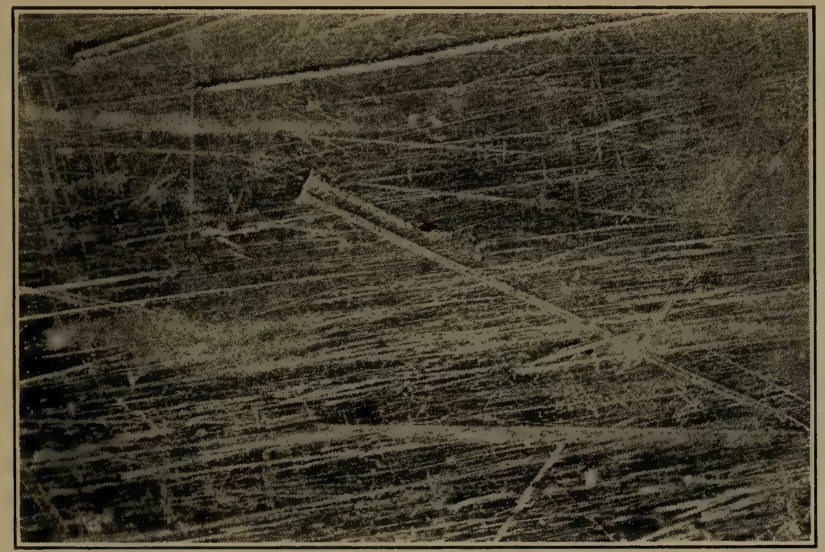

Fig. 211

Smoothed and striated (glaciated) limestone.

(W. J. Miller, photo.)

glaciated region of the continent (Fig. 211). Hard rock ledges most frequently exhibit glacial marks, and the freshness and hardness of such surface rock proves that the ice eroded all of the deep residual soil as well as the zone of rotten rock, and an unknown amount of live or fresh rock.

In former years a very great erosive power was ascribed to flowing ice, but today some glacialists consider ice erosion to be almost negligible, while many others maintain that, under favorable conditions, flowing ice may produce very notable erosive effects. During the long pre-Glacial time, rock decomposition must have progressed so far that rotten rock, including soils, had 
accumulated to considerable depths, as today in the southern states. Such soils are called "residual," because they are derived by the decomposition of the very rocks on which they rest. But now one rarely sees rotten rock or soil in its original position well within the glaciated area, because such materials were nearly all scoured off by the passage of the great ice sheet, mixed with other soils and ground up rock fragments, and deposited elsewhere. Such are called transported soils. Along the southern side of the

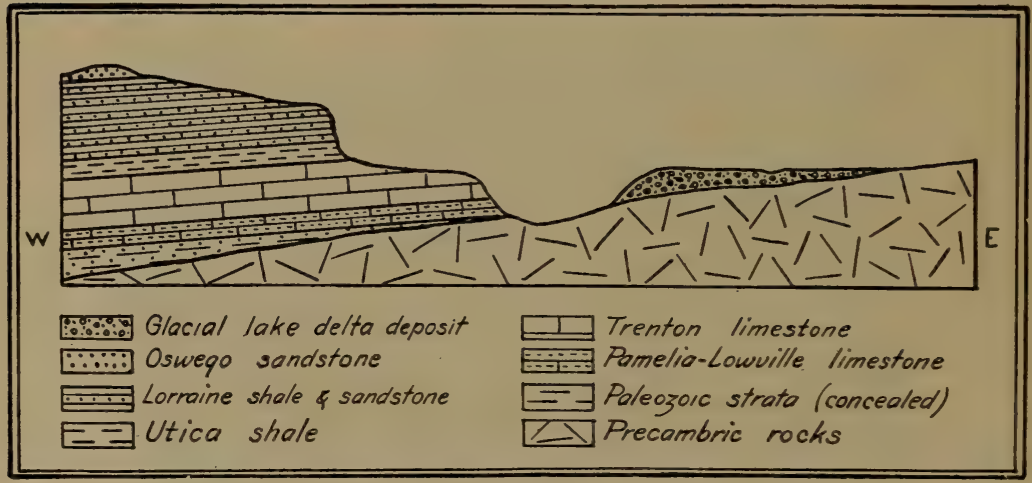

Fig. 212

Structure section across the Black River Valley of northern New York to illustrate the effect of ice erosion and glacial lake deposition. Note the steep front of the shale terrace which has been produced by ice erosion, and the conspicuous delta deposit of the extinct glacial lake on the east side. The surface of the delta deposit represents the former lake level. (After W. J. Miller, N. Y. State Mus., Bul. 135.)

glaciated area, where the erosive power of the ice was least, rotten rock is more common. Ice, shod with hard rock fragments and flowing through a deep, comparatively narrow valley of soft rock, is especially powerful as an erosive agent, because the tools are supplied, the work to be done is easy, and the increased depth of the ice where crowded into a deep, narrow valley causes greater pressure on the bottom and sides of the channel. Many of the valleys of northern New York were thus favorably situated for ice erosion, as, for example, the Champlain, St. Lawrence, Black River, Finger Lakes valleys. The writer has made a special study of ice erosion in the Black River Valley of New York, and Fig. 212 
is a structure section across it showing the rock terraces and the relations of the various rock formations. The conditions for ice erosion there were unusually favorable, because the ice, in its great sweep around the Adirondacks, was heavily shod with hard rock fragments and entered the deep valley by striking with greatest force against the soft rocks on the west side. The soft shales were worn back more than the harder limestones, while the very hard pre-Cambrian rocks were but little affected. If soft shales had made up the valley bottom, ice erosion would have caused considerable deepening, as was, no doubt, the case in the valleys of the Finger Lakes region of western New York. Even in places so favorably situated as those just mentioned there is no reason to believe that ice erosion did any more than to modify the profiles of the pre-Glacial channels.

It is also a singular fact that glacial deposits left by one ice sheet may actually have been overridden by a later advance of ice with little erosion of even such soft material. This probably happens only near the margin, where the ice is rather thin and hence would not be expected to have much erosive power.

In conclusion we may say that while many comparatively small, local features were produced by ice erosion, the major topographic features of the great glaciated area were practically unaffected by the abrasive effects of the passing ice sheets.

\section{ICE Deposits}

The vast amount of debris transported by the great ice sheet was carried either on its surface, frozen within it, or pushed along beneath it. It was heterogeneous material ranging from the finest clay, through sand and gravel, to boulders of many tons' weight. The deposition of these materials took place during both the advance and retreat of the ice, but chiefly during its retreat. Most of the deposits made during the ice advance were obliterated by ice erosion, while those formed at the time of the retreat have been left intact except for the small amount of post-Glacial erosion and weathering. The term "drift," applied to all deposits of glacial origin, was given at a time when they were regarded as flood or iceberg deposits. Drift covers practically all of the glaciated region except where bare rock is actually exposed, and its thickness is very variable, ranging from nothing to some hundreds of feet. 
The ice sheet could advance only when the rate of motion was greater than the rate of melting of the ice front, and vice versa in case of retreat. Thus it is true, though seemingly paradoxical, to assert that the ice was constantly flowing southward even while the ice front was retreating northward. Whenever, during the great general retreat, the ice front remained stationary because the forward motion was just counterbalanced by the melting, all the ice reaching the margin of the glacier dropped its load to build up a terminal moraine. Such a moraine is a more or less distinct ridge of low hills and depressions consisting of very heterogeneous and generally unstratified debris, though at times waters emerging from the ice caused stratification. The depressions are usually called kettle-holes. The so-called great terminal moraine marks the southernmost limit of the ice sheet, and is wonderfully well shown by the ridge of low, irregular hills extending the whole length of Long Island. It is also more or less clearly traceable across the United States, where it marks the southernmost limit of glaciation. Terminal moraines farther northward are generally not so long or sharply defined, though many have been located and described. These are either terminal moraines found at the southernmost limits of ice sheets which did not extend as far south as earlier sheets, or recessional moraines formed during each considerable pause of a waning or northward retreating ice sheet.

When the ice front paused for a considerable time upon a rather flat surface, the debris-laden streams emerging from the ice formed what is called an overwash plain by depositing layers of sediment over the flat surface. An excellent illustration of such an overwash plain is all of that part of Long Island lying just south of the great terminal moraine, and known as the Jamaica plain toward the west.

When the ice front extended across a more rugged country, with valleys sloping away from the ice, the large glacial streams, heavy laden with debris, caused more or less deposition of materials on the valley bottoms often for many miles beyond the ice front. Such deposits, known as valley trains, are especially well developed along many of the larger south-flowing streams of the glaciated area.

Glacial boulders (erratics) have already been referred to. They are simply blocks of rock or boulders from the top of the ice or within it which have been left strewn over the country as a result of the melting of the ice. They vary in size from small pebbles to 
those of many tons' weight, and are naturally most commonly derived from the harder and more resistant rock formations. Thus erratics from the Adirondack Mountains are very numerous from central to southern New York. Erratics are often found high up on the mountains, where they have sometimes been left stranded in remarkably balanced positions.

A very extensive glacial deposit, called the ground moraine, is simply the heterogeneous, typically unstratified debris from the bottom of the ice which was deposited, sometimes during the ice advance, but most often during its melting and retreat. When it

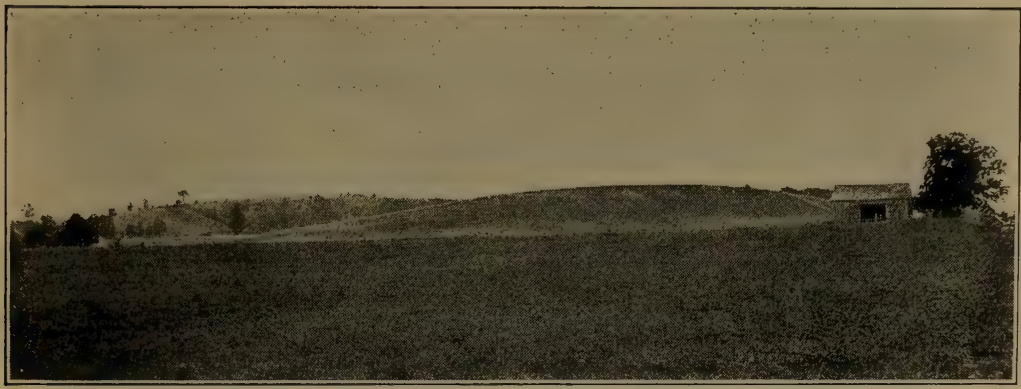

Fig. 213

Typical drumlins (side view) in western New York. (After H. L. Fairchild, N. Y. State Mus., Bul. 111.)

is mostly very fine material with pebbles or boulders scattered through its mass, it is known as till or boulder clay. The pebbles or boulders of the till are commonly faceted and striated as a result of having been rubbed against underlying rock formations.

Another type of glacial deposit of unusual interest is the drumlin, which is in reality only a special form of ground moraine - material. The typical drumlins of western New York, Wisconsin, and western Massachusetts are low, rounded mounds of till with elliptical bases and steeper slopes on the north sides. Their long axes are parallel to what was the direction of ice movement (see Fig. 213). In height they rarely exceed 200 feet, being most often less than 100 feet. The origin of the drumlins has not yet been satisfactorily determined, though it is known that they formed near the margin of the ice either by the erosion of an earlier drift layer or by accumulation beneath the ice under peculiarly favorable 
conditions, as perhaps along longitudinal crevasses or fissures. Two of the finest and most extensive exhibitions of drumlins in the world are in New York, between Syracuse and Rochester, and in eastern Wisconsin, where thousands of them rise above the general lavel of the plains and give rise to a unique topography.

Another type of glacial deposit in the low hill form is the kame, which, in contrast with the drumlin, always consists of stratified drift. Kames are seldom as much as 200 feet high, and typically they have nearly circular bases, though frequently they are of

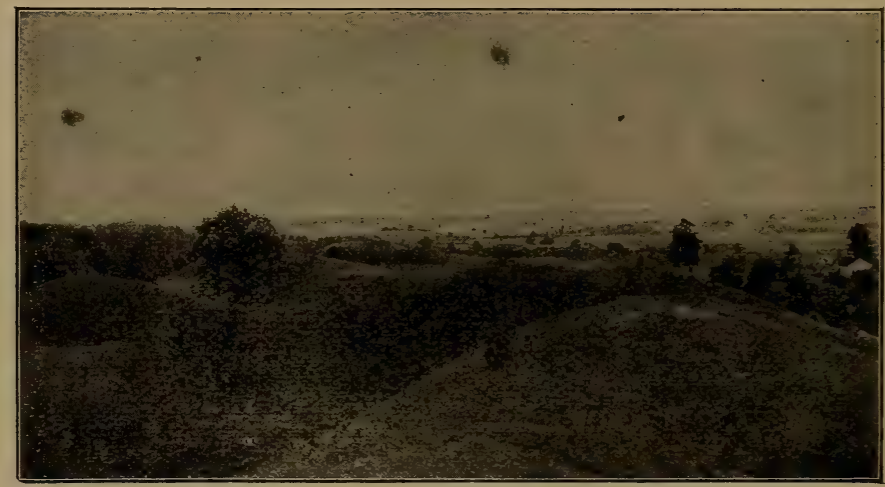

Fig. 214

A group of kames in New York state. (From Norton's "Elements of Geology," by permission of Ginn and Company, Publishers.)

very irregular shapes. At times they exist as isolated hills or in small groups (Fig. 214), while often they are associated with the unstratified deposits of the moraines. When grouped, deep depressions occur between the hills to form what is called the knob and kettle structure. Kames were formed at or near the margin of the retreating ice, and so are found in all parts of the glaciated area, but more especially where there is considerable relief, as in New York and New England. They most generally are located in valley bottoms, but sometimes on hillsides or even hilltops. They are especially abundant along the line of the great terminal moraine (e.g. Long Island) and along the lines of the more important recessional moraines. They were formed as deposits by debrisladen streams emerging from the margin of the ice, the water 
sometimes having risen like great fountains because of pressure. Such deposits are now actually in process of formation along the edge of the great Malaspina glacier of Alaska.

During the ice retreat glacial lakes were numerous, particularly where the north-sloping valleys were dammed by the ice thus ponding the waters in the valleys. Some materials were directly deposited from the glacier in those lakes, but more was brought in by debris-laden streams flowing from the land already freed from the ice. Such glacial lakes and their deposits were common and of unusual interest, but they will be described under a subsequent heading.

In conclusion we may say that the deposition of glacial materials, like glacial erosion, has not changed the major topographic features of the glaciated region. The general tendency of ice deposits has been to fill, or partially fill, depressions and thus to diminish the ruggedness of the topography.

\section{The Loess Deposits}

Loess deposits are widespread over much of the region from eastern Nebraska, across Iowa, Illinois, and Indiana. Its distribution is pretty largely independent of topography. Typically it is a soft, buff to yellowish-brown, very fine grained, sandy clay which seldom shows signs of stratification. Its thickness usually varies from 10 to 100 feet. Where eroded or cut into, the loess exhibits a remarkable tendency to stand in perpendicular cliffs, sometimes with suggestions of a sort of columnar structure. For this reason it was once known as the Bluff formation. It is remarkably free from coarse materials, except for certain carbonate of lime and oxide of iron concretions and fossils, the latter being chiefly shells of land Gastropods. Most of the loess was deposited during the Iowan Glacial stage, because it rests upon the eroded and weathered surfaces of older glacial deposits and often passes under the later or Wisconsin deposits.

The question as to whether the loess was of aqueous or eolian origin has long been discussed. "In part the loess seems to have been washed from glacial waste and spread in sluggish glacial waters, and in part to have been distributed by the wind from plains of aggrading glacial streams" (W. H. Norton). 


\section{Great Lakes History}

The Great Lakes certainly did not exist before the Ice age, but instead the depressions in that region were occupied by stream channels. During the very long erosion period from the Paleozoic to the Cenozoic, no lakes of any consequence could have persisted. Compared with such an immense length of time lakes are, at most, only ephemeral features of the earth's surface because they are soon destroyed either by being filled with sediments, or by having their outlets cut down, or both. Since the Great Lakes are of postGlacial origin it is, then, proper to ask how they came into existence. During pre-Glacial time broad valleys were cut out along belts of weak rock in the Great Lakes region, and these old valleys, to a considerable extent at least, account for the present depressions, but not for the closed lake basins. This idea of pre-Glacial stream valleys is not at all opposed by the fact that some of the lake bottoms are now well below sea level, because there has been notable subsidence of the region since pre-Glacial time. The surface of Lake Erie is 573 feet, and its deepest point 369 feet, above sea level, while the surface of Lake Ontario is 247 feet above, and its deepest point is 491 feet below, sea level. The greatest depth (738 feet) of Lake Ontario is well toward the east end not far from the south shore, and if we consider this deep place as due to pre-Glacial erosion, we ought to find an outlet channel. But no such outlet channel exists because the whole east end, at least, of the lake is rock-rimmed. As Tarr has said: "There could hardly be a valley over 700 feet deep and broad enough to form the continuation of the pre-Glacial Ontario Valley, which is so completely obscured by drift that not the least trace of it has been found on the surface." 1 To assume that this deep part of the basin was formed by warping of the land is not borne out by examining the exposed strata on all sides. It therefore seems quite certain that the pre-Glacial Ontario depression was considerably deepened by ice erosion. The conditions were very favorable for such erosion because the rocks were chiefly soft Ordovician shales; because the ice flowed through a deep pre-Glacial valley; and because there was an unusual crowding of the ice into this valley due to pronounced deflection of a great ice current around the Adirondacks on the west side. Strong arguments might be adduced

${ }^{1}$ R. S. Tarr: Physical Geography of New York State, p. 235. 
to show that by ice erosion portions, at least, of all the lake basins were appreciably deepened. Even so, however, we have not yet accounted for the present closed basins. Probably the two most important phenomena which have contributed to the formation of the closed basins of the Great Lakes are (1) the great drift accumulations along the south side and (2) the tilting of the land downward on the north side of the region. The deep drift deposits must certainly have been very effective in damming up the south or southwest-flowing pre-Glacial streams of the region. A great

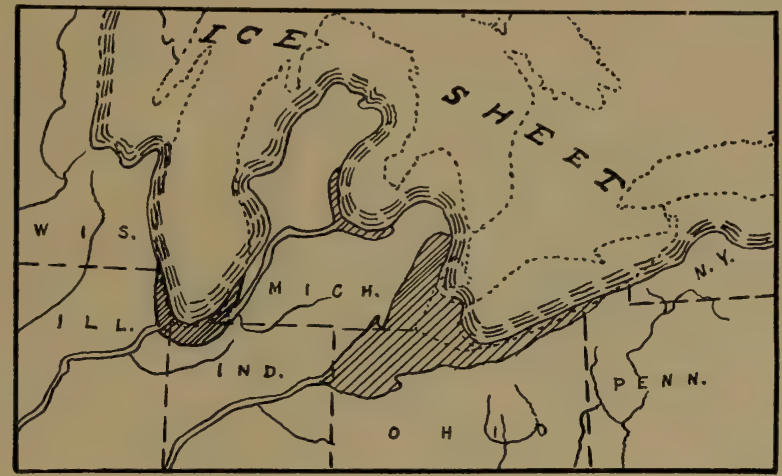

Fig. 215

First stage in the history of the Great Lakes, when all the rest of the lake basins were still buried under the ice. Shaded portions show Lake Chicago on the left and Lake Maumee on the right. (After Taylor and Leverett, redrawn by W. J. M.)

dumping ground of ice-transported materials from the north was in general along the southern side of the Great Lakes and southward. Late in the Ice age the land on the northern side of the Great Lakes region was lower than it is today, as proved by the tilted character of certain well-known beaches of extinct lakes (see below). Such a differential tilting or warping of the land must have helped to form the closed basins by tending to stop the southward or southwestward drainage from the region. To summarize, we may say that the present Great Lakes basins are due to a combination of factors, the more important of which were: (1) the formation of pre-Glacial valleys by stream erosion; (2) a more or 
less deepening of these valleys by ice erosion; (3) the great accumulation of glacial debris along the southern side of the Lake district; and (4) the tilting of the land relatively downward toward the north.

We are now ready to trace out the principal stages in the history of the Great Lakes region during the final retreat of the great ice sheet. When the ice front had receded far enough northward to uncover the southern end of Lake Michigan, and an area

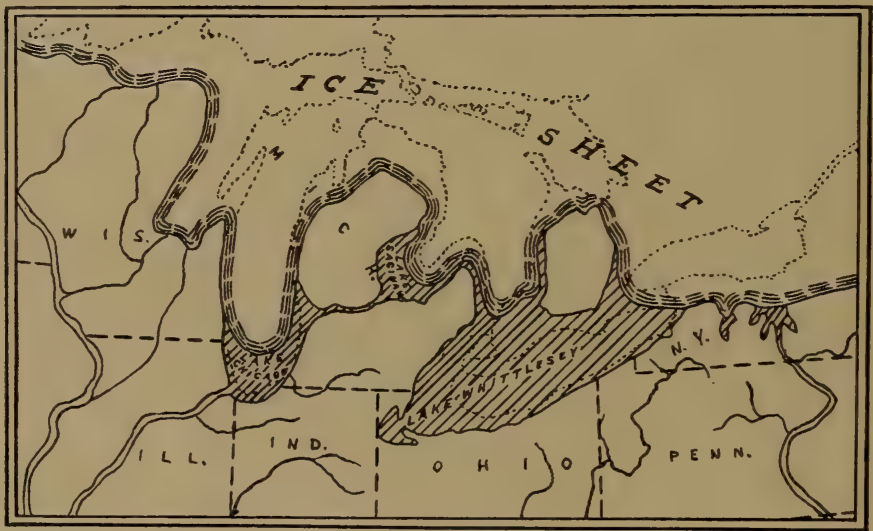

Fig. 216

Lake Whittlesey stage of the Great Lakes history, when the eastern and western ice-margin lakes combined with outlet past Chicago. (After Taylor and Leverett, redrawn by W. J. M.)

west of the present end of Lake Erie, small lakes were formed against the ice walls (see Fig. 215). The first of these has been called Lake Chicago, which drained past Chicago through the Illinois River and into the Mississippi; and the second, Lake Maumee, which drained southwestward past Fort Wayne through the Wabash River and thence into the Ohio and Mississippi.

At a later stage the conditions shown on map Fig. 216 existed. Lake Chicago was then larger, and Lake Maumee had expanded into the extensive Lake Whittlesey, which covered nearly all of the area of Lake Erie as well as some of the surrounding country. Lake Whittlesey was at a lower level than the former Maumee, and the outlet past Fort Wayne ceased, but the drainage from Whittle- 
sey was westward by a large river flowing through small Lake Saginaw and into Lake Chicago, which latter still emptied through the Illinois River.

At a still later stage (Fig. 217) Lake Saginaw merged with the waters of the Erie Basin to form the large Lake Warren which extended along the ice front eastward nearly to central New York. As the map clearly shows, the Finger Lakes Basins of New York were then occupied by Warren waters, while Niagara Falls were

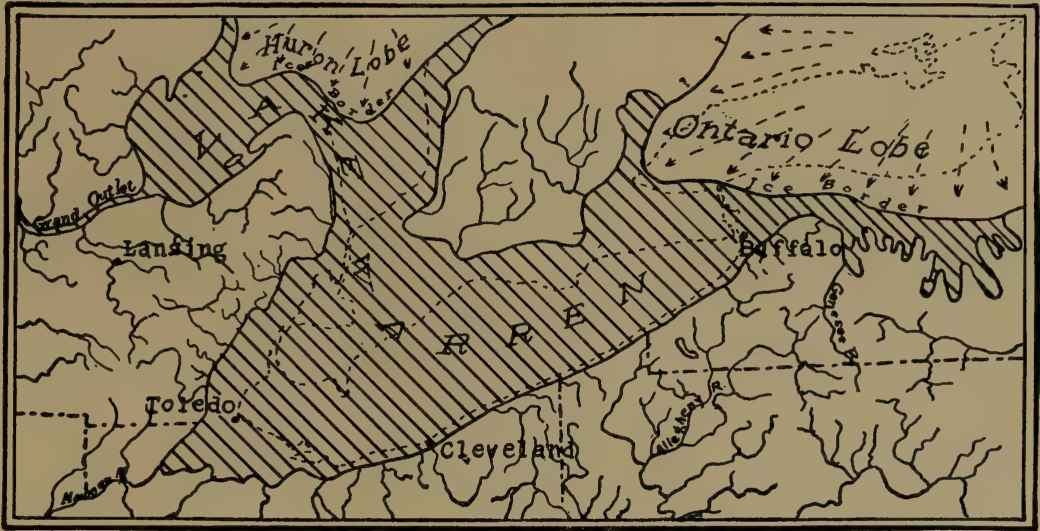

Fig. 217

Glacial Lake Warren. At this stage the discharge of the lake was still westward to Lake Chicago, while the eastern end of the lake covered most of the Finger Lakes region of New York. (Modified by W. J. M., after Taylor and Leverett.)

not then in existence, because that region was also covered by Lake Warren. Lake Warren continued to discharge westward into Lake Chicago and the Mississippi River until a very late stage, when the waters had worked their way along the border of the Ontario ice lobe into the Mohawk Valley of New York, which was then occupied by a large glacial lake (held up by the Ontario ice lobe on the west and the Champlain-Hudson lobe on the east), and then into the Hudson Valley. Thus, for the first time, the Great Lakes drainage passed eastward into the Atlantic Ocean. This great volume of water draining eastward was often in the form of distinct streams with the ice front for north wall and the high 


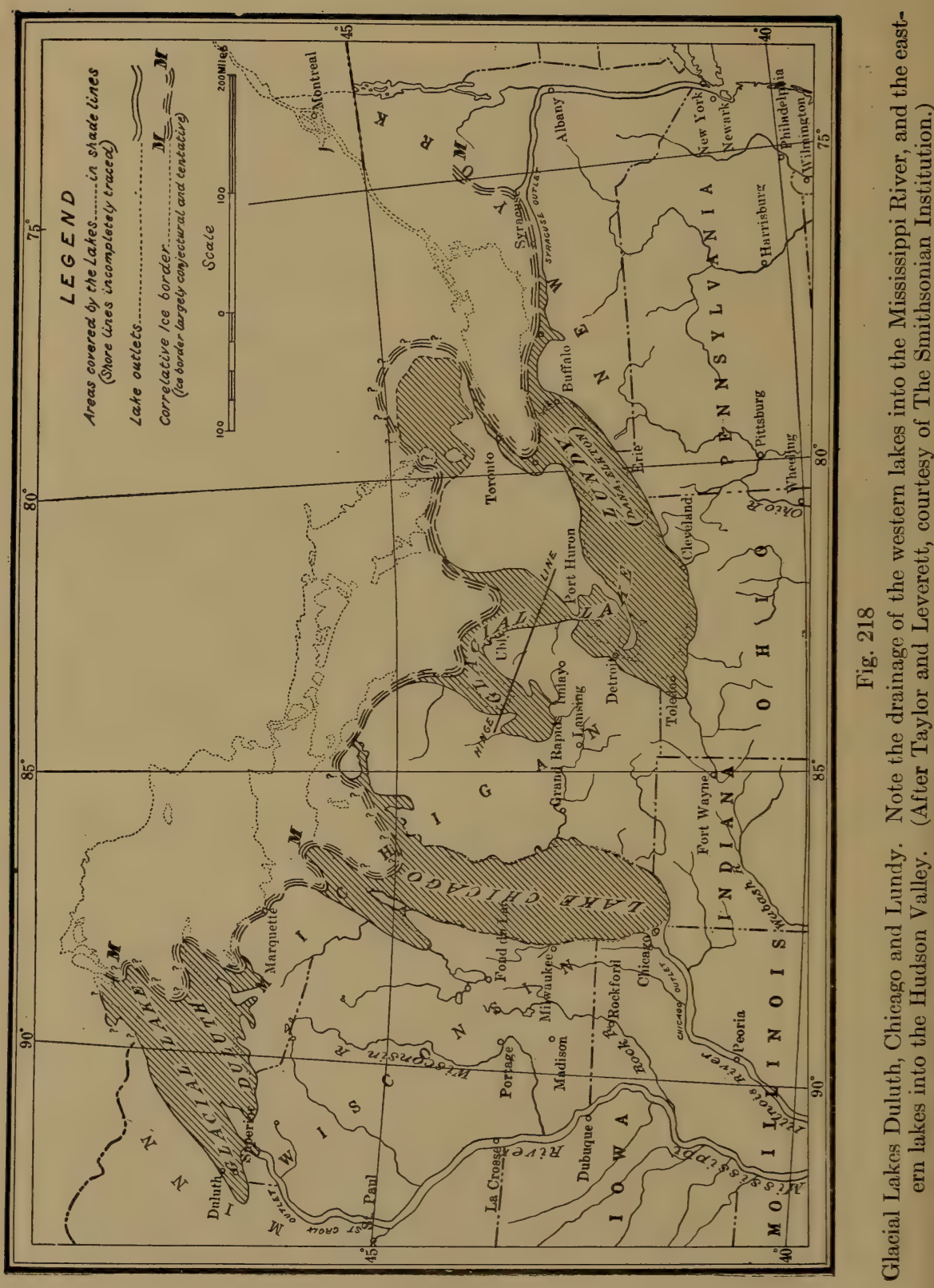


land of the Helderberg escarpment for wall on the south. Many of these glacial stream channels, often high up on the hills of central to western New York, are still plainly visible.

By successive stages, due to complete removal of ice from central New York, and a draining of the glacial lake in the Mohawk Valley, the waters dropped to below Warren level until Lake Iro-

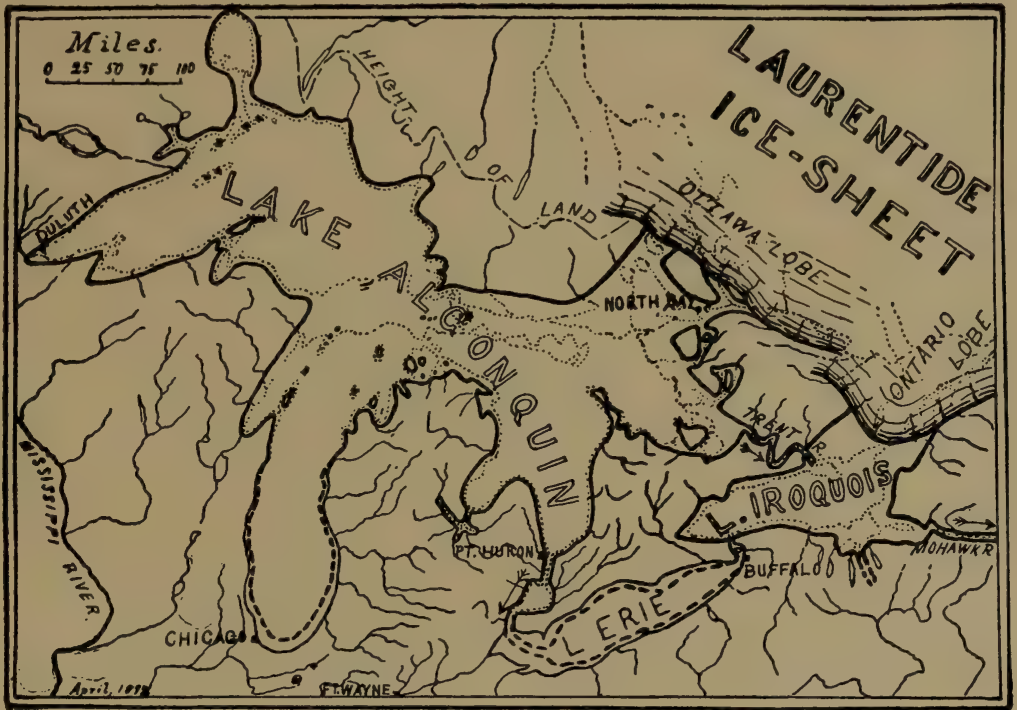

Fig. 219

The Algonquin-Iroquois stage of the Great Lakes, with outlet through the Mohawk-Hudson Valleys of New York. (After Taylor, courtesy of the New York State Museum.)

quois was formed (see Fig. 219). The old beach line of this lake is still plainly visible in New York. Lake Iroquois covered somewhat more than the present area of Lake Ontario, and the distinctly lower water level here than in the Erie Basin allowed the modern Niagara River to begin its history by flowing northward over the limestone plain near Buffalo. Meantime the waters of the upper lake basins had merged to form Lake Algonquin, which at first probably discharged past Detroit through the Erie Basin and into Lake Iroquois by way of Niagara River. Later, however, 
when the ice had withdrawn a little farther northward, a lower outlet was formed through the Trent River by which Lake Algonquin drained into Lake Iroquois. The old Trent River channel is now higher than the Detroit outlet, but some of the proofs for the former Trent outlet are as follows: (1) The presence there of a large, distinct river channel; (2) the convergence of the beaches toward that channel; and (3) the fact that the land was then considerably lower on the north or northeast side of Lakes Ontario and Erie than on the south side. For example, in following the old Iroquois beach we find that it gradually rises to higher levels until it is several hundred feet higher at the east than near the mouth of Niagara River. This tilting of the beach has been due to warping of the land since the lake existed, and it is evident therefore that during the Algonquin-Iroquois stage the Trent River channel was lower than that past Detroit. During the Algonquin-Iroquois stage the waters of all the Great Lakes region discharged through the Mohawk-Hudson valleys, and the volume of water which flowed through the Mohawk Valley must have been as great, if not greater, than that which now goes over Niagara Falls. During this time the St. Lawrence Valley was still buried under ice.

Still later the ice withdrew enough to allow the AlgonquinIroquois waters to discharge along the northern base of the Adirondacks and into what appears to have been ice-ponded waters in the Champlain Basin, and thence into the Hudson Valley. The Mohawk Valley outlet was thus abandoned.

Finally the ice withdrew far enough to free the St. Lawrence Valley when the waters of the Great Lakes region dropped to a still lower level, bringing about the Nipissing Great Lakes stage (see Fig. 220). The Nipissing Lakes found a low outlet through the Ottawa River (then free from ice) and into the Champlain arm of the sea. Post-Glacial warping of the land brought the Great Lakes region into the present condition, but this, and the Champlain subsidence, being really post-Glacial features, will be described below.

\section{Other Existing Lakes and Their Origin}

Counting all, from the smallest to the largest, there are within the glaciated area of North America tens of thousands of lakes, 


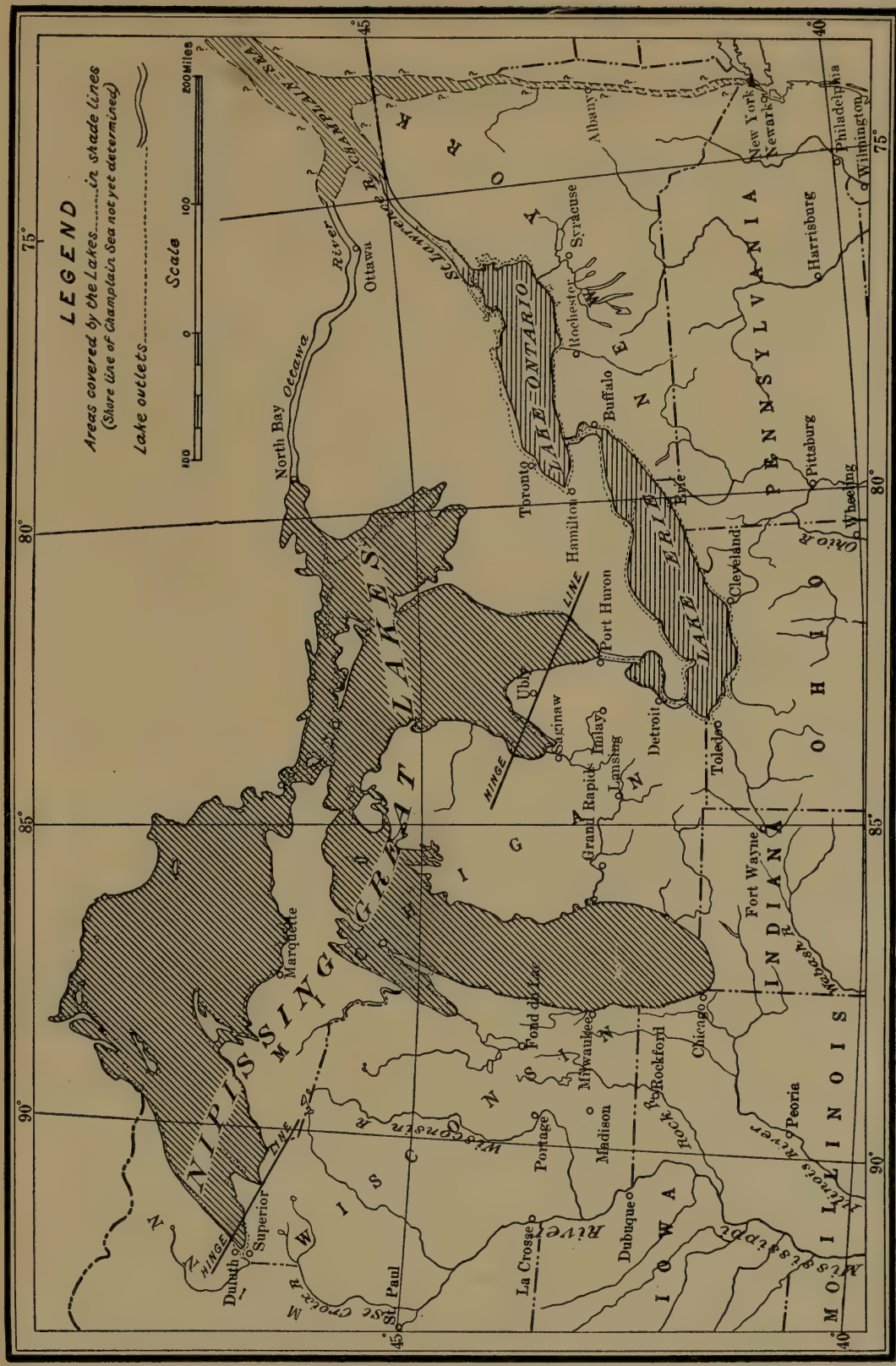

हี

कै

30

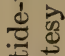

응

?

ำ

ల)

హิ

ㅎํำ

E

호

ฮㄴ

:

ठ

- 그

ลั 릉

si․를

다요

응

F

$\dot{0} 0$

$\pm D$

ज़

รั ซ

클

률

ขै

สै อ

$\neg$ 잉

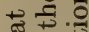

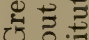

क

을

०

.들. 크

沅 $\frac{\pi}{2}$

E 
and these constitute one of the most striking differences between the geography of the present and that of pre-Glacial time. These lakes are widely scattered, though in the United States they are most abundant in the regions of greater relief, such as Maine, New Hampshire, New York, and Minnesota, because lake basins were more readily formed by drift dams across the deeper pre-Glacial valleys of those regions.

It is well known that most of the larger lakes, especially those of the linear type, occupy portions of pre-Glacial stream channels. All the existing lakes are due, either directly or indirectly, to glacial action. Among the ways by which such bodies of water may be formed are these: (1) by building dams of glacial drift across old river channels; (2) by ice erosion; and (3) by accumulation of water in the numerous depressions which were formed by irregular deposition of the drift (kettle-holes, etc.). Hundreds of small lakes, often not more than mere pools in size, belong to the last named type, while very many of the large and small lakes are due chiefly to the existence of drift dams. Certain lakes in southeastern Canada and elsewhere appear to occupy rock basins scoured out by ice erosion.

In considering the origin of glacial lakes, the so-called Finger Lakes of central-western New York deserve special mention. All are agreed that the lakes of this remarkable group occupy preGlacial valleys, most of which, at least, contained north-flowing streams. These lakes have dams of glacial drift across their lower (north) ends, and the dams have been important factors in the formation of the lakes, being in some cases perhaps the sole cause. But in the cases of the two largest lakes - Seneca and Cayuga there is strong evidence, from the hanging valley character of the tributaries, that the pre-Glacial valleys were notably deepened by ice erosion.

The presence of Lake Champlain is due principally to a combination of factors, including late elevation of the land, with greater uplift on the north; heavy glacial accumulations toward the north; and possibly some deepening as a result of ice erosion.

In the basin of Lake George there was a pre-Glacial divide where the "Narrows" are now located, and this divide appears to have been considerably lowered by ice erosion when part of the Champlain ice lobe ploughed its way through the deep, narrow valley. The waters are now held in by drift dams at each end. 
Well within the glaciated region of the interior of the continent the history of Lake Winnipeg is of special interest, but since this lake is merely a remnant of a former much larger body of water, it will be described in connection with extinct glacial lakes.

\section{Extinct Glacial Lakes}

Thousands of extinct glacial lakes are known to be scattered over the glaciated area. Some of these existed only during the time of the ice retreat, while others persisted for a greater or lesser length of time after the Ice age. Lakes Warren, Iroquois, etc., already described, were fine examples of the first type. Northsloping valleys were particularly favorable for the development of glacial lakes during the retreat of the ice, because the ice front always acted as a dam across such valleys, thus causing the waters to become ponded. Among the best criteria for the recognition of these extinct glacial lakes are typical, flat-topped, delta deposits formed by inflowing streams and distinct beaches.

A very fine example of many large, wholly extinct glacial lakes is Black Lake, which occupied a good portion of the Black River Valley on the western side of the Adirondacks in New York. This body of water, small at first, was formed by ponding the waters in the valley by the waning (northward retreating) ice lobe. Its earlier discharge was southward. Further retreat of the ice front allowed Black Lake to expand greatly until it had a width of from 5 to 10 miles and a length of from 25 to 30 miles. Finally the ice withdrew far enough northward to permit a discharge of the lake waters northward and the lake soon drained away entirely. A great delta deposit, formed by the coalescence of smaller deltas produced by the streams which drained into Black Lake from the Adirondack Mountains, may now be seen in a remarkable state of preservation on the west side of the valley (Fig. 212). It is some 30 miles long, several miles wide, very flat-topped except where trenched by post-Glacial streams, presents a steep front toward the west, and shows a depth of from 200 to 250 feet along its western edge.

A fine example of a very large glacial lake in the interior of North America, and now represented only by remnants (e.g. Lake Winnipeg), has been called Lake Agassiz in honor of the discoverer of the fact of the Quaternary Ice age. This lake, fully 
700 miles long and several hundred miles wide, extended over the whole valley of the Red River of the North in North Dakota and Minnesota, and northward over much of Manitoba. It covered a larger area than the combined Great Lakes. Its water was held up by the united fronts of the Kewatin and Labradorean ice sheets as they retreated northward. Its outlet was southward through the Minnesota and Mississippi rivers until the ice

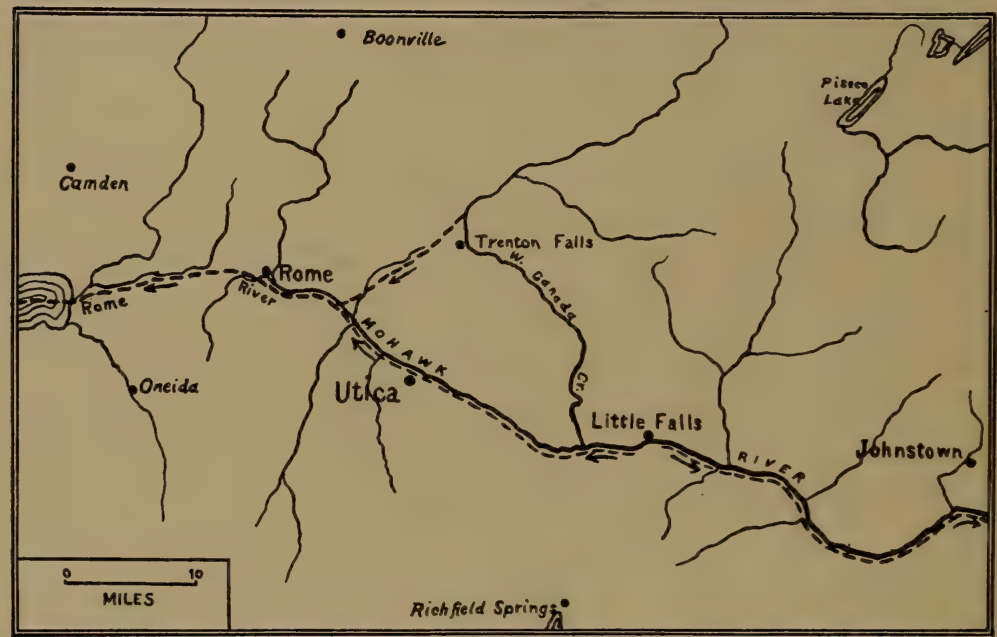

Fig. 221

Sketch map of central New York, showing the relation of the pre-Glacial drainage to that of the present. Pre-Glacial drainage shown by dotted lines only where essentially different from existing streams. (By W. J. M., based on work by A. P. Brigham.)

melted back (northward) far enough to open the outlet by way of Nelson River to Hudson Bay, when the great body of water was rapidly lowered, leaving only the present-day remnants, principally Lake Winnipeg. The soil of this smooth old lake bed is wonderfully rich.

\section{Drainage Changes Due to Glaciation}

In addition to its lakes, the glaciated area is also characterized by numerous gorges and waterfalls, which are largely due to glaciation. As a result of the very long time of pre-Glacial erosion, it 
is certain that typical, steep-sided, narrow gorges, as well as waterfalls, must have been very uncommon, if present at all. Like lakes, such features are ephemeral, because, under our conditions of climate, gorges soon (geologically) widen at the top, and waterfalls disappear by retreat or by wearing away the hard rock which causes them.

Changes of stream courses are also numerous in many parts of the glaciated territory. It is the present purpose to describe only a few typical, well-studied cases of such stream changes.

From the standpoint of both geology and human history, the gorge at Little Falls (on the New York Central R. R.) in central New York is the most important in that state. Before the Ice age there was a divide instead of a gorge several hundred feet

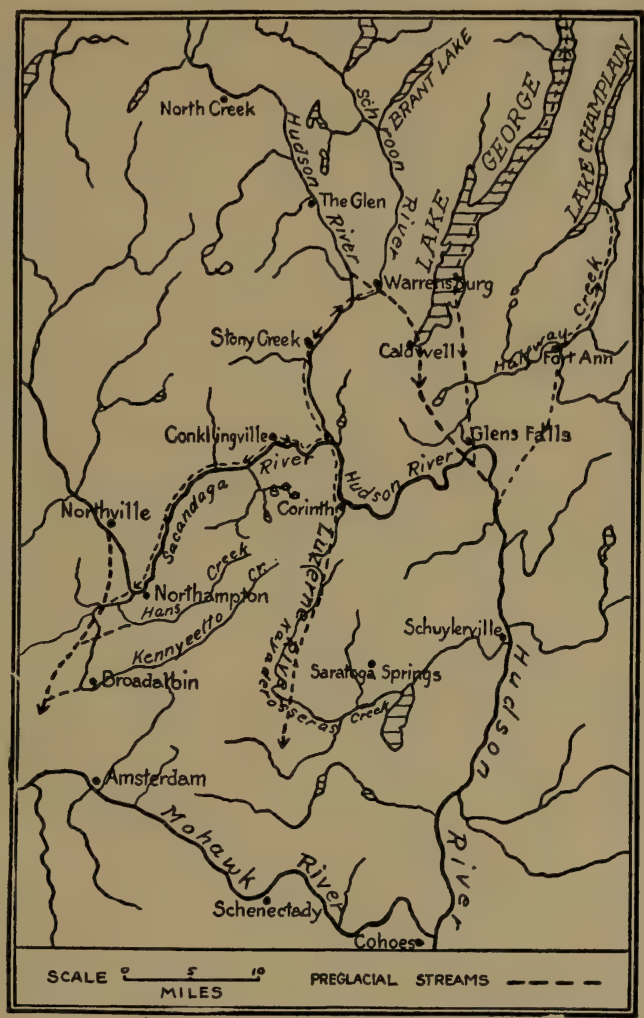

Fig. 222

Sketch map of the southeastern Adirondack region, showing the relation of the pre-Glacial drainage to that of the present. Pre-Glacial courses shown by dotted lines only where essentially different from present streams. (After W. J. Miller, Bul. Geol. Soc. Amer., vol. 22.) above the present river level. The Mohawk River flowed eastward, and the now extinct Rome River flowed westward from that divide (see Fig. 221). During the Algonquin-Iroquois stage of the Great Lakes 
history, those lakes discharged through the Mohawk Valley and across the Little Falls divide. It was the passage of this great

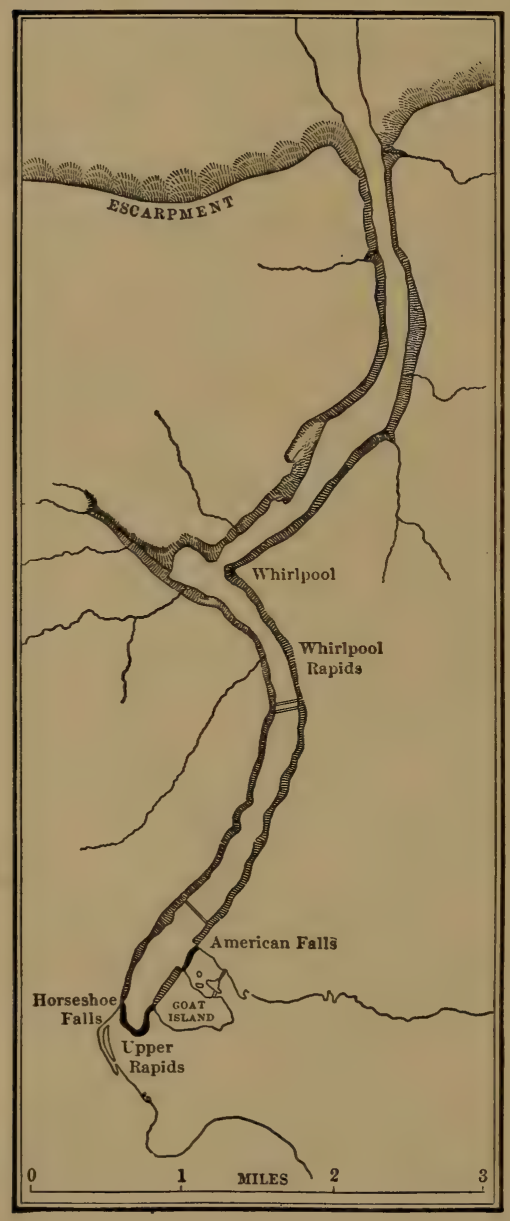

Fig. 223

Sketch map of the Niagara River gorge. (Modified after Gilbert, from Norton's "Elements of Geology," by permission of Ginn and Company, Publishers.) volume of water over the divide which caused the cutting of most of the gorge as we now see it, except for the narrow trench in the hard, low-lying rock, which is no doubt due to post-Glacial erosion. During the gorge cutting, aggradation (building up by sediments) of the valley bottom took place westward from Little Falls, so that the drainage from Rome, N. Y., was able to continue eastward even after the disappearance of Lake Iroquois. Thus we have here an excellent illustration of exact reversal of drainage due to glaciation, and by this means the upper waters of the present Mohawk River were added to what was the pre-Glacial Mohawk.

In the southeastern Adirondack Mountains certain important principles of drainage changes due to glaciation are illustrated by the upper waters of the Hudson River. The accompanying sketch map (Fig. 222) gives an idea of the changes. Near Warrensburg the Hudson River was deflected westward from its preGlacial channel because of the presence of a lobe of the waning ice sheet in the Lake George depression. At Corinth 
and Northampton, respectively, the Hudson and Sacandaga rivers show remarkable eastward deflections instead of following broad, deep pre-Glacial valleys southward into the Mohawk Valley. These deflections were caused by heavy morainic deposits acting as dams across the valleys south of Corinth and Northampton.

The world-famous Niagara Falls and gorge are wholly post-Glacial in origin. After plunging 167 feet at the falls, the river rushes for 7 miles through the gorge, whose depth is between 200 and 300 feet. When the glacial waters in the eastern Great Lakes region had dropped to the Iroquois level, the Niagara limestone terrace in the vicinity of Buffalo and with steep escarpment or northern front at Lewiston and Queenston, ceased to be covered with lake water, and the Niagara River came into existence by flowing northward over this limestone plain. The river first plunged over the escarpment at Lewiston, thus inaugurating the falls there. Since that time the falls have receded the 7 miles up stream to their present position. Soft shales underlie the layer of harder Niagara limestone, and the recession of

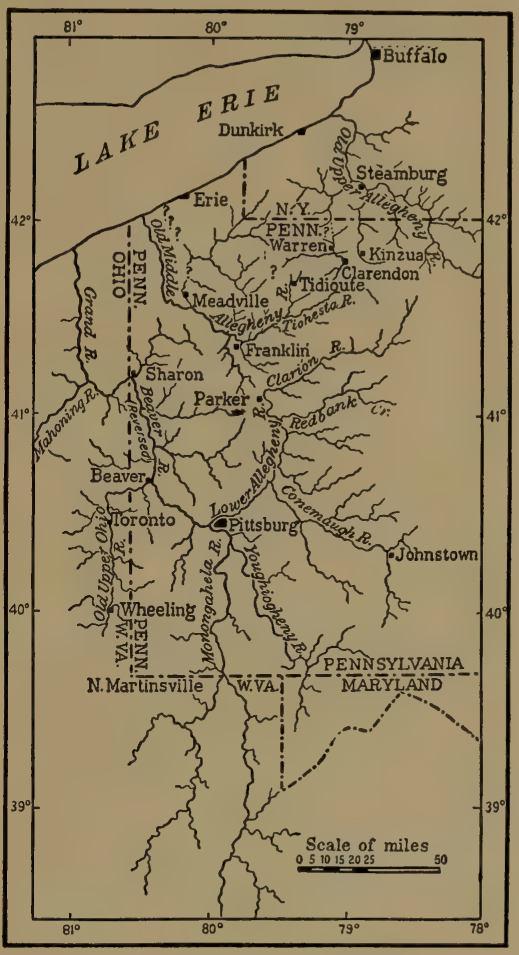

Fig. 224

Pre-Glacial drainage of the upper Ohio River Basin. (After Chamberlin and Leverett, from Norton's "Elements of Geology," by permission of Ginn and Company, Publishers.) the falls has clearly been caused by the breaking off of blocks of limestone due to undermining of the soft shales. A glance at the map (Fig. 223) will show that the gorge development is really taking place on the Horseshoe Falls side, where the volume of 
water is much greater, and that in a short time, geologically considered, the American Falls will be dry.

The drainage of the upper Ohio River Basin has been well-nigh revolutionized as a result of glaciation. By comparing the preGlacial drainage map (Fig. 224) with one showing present-day drainage, the principal changes will be readily understood. The pre-Glacial upper Ohio flowed northward from Beaver, Pennsyl-

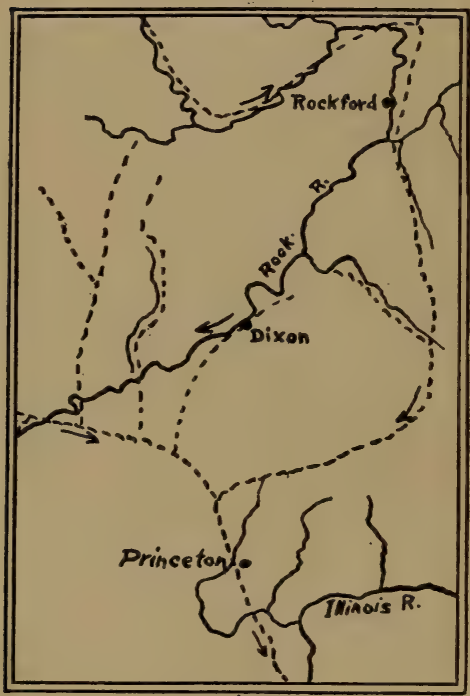

Fig. 225

Pre-Glacial drainage (dotted lines) of a part of northwestern Illinois. (Modified after Leverett.) vania, instead of southward, as at present, and, between Beaver and Sharon, the direction of preGlacial drainage has been exactly reversed. Also, all of what is now known as the drainage area of the upper Allegheny River passed northward through two pre-Glacial streams. The drainage changes were caused by ice occupancy and deposition of heavy drift across the northwestern portion of Pennsylvania.

Another well-studied example of important drainage change is shown by the accompanying map (Fig. 225) of part of northern Illinois. The pre-Glacial Rock River flowed southward into the Illinois River, instead of southwestward into the Mississippi as at present.

Even such large rivers as the Mississippi and Missouri were sometimes notably shifted out of their pre-Glacial channels by the invasion of the ice sheets. Thus the Missouri River, which formerly followed what is now the James River Valley in eastern South Dakota, was forced many miles westward to its present course across the state.

The above cited cases are sufficient to illustrate the general principles of drainage modifications due to glaciation, the two chief factors having been (1) actual presence of the ice or (2) heavy drift filling in pre-Glacial valleys. 


\section{Advantages and Disadvantages of Glaciation}

Advantages. - As a result of late Tertiary stream dissection, much of what is now the glaciated area of the United States had been converted into a fairly rugged country. Because of the heavy accumulations of drift, chiefly in the depressions, this ruggedness was greatly diminished and, in fact, many districts were actually converted into almost featureless plains. Old lake beds (e.g. that of Lake Agassiz) also are usually very smooth. Thus, agricultural pursuits, transportation, and travel have been made easier.

Over very extensive areas, such as the upper Mississippi Valley, the soils have been made deeper and richer on the average because the pre-Glacial soils were not only comparatively thin on the numerous hillsides, but also they were sandy or clayey residual materials from which much of the rich (soluble) mineral plant foods had been washed out. The glacial drift soils are usually more uniformly deep and consist of finely ground rocks of many kinds still rich in the soluble plant foods.

Water-power facilities have been vastly increased because of the development of thousands of waterfalls, rapids, and lakes. PreGlacial streams were mostly graded and hence without waterfalls or rapids, while pre-Glacial lakes were almost entirely absent. Lakes, by acting as reservoirs, help much in causing a more uniform flow of streams. In many places such reservoir effect is furthered by artificially increasing the heights of the natural dams, as e.g. in the Adirondacks. Also many large reservoirs can easily be constructed at comparatively little expense by restoring dams of extinct lakes.

Large lakes afford cheap transportation facilities, and often have a tempering influence upon the climate. Many lakes furnish abundant water supplies for towns and cities, as well as more or less fish for food.

The benefit of lakes, waterfalls, gorges, etc., from the æsthetic or scenic standpoint would be difficult to overestimate.

Drift deposits are often used, e.g. clays, for the manufacture of brick, tile, etc., and sand and gravel for various construction purposes.

Disadvantages. - In some cases the earth's surface has been increased in ruggedness by the drift accumulations, especially in 
extensive kame-moraine areas, thus hindering agriculture, transportation, and travel.

In many places, as in parts of New England, New York, and eastern Canada, the cultivation of the soil has been made difficult because of the numerous glacial boulders it contains. In these same regions many of the old lake or other deposits are too sandy or gravelly to be very fertile.

Large areas now covered by lake waters would make valuable farming land. This is particularly true of the Great Lakes.

All things considered, it seems certain that the advantages due to glaciation are notably greater than the disadvantages.

\section{Duration of the Glacial Epoch}

According to Chamberlin and Salisbury, the most important criteria for estimating the duration of the Glacial epoch include: "(1) the amount of erosion of the drift; (2) the depth of leaching, weathering, and decomposition of its materials; (3) the amount of vegetable growth in interglacial intervals; $(4)$ the climatic changes indicated by interglacial and glacial floras and faunas; (5) the times needful for the migration of faunas and floras, particularly certain plants whose means of migration are very limited; $(6)$ the time required for advances and retreats of the ice; and some others." A few of these, as the first, are subject to direct measurement, but most of them are matters of judgment.

The average of the estimates of five glacial geologists who have most studied the data is shown in the following table:

From the Late Wisconsin to the present.......... From the Iowan to the present............. From the Illinoian to the present........... 7 to 9 time units. From the Kansan to the present.......... 15 to 17 time units. From the Sub-Aftonian (Jerseyan) to the present ... X $\mathrm{X}$ time units. ${ }^{1}$

"After carefully considering many points, these same authors (Chamberlin and Salisbury) offer the following table accompanied

Climax of the (Late) Wisconsin .......20,000 to 80,000 years ago.

Climax of the Iowan .............60,000 to 400,000 years ago.

Climax of the Illinoian. . . . . . . .

Climax of the Kansan............

Climax of the Sub-Aftonian (Jerseyan)........ Y to $\mathrm{Z}$ years ago.

1 Chamberlin and Salisbury: College Geology, pp. 890-891. 
by the statement that "little value is to be placed on estimates of this kind, except as a means for developing a conception of the order of magnitude of the time involved." 1

\section{Length of Time since the Glacial Epoch}

Estimates of the length of time since the close of the Ice age are perhaps more satisfactory, though it must be remembered that the close of the Ice age was not the same for all places. The ice retreated northward very slowly and when, for example, southern New York was free from the ice, northern New York was still occupied by the glacier. The best estimates of the length of time since the close of the Ice age are based upon the rate of recession of Niagara Falls. We have learned that Niagara River began its work about the time the glacial waters in the Erie-Ontario basins dropped to the Iroquois level, and that the falls were first formed by the plunging of the river over the limestone escarpment at Lewiston. Studies based upon actual surveys, drawings, daguerreotypes, photographs, etc., made between the years 1842 and 1905, have shown that the Horseshoe Fall had receded about 5 feet a year, while the American Fall, between 1827 and 1905 , had receded about 3 inches a year. Thus the gorge cutting is clearly taking place on the Canadian side. The length of the gorge is 7 miles, and if we consider the rate of recession to have been always 5 feet a year, the length of time necessary to cut the gorge would be something over 7000 years. But the problem is not so simple, since we know that at the time of, or shortly after, the beginning of the river, the upper lakes drained out through the Trent River, and then still later through the Ottawa River. So it is evident that, for a good part of the time since the ice retreated from the Niagara region, the volume of water passing over the falls was notably diminished, and hence the length of time for the gorge cutting increased. The best estimates for the length of time since the ice retreated from the Niagara region vary from 7000 to 50,000 years, an average being about 25,000 years. In a similar way, the time based upon the recession of St. Anthony's Falls, Minnesota, ranges from about 10,000 to 16,000

1 Obviously, the determination of the number of years equivalent to one time unit involves the determination of the time since the disappearance of the last ice sheet, and this is discussed under the next heading. 
years. While closer estimates are practically impossible, it is at least certain that the time since the Ice age is far less than its duration, and that, for the region of the northern United States, the final ice retreat occurred only a very short (geological) time ago.

When we consider the slight amount of weathering and erosion of the latest glacial drift, we are also forced to conclude that the time since the close of the Ice age in the United States is to be measured by only some thousands of years. Thus kames, drumlins, extinct lake deltas, and moraines with their kettle-holes, have generally been very little affected by erosion since their formation.

In order to determine the number of years ago since the last (Wisconsin) ice sheet reached its climax, it is further necessary to know how long it took this ice sheet to recede from its southernmost limit to Niagara Falls, or about 600 miles. $^{1}$ If we allow for a rate of retreat of 100 to 200 feet per day, it required about 15,000 to 30,000 years for the retreat to Niagara. Combining these figures with those above given for the time since the inauguration of Niagara Falls, we get some idea of the time since the last ice sheet reached its climax, or about 22,000 to 80,000 years ago.

\section{Cause of the Glaciation}

The cause of the glaciation has been a very perplexing problem. Various hypotheses, often of widely different character, have been offered by way of explanation, but there is nothing like general agreement on the subject. We have here a fine illustration of the difference between "fact" and "hypothesis" which the student of natural science must always keep clearly in mind. Thus, the fact of the Glacial epoch (including much of its history) is conclusively established, but the cause of the glaciation is a matter concerning which we have only hypotheses or speculations.

In this elementary work we can do no more than suggest several of the leading hypotheses. Those further interested in the subject are referred to special articles and larger general works, particularly Chamberlin and Salisbury's "Geology," Vol. 3. One point to be borne in mind is that no hypothesis is required to account for an average yearly temperature of more than 10 or possibly 15 de-

${ }^{1}$ It should be remembered that the latest or Wisconsin ice did not extend as far south as certain earlier ice sheets. 
grees lower than at present over the glaciated area in order to have brought on the Ice age.

A Geologic (elevation) Hypothesis. - As we have already pointed out, the evidence, chiefly from the submerged river channels along the Atlantic Coast, clearly indicates greater altitude of northeastern North America late in the Tertiary and probably also in the early Quaternary. An altitude of from 4000 to 5000 feet greater than now has been claimed for this region. Since it is well known that the temperature becomes lower with increasing altitude (one degree for about 300 feet), it has been argued that the greater altitude of the glaciated area was in itself sufficient cause for the glaciation. "Northern elevation produced iceaccumulation; ice-accumulation by weight produced subsidence; subsidence produced moderation of temperature and melting of ice; and this last by lightening of load produced re-elevation" (J. Le Conte). It is not necessary to assume that maximum elevation and ice-accumulation were coincident, because an effect often lags behind its cause. This northern elevation also is believed to have sufficiently upraised the northern ocean basins to cut off warm currents, like the Gulf Stream, thereby depriving the northern lands of such warming influences.

It has been urged against this hypothesis that there is no positive evidence for nearly as much as 4000 to 5000 feet of elevation of the glaciated region; that it is not at all proved that the northern elevation occurred at the proper time to produce glaciation; and that the only way glacial and interglacial stages could be accounted for would be by the unreasonable assumption of repeated elevation and subsidence corresponding to each advance and retreat of the ice.

Croll's Astronomic Hypothesis. ${ }^{1}$ - According to Croll, as excellently interpreted by Le Conte, the glaciation was caused by "the combined influence of precession of the equinoxes and secular changes in the eccentricity of the earth's orbit. By the former - viz., precession - winter, which in the northern hemisphere occurs now when the earth is nearest the sun (perihelion), is gradually in 10,500 years brought round so as to occur when the earth is farthest off from the sun (aphelion) (Fig. 226). The effect of this, it is claimed, would be to make longer and colder winters,

${ }^{1}$ For a fuller statement of this hypothesis see Croll's Climate and Time in their Geological Relations, 1890. 
and shorter but hotter summers in the northern hemisphere, such as now occur in the Antarctic regions. By the latter - viz., increasing eccentricity (which forms a much longer cycle) - these effects, which are now small on account of the nearly circular form of the earth's orbit, would become very great. At the time of greatest eccentricity, the earth would be $14,000,000$ miles farther off from the sun in winter than in summer, the winter would be twenty-two days longer and $20^{\circ}$ colder, and the summers twenty-
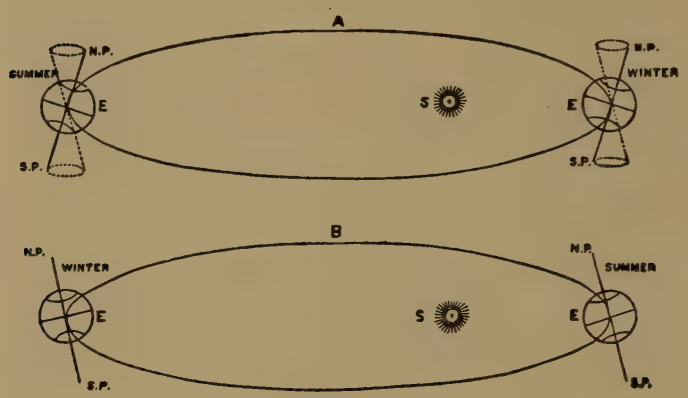

Fig. 226

Diagram showing effect of Precession: $A$, present condition; $B$, condition 10,500 years hence. Eccentricity much exaggerated. (After Le Conte's "Geology," permission of D. Appleton and Company.)

must have been shifted farther away from the glaciated hemisphere with consequent shifting of direction of warm ocean currents. Thus, during the Quaternary Glacial epoch, the Gulf Stream must have been diverted southward by the eastern point of South America.

According to Croll's hypothesis (1) there must have been many Glacial epochs during the earth's history; (2) alternations of cold and warm stages (seven or eight) must have occurred during the Glacial epoch; (3) these cold and warm stages alternated between northern and southern hemispheres; and (4) the Quaternary Glacial epoch in the northern hemisphere began 240,000 years ago, lasted 160,000 years, and declined 80,000 (or possibly 60,000 ) years ago.

At present we have positive evidence for five or six times of 1 J. Le Conte: Elements of Geology, 5th ed., pp. 613-614. 
glaciation during geologic history and still more may be discovered. ${ }^{1}$ Also it has been proved that there were five, and probably six, ice advances and retreats corresponding to colder and warmer stages during the Quaternary Glacial epoch. As regards the duration of this Ice age and the time since its close, it seems impossible to imagine seven or eight advances and retreats of the ice within 160,000 years unless we postulate rates of advance and retreat much greater than studies of existing glaciers show. Also the best geological evidence does not place the close of the Ice age so far away as 60,000 to 80,000 years. One of the most serious objections to Croll's hypothesis is the fact that, during the Permian period, there was widespread glaciation in comparatively low latitudes $\left(20^{\circ}\right.$ to $\left.35^{\circ}\right)$ either side of the equator.

Chamberlin's Atmospheric Hypothesis. ${ }^{2}$ - Among the atmospheric hypotheses, the one which Chamberlin has put into its best form "is based chiefly on a postulated variation in the constituents of the atmosphere, especially in the amount of carbon dioxide and water. Both these elements have high capacities for absorbing heat, and both are being constantly supplied and constantly consumed. ... The great elevation of the land at the close of the Tertiary seems to afford conditions favorable both for the consumption of carbon dioxide in large quantities, ${ }^{3}$ and for the reduction of the water content of the air. Depletion of these heatabsorbing elements was equivalent to the thinning of the thermal blanket which they constitute. If it was thinned, the temperature was reduced, and this would further decrease the amount of water vapor held in the air. The effect would thus be cumulative. The elevation and extension of the land would also produce its own effects on the prevailing winds and in other ways, so that some of the features of the Hypsometric (elevation) hypothesis form a part of this hypothesis. . . . By variations in the consumption of carbon dioxide, especially in its absorption and escape from the ocean, the hypothesis attempts to explain the periodicity ${ }^{4}$ of

${ }^{1}$ It should of course be remembered that the proper temperature conditions for glaciation may have recurred many times when other factors such as requisite precipitation of snow may not have obtained, and hence great ice sheets may not actually have formed.

${ }^{2}$ For a fuller treatment of this hypothesis see Chamberlin and Salisbury's Geology, Vol. 3, pp. 432-446.

${ }^{3}$ Much carbon dioxide is used up in the decomposition or carbonation of the rocks. ${ }^{4}$ That is, the successive advances and retreats of the ice sheets. 
glaciation. Localization (of glaciation) is attributed to the two great areas of permanent low pressure in proximity to which the ice sheets developed." 1

In conclusion we may say that, as is true of so many other great natural phenomena, no one hypothesis or explanation is sufficient to account for all the features of glacial epochs. Probably several or all, or at least parts of several or all, of the above hypotheses must be properly combined in order to explain the phenomena of glaciation, and hence it is more readily understood why great glacial epochs have not been more common throughout the history of the earth.

\section{Post-Glacial (Recent) History of the Glaciated Area}

We have already shown that, about the beginning of the Glacial epoch, the north Atlantic Coast region at least was much higher than it is today, positive proof for this being afforded by the submerged lower Hudson, St. Lawrence, and other channels which must have been cut when the land was higher. Toward the close of the Glacial epoch, and shortly after, we know that the land was relatively lower even than it is today. It was during this time of subsidence (sometimes called the Champlain epoch) that the lower Hudson and St. Lawrence channels were submerged and the sea coast was transferred to more nearly its present position. But the land being even lower than now, the lowlands of Long Island and in the vicinity of New York City were under water and a narrow arm of the sea extended through the Hudson and Champlain Valleys to join a broad arm of the sea which reached up the St. Lawrence Valley and possibly even into the Ontario Basin (see Fig. 220). This so-called Champlain Sea existed at the time of the Nipissing stage of the Great Lakes already described. Champlain Sea beaches, containing marine shells and the bones of Walruses and Whales, have been found at altitudes of about 400 feet near the southern end of Lake Champlain, 500 feet at its northern end, and 600 or more feet at the eastern end of Lake Ontario. In the lower Hudson Valley the deposits of this age are about 70 feet above sea level, and at Albany a little over 300 feet. The altitudes of these so-called raised beaches show how much lower the land was during the time

1 Chamberlin and Salisbury: College Geology, pp. 898-899. 
of greatest submergence, and that the subsidence was most toward the north. That this greatest submergence occurred after the close of the Ice age in this region, is proved by the fact that the now raised beaches and marine deposits rest upon the last or Wisconsin ice drift.

The most recent movement of the earth's crust in the region under discussion was the very gradual elevation which expelled the Champlain Sea and left the land at its present altitude. The altitudes of the raised Champlain beaches show that the greatest elevation was on the north. The warping of the Iroquois Lake beaches already described occurred at this same time. Actual surveys during the past century have proved that this upward movement in the northern Great Lakes region is still progressing at the rate of 5 inches in 100 miles in 100 years.

\section{Quaternary Conditions in the Non-Glaciated Regions}

Over many parts of the continent there was deposition of sediments during Quaternary time outside of the glaciated area, but little or nothing can be done by way of correlating these with different glacial and interglacial stages because of the lack of the usual means of comparison. These deposits were of various sorts, including those of river flood-plain, wind, terrestrial, lacustrine, volcanic, and marine origin.

Atlantic and Gulf Coasts. - On the Atlantic and Gulf Coastal Plains, and in addition to the Lafayette (Pliocene?) already described, there is a well-known series of unconsolidated deposits of sands, gravels, clays, etc., usually comprised under the name Columbia. Like the Lafayette, the Columbia is wholly a surficial deposit but at lower altitudes, never rising more than a few hundred feet above sea level and generally less than 200 feet. On the north Atlantic Coastal. Plain, at least, the Columbia is pretty clearly divisible into three formations (Sunderland, Wicomico, and Talbot), each of which is represented topographically by a more or less distinct terrace with the oldest at the top.

There has been much difference of opinion regarding the origin and significance of these Columbia deposits, but they are now quite certainly known to be marine terraces. According to Shattuck, ${ }^{1}$ each of the formations and terraces of the Columbia is explained

${ }^{1}$ G. B. Shattuck: Pliocene and Pleistocene, Md. Geol. Survey, p. 137. 
as due to subsidence (or submergence) below sea level and deposition of sediments, followed by elevation (or emergence) and erosion. The fossil evidence regarding non-marine or marine origin of the deposits is far from conclusive.

Western United States. - Quaternary deposits, representing many types of origin, are known in the west.

Volcanic deposits of this age in the west are not always clearly separable from those of the Tertiary, but it is certain that pretty vigorous vulcanism continued into the Quaternary. Such volcanic deposits, including lava-flows, cinders, and volcanic ashes, are known in New Mexico, Utah, Idaho, and all the states farther west as well as in Alaska. Mount Shasta shows lava flows of postGlacial or recent age, while small lava fields and cinder cones in northern and southern California and in northern Arizona must be of late Quaternary age because they are so unaffected by weathering and erosion. As already mentioned in the discussion of Tertiary vulcanism, a cinder cone and small lava field have certainly been built up within the last 200 years, while Lassen Peak in northern California is now (1916) actually in eruption.

At the bases of mountains throughout the arid and semi-arid regions of the west, great accumulations of talus and alluvial materials took place. Some of the alluvial cones or fans have a thickness of fully a thousand feet. Extensive flood-plain deposits are found in many places.

Recent studies have shown that the wind has been, and is, a very important agent of erosion and deposition, particularly in the arid western regions. Deep and extensive wind-blown deposits are still forming in many of the intermontane basins.

During part of the Quaternary, at least, the Great Basin region had a moister climate than at present, because lakes were much more numerous and larger than now (Fig. 227). One of the largest of these was Lake Bonneville, which represented a greatly enlarged stage of the Great Salt Lake. Lake Bonneville was of fresh water; covered 19,000 square miles; and had a maximum depth of 1000 feet. Its remnant, the present heavy brine of the Great Salt Lake, covers about 2000 square miles and has a maximum depth of only about 50 feet. The outlet of Lake Bonneville was northward into Snake River. The former existence of this great body of water is positively proved by the perfectly preserved beaches, wave-cut terraces, deltas, etc. Another very large body of water, called 
Lake Lahontan, occupied some thousands of square miles of western Nevada, but it had no outlet. Since the lowering of the water levels in these basins, crustal disturbances have caused a tilting of the old shore lines some hundreds of feet.

Locally, along the Pacific border, Quaternary fossiliferous marine deposits occur up to altitudes of 200 or 300 feet or more. "Important and more or less widespread periods of diastrophism later than the one terminating the Monterey (middle Miocene) period of deposition occurred in the Pleistocene. . . . Minor movements producing local unconformities took place in central and southern California at various times during the Pleistocene in addition to the more far-reaching disturbances in the same epoch." 1

The islands off the coast of southern California were connected with the mainland late in the Tertiary, or early in

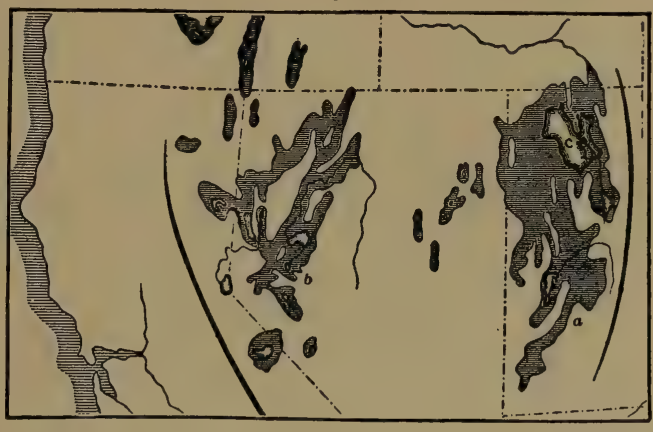

Fig. 227

Map showing extent of the extinct Lakes Bonneville $(a)$ and Lahontan $(b)$ in the western United States. Heavy black lines are axes of Sierra Nevada and Wasatch Mountains respectively. $c$, area of Great Salt Lake. (After Gilbert and Russell, from Le Conte's "Geology," permission of D. Appleton and Company.)

the Quaternary, as shown by the flora, and in one case the remains of a Mammoth. A subsidence, causing the separation of the islands from the mainland, was followed by partial re-elevation to the extent of at least 1500 feet, as proved by the raised sea-beaches on the mainland and on some of the islands. A remarkable fact is that some of the adjacent islands were subsiding during this whole time. Raised beaches near San Francisco testify to Quaternary upward movements of 1500 to 1800 feet. Similar beaches on the northern coast of Oregon lie at 200 feet or more above the sea.

1 Ralph Arnold: Outlines of Geologic History, by Willis and Salisbury. 


\section{The Glacial Epoch in Europe}

In many important respects the history of the Quaternary period in Europe is much like that of North America. The accompanying map (Fig. 228) shows the extent (about 600,000 square miles) of the ice sheet at the time of maximum glaciation. As the map also shows, the great center of dispersal was over the Scandinavian peninsula, with apparently a small, secondary centre over Scotland. The ice over Scandinavia is estimated to have been

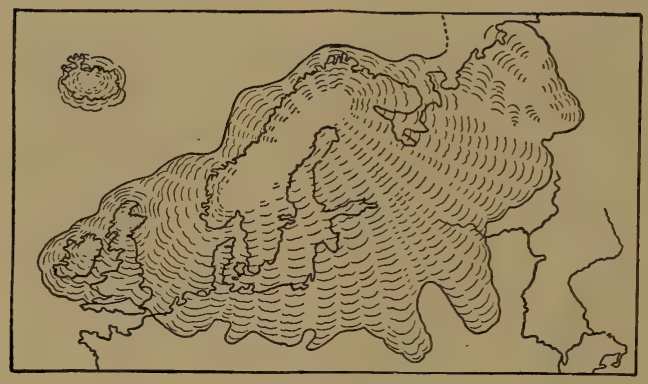

Fig. 228

Map showing the extent of ice in Europe at the time of maximum glaciation. (After J. Geikie, from Norton's "Elements of Geology," by permission of Ginn and Company, Publishers.) 6000 to 7000 feet deep. The Baltic, North, and Irish Seas were completely filled by the great ice sheet which extended well south into Germany and Russia. As in North America, five or six glacial and interglacial stages have been recognized. During the Glacial epoch, the glaciers of the Alps were far larger and more numerous than today, and they often flowed down to the lowlands on all sides. The Pyrenees and the Caucasus Mountains were also vigorously glaciated.

As in North America, also, northern Europe was notably higher than now, apparently late in the Tertiary or early in the Quaternary; then, toward the close of the Glacial epoch, there was subsidence (of Scandinavia at least) to below the present level; and this was followed by partial re-elevation of at least some hundreds of feet to the present level. Actual surveys have proved that from central to northern Sweden the land is still rising. The great fiords of Norway, with their raised beaches, testify to the important changes of level above mentioned.

In other continents many of the higher mountains bore glaciers, even where none at all exist today. Also, so far as known, the Antarctic region was heavily glaciated much as it is today. 


\section{LIFE OF THE QUATERNARY}

The species of plants and invertebrate animals of the whole Quaternary period were much the same as those now living; therefore we shall pass them by without special description. Among the Vertebrate animals, the species of the lower classes, such as Fishes, Amphibians, Reptiles, and Birds, were almost all the same

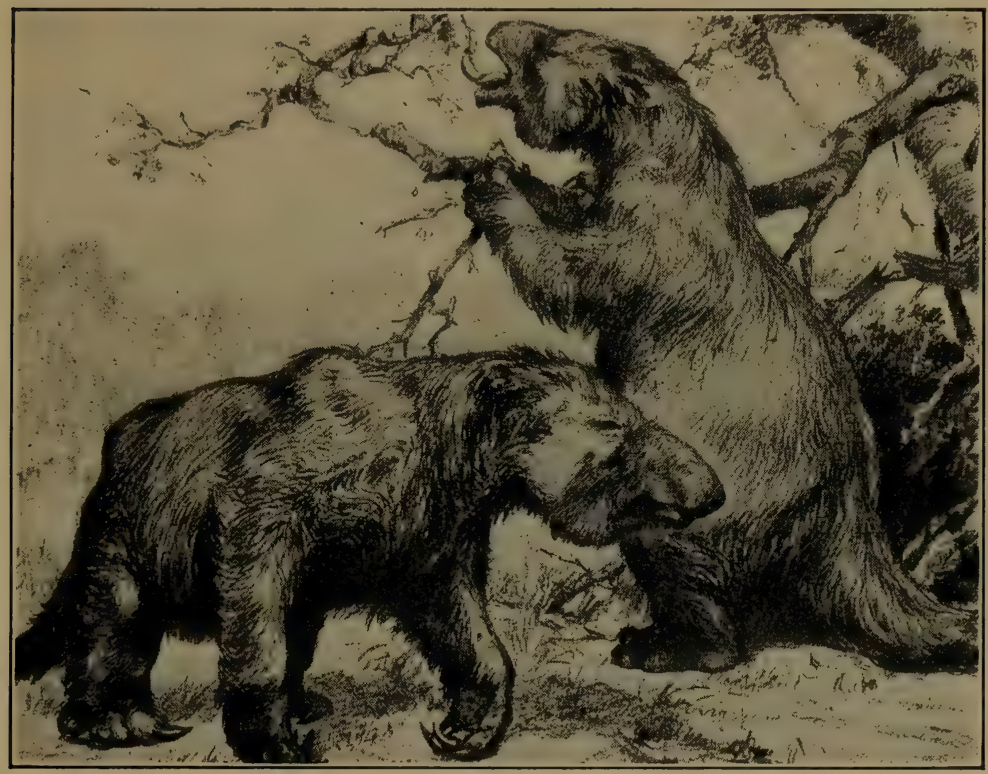

Fig. 229

A great Ground-sloth, Megatherium americanum. (After W. B. Scott, by permission of The Macmillan Company.)

as those now living, but in the highest class of Vertebrates (Mammals) there were important changes.

Mammals, except Man. - One of the most characteristic features of Quaternary (especially Pleistocene) Mammals was the great size of so many. In fact, as regards size and diversity of forms, the Mammals may be said to have attained their culmination during the Pleistocene epoch. Comparing the Mammals of that epoch with those of today, we find that many species, espe- 
cially of the large animals, have become extinct, and the world is now (except for Man) said to be "zoölogically impoverished." The vicissitudes of the climate, i.e. alternations of glacial and interglacial conditions, appear to have "produced a very severe struggle for existence and were fatal to a great many large Mammals, causing numerous extinctions over the larger part of the

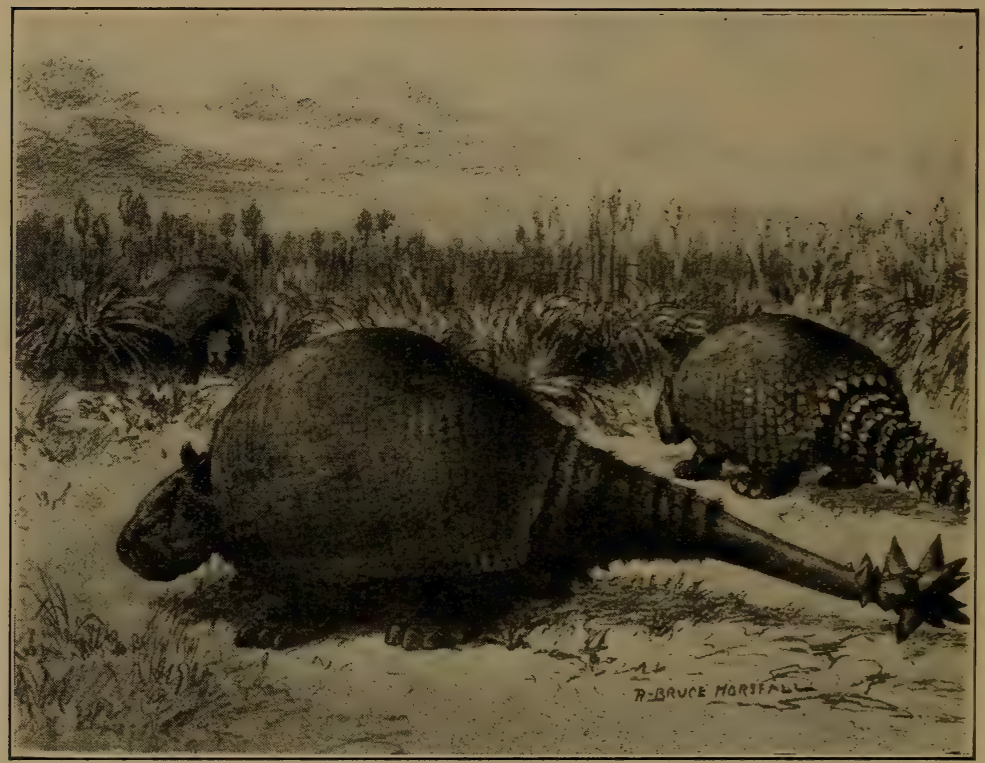

Fig. 230

Great armored Glyptodonts, Doedicurus clavicaudatus and Glyptodon clavipes. (After W. B. Scott, by permission of The Macmillan Company.)

world" (W. B. Scott). It is our present purpose to refer to only a few of the most interesting now extinct Pleistocene Mammals.

Among the Edentates (Sloths, Armadillos, etc.), which belong to the simplest Placental Mammals, the Megatherium and the Glyptodon are of special interest. The former (see Fig. 229), a sort of giant ground Sloth, was remarkably massive and attained a length of 15 to 18 feet. Its thigh bones were two or three times the thickness of those of the Elephant, and its front feet were about a yard long. The tooth structure shows it to have been a plant 
feeder. This powerful creature could easily have toppled over small trees in order to strip off the leaves. The Glyptodon (see Fig. 230) was a giant Armadillo up to 8 feet long and armed with a very strong turtle-like carapace. These Edentates, including many species, were common in South America and in North America as far north as Pennsylvania and Oregon.

The Proboscidians were well represented by both the Mastodons and the Mammoths. These were smaller than those of the late Tertiary or about the size of modern Elephants. "During Pleistocene times the Proboscidia covered all of the great land masses except Australia, but were diminishing in numbers, and toward the close of the Pleistocene the period of decadence began, resulting in the extinction of all but the Indian and African Elephants of today." 1 The Mastodon roamed only over much of North America and part of South America, having become extinct in the Old World in the late Tertiary. The Mammoth had a much wider range from the Atlantic states to Alaska; across Siberia; through central Europe; and even to the British Isles. Fine examples of the almost perfect preservation of entire organisms of now extinct forms are furnished by specimens of frozen Mammoths which have been in nature's "cold storage" for thousands of years in the gravels or ice of Siberia. In several cases much of the hide, long brown hair, and even the flesh are known to have been perfectly preserved, the flesh having been eaten by dogs or even the natives themselves. Two of the finest specimens were discovered in 1806 and 1901.

In addition to the above-mentioned animals in North America, were gigantic Bisons, with spread of horns up to 10 feet; great Moose-like Elks; Rodents, up to 5 feet long; Sabre-toothed Tigers; huge Lions, and several species of Zebra-like Horses.

Distribution of Quarternary Plants and Animals. - The alternations of glacial and interglacial climates caused corresponding migrations of colder and warmer climate animals and plants. While a great ice sheet was advancing, Arctic animals and plants ranged farther and farther southward even into what are now temperate latitudes. Thus the Musk-ox ranged southward to Iowa and Kentucky, and the Walrus to Virginia, while in Europe the Reindeer, Arctic Fox, etc., ranged southward into France. During the retreat of a great ice sheet, the Arctic fauna and flora

1 R. S. Lull: Amer. Jour. Sci., Vol. 25, March, 1908, p. 11. 
retreated to colder climatic conditions, either by following the ice front northward or by going up the mountains as they were freed from the ice. This retreat up the mountains affords a ready explanation of the fact that certain Arctic plants and animals (especially Insects) are now found, in the Alps and higher parts of the White Mountains of New Hampshire, separated from their former habitat by many hundreds of miles of climate now too mild for them to cross.

Until late in the Quaternary, the geographical environment favored a very widespread distribution of Mammals over most of the land areas. Thus North America and South America were connected; North America and Asia were joined across what is now the Bering Sea; and Eurasia and Africa were well connected. Australia was one of the largest isolated land masses, and herein lies the explanation of its most peculiar fauna and flora. For example, of the many known species of Mammals all are nonPlacentals, that is they are Monotremes and Marsupials. NonPlacentals inhabited most of the great land areas (including Australia) during the Mesozoic era. Since true Placental Mammals made their appearance in the early Tertiary, it is quite certain that Australia was isolated from the Asiatic continent before the Tertiary and that under the more local conditions and less severe struggle, Placentals were never evolved there and they never could get there from other continents, except as artificially introduced by Man.

Madagascar also has a mammalian fauna very peculiar to itself. This island was separated from the mainland before Quaternary time, and its Mammals, because of less severe struggle for existence, have changed more slowly and in their own way as compared with those of the African continent.

The coast islands of southern California show similar relation to the mainland, but more especially as regards the plant species.

Antiquity of Man. - Thus far we have said little about the interesting and important subject of Man's first appearance, and nothing about his early history. Since Man, who represents the very highest type of organism which has ever inhabited the earth, belongs to one of the most recent and important groups of animals, it is appropriate that a brief discussion of his origin and early history be reserved for the very last. Up to the present, at least, 
progressive organic evolution through the many millions of years has reached its climax in Man.

Because of additional discoveries and better methods of study, our knowledge of prehistoric Man is becoming more satisfactory year by year. The ablest students of the subject are agreed upon several important points, while regarding others there is still much disagreement. There is quite a general agreement (1) that Man (physical Man at least) has evolved from lower forms of Primates; ${ }^{1}$ (2) that there are clearly recognizable at least two types or species of Man, namely, (a) Homo primigenius (Paleolithic), a primitive type now extinct, and (b) Homo sapiens (Neolithic to modern), represented by existing Man; (3) that true Man certainly existed during the Pleistocene; (4) that, on a most conservative basis, true Man was on the earth no less than 100,000 years ago; and (5) that there is no positive evidence for the existence of true Man earlier than the Pleistocene or Glacial epoch.

Differences of opinion commonly surround such as: (1) The classification of the early ancestral forms, that is whether they should be called Apes, Man-like Apes, or Ape-like Men; ${ }^{2}$ and (2) the portions of the Quaternary system represented by the deposits in which Man's bones or implements are found, or by the remains of animals found associated with Man's bones or implements.

Bones and implements of ancient Man and his early ancestral forms are found chiefly in high river terraces, loess, caves, and glacial deposits. In this connection; it should be stated that, in spite of various reported discoveries, there is no well proved evidence for Man's existence in North America during the Pleistocene.

The following tabular arrangements are introduced in order to graphically represent (synoptically) certain of the most significant features in connection with the geologic history of Man. The first table is by Clark Wissler and the second by the author. It should be clearly borne in mind that, in some respects, these are only tentative arrangements, though they do summarize our

1 There is a prevalent popular misconception that the evolutionist considers Man to be a direct descendant of the Monkey. What the evolutionist really believes, however, is that Man and Monkey may have sprung from a common ancestry.

${ }^{2}$ It is important to note that this very difference of opinion is one of the strongest arguments in favor of the organic evolution of Man, because practically all intermediate types between true Men and certain higher Primate forms are known. 
most recent knowledge based upon the work of able students of the subject.

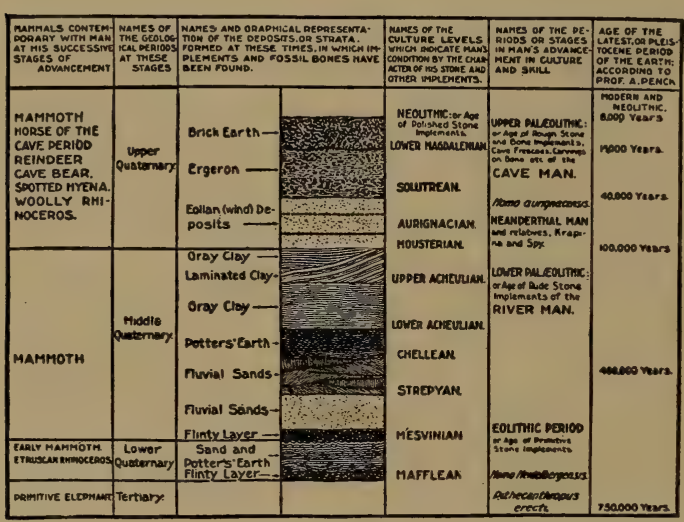

Fig. 231

Table to show the principal geologic stages in the history of Man. (After C. Wissler, courtesy of the American Museum of Natural History.)
The introduction of the socalled "Eolithic" period into this table seems doubtfully appropriate in the light of our best knowledge, though it is possible that certain very rude stone implements such as those found by Prestwich in the high river gravels in Kent (England) belong to such an early period.

\section{Homo sapiens}

(e.g. modern Men).

\section{Homo primigenius}

(Primitive Men, e.g. Men of Neanderthal,

La Chapelle, Spy, Lower Paleolithic ("ancient stone") Middle PleisKrapina, etc.).

1. Early ancestral forms (Apes, or Man-like Apes, e.g. Pithecanthropus erectus and Homo heidelbergensis).
Historic (bronze and iron) age. Neolithic ("recent stone") age. (Carefully shaped and polished stone implements.)

Upper Paleolithic ("ancient stone") age. (Rough bone and stone im-Late Pleistoplements, cave frescoes, bone car- cene. vings, etc.) age. (Rude stone implements of tocene. so-called "River Man.")

Modern.

Post-Glacial

but preHistoric.

\begin{tabular}{|l|l}
\hline (No known implements.) & Early Pleisto- \\
cene \\
or \\
Pliocene. \\
\end{tabular}


Early Ancestral Forms. - Among the most ancient known remains of Man's early ancestral forms, two are of special interest. These are the socalled Pithecanthropus erectus and Homo heidelbergensis which are of greater antiquity than any bones of undoubted human beings.

Pithecanthropus erectus was found in Java in 1891 and, according to its discoverer (Dubois), it was of Pliocene age and had an erect attitude. Others, however, who have examined the locality and the remains claim its

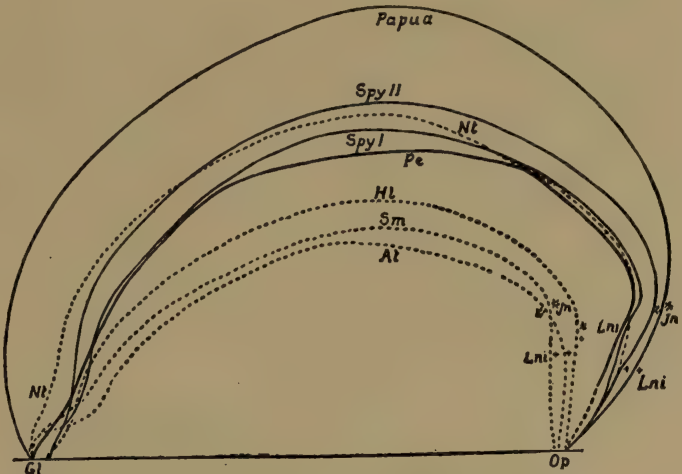

Fig. 232

Comparison of skull profiles of lowest types of Men and highest Apes. Papua, modern native of New Guinea; Spy 1 and 2, Men of Spy; Nt, Neanderthal Man; Pe, Pithecanthropus erectus; $\mathrm{Hl}$, a Gibbon; At, a modern Chimpanzee. (By Marsh after Du Bois, from Le Conte's "Geology," courtesy of D. Appleton and Company.) age to have been not earlier than early Pleistocene, and that there

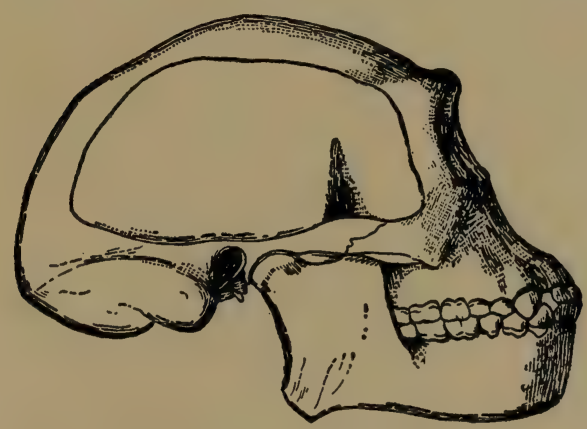

Fig. 233

Restoration of the head of Pithecanthropus erectus. (After Du Bois, from Norton's "Elements of Geology," by permission of Ginn and Company, Publishers.) is no proof whatever that it had an erect attitude. The actual remains include the upper portion of a skull, a lower jaw, several teeth, and a left thigh bone. A considerable amount of sediment rested upon the remains.

So-called Homo heidelbergensis, represented by a lower jaw with a number of teeth well preserved, was discovered (1907) near Heidelberg, Germany, in a sand-pit seventy feet be- 
low the surface. In this case, as well as that of Pithecanthropus, the depth of over-lying materials and the close associations of the remains of other Mammals, including certain now extinct species (e.g. Rhinoceros etruscus), pretty clearly point to an age not later than about the early Pleistocene.

Summarizing the characteristics of the forms represented by these two specimens (Pithecanthropus erectus and Homo heidelbergensis), Duckworth says: "Evidence exists in each case to the effect that far-distant human ancestors are hereby revealed to their modern representatives. Of their physical characters, distinct indications are given of the possession of a small brain in a flattened brain-case (see Fig. 234) associated with powerful jaws

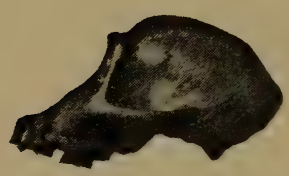

$a$

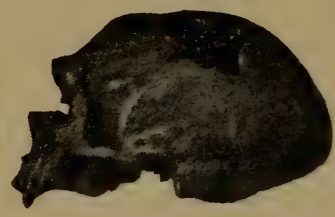

$b$

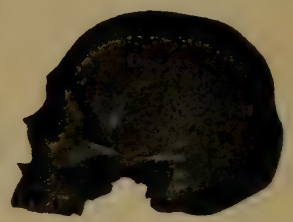

$c$

Fig. 234

Comparison of skulls: $a$, modern Chimpanzee; $b$, Paleolithic Man; $c$, modern Frenchman. (After E. Rivet, from New York State Museum Bulletin 173.)

and massive continuous brow-ridges; the lower part of the face being distinguished by the absence of any projection of the chin. The teeth indicate with some degree of probability that their diet was of a mixed nature, resembling in this respect the condition of many modern savage tribes. ... Whether they habitually assumed the distinctive erect attitude is a point still in doubt. . . . It is probable that in stature they were comparable, if not superior to, the average man of today." 1 It seems clear, therefore, that these remains represent a type intermediate between Men and the more highly developed Apes.

Paleolithic Men. - Many examples of the bones and implements of Pleistocene Men have been found in Europe, principally in caves within and without the glaciated area. It is very difficult, if not impossible, in any case to determine the precise glacial or

1 W. H. L. Duckworth: Prehistoric Man, pp. 60-61. 
interglacial stage to which such specimens belong, but their "great antiquity is inferred from the circumstances under which they were discovered. The evidence relates either to their association with extinct animals such as the Mammoth, ${ }^{1}$ or again the bones may have been found at considerable depths from the surface, in strata judged to have been undisturbed since the remains were deposited" (W. H. L. Duckworth). These Pleistocene Men are called Paleolithic because they are known to have fashioned many rude stone implements or weapons. Although their structure, particularly of the skull, shows them to have been low type savages, nevertheless all agree that they were truly human though of different species from modern Men. It is generally customary to group the more typical examples of Paleolithic Men together under the name Homo primigenius, while modern Men are called Homo sapiens. The nearest living approaches to the Paleolithic type are such as the native Papuan of New Guinea or the Bushman of Australia. That Paleolithic Men hunted the wild beasts of their day is certain because of the direct and frequent associations of the bones of such animals with their own.

A few of the best known and more typical examples of Paleolithic Men will now be described. "In a cave at Neanderthal, near Düsseldorf, was found (1856) a very remarkable human skeleton, which has greatly excited the interest of the scientific men. The limb-bones are large, and the protuberances for muscular attachments very prominent; the skull very thick, very low in the arch, and very prominent in the brows. It has been supposed by some to be an intermediate form between Man and the Ape; but, according to the best authority, it is in no respect intermediate, but truly human. It is probably the skeleton of a man exceptionally muscular in body and low in intelligence (see Fig. 232). . . . Recently there have been found in a cave at Spy, Belgium, two nearly complete skeletons, which seem to be of the same type as the Neanderthal Man, and with the latter are supposed to belong to a distinct and very early race. They are believed to have been Men of short stature, broad shoulders, bowed thighs, slightly bent knees, and semi-erect posture, but nevertheless distinctly human. The skeletons were found associated with the remains of all the

1 Also Cave-Bear, Cave-Hyena, woolly Rhinoceros, Reindeer, MuskOx, Hippopotamus, etc., which are either wholly extinct or extinct in Europe. 
characteristic Quaternary animals and with implements of the rudest kind." 1

In the Perigord district of southwestern France there are a number of caves in which were found relics of Men which are thought to range from early to late Paleolithic time. Among the more interesting relics are fish-hooks made of bone, and crude drawings of certain animals with which the Men were familiar, such as the Mammoth, which is now wholly extinct, and the Reindeer and Horse, now (naturally) extinct in that region.

The Aurignac cave of France was probably a family or tribal burial place. Near the entrance were found ashes and cinders mixed with split and burnt bones of now extinct animals. Within the cave were seventeen human skeletons of various sizes associated with ancient art works and bones of extinct animals.

An important discovery (1908) was in a cave at La Chapelleaux-Saints (Corrèze). The remains are a nearly perfectly preserved skull as well as the lower jaw and many bones of the body. In most respects the specimen very closely resembles the Neanderthal skeleton above described. Among animal remains found associated with this skeleton were the Reindeer, Horse, Bison?, Rhinoceros, Ibex, Wolf, Marmot, Badger, and Boar. This La Chapelle specimen seems to be a very fine typical example of the Paleolithic, or Neanderthal, type of Man.

Very recently (1911-1912) an important discovery was made at Piltdown Common in Sussex, England. The remains consist of most of a skull and lower jaw, with portions of the front of each missing. After considering all the evidence, Dawson and Woodward 2 say: "It appears probable that the skull and mandible cannot safely be described as being of earlier date than the first half of the Pleistocene epoch," and according to Woodward the skull represents the "oldest typically human brain-case hitherto found." The lower jaw is pretty Ape-like in character, while the skull, on one hand, has a much smaller brain capacity than the typical examples of Paleolithic Man above described, and, on the other hand, the front (forehead) of the skull is distinctly steeper (relatively higher) than in typical Paleolithic Man, this latter feature being exceptionally modern. Because of this unusual combination of characters, the Piltdown specimen may

1 J. Le Conte: Elements of Geology, 5th ed., p. 635.

2 Dawson and Woodward: Quar. Jour. Geol. Soc., Mar., 1913, p. 123. 
represent a different species and has been named Eanthropus dawsoni.

Another interesting feature concerning Paleolithic Man is the fact that many caves which he occupied have their walls decorated with drawings and even pictures in colors -- veritable art galleries. One of the finest examples is the Altamira cavern in northern

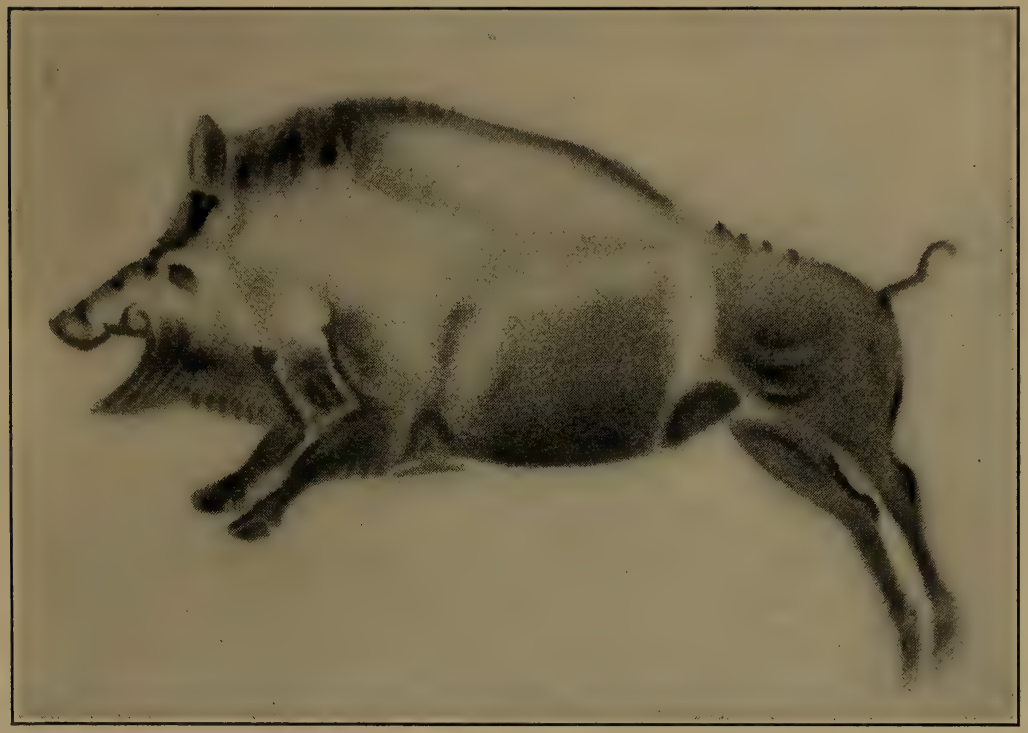

Fig. 235

A charging wild Boar, one of the best paintings by Paleolithic Man in the cave at Altimira, Spain. (After Cartailhac and Breuil, courtesy of the American Museum of Natural History.)

Spain. "As we gaze at the pictures one of the first things to impress us is the excellence of the drawing, the proportions and postures being unusually good. The grand Bison and the charging Boar are masterpieces in this respect (Fig. 235). The next observation may be that, in spite of this perfection of technique, there is no perspective composition - that is, no attempt to combine or group the figures (Figs. 236, 237). . . . In addition to these remarkable sketches in colors, the other walls of Altamira have numerous figures in black outline and also engravings. . . . It is also clear 


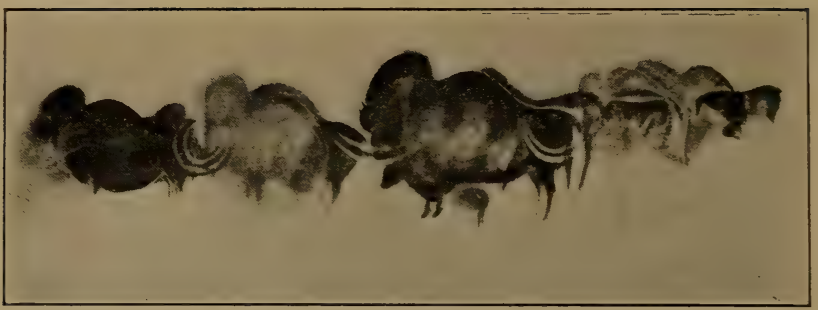

Fig. 236

The "Procession of Mammoths"; a painting by Paleolithic Man in a cave at Font-de-Gaume in west-central France. Note the lack of perspective composition. (After Capitan and Breuil, courtesy of the American Museum of Natural History.)

that the work of many different artists is represented, covering a considerable period of time. The walls show traces of many other paintings that were erased to make way for new work." 1

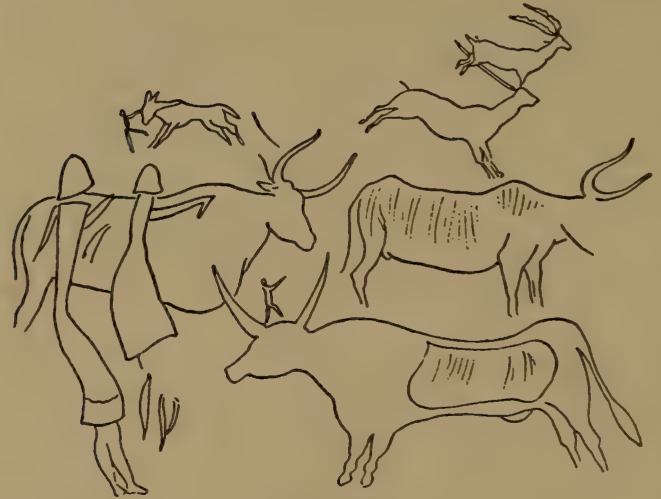

Fig. 237

Many other caves containing works of art have been discovered in northern Spain and in France.

The appearance of true Man "was an event which in importance ranks with the advent of life upon the planet, and marks a new manifestation of creative energy upon a higher plane. There now appeared intelligence, reason, a moral nature, and a capacity for self-directed progress such as had never been before on earth" (W. H. Norton).

1 Clark Wissler: Amer. Mus. Jour., Dec., 1912, pp. 290-292. 
Neolithic Man. - So far as known the late Paleolithic passed gradually into the Neolithic or recent stone age when Men were more highly developed and similar in structure, at least, to those of today. The stone implements of Neolithic Men were usually more perfectly made and often polished. "The remains of Neolithic Man are found, much as are those of the North American Indians, upon or near the surface, in burial mounds, in shell heaps (the refuse heaps of their settlements), in peat-bogs, caves, recent flood-plain deposits, and in the beds of lakes near shore where they sometimes built their dwellings upon piles. . . . Neolithic Man in Europe had learned to make pottery, to spin and weave linen, to hew timber, and build boats, and to grow wheat and barley. The Dog, Horse, Ox, Sheep, Goat, and Hog had been domesticated." 1 This stage of culture gradually passed into the historic age.

"Man is linked to the past through the system of life, of which he is the last, the completing creation. But, unlike other species of that closing system of the past, he, through his spiritual nature, is more intimately connected with the opening future" (J. D. Dana).

1 W. H. Norton: Elements of Geology, p. 448. 


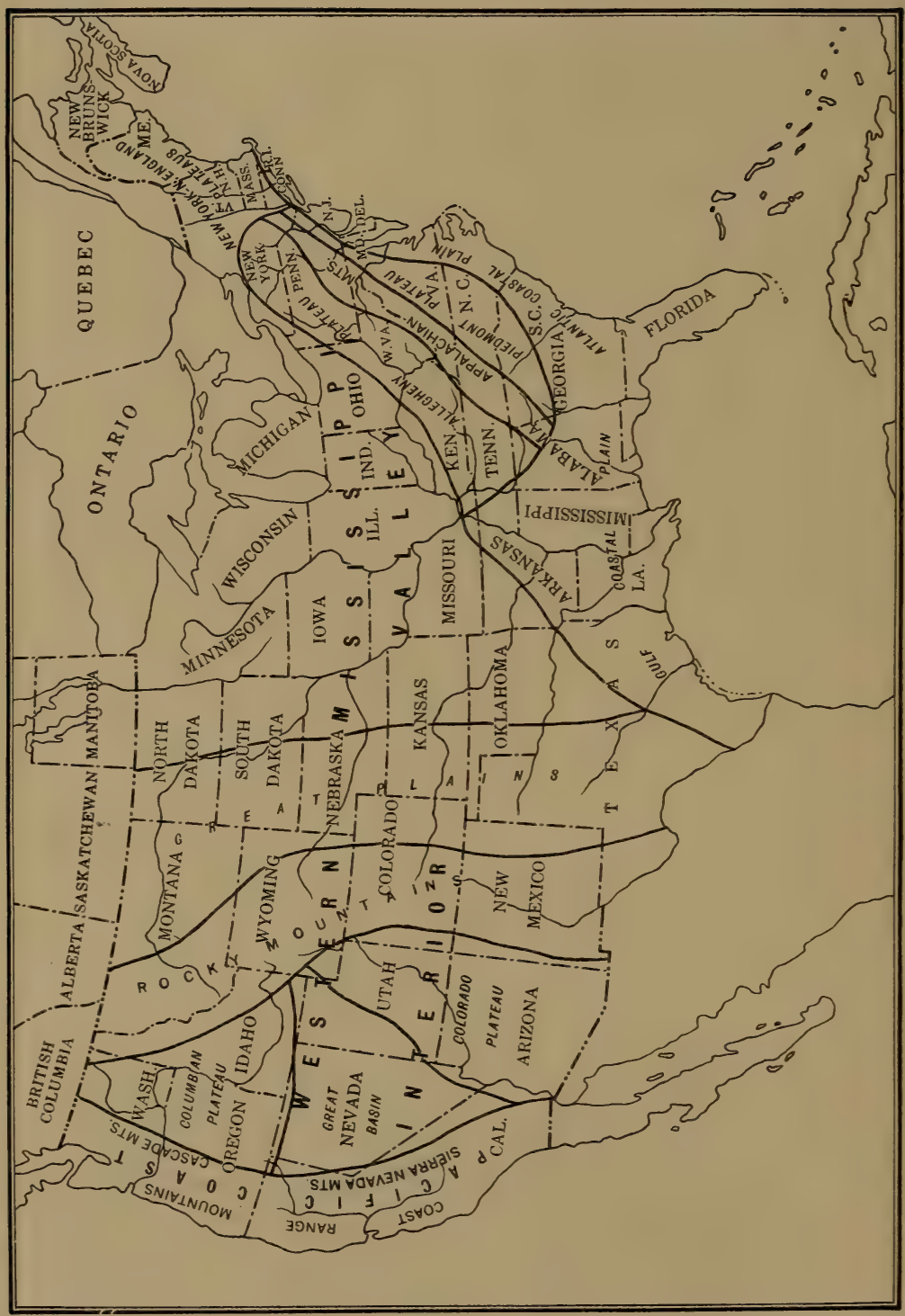

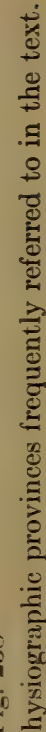

를

造

$\stackrel{2}{2}$

ED

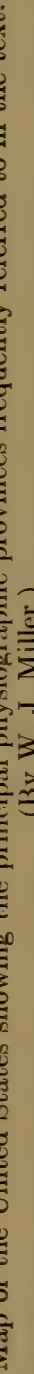




\section{N D E X}

Acadian series, 57 .

Acidaspis, 101.

Actinopteriate, 135.

Adirondack Mountains, 42-45, 81, 296,332 .

Africa, 89, 112, 132, 152, 168, 188, $189,210,211,225,255,305,307$, 308,372 .

Agassiz, L., 140.

Age, 31 .

Alabama, 112, 122, 126, 164, 169, 236-237, 240-241, 248, 286, 287.

Alaska, 9, 128, 144, 147, 1C0, 163, $169,181,183,204-205,212,220$, $221,248,256,284,289,330,341$, 366,371 .

Albian formation, 237.

Algæ, 11, 54, 71-72, 91, 132-133, 170.

Algonkian (see also Proterozoic) period, 32, 42; rocks, 47-49; subdivisions, 42, 49; correlation, 51 ; distribution of rocks, 53 ; foreign, 53 .

Allegheny series, 158, 161-162.

Allen, J., 174.

Allosaurus, 270.

Alps, 132, 187, 210, 255, 305, 306, $307,308,368,372$.

Amber, fossils in, 4, 316.

Ambonychia, 96.

Ammonoids, 98-99, 135, 156-157, 175, 191, 214, 230, 258.

Ammonites, 13, 99, 230, 258, 260, 314.

Amoba, 14.

Amphibians, 13, 21; Devonian, 142; Mississippian, 157; Pennsylvanian, 173, 177-179; Permian, 191, 193; Triassic, 215; Jurassic, 232; Cretaceous, 261; Tertiary, 317.

Ancyloceras, 260.
Andes Mountains, 210, 249, 255, 309.

Angiosperms, 11, 13, 170, 228, 256257.

Animals, classification, 10, 11, 13-22; earliest forms, 70-71.

Animikean, 42, 49.

Antarctica, 329, 368.

Anthozoans, 13, 15, 73, 92-93, 114, 228.

Anthrapalæmon, 176.

Ants, 232.

Apalachicola formation, 282, 287.

Apennine Mountains, 306, 307, 308, 309.

Appalachia, 62; Cambrian, 65; Ordovician, 84; Silurian, 108; Devonian, 128; Mississippian, 148; Permian, 185-186; Paleozoic, 195196; Triassic, 206; Cretaceous, $244,276$.

Appalachian Mountain district, Cambrian, 58-59, 63; Ordovician, 81; Silurian, 105-107, 110; Devonian, 121-126, 128, 130; Mississippian, 144-148; Pennsylvanian, 158-166; Permian, 181-187; Paleozoic, 195197; Triassic, 203, 206; Cretaceous, 251-252; Tertiary, 292, 296-298.

Appalachian Revolution, 183-187, 197.

Aptian formation, 237.

Aquia formation, 282.

Arachnids, 13, 21, 76, 100, 116, 118, 136, 157, 175-176, 191.

Arbuckle Mountains, 150.

Archean, period, 32; rocks, 40-41; subdivisions, 41-42; correlation of rocks, 42-43; distribution of rocks, 44-45; foreign, 45-46; economic products, 46. 
Archeocyathus, 73.

Archeopteryx, 234.

Archeozoic era, 32, 40-46; life of, 46 ; climate, 46.

Archimedes, 156.

Arctic Islands, 79, 104, 106, 112, 121, $122,225$.

Argentina, 68, 89, 152, 188, 210, 306, $308,309$.

Arikaree formation, 282, 288.

Arizona, 53, 65, 84, 128, 181, 213, $220,221,276,304$.

Arkansas, 90, 163, 187.

Armor-fishes, 13, 21.

Arnold, R., 290, 294, 295, 297, 367.

Arthrodirans, 138-140, 157.

Arthropods, 13, 20, 21; Cambrian, 75-76; Ordovician, 99-101; Silurian, 116-118; Devonian, 136; Mississippian, 157; Pennsylvanian, 175-177; Permian, 191; Triassic, 215; Jurassic, 231-232; Cretaceous, 261; Tertiary, 314-316.

Artiodactyls, 319, 321-322.

Arundel formation, 237, 240.

Asia, 152, 168, 188, 210, 225, 227, $255,305,306,307,308$.

Asteroids, 13, 17, 93 .

Asterozoans, 13, 17, 115, 134, 156, $174,191,213,229$.

Augusta series, 143.

Ausable Chasm, 62.

Austin formation, 237, 242, 246.

Australia, 10, 46, 68, 89, 92, 112, 132, $152,153,168,188,190,200,210$, $225,227,255,256,306,372$.

Austria, 132.

Baculites, 99, 258, 260.

"Bad Lands," 296, 303.

Barrande, J., 97, 115.

Barremian formation, 237.

Barrows and Blackwelder, 34, 118.

Bassler, R. S., 94.

Bavaria, 46, 227, 234.

Becraft formation, 121.

Bedford limestone, 153, 154.

Beecher, C. E., 101.
Beekmantown formation, 78.

Bees, 232.

Beetles, 232.

Belemnites, 215, 231, 314.

Belemnoteuthis, 231.

Belgium, 120, 152, 305, 309.

Berkey, C. P., 87, 251-252.

Berkshire Hills, 86, 87, 250, 332.

Berry, E. W., 312.

Big Blue series, 180, 181.

Billings, E., 93.

Birds, 13, 22; Jurassic, 234-235; Cretaceous, 262; Tertiary, 317.

Bisons, 371.

Black Hills, 82, 147, 220, 243.

Black Lake, 351.

Black River formation, 78.

Black River Valley, 332, 336-337.

Blackwelder, E., 33.

Blackwelder and Barrows, 34, 118.

Blake, J. H., 21.

Blanco formation, 282, 289.

Blastoids, 13, 16, 17, 93, 114, 134, 155, 173.

Bohemia, 67, 152, 190, 307, 312.

Boulder clay, 339 .

Brachiopods, 13, 19, 53, 73-74, 94$95,116-117,134-135,156,174$, 191, 214, 229, 230.

Branchiosaurs, 178.

Branner, J. C., 297.

Brazil, 53, 168, 188, 189, 190, 255, 306.

Breuil, 379, 380.

Bridger formation, 282, 287.

Brigham, A. P., 34, 352 .

British Columbia, 53, 59, 144, 204, $205,209,220,221,223,243,248$, $250,256,276,284$.

British Isles (see also England), 56, $89,92,103,111,112,131,151,187$, 227, 305, 309, 310, 371.

Brittany, 67.

Brittle-stars, 13, 17.

Brogniart, A. T., 177.

Bronteus, 101.

Brontotherium, 318.

Brooks, W. K., 70. 
Brooksella, 73 .

Broom, 192.

Bryophytes, 11, 133, 153, 170.

Bryozoans, 13, 18-19, 94, 115-116, 134, 156, 174, 191, 214, 229.

Bumastus, 101.

Bunter series, 201, 210.

Butterflies, 21, 232.

California, Mississippian, 147; Pennsylvanian, 163; Permian, 181, 183; Triassic, 201, 204, 212; Jurassic, $220,221,223,225,227$; Cretaceous, $237,243,246,248,256,276$; Tertiary, 282, 289, 290, 297, 300, $303,310,312,313$; Quaternary, $331,366,367,372$.

Calkins, F. C., 303.

Callithamnopsis, 91.

Caloosahatchee formation, 282, 287.

Calvert formation, 282.

Calvin, S., 257.

Calymmene, 101, 115.

Cambrian period, 32 , 56-76; origin of name, 56 ; subdivisions, 57 ; distribution of rocks, 57-59; character of rocks, 59 ; thickness, 59 ; igneous rocks, 59, 61; physical history, 61-67; length of time, 65; foreign, 67-68; climate, 68-69; glaciation, 68 ; economic products, 69 ; life of, 69-76.

Camel, evolution of, 321-322.

Campbell, M. R., 62, 187.

Canada (see also various provinces), $42,44,45,53,55,65,82,84,106$, $108,121,128,148,197,287,332$, $350,358$.

Canadian series, 78.

Capitan, 380.

Carboniferous (see Mississippian and Pennsylvanian).

Carbonization, 4.

Cardiola, 96.

Carnivores, 319, 325-326.

Carpathian Mountains, 307.

Cartailhac, 379, 380.

Caryocrinus, 114.
Cascade Mountains, 220, 223, 277, $289,300,301,304$.

Castle Hayne formation, 282.

Casts, 4.

Catopterus, 216.

Catskill formation, 120, 124, 130.

Catskill Mountains, 332.

Caucasus Mountains, 307, 308-309, 368.

Cayugan series, 103, 106-107, 113.

Cenomanian formation, 237.

Cenozoic era, 32, 281-381.

Centipedes, 13, 21.

Cephalopods, 13, 20-21, 75, 97-99, $117,135-136,156-157,175,191$, 214-215, 230-231, 258, 260-261, 314.

Ceratites, 99, 214.

Ceraurus, 101.

Cereals, 313.

Cetaceans, 319, 325-326.

Chamberlain, C. J., 226.

Chamberlin, T. C., 25, 37, 355, 363.

Chamberlin and Salisbury, 28, 33, $37,49,61,71,75,115,137,150$, $155-156,159,174,189,192,211$, $326,358,363-364$.

Champlain sea, 364, 365 .

Champlain Valley, 297, 332, 336, 348, 364.

Chautauquan series, 120, 124; time, 130.

Chemung formation, 120, 124, 130.

Chester series, 143, 147, 153; time, 148.

Chico formation, 237, 243.

Chili, 152, 210.

China, 46, 68, 89, 112, 132, 168, 169, $188,255$.

Choctawhatchee formation, 282, 287.

Choptank formation, 282.

Chouteau series, 143.

Chronology, of earth, 7 .

Chuar group, 51.

Cimarron series, 180, 181.

Cincinnati Anticline, 88, 148.

Cincinnati series, 78.

Citronelle formation, 282, 287. 
Cladoselache, 139.

Claiborne formation, 282.

Clams, 13, 20.

Claosaurus, 272.

Clark, W. B., 23, 220, 240-241, 292.

Clarke, J. M., 8, 116, 128, 129, 134, 137.

Classification, animals and plants, 10-22; geologic time, 31-32.

Clear Fork series, 180.

Cleland, H. F., 33.

Climacograptus, 92.

Climate, past conditions, 9 ; see also the different periods.

Clinton formation, 103, 105, 106, 107, 108, 112.

Clitambonites, 95.

Coal, Pennsylvanian, 158-162; origin of, 164; areas in North America: Permian, 189, 190; Triassic, 212; Jurassic, 227; Cretaceous, 256.

Coal Measures, 158, 161, 177.

Coastal Plain, Atlantic, 237-244, 251$252,256,275,276,282,284-286$, 290-292, 317, 365-366.

Coastal Plain, Gulf, 237-245, 256, $275,276,282,284,287,290,292$, 293, 365-366.

Coast Range Mountains, 220, 223, $243,248,277,289,290,297,299-$ 300,304 .

Coast Range Revolution, 300.

Cobalt, 46.

Cobleskill formation, 103, 107, 110.

Coccosteus, 139.

Coe, 18.

Coelenterates, 13, 15; Cambrian, 7273; Ordovician, 91-92; Silurian, 114; Devonian, 133-134; Mississippian, 155; Pennsylvanian, 173; Permian, 191; Triassic, 213; Jurassic, 228; Cretaceous, 258; Tertiary, 313.

Coeymans formation, 121.

Coleman, A. P., 55.

Colorado, 102, 128, 147, 164, 181, $190,220,242,243,246,287,288$, $310,316$.
Colorado formation, 237, 242; time, 246.

Colorado Plateau, 301, 304.

Columbia formation, 365 .

Columbian Plateau, 303-304.

Comanchean, 236.

Conemaugh series, 158, 161-162.

Conifers, 11, 13, 172, 190, 212, 213, 227, 256, 257.

Connecticut Valley, 5, 203-204, 208209, 212, 216-217, 270, 297.

Cope, E. D., 319.

Copper, 55, 212.

Corals (see also Anthozoans), 13, 16, 73, 92-93, 113-114, 133-134, 154155, 173, 191, 228, 258.

Cordaites, 11, 12, 172, 175, 190, 212. Cordillera, 195-197.

Correlation of rock formations, 23-27. Correlation, inorganic criteria, 2326; paleontological criteria, 26-27. Corydaloides, 177.

Couch, 233.

Crabs, 13, 20, 231, 233, 261, 314.

Creodonts, 325-326.

Cretaceous peneplain, 250-251, 296.

Cretaceous period, 32, 236-273; origin of name, 236; subdivisions, 237; distribution of rocks, 236-240; character of rocks, 240-244; thickness, 243; igneous rocks, 243-244; physical history, 244-252; foreign, 252-255; climate, 255; economic products, 256 ; life of, 256-263.

Crinoids, 13, 16-17, 114-115, 134, 155, 173-174, 191, 213, 229, 258.

Crioceras, 260.

Crocodiles, 22, 234, 273.

Croll's hypothesis, 361-363.

Crustaceans, $13,20-21,53,75-76$, $99,100,101,117-118,157,191$, $215,231,314$.

Cryptogams, 11, 91, 154, 170, 190.

Cryptozoön, 71-72.

Cushing, H. P., 72 .

Cuttle-fishes, 13, 20.

Cycads, 11, 12, 172, 190, 226-228, $256,257$. 
Cycadeoidea, 227.

Cycadofilices, 11, 12, 172-174.

Cyphaspis, 115.

Cyrtoceras, 97-99.

Cystoids, 13, 16-17, 73, 93, 114, 134, 155.

Dakota, formation, 237, 242, 256, 277 ; time, 246.

Dall, W. H., 292.

Danian formation, 237.

Dana, J. D., 11, 33, 34, 312, 381.

Darton, N. H., 182, 205, 227, 249, 259, 296.

Darwin, C., 3.

Dawson, 387.

Dean, B., 137, 138.

Decapods, 215, 231-232, 261.

Deccan, 255.

Deiphon, 115.

De Lapparent, A., 89, 111, 131, 151, $167,189,211,224,253,254,306$, $307,308$.

Delaware, 240.

Delaware River, 297.

Deposits, land, 5; river and lake, 6; marine, 6 .

Devonian, period, 8, 32, 120-142; origin of name, 120 ; subdivisions, $120-121$; rock distribution, 121124; character of rocks, 122-125; thickness, 125; igneous rocks, 125; physical history, 125-130; foreign, 131-132; climate, 132; economic products, 132; life of, 132-142.

Diatoms, 133, 311-312.

Dibranchs, 13, 20, 215, 231, 314.

Dicotyledons, 11, 13.

Dictyonema, 92.

Didymograptus, 92.

Dikellocephalus, 57,75 .

Dinosaurs, 215, 234, 263, 266-271, 311.

Dioon, 226.

Diplodocus, 268.

Diplograptus, 92.

Diplomystus, 316.

Dipnoans, 138-139, 157, 215, 232.
Dipterus, 139.

Dismal Swamp, 164.

Doedicurus, 370.

Dogger series, 219.

Dolomite, 69.

Double Mountain series, 180.

Drift, glacial, 329, 337.

Drumlins, 339-340.

Du Bois, 375.

Duckworth, W. H., 376, 377.

Dunkard series, 180-181.

Eagle Ford formation, 237-242.

Eanthropus, 378-379.

Earth, age of, 1; physical geography of, 1 ; chronology, 7 ; origin, $35-39$; pre-geologic, 35.

Earth's history, summary of stages, 39.

Eastman-Zittel, book by, 34 .

Echinoderms, 13, 15-17; Cambrian, 73; Ordovician, 93; Silurian, 114115; Devonian, 134; Mississippian, 155-156; Pennsylvanian, 173; Permian, 191; Triassic, 213214; Jurassic, 229-230; Cretaceous, 258; Tertiary, 313.

Echinoids, 13, 17, 18, 93, 115, 156, 174, 191, 213-214, 229-230, 258.

Echinozoans (see also Echinoids), 13, $17,18,134$.

Edentates, 370-371.

Edwards and Haime, 113.

Elephant, evolution of, 322-325.

Elephas, 323.

Emergence, of land, 29.

Emerson, B. K., 203, 208.

Enaliosaurs, 215, 234, 263-266.

Endogenous plants, 12.

England (see also British Isles), 9, $115,120,152,210,219,225,231$, $236,254,309,378$.

Eocene series, 281-288.

Eohippus, 319-321.

Epoch, 31.

Equisetæ, 11, 12, 133, 154, 171, 173, $190,212,227,256$.

Equus, 318, 320-321. 
Era, 31, 32.

Erian series, 120, 122, 124; time, 128.

Erratics, 329, 338-339.

Eryops, 173, 178.

Esopus formation, 121.

Eucalyptocrinus, 114.

Eucrustaceans, 13, 76, 100, 117-118, 136, 157, 175-176, 215, 231.

Euproöps, 176.

Europe, Cambrian, 67-68; Ordovician, 88-89; Silurian, 111-112; Devonian, 128, 130-131; Mississippian, 151-152; Pennsylvanian, 167-169; Permian, 187-188, 190, 194, 197, 200; Triassic, 210-211; Jurassic, 224-225; Cretaceous, 237, 252-255; Tertiary, 305-309, 310, 313; Quaternary, 368, 371, 375381.

Eurypterids, 13, 76, 100, 116, 118, 136, 177, 191.

Eurypteris, 116.

Eutaw formation, 237, 241.

Exogenous plants, 12.

Exogyra, 230, 259.

Fairchild, H. L., 339.

Ferns, 11, 12, 133, 154, 172, 190, 212, $227,256$.

Filices, 11, 12, 172.

Finger Lakes, 336, 337, 350.

Finland, 46, 53.

Fishes, 13, 21; Silurian, 119; Devonian, 137-142; Mississippian, 157; Pennsylvanian, 177; Permian, 191; Triassic, 215; Jurassic, 232-233; Cretaceous, 261; Tertiary, 316317.

Flagstones, 132.

Flies, 13, 232.

Florida, 284, 287, 292, 294, 310.

Florissant formation, 282, 288.

Footprints, fossil, 5, 203, 208, 216217.

Foraminifers, 13, 14, 15, 71-72, 91, $133,154,172-173,190,228,257$, $258,313$.
Forbesiocrinus, 155 .

Fordilla, 74 .

Fort Union formation, 282, 287.

Fossils, significance, 3,6 ; preservation, 4 ; rocks in which found, 5 .

Fraas, E., 213, 265.

France, 46, 53, 67, 113, 132, 152, 187. $190,236,254,305,307,309,371$, 378,380 .

Frankfort formation, 78, 88 .

Fredericksburg, formation, 237, 242, 276 ; time, 246.

Frogs, 13, 22.

Fungi, 11.

Ganoids, 138-140, 157, 215-216, 232, 261.

Gas, in Ordovician strata, 90; in Silurian, 113; in Devonian, 132; in Mississippian, 153; in Pennsylvanian, 169.

Gastropods, 13, 20, 74-75, 96-97; $117,135-136,156,175,191,214$, $230,258,313,315$.

Gaudry, A., 326.

Geikie, A., 23, 33.

Geikie, J., 368.

Genesee formation, 120, 124.

Geological divisions, 32 .

Geologic and human history compared, 32-33.

Geologic time, classification, 31-32.

Georgia, 314.

Georgian series, 57 .

Germany, Proterozoic, 53; Cambrian, 67; Devonian, 132; Mississippian, 152; Permian, 187, 190; Triassic, 201, 210; Jurassic, 219, 225; Cretaceous, 256; Tertiary, $305,306,307,309,310,316$; Quaternary, 368, 375, 377.

Gibbes, 317.

Gilbert, G. K., 354, 367.

Glacial boulders (see erratics)

Glaciation, Proterozoic, 55; Cambrian, 68; Mississippian, 153; Permian, 188-190; Quaternary, 328-364, 368 . 
Glacial epoch, 328-364; fact of, 328329 ; ice extent and centers, 329 331; movement and depth of ice, 331-333; successive ice invasions, 333-334; driftless areas, 334; ice erosion, 334-337; ice deposits, 337-341; loess, 341; Great Lakes history, $342-349$; other existing lakes, 348, 350; extinct lakes, 351352 ; drainage changes, 352-356; advantages and disadvantages, 357-358; duration, 358; time since, 359-360; cause of, 360-364; in Europe, 368.

Glacier National Park, 33.

Glyptodonts, 369, 371.

Glyptocrinus, 93.

Gold deposits, in Jurassic, 225-226; in Tertiary, 310-311.

Goldfuss, A., 229.

Goniatites, 99, 135-136, 156-157, 175.

Grabau, A. W., 34 .

Grammysia, 135.

Grand Canyon of Arizona, 51-52, 147, 301.

Granger, W., 288.

Granite, Archean, 46.

Graphite, 46, 54 .

Graptolites, 13, 15, 72-73, 91-92, $114,133,155$.

Grasses, 313.

Grasshoppers, 13, 21, 232.

Great Basin, 82, 104, 107, 181, 183, 289, 301 .

Great Lakes, 106; history of, 342349.

Great Salt Lake, 366.

Greenbrier formation, 143, 147.

Greenland, 255, 313, 329.

Green Mountains, 86, 87, 250, 332.

Green River formation, 282, 287.

Greensands, 256.

Grenville series, 42-43.

Ground-sloths, 370 .

Group, 31, 32.

Gryphea, 230.

Guelph formation, 103-106.
Guettard, J., 113.

Guth, F. B., 81.

Gymnosperms, 11, 12, 133, 154, 170, $172,190,212-213,256$.

Gypsum quarries, Silurian, 113; Permian, 190; Triassic, 212.

Haime and Edwards, 113.

Hall, J., 92, 96, 97, 114, 115, 136, $137,155$.

Halysites, 113.

Hamilton formation, 120, 122-124, 133.

Haug, E., 33.

Helderbergian series, 121-122; time, 125-126.

Helioceras, 260.

Heliolites, 113.

Hemiaster, 230.

Hesperornis, 262.

Hexacoralla, 93, 191, 213, 226.

Highlands of the Hudson, 87, 298.

Hill, R. T., 229, 230, 242, 259.

Himalaya Mountains, 188, 210, 225, $255,306,308,309$.

Hitchcock, E., 217.

Holland, 305.

Holothuroids, 13, 17, 18, 73, 93.

Holyoke Range, 208, 209, 277.

Homalonotus, 137.

Homo heidelbergensis, 375-376.

Homo primigenius, 373-374.

Homo sapiens, 373-374.

Horse, evolution of, 319-321.

Horse-shoe Crabs, 13, 117.

Horsetown formation, 237, 243.

Howes, 19.

Hudson River, 279, 298, 299, 355.

Hudson Valley, 108, 112, 297, 298, $332,348,364$.

Human and geologic history compared, 32-33.

Hungary, 227.

Hunter, 117.

Hunter, G. W., 11.

Huronian, 42, 49, 50, 55 .

Hydrozoans, 13, 15, 72-73, 91-92.

Hypsocormus, 233. 
Ice Age (see Glacial epoch).

Iceland, 307.

Ichthyornis, 262.

Ichthyosaurs, 263-265.

Idaho, 220, 366.

Illinois, 90, 105, 122, 153, 164, 169, $334,341,356$.

India, 46, 53, 68, 89, 188, 225, 255.

Indiana, 90, 105, 107, 130, 153, 154, $155,156,169,341$.

Inoceramus, 259.

Insectivores, 319, 325 .

Insects, 13, 21, 100, 119, 136, 157, $173,177,191,215,232,314,315$, 316.

Iowa, $60,90,123,150,155,169,181$, $190,256,334,341,371$.

Ireland, 307.

Iron ore, Archeozoic, 46; Proterozoic, 55; Silurian, 112; Pennsylvanian, 169 .

Isotelus, 101.

Italy, 305, 306, 309.

Jackson formation, 282.

Jacksonville formation, 282, 287.

Japan, 46, 210, 225, 255, 308.

Java, 327, 375.

Jelly-fishes, 13.

Johnson, B. L., 291-292.

Jordan and Kellogg, 34 .

Jura Mountains, 219.

Jurassic period, $32,219-235$; origin of name, 219; subdivisions, 235; distribution of rocks, 219-220; character of rocks, 220-221; thickness, 221; igneous rocks, 221 ; physical history, 221-224; foreign, 224 ; climate, 225 ; economic products, 225-226; life of, 227-235.

Kames, 340.

Kansas, 153, 169, 180-183, 190, 242, $256,289$.

Kaskaskia series, 143.

Kayser, E., 33.

Keith, A., 83.

Kellogg and Jordan, 34.
Kentucky, 122, 133, 169, 371.

Kettle-holes, 338.

Keuper series, 201, 210.

Kewatin, 42-43.

Keweenawan, 42, 49, 50, 55 .

Keyes, C. R., 150.

Kinderhook series, 143, 146.

Klamath Mountains, 223.

Knight, C. R., 264, 267, 268, 269, $270,321,323$.

Knowlton, F. H., 213, 257.

Knoxville formation, 237, 243.

Kootenai formation, 237, 242, 246.

Labrador, 84.

Labyrinthodonts, 178-179.

La Chapelle, Men of, 374, 378.

Lafayette formation, 282, 286, 291292.

Lake Agassiz, 351-352.

Lake Algonquin, 347-348.

Lake Bonneville, 366-367.

Lake Champlain, 350.

Lake Chicago, 343-345.

Lake George, 350.

Lake Iroquois, 347-348.

Lake Lahontan, 367.

Lake Maumee, 343-344.

Lake Saginaw, 344-345.

Lake Superior district, 42, 46, 48-50, $55,58,84$.

Lake Warren, 345, 347.

Lake Whittlesey, 344-345.

Lamp-shells, 13.

La Place, P., 36.

Lapworth, C., 77.

Laramie formation, 237,243 ; time, 246.

Laramide Range, 249.

Lassen Peak, 304, 305, 366.

Laurentian, 42-43.

Lawson, A., 54.

Lead ore, 90.

Le Conte, J., 33, 40, 98, 100, 117, 141, $176,177,194,233,234-235,257$, $260,261,266,313,315-316,361-$ $362,367,375,377-378$.

Leith and Van Hise, 41, 48, 55. 
Lemuroids, 327.

Lepidodendrons, 170, 173, 190.

Leptomites, 73.

Leverett, F., 343, 344, 345, 346, 355, 356.

Lias series, 219; time, 224.

Lignite, 310.

Limestone quarries, 90, 112, 153, 256.

Limnoscelis, 173.

Lindgren, W., 220.

Lingula, 95.

Lingulella, 74.

Linnæus, C., 113.

Lithographic limestone, 225, 227.

Little Falls formation, 57.

Lizards, 13, 216, 234, 273.

Lobsters, 13, 20, 215, 231.

Lockport formation, 103, 106.

Long Island, 338, 340.

Lonsdaleia, 154.

Lorraine formation, 78,82 .

Louisiana, 256.

Loup Fork formation, 282, 288.

Lower Carboniferous period (see Mississippian).

Loxonema, 136.

Lucas, F. A., 269.

Lull, R. S., 271, 323, 324, 325, 371.

Lung-fishes, 138-140.

Luther, D. D., 129.

Lycopods, 11, 12, 133, 154, 170-171, 190, 212.

Lyell, C., 27, 28, 281.

Maclurea, 96.

Macrurans, 215, 231-232.

Madagascar, 372.

Magothy formation, 237, 240-241.

Maine, 107, 122, 130, 299, 350.

Malm series, 219.

Mammals, 10, 13, 22; Triassic, 217; Jurassic, 235; Cretaceous, 263; Tertiary, 317-327; Quaternary, $369-381$.

Mammoth coal bed, 166 .

Mammoths, 4, 322-323, 371.

Man, 13, 22, 327; evolution of, 372381 .
Manasquan formation, 237, 241.

Manganese ore, 90.

Manitoba, 106, 123.

Manlius formation, 103, 110.

Mantell, G., 231.

Manticoceras, 136.

Map of United States, Physiographic provinces, 382.

Maps showing rock distribution, preCambrian, 44; Cambrian, 58; Ordovician, 79; Silurian, 105; Devonian, 123; Mississippian and Pennsylvanian, 145; Mississippian, 146; Pennsylvanian, 159; Triassic and Jurassic, 202; Lower Cretaceous, 238; Upper Cretaceous, 239; Lower Tertiary, 283; Upper Tertiary, 285; Cenozoic volcanic rocks, 302 .

Maps showing paleogeography of North America, Lower Cambrian, 64; Middle and Upper Cambrian, 66; Middle Ordovician, 85; Silurian, 109; Early Devonian, 126; Middle Devonian, 127; Mississippian, 149; Pennsylvanian, 165; Permian, 184; Triassic, 207; Jurassic, 222; Lower Cretaceous, 245; Upper Cretaceous, 247; EoceneOligocene, 293; Miocene, 295.

Maps showing paleogeography of Europe, Ordovician, 89; Silurian, 111; Devonian, 131; Mississippian, 151; Pennsylvanian, 167; Permian, 189; Triassic, 211; Jurassic, 224; Lower Cretaceous, 253; Upper Cretaceous, 254; Eocene, 306; Miocene, 307; Pliocene, 308.

Marble, 46, 90.

Marcellus formation, 120, 122-124, 133.

Mariopteris, 171.

Mariposa slate, 220-221, 223.

Marsh, O. C., 262, 269, 272, 318, 375.

Marsupials, 318.

Martha's Vineyard, 239.

Martinez formation, 282. 
Maryland, 143, 147, 161, 220, 240, 285, 292.

Massachusetts (see also Connecticut Valley), 163, 197, 203, 204, 208, 209, 271, 279, 339.

Mastodons, 322-324, 371.

Mastodonsaurus, 215.

Matawan formation, 237, 241.

Matherella, 74 .

Matthew, W. D., 92, 320.

Mauch Chunk shales, 143, 147, 148.

Medina formation, 103-104, 113.

Meek, F. B., 93, 175, 176, 260.

Megatherium, 370.

Merced formation, 282.

Merostomes, 13, 117.

Mesohippus, 320 .

Mesopithecus, 326.

Mesozoic era, 32, 201-280; reptiles, 263-273; summary of history, 274-280; rocks, 274-275; physical history, 275-277; climate, 277-278; organic history, 278-280; summary of life, 278-279.

Mexico, 183, 219, 221, 226, 242, 246, 288, 294.

Michigan, 55, 106, 110, 112, 113, 122, $128,130,146,148,153,169,200$.

Microsaurs, 178-179.

Midway formation, 282.

Minnesota, 45, 55, 350, 359.

Miocene series, 281-282, 284, 286290.

Mississippian period, 32, 143-157; origin of name, 143; subdivisions, 143-144; rock distribution, 144147; character of rocks, 145-147; thickness, 147; igneous rocks, 147; physical history, 148-151; foreign, 151-152; climate, 153; economic products, 153; life of, 153-157.

Mississippi Valley, Archean, 45; Algonkian, 53; Cambrian, 59, 65; Ordovician, 81-82, 84, 88, 90; Silurian, 104-107; Devonian, 122126, 128; Mississippian, 143-150; Pennsylvanian, 158-161, 163-165; Permian, 181, 185, 187; Paleozoic,
194-196; Triassic, 201; Tertiary, 299; Quaternary, 330-334, 357.

Missouri, 58, 82, 84, 90, 105, 106, $122,123,153,334$.

Missouri River, 356.

Mohawkian series, 78.

Mohawk Valley, 82, 297, 332, 348, $352,353,354$.

Molds, 4.

Molluscoids, 13, 18, 19; Cambrian, 73-74; Ordovician, 94-95; Silurian, 115-116; Devonian, 134-135; Mississippian, 156; Pennsylvanian, 174; Permian, 191; Triassic, 214; Jurassic, 229-230; Cretaceous, 258; Tertiary, 313.

Mollusks, 13, 20; Cambrian, 75; Ordovician, 94-99; Silurian, 117; Devonian, 135-136; Mississippian, 156-157; Pennsylvanian, 175; Permian, 191; Triassic, 214-215; Jurassic, 230-231; Cretaceous, 258-261; Tertiary, 313-315.

Monkeys, 326-327.

Monmouth formation, 237, 241.

Monocotyledons, 11, 13, 228.

Monongahela series, 158, 161-162.

Monotremes, 318 .

Montana, 153, 200, 220, 250, 287, $310,331$.

Montana formation, 237, 242-243.

Monterey formation, 282, 289, 300.

Moraines, 338-339.

Morrison formation, 237, 242, 246.

Mosasaurs, 262, 263, 266-267.

Moulton, F. R., 34, 37-38.

Mount Lassen, eruptions, 304-305.

Mount Shasta, 305, 366.

Murchison, R., 56, 77, 120, 180.

Muschelkalk series, 201, 210.

Myriapods, 13, 21, 136, 157, 177.

Nanjemoy formation, 282.

Naosaurus, 192.

Naumann, 215.

Nautiloids, 98-99, 117, 136, 156, $175,191,214,230,258,314$.

Nautilus, 13, 20-21, 98, 99, 191, 314. 
Navarro, formation, 237, 242; time, 246.

Neanderthal Man, 374, 375, 377.

Nebraska, 181, 249, 256, 288, 289, 296.

Nebula, 36-38.

Nebular hypothesis, 36-37.

Neocomian formation, 237.

Neolemus, 76.

Neolithic age, 374.

Neolithic Man, 381.

Neumayr, M., 232.

Nevada, 53, 59, 122, 125, 128, 204, $220,221,224,303,310$.

Newark series, 201, 203-204, 206-208, $212,221,276$.

Newberry, J. S., 216.

New Brunswick, 63, 82, 88, 107, 122, $125,126,128,130,147,160,163$, 169, 181-183.

New England, 45, 57, 59, 81-82, 86, $90,195,251-252,297,332,334,340$, $350,358$.

Newfoundland, 45, 53, 57, 131, 187.

New Jersey, 203, 223, 240, 256.

New Mexico, 164, 181, 183, 190, 304, 366.

"New Red Sandstone," 203.

New Scotland formation, 121.

Newsom, J. F., 297.

New York, Archeozoic, 42-46; Cambrian, 57, 58, 62, 65, 67, 69; Ordovician, 77-78, 80, 82, 86, 87, 88; Silurian, 103-108, 110, 112, 115; Devonian, 120-124, 128-130, 132; Paleozoic, 200; Triassic, 203, 208; Cretaceous, 250-251; Tertiary, 297; Quaternary, 332-340; 345$355,358-359$.

New Zealand, 89, 132, 152, 188, 210 , $225,255,256,313$.

Niagara River, 347; Falls, 354-355, 359.

Niagara formation, 106, 107.

Niagaran series, 103-108.

Nicholson, H. A , 97, 139.

Nickel, 46.

Nipissing Lakes, 348-349.
Noble, L. F., 52.

North Carolina, 164, 212, 213, 291.

North Dakota, 287.

Norton, W. $\mathrm{H}_{s}, 2,34,60,179,230$, $231,263,303-304,322,330,340$, $354,355,368,375,381$.

Norway, 68, 368.

Nova Scotia, 53, 106-107, 122, 125, $126,130,147,148,153,160,163$, $164,169,181,183,200,201,203$, 331 .

Nummulina, 313.

Nummulites, 313.

Oakville formation, 282, 287.

Odontopteryx, 317.

Oeningen, 315-316, 317.

Ohio, $88,90,106,110,112,153,169$, 181-182.

Ohio River (Upper), 355-356.

Oil, in Ordovician strata, 90; Silurian, 113; Devonian, 132; Mississippian, 153; Pennsylvanian, 169; Jurassic, 225; Cretaceous, 256; Tertiary, 310.

Oklahoma, 58, 82, 86, 106, 122, 153, 169, 181, 190, 242.

"Old Red Sandstone," 131-132, 203.

Olenellus, 57, 75 .

Oligocene series, 281-284, 286-289.

Oneida formation, 103-104, 108.

Onondaga, formation, 120, 122; time, 128.

Ontario, 46, 54, 106, 110.

Oölite series, 219.

Ophileta, 96.

Ophiuroids, 13, 17, 93.

Orbiculoidea, 95.

Order of Superposition, 7.

Ordovician period, $32,77-102$; origin of name, 77; subdivisions, 78; rock distribution, 78-81; character of rocks, 81-83; thickness, 82; metamorphism, 82; igneous rocks, 82 ; physical history, $84-88$; foreign, 88-89; climate, 90 ; economic products, 90; life of, 90-102. Oregon, 220, 221, 223, 289, 300. 
Organisms, changes in, 2, 3 ; modern relations, 10 .

Oriskany, formation, 121-122; time, 126.

Oriskanian series, 121-122.

Ornithopods, 263, 271-272.

Orthoceras, 97-99.

Orthodesma, 96.

Osage series, 143, 146; time, 148, 155.

Osborn, H. F., 192, 264, 267, 268, $270,321,326$.

Osmeroides, 261.

Osteolepis, 139.

Ostracoderms, 13, 21, 119, 137-138, 157.

Ostrea, 230, 258-259, 314.

Oswegan series, 103-104.

Oswego formation, 103, 104.

Overwash plain, 338.

Owen, R., 179, 317.

Oysters, 13, 20, 229, 258, 313-314.

Ozarkian, 65.

Ozark Mountains, 84, 148.

Paintings, Paleolithic, 379-380.

Paleaster, 134.

Paleasterina, 93.

Paleogeography, 29-31 (see also maps).

Paleolithic Age, 374; Men, 376-380; paintings, 379-380.

Paleontology, definition, 3.

Paleophonus, 117.

Paleospondylus, 136-137.

Paleozoic era, 32, 56-200; summary of history, 194-200; rocks, 194; physical history, 195-197; climate, 197,200 ; summary of life, 198199; organic history, 200.

Palisades, of the Hudson, 208, 277.

Palms, 312-313.

Pamelia formation, 78.

Panama, 9.

Paradoxides, 57, 75.

Pareiasaurus, 192.

Pascagoula formation, 282, 287.

Patagonia, 255.
Patapsco formation, 237, 240.

Patriofelis, 326.

Patten, W., 138.

Patuxent formation, 237, 240.

Peach, B. N., 117.

Peale, A. C., 250.

Pelagiella, 74.

Pelecypods, 13, 19-20, 74-75, 94-96, $117,135,156,175,191,214,230$, 258-259, 313-315.

Pelmatozoans, 13, 16, 17, 173.

Pemphix, 215.

Pennsylvania, Ordovician, 90; Devonian, 122, 124, 132, 142; Mississippian, 143, 145, 147, 150, 153; Pennsylvanian, 158, 160-164, 166, 169; Permian, 180, 181-182; Cretaceous, 251; Quaternary, 355, 356.

Pennsylvanian period, 32, 158-180; origin of name, 158 ; subdivisions, 158; rock distribution, 159-160; character of rocks, 161-163; thickness, 163; igneous rocks, 163; physical history, 163-166; length of time, 166; foreign, 167-168; climate, 168; economic products, 168-169; life of, 169-180.

Pentacrinus, 227.

Pentamerus, 117, 156.

Pentrimites, 155.

Period, 31, 32.

Perissodactyls, 319-321.

Permian, period, 32, 180-193; origin of name, 180; subdivisions, 180 ; rock distribution, 181-182; character of rocks, 181-182; thickness, 182; igneous rocks, 182 ; physical history, 183-188; foreign, 187-189; climate, 189-190; economic products, 190; life of, 191193.

Persia, 225.

Peru, 89.

Petrifaction, 5.

Pfurtscheller, 16.

Phacops, 137.

Phanerogams, 11, 12, 154, 170. 
Phenacodus, 319.

Phosphate, 132, 311.

Physiographic provinces of United States, 382.

Pictet, F. J., 260.

Piedmont Plateau, 45, 53, 82, 86-87, 90, 251, 292.

Pirsson and Schuchert, 33.

Pithecanthropus, 327, 374-375.

Pittsburg coal bed, 106.

Placentals, 318.

Placenticeras, 260.

Plaesiomys, 95.

Planetesimal hypothesis, 37-39.

Planets, 35-36.

Plants, classification, 11-14; earliest forms, 70-71; Cambrian, 71; Ordovician, 91 ; Silurian, 113; Devonian, 132-133; Mississippian, 153154; Pennsylvanian, 169-172; Permian, 190; Triassic, 212-213; Jurassic, 227-228; Cretaceous, 256-258; Tertiary, 311-313.

Platyceras, 136.

Plectambonites, 95 .

Plectorthis, 95.

Pleistocene epoch (see Glacial epoch).

Plesiosaurs, 263, 265-266.

Pleurocystis, 93.

Pleuromaria, 136.

Pliocene series, 281-282, 284, 286287, 289-290.

Pocono sandstone, 143, 145, 148.

Podokesaurus, 271.

Porifers, 13, 15; Cambrian, 72; Ordovician, 91; Silurian, 113-114; Devonian, 133; Mississippian, 155; Pennsylvanian, 173; Permian, 191; Triassic, 213; Jurassic, 228; Cretaceous, 258; Tertiary, 313.

Portage formation, 120, 124 .

Potomac series, 244, 276.

Potsdam sandstone, 57, 62.

Pottsville series, 158, 161-163.

Poughquag quartzite, 57.

Primates, 319, 326-327.

Proboscidians, 319, 322-325, 371.

Productus, 135, 156.
Proterozoic (see also Algonkian) era, $32,42,47-55$; life of, 53-54; climate, 55 ; glaciation, 55 ; economic products, 55 .

Protohippus, 320-321.

Protorohippus, 320.

Protozoans, 13-15; Cambrian, 7172; Ordovician, 91; Silurian, 113; Devonian, 133; Mississippian, 154; Pennsylvanian, 172-173; Permian, 190; Triassic, 213; Jurassic, 228; Cretaceous, 258; Tertiary, 313.

Pseudodiadema, 229.

Pterichthys, 138.

Pteridophytes, 11, 133, 154, 170-172, 212.

Pterodactyls, 263-271.

Pterosaurs, 215, 234, 263, 271-272.

Pulaski formation, 78.

Pyrenees Mountains, 305, 306, 307, 368.

Quaternary period, 32, 328-381; origin of name, 328; Glacial epoch, 328-364 (see also special heading); non-glaciated regions, 365-367; life of, 369-381; Mammals (except Man), 369-372; Man, 372-381. Quebec, 122, 125.

Quicksilver, 227.

Radiolarians, 13, 15, 53, 72, 91, 133, 154, 190, 228.

Rancocas formation, 237, 241.

Raritan formation, 237, 240.

Recapitulation, law of, 232-233.

Recent epoch, 328.

"Red Beds," 181-182, 188, 194, 197, 204, 205, 210, 211, 220, 221, 274.

References, general geological, 33-34. Reptiles, 13, 22; Pennsylvanian, 173, 179; Permian; 192-193; Triassic, 215-216; Jurassic, 233; Cretaceous, 262; Mesozoic, 263-273; Tertiary, 317.

Republican River formation, 282, 289.

Restinson, 304. 
Rhamphorhyncus, 263, 271-272.

Rhinoceros, 4.

Rhizocarps, 133.

Rhizopods, 13, 14.

Rhode Island, 163, 187.

Ries, H., 164.

Ripley formation, 237, 241-242.

Rivet, E., 376.

Rock scale, 31 .

Rocky. Mountain district, 50, 53, 58, $63,104,148,163,195,204,220$, $221,240,242,246,249,276,277$, 289, 301-304.

Rocky Mountain Revolution, 248250, 277.

Rodents, 319, 325, 371.

Rondout formation, 103, 110.

Ruedemann, R., 91, 92, 95, 96, 116.

Russell, I. C., 367.

Russia, 68, 111, 132, 152, 167, 180, $188,210,254,368$.

Salamanders, 13, 22, 317.

Salina formation, 103, 106-108, 110, 112.

Salisbury, R. D., 29, 330.

Salisbury and Chamberlin (see Chamberlin and Salisbury).

Salisbury and Willis, 33 .

Salt, 106, 110, 112, 153, 188, 190.

Salter, J. W., 96.

San Diego formation, 282.

Sandstone quarries, 69, 112, 212.

San Juan formation, 282, 287.

San Lorenzo formation, 282.

San Pablo formation, 282.

Santa Margarita formation, 282.

Saratogan series, 57 .

Sardinia, 67.

Sauropods, 263, 266-268.

Say, 114.

Scandinavia, 45, 53, 68, 111, 254, 368.

Schoharie formation, 120, 122.

Schuchert, C., 15, 16, 18, 19, 20, 30, 54, 126, 175, 196, 232.

Schuchert and Pirsson, 33.

Scorpions, 13, 21, 117-118, 136, 175176.
Scotland, 45, 53, 152, 157, 307.

Scott, D. H., 13, 174.

Scott, W. B., 6, 7, 8, 33, 76, 101, 125, $155,192,213,233,267,324,369$, 370.

Sea-cucumbers, 13, 18, 73.

Sea-mosses, 13.

Sea transgressions, 28; retrogressions, 28.

Sea-urchins, 13, 17, 18, 115, 134.

Sea-weeds, 91, 113, 132-133, 212.

Sedgwick, A., 56, 77, 120.

Seed-ferns (see also Cycadofilices), $11,133,154,172-174$.

Selachians (see also Sharks), 138139, 157, 215, 232.

Selma formation, 237, 241, 248.

Senecan series, 120, 124; time, 130.

Senonian formation, 237.

Sequoias, 256, 313.

Series, 31.

Sharks (see also Selachians), 119, 138-139, 157, 261, 316-317.

Shattuck, G. B., 292, 365.

Shawangunk formation, 103, 106108; Range, 106, 108.

Shimer, H. W., 14, 17, 18, 21, 34, 73, $234,257,318$.

Shumard, 155.

Siberia, 68, 89, 90, 132, 200, 210, $225,255,371$.

Sierra Nevada Mountains, 220, 223, 277, 289, 300, 301, 304, 305.

Sierra Nevada Revolution, 223, 277.

Sigillarians, 170-171, 173, 212.

Silurian period, 32, 103-119; origin of name, 103; subdivisions, 103; rock distribution, 104-105; character of rocks, 104-107; thickness, 107; physical history, 107-110; foreign, 111-112; climate, 112; economic products, 112-113; life of, 113-119.

Sinclair, W. J., 288, 324.

Slate, 69.

Smith, G. O., 303.

Smith, J. P., 214.

Smith, William, 6, 7, 219. 
Smith, W. S., 227.

Smith and Verrill, 18.

Snails, 13, 20.

Snakes, 13, 22, 262, 273.

Solar system, 35-36.

Solenhofen limestone, 225, 234.

South America, 9, 132, 168, 171, 210, 225, 255, 306, 308, 309, 371.

South Dakota, 181, 190, 220, 284, $288,356$.

Spain, 46, 53, 67, 132, 210, 255, 307, 379,380 .

Sphærexochus, 115.

Spiders, 13, 21, 175-176.

Spiral nebula, 37-39.

Spirifers, 117, 135, 156.

Sponges (see also Porifers), 13, 15, $72,91,113-114,133,155,173$, $228,258$.

Spy, Men of, 374, 375, 377.

Squids, 13, 21.

Stage, 31 .

Star-fishes, 13, 17, 115, 134.

Staurocephalus, 115.

Stegocephalians, 157, 178.

Stegosaurs, 263, 267-269.

Stephenson, L. W., 241, 242, 248, 259, 286, 291-292, 314.

Stissing limestone, 57.

St. Lawrence Valley, 63, 88, 104, 144, 299, 332, 335, 336, 348, 364.

St. Louis series, 143, 147; time, 148.

St. Marys formation, 282.

Stoek, H., 160.

Stratigraphy, defined, 23.

Stropheodonta, 135.

Submergence, of land, 28.

Sulphur deposits, 256.

Sun, 35-38.

Superposition, order of, 7 .

Susquehanna, River, 297.

Sweden, 67, 115, 368.

Switzerland, 132.

Syria, 308.

System, 31, 32.

Taconic Range, 86-88, 107, 206.

Taconic Revolution, 86-88, 197.
Talbot, M., figure, 271.

Tarr, R. S., 34, 342.

Tasmania, 68, 89, 152, 188.

Taylor, F. B., 343, 344, 345, 346, 347.

Taylor formation, 237, 242.

Tejon formation, 282.

Teleosts, 140, 232-233, 261, 316.

Tennessee, 82, 83, 88, 90, 106, 122, 130, 132.

Terebratula, 257.

Tertiary period, $32,281-327$; origin of name, 281 ; subdivisions, 281282 ; rock distribution, $283-284$; character of rocks, 284-291; thickness, 290-291; igneous rocks, 291; physical history, 291-304; igneous activity, 303-304; foreign Eocene, 305-306; foreign Oligocene, 306307; foreign Miocene, 307-309; foreign Pliocene, 308-309; climate, 309-310; economic products, $310-$ 311 ; life of, 311-327.

Tetrabeledon, 324-325.

Tetrabranchs, 13, 20, 97-99.

Tetracoralla, 92, 191, 213.

Tetragraptus, 92 .

Texas, 53, 58, 106, 128, 160, 169, $180-182,190,219,242,244,246$, 256, 275, 284, 287, 289, 292.

Thallophytes, 11, 153, 170, 212.

Theropods, 263, 270-271.

Thibet, 305.

Thrimax, 312.

Till, 339.

Time scale, geological, 31 .

Torridon sandstone, 53 .

Toxaceras, 260.

Tracks of animals (see footprints).

Traquair, R., 137, 139.

Tremataspis, 138.

Trent formation, 282.

Trenton formation, 78, 81, 82, 90, 91 .

Triarthrus, 101.

Triassic period, 32, 201-218; origin of name, 201; subdivisions, 201; rock distribution, 201-203; character of rocks, 203-206; thickness, 206 ; igneous rocks, 206; physical 
history, 206-210; foreign, 210; climate, 211; economic products, 212; life of, 212-218.

Tribes Hill formation, 78.

Triceratops, 262-263, 268-270.

Trilobites, 57, 75-76, 99-101, 115, 117-118, 136-137, 157, 175, 191.

Trinity, formation, 237, 242, 276; time, 244.

Trinucleus, 101.

Trochoceras, 97-99.

Trocholites, 97-99.

Troost, 114.

Troostocrinus, 114.

Tully formation, 120, 124.

Turkestan, 225.

Turonian formation, 237.

Turtles, 216, 234, 273.

Tuscaloosa formation, 237, 241.

Uinta formation, 282, 287.

Uinta Mountains, 82.

Uintatherium, 318.

Ulrich, E. O., 18, 65, 154.

Ulsterian series, 120,122 ; time, 128.

Unconformities, significance of, 27; Archean-Algonkian, 47; base of Cambrian, 61.

Underground water, 256.

United States, Physiographic provinces of, 382.

Unkar group, 51.

Upper Carboniferous period (see Pennsylvanian).

Ural Mountains, 305, 306.

Utah, 181-183, 266, 287, 304, 366.

Utica formation, 78,82 .

Valley trains, 338.

Van Hise and Leith, 41, 48, 51.

Vanuxem, L., 96.

Vaqueros formation, 282.

Vaughn, T. W., 229, 230, 259.

Veatch, A. C., 316.

Vermes, 13, 18.

Vermont, 59, 69.

Verrill and Smith, 18.
Vertebrates, 13, 21, 100, 119, 136, 157, 177-179, 191-193.

Vicksburg formation, 282, 287.

Vinci, Leonardo da, 6.

Virginia, 86, 110, 145, 153, 164, 187, $203,212,213,251,256,312,371$.

Voltzia, 213.

Waagenoceras, 99, 191.

Waccamaw formation, 282, 286, 291.

Walcott, C. D., 53, 54, 61, 65, 71, $73,74,76$.

Wales, 56, 67, 68, 69, 103.

Ward, L., 228.

Wasatch formation, 282, 287.

Wasatch Mountains, 82, 181, 183, $220,301$.

Washington, 223, 289, 303.

Washita formation, 237, 242, 276; time, 246.

Wasps, 232.

Waterlime, 112.

Waucobian series, 57.

Well records, diagram, 60.

West Virginia, 132, 147, 153, 169, 181.

Whales, evolution of, 325-326.

White, D., 161, 168, 171.

White Mountains, 86, 87, 250, 332, 372.

White River formation, 282, 287-288.

Wichita Mountains, 82, 86.

Wichita series, 180.

Wilcox formation, 282.

Willis, Bailey, $30,33,44,58,64,66$, $68,85,105,109,123,127,145,146$, $149,159,165,184,202,207,222$, $238,239,245,247,283,285,293$, 295.

Willis and Salisbury, 33.

Williston, S. W., 173, 178-179.

Wind River formation, 282, 287.

Wisconsin, 55, 90, 105-107, 110, 115, $128,334,339,340$.

Wissler, C., 374, 379-380.

Woodbine, formation, 237, 242; time, 246.

Woods, 34.

Woodward, 138, 139, 378. 
Worms, 13, 18, 53, 73.

Worthen, A. H., 176.

Wyoming, 65, 84, 102, 160, 164, 181, $182,205,220,242,256,287,288$, 303.

Yellowstone Park, 303.
Yorktown formation, 282.

Yosemite Valley, 301.

Zaphrentis, 113.

Zine ore, 90, 153.

Zittel, Carl, 13.

Zittel-Eastman, 34. 


\section{VAn Nostrand Company}

are prepared to supply, either from their complete stock or at short notice,

Any Technical or

\section{Scientific Book}

In addition to their own extensive list of publications embracing every branch of SCIENCE, TECHNOLOGY and Engineering, D. Van Nostrand Company have on hand the largest assortment in the United States of such books issued by American and foreign publishers.

All inquiries are cheerfully and carefully answered and complete catalogs sent free on request.

25 Park Place - - - - New York 



